UNIVERSIDADE DE SÃO PAULO

FACULDADE DE FILOSOFIA, LETRAS E CIÊNCIAS HUMANAS DEPARTAMENTO DE LETRAS CLÁSSICAS E VERNÁCULAS PROGRAMA DE PÓS-GRADUAÇÃO EM LETRAS CLÁSSICAS

JOSÉ MARCOS MARIANI DE MACEDO

\author{
A PALAVRA OFERTADA
}

Uma análise retórica e formal dos hinos gregos e da tradição hínica grega e indiana 
UNIVERSIDADE DE SÃO PAULO

FACULDADE DE FILOSOFIA, LETRAS E CIÊNCIAS HUMANAS DEPARTAMENTO DE LETRAS CLÁSSICAS E VERNÁCULAS PROGRAMA DE PÓS-GRADUAÇÃO EM LETRAS CLÁSSICAS

\title{
A PALAVRA OFERTADA \\ Uma análise retórica e formal dos hinos gregos e da tradição hínica grega e indiana
}

José Marcos Mariani de Macedo

\begin{abstract}
Tese apresentada ao Programa de PósGraduação de Letras Clássicas do Departamento de Letras Clássicas e Vernáculas da Faculdade de Filosofia, Letras e Ciências Humanas da Universidade de São Paulo, para a obtenção do título de Doutor em Letras.
\end{abstract}

Orientadora: Profa. Dra. Paula da Cunha Corrêa

São Paulo

2007 


\section{AGRADECIMENTOS}

É comum a quem faz os seus agradecimentos acadêmicos ceder a certa tentação hiperbólica e ser levado a dizer que, sem fulano ou beltrano, o trabalho jamais teria sido realizado. Dito isso, afirmo que sem a minha orientadora, Paula, essa tese jamais teria visto a luz do dia; que ela não tome isso como um exagero. Foi ela quem aceitou o meu projeto inicial, quem me apoiou a cada passo, quem me incentivou a passar um ano em Oxford, quem leu e comentou em detalhes cada capítulo, quem me facilitou o caminho para seguir adiante, quem nunca me faltou em assuntos acadêmicos ou administrativos. A ela toda a minha gratidão.

Partes da tese foram apresentadas, sob forma diversa, em alguns seminários. Uma primeira versão dos itens 1.1.2 e 1.1.4 reunidos foi exposta em 2005 num seminário de pós-graduação na FFLCH-USP sob o título "Dois Hinos: Peã a Higiéia de Arífron ( $P M G$ 813) e Hino a Dioniso de Sófocles (Antígone, 1115-54)"; agradeço aos participantes pelos comentários e sugestões. O mesmo texto, ligeiramente mais elaborado, foi apresentado em 2006 no Corpus Christi Classical Seminar (Oxford) sob o título "In Between Poetry and Ritual: Two Hymns by Ariphron ( $P M G$ 813) and Sophocles (Antigone 1115-54)". Sou grato a Jan-Mathieu Carbon pelo convite, a Scott Scullion e Lucia Athanassaki pelo vivo interesse demonstrado e sobretudo a Martin West, Philomen Probert, Ewen Bowie, David Fearn, Daniel Kölligan e Victor Davella, que leram previamente o texto e corrigiram vários erros de forma e de fundo. Uma versão preliminar do capítulo 2 foi apresentada no Comparative Philology Graduate Seminar da Universidade de Oxford (2006), sob o título "Short Notes on the Structure of Some Rig Vedic Hymns”. Agradeço de coração a Andreas Willi pelo generoso convite e sobretudo a Elizabeth Tucker, com quem trabalhei cada detalhe do texto e que dedicou várias horas do seu trabalho para aperfeiçoá-lo. Elizabeth apresentou-me ao grupo de filologia comparada da universidade, convidou-me a fazer parte de grupos de estudo e incentivoume imensamente toda vez que surgiram dúvidas e hesitações da minha parte - sempre com a sua enorme modéstia, circunspecção e elegância. Ela é meu modelo de competência e generosidade intelectual. Aos participantes do seminário, sou grato pelas inúmeras sugestões e críticas. 
O período de um ano que passei em Oxford não teria sido tão proveitoso, como foi, sem a hospitalidade de Ewen Bowie, a quem expresso o meu sincero agradecimento. Daniel Kölligan também contribuiu em muito para que esse período de estudos fosse dos mais agradáveis: sempre disposto a ajudar, ele foi e continuará sendo um permanente estímulo, e com ele aprendi um bocado. Sua erudição e entusiasmo ainda me servem de alento.

Não preciso dizer que todos esses profissionais que me auxiliaram durante a elaboração da tese não compartilham necessariamente das minhas opiniões a respeito da matéria. De fato, os acertos devem-se mais a eles, e os erros à minha ignorância ou obstinação.

Agradeço também à FAPESP pela bolsa de doutorado que financiou a pesquisa e à Capes pela bolsa-sanduíche que, durante doze meses, me possibilitou dar seqüência aos estudos na Universidade de Oxford. Devo agradecer ainda aos comentários da banca de qualificação.

Aos meus pais, a quem devo tanto, sou grato entre outras coisas por nunca me terem perguntado para que servem essas coisas que eu estudo, embora tivessem todo o direito de fazê-lo.

Agradecer aqui à Adriana, minha companheira por mais de vinte anos, dedicar-lhe essa tese, é infinitamente pouco diante de tudo aquilo que ela representa para mim. Mas como ela sabe muito bem disso, que lhe baste a simples dedicatória.

São Paulo, outubro de 2007 


\title{
RESUMO
}

\author{
MACEDO, J. M. M. A palavra ofertada. Uma análise retórica e formal dos hinos \\ gregos e da tradição hínica grega e indiana. 2007. 301 p. Tese (Doutorado) -
} Faculdade de Filosofia, Letras e Ciências Humanas da Universidade de São Paulo, 2007.

O objetivo do trabalho é analisar alguns elementos retóricos e estilísticos de certos hinos gregos de várias épocas. Partindo deles, são estudos também alguns hinos da tradição indiana mais antiga, contidos no Rig Veda, a fim de sugerir traços comuns a essas duas tradições hínicas indo-européias e as suas respectivas especificidades. A tese procura apontar, com base na leitura de hinos paradigmáticos, as estratégias formais dos poetas para louvar a divindade. A preocupação básica é com as estruturas dos hinos, com os expedientes de que se vale o poeta para expressar seu louvor. São descritos os meios com que, no hino grego, a divindade é atraída para perto e como, em certos poemas, essa convenção é quebrada para alcançar efeitos literários. Estudam-se pares contrastantes que estruturam a composição de determinados hinos e também como esse mesmo contraste, em outros casos, é deliberadamente borrado em benefício do louvor. Quanto aos hinos rigvédicos, sugere-se uma forma peculiar a partir do qual se estruturam, a saber, a partir do seu centro. Conclui-se que, em ambas as tradições - a grega e a indiana - o hino é uma oferenda que instaura entre deus e devoto uma relação de reciprocidade na qual ele próprio, hino, atua como objeto de troca - um objeto de troca digno da estima divina, que chama atenção sobre si mesmo à força da sua elaboração estilística e retórica.

Palavras-chave: Hino. Grécia antiga. Rig Veda. Estilo. Retórica.

\section{ABSTRACT}

MACEDO, J. M. M. The word as an offering. A rhetorical and stylistic study of the Greek hymns and of the Greek and Indian hymnic tradition. 2007. 301 p. Thesis (Doctoral) - Faculdade de Filosofia, Letras e Ciências Humanas da Universidade de São Paulo, 2007.

This work aims at analyzing some rhetorical and stylistic features of some Greek hymns from various periods. Taking them as a starting point, some hymns from the Rig Veda will be studied as well, in order to assess certain common characteristics of both hymnic traditions and their peculiarities. Based on the close reading of the hymns, the author tries to show the poet's formal strategy to praise the deity. The structure of each hymn is a main concern, as are the devices used by the poet to give voice to his praise. As for the Greek hymns, it will be described how the poet persuades the deity to come near and how he builds his work based on contrasting pairs. As for the Rigvedic hymns, it is suggested that some of them are organized around its middle section. The conclusion to be drawn is that in both traditions - in the Greek and the Indian one - the hymn is an offering that creates a bond of reciprocity between deity and his worshipper. The hymn itself is valued in the exchange by means of its stylistic and rhetorical quality.

Keywords: Hymn. Ancient Greece. Rig Veda. Style. Rhetoric. 


\section{SUMÁRIO}

NOTA INTRODUTÓRIA.

CAPÍTULO 1.

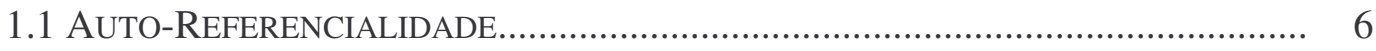

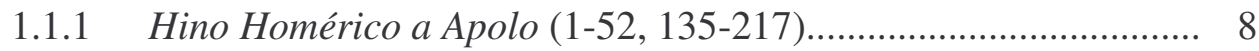

1.1.2 Sófocles, Antígone (1115-1154)................................................ 22

1.1.3 Calímaco, Hino a Apolo (55-104)............................................. 32

1.1.4 Arífron, Peã a Higiéia (PMG 813).......................................... 38

1.1.5 Aristóteles, Hino à Virtude (PMG 842)..................................... 47

1.1.6 Píndaro, Neméia 7, 1-8.......................................................... 53

1.1.7 Hino Homérico a Héracles.......................................................... 55

1.1.8 Hino Homérico a Hefesto........................................................ 57

1.1.9 Píndaro, Olímpica 12........................................................... 59

1.1.10 Hesíodo, Os Trabalhos e os Dias (1-10)..................................... 62

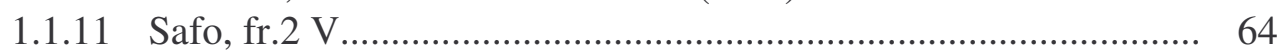

1.1.12 Píndaro, Pe ã 6..................................................................... 66

1.1.13 Sófocles, Antígone (781-800)................................................. 74

1.1.14 Aristófanes, Cavaleiros (551-564 / 581-594)............................. 77

1.1.15 Sófocles, Traquínias (205-224)............................................. 81

1.1.16 Hino ao Kouros do Monte Dicta................................................... 83

1.1.17 PMG 887 .............................................................. 89

1.2 QUEBRAS DE CONVENÇÃO........................................................................ 91

1.2.1 Píndaro, Olímpica 14............................................................ 91

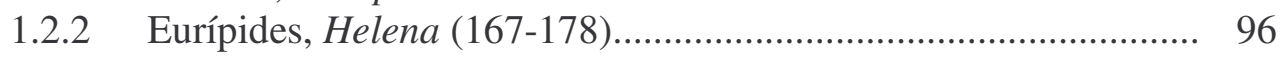

1.2.3 Eurípides, Hipólito (525-564)................................................. 100

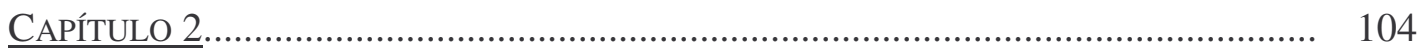

2.1 A Estrutura do Hino RigVÉdico............................................................ 104

2.1.1 Grupo central.................................................................. 107

2.1.1.1 Repetição simples..................................................... 107

2.1.1.2 Repetição complexa................................................. 108

2.1.1.2.1 Palavras gêmeas......................................... 108

2.1.1.2.2 Numerais................................................ 111

2.1.1.2.3 Termos afins.......................................... 114

2.1.2 Divisão ao meio............................................................... 116

2.1.2.1 Repetição simples.................................................... 116

2.1.2.2 Repetição complexa.................................................. 121

2.1.3 Palavra-chave....................................................................... 125

2.1.4 Ambigüidade.................................................................... 131

2.1.5 Clímax ....................................................................... 136 


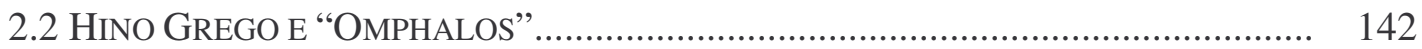

2.2.1 Anacreonte (PMG 357)........................................................... 144

2.2.2 Arístono, Hino a Héstia ................................................................ 149

2.2.3 Eurípides, Ifigênia em Táuris (1234-1258)................................. 153

2.2.4 Calímaco, Hino a Delos............................................................... 156

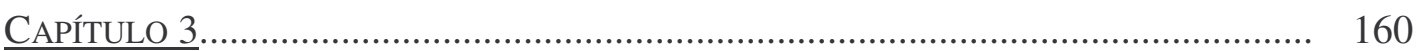

3.1 PARES CONTRASTANTES.......................................................................... 160

3.1.1 Alternância passado - presente: Limênio, Peã a Apolo................ 160

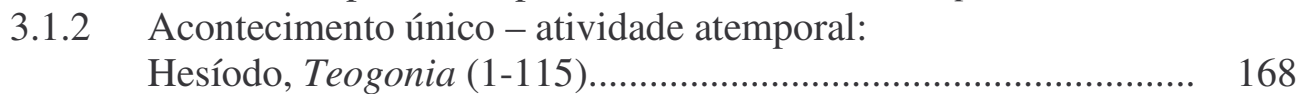

3.1.3 Planos temporais no Rig Veda................................................. 179

3.1.4 Passado mítico / passado histórico e presente............................... 184

3.1.4.1 Aristófanes, Lisístrata (1247-1294).......................... 185

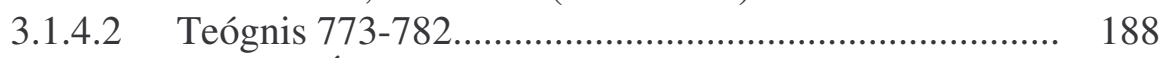

3.1.4.3 Píndaro, Ístmica 7, 1-22 ........................................ 191

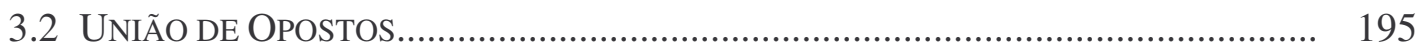

3.2.1 União de gêneros: Filodamo, Peã a Dioniso................................. 196

3.2.2 Presente da celebração............................................................ 210

3.2.2.1 Píndaro, Pítica 5, 54-93............................................. 212

3.2.2.2 Hino dentro do hino: Hino Homérico a Pã................... 219

3.2.3 Ambigüidade..................................................................... 224

3.2.3.1 Peã Eritreu................................................................ 224

3.2.3.2 Píndaro, Olímpica 4, 1-16.......................................... 227

3.2.3.3 Hino matinal a Asclépio............................................ 232

3.2.3.4 Hino mágico a Apolo.................................................. 236

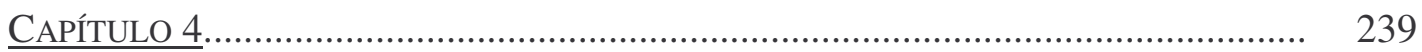

4.1 RECIPROCIDADE COMO TEMA..................................................................... 239

4.1.1 Arístono, Peã a Apolo............................................................... 239

4.1.2 Macedônico, Peã a Apolo e Asclépio............................................ 244

4.1.3 Louvor e pedido: Hino Homérico a Gaia...................................... 249

4.1.4 Paronomásia......................................................................... 252

4.1.5 Justaposição de pronomes....................................................... 257

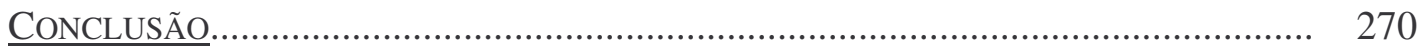

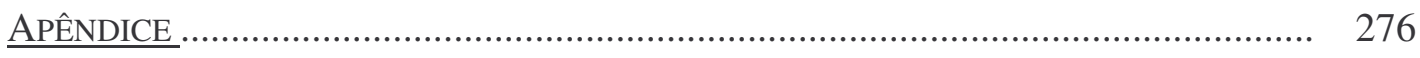

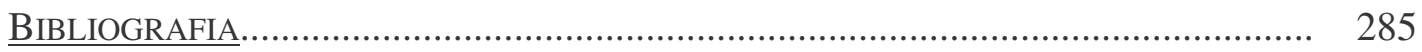




\section{TEXTOS E ABREVIAÇÕES}

Os textos gregos são citados de acordo com as seguintes edições:

Hinos Homéricos: T. Allen, W. Halliday e E. Sikes, The Homeric Hymns, Oxford, 1936; Calímaco: R. Pfeiffer, Callimachus, Oxford, 1949-53;

Píndaro: B. Snell e H. Maehler, Pindari Carmina cum Fragmentis ( $8^{\text {a }}$ ed.), Leipzig, 1987; os peãs seguem a edição de I. Rutherford, Pindar's Paeans, Oxford, 2001.

Sófocles: H. Lloyd-Jones e N. G. Wilson, Sophoclis Fabulae, Oxford, 1990.

Poetas líricos: D. L. Page, Poetae Melici Graeci (PMG), Oxford, 1962.

Hesíodo: M. L. West, Theogony, Oxford, 1966, e Works \& Days, Oxford, 1978.

Aristófanes: J. Henderson, Lysistrata, Oxford, 1987; demais: F. W. Hall e W. M. Geldart, Aristophanis Comoediae, Oxford, 1906.

Eurípides: salvo indicação em contrário, J. Diggle, Euripidis Fabulae, Oxford, 1981-94.

Teógnis: M. L. West, Iambi et Elegi Graeci (2 ${ }^{\mathrm{a}}$ ed.), Oxford, 1989.

Referências às demais edições utilizadas serão feitas ao longo da tese.

O Rig Veda é citado segundo o texto metricamente restaurado por B. A. Van Nooten e G. B. Holland, Rig Veda: A Metrically Restored Text with an Introduction and Notes, Harvard Oriental Series (vol. 50), Cambridge, Mass., 1994.

Abreviações de periódicos seguem no geral as convenções de L'Année philologique. 


\section{NOTA INTRODUTÓRIA}

“A poesia cultual da época antiga perdeu-se", notou Wilamowitz em 1921, ${ }^{1}$ e de fato o que restou dos hinos gregos da era arcaica e clássica é muito pouco em comparação com a relevância do canto hínico na vida religiosa. Na era helenística, cresce um pouco o número de documentos graças aos hinos destinados a cultos locais ou a determinados eventos do calendário litúrgico, principalmente em Delfos e Epidauro. O material inclui os Hinos Homéricos, utilizados como prefácio à récita dos épicos, o canto monódico de poetas líricos e elegíacos, composto para ocasiões privadas ou banquetes, a lírica coral tanto dos hinos entoados pelos coros dramáticos quanto dos peãs e ditirambos atestados em papiro, os hinos inseridos na poesia laudatória dos epinícios, os hinos de Calímaco, os quais retomam as antigas convenções do gênero e por vezes buscam recriar, de maneira "mimética", as ocasiões de performance, os hinos de culto gravados em pedra, os hinos órficos, os hinos contidos nos papiros mágicos, os hinos filosóficos e alegóricos e ainda os hinos em prosa dos escritores retóricos Élio Aristides, Menandro Retor e das chamadas aretalogias de Ísis.

O volume de textos que nos foi transmitido é pequeno também em comparação, por exemplo, com a riqueza de um corpus hínico como o Rig Veda, com seus mais de mil hinos que correspondem aproximadamente - como mais de um já observou - ao tamanho da Ilíada e Odisséia juntas. No horizonte da religião indo-européia, no entanto, os hinos gregos sobressaem por compor, ao lado dos hinos indo-iranianos, os principais exemplos de poética hínica que remontam à matriz comum. ${ }^{2}$ Serão eles, os hinos gregos, meu ponto de partida e de chegada nesse trabalho, com eventuais incursões no terreno indiano, a fim de estudar temas estilísticos abrangentes da tradição hínica grega e confrontá-los, quando oportuno, com o uso que deles é feito pela tradição irmã no campo indo-europeu.

\footnotetext{
${ }^{1}$ Wilamowitz (1921), 242.

${ }^{2}$ No processo de transmissão oral, perderam-se praticamente todas as informações sobre os hinos celtas, eslavos, bálticos e germânicos; os hinos hititas são numerosos, mas a sua natureza é tributária sobretudo da tradição mesopotâmica, não da indo-européia; quanto aos hinos em latim, vários dos seus recursos retóricos foram tomados de empréstimo aos gregos e não representam (com a possível exceção do Hino Saliar dos irmãos Arval) uma herança autônoma. Cf. West (2007), 304s., Schmitt (1967), 195-220, e Durante (1976), 155-66.
} 
Meu objetivo básico é analisar a expressão formal da intenção retórica de louvar as divindades. Uma das minhas preocupações constantes, como logo ficará claro, é com a estrutura dos hinos, com as suas repetições expressivas em diversos níveis - temático, verbal, fonético etc. - que obedecem ao propósito laudatório específico de cada poeta. Não basta, para tanto, fazer uma listagem deste ou daquele recurso retórico ou arrolar os poemas que os contêm; é preciso mostrá-los em uso, descrever como o poeta lança mão de determinadas estratégias para criar certos efeitos estéticos, como os integra no poema. Daí por que procuro, na medida do possível, fazer uma leitura cerrada das obras, ao contrário de autores como por exemplo Keyssner, que raramente levam em conta o hino como unidade de sentido. ${ }^{3}$

Cabe aqui uma palavra sobre o meu corpus. Como se sabe, o Rig Veda é um conjunto de hinos composto e transmitido oralmente entre 1500-1000 a.C. e organizado em dez livros ou mandalas, sendo seis deles - os chamados "Livros Familiares" (II-VII) atribuídos a diferentes famílias de bardos. Nesses livros, por exemplo, a divisão em hinos e as suas fronteiras seguem princípios claros, identificados por Bergaine e Oldenberg: ${ }^{4} \mathrm{o}$ número de hinos por livro cresce; uma pequena série de hinos endereçados a Agni, Indra e outras divindades são dispostos segundo o número total decrescente de hinos em cada grupo; dentro de cada série, os hinos progridem do maior para o menor, e outro fator para decidir a ordem é o metro: uns precedem os outros, em seqüência rígida. Embora o hino forme assim uma unidade autônoma, e embora nos últimos cento e cinqüenta anos os indólogos e indo-europeanistas tenham feito avanços monumentais na compreensão de um texto freqüentemente obscuro, repleto de elipses e alusões enigmáticas, são raros os autores que se dedicaram ao estudo dos poemas como conjunto independente, dotado de estrutura própria. Uma das exceções recentes é Stephanie Jamison, cujo trabalho inspirou a parte relativa aos hinos védicos dessa tese. ${ }^{5}$

\footnotetext{
${ }^{3}$ Esta é a razão pela qual deixo de fora os hinos avésticos, que compõem, a par dos hinos indianos, a outra vertente da hinologia indo-iraniana: sua estrutura já foi e continua sendo amplamente tratada - ao contrário do que ocorre com os hinos rigvédicos - por Schmidt (1968b), (1974) e (1985), Schwartz (1998), e Hintze (2002). Que os hinos gregos tenham por característica "die besonders konsequente literarische Formung, die Integration in Poesie", é assinalado por Burkert (1994), 16.

${ }^{4}$ Bergaine (1886), Oldenberg (1884) e (1888), esp. 191-270.

${ }^{5}$ Cf. Jamison (2004) e (2007), esp. 51-89 (“Structuring Devices in Rigvedic Hymns”). Faço notar que só tive acesso a esse último texto quando a tese já havia sido escrita.
} 
Se o Rig Veda representa um corpus fechado, inverso é o caso dos hinos gregos de que trato. Aqui os limites são mais flexíveis, tanto em termos diacrônicos quanto pela função que cumprem os poemas. Trata-se de hinos rapsódicos, cultuais, simpóticos ou líricos, empregados em culto ou de fundo literário - porém a todos, em diversos graus, é comum a forma conservadora da poesia hierática. ${ }^{6}$ De uns, o recurso retórico está calcado na prática cultual efetiva, de outros, o elemento formal ganha precedência na tentativa de recriar a imagem associada ao gênero. Em hinos tardios, portanto, não é raro que traços estilísticos sejam tanto mais evidentes, mas a verdade é que já na era clássica existe uma sofisticada manipulação do gênero, cujas regras são observadas ou então deliberadamente infringidas para criar efeitos literários. Estejam estreitamente ligados à prática religiosa ou não, os hinos gregos de todas as épocas costumam utilizar certas estratégias retóricas que se repetem, empregadas com maior ou menor sucesso segundo o contexto ou a habilidade do poeta.

São algumas dessas estratégias que procuro descrever neste trabalho. No primeiro capítulo, trato inicialmente de um dos aspectos formais mais marcantes dos hinos gregos: a auto-referencialidade, o meio formal e estilístico de que se vale o poeta hínico para atrair a divindade para perto, para seduzi-la ao instante presente da celebração, em um movimento que leva do universal ao particular, do geral ao concreto (itens 1.1.1 a 1.1.17). Em seguida, mostro como tais estratégias, certamente reconhecíveis pelo público, são utilizadas pelo poeta para frustrar ou corroborar as expectativas dos ouvintes, ou ainda conferir um colorido especial à sua obra (itens 1.2.1 a 1.2.3). No capítulo 2 , sugiro uma forma particular pela qual alguns dos hinos rigvédicos estruturam-se, a saber, a partir do seu centro. Vários são os meios utilizados pelos rọsis ou bardos védicos para dar relevo à parte central da composição: acúmulo expressivo de vocábulos conexos nas estrofes nucleares (2.1.1), divisão estrutural da obra em duas metades (2.1.2), palavra-chave posicionada no exato centro do poema (2.1.3), frase ambígua que, aninhada na seção média, fornece a chave para a compreensão do hino (2.1.4), clímax temático antecipado para a estrofe central (2.1.5). Sugiro a seguir, no restante do capítulo, possíveis paralelos

\footnotetext{
${ }^{6} \mathrm{Cf}$. Hunter (1996), 53: “[...] the language and ideas of hymnic praise are of necessity conservative, because it is part of the point of such praise that its object is thereby placed (or confirmed) in a familiar category of divine - radical innovation would threaten to defeat the very purpose of praise".
} 
na tradição grega, na qual alguns poucos hinos parecem seguir princípio composicional análogo (2.2).

Já no capítulo 3, estudo pares contrastantes que estruturam a composição de determinados hinos. No item 3.1.1, enfoco o par antitético presente - passado; no item 3.1.2, a contraposição entre acontecimento único e atividade temporal; no item 3.1.4, os planos antagônicos e complementares do passado mítico-histórico e o presente da celebração. Incluo ainda a análise de dois hinos rigvédicos para servir de termo de comparação entre as duas tradições (item 3.1.3). Em um segundo momento (3.2), indico alguns expedientes que borram deliberadamente as fronteiras entre passado e presente, entre mito e realidade para uni-los indissoluvelmente no instante presente da celebração do próprio hino. Trata-se da união de gêneros tradicionalmente opostos (3.2.1), do rito atual que se confunde com o rito mítico (3.2.2) e da ambigüidade como recurso estilístico destinado a unir o deus louvado e seu devoto (3.2.3). Finalmente, no capítulo 4, analiso alguns hinos nos quais a reciprocidade, cuja idéia está na base de toda a relação em que o poema figura como objeto de troca por dádivas divinas, torna-se o próprio tema da composição. Neles, a reciprocidade entre os deuses serve de paradigma para a relação que o fiel deseja instaurar com a divindade (4.1.1), ou então os mortais inserem-se no vínculo mútuo entre os deuses a quem prestam homenagem (4.1.2). A troca mútua de bens revela-se ainda no louvor entoado pelo poeta, que já traz implícito o pedido endereçado ao deus (4.1.3), na paronomásia entre termos referentes à esfera divina e humana (4.1.4) e na justaposição de pronomes dos dois pólos da relação, fiel e imortal (4.1.5). Em conclusão, em ambas as tradições - a grega e a indiana - o hino é uma oferenda que instaura entre deus e devoto uma relação de reciprocidade na qual ele próprio, hino, atua como objeto de troca - um objeto de troca digno da estima divina, que chama atenção sobre si mesmo à força da sua elaboração estilística e retórica.

Essas estratégias, como é natural, raramente aparecem isoladas nos hinos; várias delas costumam entremesclar-se, embora em geral uma prevaleça. É inevitável que os exemplos sejam em certa medida intercambiáveis, mas sob cada rubrica procuro escolher os mais paradigmáticos para ilustrar a questão. Meu argumento é em parte cumulativo, devido à própria natureza da matéria: mostrar como certos recursos estilísticos repetemse em poemas diversos, sob diversas formas. O principal desafio é apontar a semelhança 
de tais artifícios retóricos ao longo dos hinos sem deixar de fazer jus à especificidade de cada poema em particular, sem sucumbir à tentação de impor um gabarito que empobreça as obras no afã de comprovar o raciocínio. É claro que sempre entrarão em linha de conta as preferências pessoais do pesquisador e a capacidade deste ou daquele hino prestar-se como exemplo de um aspecto retórico característico, mas caberá sempre - e espero não ter fugido muito a este preceito - esforçar-se por tomar o poema como base para, a partir dele, identificar estratégias comuns, não o contrário.

$\mathrm{Na}$ escolha do material grego, o trabalho foi imensamente facilitado pelos dois volumes de hinos gregos selecionados e comentados por William Furley e Jan Maarten Bremer, Greek Hymns (2001), que serviram de guia a várias partes da tese. Ficará clara, ainda, a influência do livro ainda hoje fundamental de Eduard Norden, Agnostos Theos (1913), e das obras de Lutz Käppel (1997) e Ian Rutherford (2001) sobre os peãs. ${ }^{7}$ O modelo geral, enfim, de como ler poemas antigos e conceber a sua poética foi fornecido pelo trabalho de Calvert Watkins.

\footnotetext{
${ }^{7}$ Todas as traduções oferecidas ao longo do texto são minhas e visam a proporcionar um simples apoio à leitura; são tradução literais, sem nenhum propósito poético. Menciono aqui, para benefício do leitor, algumas outras obras brasileiras que tratam dos poemas aqui analisados: Hesíodo - Os Trabalhos e os Dias, trad. M.C.N. Lafer, São Paulo, 1991; Hesíodo - Teogonia: a origem dos deuses, trad. J.A.A. Torrano, São Paulo, 1991; Adriane da Silva Duarte, O dono da voz e a voz do dono: a parábase na comédia de Aristófanes, São Paulo, 2000; Aristófanes - Duas comédias: Lisístrata e Tesmoforiantes, trad. A.S.Duarte, São Paulo, 2005; O Hino Homérico a Apolo, trad. Luiz Alberto Machado Cabral, Campinas, 2004; Giuliana Ragusa, Fragmentos de uma deusa: a representação de Afrodite na lírica de Safo, Campinas, 2005. Entre as teses não publicadas, menciono a de M.L.G. Massi, Zeus e a poderosa indiferença, USP, 2005, e a de E.P.N. Werner, Os hinos de Calímaco, USP, 2005.
} 


\section{Capítulo 1}

\subsection{AUTO-REFERENCIALIDADE}

Ruhnkenius foi o primeiro a sugerir, em 1782, que o Hino Homérico a Apolo seria uma combinação de dois poemas originalmente separados: um hino délico, recitado em Delos e tendo por tema o nascimento de Apolo na ilha, a par de uma viva descrição do festival ali realizado, onde gente de toda a Jônia se reúne para celebrá-lo; e um hino pítico, que narra o advento do deus em Delfos e a posterior instauração do seu oráculo. Abriu-se então uma disputa que dura até hoje entre os críticos, reproduzindo em ponto menor a querela entre analistas e unitários sobre a "questão homérica". ${ }^{8}$ Uns concordam com Ruhnkenius e alegam em defesa da sua tese divergências de estilo, linguagem, técnica métrica de versificação e perspectiva ideológica entre as duas partes; outros lembram que a combinação não é fortuita nem resultado de corrupção dos manuscritos, pois a estrutura de ambas as seções revela paralelismos tais que só podem ser obra de um único autor. Mas que autor seria esse? Para Tucídides (3.104,5), ninguém menos que o próprio Homero. Fato único entre os hinos homéricos, o cantor do hino a Apolo alude a si mesmo como o cego que vive em Quios, cujas canções, vangloria-se, são todas elas reconhecidas como supremas (172-3). Tucídides identifica Homero ao cantor cego, ${ }^{9}$ porém um famoso escólio sobre a Segunda Neméia de Píndaro (FgrHist 568 F 5) diz tratar-se de um caso de pseudepigrafia: compositor do hino seria um certo Cineto, homerida proveniente de uma família de Quios, o qual teria escrito a obra e atribuído a autoria a Homero, patrono da companhia de rapsodos da qual era ilustre representante. Cantor e autor, portanto, seriam duas figuras diversas: nem Cineto, lembrado pela posteridade como aquele que ocultou a sua identidade sob a de Homero, estaria reivindicando que as suas canções eram famosas pela Grécia afora, nem o público o identificaria à pessoa de Homero, famoso cantor do passado que vivera algumas gerações

\footnotetext{
${ }^{8}$ Detalhes da disputa, até 1975, são descritos em Förstel (1979), 20-62; cf. ainda Burkert (1979 e 1987a); Janko (1982), 99-115; West (1999), 368-372.

${ }^{9}$ É possível que também Aristófanes supusesse ser Homero o autor do hino (cf. Aves, 575, e HHom.Apolo, 114), como sugere Wünsch (1916), 151-52.
} 
antes. Resta no entanto a dúvida se tal Cineto a que se refere o escólio como o primeiro a recitar os poemas de Homero em Siracusa na $69^{a}$ Olimpíada (= 504/1 a.C.) ${ }^{10}$ é a mesma pessoa a quem a autoria do hino é imputada: West acredita que sim, Burkert não vê necessidade para tanto. ${ }^{11}$ Dúvida paira também a respeito da cronologia dos hinos délico e pítico. Qual teria sido composto primeiro? Qual imitaria qual? Enquanto a maioria segue Wilamowitz ${ }^{12}$ e vê a seção pítica como posterior à délica, há quem sustente ${ }^{13} \mathrm{a}$ ordem inversa.

Seja quanto à unidade ou não do hino, seja quanto ao seu autor, seja ainda quanto à ordem cronológica das duas seções - até hoje não se chegou a um consenso mínimo sobre tais questões. Partidários desta ou daquela teoria, contudo, parecem estar de acordo acerca de um único ponto: a data provável em que o hino foi apresentado pela primeira vez ao público. Burkert e Janko, ${ }^{14}$ de forma independente, chegaram à mesma conclusão, e sugerem a data de 523 ou 522 a.C, quando Polícrates, tirano de Samos, celebrou em Delos - com o aval do oráculo de Delfos - um festival chamado ao mesmo tempo pítico e délico. Na ocasião, Polícrates dedicou a ilha de Renéia a Apolo ao prendê-la com uma corrente a Delos - ato simbólico que visava a marcar o controle do tirano sobre o Egeu após a morte de Pisístrato e diante do domínio persa sobre o continente, onde antes era realizado o grande festival pan-iônico em Micale.

O que aqui nos interessa é o fato de esse festival délico, no qual o hino foi recitado pela primeira vez, ser evocado em imagens no corpo do próprio hino. Não pela simples evocação, embora o relato seja único entre os hinos homéricos, mas sim porque o autor toma cuidado extremo (como veremos) para ressaltá-la dentro da obra. Não apenas se alude ao festival, ele não é apenas descrito em cores vivas, mas a sua posição no interior do hino é minuciosamente demarcada à força de repetições, temáticas e vocabulares, que lhe emprestam destaque. Apolo, destinatário do hino, é aos poucos trazido para perto, atraído para o hic et nunc do festival com auxílio de balizas formais e retóricas que o poeta faz questão de sublinhar. Delos - o seu festival - é o ponto de

\footnotetext{
${ }^{10}$ Cineto é um nome raro; em Gela, porém, outra importante cidade da Sicília, foi encontrada uma base de

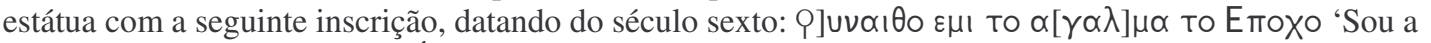
es[tát]ua de [C]ineto, filho de Époco'. Cf. West (1999), 368, com bibliografia.

${ }^{11}$ West (1999), 372; Burkert (1979), 61 e (1987a), 55.

${ }^{12}$ Wilamowitz (1916), 411.

${ }^{13}$ West (1975), 163-65.

${ }^{14}$ Burkert (1979), 59-60; Janko (1982), 112-13. Cf. também Aloni (1989).
} 
chegada no qual deus e devoto unem-se em uma mesma celebração. E ao mesmo tempo a ilha de Delos, ora como local de nascimento, ora como ponto alto das festividades paniônicas que tanto agradam a Apolo, figura no centro da seção délica do hino, delimitada de modo claro por molduras que a põem em evidência. É por prestar-se a essa dupla interpretação, como expediente retórico que faz convergir a atenção da divindade para o instante presente do culto e instala simultaneamente esse instante no centro do poema, que o Hino Homérico a Apolo servirá de introdução aos demais exemplos que pretendo analisar nesse e no próximo capítulo - uns marcados pelo foco progressivo que se fecha sobre o momento presente, sobre o próprio hino, outros pela estratégia de fazer o hino irradiar o seu significado a partir do centro. Estes últimos servirão de gancho para uma comparação entre os hinos da tradição indiana mais arcaica, representada pelo Rig Veda, e alguns hinos gregos que lançam mão de um expediente análogo.

Como para verificar as estratégias retóricas e estilísticas é necessário uma leitura cerrada dos hinos, e como para estudar a sua estrutura é desejável uma visão de conjunto, adoto como praxe transcrever as passagens e as analiso em seguida.

\subsubsection{Hino Homérico a Apolo (1-52, 135-217)}

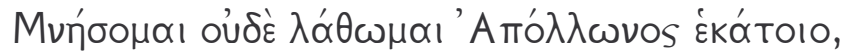

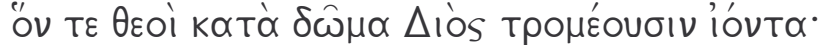

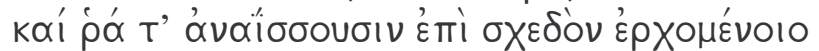

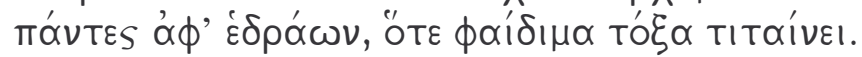

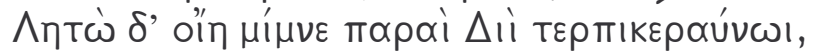

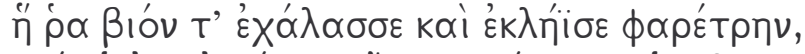

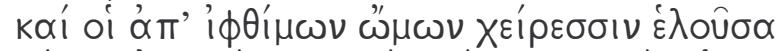

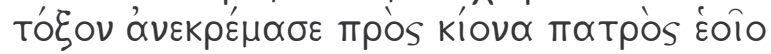

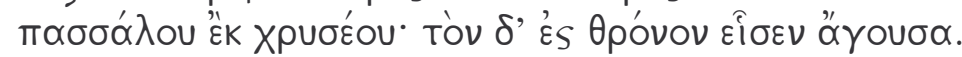

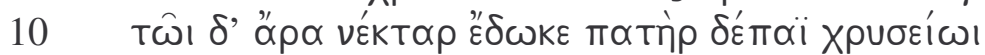

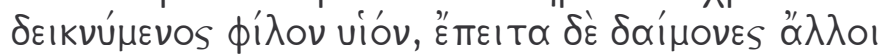

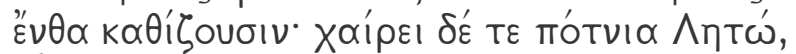

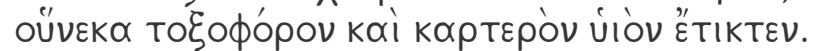

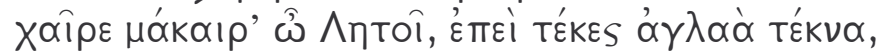

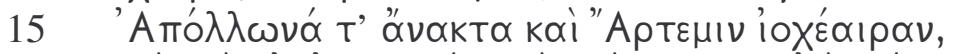

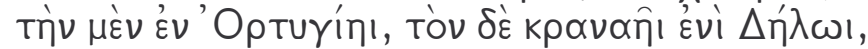

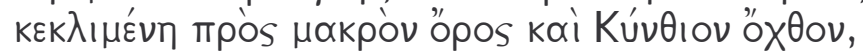

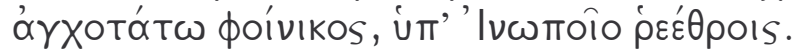

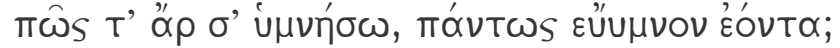

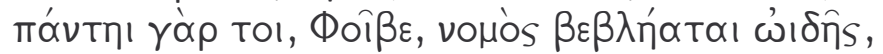




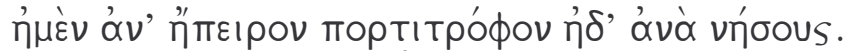

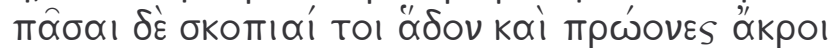

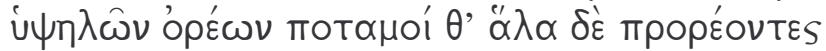

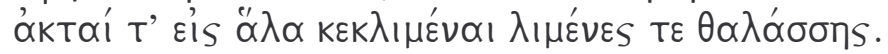

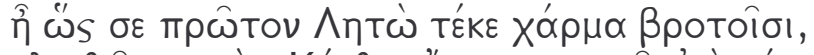

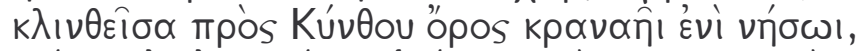

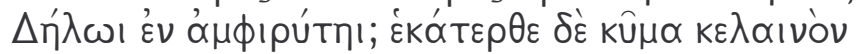

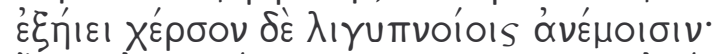

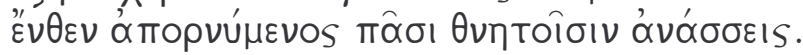

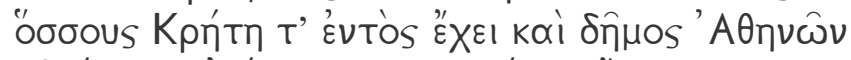

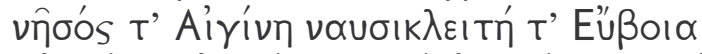

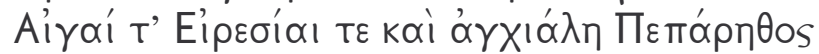

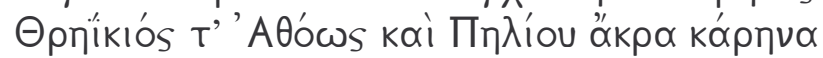

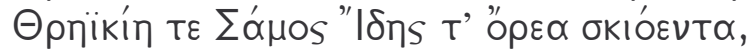

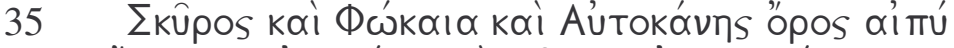

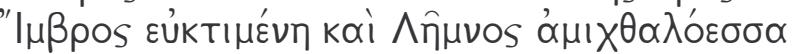

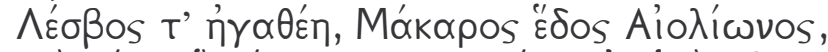

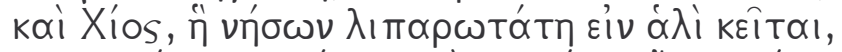

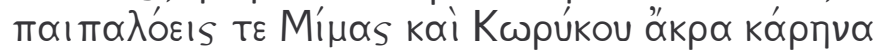

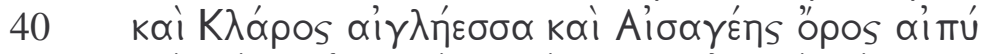

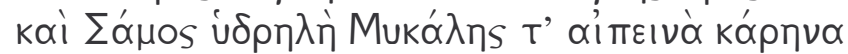

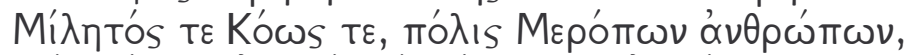

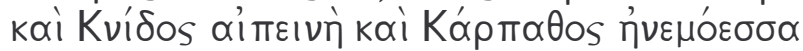

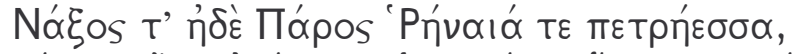

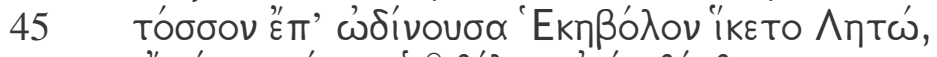

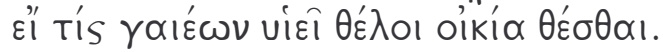

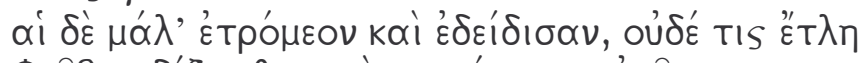

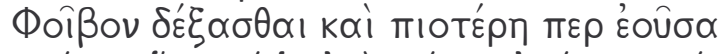

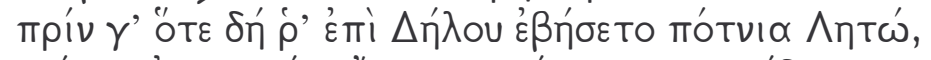

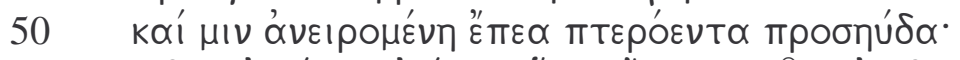

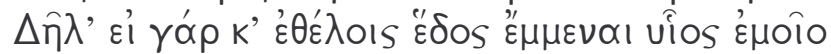
Фoíßou 'A

\section{(...)}

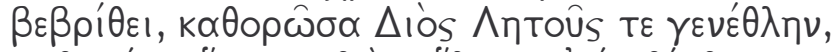

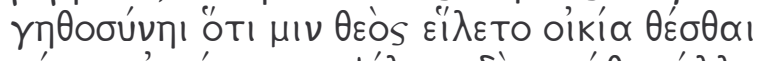

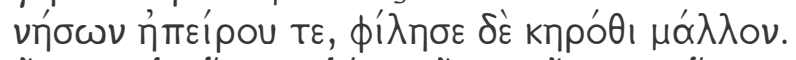

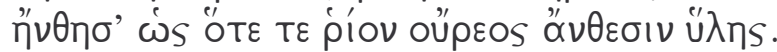

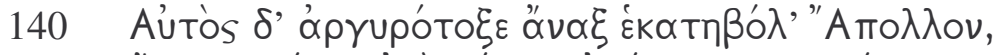

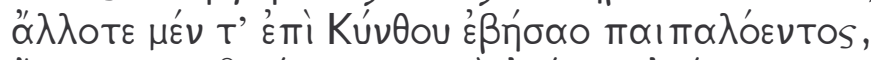

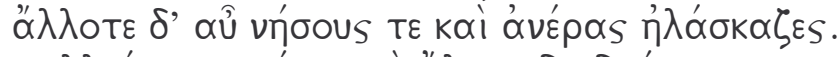

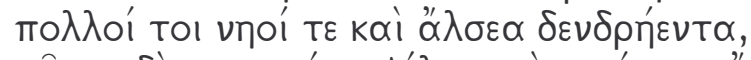

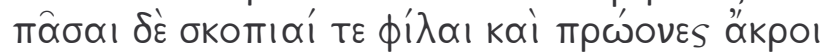

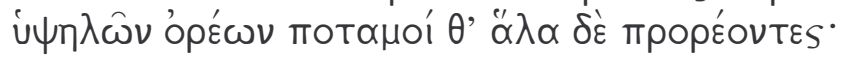




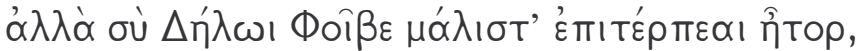

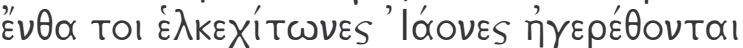

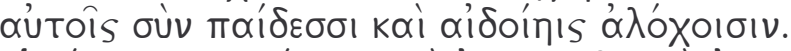

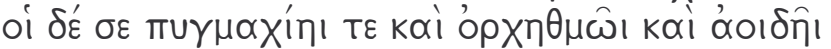

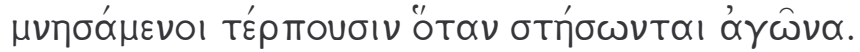

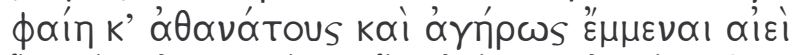

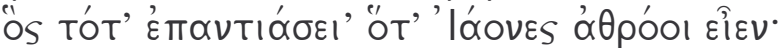

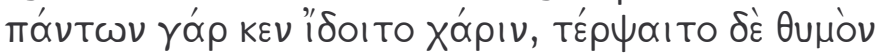

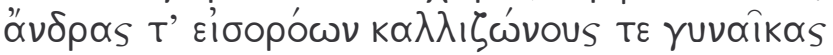

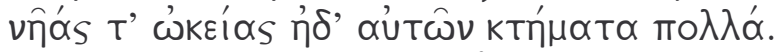

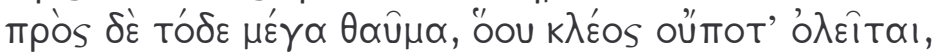

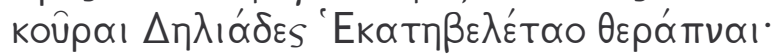

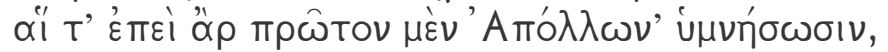

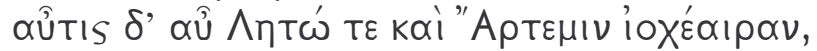

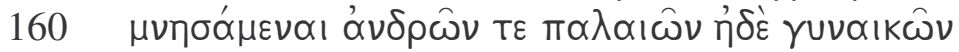

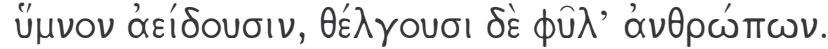

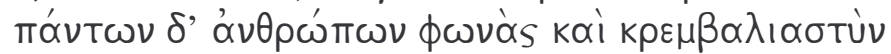

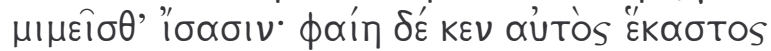

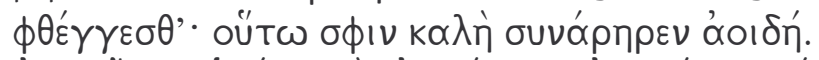

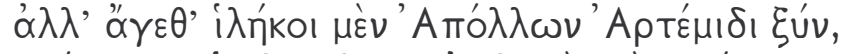

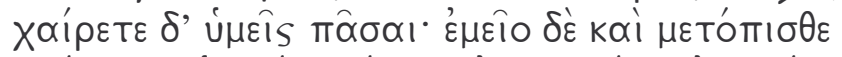

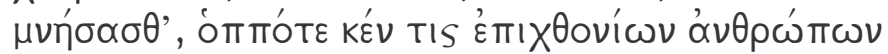

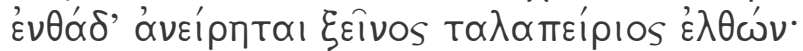

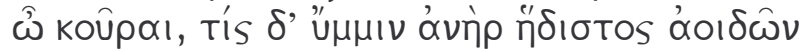

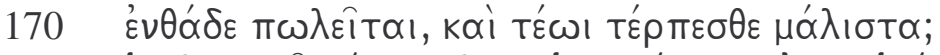

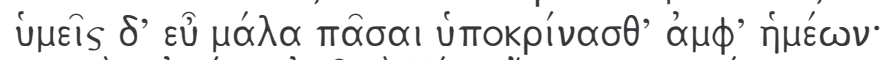

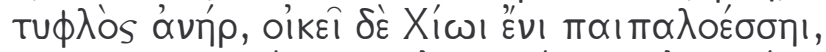

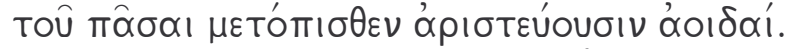

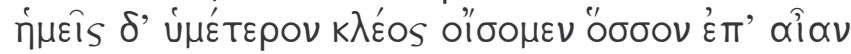

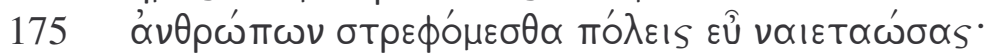

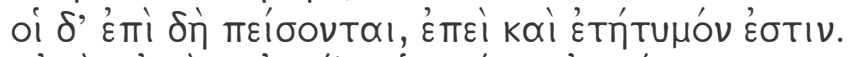

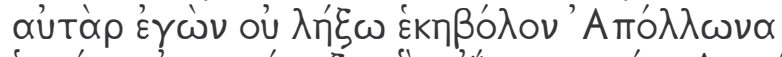

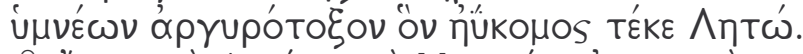

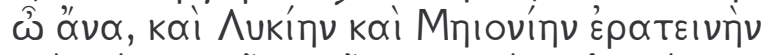

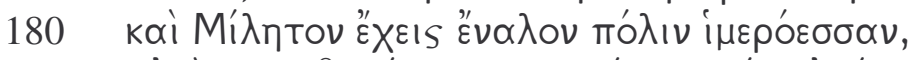

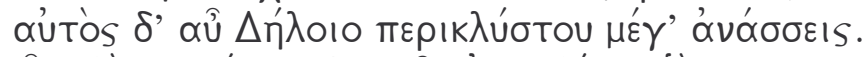

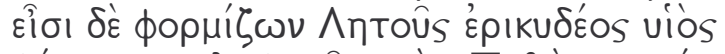

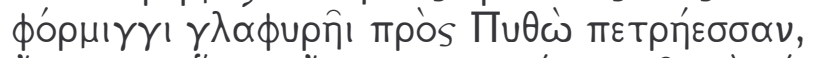

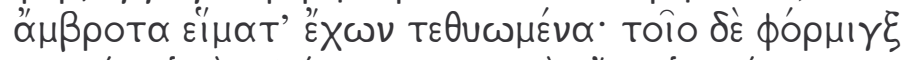

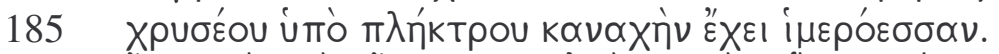

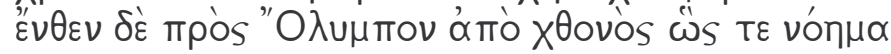

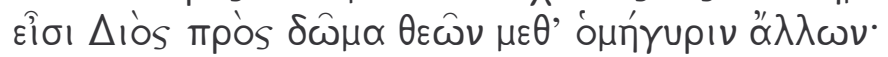

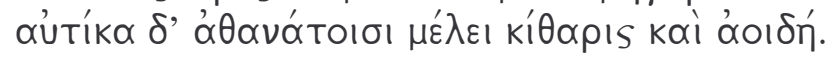

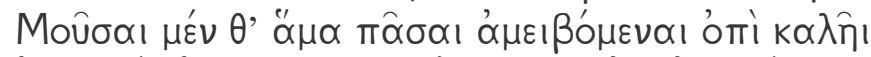

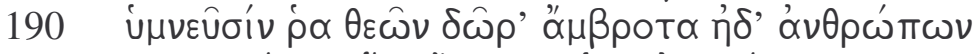

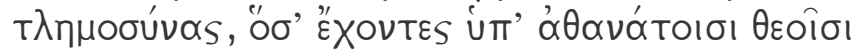




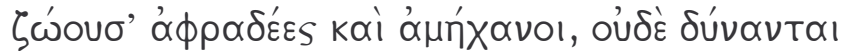

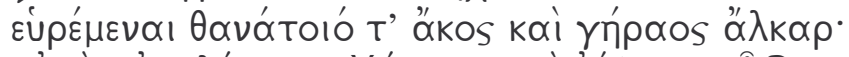

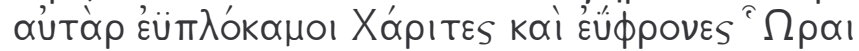

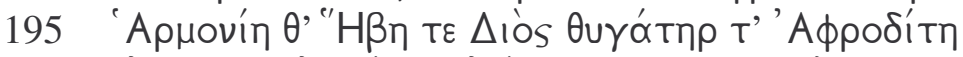

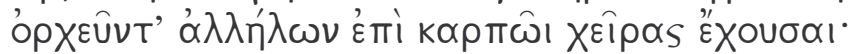

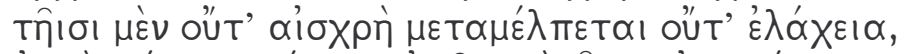

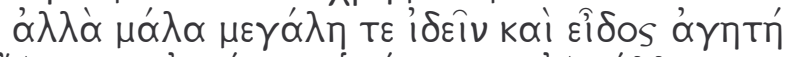

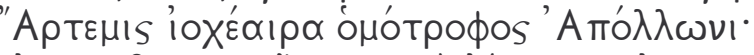

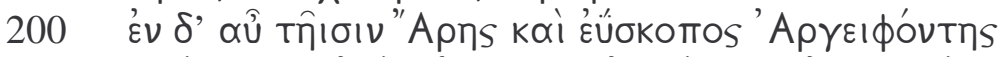

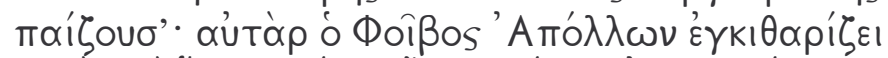

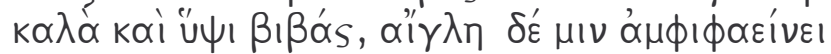

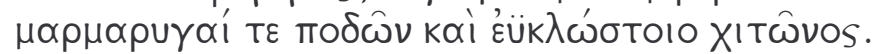
oi $\delta$ ' '

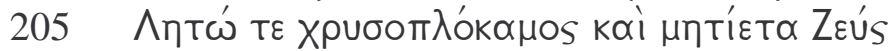

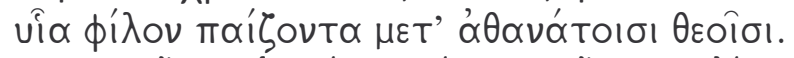

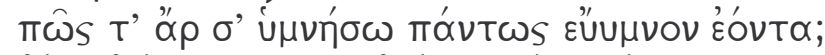

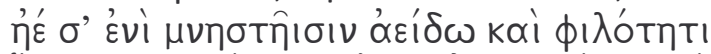

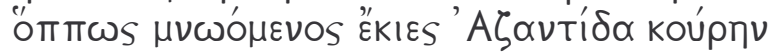

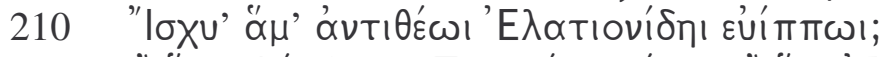

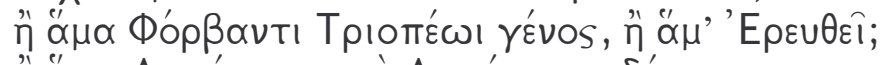

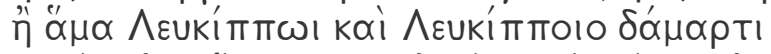

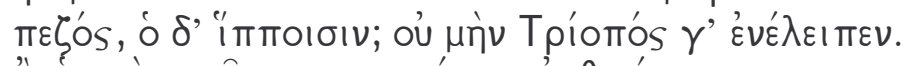

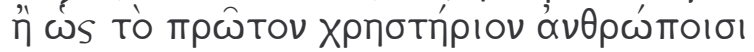

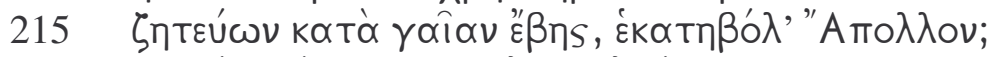

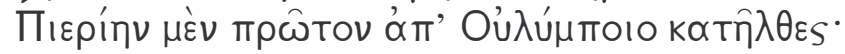

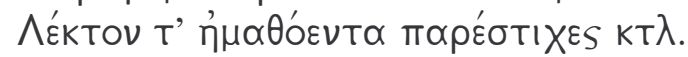

(Que eu me lembre e não me esqueça de Apolo que atira longe, diante da chegada de quem tremem os deuses na casa de Zeus. Todos se erguem num pulo dos seus assentos quando ele distende o seu arco brilhante. [5] Somente Leto permanece ao lado de Zeus cuja diversão é o raio; ela afrouxa-lhe o arco e fecha-lhe a aljava, e após retirar o arco dos seus ombros fortes ela os pendura em um pilar da casa do seu pai, em um gancho de ouro, e o conduz a uma cadeira, fazendo-o sentar-se nela. [10] Seu pai lhe oferece néctar em uma taça dourada, erguendo um brinde a seu filho, e então as demais divindades fazem o mesmo de onde se acham sentadas, enquanto a senhora Leto deleita-se em ter dado à luz um filho arqueiro poderoso.

Salve, ó bem-aventurada Leto, pois deste à luz filhos esplêndidos, [15] o senhor Apolo e Ártemis que empunha as flechas: ela em Ortígia, ele na rochosa Delos, apoiada na longa eminência do Cintos, junto à palmeira, sob as correntes do Ínopos.

Como te cantarei, tão celebrado que és em canto em todos os aspectos? [20] Pois por toda a parte, Febo, estende-se o campo para a tua canção, tanto no continente que cria novilhos quanto nas ilhas. Todos os picos te agradam, e as cristas superiores das altas montanhas e os rios que correm para o mar, e os promontórios que se inclinam para as águas e os portos costeiros. [25] Ou então como primeiro Leto te deu à luz para deleite dos mortais, inclinada contra o monte Cintos em uma ilha rochosa, Delos cercada pelo mar, enquanto 
de ambos os lados as ondas escuras chegavam às praias sob os ventos penetrantes? De lá partindo, tu reinas sobre todos os mortais.

[30] Todos quantos Creta possui dentro de si, e a terra de Atenas, e a ilha de Egina e Eubéia famosa pelos navios, e Ege e Irêsie, e a marítima Pepáretos, e o Átos trácio e os picos elevados do Pélion, e Samotrácia e as montanhas sombreadas do Ida, [35] Ciro e Fócia, e o monte íngreme de Autocane, e o Ímbros bem cultivado e Lemnos inóspita, e a sagrada Lesbos, colônia de Mácar o Eólida, e Quios, a mais lustrosa das ilhas que jazem no mar, e o escarpado Mimas, e os picos elevados do Córico, [40] e Claro esplendorosa e o monte íngreme de Esagéia, e Samos rica em águas e os picos excelsos de Micale, e Miletos e Cós, cidade dos méropes, a excelsa Cnidos e Cárpatos batido pelo vento, e Naxos e Paros e a rochosa Renéia - [45] tanto foi quanto Leto percorreu quando grávida do deus que atira longe, para ver se alguma dessas terras estava disposta a dar morada ao seu filho. Mas elas tremiam e temiam muito, e nenhuma, por mais rica que fosse, ousava aceitar Febo, até que afinal a senhora Leto pôs os pés em Delos, [50] e perguntou-lhe com palavras aladas: "Delos, se tu quisesses ao menos ser a sede do meu filho, Febo Apolo..."

\section{$[\ldots]$}

... e Delos inteira carregou-se de ouro ao contemplar o rebento de Zeus e Leto, em júbilo que o deus a tivesse elegido para fazer sua morada entre todas as ilhas e o continente, e a havia preferido no seu coração. Ela floresceu como quando floresce com flores selvagens um declive da montanha.

[140] Tu mesmo, senhor do arco de prata, deus que atira longe, caminhavas por vezes pelo escarpado Cintos, por vezes tu vagavas pelas ilhas e por entre os homens. Muitos são os teus templos e bosques cobertos de árvores, e todos os picos te são caros e as cristas [145] superiores das altas montanhas e os rios que correm para o mar, mas é em Delos que tu, Febo, mais deleita-te no teu coração, onde os jônios com túnicas que se arrastam reúnem-se com os seus filhos e as suas nobres esposas. Estes, uma vez estabelecida a reunião, [150] lembram de ti e te divertem com boxe, dança e canto. Um homem pensaria que eles são imortais que não envelhecem nunca, se lá chegasse quando os jônios estão todos juntos: veria a beleza de toda a cena, deleitaria o seu coração ao observar os homens e as mulheres de belos cintos, [155] os navios velozes e os seus inúmeros pertences. E também esta grande maravilha, cuja fama jamais perecerá: as donzelas de Delos, servas do deus que atira longe, as quais, após celebrarem primeiro Apolo em canto, e depois Leto e Ártemis que empunha flechas, [160] lembram-se dos homens e das mulheres do passado e entoam uma canção que encanta os povos. Elas sabem imitar as vozes e o balbucio de todas as gentes; cada qual pensaria estar ele próprio falando, tão bem armado é o seu canto.

[165] Mas que agora Apolo seja favorável, juntamente com Ártemis, e salve todas vós, donzelas. Lembrai-vos de mim no futuro, se algum dia um dos homens que vivem sobre a terra, um estrangeiro, que após muito sofrer aqui vier e perguntar: "Ó donzelas, qual é o vosso cantor favorito [170] que aqui costuma vir, e quem mais vos deleita?" Então vós todas respondei a meu respeito: "É o cego, e ele mora na rochosa Quios; todas as suas canções permanecem supremas para sempre". E nós levaremos a vossa reputação onde quer que formos ao vagarmos [175] pelas cidades bem ordenadas dos homens, e eles 
acreditarão, pois que é verdade. E quanto a mim, eu não cessarei de cantar Apolo do arco prateado, o deus que atira longe, que Leto dos belos cabelos deu à luz.

Ó senhor, a Lícia também é tua, e a adorável Lídia, [180] e Miletos, adorável cidade costeira; e tu mesmo, ninguém mais, reina soberano sobre Delos banhada pelo mar; e tocando a sua lira côncava o glorioso filho de Leto dirige-se à rochosa Pito, vestindo fragrantes roupas imortais, enquanto sua lira [185] sob o plectro dourado produz um delicioso clangor. De lá ele sobe da terra ao Olimpo, rápido como pensamento, até a casa de Zeus, para reunir-se à congregação dos demais deuses; de pronto os imortais dedicamse à lira e à canção. As Musas, respondendo todas juntas com voz adorável, [190] cantam as dádivas imortais dos deuses e os sofrimentos humanos - tudo quanto eles recebem dos deuses imortais e ainda assim vivem sem tino e desamparados, incapazes de encontrar um remédio contra a morte ou uma defesa contra a velhice. As Graças de belos cabelos e as animadas Horas, [195] e Harmonia, e Hebe, e a filha de Zeus Afrodite dançam segurando uma o pulso da outra; entre elas canta, por certo não indigna nem inferior, mas majestosa e bela de se ver, Ártemis que empunha as flechas, deusa criada junto com Apolo. [200] Entre eles Ares e o assassino de Argos, de olhar agudo, brincam, enquanto ele, Febo Apolo, toca a sua lira em meio aos outros, com passos ágeis e altos, e um fulgor o envolve, e o rebrilho dos seus pés e a sua túnica bem-tecida. [205] Leto de cachos dourados e Zeus perspicaz deleitam-se em seus grandes corações ao contemplarem os seus filhos brincando entre os deuses imortais.

Como te cantarei, tão celebrado que és em canto em todos os aspectos? Será que devo cantar-te como galanteador e amante, como foste cortejar a donzela azântida em disputa [210] com Ísquio, filho de Elato, semelhante a um deus, rico em cavalos? Ou com Forbas, nascido de Tríopas, ou com Ereuteu, ou com Lêucipo e a mulher de Lêucipo, tu a pé, ele sobre a carruagem - e ele não era inferior a Tríops? Ou como primeiro vagaste pela terra, [215] Apolo que atira longe, em busca de um oráculo para os homens? A Piéria chegaste primeiro vindo do Olimpo; passaste pela arenosa Lectos etc.)

Inicia o hino com uma cena no Olimpo. Após o cantor declarar que se lembrará, que não se esquecerá de Apolo, ${ }^{15}$ segue a cena olímpica introduzida por uma frase relativa característica do gênero hínico. ${ }^{16}$ Apolo causa sobressalto aos deuses reunidos na casa de Zeus; todos se põem de pé diante do seu arco tendido; Leto, porém, logo os acalma ao afrouxar-lhe o arco, fechar-lhe a aljava e pendurá-los num gancho de ouro fixado a uma coluna. Zeus ergue um brinde de néctar a seu filho, Leto orgulha-se de tê-lo dado à luz. Como fecho ao episódio (14-18), o poeta saúda Leto e acena com um novo tema, Delos, local onde Apolo veio ao mundo. Do episódio ao seu fecho a transição é

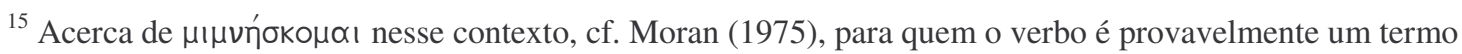
técnico dos bardos com o sentido de "eu lembrarei-cantarei" (cf. ainda Richardson (1974), 325, e Simondon (1982)). Para outros exemplos nos hinos gregos, cf. Keyssner (1932), 14. Sobre a natureza convencional da forma futura ("futuro encomiástico"), cf. Slater (1969b) e Faraone (1995). Convencional

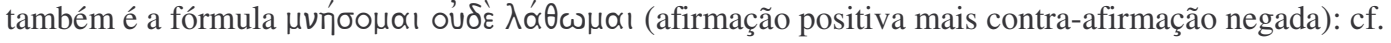
Humbach (1959) e a coletânea de exemplos em Tzamali (1997).

${ }^{16}$ Cf. Norden (1913), 168-76.
} 


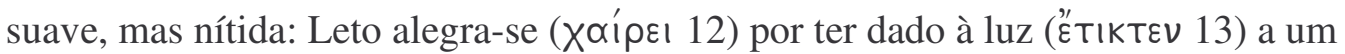
poderoso filho arqueiro; eu te saúdo ( $\chi \propto$ îp 14 ), diz o poeta, ó Leto, porque deste à luz

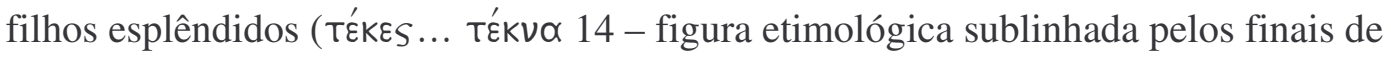

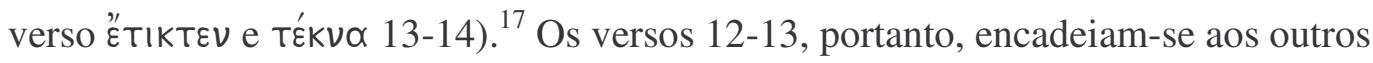
cinco que sucedem (14-18) - bloco de versos este bem-burilado e que conclui a cena olímpica (1-18), antes da quebra na narrativa que ocorre com a pergunta aporética do

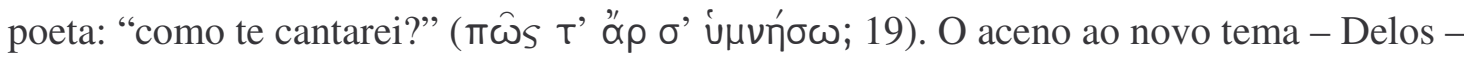
resulta aqui de paralelismos formais. São cinco versos, cinco frases, no exato centro das quais a ilha de Delos sobressai: ${ }^{18}$

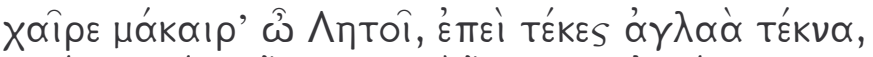

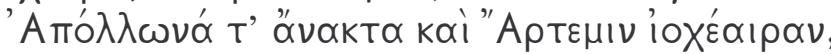

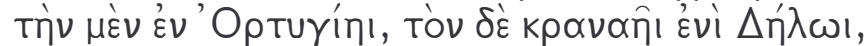

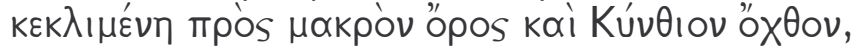

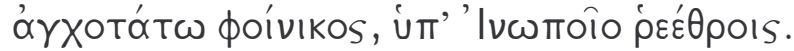

'Salve, ó bem-aventurada Leto, pois deste à luz filhos esplêndidos, o senhor Apolo e Ártemis que empunha as flechas: ela em Ortígia, ele na rochosa Delos, apoiada na longa eminência do Cintos, junto à palmeira, sob as correntes do Ínopos.'

Versos 15 e 16 figuram em ordem quiástica: as referências a Apolo e Delos emolduram as alusões a Ártemis e Ortígia; ${ }^{19}$ a marcada cesura masculina no verso 16, acrescida do

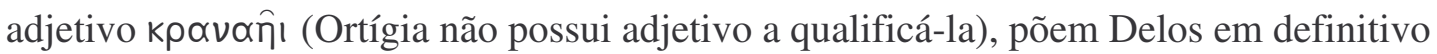
destaque, tanto mais sublinhado pela hendíadis do verso seguinte - dois termos ( $\mu \propto \alpha$ kòv

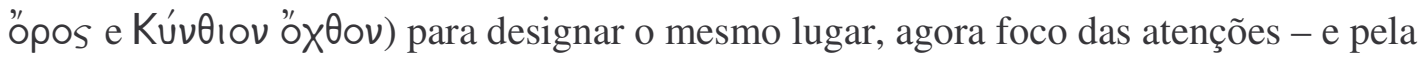
precisão topográfica do último verso. A narrativa nos trouxe, de forma sutil mas firme, do Olimpo a Delos, num movimento de aproximação que se repetirá posteriormente, agindo tanto como tema geral do hino quanto como encaixe entre as partes. Que este seja de fato um movimento desejado pelo autor é comprovado pela interrupção da narrativa no verso 19, com uma pergunta aporética ${ }^{20}$ que fecha um ciclo e abre outro.

\footnotetext{
${ }^{17}$ Cf. Forderer (1971), 64.

${ }^{18}$ Ibid., 65.

${ }^{19}$ Miller (1986), 18, afirma que Ártemis e Ortígia servem de contraste para Apolo e Delos: “[...] the focus widens momentarily only to be narrowed again with greater precision".

${ }^{20}$ Para uma análise detalhada do modo aporético no gênero hínico, ver Bundy (1972), 57-77.
} 


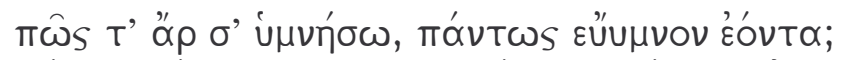

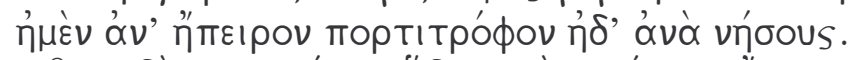

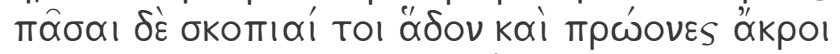

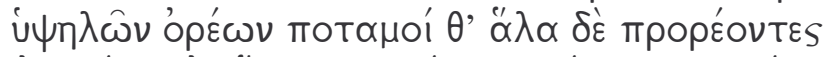

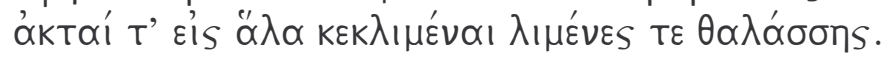

'Como te cantarei, tão celebrado que és em canto em todos os aspectos? Pois por toda a parte, Febo, estende-se o campo para a tua canção, tanto no continente que cria novilhos quanto nas ilhas. Todos os picos te agradam, e as cristas superiores das altas montanhas e os rios que correm para o mar, e os promontórios que se inclinam para as águas e os portos costeiros.'

A aporia é explicada e amplificada nos versos seguintes. Como cantar-te, ó Apolo, se há cantos teus por toda a parte, no continente bem como nas ilhas? Continente e ilhas são um merismo, um modo de expressão polar ${ }^{21}$ com significado universalizante, mas não só isso. Da terra firme às ilhas inaugura-se um movimento retomado nos três versos seguintes (22-24), mas agora como sentido descendente, de cima para baixo ${ }^{22}$

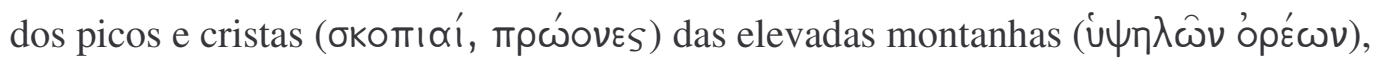

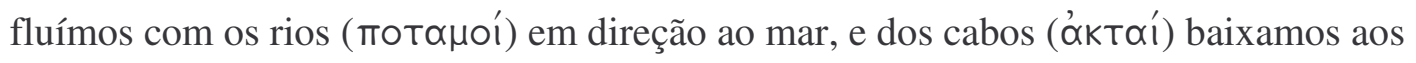
portos marítimos ( $\lambda_{\Perp} \mu \varepsilon^{\prime} v \varepsilon s$ $\left.\theta \alpha \lambda \propto \alpha \sigma \sigma \eta S\right)$. O relato ganha ritmo com o enjambement dos versos 22-23, onde do alto das montanhas somos conduzidos ao som de versos predominantemente dactílicos rumo ao mar que - após duas repetições, uma com a

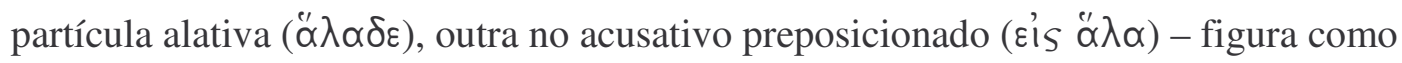
última palavra e ponto de chegada da frase ( $\left.\theta \alpha \lambda \alpha^{\prime} \sigma \sigma \eta s\right)$.

Tal como ocorrera na cena olímpica (1-18), quando fôramos baixados do Olimpo até Delos, aqui também repete-se o movimento, mas agora em outro contexto. Trata-se agora de um priamel, ${ }^{23}$ cujo objetivo é ressaltar, por contraste, o tema específico a que se propõe o poeta. Seu embarras de richesse traduz-se em termos geográficos, do alto das montanhas até o mar, para então fixar-se num ponto - a história do nascimento de Apolo. Que se dá, obviamente, em Delos, ilha cercada do mesmo mar que dá fecho ao verso 24.

\footnotetext{
${ }^{21}$ Sobre a expressão polar (ou merismo), na qual dois substantivos (A e B) numa relação de cópula servem para designar, juntos, um conceito superior (C), cf. Watkins (1995), 44ss. et passim.

${ }^{22}$ Cf. Roux (1964), 1-6.

${ }^{23}$ Sobre o priamel em geral, ver Race (1982b). Acerca dos propósitos do poeta ao dramatizar o processo de decisão poética, cf. Miller (1979), 185s., e (1986), 27. Cf. ainda Bundy (1972), 63.
} 
...

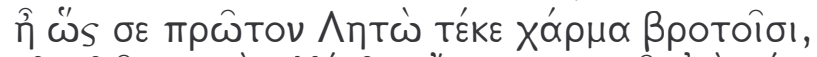

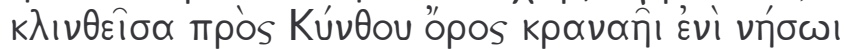

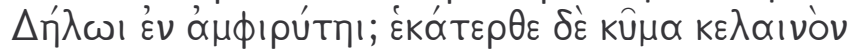

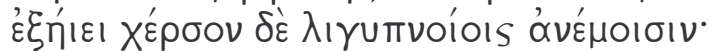

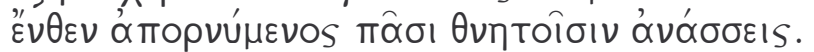

'... e os portos costeiros. Ou então como primeiro Leto te deu à luz para deleite dos mortais, inclinada contra o monte Cintos em uma ilha rochosa, Delos cercada pelo mar, enquanto de ambos os lados as ondas escuras chegavam às praias sob os ventos penetrantes? De lá partindo, tu reinas sobre todos os mortais.'

De todas as ilhas onde se oferece campo aberto a seu canto (ơvờ víoous 21),

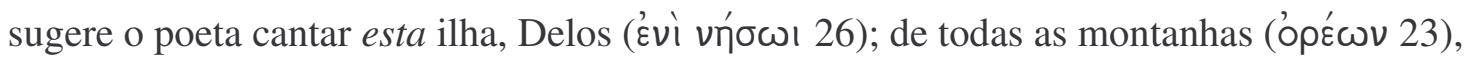

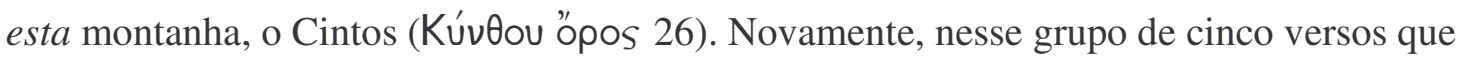
faz eco aos versos 14-18, Delos figura no centro, agora encabeçando o hexâmetro

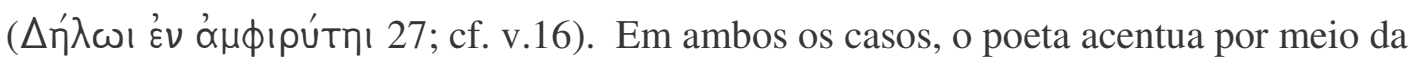
forma o posto de destaque conferido à ilha, ao término de dois movimentos que levam do

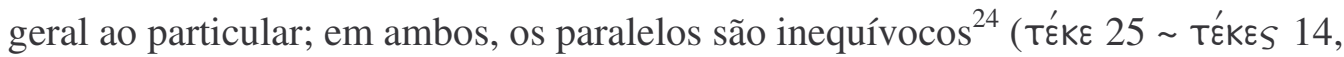

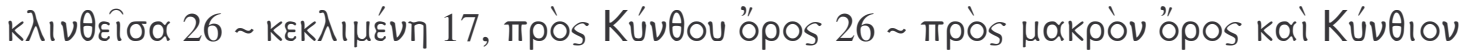

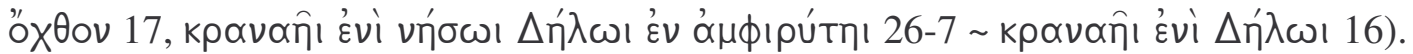
Assim são encadeadas as duas seções do relato, tal como se havia encadeado, no interior de uma mesma seção (1-18), começo e fim da narrativa (1-13/14-18), como sugeri acima.

Ao final do verso 29, portanto, após um duplo movimento que posiciona Delos no centro temático e formal da narrativa, parece que afinal estamos prontos para o relato do nascimento de Apolo a que se propusera o autor. Somos frustrados, todavia, por uma aparente digressão em forma de catálogo, no qual são arrolados, à primeira vista, as ilhas, cidades e regiões sobre as quais Apolo mantém domínio. Partindo de Delos, para onde acabáramos de ser conduzidos, Apolo reina (assim nos informa o poeta), sobre todos os mortais quantos Creta contém dentro de si e a terra de Atenas e a ilha de Egina etc. (

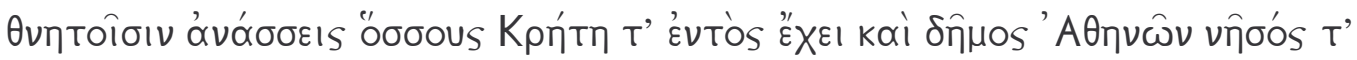
Airívi... 29-31). Mas trata-se na verdade de um trompe-l'œil sintático. Ao cabo de quinze versos, descobrimos que o relativo öбøous (29) correlaciona-se com o tóøбov do

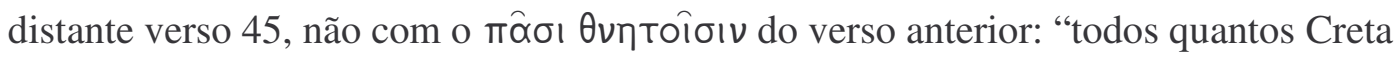

${ }^{24}$ Cf. Miller (1986), 28s. e Forderer (1971), 66. 
contém dentro de si e a terra de Atenas e a ilha de Egina... tanto foi quanto Leto percorreu

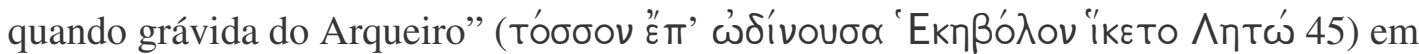
sua busca por um local onde dar à luz, até finalente pôr os pés em Delos. ${ }^{25}$

Ou seja, longe de ser uma digressão que desvia o foco da ilha, o catálogo nela faz incidir as atenções - já pela terceira vez no hino - mediante um truque de $\operatorname{sintaxe}^{26}$ e pela meticulosa construção dos seus elementos constituintes. É que, a despeito dos ziguezagues, o movimento geral deixa-se entrever com facilidade. ${ }^{27}$ Partindo de Creta ao sul e seguindo no rumo norte pelo desvio do oeste, os versos 31-36 descrevem um trajeto em semi-círculo. Dali tornamos ao sul pelo desvio do leste, onde o círculo quase se fecha em Cárpatos (43), para então, num último salto, irmos de Naxos a Paros e a Renéia ${ }^{28}$ - ilha contígua a Delos, dedicada a Apolo por Polícrates com grande aparato, unindo-as com

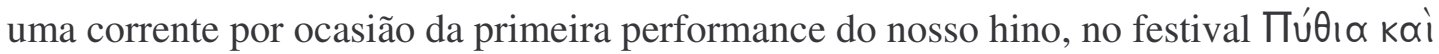
$\Delta \eta \dot{\lambda} \wedge \alpha$.

Também a ordem da localidades obedece a uma simetria quase perfeita: ${ }^{29}$ são cinco os grupos de três versos $(30-32,33-35,36-8,39-41,42-44)$, cada qual com um número fixo de locais mencionados. Em geral duas a três localidades são referidas em cada verso, sendo a única exceção o grupo central, cujos versos 37 e 38 descrevem respectivamente um único sítio geográfico (Lesbos e Quios). Tal grupo central é flanquado por dois outros cujos versos assemelham-se em suas partes finais.

Importa-nos aqui observar que o catálogo, além de servir ao claro propósito de concentrar pela terceira e última vez as atenções do público em Delos, antes da narrativa do nascimento e infância de Apolo, atrai também a atenção sobre si próprio - mediante a sua rebuscada articulação interna - como bloco articulador essencial da narrativa. Isso se torna claro quando, ao fim do relato do nascimento e da infância de Apolo, outro catálogo

\footnotetext{
${ }^{25}$ Ao leitor, a ambigüidade da frase é anulada pelo ponto final ao termo do verso 29; ao ouvinte, só lhe dado compreender a frase nesse segundo sentido após escutar o verso 45. Até ali, é natural supor que

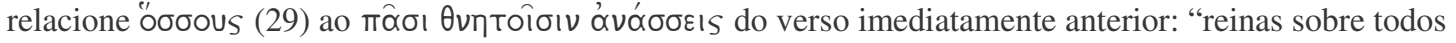
os mortais quantos...".

${ }^{26}$ Miller (1986), 39, n.79, comenta que "this passage has posed problems to editors and commentators precisely because it makes good syntactical and rhetorical sense construed in either direction". ${ }^{27}$ Cf. Forderer (1971), 70s., Förstel (1979), 110, e Wilamowitz (1916), 444-6.

${ }^{28}$ A pequena ilha ganha especial relevância por figurar ao cabo do elaborado catálogo. Infundada, portanto, a hesitação de Bowie (1985), 242, sobre a sugestão de Janko a respeito da ocasião original da performance do nosso hino: "[...] one might have expected more prominence of Rheneia than a single reference in a list at verse 44".

${ }^{29}$ Cf. Baltes (1982), 25-28, para uma discussão em detalhes, e Miller (1986), 34.
} 
(140-146) atua como fecho da narrativa e ao mesmo tempo como introdução às

festividades na ilha descritas pelo poeta.

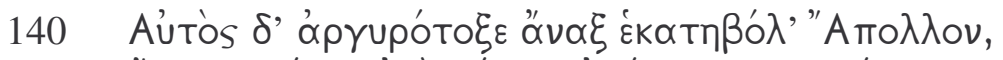

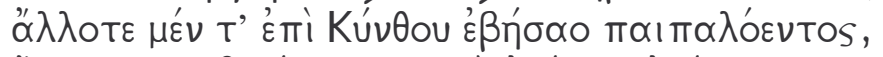

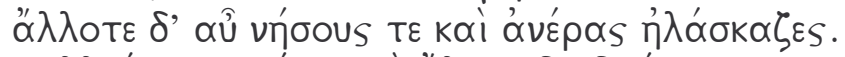

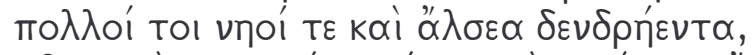

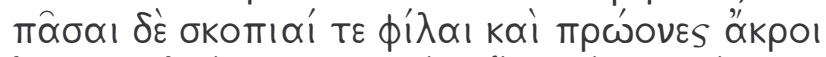

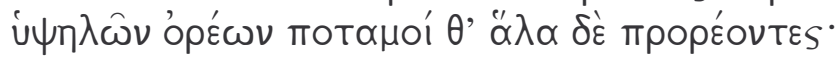

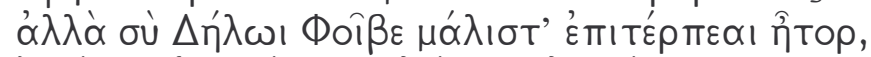

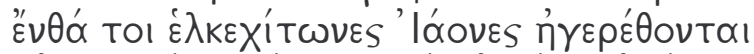

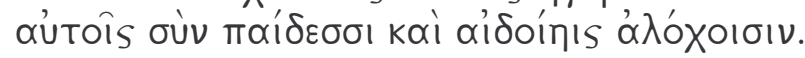

'Tu mesmo, senhor do arco de prata, deus que atira longe, caminhavas por vezes pelo escarpado Cintos, por vezes tu vagavas pelas ilhas e por entre os homens. Muitos são os teus templos e bosques cobertos de árvores, e todos os picos te são caros e as cristas superiores das altas montanhas e os rios que correm para o mar, mas é em Delos que tu, Febo, mais deleita-te no teu coração, onde os jônios com túnicas que se arrastam reúnemse com os seus filhos e as suas nobres esposas.'

Após saborear comida divina, néctar e ambrosia, Apolo livra-se dos cordões dourados que lhe tolhem os movimentos e começa a andar sobre a terra, ao que Delos cobre-se de ouro à vista do deus (124-139). Mais uma vez, a exemplo do que ocorrera no verso 29, Apolo parece pronto a ganhar o mundo; o catálogo, porém, torna a fechar o

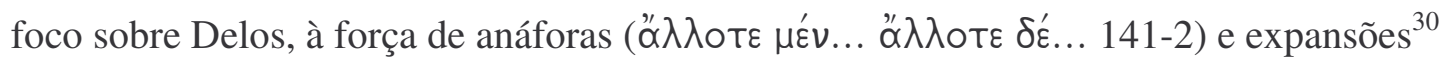

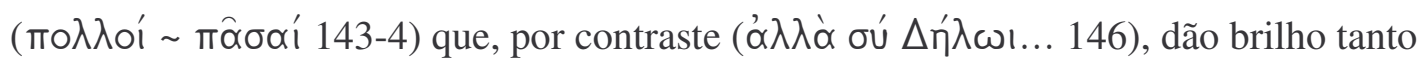
maior ao local das festividades - das quais o hino faz parte - descritas nos versos 147176. Somos trazidos ao momento presente em etapas progressivas, do aoristo घ́ (141) passando pelo imperfeito $\eta^{\lambda} \lambda \alpha_{\sigma} \sigma \alpha \zeta \varepsilon S$ (142) e por uma frase nominal (143-5) sem

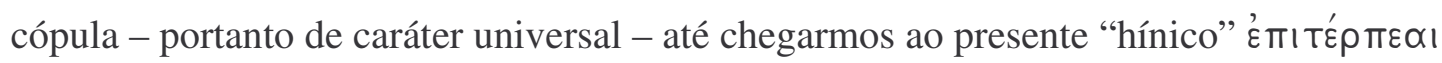
$(146){ }^{31}$

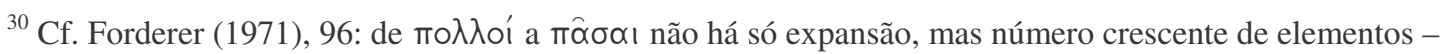
"erst ein Vers mit zwei, dann zwei Verse mit drei Subjekten".

${ }^{31}$ Groningen (1948), 308: "[...] les formes des verbes sont tour à tour à l'aoriste, à l'imparfait, au présent". Cf. Miller (1979), 183, n.37, e Vamvouri (2004), 87s.: "En décrétant son arrivée au présent, le locuteur introduit Apollon dans l'espace et le temps de son énonciation. C'est comme si le chant avait progressivement entraîné l'arrivée du dieu dans le lieu même où les Ioniens étaient rassemblés". Sobre a natureza universal da frase nominal, cf. Benveniste (1966); contra, Kahn (1973), 435-52.
} 
Outro breve catálogo (179-81) remata, por sua vez, a narrativa do festival em Delos, formando mais uma moldura que lhe confere saliência tanto maior na sequiência do relato.

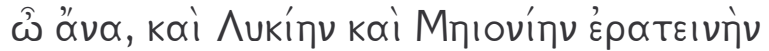

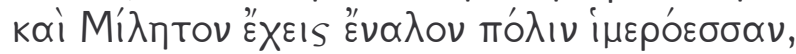

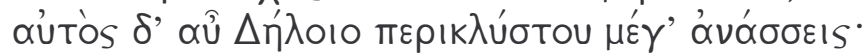

'Ó senhor, a Lícia também é tua, e a adorável Lídia, e Miletos, adorável cidade costeira; e tu mesmo, ninguém mais, reinas soberano sobre Delos banhada pelo mar.'

Da Lícia à Meônia, duas regiões respectivamente a sudeste e nordeste de Delos ${ }^{32}$ e que partilham o mesmo verso, segue-se para Miletos, cidade localizada entre as duas regiões e que preenche o hexâmetro inteiro, para então fechar-se novamente o foco sobre Delos no verso seguinte, marcado pela expressão enfática oưừs $\delta^{\prime} \varepsilon$ (em posição métrica de destaque) que faz eco à mesma construção que abre o catálogo anterior (140), com a abrupta interpelação de Apolo. Mas este segundo catálogo, que com o primeiro emoldura as festividades délicas, não cumpre apenas a função de salientar a narrativa que encerra;

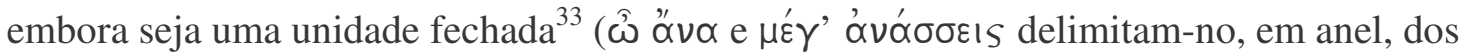
versos adjacentes), ele forma com os versos 177-8 uma unidade maior. Estes últimos representam uma ruptura com a narrativa anterior: o poeta despede-se das delíades

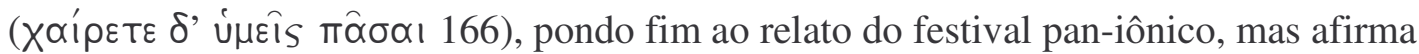
que continuará cantando Apolo. ${ }^{34} \mathrm{E}$ de fato o faz, $\log$ após o breve catálogo que põe termo às celebrações em Delos, a fim de relatar a sua ascensão ao Olimpo passando por

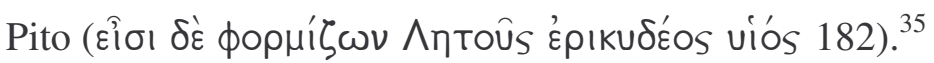

Notamos assim que as duas principais narrativas que têm Delos como palco - o nascimento e infância de Apolo e as celebrações por ocasião do festival pan-iônico - são ladeadas por três molduras em forma de catálogo geográfico, que as delimitam e lhes dão destaque:

\footnotetext{
${ }^{32}$ Forderer (1971), 111.

${ }^{33}$ Ibid., 112.

${ }^{34}$ Acerca da controvérsia sobre o sentido desses versos, cf. Miller (1979).

${ }^{35}$ Sobre os paralelos entre os versos 140-45 e 179-87, ver Heubeck (1972), 141.
} 
. moldura (30-46)

. nascimento e infância de Apolo (47-139)

. moldura (140-146)

. festival (147-176)

. moldura (177-181)

Cada uma das molduras, de modos diversos, afunila as atenções para Delos, e o mesmo movimento de aproximação reflete-se ainda nas duas narrativas que elas abarcam: da Delos do passado mítico (47-139) a platéia é conduzida à Delos do presente (147-76), onde o próprio hino é recitado como parte das festividades por ele descritas. ${ }^{36}$

Mas o zelo do poeta em construir uma estrutura clara embora fluente não pára por aí. Ao último catálogo que emoldura a narrativa délica segue-se a ascensão de Apolo ao Olimpo. Da Lícia a Miletos, passando pela Meônia, chega-se num tricólon crescente (179-80) a Delos, verso final da seção. Mas Delos é também o primeiro membro na seqüência que leva até o Olimpo, passando por Pito - igualmente num tricólon crescente; a Delos dedica-se um verso (181), a Pito quatro (182-85), ao Olimpo vinte e um (186206). ${ }^{37}$ Duas seções são assim encadeadas, e esta última, uma cena no Olimpo, serve de contraponto à cena olímpica que abre o hino (1-18). Na primeira, Apolo e seu arco foram o tema; agora, Apolo e a sua lira, cujos sons fazem os deuses devotarem-se à música e incitam as Musas ao canto, pondo as Graças, as Horas, Harmonia, Hebe e Afrodite a dançarem. Cumpre-se portanto, em ordem inversa, os votos de Apolo para que lhe sejam

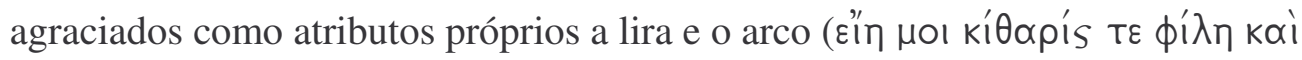

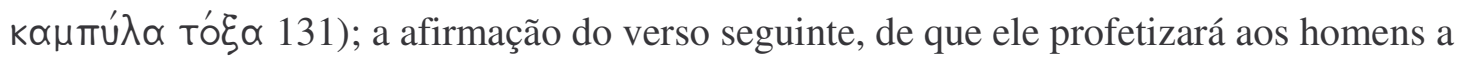

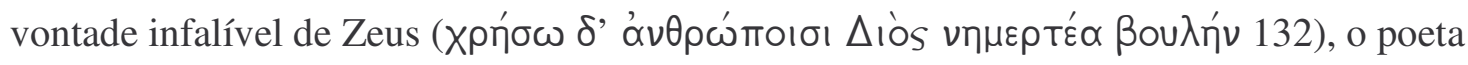
irá desdobrá-la na segunda parte do hino - a seção pítica (216-546). Entre o fim da segunda cena olímpica, porém, e o início dessa seção pítica, o poeta abre espaço para outra pergunta retórica (207-215), em tom aporético muito próximo aos dos versos 19-29, cujo propósito agora é servir de priamel para a narrativa pítica que lhe segue.

Expandindo o esquema estrutural do hino délico proposto acima, observamos que as próprias molduras são emolduradas por duas seções paralelas:

\footnotetext{
${ }^{36}$ Fantuzzi e Hunter (2004), 363, observam corretamente que "the description of parts of the ritual with which the song is associated, a description which often involves reflexive self-reference by the singers, is one of the most persistent features of Greek cultic song”. Cf. ainda Nagy (1990), 53ss.

${ }^{37}$ Kakridis (1937), 107.
} 


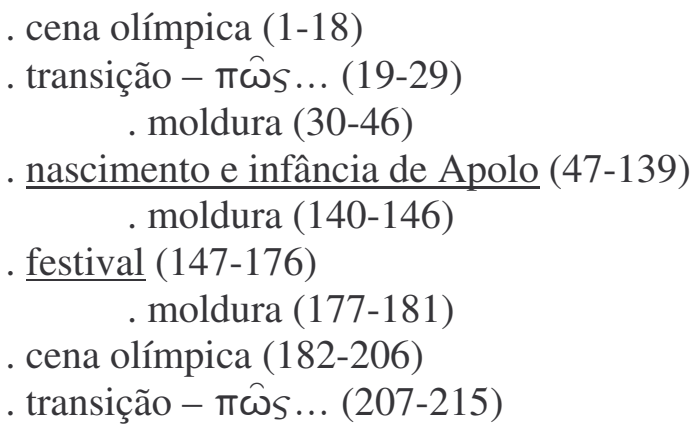

Não se trata de compartimentos estanques; como vimos a respeito das duas primeiras seções, o poeta esforça-se por encadeá-las, e o mesmo se dá com relação às demais, a fim de gerar significado por meio da comparação e contraposição. A segunda cena olímpica, por exemplo, não se contrapõe somente à primeira cena olímpica, mas ao próprio festival celebrado em Delos: ${ }^{38}$ em ambos os casos trata-se de uma festa na qual um coro de donzelas dança e canta ao som de música (157-61, 164 189-99); em ambos a dança se dá diante de pessoas/deuses reunidos (147 187), que dela tiram prazer $(146,153-5,161$ 204-6). Aliás, o hiato que separa homens e deuses (190-93) parece ser abreviado só mesmo em ocasiões como o festival em Delos (151-2), onde a ambos é dado celebrarem juntos.

Outro fator que empresta especial relevo à descrição do festival em Delos é o fato de ela poder ser destacada da narrativa geral, de constituir como que um intervalo entre o final da infância de Apolo, quando o deus se prepara para ganhar o mundo após ingerir néctar e ambrosia (127-39), e a sua efetiva ascensão ao Olimpo (182-206). ${ }^{39}$ Plenamente articulado à narrativa, em parte graças às molduras que nela o inserem, tal intervalo (14081) sobressai por obra das próprias molduras que lhe dão destaque.

Composição de estrutura complexa, na qual a clara delimitação das partes é usada ao mesmo tempo em benefício do encadeamento entre elas - seja ele próximo ou a distância, por contraste ou identidade -, o Hino Homérico a Apolo, em sua seção délica, permite reconhecer simultaneamente duas estratégias retóricas comuns a vários hinos gregos. De um lado, o esforço de atrair o deus para o instante presente do culto, e fazê-lo através de elementos formais habilmente laborados pelo poeta. De outro, o artifício - esse

\footnotetext{
${ }^{38}$ Ibid., 104ss.; Forderer (1971), 127s.; Heubeck (1972), 143s.

${ }^{39}$ Baltes (1982), 29, designa os versos intervalares 140-181 de "Delosverherrlichung".
} 
já mais raro - de situar em seu centro o núcleo da mensagem, para assim lhe conferir relevo. Em várias etapas, como tentamos mostrar, o poeta do nosso hino acerca-se progressivamente de Delos, com o intuito de louvar Apolo em duas narrativas consecutivas, a do seu nascimento ali ocorrido e a do festival celebrado em seu louvor. Entre as duas, passa-se da Delos mítica à Delos do presente, onde, em meio a honras cultuais de que o nosso próprio hino faz parte, as delíades entoam um hino a Apolo (158) e onde o deus, agora presente (146), alegra-se de pleno coração à vista das celebrações conjuntas que o unem aos seus devotos.

Delos e Apolo estão duplamente presentes nas narrativas centrais, flanqueadas por molduras que ecoam uma a outra, no foco temático e formal do hino. Uma vez atraído o deus para perto, uma vez posicionado no centro do relato, o poeta permite-se expandir a narrativa ao tema tradicional da recepção do deus no Olimpo. Começo e fim do hino são marcados pelo advento de Apolo na morada de Zeus; no seu centro, Apolo mistura-se aos homens na terra.

\subsubsection{Sófocles, Antígone (1115-1154)}

Esse movimento, do universal para o particular, do atemporal para o hic et nunc do culto também caracteriza, sob outra perspectiva, outro hino de grande refinamento, o hino a Dioniso que compõe o quinto estásimo da Antígone de Sófocles. Creonte, após ser duramente repreendido por Tirésias, acaba de sair de cena com o firme propósito de desfazer a injustiça cometida ao impedir o sepultamento de Polinice e ao pôr Antígone a ferros. É nesse ponto que o coro entoa uma ode a Dioniso:

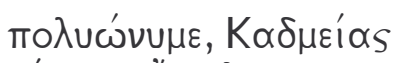

$$
\begin{aligned}
& v \cup ́ \mu \phi \alpha s \text { "ै } \gamma \alpha \lambda \mu \alpha
\end{aligned}
$$

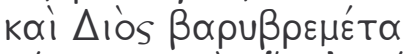

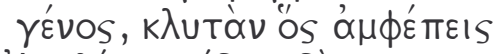

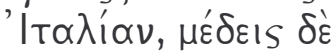

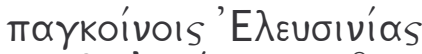

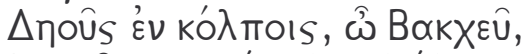

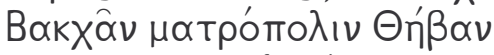

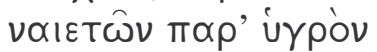

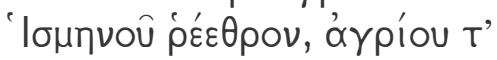

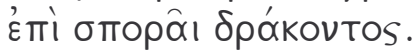




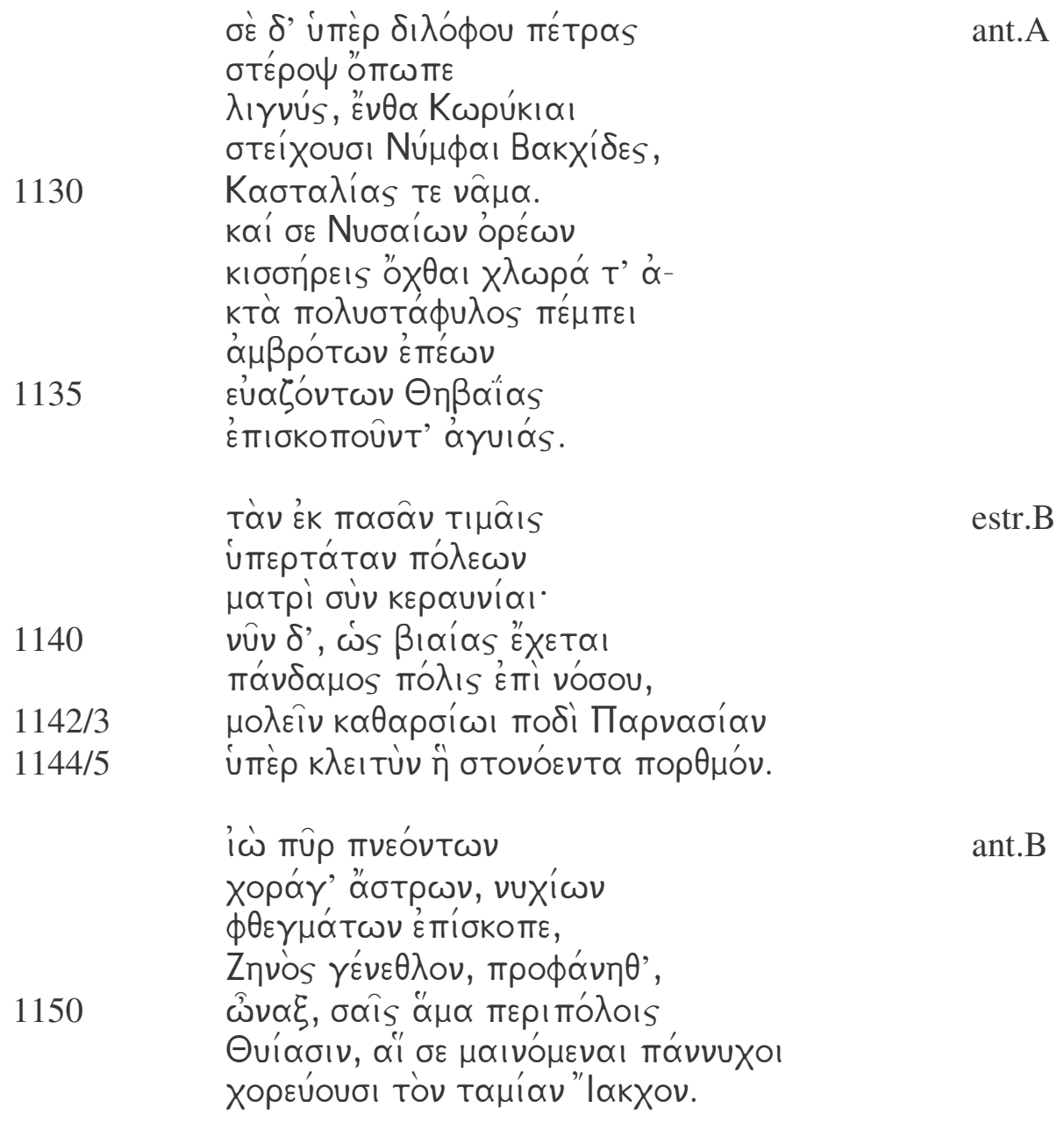

(Tu de muitos nomes, glória da noiva cadméia e gerado por Zeus que troveja fundo, tu que abraças a famosa Itália bem como imperas sobre os hospitaleiros recessos da eleusínia Deo, ó Baco, morando em Tebas, cidade mãe das bacantes, junto às fluidas correntes do Ismeno e sobre a semente do dragão agreste; /

tu foste visto ainda pela chama fumarenta sobre a rocha de crista dupla, onde as báquicas ninfas corícias executam seus passos, e pela torrente da Castália. E tu és escoltado pelas encostas cobertas de hera do monte Nisa e pelo verde litoral de muitas vinhas para zelares pelas avenidas tebanas que ecoam com versos imortais aos brados de "evoé!"; /

a Tebas, que das cidades é a que tu honras acima de todas, junto com tua mãe visitada pelo raio. Mas agora, como todo o povo da cidade está nas garras de uma violenta enfermidade, vem com pé catártico do alto do Parnaso ou através do estreito ressonante; / eia, corego das estrelas que respiram fogo, guardião dos gritos noturnos, rebento de Zeus, aparece, ó senhor, com teu séqüito de tíades que, em transe, dançam a noite inteira em tua honra, Íaco dispensador.)

Do diálogo que o precede, o hino mantém o alto grau de tensão emotiva e a verte na devotada esperança de que, com a vinda de Dioniso, a catástrofe que se anuncia seja 
afinal evitada. $\mathrm{O}$ artifício do poeta está em fazer com que a universalidade do poder de Dioniso, tal como se revela nos seus vários sítios de devoção, aflua a um ponto comum, Tebas, onde transparece a essência cósmica da divindade num único local - a sua cidade predileta.

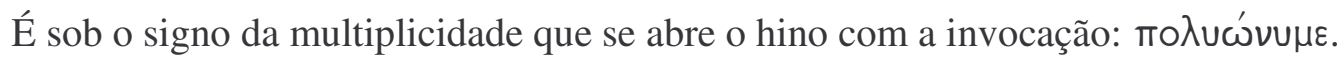
Mas o que vem em seguida está longe de ser uma sucessão de epítetos, como por exemplo no peã de Filodamo a Dioniso, que começa com um chorrilho de epítetos e títulos cultuais: "Ditirambo, Baco evoé, Touro cingido de coroa de heras, Bramador"

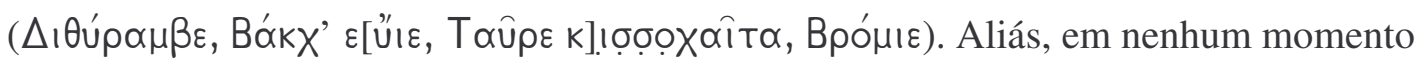
Dioniso é interpelado ou referido pelo nome; o que interessa é divulgar a abrangência geográfica do seu poder. Após breve menção genealógica dos pais, Sêmele e Zeus, ${ }^{40}$ segue-se um catálogo dos locais que o deus mantém sob a sua autoridade (Itália, Elêusis, Tebas), numa seqüência ascendente que culmina na cidade natal do coro. ${ }^{41}$ Nesse crescendo, que constitui um recurso retórico bastante difundido nos epinícios de Píndaro, ${ }^{42}$ a importância dos seus elementos constitutivos reflete-se no tamanho que cada um ocupa na estrofe. O primeiro, relativo à Itália, soma apenas dez sílabas, e um único adjetivo ( $\left(\lambda \lambda_{u} \tau^{\prime} v\right)$ qualifica a localidade, a mais afastada de Tebas. Já Elêusis, mais

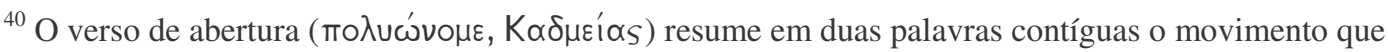
ditará o curso de todo o hino: do múltiplo para o específico, dos muitos nomes para um nome só, Cadmo,

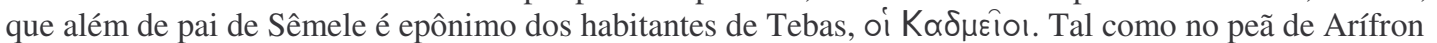

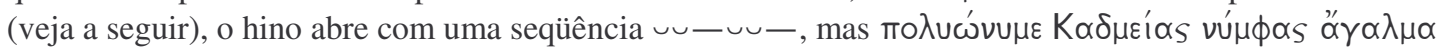
é, de acordo com Dale (1968), 191 n.3, 'a dicolon $\cup \cup-\cup \cup-\ddot{-}-|=| \_\cup-l v$ in which one double-short has contracted to accommodate the proper name'. Assim, $K \alpha \delta \mu \varepsilon i \alpha_{S}$ recebe, pode-se dizer, ênfase

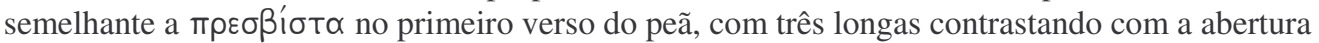
anapéstica.

${ }^{41}$ Várias conjeturas foram avançadas para corrigir' ${ }^{\prime} \alpha \alpha \lambda i ́ \alpha v$ (1119). Dawe (1978), 116, declara-se surpreso que "Italy should be named alongside Thebes (1115), Eleusis (1120), Thebes again (1122), the river Ismenus (1124), a cave on Mt. Parnassus (1127), a stream at Delphi (1130), Nysa in Euboea (1131), and lastly Thebes again (1135)". Ele sugere então O'ix $\propto \lambda \lambda_{i} \propto \nu$, argumentando que "since Euboean sites are only mentioned once in the list, that area ought perhaps to be strengthened". No que segue, procuro explicar a razão pela qual os nomes das localidades aparecem nessa ordem específica, e não em outra. Veja também Henrichs (1990), 268, para uma discussão a respeito e Förstel (1979), 396 n.394, para quem a descrição "ganha autonomia" no meio do catálogo: "Nachdem in der konventionellen Form der relativischen Anknüpfung Dionysos Walter über Italien, Gebieter von Eleusis und Bewohner von Theben genannt ist, verselbstständig sich die Darstellung, und es werden die Höhe des Parnaß und die nysäischen Berge als die vom Gott bevorzugten Orte backischer Feiern andeutend beschrieben".

${ }^{42}$ Cf. Race (1990), 9-40. Exemplo de aproximação geográfica expressa com membros crescentes: ^úkı\&

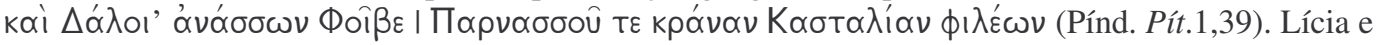
Delos, centros cultuais de Apolo, articulam o crescendo que culmina no monte Parnaso (Delfos), onde se concentra o interesse do poeta que, não por acaso, celebra uma vitória pítica.
} 
próxima, espalha-se por dezesseis sílabas com densidade algo maior, não só por conter o nome de uma deusa (Deo), mas pelo epíteto que sugere escopo mais amplo ( $\pi \propto \gamma$ koívols). Chegamos então finalmente a Tebas, que inunda com as suas 29 sílabas quatro versos inteiros, não sem antes passar por uma sutil transição que aproxima de vez o deus e a sua cidade. Entre Elêusis e Tebas o coro insere no final do verso o vocativo $\omega$ '

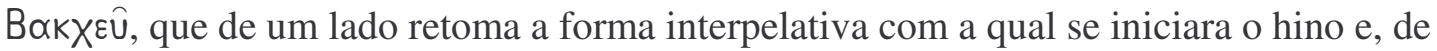
outro, atrela a epiclese divina ao nome daquelas que o celebram, cuja cidade-mãe é Tebas.

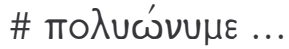

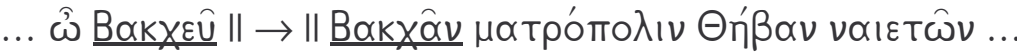

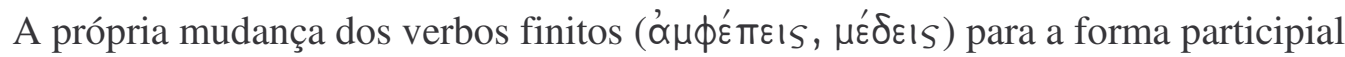
( $v \propto ı \tau T \hat{v} v)$ trai a maior proximidade do deus: ele ampara a Itália, governa Elêusis, mas é morando em Tebas que o faz, onde se acha realmente em casa. ${ }^{43}$

$\mathrm{Na}$ antístrofe $\mathrm{A}$, mais uma vez nos deparamos com o fluxo que conduz de outras localidades ao centro da ação dramática em Tebas. Agora, porém, o contraste não é entre longe e perto, e sim entre alto e baixo. Do alto do santuário de Delfos, assinalado pelas Fedríades (a rocha de crista dupla) e pela gruta corícia, rumamos montanha abaixo ao longo da torrente que brota da fonte Castália. E do alto do monte Nisa descemos as suas encostas até o litoral da Eubéia, repleto de vinhas, que escolta o deus para o seu destino final, as avenidas tebanas. Ambas as localidades, Delfos e Eubéia, denunciam a presença divina em seus sítios naturais, seja pelas ninfas báquicas a dançarem na montanha, seja pela hera que recobre as encostas e a vinha do litoral - uma e outra atributos de Dioniso. Mas é em Tebas que o deus assume postura ativa, como alguém que zela pelas avenidas que ecoam com a poesia imortal e os seus gritos festivos. Até então ele fora simples objeto: a chama fumarenta é que o vê, e também as águas da fonte Castália; são as encostas do monte Nisa que o escoltam, e também o litoral eubeu. A intervalos regulares, em destaque no verso, o deus é referido no acusativo:

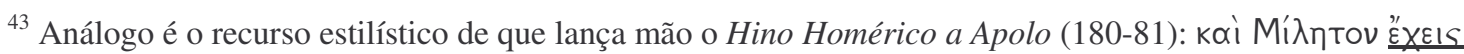

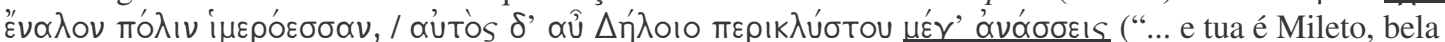
cidade junto ao mar, mas tu próprio, ninguém mais, é senhor supremo de Delos cercada pelas ondas").
} 

$1126 \sigma \dot{\varepsilon} \delta^{\prime} \varepsilon_{\ldots}$.
1131 kơi $\sigma \varepsilon . .$.

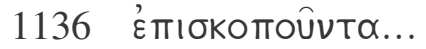

Nos dois primeiros casos, ele sofre a ação externa; no terceiro, embora objeto, o deus é simultaneamente sujeito de outra ação, cujo objeto não é outro senão Tebas. Antes ele fora visto (ö $\pi \omega \pi \varepsilon)$ por chama e torrente; agora é escoltado a Tebas para inspecionar

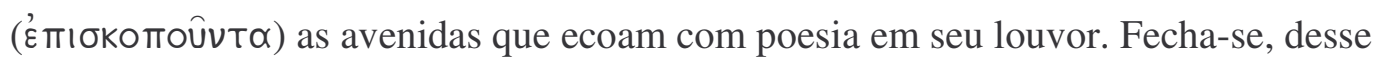
modo, o círculo descrito por estrofe e antístrofe: todos os caminhos levam a Tebas, seja no plano horizontal da estrofe (da Itália a Tebas passando por Elêusis), seja no plano vertical da antístrofe (de Delfos a Tebas passando pelo Nisa eubeu e o seu litoral). Uma e outra adotam progresso semelhante, do distante rumo ao próximo, e em Tebas atingem o seu destino. Após a repetição do esquema, Tebas assume de vez o foco das atenções, a começar pelo pronome anafórico em destaque (\#Tó́v... 1137) que inaugura a estrofe B.

Sófocles esmera-se em soldar as três primeiras estrofes, embora deixe entrever ao mesmo tempo a excitação do coro tal como refletida na sintaxe: a primeira estrofe, preenchida pela invocação, é conduzida adiante no início da antístrofe por uma partícula anacolútica $\delta^{\prime} \varepsilon$ e por um pronome relativo ${ }^{44}$ à testa da segunda estrofe; a falta de uma

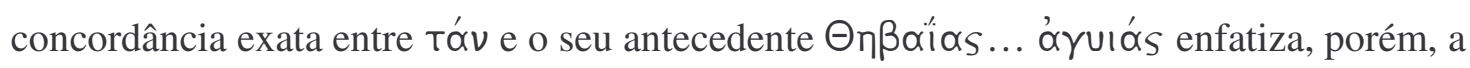
quebra ${ }^{45}$ sublinhando o que segue. Agora já não é mais necessário o contraste oferecido pelas demais localidades; Tebas, diz o coro, é a cidade que Dioniso mais honra na companhia de sua mãe. Todo o caminho percorrido até ali conduz naturalmente a convergir o foco para o hic et nunc do pedido ( $\left.\nu \hat{\cup} \nu \delta^{\prime} \varepsilon_{\ldots} . .1140 \mu \mathrm{o} \lambda \varepsilon_{\hat{i}} \nu 1142\right){ }^{46}$ que Dioniso venha com pé catártico, ou seja, com passos de dança - como sugere Scullion ${ }^{47}$ para libertar a cidade, cujo total desamparo, sob as garras de uma enfermidade violenta, é

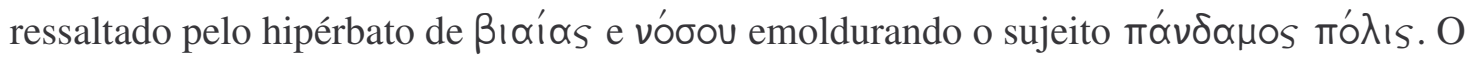

\footnotetext{
${ }^{44}$ Ver Kranz (1933), 178: "so reißt die Erregung [...] über die Strophenabsätze hinweg, freilich so, daß die Gedankengliederung immer ganz durchsichtig bleibt”.

${ }^{45}$ Taragna (1979) 136.

${ }^{46}$ vÛv $\delta$ ' é a leitura de Lloyd-Jones e Wilson; os manuscritos trazem kåi vûv, cujo sentido é próximo, embora sublinhe a habitualidade das visitas de Dioniso a Tebas: pede-se a ele que "agora também" (como antes) venha à cidade. O texto corrigido quadra melhor numa frase de transição para o pedido propriamente dito, expresso num infinitivo jussivo com valor de imperativo ( $\mu \circ \lambda \varepsilon \hat{\imath} \nu)$. Cf. ainda Lloyd-Jones and Wilson

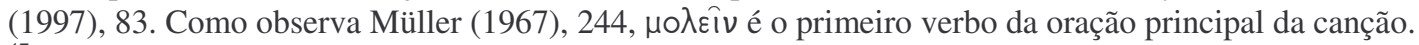

${ }^{47}$ Cf. Scullion (1998) sobre essa expressão, esp. 101-114. Acerca da dança em geral na Grécia Antiga, cf. Lonsdale (1993).
} 
nosos, segundo Scullion, é a "enfermidade cívica", 48 a luta política que dilacera a família real e acaba por minar todo o corpo de cidadãos. O poder de desatar próprio de Dioniso Báquico é amplamente atestado no contexto eleusínio e órfico, ${ }^{49}$ e Elêusis, de fato, figura

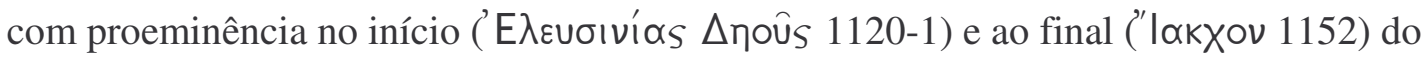
nosso hino - Íaco, lembre-se, é o nome de Dioniso em Elêusis. Diz-se que o seu pé é katharos, o que talvez endosse o vínculo etimológico com o sânscrito śithirá- "desatado, frouxo" que Martin Peters trouxe novamente à baila (uma hipótese que nem sequer é mencionada por Frisk ou Chantraine). ${ }^{50}$ Afora a prática de dança coribântica e dionisíaca como cura para desordens mentais referida por Scullion, ${ }^{51}$ a dança catártica ou dotada do poder de desatar a que o deus é chamado a pôr em prática talvez guarde também alguma relação com o fato de Antígone ser mantida no confinamento da sua cela rochosa e estar próxima - o público bem o sabe $e^{52}$ - do Hades, a divindade "que ata". ${ }^{53}$ Não é tanto que Sófocles esteja fazendo uma alusão à "resposta de Elêusis à mortalidade humana" a fim de acalentar as esperanças de Antígone, como Henrichs sugere ${ }^{54}$ antes, ele faz uso do mito, não do culto, para aumentar as expectativas do público, que assim ficaria tanto mais propenso a acreditar na pronta libertação de Antígone ao associá-la a Perséfone. ${ }^{55}$

Assim é que o deus é chamado a vir, com passos de dança, do alto do Parnaso ou através do estreito ressonante. Parnaso e estreito referem-se às localidades não-beócias mencionadas na antístrofe A (o Êuripos separa a Eubéia da Beócia). Essa referência dupla ladeia e abraça a dupla referência a Tebas feita no final da antístrofe e no começo da estrofe seguinte, num esquema quiástico ABBA:
A $\quad 1126-33$ (Delfos e Eubéia)
B $1134-6$ (Tebas)
B $\quad 1137-42$ (Tebas)
A $1143-5$ (Delfos e Eubéia)

\footnotetext{
${ }^{48}$ Sobre as várias acepções do termo nosos, cf. Lloyd (2003), 12 n.2, com referências. Para uma sugestão de nova etimologia da palavra, cf. Willi (2006).

${ }^{49}$ Cf. Krummen (1998), 309 n.32.

${ }^{50}$ Cf. Peters (1993), 95-101.

${ }^{51}$ Scullion (1998), 106-20.

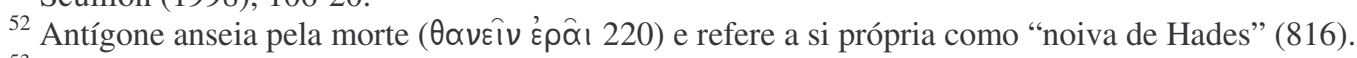

${ }^{53}$ Para a etimologia de Hades como "aquele que ata, amarra", cf. Janda (2000), esp. 114ss.

${ }^{54}$ Henrichs (1990), 267.

${ }^{55}$ Ver Seaford (1994), 381s.: "Perhaps [...] the invocation of Dionysos to come as the torch-bearing Iakchos of the mysteries implies an analogy between the joyful release of Antigone and of Kore, each from her dark bridal chamber in Hades".
} 
Tebas ocupa o centro da composição e, além de centro geográfico, é também centro temporal: é agora ( $\left.\nu \cup \hat{\nu} \delta \delta^{\prime}\right)$ que se pede a vinda do deus com a sua dança catártica à cidade para a qual ele é escoltado ( $\pi \varepsilon ́ \mu \pi \varepsilon$ 1133, presente de um verbo de ação, em

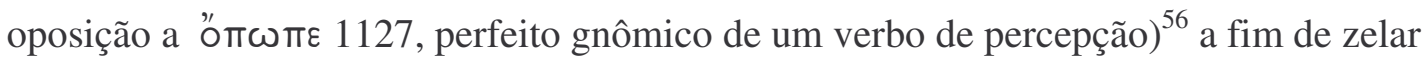
pelas avenidas que agora ecoam ao som da poesia imortal. Mas que poesia imortal seria essa? Não é preciso buscar muito longe: a poesia imortal outra não é senão aquela que entoa o coro nesse mesmo instante, isto é, o próprio hino cujos versos estamos ouvindo.

Tal expressão, versos imortais, é usada por Píndaro ao final da Pítica 4 (298-9) como uma forma de aludir a si mesmo e a este próprio epinício que celebra Arcésilas:

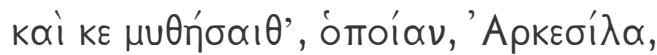

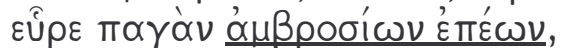

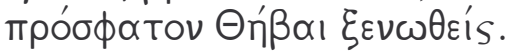

"E ele [Damófilo] contaria, Arcésilas, que fonte de versos de ambrosia encontrou ao ser recentemente entretido como hóspede em Tebas."

Todo o movimento até aqui foi na direção da cidade de Tebas (repete-se três vezes a palavra mó $\lambda_{\text {IS }}$ ao longo do hino, sempre com referência a Tebas e em três casos diversos: 1122, 1138 e 1141). Na antístrofe B inverte-se a tendência, agora sublinhada pela renovada interpelação direta encontrada no início, em um movimento circular. ${ }^{57} \mathrm{O}$ que era local assume ares cósmicos. As mesmas avenidas tebanas pelas quais o deus zela

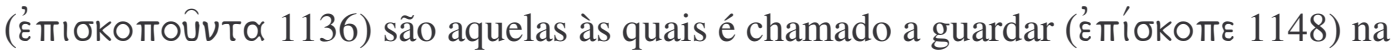
condição de corego das estrelas que respiram fogo (contrapartida divina das tochas utilizadas nos rituais dionisíacos). Há uma certa progressão do local para o universal

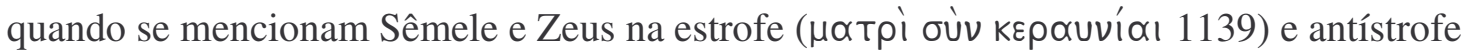

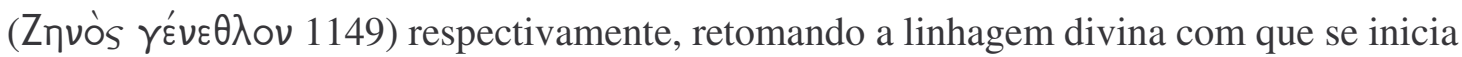

\footnotetext{
56 ”̋ perfeito gnômico: "hath (oft) seen thee". Cf. Taragna (1979), 134.

${ }^{57}$ Cf. Taragna (1979), 138, e Kranz (1933), 197: “[...] die gedankliche Gliederung des Chorliedes von zwei Strophenpaaren in die Form $\alpha \alpha^{\prime} \beta$ : $\beta$ ', also eine gewisse Zerteilung des zweiten Paares und die gedankliche Lösung der Antistrophe vom Vorangehenden, die sich davon durch Kontrastierung [...]

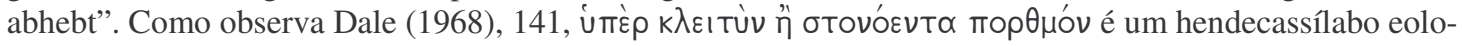

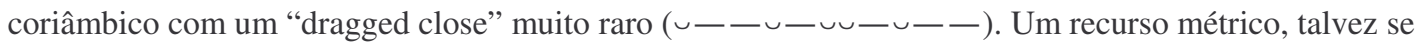
possa dizer, que focaliza a atenção na antístrofe que segue, de maneira análoga ao verso itifálico (7) do peã de Arífron (veja item 1.1.4).
} 
o hino. A noiva/ninfa tebana serve de signo da cidade, e Zeus, do cosmo. Mas os limites

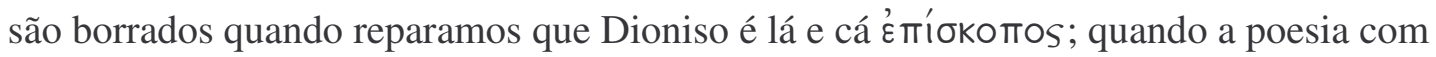
que ressoam as avenidas de Tebas é dita imortal; quando os gritos de "evoé!" lançados pelo coro simplesmente ao mencioná-los ( $\varepsilon \dot{u} \propto \zeta \zeta^{\prime} \nu T \omega \nu$ 1135) encontram paralelo nos

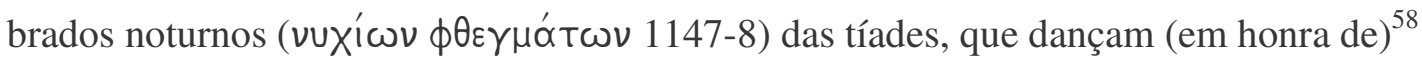

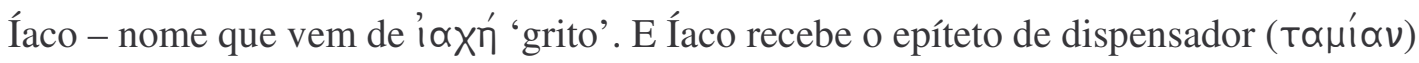
pelas suas virtudes salutares, cuja eficácia está intimamente ligada às atividades que o próprio coro desenvolve no momento: é pela dança, com o seu pé catártico, que o deus há

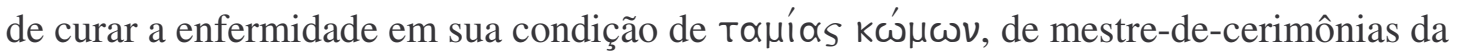
celebração que, naquele exato momento, ocorre em sua honra. ${ }^{59}$

Assim, o coro alcança máxima eficácia no seu canto ao mimetizar o processo no qual Dioniso é habilmente guiado pelos seus centros de culto até a localidade onde ele, coro, se acha, transformando-a em seguida no palco de uma celebração cósmica que tem por centro o próprio canto entoado ${ }^{60}$ Tebas, destino do trajeto divino minuciosamente traçado pelos versos, converte-se em última instância na própria Atenas, onde o coro, no palco construído em homenagem ao deus, celebra Dioniso no contexto de uma competição trágica em seu louvor. ${ }^{61}$ Ponto final das andanças do deus, Tebas o celebra

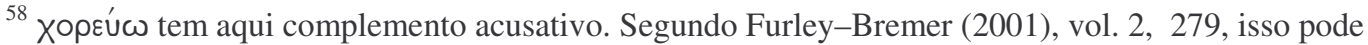
significar tanto que as tíades honram Dioniso através da dança (obiectum affectum) como incitam a sua epifania por meio dela (obiectum effectum). A dança do coro teria então como contrapartida a dança divina catártica; as evoluções do coro seriam espelhadas nos seguidores do deus, ditos пєрí то入о (1150), cujo nome, por sua vez, bem pode ser uma alusão às revoluções dos astros. Cf. Taragna (1979), 140: "Le Tiadi che danzano in onore del dio riproducono lo stesso movimento circolare delle stelle che ruotano intorno al xoparós; come il movimento degli astri è tramutato in danza rituale, cosí la danza delle Tiadi è tradotta in immagine del movimento stellare'.

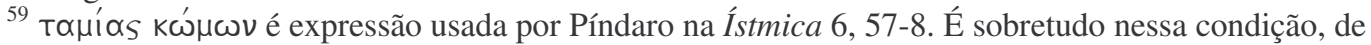

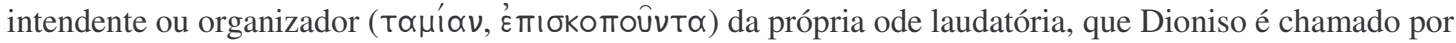
esse hino clético a fazer a sua epifania. Pela dança o deus cura a enfermidade em reconhecimento ao louvor que lhe é dirigido pela própria dança do coro. Kamerbeek (1978), 190, faz referência à passagem pindárica, sem maiores comentários; Furley-Bremer (2001), vol. 2, 279, sugerem que o encargo de "Íaco dispensador" refere-se à dupla função divina de distribuir os frutos da terra e guiar os iniciados a uma espécie de felicidade no Hades.

${ }^{60}$ Cf. Segal (1981), 205: "The Dionysos who leads the remote 'fire-breathing stars' in the last ode is also the Dionysos celebrated by the performance itself". Cf. Wilamowitz (1859), vol. 3, 149: “[...] das Dionysoslied der Antigone is nur so erklärlich". Contra: Dorsch (1983), 221 n.120. Como se vê, a autoreferência do coro pode expressar-se não apenas no uso da primeira pessoa, ao contrário do que afirma Henrichs (1994-5), 26, em artigo fundamental sobre o assunto: "In choral lyric as well as in the choral odes of tragedy and comedy, choral self-referentiality is always expressed in the first person".

${ }^{61}$ Acerca do "nexo ateniense" de nossa ode, cf. Vicaire (1968), esp. 358-65, Bierl (1989), 51s., Bierl (1991), esp. 131s., e Henrichs (1990), 266ss. Para Furley-Bremer (2001), vol. 2, 279, "the poet contrives a
} 
em cantos (dos quais nosso hino é porta-voz) cuja magnitude só tem paralelo na dança cósmica das estrelas. Dessa dança, ${ }^{62}$ o cenário é a própria Tebas, e reúnem-se nela o universal e o local; as estrelas são trazidas para perto, onde se confundem astros e fiéis em uma única celebração, na qual falta apenas o convidado principal - Dioniso.

Com Dioniso bem pode ser que a tragédia nada tenha a ver, e estou inclinado a concordar com quem ${ }^{63}$ nega que o coro tenha uma identidade ritual onipresente - ou seja, que o coro é sempre parte da ação trágica e rende simultaneamente culto a Dioniso. E tampouco me parece que o papel dos coristas como participantes de um ritual dionisíaco condiciona fundamentalmente a interpretação das odes. Mas no caso específico da nossa ode, creio que o contexto cultual do festival, longe de ser irrelevante, foi tomado em consideração pelo autor precisamente para salientar a função irônica que em geral ele atribui a essas odes extáticas (antes chamadas “hiporquemas”) em outras peças (Édipo Rei 1086-97, Ájax 693-705, Traquínias 205-21). Mal terminado o nosso hino, sobrevém a notícia das mortes de Hêmon e Antígone; o contraste entre as esperanças frustradas do coro e a sua celebração eufórica ${ }^{64}$ torna-se tanto mais incisivo pela aparente impressão de normalidade ritual criada pela ode, que mescla a ordem cósmica com a Tebas mítica para daí baixá-las à performance coral na própria Atenas. Não atribuo, note-se, poder ritual efetivo à ação ritual realizada pelos coreutas; o ritual mantém o seu caráter metafórico,

sort of ring composition, in so far as the identification of the Eleusinian Iakchos with Dionysos here corresponds to the juxtaposition of Dionysos with Eleusinian Deo in the opening stanza".

${ }^{62}$ Cf. Henrichs (1996b), 46: "Wie so oft, wenn das rituelle Rollenverhalten seiner Verehrer auf den Gott übertragen wird, erscheint Dionysos auch hier in doppelter Funktion: als aktiver Mittänzer, aber auch als göttlicher Rezipient des Tanzes, dem zu Ehren das kultische Tanzen stattfindet und der sozusagen 'betanzt' wird".

${ }^{63}$ Scullion (2002), esp. 118, 121 e 134, e Furley (1999-2000), 186s.: "I do not believe these moments of self-referentiality in choral odes represent any kind of break with the dramatic illusion. [...] I believe that choric self-referentiality in tragedy mirrors the self-referentiality of such cult hymns, and in no way reminds the audience that the chorus is dancing for Dionysos, rather than the purpose required by the play". Contra, por exemplo, Henrichs (1994-5), (1996a), (1996b) e Sourvinou-Inwood (2003), 52: "If tragic choruses were indeed perceived, albeit not as dominantly, as choruses for Dionysos in the present, it follows that in the fifth century tragic performances were not perceived as ritual only in the sense that they were part of the festival of Dionysos and were framed by ritual; the tragedies themselves were shot through by ritual, not only insofar as ritual acts were important in the action in the other world enacted by the tragedy, but also, and more importantly, it was shot through by ritual performed in the present; so tragedy itself could not have been perceived as other than fundamentally religious". Sobre a relação entre ritual e drama, cf. Parker (2005), cap. 7 ("Religion in the Theatre"), 136-52, Krummen (1998), Friedrich (1996), esp. 269, e Easterling (1993).

${ }^{64}$ Kranz (1933), 213: “[...] ist es [das hoffnungsfreudige Lied] verklungen, so öffnet sich ein Abgrund". Ver ainda Stehle (2004), 150, tecendo comentários sobre o Íon de Eurípides: “[...] the more intense a spectator's identification with the choral 'I', the more sharply the outburst of violence at the end would intrude on the illusion". 
continua a ser parte da ficção, mas Sófocles o explora, como fato, em benefício do efeito artístico. ${ }^{65}$ Nesse caso específico talvez seja lícito afirmar com Christiane SourvinouInwood que há "uma certa permeabilidade" entre o mundo da peça e o aqui e agora da perfomance trágica, ou antes uma "dupla identidade" ${ }^{66}$ dos hinos cantados pelo coro. As expectativas do público são assim insufladas; a dramatização trágica das ações rituais produz uma sensação de realidade cultual justamente em benefício do efeito literário, amplificando o impacto das notícias aterradoras trazidas pelo mensageiro. A presença de Dioniso, tão almejada, revela-se absoluta ausência. Sófocles, porém, insiste em manter viva a ambigüidade quanto à presença ou ausência divina; a catástrofe que põe fim à peça, pode-se argumentar, é talvez maquinada voluntariamente pelo deus - sua presença nos eventos é mais notável do que nunca, muito embora frustre ironicamente os anseios mais profundos do coro. Se Sófocles "via o culto orgiástico com uma certa distância irônica", como sugere Scullion ${ }^{67}$ - isso deve necessariamente permanecer uma questão em aberto; mas é razoável supor, como faz Burton, que "uma prece endereçada por cidadãos tebanos ao deus tebano suscitaria uma pronta resposta dos atenienses sentados no teatro desse mesmo deus Dioniso para assistir a peças representadas como parte do culto a ele devido". 68

A ode une inextricavelmente o instante presente da celebração (a Atenas histórica da Dionísia urbana), o passado mítico (a Tebas de Antígone e Creote) e o universo cósmico das entidades celestes - todos eles imbuídos da presença divina. Fatos tebanos são amplificados de modo a serem vistos em seu contexto cósmico ${ }^{69}$ e simultaneamente afunilados para o hino entoado pelo coro ateniense. Ao valer-se de estratégias retóricas para canalizar a atenção e favor divinos, o coro instiga Dioniso a deixar os seus centros cultuais mais remotos e vir a Tebas a fim de curar a cidade pela dança, e o faz oferecendo em troca a canção-dança que eles, como grupo de dançarinos na orquestra, apresentam. Tebas entrelaça-se a Atenas, e ambas são subsumidas sob a ordem cósmica.

\footnotetext{
${ }^{65}$ Cf. Friedrich (1996), 269.

${ }^{66}$ Ver Sourvinou-Inwood (2003), 51 n.126, e 52.

${ }^{67}$ Scullion (2002), 136.

${ }^{68}$ Burton (1980), 134

${ }^{69}$ See Rohdich (1980), 211s.: "Das Lied stellt das menschliche Leben in den Rahmen des kosmischen [...]; diesselbe Kraft, die den Kosmos erhält, wird auch die Polis bewähren".
} 


\subsubsection{Calímaco, Hino a Apolo (55-104)}

Outro exemplo bastante requintado da capacidade poética de seduzir o deus para perto através da estrutura do poema é o Hino a Apolo de Calímaco. Interessam-me aqui os versos $55-104$.

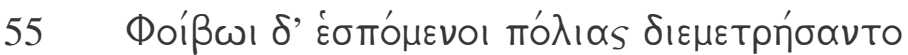

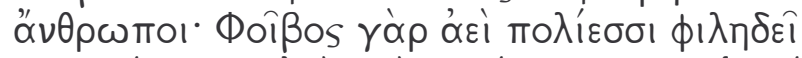

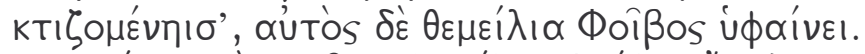

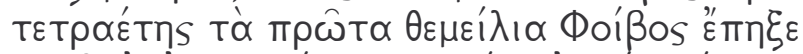

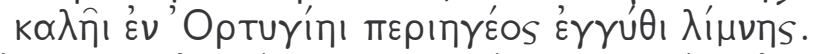

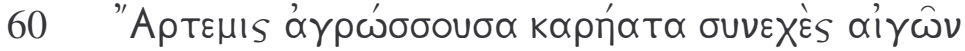

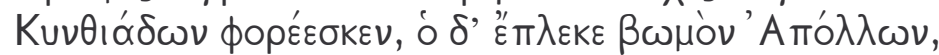

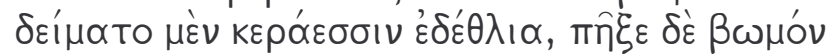

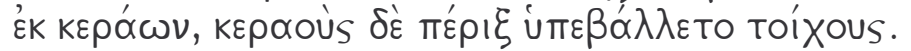

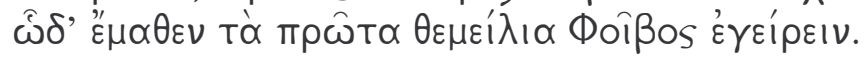

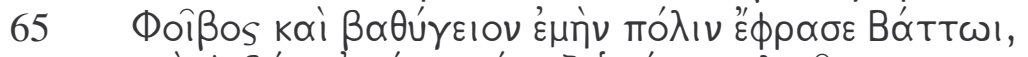

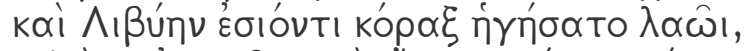
$\delta \varepsilon \xi i o s$ oikı

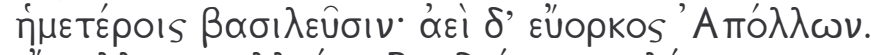

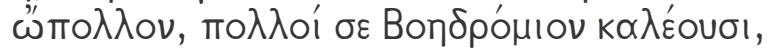

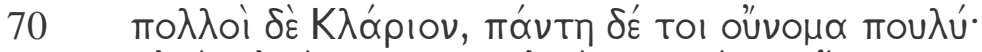

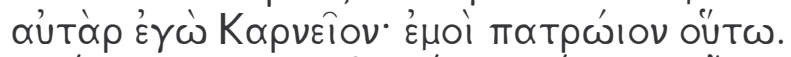

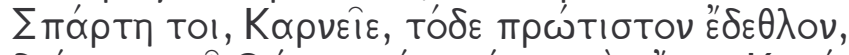

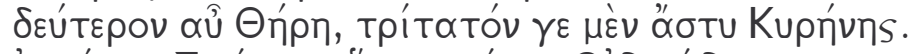

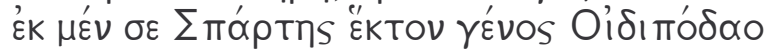

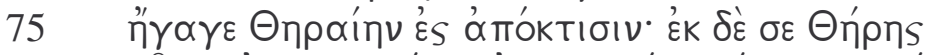

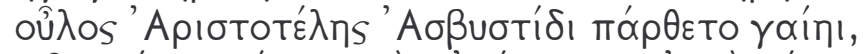

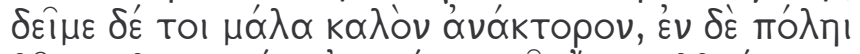

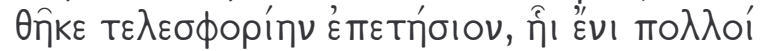

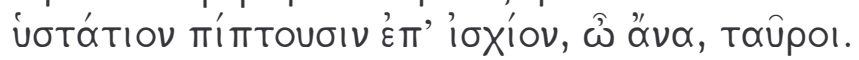

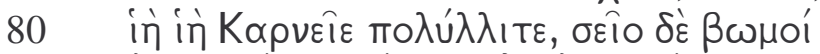

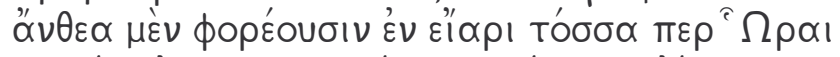

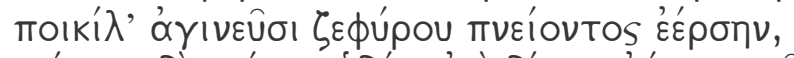

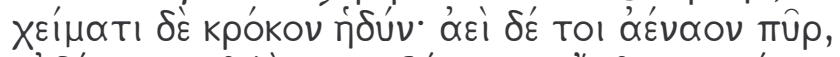

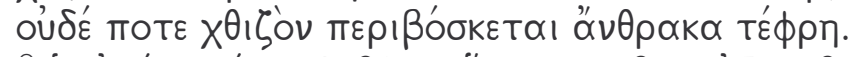

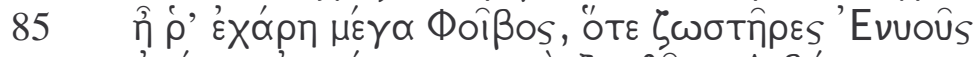

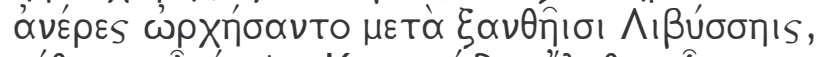

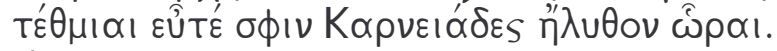

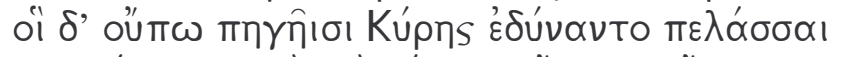

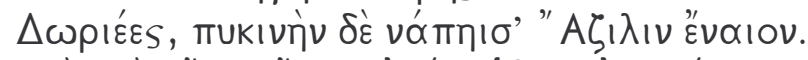

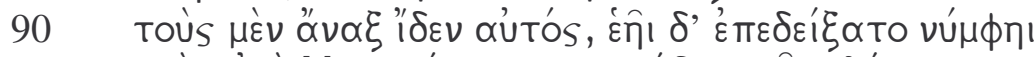

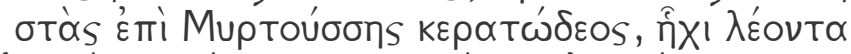

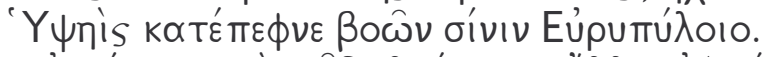

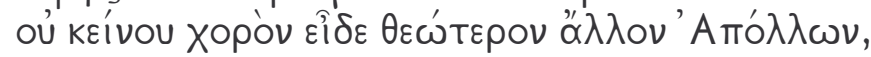




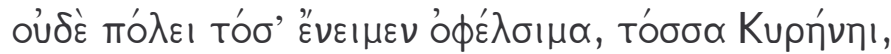

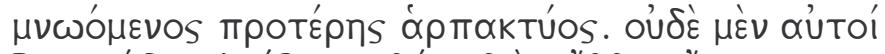

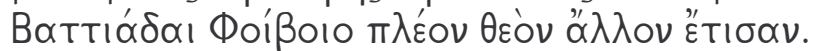

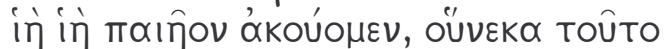

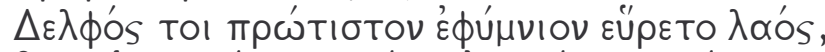

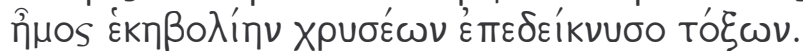

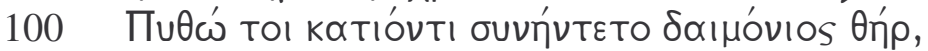

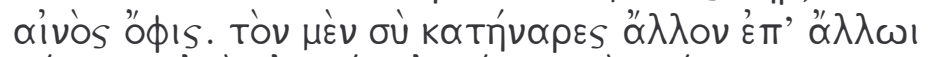

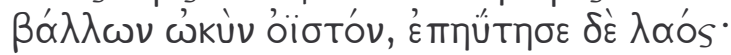

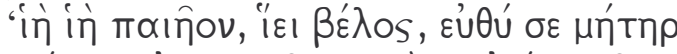

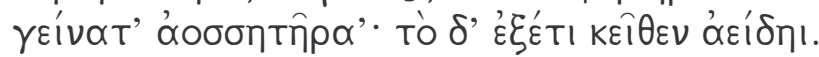

(É seguindo os passos de Febo que nós homens traçamos os limites das cidades, pois a Febo sempre agrada a sua construção, e Febo ele próprio lhes tece os fundamentos. Aos quatro anos, Febo firmou pela primeira vez os fundamentos na bela Ortígia, próximo ao lago circular. [60] Ártemis em caça acumulava cabeças e mais cabeças de cabras do Cintos, enquanto ele, Apolo, firmava um altar. De chifres ele construiu a base, de chifres firmou o altar, com chifres ergueu as paredes ao redor. Assim Febo aprendeu pela primeira vez a erguer fundamentos.

[65] Febo também a Battos indicou a minha cidade de solo fecundo e guiou, na forma de corvo, à direita do chefe, a entrada do seu povo na Líbia, e jurou que daria as muralhas a nossos reis. Apolo sempre cumpre os seus juramentos.

Ó Apolo, muitos chamam-te Boedrômio, [70] muitos Clário, em toda a parte inúmeros são os teus nomes. Mas eu, eu chamo-te Carneio: tal é a minha tradição. Esparta, Carneio, foi a tua primeira sede, Tera a segunda, a terceira foi a cidade de Cirene. De Esparta um descendente de Édipo, seis gerações depois dele, [75] conduziu-te com os seus colonos a Tera; e de Tera Aristóteles o Forte levou-te à terra dos Asbistas; ele te construiu um templo esplêndido e instituiu o sacrifício no qual, a cada ano, touros em quantidade têm o seu fim, caindo sobre os seus flancos. [80] I $\hat{e}, i \hat{e}$ Carneio, deus de muitas preces, os teus altares na primavera carregam-se de tantas flores variegadas quantas as Horas trazem sob o Zéfiro que sopra orvalho, e no inverno, do doce açafrão; sempre brilha para ti o fogo que jamais se extingue, e nunca o carvão do dia anterior é engolido pela cinza. [85] Grande foi o júbilo de Febo quando, chegado o tempo das festas carnéias, os homens de Ênio, dotados dos seus cinturões, organizaram uma dança entre as líbias loiras. Os dórios ainda não haviam sido capazes de aproximar-se da fonte de Cire: eles moravam em Azílis de vales cerrados. [90] O rei Febo os viu e os mostrou à sua noiva, do alto do rochedo Mirtousa, lá mesmo onde a filha de Hipseu dera cabo do leão que dizimava os bois de Eurípilo. Jamais Apolo viu coro mais divino que aquele, jamais concedeu tantos benefícios a uma cidade quanto a Cirene, [95] em recordação do rapto de outrora. E os batíadas eles próprios também não renderam homenagens a outro deus mais que a Apolo. "Iê, iê peã!", nós ouvimos, pois o povo de Delfos inventou primeiro esse refrão, quando com o teu arco dourado tu deste prova de ser arqueiro habilidoso. [100] Ao descer a Pito, tu encontraste a fera prodigiosa, a terrível serpente. Tu a mataste atirando uma flecha veloz atrás de outra, e o povo bradou: "Iê, iê peã! Lança a tua flecha, deus auxiliador desde que a tua mãe te deste à luz”. E desde então, assim tu és aclamado.) 
Num primeiro movimento, Calímaco conduz deus (e público) do geral ao particular. Versos 55-64 mantêm-se no plano geral, e narram a predileção de Apolo pelas cidades, sua participação ativa em lhes tecer os fundamentos, seu gosto precoce tal como manifesto na confecção do Altar dos Chifres em Delos; nos versos seguintes (65-8) passa-se do geral ao particular, das cidades à cidade de Cirene, ao papel ativo da divindade na sua fundação, sua promessa de edificar muralhas e transferi-las aos reis cirenos.

A princípio, a relação de Apolo é com os homens em geral - com os homens e as suas cidades. Abrem os dois primeiros versos, em posição enfática, os dois pólos dessa

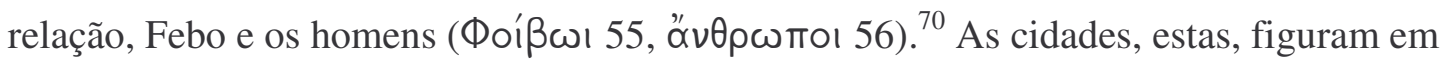

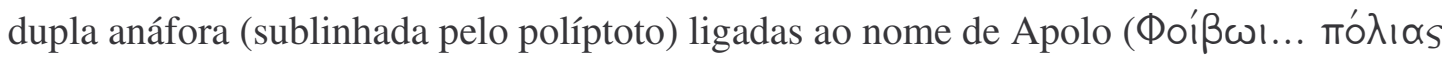

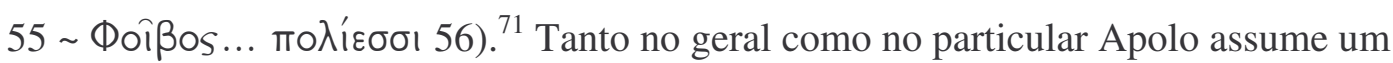
papel ativo, é sujeito das ações; no trato com os homens, é ele quem age, quem indica

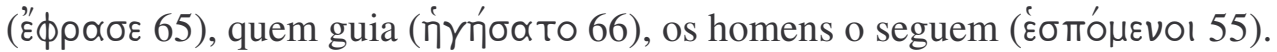

Dos homens passamos a um único homem, Battos, e ambos, deus e mortal, para maior ênfase, figuram também em posição de destaque, abrindo e fechando o hexâmetro (\#Фoîßos... Bóttwı\# 65). Aliás, essa seção dedicada a fornecer um exemplo específico aos poderes fundadores do deus, dos quais Battos é beneficiário, começa e termina com Apolo (\#Фоîßos 65 - 'Aто́ $\lambda \lambda \omega \nu \#$ 68), ${ }^{72}$ formando uma unidade. A seção de caráter geral também é circunscrita pela tripla repetição, duas no início, uma no verso final, do sintagma $\theta \varepsilon \mu \varepsilon i ́ \lambda_{\curlywedge} \propto$ Фoißßos $(57,58$ e 64), nas três vezes seguido de um verbo incomum

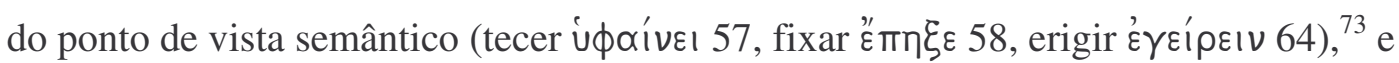
duas vezes precedido pela locução adverbial tò $\pi \rho \hat{\tau} \tau \alpha(58,64)$. Três também são as vezes que a conjunção kớ é repetida, a primeira delas (65) com valor particularizante, ${ }^{74}$ convergindo o foco para o exemplo específico.

Finda, portanto, essa marcha do geral ao particular - na qual o deus foi sujeito ativo e descrito na terceira pessoa ("Er-Stil") -, com Apolo na ponta do verso, no caso

\footnotetext{
${ }^{70}$ Williams (1978), 55.

${ }^{71}$ Ibid., 56.

${ }^{72}$ Cf. a posição métrica polar de Ártemis e Apolo nos versos 60-1.

${ }^{73}$ Cf. Williams (1978) ad loc., o qual observa também que se trata de uma alusão a uma passagem do Hino Homérico a Apolo (254=294).

${ }^{74}$ Cf. Race (1990), 97 n.33, e veja a seguir análise da Neméia 7, 1-8, de Píndaro (item 1.1.6).
} 


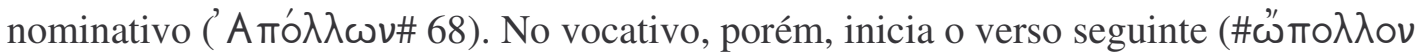
69), e agora, tratado na segunda pessoa ("Du-Stil"), ${ }^{75}$ ele não é mais sujeito, mas objeto ${ }^{76}$

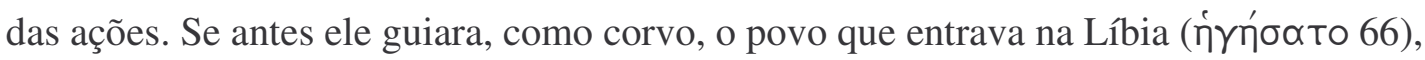

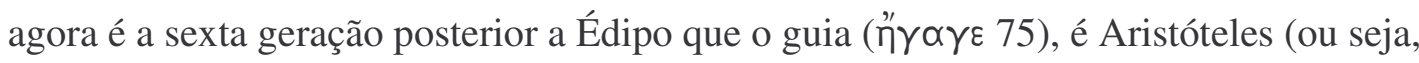
Battos) que o porta ( os pronomes enclíticos que a ele se referem ( $\sigma \varepsilon 69,74,75$, то। 70, 72, 77), mas é também pelos pronomes, estes de primeira pessoa, que se torna mais suave o encadeamento entre as partes descritiva (55-68) e apelativa (69ss.): foi a minha cidade ( $\varepsilon \mu \eta \dot{\nu} \nu$ mó $\lambda ı$ v 65), diz o

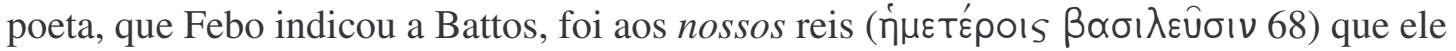
prometeu dar muralhas. Passando ao "Du-Stil", após o vocativo (69), Calímaco constrói

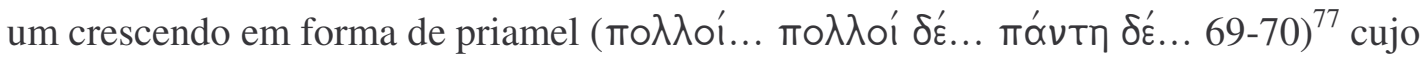

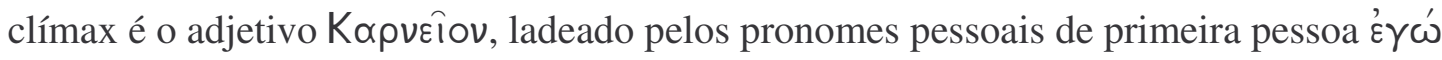
e $\varepsilon \mu o i ́$.

Na verdade, o encadeamento das partes promovido pelos pronomes reflete uma estrutura mais ampla. Versos 65-96 formam um conjunto dedicado a Cirene, e também aqui Calímaco cuidou de lhe demarcar os limites: ${ }^{78}$ o primeiro verso contrabalança o último, expressando o vínculo entre Apolo e os batíadas na ordem quiástica dos termos Фoîßos... Bóttwı (65) e Batrıódaı Фoíßoı (96). Assim, os mesmos versos (65-8) que haviam servido para particularizar o relato que o precede (55-64), inauguram agora uma seção que irá pelo mesmo caminho, não mais do geral ao particular, mas do passado ao presente, do distante ao próximo. Tema da narrativa é como Apolo foi levado - ou antes, trazido - de Esparta até Cirene via Tera. O trajeto é dado a ver in nuce nos versos 72-3, na clareza da disposição dos seus membros: Esparta e Cirene nas duas pontas do hexâmetro, Tera junto à cesura. O restante da seção desdobra e detalha esse esquema, numa crescente aproximação a Cirene que se dá, porém, em duas etapas, cada qual marcada por um estilo - apelativo ou descritivo. A partir do verso 69, como vimos, Apolo

\footnotetext{
${ }^{75}$ Sobre ambos os estilos, convencionais nos hinos, cf. Norden (1913), 143-63 ("Du-Stil”) e 163-66 ("ErStil").

${ }^{76}$ Cf. Calame (1993), 39.

${ }^{77}$ Cf. Williams (1978), 66, sobre a combinação de anáfora, políptoto e trocadilho etimológico na sequiência

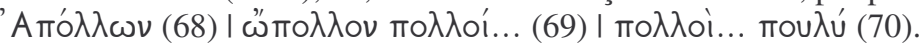

${ }^{78}$ Williams (1978), 63.
} 
é interpelado de forma direta, e o "Du-Stil" estende-se até o verso 84; dos versos 85-96, torna-se ao "Er-Stil".

Primeiro narram-se em ordem cronológica (69-84) as etapas da colonização, como os descendentes de Édipo conduziram Apolo Carneio de Esparta a Tera, onde Battos o levou até o território da população nativa da Líbia, os Asbistes, e lhe edificou um templo e lhe instituiu um sacrifício anual de touros em massa. Ainda não chegamos a Cirene propriamente dita, mas do passado somos transferidos ao instante atual, com a

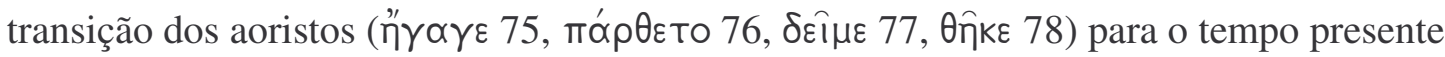

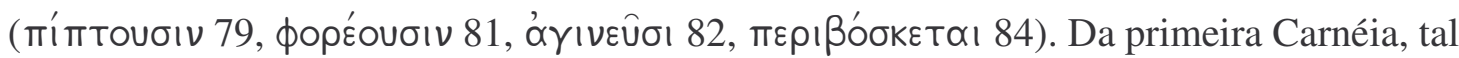
como a viu nascer Battos, passamos sem sobressaltos à sua repetição anual, ou antes aos sacrifícios que se prolongam pelo ano afora, ${ }^{79}$ até o momento presente. Antecipa-se aqui o fecho etiológico da nossa passagem (98-104), no qual passado e presente se fundem ao

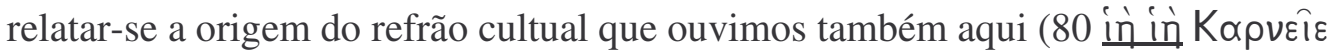
по $\lambda u ́ \lambda \lambda ı$ เт 'iê iê Carneio, deus de tantas preces'). Por meio do jogo dos tempos verbais e sobretudo pelo refrão, o poema é alçado ao contexto dos primeiros colonizadores - refrão este posto em destaque por Calímaco não só pela sequiência de homeoteleutos ${ }^{80}$ dos versos 78-80, todos marcados pela cesura bucólica,

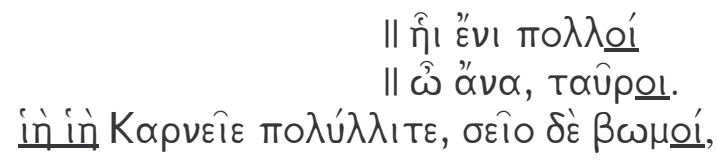

mas também por localizar-se bem no centro da seção dedicada a Cirene (65-96).

Numa segunda etapa (85-96), novamente em "Er-Stil", seguimos no rumo de Cirene, mas o assunto já não são os sacrifícios, e sim a dança. Tornam ao tempo passado os verbos para narrar qual não foi a alegria de Febo ao assistir às danças (pírricas?) de homens em meio a líbias loiras, não ainda em Cirene, mas em Azílis, pois os dórios, sublinha o poeta, "ainda não haviam podido aproximar-se da fonte Cire" (88). Quem se acha, ele sim, no futuro sítio de Cirene, é Apolo, que com a sua noiva (a ninfa Cirene)

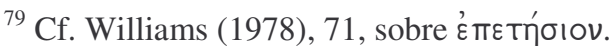

${ }^{80}$ Ibid., 72.
} 
aprecia o espetáculo do coro, sobre o rochedo Mirtousa, ${ }^{81}$ onde ela (filha de Hipseu) dera cabo do leão que dizimava os bois de Eurípilo. Aqui finalmente chegamos a Cirene, cidade à qual Apolo concedeu benesses como a nenhuma outra (94); coro e deus agora se fundem em dois hexâmetros balanceados: ${ }^{82}$

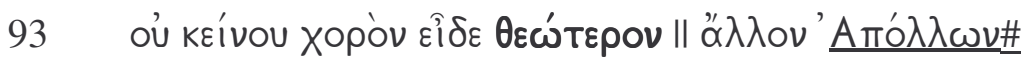

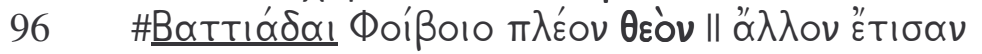

(Jamais Apolo viu coro mais divino que aquele; [Nem] os batíadas [eles próprios] honraram outro deus mais que a Febo.)

Vindos de Esparta, Tera e Azílis, alcançamos Cirene em meio às celebrações do

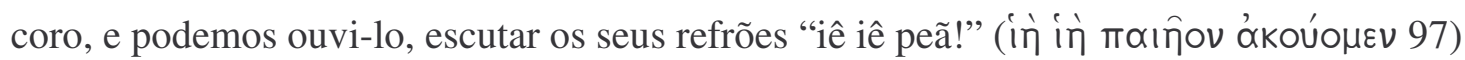
- ou será que é o coro de jovens a quem o narrador, no começo do hino, ordenara aprestar

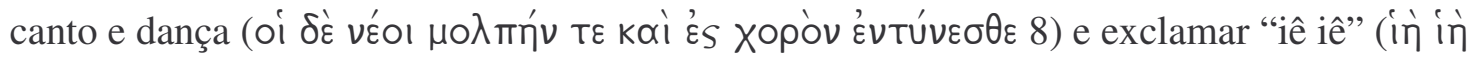

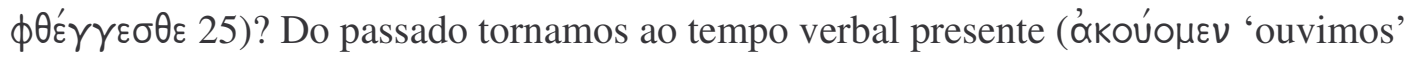
97) num breve relato (97-104) sobre a origem desse grito ritual - num aition que mescla presente e passado na ficção de um cenário cultual para o hino. ${ }^{83}$ Ouvimos agora o refrão

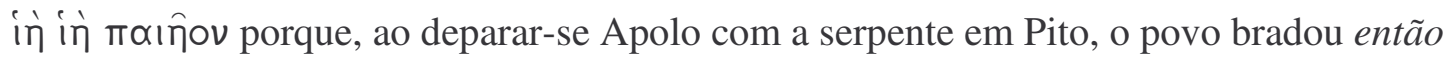

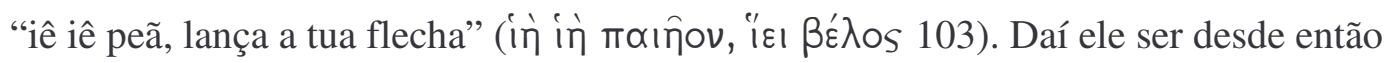

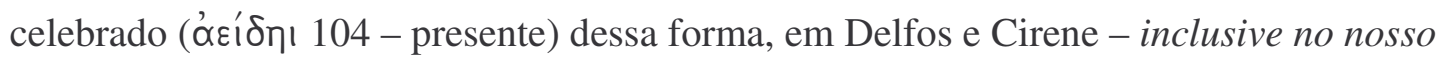
próprio poema.

Complexa é assim a estrutura do hino, com as suas antecipações, transições marcadas, com a sua integração de planos temporais e geográficos. Faço aqui um esboço do esquema para melhor visualização:

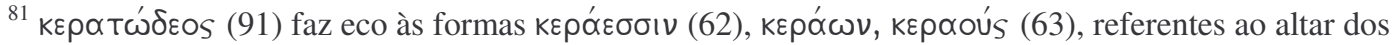
chifres construído por Apolo em Delos. Sugere-se, assim, uma ligação entre Delos e Cirene.

${ }^{82}$ Cf. Williams (1978), 80.

${ }^{83}$ Calame (1993), 45: "In the play with verbal tenses and enunciative stances, the interaction tends to efface limits between legendary or 'mythological' time and the time taken to perform the poem, the 'ritual' time, a continuity is woven between these two temporal dimensions which aims at superimposing them". Cf. ainda Bing (1993), 186 n.16, e, sobre o caráter mimético do hino, Harder (1992), Falivene (1990) e Prestagostini (1991).
} 
55-68 geral-particular (Er-Stil)

55-64 geral

65-68 particular

65-96 aproximação a Cirene

65-68 Apolo sujeito (Er-Stil)

69-84 Apolo objeto (Du-Stil); sacrifícios; passado $\rightarrow$ presente

85-96 coro (Er-Stil); passado $\rightarrow$

97-104 aition (Du-Stil); presente

A complexidade estrutural, no caso de Calímaco, é parte integrante do propósito por ele perseguido, de borrar as fronteiras entre presente cultual e passado mítico. Nem sempre, é claro, as estratégias retóricas para atrair a divindade são tão refinadas - mas nem por isso elas revelam-se menos eficazes. Um bom exemplo é o peã de Arífron ( $P M G 813)$.

\subsubsection{Arífron, Peã a Higéia (PMG 813)}

Poucos foram os hinos que desfrutaram durante séculos de tão ampla notoriedade como o peã a Higiéia composto por Arífron de Sícion. Datado provavelmente do século IV a.C., é mencionado por Luciano como um poema conhecidíssimo e sempre na boca de

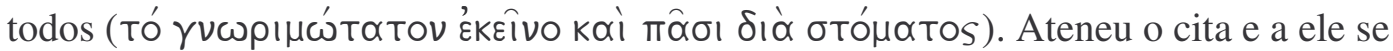
refere como "peã"; ao todo quatro autores dos séculos segundo e terceiro depois de Cristo lhe fazem alusão ou o transcrevem ${ }^{84}$ além da lápide de Epidauro, onde o poema fazia parte do culto a Asclépio, há uma outra, que se encontra em Kassel na Alemanha - uma peça volumosa, para lá transportada como troféu ou talismã por tropas de Hessen no século XVII. ${ }^{85}$

Parece, no entanto, que o poema permaneceu na obscuridade por quatrocentos anos antes de ganhar fama. O silêncio que se interpõe entre a primeira inscrição e um punhado de atestações séculos mais tarde pode muito bem ser imputado ao caráter fragmentário da transmissão, mas sugere antes um renascimento. Um renascimento que, de acordo com Ewen Bowie, ${ }^{86}$ é comparável ao do peã de Sófocles inscrito no

\footnotetext{
${ }^{84}$ Luciano, Pro lapsu inter salutandum 6; Ateneu, Deipnosophistae 15,701f-702b; Máximo de Tiro 7,1a; Sexto Empírico, Adversus mathematicos 11,49; Plutarco, De fraterno amore 2,3 = Mor. 479a; id., De virtute morali 10,3 = Mor. 450b. Além de Ateneu, o poema acha-se preservado em outro manuscrito, que dele oferece, em termos gerais, a melhor versão: o código grego anônimo Ottobonianus 59 II, fol. $31^{\mathrm{v}}$. ${ }^{85}$ Epidauro $I G$ 4.1.132; Kassel $I G 3^{2} 4533$.

${ }^{86}$ Comunicação pessoal.
} 
monumento de Serápion e também ao peã eritreu, cuja história epigráfica possui perfil bastante semelhante ao do de Arífron.

Não é algo inusitado a sobrevivência de antigos hinos em cultos recentes. Além do peã a Asclépio de Sófocles (PMG 737) e da pedra na qual o poema de Arífron está inscrita, que junto com duas outras pedras encontradas em Epidauro acham-se gravadas com hinos, pode-se mencionar também o hino de Creta a Zeus do Monte Dicta, preservado através de um registro tardio (III século d.C.?) copiado de uma inscrição bem mais antiga ${ }^{87}$ Quanto a nosso poema, parece quase certo que ele integrava o programa ritual do culto a Asclépio em Epidauro, sendo cantado nas primeiras horas do dia entre demais canções que acompanhavam a abertura do santuário durante a alvorada. ${ }^{88}$ Embora provável que as inscrições envolvessem leitura e performance, possível é também, devemos admiti-lo, que elas fossem utilizadas, não como parte do ritual diário, mas sim como oferendas votivas. ${ }^{89}$ Maas ${ }^{90}$ expressa as suas dúvidas quanto ao fato de que oferendas votivas a Asclépio em Epidauro - ou mesmo qualquer outro hino inscrito, como os de Filodamo, Arístono, Ísilo e Limênio - tivessem algo a ver com canções empregadas no culto: antes, tais hinos haverão de ter sido inscritos às expensas do próprio autor ou em sua honra. O Certame entre Homero e Hesíodo ${ }^{91}$ narra como Homero, tendo aportado a Delos para o festival, tomou posição junto ao altar dos chifres e recitou seu "hino a Apolo", ao que os délios lhe redigiram o poema numa tábua pintada de branco $(\lambda \varepsilon u ́ k \omega \mu \alpha)$ e a dedicaram no templo de Ártemis. O historiador Górgon, ${ }^{92}$ por sua vez, menciona a consagração do texto da Olímpica 7 de Píndaro, cinzelado na pedra com letras douradas, no templo de Atena em Lindos.

Solene, e não em pequeno grau, parece ter sido a inscrição de hinos em locais de culto. ${ }^{93}$ Antes de transferir à pedra o peã que compusera a Apolo e Asclépio, Ísilo encarregou um certo Astiledas de consultar o oráculo em Delfos sobre a conveniência do seu propósito. Como o procedimento parece ter-se revestido de uma função simbólica, não admira que muitos dos peãs délficos fossem inscritos em tabletes nos muros do

\footnotetext{
${ }^{87}$ Cf. item 1.1.16.

${ }^{88}$ Cf. Wagman (1995), 172, e Maas (1933), 154.

${ }^{89}$ Devlin (1995), 114.

${ }^{90}$ Maas (1933), 155 n.3.

${ }^{91}$ Certamen Homeri et Hesiodi, 314-320.

${ }^{92}$ Schol. Pind. Ol. 7,1 (Drachmann), FGrHist 515 F 18.

${ }^{93}$ Devlin (1995), 114 n.9.
} 
Tesouro ateniense. ${ }^{94}$ Seja como for, o peã de Arífron - após jazer em estado dormente por tão longo tempo - despertou para a vida tanto em sua versão escrita (embora a pedra de Kassel, infestada de erros, mal se preste à leitura) quanto em sua versão oral (o peã simpótico tal como o conhecemos da prece prandial relatada por Ateneu).

Se o peã possuía, como é plausível supor, uma função diária no culto de Epidauro, não menos em casa ele achava-se no contexto da libação ao término de um banquete. Seria, no entanto, um erro identificar nisso uma mudança de um cenário estritamente religioso para uma forma de canto mais secularizada. Talvez se possa dizer que o peã simpótico, mais que uma simples formalidade indispensável, era cantado como um verdadeiro rito em reuniões festivas, por gente imbuída das suas origens religiosas. Uma vez concluída a refeição, as mesas eram recolhidas e aos deuses ofertavam-se três libações, antes que se começasse propriamente a beber. A terceira delas era acompanhada pelo peã entoado em uníssono. ${ }^{95}$ Sendo o peã de Arífron o único exemplo que restou de um peã simpótico (com exceção, talvez, do "Hino a Virtude" 96 de Aristóteles), é difícil precisar os detalhes. Talvez baste dizer que, ao cumprir a sua dupla função como objeto cultual ou votivo e como canção entoada em simpósios, o nosso hino revela como a religião costumava permear todas as esferas da vida grega antiga, não sendo apropriada a rígida distinção entre "religioso" e "profano".

Tendo em mente esse breve pano de fundo, voltemos ao peã de Arífron ( $P M G$ 813). Muito do seu sucesso e longevidade deve-se a uma combinação de conteúdo singelo e delicadeza de expressão. A mensagem é simples: ninguém é feliz sem saúde, sem ela ninguém pode usufruir as outras dádivas divinas. ${ }^{97}$

\footnotetext{
${ }^{94}$ Ibidem. Os atos da irmandade dos Arvais, que Devlin cita como exemplo, talvez sejam um paralelo interessante. Beard (1985) afirma que "the writing of the Arval record is [...] essentially a non-utilitarian activity. [...] there is no good reason to suppose that any of the Arval Acta were ever used or read at all" (137); "The act of writing in the Arval cult formed part of the ritual activity itself and its purpose was as 'symbolic' as the rites and sacrifices it records" (139).

95 Xen. Simp. 2,1, Pl. Simp. 176a, Feréc. Pers. fr.138.5 Kassel-Austin, Antífon fr.4 Kock; Plut. Quaest. conv. 615b; cf. Ésquilo, Ag. 246-7, Supl. 27, Coé. 578, Eum. 759-60, Sófocles fr.425 Radt. Cf. Murray (1990), 6 .

${ }^{96}$ Bowra (1938) 186: "Aristotle modelled his poem on the Paean but added to it some characteristics of the

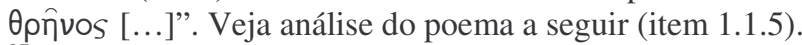

${ }^{97}$ Este é um topos hínico: "contigo tudo é possível, sem ti, nada”. Cf. Pínd. N.7,3-8, O.14,5-8, Cleantes Zeus 15, Keyssner (1932), 29, Norden (1913), 157, 159 n.1, Libânio Hino a Ártemis 25 e Devlin (1995) 383 n.106, 279. A formulação binária, na qual um termo negativo é aliado ao seu equivalente positivo, é traço estilístico característico da linguagem hínica indo-européia. Cf. Schmitt (1967), 266-9, Gonda (1959),
} 


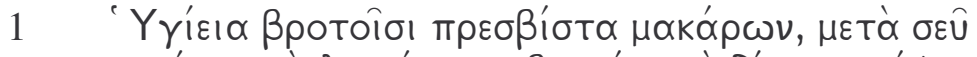

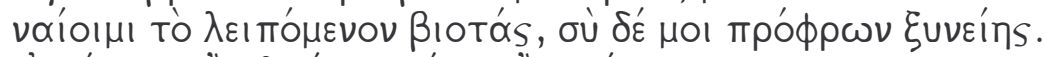

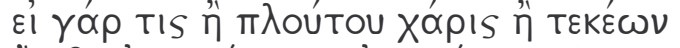

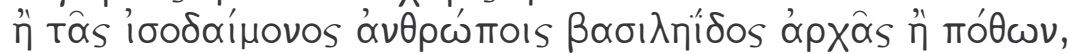

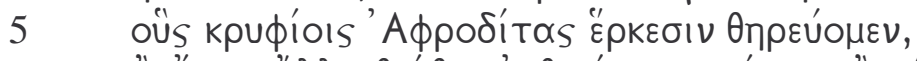

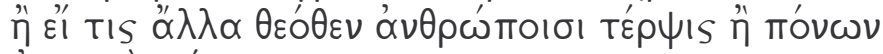

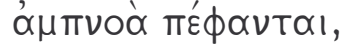

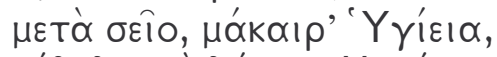

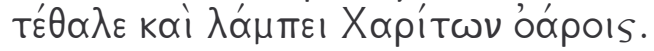

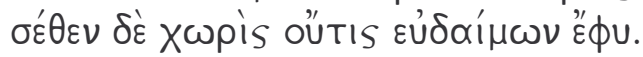

(Higiéia, para os mortais a mais venerável entre os deuses, contigo possa eu conviver o resto da minha vida, e possas tu benigna acompanhar-me. Pois se reluz algum deleite propiciado pela riqueza ou pelos filhos, ou pelo poder régio que iguala os homens às divindades, ou pelos desejos, de que saímos à caça com as armadilhas secretas de Afrodite, ou se [reluz] algum outro prazer concedido aos homens pelos deuses ou algum alívio dos pesares, contigo, abençoada Higiéia, eles vicejam e brilham na fala das Graças. Ora, sem ti ninguém é feliz na vida.)

São dois os temas em torno dos quais gira todo o hino, cada qual firmado em uma oposição: 1) homens - deuses; 2) presença - ausência.

O contraste entre deuses e homens resulta explícito já nas duas primeiras palavras do peã. Como é costume da dicção hínica, a deusa figura em primeiro lugar, em posição de destaque; que entre os deuses ela seja a mais venerável para os mortais é reforçado pela posição que os mortais ocupam em relação à deusa no interior do verso, em

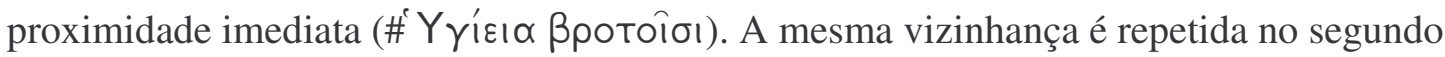

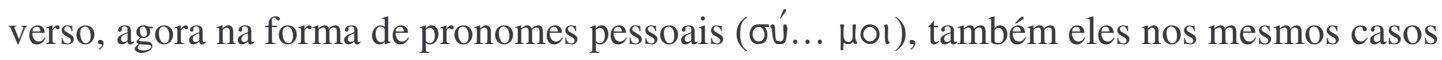
- nominativo e dativo - que os nomes a que se referem. Mas com uma diferença: se antes a menção era aos mortais em geral, agora o poeta, ao fazer a sua prece, converge o foco sobre si próprio ("possas tu... acompanhar-me"), num movimento que, como veremos, percorre todo o hino.

Nesses dois versos introdutórios, a adjacência imediata dos nomes e pronomes a que aludimos cumpre um propósito claro: reforçar a estrutura redundante das duas

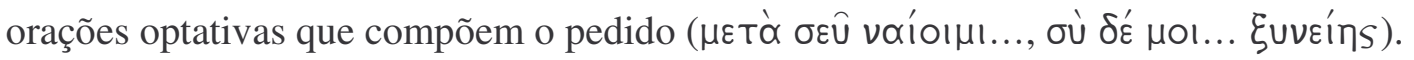


Em apoio às frases optativas, cuja redundância tem por objetivo sublinhar os votos do poeta para ter Higiéia a seu lado, formam-se três blocos de palavras contíguas nos quais

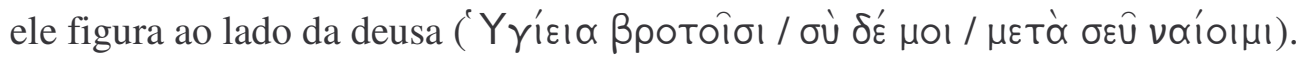

Que a posição dessas palavras cumpre um papel expressivo, não sendo produto do acaso, é o que se torna patente no verso 8, no qual alguns termos do verso 1 reaparecem para compor uma estrutura quiástica ${ }^{98}$ :

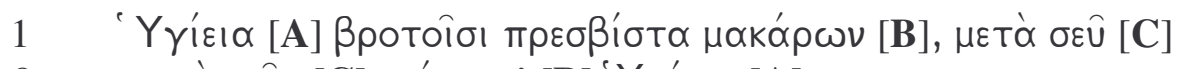

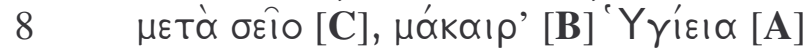

O paralelismo destina-se a unir abertamente a primeira parte do hino (1-2) à segunda (3-9), preparando assim para a gnoma final (10). Ainda na segunda parte, o tema "homens - deuses" ressurge outras duas vezes, expresso na contigüidade dos seus termos:

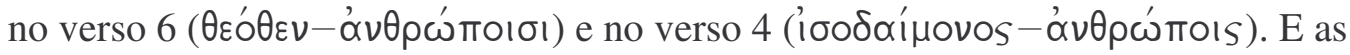
próprias armadilhas com que os homens saem à caça dos desejos são armadilhas secretas da deusa Afrodite (5); e é na fala das Graças que as dádivas divinas vicejam (9). Enfim, a

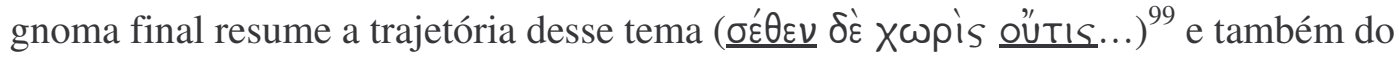
segundo tema a que me referi: o jogo entre presença e ausência da deusa Higiéia ( $\underline{\sigma \varepsilon} \theta \varepsilon v$

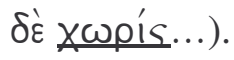

Após expressar o desejo, nos dois versos introdutórios, de que Higiéia "conviva" com ele e o "acompanhe", o poeta desdobra um longo período hipotético que preenche boa parte do hino (3-9). A prótase alonga-se por cinco versos, metade de todo o poema, e subdivide-se em várias partes que compõem um crescendo, enquanto são dedicados apenas dois versos em staccato à apodose, o que a torna por contraste tanto mais saliente. Unido aos versos anteriores pela conjunção $\gamma$ $\alpha$ p, o período hipotético começa na mesma chave otimista que a introdução, marcada pelos votos de partilhar a presença da "mais

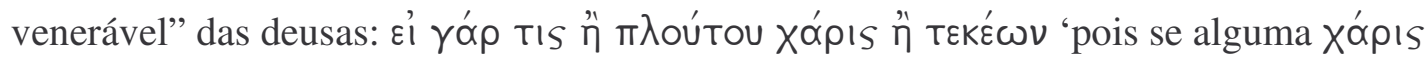
de riqueza ou de filhos' - mas em vez do verbo, a frase acrescenta mais duas conjunções

\footnotetext{
${ }^{98}$ Cf. Wagman (1995), 166, que ressalta a estrutura "em anel” levada a efeito também em termos métricos, com o retorno da cadência anapéstica no verso oitavo.

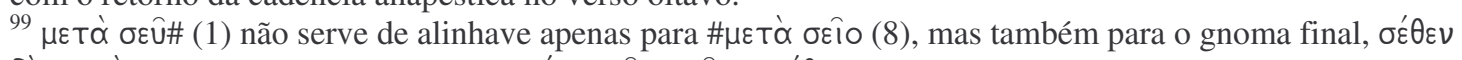

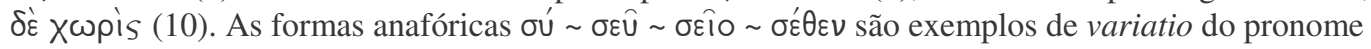
pessoal relacionado à divindade louvada, cf. Norden (1913), 149-63, esp. 159.
} 
disjuntivas no verso seguinte, cujos elementos, ambos no genitivo, dependem igualmente do substantivo Xápıs. O último deles é ampliado com uma frase relativa, e mais uma vez somos frustrados em nossa expectativa de encontrar o verbo; terminada esta, sobrevêm mais duas disjunções, agora com um agravante: a reiteração do દi tıs do verso 3. Quando o período parece ramificar-se indefinidamente, o poeta descontinua a cadência num verso catalético de transição (7), na extremidade do qual suspende-se o tão esperado verbo

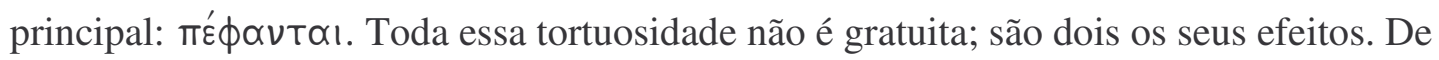
um lado, salientam-se os termos das pontas, dos quais depende a compreensão da frase:

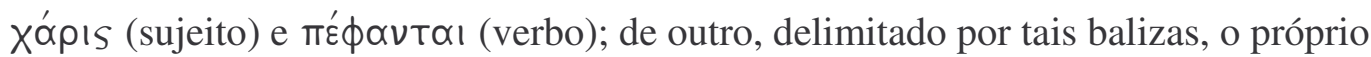
conteúdo das disjunções ganha relevo.

Estas, como dissemos, obedecem a um crescendo: no primeiro par de disjunções, que soa como uma hendíadis ${ }^{100}$, riqueza e filhos não possuem adjetivos que os qualifiquem; na disjunção seguinte, o poder já recebe as atribuições de régio e apto a elevar os homens a deuses; a seguir, os desejos ( relativa, cujo verbo, além do mais, conjuga-se na primeira pessoa ( $\theta \eta \rho \varepsilon v ́ o \mu \varepsilon v)$, o que confere maior candência ao relato: cresce o grau de envolvimento do poeta, que dos

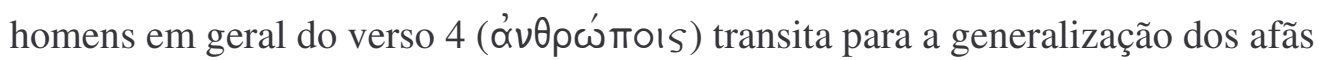
amorosos dos quais ele próprio toma parte.

A seqüência é rematada, enfim, por outro par disjuntivo que simboliza o ápice do crescendo que se avoluma desde o verso 3. Esse remate ganha relevo não apenas pelo seu próprio tamanho (22 sílabas, maior que qualquer outro par de disjunções), mas também por reiterar o Ei TIS e fazer assim com que o elenco isolado das dádivas - a Xópıs de riqueza e filhos, de poder régio e desejos - estenda-se aos prazeres ou alívio de pesares concedidos em geral pelos deuses aos seres humanos. O movimento ascendente do particular ao genérico é acompanhado pelo esquema rítmico: os dáctilos prevalecentes no

\footnotetext{
100 "Riqueza" e "filhos" aparecem muitas vezes juntos nos hinos do Rig Veda. O substantivo suvîrya "rico em heróis, em filhos' costuma fazer par com rayí 'riqueza, tesouro'. Suvîrya é um composto cujo segundo elemento, vīrá, significa "homem, herói" ou ainda "filho homem, vigoroso". Alguns exemplos: sá nạ̣... ă bhara rayím stotré suviri yam 'traze a nosso poeta riqueza plena de filhos/heróis' (9.40,5ab); sá tvám na ūrjām pate rayím rāsva suvîr ${ }_{i}$ yam 'tu, senhor da força, concede-nos riqueza plena de filhos/heróis' $(8.23,12 a b)$; vanéma rayím rayivaḥ suvî́i yam 'queremos ganhar, ó rico em tesouros, riqueza plena de filhos/heróis' $(1.129,7 b)$. Cf. ainda o adjetivo sárvavīra 'composto só de filhos/heróis' (ou 'de filhos/heróis sãos'): ${ }_{a}$ smé rayím sárvavīram ní yachatam 'concede-nos riqueza toda ela de filhos/heróis' $(4.50,10 d)$. Sobre a figura da hendíadis em grego, cf. Sansone (1984).
} 
início do período dão lugar progressivamente aos $\mathrm{E}(-\cup-\times-\cup-)$ para culminar no itifálico (—৩-৩-— ) do verso 7, um pé catalético de transição que, em seu stacatto, faz convergir todas as atenções para a apódose dos versos seguintes. ${ }^{101}$ Esta, por sua vez, sobressai pela sua brevidade, em flagrante contraste com as sinuosidades daquilo que a precede: toda a Xópıs de origem divina, seja de filhos, riqueza, poder, desejos ou quaisquer outros prazeres e alívios - tudo isso prospera na presença de Higiéia. ${ }^{102}$ As bênçãos divinas, cujo esplendor intensifica-se ao longo da prótase, demonstram ter, segundo a apódose, um valor condicionado, e não absoluto: somente com Higiéia elas ganham sinal positivo; sem ela, nada são. A litotes final potencializa a presença benfazeja da deusa ao lembrar que, ela ausente, ninguém é feliz (dupla negação num único verso, que serve de contraponto ao voto duplo e positivo dos dois versos iniciais).

Dividido em três partes (1-2, introdução; 3-9, parte central; 10, conclusão), o poema sinaliza com grande cuidado a junção entre elas, inclusive em termos métricos: a introdução é anapéstica, a parte central transita para os dáctilos-epitritos, a conclusão exibe um trímetro jâmbico. Já indicamos a composição em anel que une os versos 1-2 e

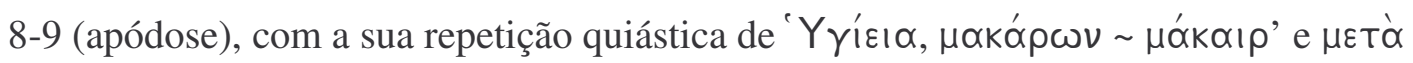

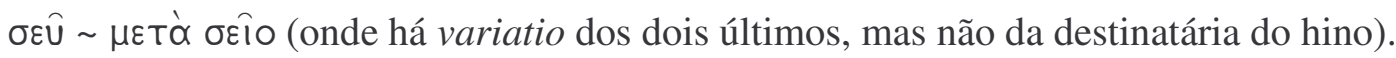
Além disso, os versos 2 e 9, que fecham respectivamente a primeira e segunda partes, concentram os verbos ativos do poema: o verso 2 com dois verbos $\left(1^{\mathrm{a}}\right.$ e $2^{\mathrm{a}}$ pessoas $)$ adjacentes às fronteira métricas, o verso 9 com outros dois ( $3^{\mathrm{a}}$ pessoa), postados no início e ligados por conjunção aditiva. As balizas dessa Ring-Komposition não fazem atentar somente para si mesmas, mas já para aquilo que encerram - a prótase (3-7). Nesta, dois versos em posição simétrica (4 e 6) assemelham-se pelo homeoteleuto (

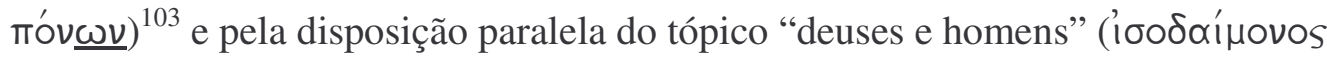

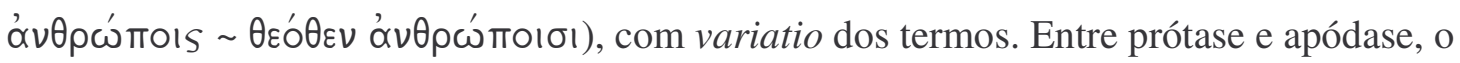

\footnotetext{
${ }^{101}$ Para detalhes métricos, cf. Wagman (1995), 168, Furley-Bremer (2001), vol. 2, 176, e Bremer (1981), 211.

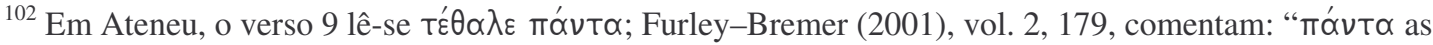
subject to $\tau \dot{\varepsilon} \theta \alpha \lambda \varepsilon$ and $\lambda \alpha^{\prime} \mu \pi \varepsilon$ । destroys the build-up of the previous six lines, which have accumulated possible subjects: "if there is any a, b, c or d then it flourishes and shines...". Sigo-lhes a tradução, pondo o verbo no plural.

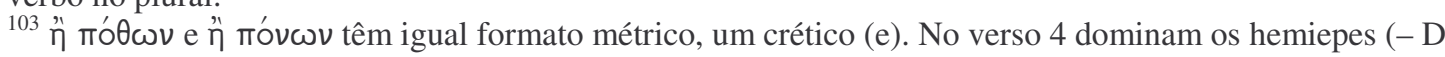
$-\mathrm{D}-\mathrm{e})$, no verso 6 os créticos $(-\mathrm{E}-\mathrm{E})$, mas, talvez para marcar a semelhança mútua, ambos terminam em créticos.
} 
mesmo vocábulo - um no primeiro verso da prótase, o outro no último da apódose - atua

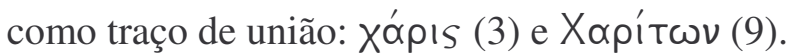

Todo o poema, como vimos, sublinha a importância que a presença ou ausência da deusa Higiéia tem para os seres humanos: nada mais natural, quando se trata de louvar uma abstração personificada cuja área de atuação (a saúde) diz respeito de perto aos mortais. Por maior que seja a graça divina, é somente com Higiéia que ela prospera na fala das Graças. E a Xópıs, um dos termos básicos da hinologia, serve para expressar esse caminho de mão dupla que conduz dos deuses aos homens e dos homens aos deuses: Xópıs é tanto o favor dispensado pelos deuses quanto as honras que os homens lhes

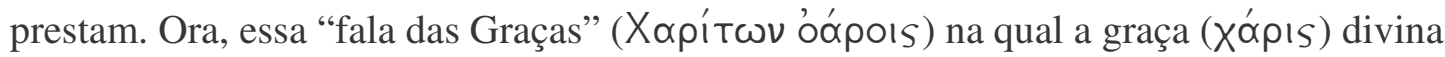
brilha e viceja na presença de Higiéia nada mais é senão o canto ${ }^{104}$ no qual os homens retribuem aos deuses as graças obtidas. Não todo e qualquer canto, note-se, mas este canto em específico, ou seja, o próprio poema, em cuja fala das Graças brilha cada uma das graças divinas dispostas em forma de catálogo na parte central do hino.

Ao cabo da progressão que culmina na ampla generalização do último termo do catálogo (“qualquer outro prazer ou alívio de pesares concedidos pelos deuses"), o poema converge bruscamente o foco para o campo individual, referindo-se a si mesmo como o local privilegiado onde, presente Higiéia, se fazem também presentes as demais graças. ${ }^{105}$ Ou numa paráfrase da apódose: "Na tua presença, ó Higiéia, elas - as graças divinas que acabo de enumerar - vicejam e brilham na fala das Graças que é este hino”. Em apoio ao

\footnotetext{
104 ơopos, no sentido de canto ou poema, é usado por Píndaro em três passagens: N. 3,11-2, P. 1,98; 4,137. De resto, a influência pindárica nesse hino me parece clara. O paralelo mais nítido, quanto a dicção e tema,

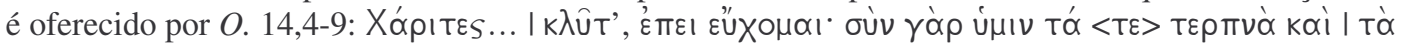

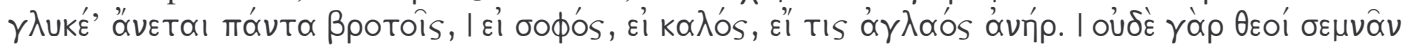

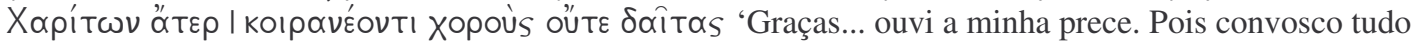
quanto há de agradável e doce acontece aos mortais, seja o homem sábio, belo ou ilustre. Nem mesmo os deuses preparam coros ou banquetes sem as augustas Graças'. Wagman (1995), 177, aponta a semelhança, mas opta por outra leitura do verso 9: X $\propto$ ít como "mormorio delle Cariti". Furley-Bremer (2001), vol. 2, 180, observam com acerto que esta é uma interpretação forçada do grego; seguindo o Ottobonianus (ó́poıs), eles oferecem, contudo, uma tradução pálida do original: "endowed with charm”. A leitura ő $\propto$ poı, registrada em Ateneu, é adotada por Maas, que sugere schema Pindaricum. Uma proposta atraente, sem dúvida, mas que só funciona se destacássemos a apódose do seu contexto, tornando-a um simples apêndice, com uma forte ruptura sintática entre ela e a apódose. A leitura óópoıs, além de ser a mais clara em termos sintáticos, quadra melhor com o estreito

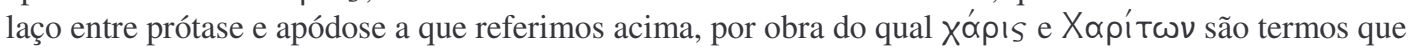
espelham um o outro.

${ }^{105}$ Tal movimento, como dissemos, já havia sido sugerido nos dois versos introdutórios, que são por si sós

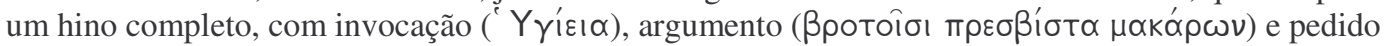

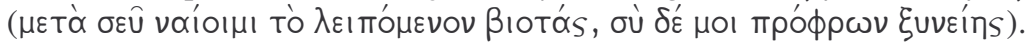


vínculo que quer deixar explícito entre as duas Xápıs complementares, o poeta utiliza verbos que fazem eco um ao outro: se a graça divina "manifesta-se, reluz" ( $\pi \varepsilon ́ \phi \alpha \nu \tau \propto ı)$,

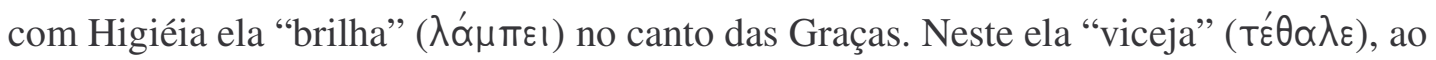

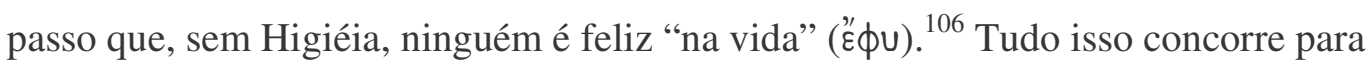
acentuar a reciprocidade entre as graças divina e humana. Os deuses concedem Xópıs aos homens e a recebem de volta na forma de canto (oópoıs) - um canto, aliás, cuja Xópıs consiste em louvar a divindade Higiéia pela graça da sua presença, sem a qual de nada valem as demais graças divinas.

Mais que apenas afirmar que a graça divina brilha nos hinos quando Higiéia está presente, a estrutura hipotética do poema parece sugerir que, se Higiéia acompanhar as graças divinas, então essas brilharão no hino cujo louvor consiste em declará-la indispensável. É como se o poeta a incentivasse a persistir na dádiva da sua presença, pois ela receberá em contrapartida a oferenda de um canto que a sobrepõe às demais dádivas. Ao chamar atenção sobre si próprio, nosso peã lança mão de um tópico largamente difundido no gênero hínico, o da auto-referencialidade. A face dupla da Xópıs faz muitas vezes com que o poeta peça à divindade que preste sua graça ao objeto de culto (neste caso, o peã), e, por meio desse mesmo objeto, renda devoção em honra do deus ou da deusa louvados.

O peã de Arífron, ao contrário dos dois últimos hinos analisados (o de Sófocles e Calímaco), tem uma função eminentemente cultual; o seu Sitz im Leben é o culto, quer como oração matutina em Epidauro, quer como prece para acompanhar as libações nos simpósios atenienses. Diversos embora, os três logram borrar a distinção entre hinos ditos "literários" e "rituais": o hino a Apolo de Calímaco e a ode a Dioniso de Sófocles são hinos "literários" cuja força dramática é alcançada, entre outras coisas, por tornarem-se poemas efetivamente cultuais; já o peã de Arífron é um hino "ritual" que exerce o seu poder persuasivo sobre a divindade por meio de recursos "literários" ou retóricos. Os três, é claro, diferem muito em qualidade literária. A ode de Sófocles, o hino de Calímaco, são

\footnotetext{
${ }^{106}$ Entre os versos 1 e 10 talvez se possa estabelecer uma correspondência análoga às indicadas acima. $\mathrm{O}$

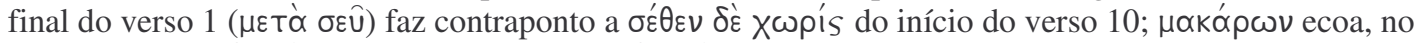

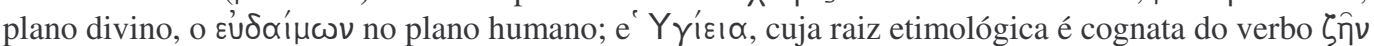
'viver', abre o peã que finda com o verbo фúw, um verbo de cópula usado no sentido de "crescer, medrar".
} 
universalmente aclamados; o poema de Arífron divide opiniões: para uns, como Maas, ${ }^{107}$ o seu estilo é chão e desbotado; West ${ }^{108}$ o inclui naquilo "que pode ser chamado de lírica burguesa letrada"; Wagman, ${ }^{109}$ por sua vez, observa "a particular elegância da forma", ao passo que Furley-Bremer ${ }^{110}$ louvam o "discurso eficaz de elevadíssima ordem”. Seja como for, há de se notar que contextos de performance diversos requerem diferentes graus de ênfase ritual e de expectativa literária. Como sustenta Devlin, ${ }^{111}$ "os termos ‘literário’ e ‘cultual' não são mutuamente exclusivos nem incompatíveis, já que um refere-se ao caráter interno do poema - estrutura, linguagem, estilo - e o outro aos fatores externos de contexto e ocasião a que se destina". A ode de Sófocles, por exemplo, é um hino "literário" que cumpre uma exigência ritual; o poema de Arífron é um hino "ritual" que aspira a um padrão literário. Em ambos, o poeta busca tornar sua obra digna de uma divindade que, invocada como indispensável à própria existência do hino, não é alheia ao valor estético da composição que lhe é oferecida e à qual ela mesma contribui.

\subsubsection{Aristóteles, Hino à Virtude (PMG 842)}

Outro poema que partilha várias semelhanças com o de Arífron e que também se vale, embora com estratégia diversa, do artifício de convergir o foco sobre si próprio para sublinhar a reciprocidade entre deuses e mortais, é o hino à Virtude, de Aristóteles ( $P M G$ 842).

\footnotetext{
${ }^{107}$ Maas (1933), 149, “der glatte farblose Stil”.

${ }^{108}$ West (1982), 139, "what may be called educated bourgeois lyric"

${ }^{109}$ Wagman (1995), 165, "la particolare eleganza della forma".

${ }^{110}$ Furley-Bremer (2001), vol. 1, 226, "effective speech of a very high order".

${ }^{111}$ Devlin (1995), 113.
} 


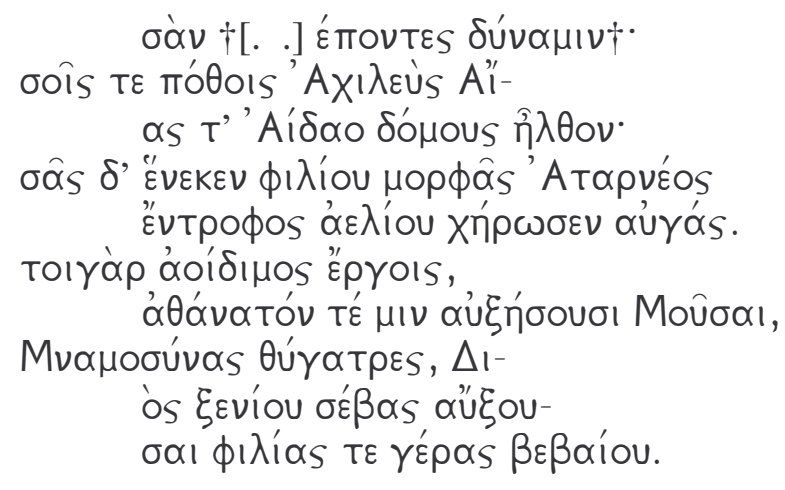

(Virtude, conquistada a muito custo pelo gênero humano, caça das mais cobiçadas ao longo da vida, por causa de ti, virgem, de tuas formas, até morrer é tido como um destino desejável na Grécia, [5] e também suportar penas esmagadoras, infindáveis - tão precioso é o fruto que implantas na mente: divino, superior ao ouro e aos pais e ao sono de olhos lânguidos. Por tua causa, o luminoso [10] Héracles e os filhos de Leda muito penaram em suas tarefas [?almejando] o teu poder, e desejosos de ti Aquiles e Ájax baixaram à morada de Hades. [15] Por causa de tuas formas o filho nativo de Atarneu deixou desolada a luz do sol. Eis por que os seus feitos são louváveis, e as Musas, filhas da Memória, promovem-no à imortalidade promovendo a reverência de [20] Zeus, deus dos hóspedes, e a honra da amizade sólida.)

Antigo aluno da Academia de Platão, Hérmias, tirano de Atarneu, ${ }^{112}$ é celebrado nessa ode de Aristóteles. De origem humilde, Hérmias logrou assumir poder sobre um território da Ásia Menor defronte a ilha de Lesbos, do qual faziam parte as cidades de Assos e Atarneu. O tirano convidou Aristóteles para uma temporada em Assos após a morte de Platão; Aristóteles aceitou e lá passou alguns anos, de 347 a 345 a.C.; os dois tornaram-se amigos; Hérmias deu-lhe a mão da sua sobrinha e filha adotiva Pítia em casamento. Em 343, depois de uma escala em Lesbos para pesquisar a fauna marinha, Aristóteles retorna à Grécia continental, e na corte de Filipe II da Macedônia assume o cargo de tutor do jovem Alexandre. Foi ali, nos idos de 342/341, que lhe chegou a notícia da prisão de Hérmias: Mentor de Rodes, sátrapa da costa oeste da Ásia Menor nomeado pelo rei persa Artaxerxes III, usara de perfídia para encarcerá-lo e enviá-lo a Susa, onde o rei persa interrogou-o sob tortura e lhe deu fim à vida. De regresso a Atenas, Aristóteles, além de erguer em Delfos uma estátua a Hérmias, ${ }^{113}$ introduziu no Liceu o costume de

\footnotetext{
${ }^{112}$ Cf. P. von der Mühll, RE Suppl. III (1918), col. 1126-1130, e Furley-Bremer (2001), vol. 1, 263-66.

${ }^{113}$ Diog. Laérc. 5,6; Dídimo 6,39-43.
} 
cantar, após as refeições, um poema da sua própria pena em homenagem ao amigo. Para tal propósito, o filósofo escolheu a forma de um hino à virtude, ou à excelência (’’óptó).

O poema apresenta inúmeros ecos vocabulares ao peã de Arífron, do qual é tido pela communis opinio ${ }^{114}$ como posterior. Bowra detalha as semelhanças apontadas por Wilamowitz. ${ }^{115}$ Mas quanto à estrutura, as duas obras são nitidamente diversas, embora igualmente claras em sua tripartição. Assim divide-se o poema de Aristóteles:

\section{1-8 elogio à Virtude \\ 9-14 exemplos heróicos \\ 15-21 Hérmias}

Em busca da Virtude, o homem está preparado a padecer dor, a morrer. ${ }^{116}$ Progride-se do

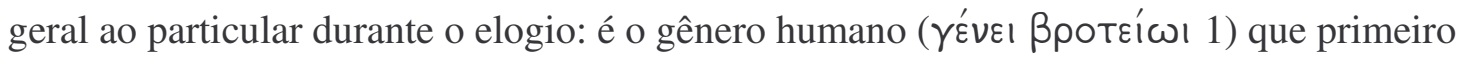
lhe faz objeto de caça, mas é na Grécia ( $\varepsilon^{\prime} \nu$ `E $\lambda \lambda{ }^{\prime} \alpha \delta$ I 4) que morrer e padecer dores são considerados como um destino digno de desejo, tal é o fruto que ela incute nas mentes.

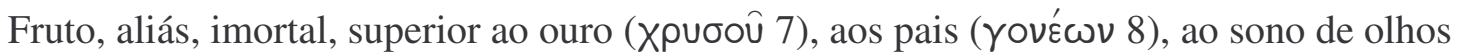

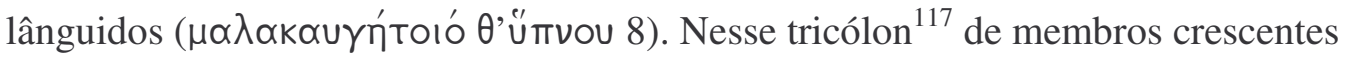

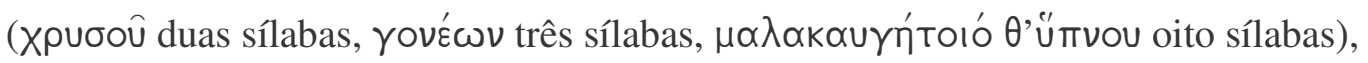

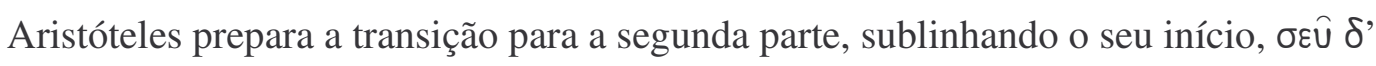

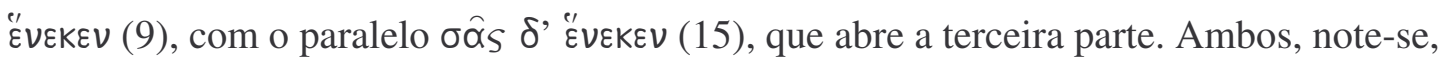

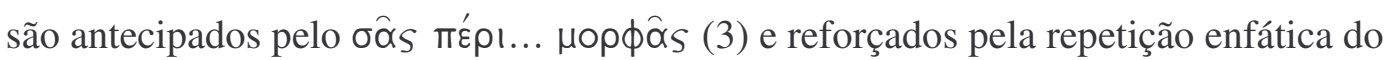

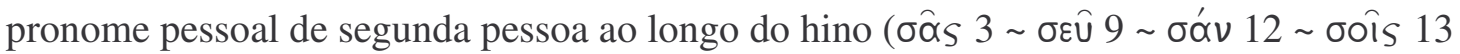
$\left.\sim \sigma \hat{\alpha}_{S} 15\right){ }^{118}$

\footnotetext{
${ }^{114}$ Mas cf. as dúvidas de Furley-Bremer (2001), vol. 1, 265s., para quem, de resto, o peã de Arífron revela marcantes aspectos helenísticos, no estilo e na dicção.

${ }^{115}$ Wilamowitz (1893), 406; Bowra (1938), 184, nota as seguintes coincidências:

\begin{tabular}{|c|c|}
\hline Aristóteles & Arífron \\
\hline 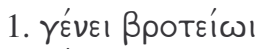 & 1. ßротоїб \\
\hline 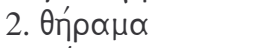 & 7. $\theta \varepsilon \rho \varepsilon \cup ́ о \mu \varepsilon \nu$ \\
\hline 5. móvous & 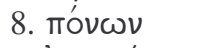 \\
\hline 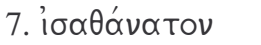 & 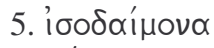 \\
\hline 12. бô̂s mótols & 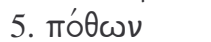 \\
\hline
\end{tabular}

${ }^{116}$ Versos 4 e 5 estão dispostos em uma espécie de hysteron proteron: pela Virtude dispõe-se o homem a morrer (4), a sofrer penas (5) - a conseqüência mais drástica mencionada primeiro, ambas marcadas pelo duplo kớ em início de verso.

${ }^{117}$ Renehan (1982), 262.

${ }^{118}$ Cf. Norden (1913), 149-60.
} 
Do comum dos homens, portanto, passamos aos gregos, dispostos a sofrer, a morrer pela Virtude, pois o seu fruto é superior a ouro, pais, sono. A segunda parte do

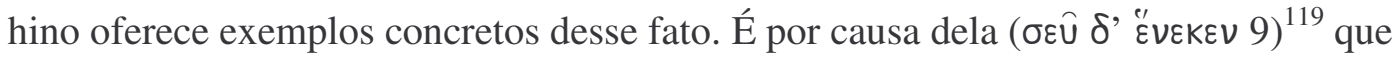
também Héracles e os filhos de Leda penaram, que também Aquiles e Ájax desceram ao Hades, dela sequiosos (9-14). E é por causa dela ( $\sigma \hat{\alpha}_{S} \delta$ ' ' terceira parte, também Hérmias abandonou esse mundo (15-6).

Transitamos assim, da segunda à terceira partes, do passado mítico ao presente dos heróis a Hérmias. A todos une a busca implacável da virtude. Hérmias é o ponto final da trajetória que leva dos semi-deuses (Héracles e Dióscuros) aos heróis homéricos (Aquiles e Ájax) até chegar a um mortal, que com eles partilha a mesma qualidade do empenho pela excelência.

E o término desse percurso é marcado por uma frase que explicita essa inversão graças à qual Hérmias, um mortal (e, de fato, já morto), assume uma característica comum aos deuses. Aristóteles diz que ele, nativo de Atarneu, deixou órfã, deixou viúva ( $\chi \dot{\rho} \rho \omega \sigma \varepsilon v ~ 16)$ a luz do sol. O mais comum seria dizer que ele, ao morrer, abandonou a luz do sol - sendo este um topos poético, ${ }^{120}$ assim como "ver a luz do sol" equivale a

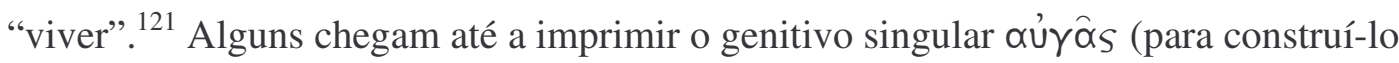

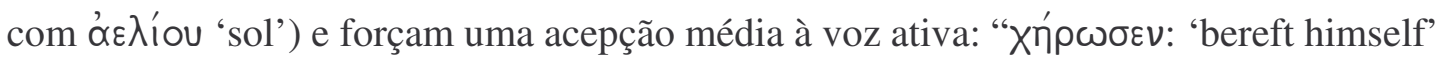

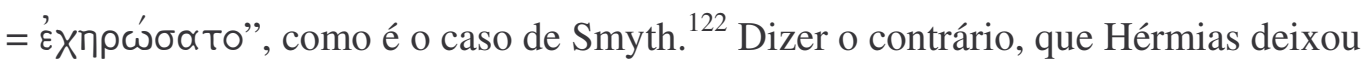
desolada a luz do sol, manifesta a grandeza da qualidade que ele partilha com os heróis, e serve ao mesmo tempo de transição para a seção final do poema (17-21). Nela, tiram-se

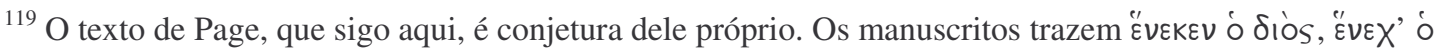

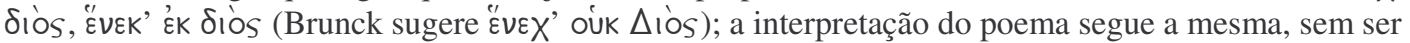
com isso afetada. Mas o kói acrescentado por Page quadra bem no contexto, sendo talvez um exemplo do uso "particularizante" da conjunção, comum em Píndaro, destinada a fazer a ligação entre a afirmação geral e o exemplo particular. Cf. Race (1990), 97 n.33.

${ }^{120}$ Cf. os paralelos citados por Renehan (1982), 266.

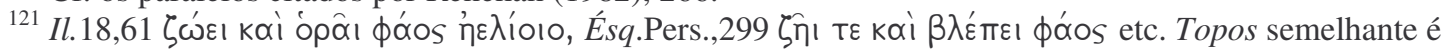
o da tradição indiana do Rig Veda: súryam drśsé 'para ver o sol' ou paśyema súryam 'que nós vejamos o sol' correspondem a "viver", cf. RV $1.23,21 ; 1.50,1 ; 10.9,7 ; 10.57,4 ; 4.25,4 b, 9.4,6 b ; 10.37,8 d$ e Renou EVP 15,1. Trata-se, na verdade, de uma perífrase de origem indo-européia, com vários paralelos na tradição grega, indiana e hitita: cf. Dunkel (1993), 106-8. Ainda sobre a metáfora da luz na poesia indo-européia, cf. Durante (1976), 115-19, esp. 116-7.

${ }^{122}$ Smyth (1900), 468s. Note-se que o torneio inusitado da frase, com aướs no acusativo plural, ecoa o

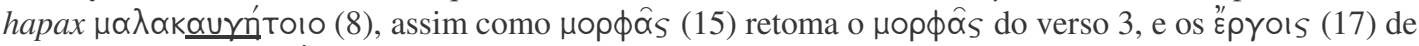
Hérmias espelham os épyoıs (11) de Héracles e dos filhos de Leda. Para uma lista das demais repetições do poema, ver Renehan (1982), 267.
} 
as conseqüências (Toıróp 17) dos versos precedentes. É por ter morrido pela virtude que Hérmias, êmulo de deuses e heróis, será celebrado pelas Musas.

A afirmação, na verdade, é um pouco mais complexa: porque os seus feitos o

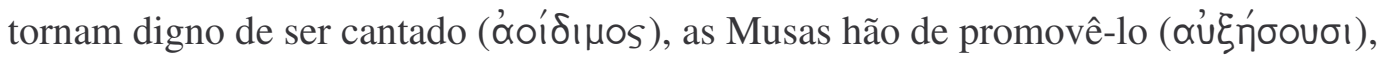

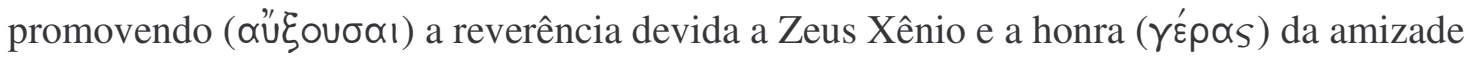

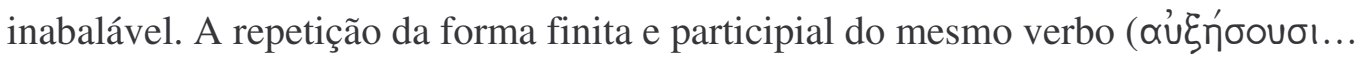

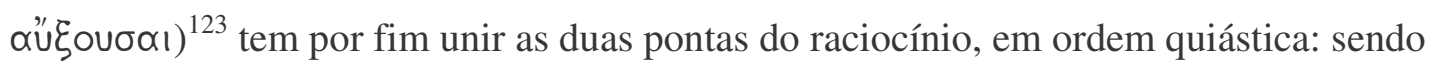
digno e passível de receber um canto, as Musas promovem Hérmias, promovendo a honra

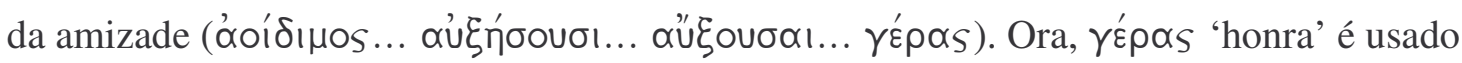
aqui em contexto marcado, assim como $\alpha u ̛ \xi \omega$ 'promover, aumentar'. Ambos referem-se ao canto, e tal campo semântico torna-se patente pelo fato de Aristóteles situar as Musas em seu centro:

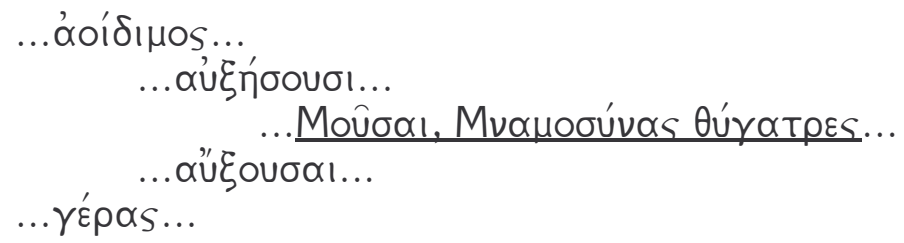

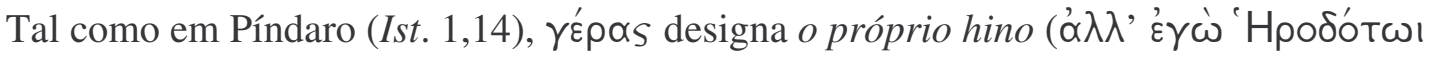

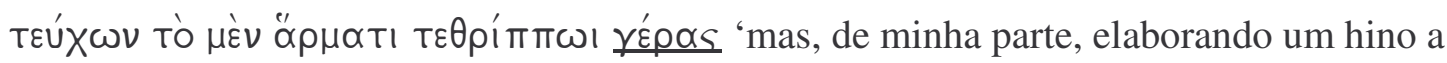

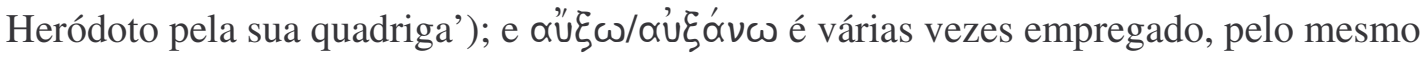
poeta, no contexto do canto que o próprio poeta entoa no momento, por exemplo ${ }^{124}$ Pít.

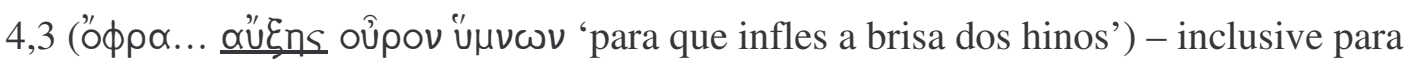

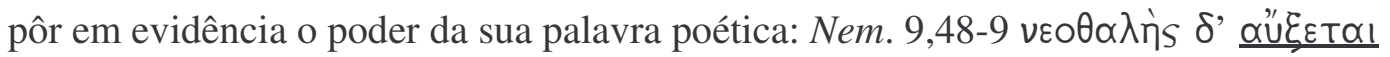

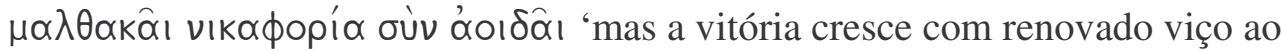

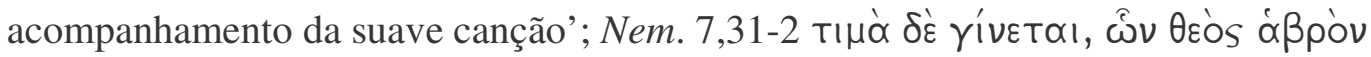

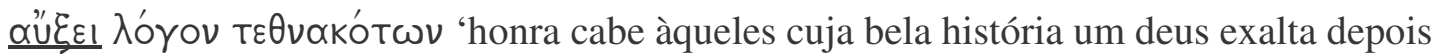
de mortos'. Aqui se dá o mesmo. Mais uma vez, Aristóteles transita do geral ao particular, agora para fechar o foco sobre o seu próprio hino: Hérmias é digno de canto

\footnotetext{
${ }^{123}$ Paralelos do uso honorífico de tal construção em Renehan (1982), 267s.

${ }^{124}$ Cf. demais exemplos em Slater (1969a), ad loc. Que Aristóteles se valha da dicção pindárica é algo plenamente plausível, já que sua fonte de inspiração é Arífron, outro poeta cujo hino é (como tentamos mostrar, item 1.1.4) fortemente influenciado por Píndaro.
} 


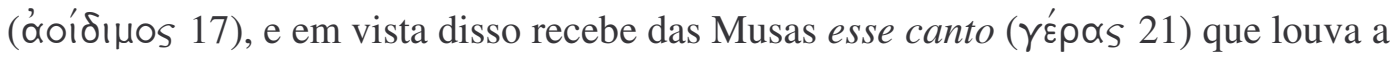
amizade inabalável entre ele e Aristóteles.

Vimos que, na primeira parte (1-8), o autor avança dos homens em geral aos gregos em particular, para então arrolar exemplos específicos do passado mítico na segunda parte, e daí poder chegar ao presente histórico de Hérmias que conclui o poema. Aristóteles parte de uma deusa (Areta), ruma para os semi-deuses (Héracles e Dióscuros), passa pelos heróis (Aquiles e Ájax) e desemboca num mortal (Hérmias), concluindo a obra e fechando o círculo com outra divindade, as Musas. A fim de celebrar a memória do seu amigo, Aristóteles elegeu a forma de um hino pindárico, desses que costumam abrir vários dos seus epinícios (por exemplo, Ol. 4, Ol. 12, Ol. 14, Pít. 8, Íst. 5). Neles, parte-se da divindade e chega-se ao vencedor celebrado na ode: o mortal é louvado pelo vínculo que guarda com o deus ou a deusa, destinatários originais do hino.

Terá sido após a morte de Alexandre, em 323, que um certo Demófilo julgou oportuna a ocasião para acusar Aristóteles de impiedade ${ }^{125}$ pelo hábito de cantar um "peã a Hérmias" (Aten. 696b). Em defesa do filósofo, Ateneu (ou Hermipo, a sua fonte) observa que o texto do poema não invoca Hérmias como deus, pelo contrário: o tirano é descrito como já morto (16). Se não é um peã, a que gênero pertence o nosso poema?

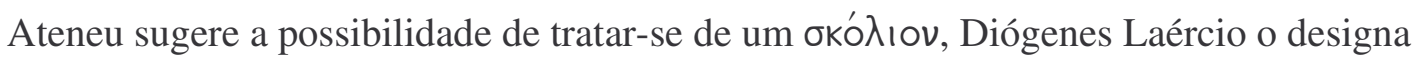
ora como peã $(5,4)$, ora como hino a Hérmias $(5,5)$, e a discussão estende-se até hoje. Harvey, ${ }^{126}$ embora se diga sem esperanças de descobrir-lhe o verdadeiro gênero, inclinase para o бKó $\lambda_{ı}$ ov; Bowra ${ }^{127}$ afirma que Aristóteles moldou o seu poema num peã, mas adicionou-lhe algumas características do $\theta \rho \hat{v}$ os; Renehan ${ }^{128}$ sustenta que não se trata nem de hino, nem peã, nem de skolion, nem de thrēnos, mas de um gênero totalmente diverso, próximo do estilo ditirâmbico. Ora, como vimos até aqui, um dos recursos estilísticos de ampla difusão nos hinos gregos é tomar a divindade louvada como ponto de partida e convergir as atenções (dela e do público) para um caso específico, no qual deus e mortal entram em contato, numa relação de reciprocidade. Outro não é o caso do

\footnotetext{
${ }^{125}$ Parker (2005b), 61: "It is fairly certain that, late in the fourth century, politically motivated accusations of impiety were brought against the philosophers Theophrastus and Aristotle; their pro-Macedonian political stance was widely resented, and the formal charge is likely to have been just a pretext for all concerned, including jurors". Cf. ainda Parker (1996), 276-7, e Rutherford (2001), 92-7.

${ }^{126}$ Harvey (1955), 173 e 162.

${ }^{127}$ Bowra (1938), 186.

${ }^{128}$ Renehan (1982), 256.
} 
nosso poema: ainda que Hérmias tenha sido o estopim para sua composição, o seu

encômio só se sustenta como reflexo do louvor à deusa Virtude (uma abstração personificada), a quem ele persegue e com quem partilha as qualidades. Hérmias, vale dizer, representa um caso paradigmático do poder universal da deusa, cujo louvor precede e possibilita o do mortal. Assim, o hino (pois de hino é que se trata) fornece um pano de fundo contra o qual a ocasião particular sobressai com tanto maior pertinência.

\subsubsection{Píndaro, Neméia 7, 1-8}

Exemplo claro dessa estratégia é um hino introdutório de Píndaro, Nem. 7,1-8.

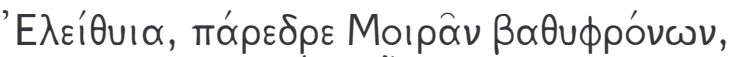

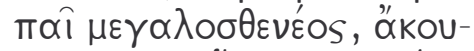

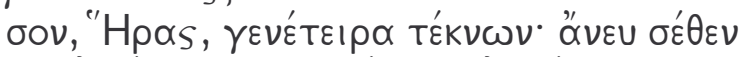

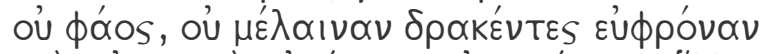

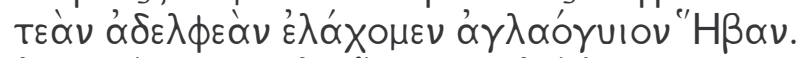

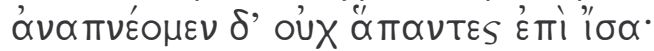

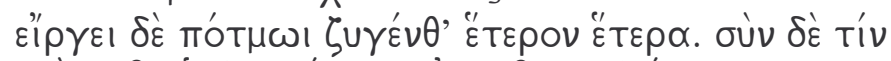

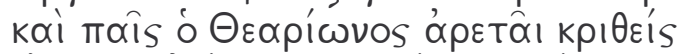

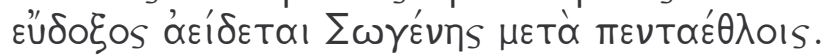

(Elêitia, entronizada ao lado das Moiras de pensamento profundo, filha da poderosa Hera, escuta-me, tu que dás crianças à luz. Sem ti não vemos nem a luz nem a escuridão da noite, nem nos cabe em lote a tua irmã, Hebe (= Juventude) de membros esplêndidos. Ora, nem todos tomamos fôlego para fins iguais, pois coisas diversas compelem cada qual ao jugo do destino. Mas graças a ti o filho de Teárion, Sógenes, é famoso em canção porque se distinguiu pela sua excelência entre pentatletas.)

Sógenes, celebrado nessa ode, é um jovem vencedor do pentatlo; o primeiro movimento de aproximação que leva até ele nesse breve hino a Elêitia é antecipado já na primeira frase (1-4), cujos pólos ${ }^{129}$ são Elêitia - nome que inaugura a sentença - e a sua irmã Hebe - nome que lhe dá fecho. Sem Elêitia, deusa do nascimento, não teríamos existência, não veríamos a noite suceder ao dia, não nos seria dado alcançar a juventude,

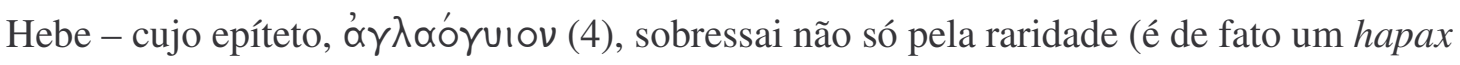

${ }^{129}$ Köhnken (1971), 43 n.35. 
legomenon), mas ainda por indicar a maturidade física para competir ( $\gamma$ viov) e conquistar

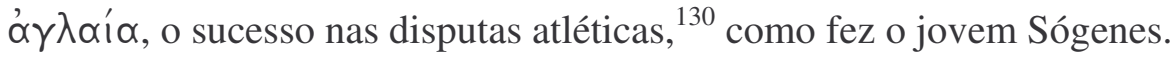

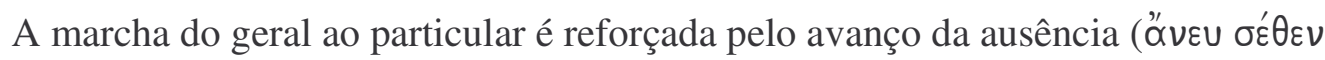

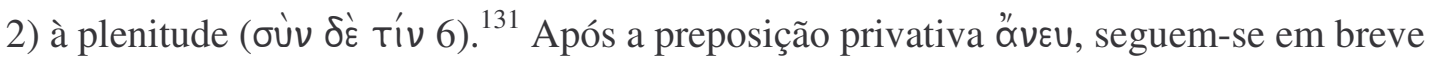
intervalo duas partículas negativas (oủ... oú), acompanhadas de um tricólon crescente

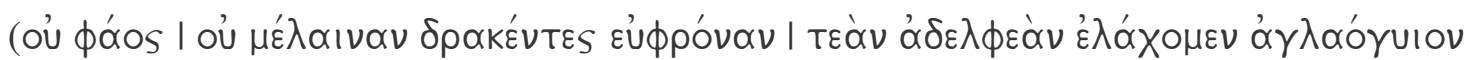
" $H \beta \propto v)$, numa frase que a todos iguala - inclusive a Sógenes - em nossa natureza humana,

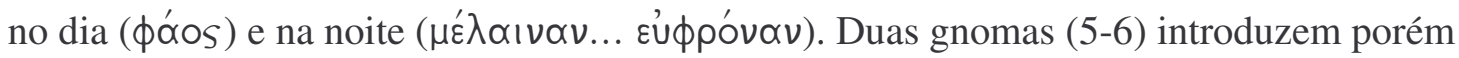

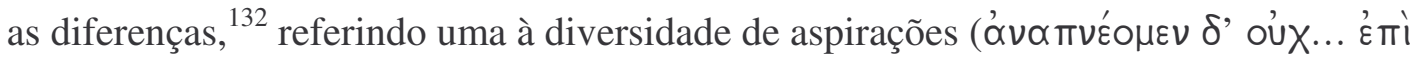

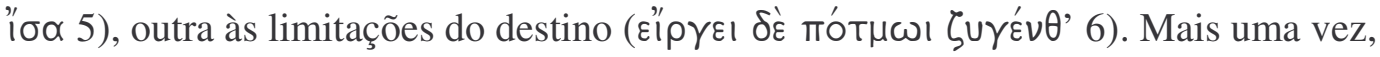

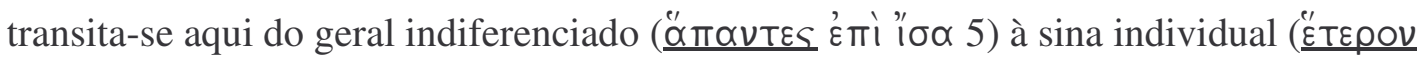

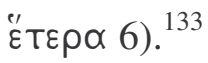

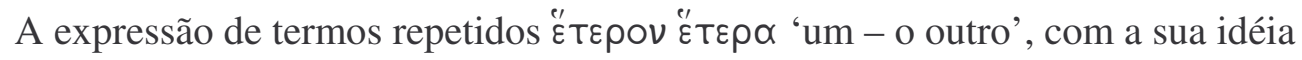
latente de reciprocidade, prepara então a inversão de sinais, do negativo ao positivo: бùv

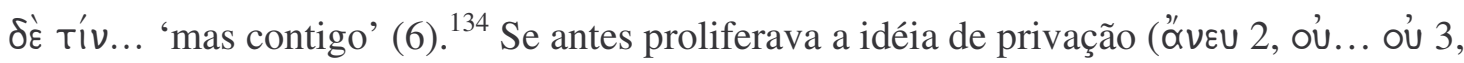

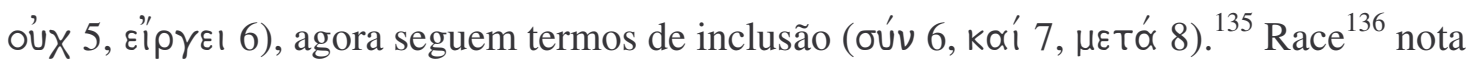
que esse kóí, que ele denomina "particularizante", é de uso especial, com vários paralelos nos epinícios de Píndaro, sobretudo antes de pronomes e nomes próprios em passagens de clímax, nas quais as reflexões precedentes são aplicadas ao caso em questão ${ }^{137}$ - aqui, à vitória de Sógenes no pentatlo.

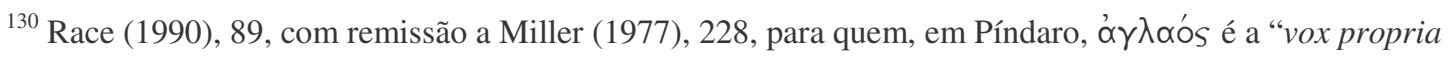
descriptive of agonistic success".

${ }^{131}$ Cf. o peã de Arífron, acima (item 1.1.4).

${ }^{132}$ Race (1990), 89.

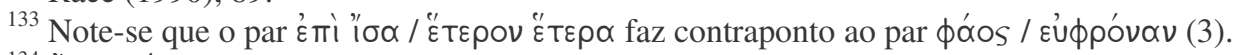

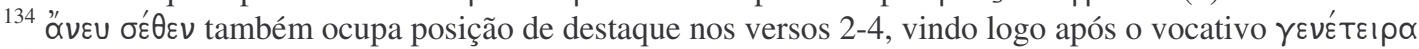

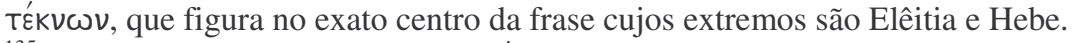

${ }^{135}$ Sobre a evolução sintática de $\mu \varepsilon \tau$ đó, cujo sentido original é "no meio de", "entre", ver Wackernagel (1924), vol. 2, 240-48.

${ }^{136}$ Race (1990), 89 n. 15 e 97 n.33.

${ }^{137}$ Interessante é observar que a conjunção coordenante $u t a ́$, numa passagem do Rig Veda (3.7,10), revela um uso particularizante análogo ao nosso kơí: proșáprayajo dravị̣aḥ suvăcaḥ suketáva uṣáso revád ūṣuh / utó cid agne mahiná prthivyặ̣ krtám cid énạ̣ sám mahé daśasya 'As auroras, de quem o culto matinal traz força, dotadas que são de boas palavras, portadoras de boa chama, brilharam ricamente, ó riqueza. / E agora portanto, ó Agni, pela grandeza da terra, perdoe o pecado cometido para (a nossa) grande (satisfação)'. Klein (1985), 458, comenta: "In this stanza the poet deals for the first time with the hic et nunc. The sense 'therefore' can take as its causal basis all of what precedes (understood as an offering which the god may
} 
De Elêitia descemos a Sógenes, portanto, em etapas, as quais levam de Elêitia a

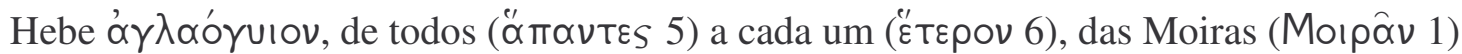

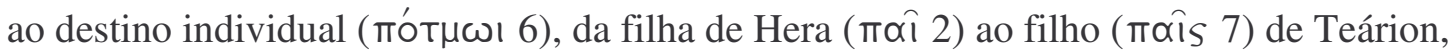
da ausência à presença. Ausência, aliás, marcada por verbos e particípio ativos

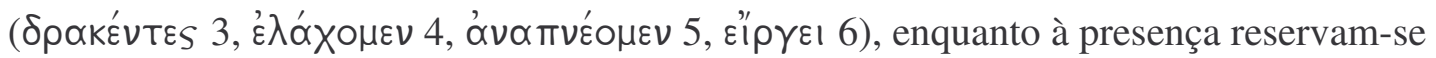
em contraste verbo e particípio passivo ( distinguido-se pela sua excelência, torna-se famoso em canção (notar o uso proléptico de

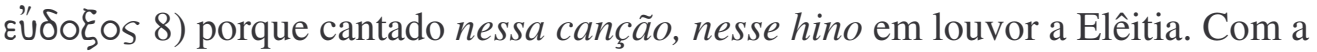
referência que o hino faz a si próprio, atingimos o ponto máximo de especificação no trajeto iniciado com a palavra que o inaugura. Do contexto negativo, ditado pela privação, passamos à presença positiva - de Elêitia, Hebe, Sógenes e ainda do próprio hino em louvor à divindade que primeiro o tornou possível.

\subsubsection{Hino Homérico a Héracles}

Do negativo ao positivo é também o caminho percorrido por outro pequeno hino, este homérico: o Hino Homérico a Héracles $\left(\mathrm{n}^{\circ} 15\right)$.

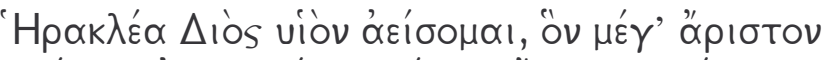

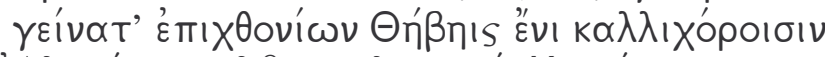

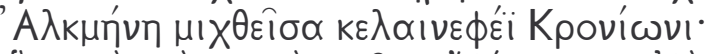

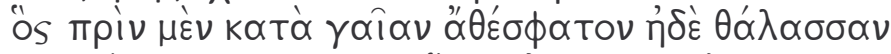

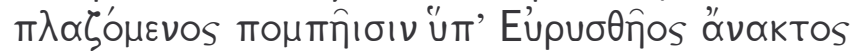

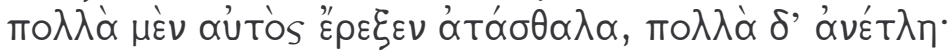

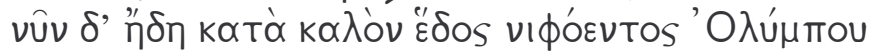

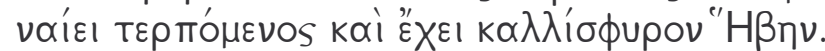

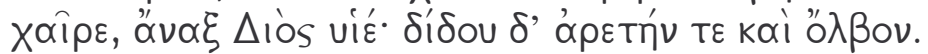

(Cantarei Héracles, filho de Zeus, de longe o melhor dos mortais, nascido em Tebas das belas danças, da união de Alcmena com Zeus das nuvens escuras. No passado ele vagou pela vastidão de terra e mar sob as ordens do rei Euristeu, causando ele próprio muito sofrimento e padecendo outro tanto. Mas agora na bela morada do nevoento Olimpo ele vive em prazer e tem Hebe dos belos tornozelos como sua esposa. Salve, senhor rei, filho de Zeus! Dá virtude e fortuna!)

requite with favour) or merely the pragmatic appearance of the dawn, the occasion of the morning worship to Agni". 
Divide-se em três partes o poema, cada uma com três versos. Nos versos 1-3, o poeta usa o tempo futuro do verbo para afirmar que cantará Héracles, no acusativo, e acrescenta uma frase relativa que lhe detalha a ascendência, divina e terrena. Tempo futuro, acusativo ("Er-Stil") e frase relativa são elementos hínicos tradicionais, sobretudo nos hinos homéricos, como tradicional é também o relato da genealogia divina. Versos 46 abrem com um novo pronome relativo, inaugurando a narrativa histórica localizada no

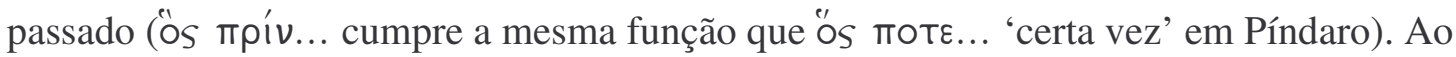
final dela, após ficarmos sabendo das peregrinações de Héracles por terra e mar à mercê dos caprichos de Euristeu, torna o poeta ao tempo presente que preenche a terceira e última parte (7-9), na qual se formula o pedido.

Do passado ao presente é clara a mudança do pior ao melhor. Da terra e mar onde errara pelas vastidões ( $\propto$ ' $\theta \dot{\varepsilon} \sigma \phi \propto$ Tov 4), Héracles transita ao Olimpo, onde agora tem sede fixa $(" \varepsilon \delta \circ 7) ;{ }^{138}$ se antes fora causa e ao mesmo tempo objeto de sofrimento, se muito mal suscitara e muito mal padecera (

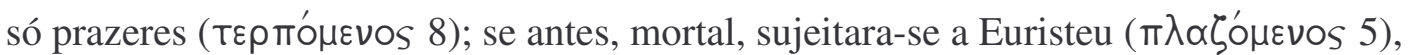
agora, imortal, ele tem por mulher ( ${ }^{\prime} \chi \chi \mid$ । 8) Hebe - a eterna juventude. Mesmo em termos neutros, a progressão é manifesta: de Tebas (2), onde nasceu, Héracles fixa moradia no Olimpo (7); de filho de Alcmena e Zeus (3), agora passa a marido de Hebe (8).

Papel importante desempenham também os ecos vocabulares e sonoros, dispostos em forma de anel:

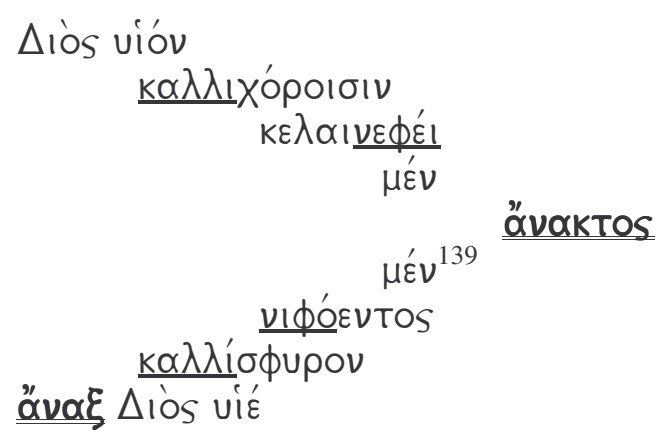

\footnotetext{
${ }^{138}$ Cf. Haubold (2001), 28, que também nota essa evolução.

${ }^{139} \mathrm{O}$ segundo $\mu \dot{\varepsilon}^{\prime} v$ ecoa o primeiro por intercalar-se entre ele e o $\delta^{\prime} \varepsilon$ ( $\left.\nu \hat{v} \nu \delta^{\prime} 7\right)$ que lhe corresponde. Trata-se de uma característica da linguagem homérica: o segundo $\mu$ '́v não é simples repetição do primeiro, como é comum na prosa, mas compõe uma nova oposição (

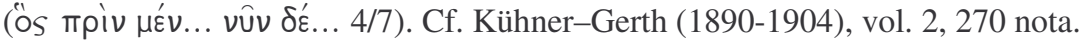


De Euristeu, o "mau” senhor (ővaktos 5) do centro do hino, passa-se a Héracles,

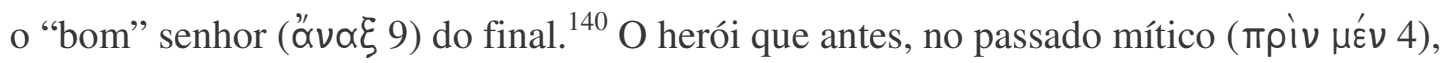
era servo, agora, no presente momento em que o hino é entoado ( $\nu u ̂ v \delta ' 8)$, transforma-se em senhor. Com isso é possível fazer-lhe o pedido - a ele, que da terceira pessoa ( $\Delta$ ios

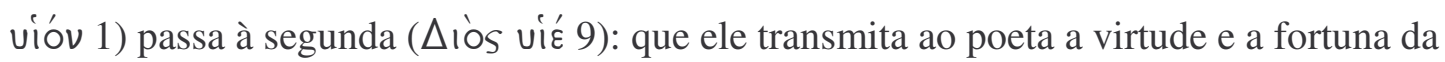
qual ele próprio se fez senhor no transcorrer do hino, com a sua apoteose. A dádiva só se torna viável em razão do progresso descrito pelo hino, do qual Héracles é o beneficiário e

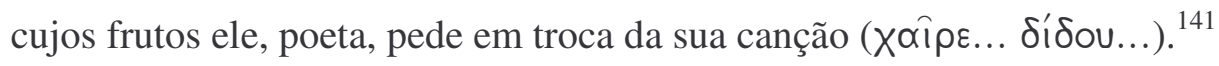

\subsubsection{Hino Homérico a Hefesto}

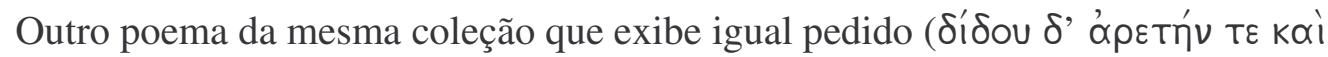
o’ $\lambda$ ßov), e cuja progressão de um estado negativo para outro, positivo, faz lembrar nosso hino a Héracles, é o Hino Homérico a Hefesto $\left(n^{\circ} 20\right)$.

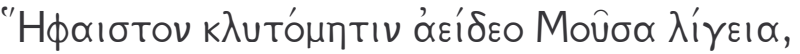

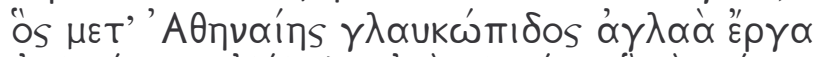

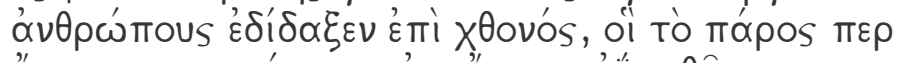

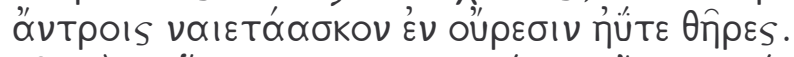

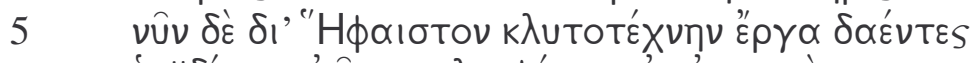

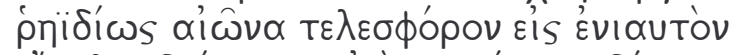

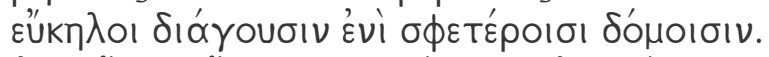

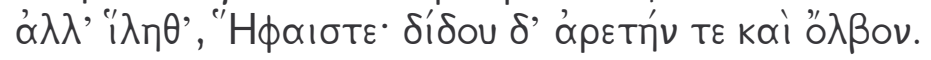

(Canta, ó Musa de clara voz, Hefesto famoso pelo seu engenho, ele que com Atena de olhos cinzas ensinou esplêndidos ofícios aos homens dessa terra, que antes costumavam viver em cavernas nas montanhas feito animais selvagens. Mas agora que aprenderam ofícios com Hefesto, famoso pela sua perícia, eles passam a vida à vontade em suas casas durante o ano inteiro. Sê assim favorável, Hefesto: dá virtude e fortuna!)

Assim como o Hino Homérico a Héracles, nosso hino a Hefesto ${ }^{142}$ inicia com o deus no acusativo e acrescenta duas frases relativas, a segunda das quais conduz, lá como

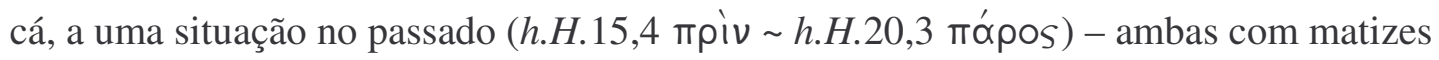

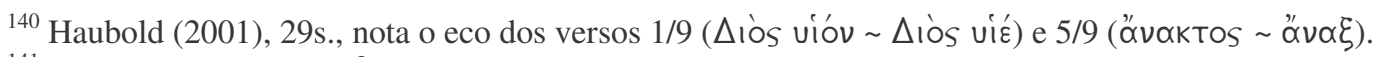

${ }^{141}$ Cf. discussão sobre $\chi \propto \hat{\imath} \rho \varepsilon$, capítulo 4.

${ }^{142}$ Paralelos apontados por Haubold (2001), 32.
} 
negativos. Em seguida passamos a épocas melhores, já no presente ( $\nu \hat{v} \nu \delta^{\prime} \varepsilon$, h.H.15,7

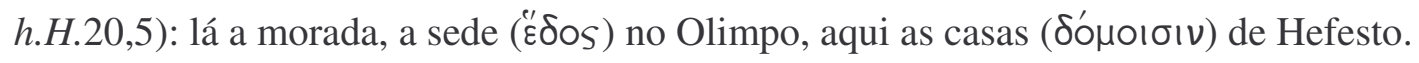

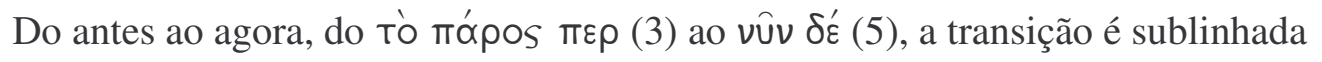

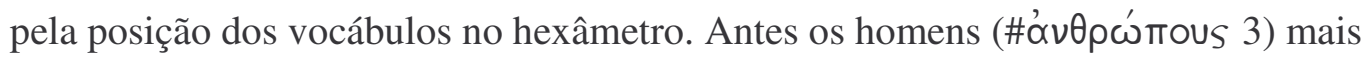

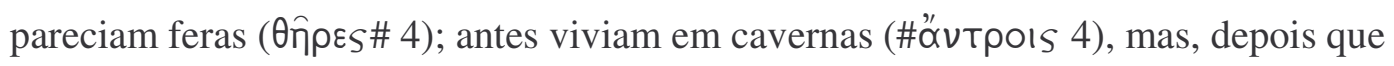

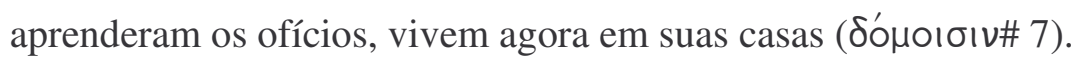

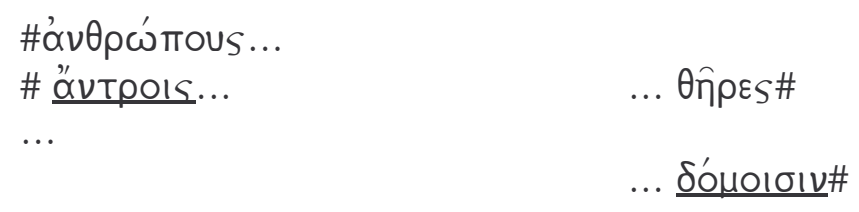

Cavernas e casas são os dois pólos, inicial e final, da evolução. Tendo aprendido

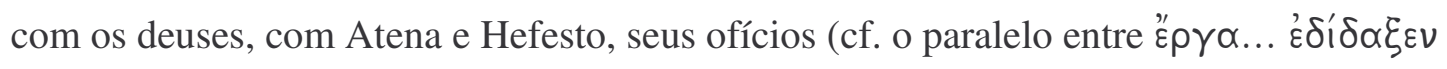
2-3 e ع

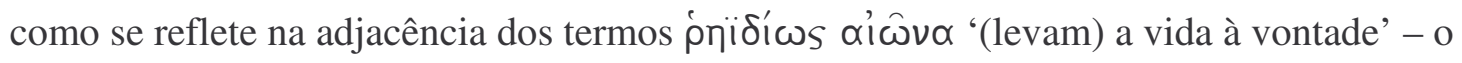
primeiro usado em geral para descrever os deuses, ${ }^{143}$ o outro empregado exclusivamente (ao menos na épica) em relação aos mortais. ${ }^{144}$ De feras selvagens, pois, que no passado costumavam viver em cavernas - voıє Tó đoKov (4) é um imperfeito iterativo ${ }^{145}$ carregado de sentido -, agora os homens levam sua vida à vontade, livre de preocupações (ṕïííss

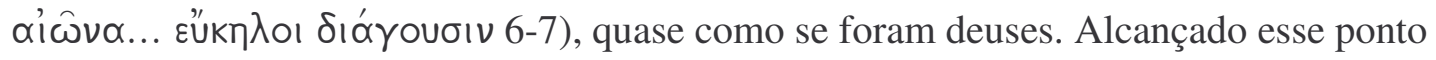
da narrativa, num presente que expressa a complementaridade entre deuses e mortais, é lícito proceder ao pedido: ${ }^{146}$ que Hefesto dê virtude e fortuna. Virtude e fortuna, de resto, das quais o deus é responsável, segundo a evolução traçada pelo próprio hino.

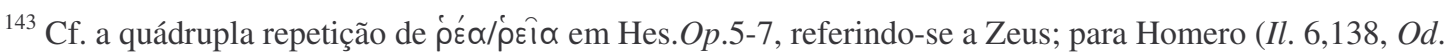

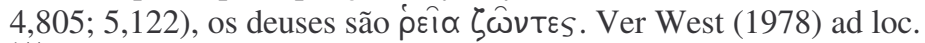

${ }^{144}$ Haubold (2001), 36s., a quem devemos a observação sobre estes termos, nota ainda dois outros paralelos

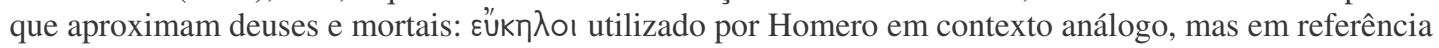
aos deuses (Il. 11,75-7), e o fato de que certos deuses da narrativa hínica (Dioniso, HHom.1; Hermes, HHom.4 e 18; Dióscuros, HHom.27) costumam transitar da caverna ao Olimpo no curso do relato.

${ }^{145}$ Mais exato é falar, nesse caso, de um imperfeito "intensivo" ou "durativo", pois não se trata de ações repetidas, nas quais o sufixo - бKov é acrescentado a um predicado dinâmico, mas de uma ação que não se repete, na qual o sufixo refere-se a uma situação estática. Cf. Zerdin (2002), 122: "we are not to understand that the state broke off and was repeated later, but that it was once the case, and is no longer".

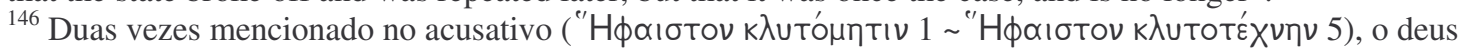

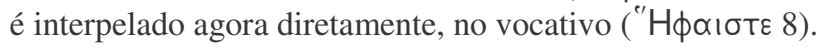




\subsubsection{Píndaro, Olímpica 12}

Um derradeiro exemplo desse tema hínico grego que conduz do estado negativo ao positivo até chegar ao presente glorioso da narrativa: a Olímpica 12 de Píndaro.

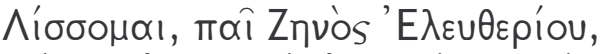

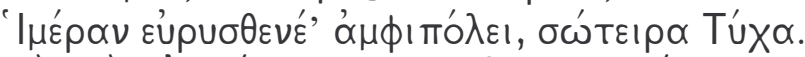

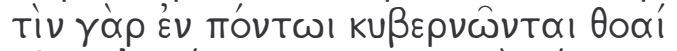

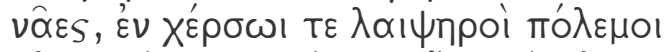

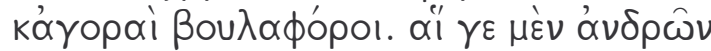

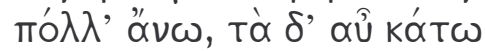

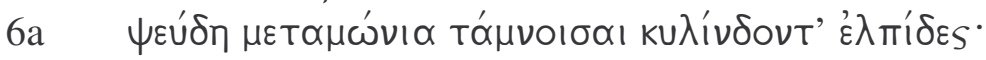

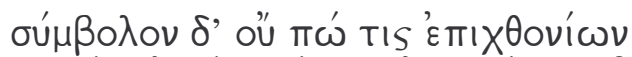

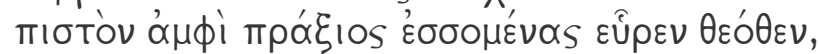

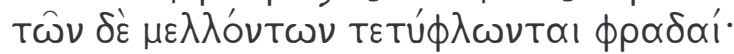

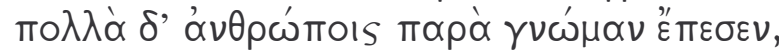

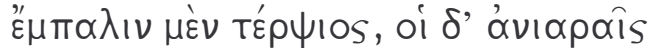

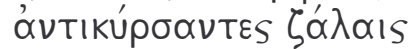

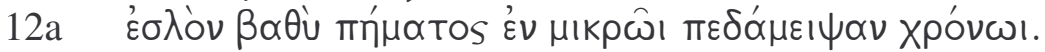

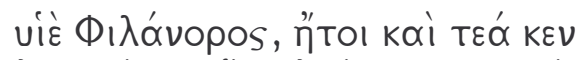

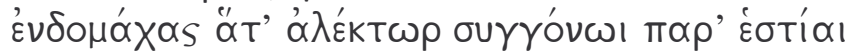

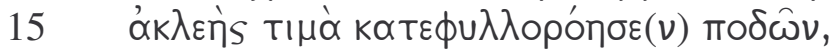

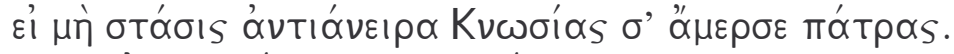

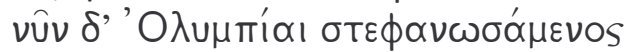

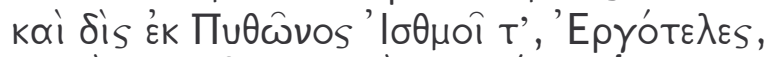

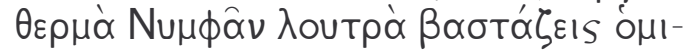

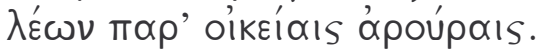

(Rogo-te, filha de Zeus Libertador, preserva o poder de Himera, ó Boa-Fortuna salvadora. Pois és tu que no mar guia barcos velozes, e na terra batalhas ligeiras e assembléias que dão conselho. Quanto às esperanças dos homens, muitas vezes elas sobem, outras vezes rolam ladeira abaixo por entre mentiras vãs. /

Nenhum mortal descobriu ainda um sinal seguro dos deuses acerca de uma ação iminente; os seus planos para o futuro escapam à vista. Muitas coisas sucedem aos homens ao arrepio do seu julgamento, uma hora contrárias a seu gosto, outra hora aqueles que enfrentaram tempestades atrozes trocam a sua dor por um bem profundo em breve espaço de tempo. /

Filho de Filânor, verdade é que a honra dos teus pés, feito um galo local de briga junto ao lar nativo, teria deixado cair as tuas penas de forma inglória, não fosse uma facção hostil haver-te deprivado da pátria. Mas agora, tendo conquistado uma coroa em Olímpia e duas vezes em Pito e no Istmo, Ergóteles, tu exaltas os banhos quentes das ninfas, no convívio com terras que são as tuas próprias.) 
Invocação e pedido endereçado à deusa Túx $\alpha^{147}$ são feitos de forma sucinta nos dois primeiros versos. Segue-se daí um esboço dos seus poderes universais em terra e mar, na guerra e na paz (3-5). Quanto aos homens, como eles lidam com tais poderes isso é descrito em um notável hipérbato introduzido pela adversativa $\gamma \varepsilon \mu \mu^{\prime} \nu$ (5):

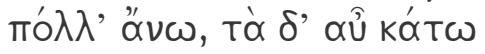

@i $\gamma \varepsilon \mu \dot{\varepsilon} \nu \stackrel{\alpha}{\alpha} \delta \rho \omega \hat{\nu} \nu$

$6 \mathrm{a}$

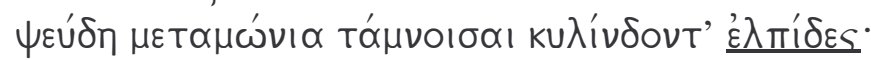

No intervalo de 24 sílabas entre artigo e substantivo, as expectativas humanas sobem e, no mesmo verso, tornam a baixar ${ }^{148}$ em rodopio até a última palavra do verso seguinte, a qual empresta (só então) sentido à frase. A antístrofe inicia na mesma chave negativa, e explica a razão pela qual tanto oscilam as esperanças: é que não se dispõe de sinal seguro, vindo dos deuses, para as ações; os seus planos nos escapam à vista. ${ }^{149} \mathrm{E}$ a conseqüência disso é esta, vertida em uma gnoma: muitas coisas sucedem aos homens ao contrário do que julgam (10). Entre elas, diz o verso seguinte, umas são desagradáveis (

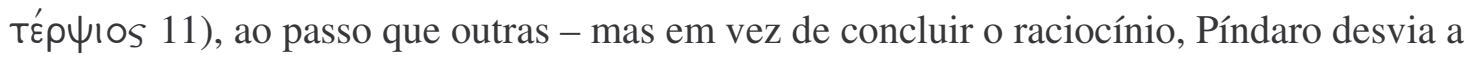
sintaxe para pôr agora em foco os próprios agentes (oi $\delta$ ' 11), ${ }^{150}$ e encerra a antístrofe,

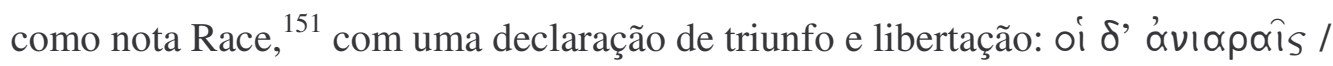

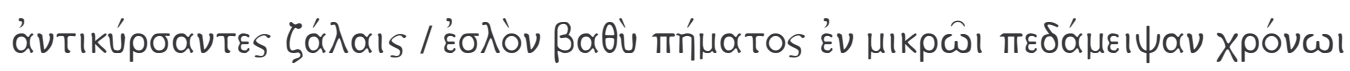
'aqueles que enfrentaram tempestades atrozes trocam a sua dor por um bem profundo ${ }^{152}$ em um breve espaço de tempo'.

Do cenário negativo, que dominara o final da estrofe e boa parte da antístrofe, passamos ao quadro positivo da salvação e do bafejo súbito da sorte. Cria-se a sensação

\footnotetext{
${ }^{147}$ Opto traduzir tukha por "boa-fortuna" uma vez que, para Píndaro, ela não se resume ao mero acaso; seu papel é sempre positivo, como manifestação das vontades divinas. Para uma discussão em detalhes da tukhe em Píndaro, ver Strohm (1944), 1-82, 96-9, e Thummer (1957), 90-109.

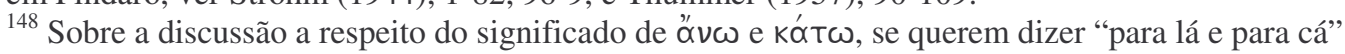
(movimento lateral) ou "para cima e para baixo" (movimento vertical), cf. Race (2004), 378-80. Sobre a função coesiva do artigo, cf. Hummel (1993), 186s. Acerca do valor estilístico da separação entre artigo e substantivo, cf. Dornseiff (1921), 108: "Ein nachträgliches, retardiertes Subjekt hat größeres Gewicht”.

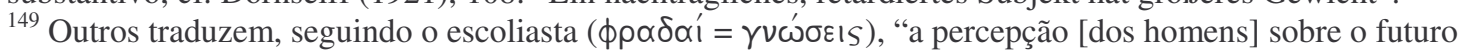
é cega”. Numa e noutra interpretação, porém, o sentido negativo mantém-se. Cf. Race (2004), 381.

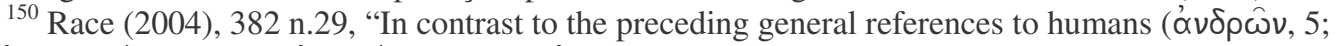

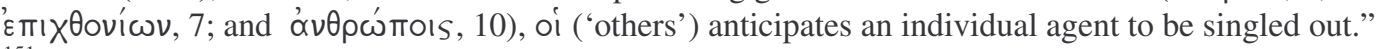

151 Race (2004), 382.

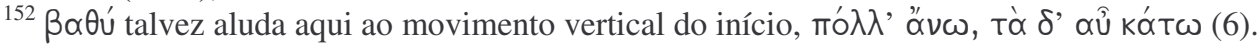


de um fecho, sobretudo porque o final da antístrofe traz à lembrança o epíteto de Tukha

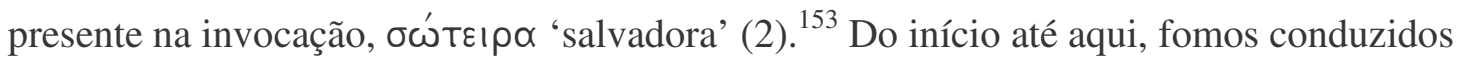
do mar ( $(4-5)^{154}-$, e da terra aos homens em geral. A fim de manter a atmosfera negativa com que fechara a estrofe, Píndaro faz avançar a antístrofe por meio de duas partículas $\delta^{\prime} \varepsilon$, uma explicativa (7), outra conclusiva (10). ${ }^{155}$ Agora, dos homens em geral, ele foca a atenção - mediante a ruptura sintática do oi $\delta^{\prime}(11)$ - naqueles que se valeram da ação benéfica de Tukha. O ambiente está pronto para aproximar ainda mais a lente de um caso concreto que dê corpo às idéias gerais desenvolvidas ao longo de estrofe e antístrofe. E este é dado por Ergóteles, introduzido de forma abrupta na apóstrofe que abre o epodo.

Entre o geral e o particular, a ligação é feita pelas palavras n̋'oı kớ (13). ${ }^{156}$ Não fosse ele ter sido privado da pátria (Creta) por uma facção inimiga (cenário negativo), não lhe teria sido possível sagrar-se vencedor olímpico (cenário positivo). Do contexto hipotético do que teria acontecido caso, no passado, ele não houvesse sofrido o exílio, passamos através do vûv $\delta \varepsilon ́(17)$ - tal como nos Hinos Homéricos a Héracles e a Hefesto - ao tempo presente, no qual o exemplo específico de Ergóteles é coroado de sucesso graças à boa ação da deusa. Também ele enfrentou tempestades atrozes e trocou a dor pelo bem profundo (12a) na sua trajetória de Creta a Olímpia, culminando em Himera e seus banhos termais.

Fecha-se assim definitivamente o círculo do poema, que termina em Himera tendo

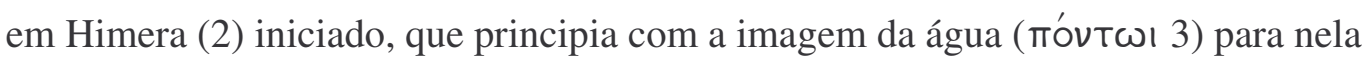

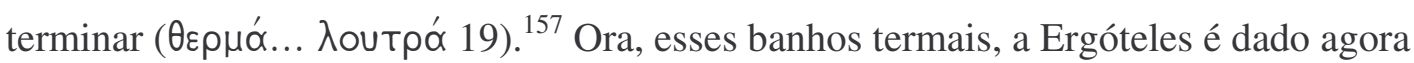

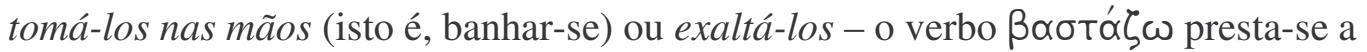
ambos os sentidos. Nessa segunda acepção, o verbo é o mesmo usado por Píndaro para a atividade poética, como em Íst. 3,7-8:

\footnotetext{
${ }^{153}$ Race (2004), 382.

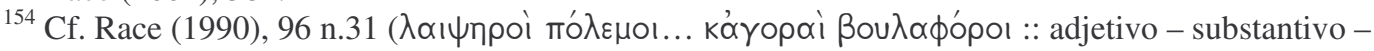
substantivo - adjetivo)

${ }^{155}$ Cf. Verdenius (1987), 96 e 97; não se tratam, portanto, de partículas adversativas.

${ }^{156}$ Cf. Race (2004), 383: "the ク̆тoı [...] looks back to the general observations, whereas the kơi points ahead to the specific example".

${ }^{157}$ Himera é famosa pelas suas fontes termais como pelo seu poder naval. Para a imagem da água no poema, cf. Kurke (1991a), 32-4.
} 


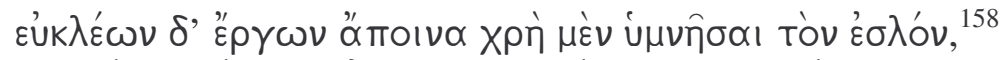

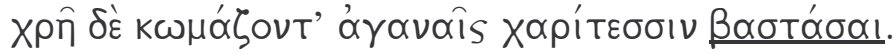

(Em recompensa por feitos gloriosos, há que celebrar-se o homem de prol, há que exaltálo, enquanto ele comemora, com delicados poemas de louvor.)

Píndaro funde assim, num verbo ambíguo, vencedor e poeta (ele próprio), ou antes, faz do seu hino, no qual louva Tukha, o ponto de chegada - o resultado último das ações da deusa em sua trajetória do universal ao exemplo específico de Ergóteles, cidadão de Himera, cidade famosa (inclusive graças ao nosso hino) pelas suas fontes termais.

\subsubsection{Hesíodo, Os Trabalhos e os Dias (1-10)}

O exemplo específico como termo do percurso pode resultar também de uma composição em anel, como no hino a Zeus que constitui o proêmio dos Trabalhos e os Dias de Hesíodo. ${ }^{159}$

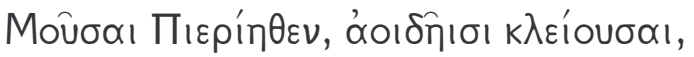

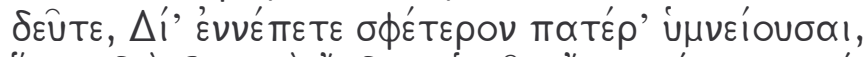

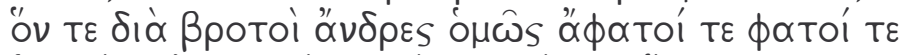

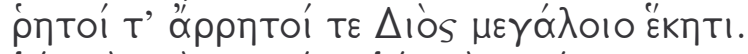

5 '

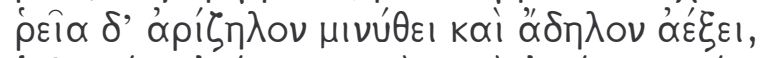

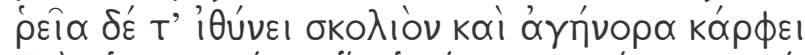

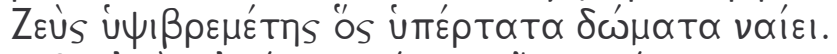

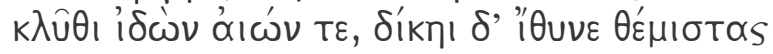

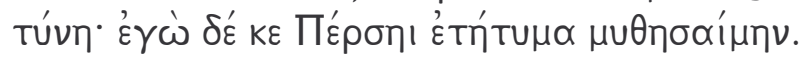

(Musas de Piéria, que glorificam pelas canções, vinde a mim, falai de Zeus vosso pai em vosso canto. Por causa dele os mortais não são mencionados ou são mencionados, são falados ou não são falados, segundo a vontade do grande Zeus. Pois facilmente ele torna forte, e facilmente ele oprime o forte, facilmente ele diminui o conspícuo e magnifica o inconspícuo, e facilmente torna o torto direito e faz murchar o orgulhoso - Zeus que troveja do alto, que habita as moradas mais elevadas. Escuta enquanto vês e ouves, e julga de maneira reta com justiça, senhor; eu, por minha vez, gostaria de dizer a Perses coisas verdadeiras.)

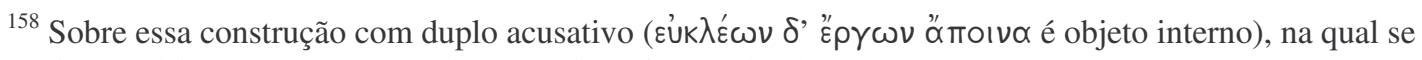
equipara o hino e a recompensa do vencedor, cf. Jacquinod (1989), 119-20.

${ }^{159}$ Sobre a composição em anel, ver Otterlo (1944).
} 
Das Musas até Perses, interlocutor de quem se ocupará Hesíodo no restante do poema, esse breve hino faz o louvor de Zeus em versos repletos de figuras retóricas. West, em seu comentário, ${ }^{160}$ indica a maioria delas: "anáfora (5-7), quiasmo $(3-4,7)$, frases balanceadas que resultam em rima (1-2, 5-8), e talvez figura etymologica em 2-3" (ou seja, jogo etimológico entre o teonímico e a preposição posposta, em posição métrica

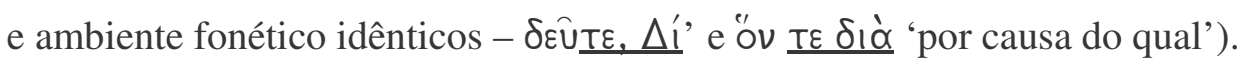

Mas o cuidado artístico do poeta vai mais além. Watkins ${ }^{161}$ aponta ainda outros artifícios que dão um colorido todo especial ao poema. Como vimos, West já indicara a anáfora de ṕعi̊ nos versos 6-7 e o quiasmo de verbo-objeto-objeto-verbo no verso 7:

6 'ं

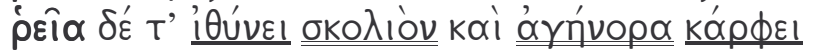

'facilmente ele diminui o conspícuo e magnifica o inconspícuo, e facilmente torna o torto direito e faz murchar o orgulhoso.'

Além desse quiasmo "horizontal", Watkins enxerga outro, "vertical", entre os versos 6 e 7, com a ordem inversa dos elementos constituintes junto à cesura:

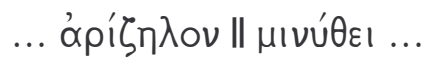

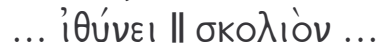

... objeto II verbo ...

... verbo II objeto ...

O contraste é sublinhado aos ouvintes pelo eco fonético entre os dois verbos:

... arizēlon $\|$ mINUTHEI ...

... ITHUNEI II skolion ...

No último verso (10), outro jogo significativo. "A Perses", afirma Hesíodo, "eu diria

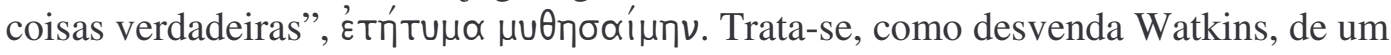
palíndromo dos elementos "verdade" e "dizer", que pode ser lido igualmente de trás para frente.

\section{etĒTUMA MUTHĒsaimēn}

Essa inversão fonética chamaria assim a atenção, segundo Watkins, para a estrutura em anel (fonética e semântica) que emoldura o poema:

${ }^{160}$ West (1978), ad loc.

${ }^{161}$ Watkins (1995), 100s., de quem reproduzo os esquemas. 
MOUSAI — MUthēSAImēn ${ }^{162}$

Das Musas de que parte o hino - um hino cuja estilização faz o ouvinte atentar a cada passo para a sua própria arte - somos conduzidos, via Zeus, até ao verbo final na primeira pessoa do singular, $\mu \cup \theta \eta \sigma \alpha$ í $\mu \eta \nu$ 'eu diria'. Poeta e Musas são assim postos em proximidade, como próximo também se tornou Zeus, interpelado diretamente nos dois últimos versos tal como as Musas haviam sido nos dois primeiros, e de quem o poeta

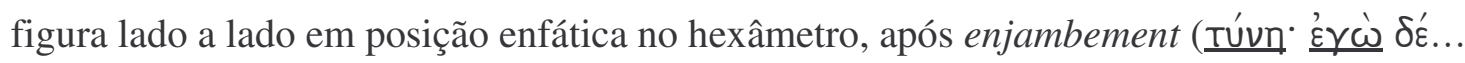

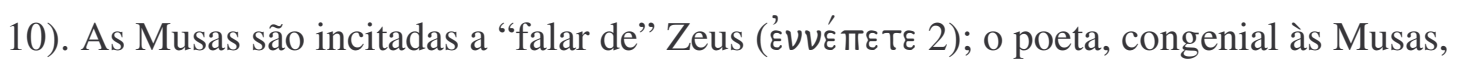
expressa seu voto de dizer ( $\mu \cup \theta \eta \sigma \alpha i ́ \mu \eta \nu)$ coisas verdadeiras a Perses, exemplo específico a que serão dedicados então os versos remanescentes da obra.

Aproximar divindade e poeta que a canta é estratégia comum dos hinos. E não só nos hinos cléticos, ${ }^{163}$ nos quais o recurso é manifesto e corriqueiro, mas também naqueles que se valem de artifícios mais sofisticados, embora nem por isso menos eficazes. Cito dois exemplos, um singelo hino clético e um elaborado peã cultual: Safo, fr. 2, e Píndaro, Peã 6. O primeiro, uma invocação a Afrodite de natureza pessoal, dir-se-ia literária, para récita entre amigos; o segundo, um hino encomendado para celebrar um culto específico, um festival - a Teoxenia em Delfos. Ambos dão prova eloqüente de que é equivocado equiparar tout court hinos "literários" à complexidade e hinos "cultuais" à banalidade de conteúdo e dicção.

\subsubsection{Safo, fr. 2 V}

Mas passemos a Safo, fr. 2 Voigt.

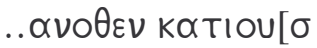

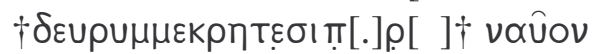

ớ

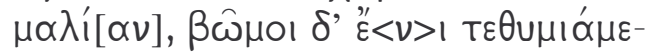

4

vol $\left[\lambda_{1}\right] \beta \alpha v \omega \dot{\tau} \omega<1>$.

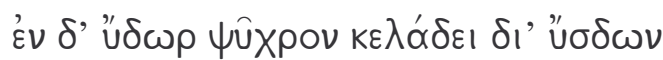

\footnotetext{
${ }^{162}$ Watkins chama essa figura de "Saussurian hypogram". Sobre o fenômeno, ver Starobinski (1971).

${ }^{163}$ Sobre os chamados "hinos cléticos" ver Menandro Retor, 334,25-336,4, com as respectivas notas de Russell e Wilson (1981).
} 


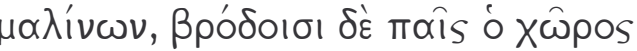

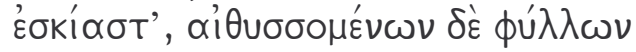

8

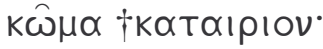

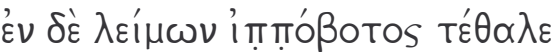

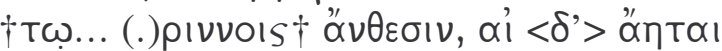

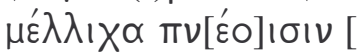

12

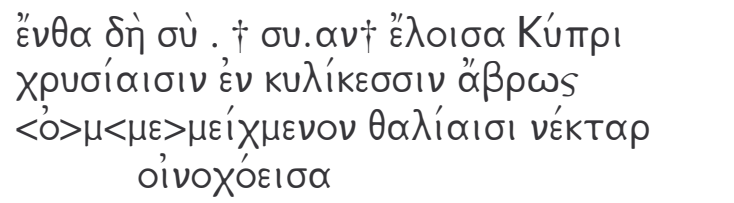

(Para cá até mim, vem! de Creta, a esse templo sagrado, onde fica o teu agradável bosque de macieiras, e altares com a fragrância do incenso que arde; nele a água fresca rumoreja por entre ramos de macieira, e o sítio inteiro é sombreado por rosas, e das folhas que tremeluzem desce ${ }^{164}$ um leve estupor; nele um prado onde pastam os cavalos viceja com flores primaveris, e suave é a brisa que sopra ... ; lá, deusa cipriota, pega ... e verte com graça, em cálices dourados, néctar mesclado a nossas festividades.)

Afrodite é chamada a vir de Creta para as festividades celebradas em um dos seus recintos sagrados. Safo os descreve - o templo, o bosque, o altar - a fim de atrair a deusa, e na mescla de impressões auditivas, olfativas e visuais - o rumor das águas, o aroma do incenso, a sombra das rosas - procura torná-los dignos aos olhos de Afrodite. A ela será dada uma acolhida à altura, parece dizer a poetisa. Mas esses locais evocam ao mesmo tempo o ambiente simpótico, onde a deusa, em meio à companhia, serve néctar à maneira de vinho em cálices dourados.

Nas três primeiras estrofes as imagens descritas guardam uma certa relação com o culto a Afrodite, em suas diversas localidades - maçãs, flores, cavalos, primavera. ${ }^{165}$ Ao terminarmos a quarta estrofe, porém, o que eram atributos cultuais destinados a seduzir a divindade a participar do seu festival transformam-se em atributos de um simpósio - uma atmosfera tão adorável quanto serena (cf. $\kappa \hat{\mu} \mu \alpha$ $\kappa \propto \tau \propto \rho \rho \varepsilon \hat{\imath}$ 8), uma reunião entre amigos, um festival privado.

$\mathrm{Na}$ interjeição que abre o hino, Safo convida Afrodite a juntar-se a ela ( $\delta \varepsilon u ̂ \rho u ́ ~ \mu ’$

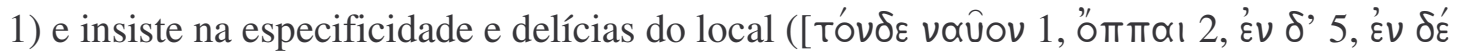

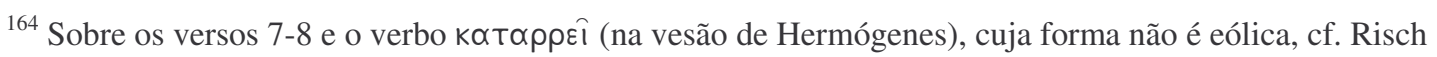
(1962).

${ }^{165}$ Bowra (1961), 197.
} 
9). Delícias que acabam por persuadir a deusa, pois, chegada a quarta estrofe, lá está ela

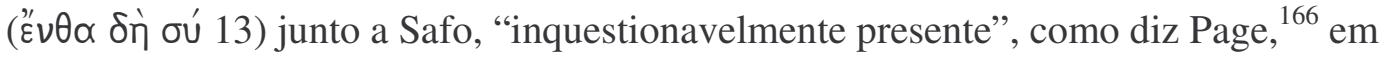
meio às festividades, a ponto de lhe ser dirigido, se aceitarmos o suplemento de Lobel e Page para o verso 16 , o primeiro imperativo do fragmento: ${ }^{167}$ o'voxócııov 'verte à maneira de vinho'. De hino clético a poema simpótico, os versos de Safo aproximam-na de Afrodite com graça e simplicidade.

\subsubsection{Píndaro, Peã 6}

Mais tortuosos são os caminhos para que deus e poeta estabeleçam um laço de reciprocidade no sexto peã de Píndaro. ${ }^{168}$

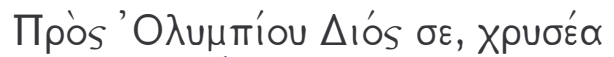

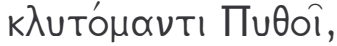

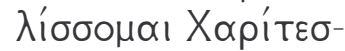

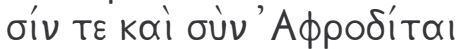

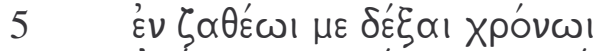

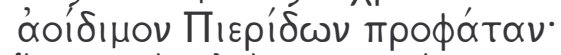

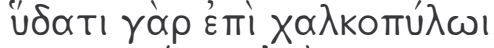

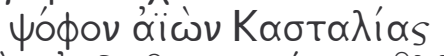

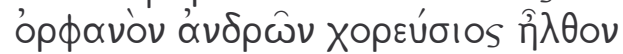

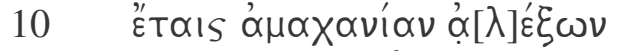

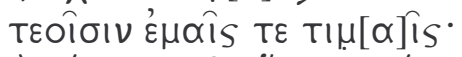

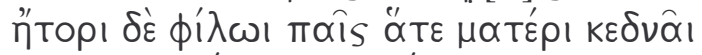

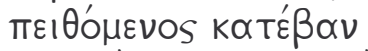

15

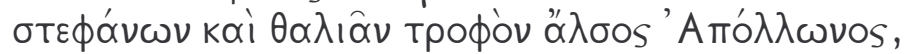

$$
\begin{aligned}
& \text { тó } \theta \text { । } \wedge \alpha \text { тої́ } \alpha \nu \\
& \theta \alpha \mu \text { Ivờ } \Delta \varepsilon \lambda \phi \omega \hat{\omega} \nu \text { kópaı }
\end{aligned}
$$

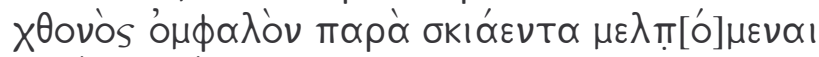

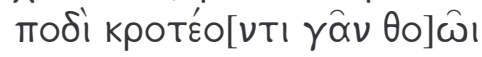

(faltam os versos 19-49 = str.A. 19-21, ant.A, ep.A. 1-7)

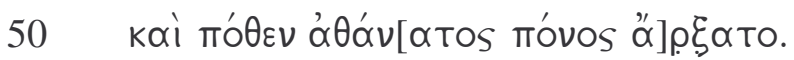

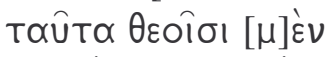

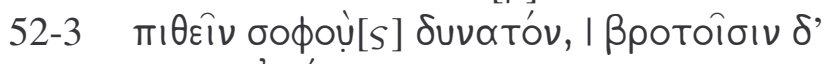

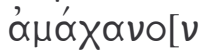

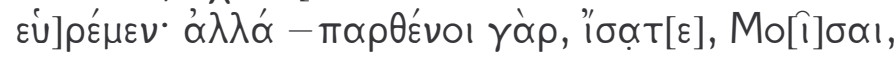

\footnotetext{
${ }^{166}$ Page (1955), 43.

${ }^{167}$ Há razões para supor que o poema continuasse para além do verso 16 e tivesse início antes do primeiro verso atestado, mas isso não compromete a minha análise.

${ }^{168}$ O texto é de Rutherford (2001), a quem sigo de perto em vários pontos do seu comentário.
} 


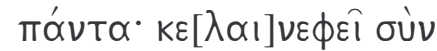

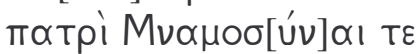

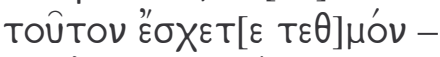

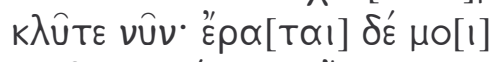

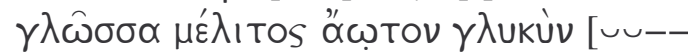

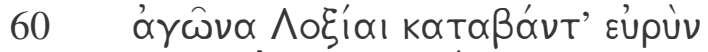
$\varepsilon \nu \theta \varepsilon \omega \hat{\nu} \nu \xi \varepsilon v i \alpha ı$.

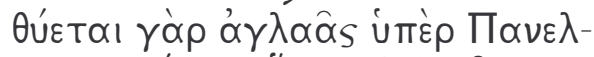

estr.B

65

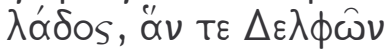

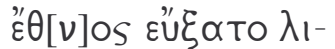

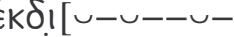

$\phi|\lambda \varepsilon|[\cup--\cup v-\backsim \bar{\sim}-$

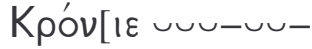

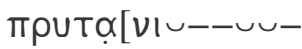

70

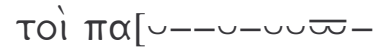

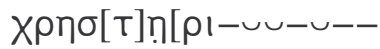

$\Pi u] \theta \omega v^{\prime} \theta[\varepsilon v-\cup--$

каі тотв

$\Pi \propto v \theta 00[-\cup \cup-$

75

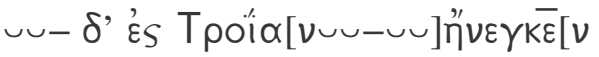

$\cup \sim-\theta \rho \alpha \sigma u \mu \eta \dot{-}]$

$\delta \varepsilon \propto$ máïs [-৩-

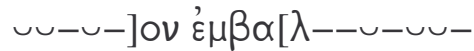

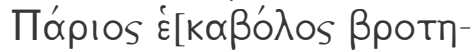

80

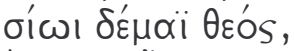

' $|\lambda і \omega| \omega \varepsilon$ Ө

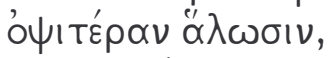

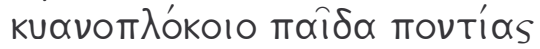

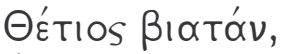

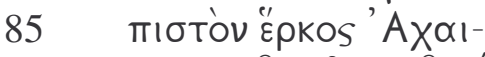

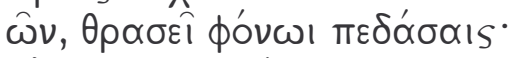

о

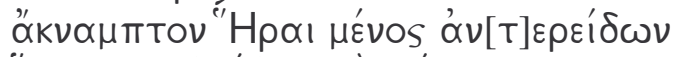

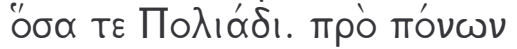

90

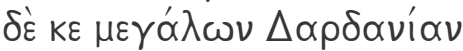

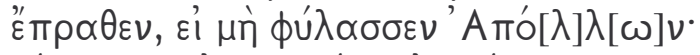

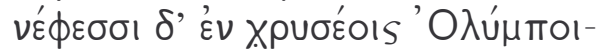

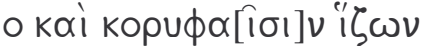

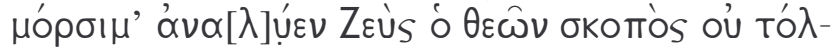

$95 \mu \alpha \cdot \pi \varepsilon \rho i$ '

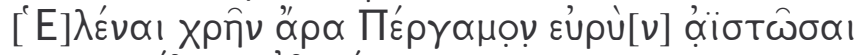

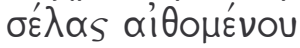
пupós ' '

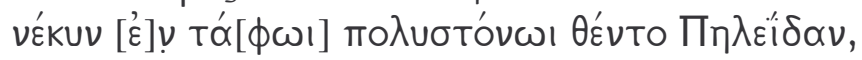




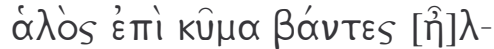

$\theta 0 v$ ó $\gamma \gamma \varepsilon \lambda \circ[1]$ oníow

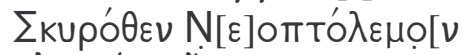

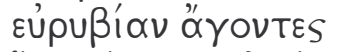

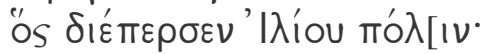

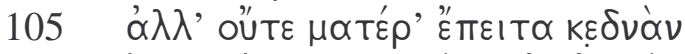

ep.B

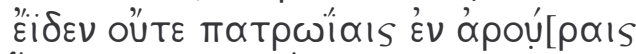

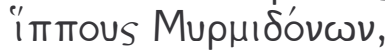

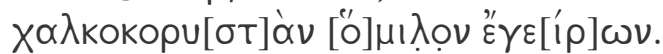

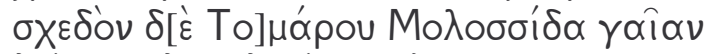

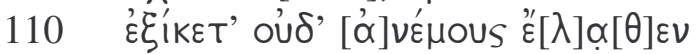

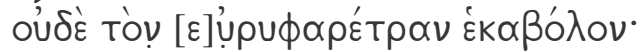

$\omega[\mu o] \sigma \varepsilon[\gamma \alpha \dot{\alpha} \rho \theta] \varepsilon o ́ s$,

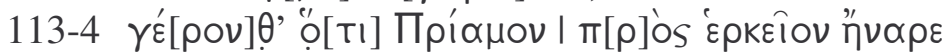

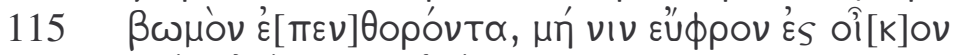

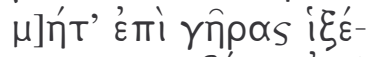

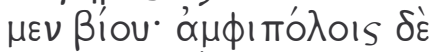

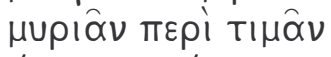

$\delta \varepsilon \rho 1] \propto \zeta{ }^{\prime} \mu \varepsilon v O \nu$ KTóvev

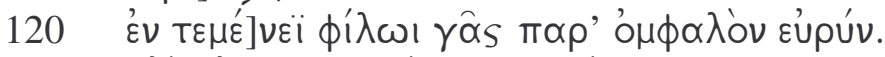

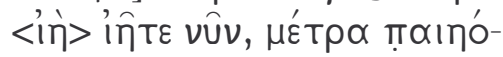

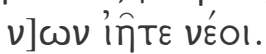

(Em nome de Zeus Olímpio, rogo-te, Pito dourada, famosa pela profecia, com as Graças e Afrodite recebe-me, porta-voz das Piérides, famoso pelo canto, [5] nesse tempo sagrado. Pois tendo ouvido, junto à água com o seu portão de bronze, o murmúrio da Castália órfã da dança dos homens, eu vim [10] para defender do desamparo os teus compatriotas e os meus privilégios. Obedecendo ao meu coração como uma criança obedece a sua querida mãe, vim até o bosque de Apolo que nutre guirlandas e banquetes, [15] onde ao lado do sombreado umbigo do mundo as donzelas de Delfos, cantando o filho de Leto, muitas vezes batem o chão com pés ligeiros ... [...] ... [50] e quanto à fonte da labuta imortal, aos deuses é possível persuadir disso os sábios, mas os mortais não têm como descobri-lo. Ora, virgens Musas, porque sabeis de todas [55] as coisas - tendes tal prerrogativa junto com vosso pai das nuvens escuras e Mnemosina -, escutai! Pois a minha língua anseia (cantar) a doce perfeição do mel ... [60] agora que vim à vasta reunião em homenagem a Lóxias, por ocasião do banquete dos deuses.

Pois o sacrifício é oferecido em favor de toda a gloriosa Grécia, que a tribo dos délfios rezou (para salvar) da [65] fome ... gosta ... filho de Cronos ... senhor ... [70] que ... oráculos ... de Pito ... e certa vez ... Pântoo ... [75] e rumo a Tróia ... levou ... uma criança de espírito valente ... atirou ... o deus que atira longe, sob a forma [80] humana de Páris, e de imediato adiou a captura de Ílion, prendendo em audaz morte o violento filho da deusa marinha Tétis de cabelos escuros, [85] confiável bastião dos aqueus. Que luta travou com Hera de alvos braços ao lançar a sua inflexível força contra ela, e que luta com Atena, guardiã da cidade! Antes de grandes [90] labutas ele teria saqueado Dardânia, não estivesse Apolo de guarda. Mas Zeus, sentinela dos deuses, sentado em nuvens douradas e nos picos do Olimpo, não se atreveu a desfazer coisas destinadas a acontecer. [95] Por 
causa de Helena de alta cabeleira, era necessário afinal que o brilho do fogo ardente destruísse a espaçosa Pérgamo. E depois que eles puseram o corpo do valente filho de Peleu em seu muito chorado túmulo, [100] mensageiros que haviam cruzado a onda do mar regressaram de Ciros trazendo o fortíssimo Neoptólemo, que saqueou a cidade de Ílion. [105] Mas ele nunca tornou a ver sua querida mãe, nem os cavalos dos mirmidões em seus campos ancestrais, enquanto incitava o exército de capacetes de bronze. Perto do monte Tômaros ele aportou, em terras da Molóssia, [110] e não escapou nem aos ventos nem ao que atira longe com sua ampla aljava. Pois o deus jurara que, porque havia matado o velho Príamo, que pulara [115] para junto do altar de Zeus Herkeios, ele não chegaria ao seu lar acolhedor nem à idade avançada em sua vida. Enquanto ele discutia com assistentes sobre um sem-número de privilégios, Apolo matou-o [120] em seu próprio santuário ao lado do vasto umbigo da terra. Iê, cantai $i \hat{e}$ agora - medidas de peãs - cantai $i \hat{e}$, jovens.)

A teoxenia, ou banquete dos deuses, para o qual Píndaro compôs esse peã, era um festival em cujo centro figurava uma refeição compartilhada pelos deuses, seja como anfitriões, seja como hóspedes. ${ }^{169}$ Em Delfos, a $\theta \varepsilon \circ \xi^{\prime} \varepsilon^{\prime} v ı \alpha$ era celebrada anualmente, talvez no mês de teoxênio (março-abril), e sua natureza era pan-helênica (cf. versos 62-3: sacrifícios em favor de toda a Grécia). O título que aparece à margem do papiro, logo no

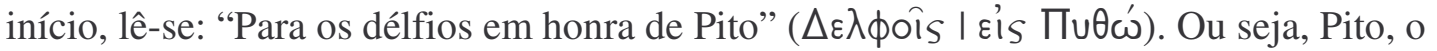
sítio do oráculo délfico, é o local destinado à apresentação do peã a cargo dos habitantes de Delfos.

O texto completo, porém, tal como preservado no papiro, contém três tríades, e não duas, como transcrevo aqui. A terceira, embora no mesmo metro das duas anteriores, pouco parece relacionar-se com elas. Boa parte dessa terceira tríade não foi preservada, mas seu início - um início abrupto, que abre com o louvor da ilha Egina para em seguida narrar a união de Zeus com a ninfa epônima, da qual nasceu Éaco - permite entrever um cenário que condiz mal com as tríades precedentes, nas quais Delfos figura em destaque. Em 1997 foi descoberto ${ }^{170}$ que o papiro continha outro título marginal, justamente ao lado do início da terceira tríade: "Para os eginetas em honra de Éaco, um prosódio"

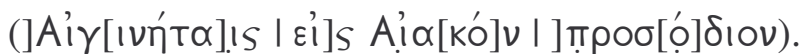

Rutherford ${ }^{171}$ sugere três possibilidades distintas para explicar os dois títulos e tentar reconciliar a canção como unidade, com uma seção délfica (tríades 1-2) e outra

\footnotetext{
${ }^{169}$ Cf. referências em Rutherford (2001), 310 n.15.

${ }^{170}$ Rutherford (1997) e D'Alessio (1997).

${ }^{171}$ Rutherford (2001), 336-38.
} 
egineta (tríade 3). Primeira hipótese: de um poema originalmente com três tríades, a terceira destacou-se em algum ponto da transmissão e passou a circular de forma independente, como prosódio; segunda hipótese: a terceira tríade é acréscimo posterior, um suplemento composto talvez como apologia a fim de aplacar a indignação egineta com o retrato que se pinta de Neoptólemo - um eácida, afinal, sepultado em Delfos - nas duas primeiras tríades; terceira hipótese: composto como uma unidade, a apresentação original foi dividida entre dois grupos, um délfico responsável por cantar o peã (duas primeiras tríades) e outro egineta, ao qual caberia entoar o prosódio. Rutherford não se decide por nenhuma delas, mas sugere que a segunda hipótese, a da apologia, talvez seja a mais próxima da realidade. ${ }^{172}$ Seja como for, como unidade ou acréscimo posterior, a terceira tríade representa uma ruptura com a narrativa que a antecede, mas a omito aqui somente porque ela não diz respeito a meus propósitos no momento.

Uma prece (1-6) inaugura o poema, endereçada a Pito. O poeta pede-lhe que o receba - a ele, porta-voz das Musas - no tempo sagrado da teoxenia, acompanhado das Graças e de Afrodite. À prece segue-se a explicação do porquê ele veio e dos propósitos a que veio: tendo ouvido que a fonte da Castália estava órfã de coros de homens, ele veio para defender de tal desamparo os cidadãos de Delfos e para defender os seus próprios privilégios ( sítio sagrado de Apolo, onde as donzelas de Delfos cantam e dançam junto ao umbigo da terra.

Após um intervalo no qual faltam vários versos no papiro, o poeta retorna com uma pergunta (indireta?) sobre a origem de algo imortal. Rutherford, ao contrário da maioria dos editores, que propõem "briga" ("ُ móvos), em referência à tarefa de celebrar a teoxenia com uma canção como essa mesma que o poeta entoa: e imortal seria ela porque apresentada a cada ano nos festivais. ${ }^{173}$ Sobre tais matérias, diz Píndaro, aos sábios é dado sabê-las através dos deuses, aos mortais não há como descobri-las (51-3). Daí seu apelo às Musas para que o auxiliem a

\footnotetext{
${ }^{172}$ Com ela concordam Furley-Bremer (2001), vol. 1, 106.

${ }^{173}$ Furley-Bremer (2001), vol. 1, 107, adotam o suplemento de Rutherford, mas sugerem ainda outras

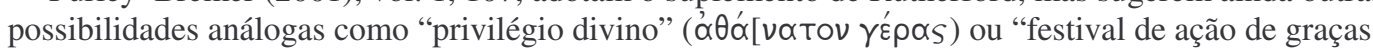

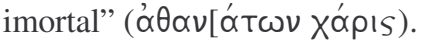


compor uma canção doce como o mel (54-9), agora que ele chegou para o banquete dos deuses (60-1).

Dois pontos até aqui merecem ser sublinhados. Píndaro insiste em destacar o fato

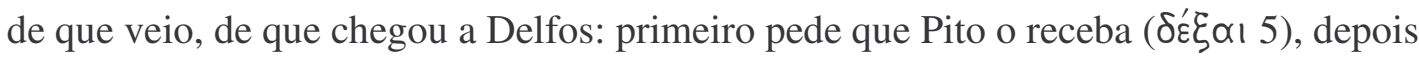

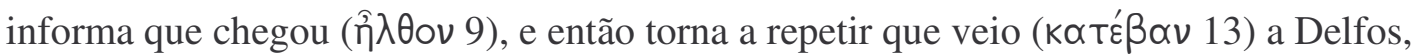
onde de fato ( $T$ tó $\left._{1} 15\right)$ a primeira estrofe chega ao fim (faltam somente dois versos para o final da estrofe no papiro). E, no fecho do epodo, outra repetição: ao banquete dos deuses

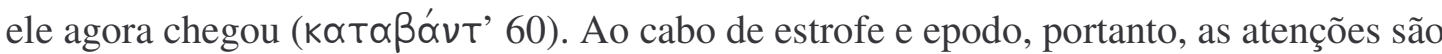
centradas no local e instante presentes, a teoxenia em Delfos.

Um segundo ponto: no que restou da primeira tríade, Píndaro é pródigo em alusões a si próprio e a sua obra. Ele é o famoso ${ }^{174}$ porta-voz das Piérides (ơoídınov

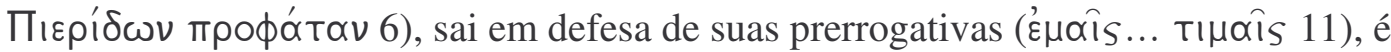
veladamente um dos "sábios" (бoфoús 52) que se vale do auxílio das Musas para

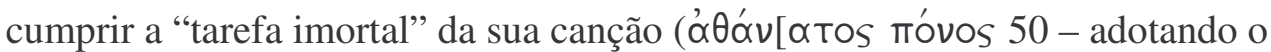

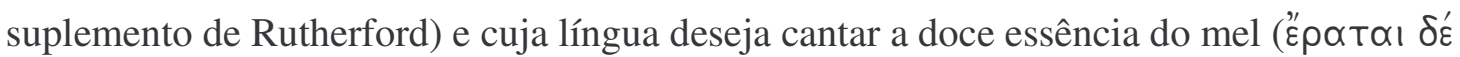

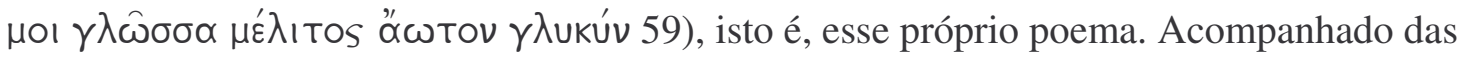
Graças e de Afrodite, ele pede a Pito que o receba ( 'Aфpodítaı 3-4) - ou talvez (o sentido é ambíguo) já esteja o seu próprio pedido, o poema em questão, ${ }^{175}$ previamente dotado da graça e do charme insuflados pelas deusas. A cada passo, pois, o poeta faz questão de mostrar as suas credenciais.

No começo da segunda tríade passamos à teoxenia, festival pan-helênico (62-3), antes de ter início a narrativa mítica de fato, que relata a morte de Aquiles em Tróia e do seu filho Neoptólemo em Delfos - ambos vítimas de Apolo. Aquiles chega a Tróia ( $\delta$ ' ' $\varsigma$ Tpoíav 75) e três versos mais tarde é morto por Apolo disfarçado de Páris (79-80). A queda de Ílion é assim postergada. Mas os verdadeiros adversários de Apolo são Hera e Atena, não Aquiles (87-9). Da disputa entre um deus e um mortal passa-se à batalha entre os deuses, a uma teomaquia. O foco se abre, aumenta a importância do que está em jogo

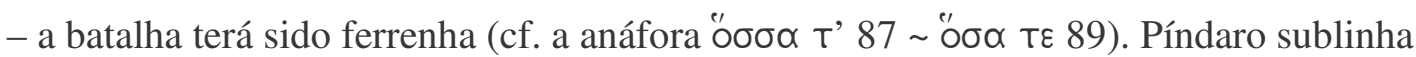

\footnotetext{
${ }^{174}$ Alguns preferem adotar a correção do escriba em cima do verso para $\alpha o$ ó $\delta^{\prime} \mu \omega \nu$, mas concordo com

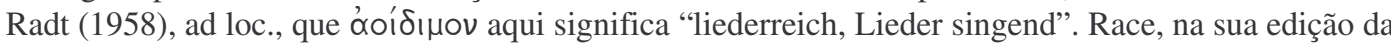
Loeb (1997), traduz por "tuneful”.

${ }^{175}$ Cf. Radt (1958), ad loc. Contra: Furley-Bremer (2001), vol. 2, 29s.
} 
essa transição de uma disputa a outra repetindo, em forma de anel, que a morte de

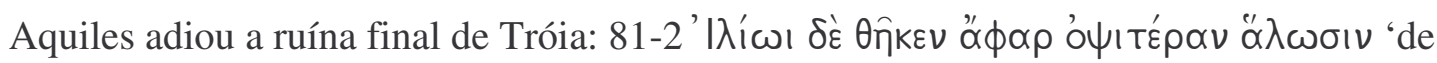

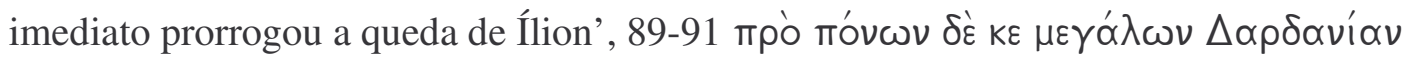

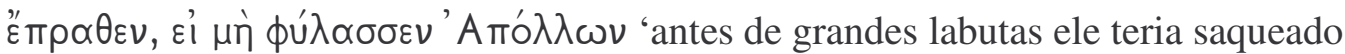
Dardânia, não estivesse Apolo de guarda'. Essa moldura encerra os versos que conduzem de Aquiles, no início da antístrofe (83-6), à teomaquia (87-9), num esquema $\mathrm{A}-\mathrm{B} \rightarrow \mathrm{C}-\mathrm{A}$. Em posição de destaque figura Apolo, última palavra que dá fecho ao anel (91) e pivô das duas disputas.

Mas então o foco se abre novamente: ${ }^{176}$ estava fadado que Tróia caísse, e Zeus não ousa revogar o destino (92-5). A disputa de Apolo contra Aquiles, de Apolo contra Hera e Atena ganha novos contornos contra esse pano de fundo: as ações de Apolo são ditadas, em um nível mais profundo, pela vontade do destino, pelo aval de Zeus.

Por causa de Helena era necessário que Tróia caísse pelo fogo (96-8), façanha da qual não foi capaz Aquiles, mas que coube ao filho, Neoptólemo. A história desse último é narrada na forma de uma progressiva aproximação de Delfos. Primeiro ele aporta em Tróia e a saqueia, logo no verso inaugural do epodo (104). Depois chega à Molóssia (109), em Épiro, sem conseguir escapar aos ventos nem a Apolo, que jurou não deixá-lo regressar a casa nem atingir a velhice por ter assassinado Príamo junto ao altar de Zeus Herkeios em Tróia. Numa última etapa Neoptólemo é morto por Apolo em Delfos junto ao seu próprio santuário (120), numa disputa por privilégios - uma referência, talvez, a oferendas feitas pelos peregrinos e mais tarde a eles redistribuídas durante o sacrifício. ${ }^{177}$

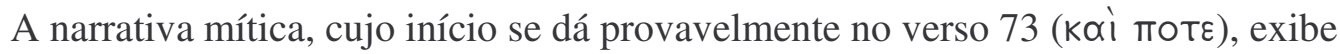
assim um duplo movimento, oposto e complementar. Da disputa entre Apolo e Aquiles expande-se o foco para a teomaquia (Apolo contra Hera e Atena), e da teomaquia o foco é novamente expandido para Zeus às voltas com o destino. Então fecha-se o foco em

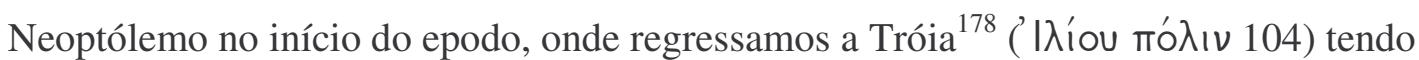
dela partido ( $\delta$ ' $\varepsilon_{S}$ T $\rho{ }^{\prime} \hat{i}_{\alpha} \nu$ 75). E de Tróia passamos à Molóssia e daí a Delfos, onde o herói é morto por Apolo, que iniciara a seção mítica como assassino de Aquiles.

\footnotetext{
${ }^{176}$ Cf. Rutherford (2001), 312.

${ }^{177}$ Ibid., 313.

${ }^{178}$ Píndaro faz com que Neoptólemo, conduzido de Ciros por mensageiros no final da antístrofe, aporte em Tróia somente no começo do epodo.
} 
Não é gratuito esse movimento de expansão e afunilamento. Expande-se o foco para depois centrá-lo com tanto mais eficácia. Que em Delfos atingimos o termo dessa progressão - isso é sugerido pela coda de dois versos (121-2), que fornece uma conclusão

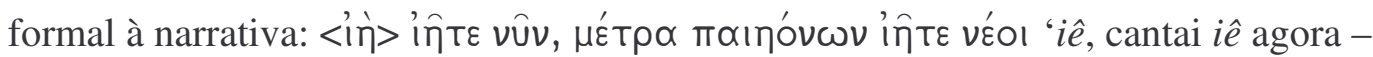

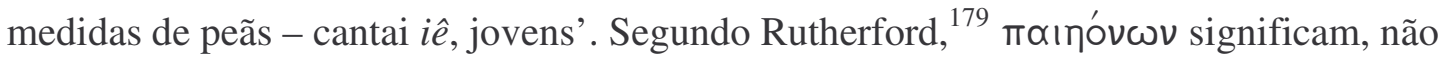
os poemas, mas os gritos de Traı́ $\nu$ dados pelo narrador, que incita os jovens a fazerem o mesmo. Trata-se de um refrão, geralmente proferido ao final das seções de um canto; e $\mu$ '́ $\rho \propto$ seriam um tipo de medida que demarcaria a seção anterior. ${ }^{180}$ A Delfos chega Neoptólemo ao término da segunda tríade (após Píndaro abrir e fechar cuidadosamente o foco), assim como o poeta chegara a Delfos ao término da primeira tríade (após repetir com toda ênfase sua própria peregrinação a Delfos). Lá e cá, poeta e herói chegam ao mesmo local, Delfos, justamente onde o presente hino é entoado, e para ambos lança-se mão do mesmo adjetivo, عủpúv 'vasto, amplo' $(60,120)$, ambos em final de verso - um para designar a assembléia reunida para o banquete dos deuses (Eủpúv, um adjetivo referente a espaço, é empregado aqui em sentido metafórico ${ }^{181}$ ), outro para referir-se ao umbigo da terra. E, sobretudo, o detalhe de que Neoptólemo foi morto numa disputa por

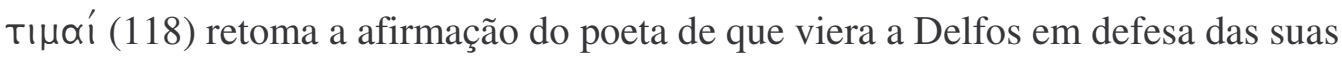
próprias тıнaí (11). Como observa Rutherford, ${ }^{182}$ que chama a atenção para esse paralelo, "a canção convida o leitor a comparar e contrastar o cantor com Neoptólemo".

A imagem do cantor e sua obra, sobre a qual ele tanto insistira na primeira tríade, destaca-se e contrario da imagem de Neoptólemo. Píndaro ressalta a simetria ${ }^{183}$ entre o crime de Neoptólemo e a sua punição: matou Príamo quando esse buscou asilo junto ao altar de Zeus Herkeios, e depois foi morto junto ao altar de Apolo em Delfos. Negativa é a reciprocidade entre deus e herói, enquanto a reciprocidade entre deus e poeta é positiva: a canção - esse peã a Apolo - que Píndaro compôs para a teoxenia defende suas próprias prerrogativas, mas também fornece aos cidadãos de Delfos um hino de louvor a Apolo; e se Delfos, ou sua fonte Castália, estava órfã de coros de homens, ele, obedecendo ao seu

\footnotetext{
${ }^{179}$ Rutherford (2001), 315s.

${ }^{180}$ Ibid., 316 n.46: "the $\mu \varepsilon^{\prime} \tau \rho \propto$ are the limit which the utterance of the $\pi \propto\llcorner\propto \alpha$-cries is imagined as imposing on the narrative and the triad".

${ }^{181}$ Cf. Radt (1958), ad loc.

${ }^{182}$ Rutherford (2001), 315. Cf. ainda p. 308.

${ }^{183}$ Furley-Bremer (2001), vol. 1, 111.
} 
coração, veio para remediar tal lacuna como um filho obedece à sua mãe. Neoptólemo é

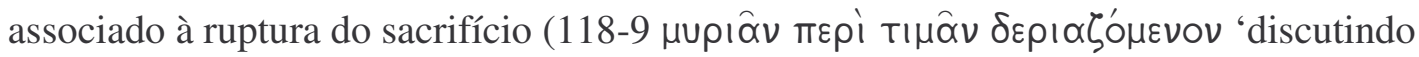

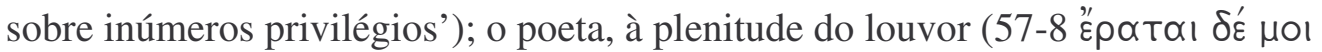

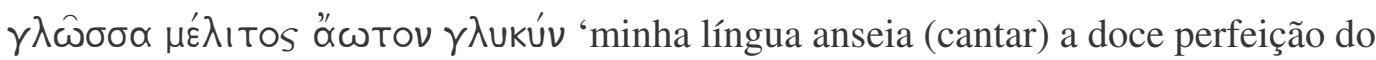
mel'). Píndaro estabelece assim, com sutileza e requinte, uma relação estreita e positiva com Apolo através de um exemplo mítico negativo.

\subsubsection{Sófocles, Antígone (781-800)}

Também a métrica é muitas vezes utilizada nos hinos para, em combinação com elementos formais, dar vida ao propósito do poeta de atrair a divindade ou relacioná-la à situação presente. Cito dois exemplos, o hino a Eros da Antígone de Sófocles (781-800) e duas canções da parábase dos Cavaleiros de Aristófanes (551-564 e 581-594).

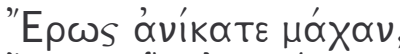
estr.

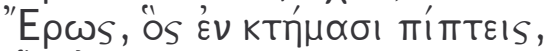
ôs Ev $\mu \alpha \lambda \alpha k \alpha i s ~ \pi \alpha \rho \varepsilon ı$ îs

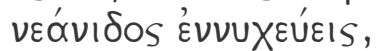

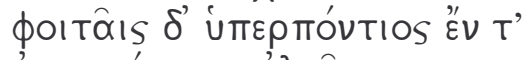

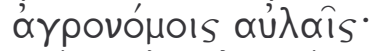

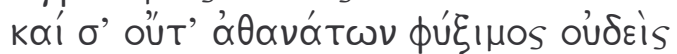

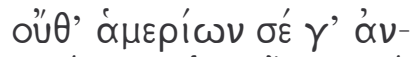

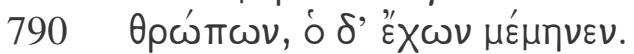

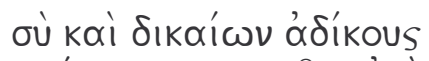

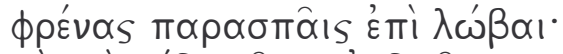
ant.

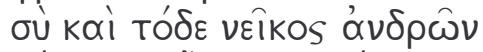

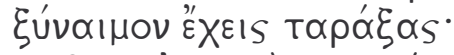

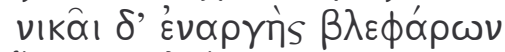

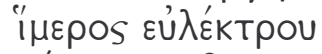

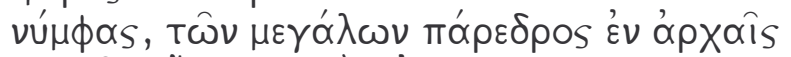

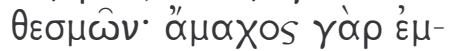

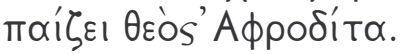

(Amor, invencível na batalha, Amor, que te abates sobre os rebanhos, que pernoitas nas delicadas faces de uma jovem e freqüentas além-mar as moradas campestres: nenhum dos imortais pode escapar-te, de ti não escapa nenhum mortal, e quem te tem, enlouquece. / Tu torces espíritos justos à injustiça e à ruína; tu provocaste essa briga entre membros da mesma família. Vence o desejo patente que vem dos olhos de uma bela noiva, desejo que tem seu assento ao lado das leis excelsas; pois irresistível é em suas brincadeiras a deusa Afrodite.) 
Hêmon acaba de ter uma violenta discussão com Creonte, tirano de Tebas. Como Antígone desobedeceu a seu edito, que proibia dar sepultamento a Polinice, Creonte está decidido a puni-la com a morte. Seu filho Hêmon, porém, estava prestes a casar-se com ela, e desafia a autoridade do pai, exigindo que volte atrás na sua decisão. Quando os dois deixam a cena, o coro canta essa ode (terceiro estásimo), cujo tema é a força do amor em geral e tal como ela se manifesta especificamente em Hêmon.

O metro é eolo-coriâmbico $(781-90=791-800)$, com elementos jâmbicos. Eis a colometria: ${ }^{184}$

\begin{tabular}{|c|c|c|}
\hline 1 & $\times-\cup--\cup v-$ & jambo coriambo \\
\hline 2 & $x-\cup--v v--\|$ & jambo coriambo - \\
\hline 3 & xーง & haguesicóreo \\
\hline 4 & $\times$ & haguesicóreo \\
\hline & $x-\cup--\cup v-$ & jambo coriambo \\
\hline & $-\cup \cup---$ & dôdrans \\
\hline & - - - vง-ーvง- & asclepíade \\
\hline & メーレレーレー & telesíleo \\
\hline & $\times$ & haguesicóreo \\
\hline
\end{tabular}

São três as seções em que se subdividem estrofe e antístrofe (notadas acima com barras verticais): A) 1-2, B) 3-4, C) 5-9. Tema métrico central é o coriambo (—u৩-). Como observa Korzeniewski, ${ }^{185}$ o coriambo na seção A aparece no final, na seção B "vem para frente" e na seção C primeiro duplica-se, para depois esvaecer em ritardando nos dois últimos versos.

Ligados às características métricas estão os aspectos formais. A estrofe inicia com

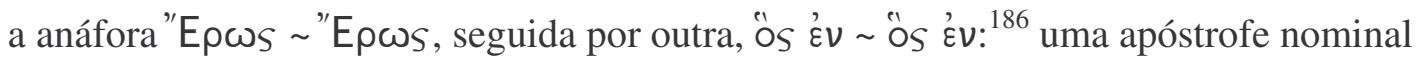
dupla em versos paralelos, da segunda das quais transita-se à predicação relativa, repetida no começo do verso seguinte. As frases relativas dão fundamento à epiclese, justificam

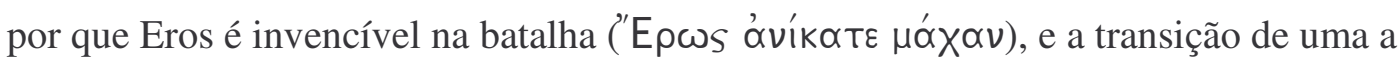

\footnotetext{
${ }^{184}$ Cf. para uma colometria algo diversa Furley-Bremer (2001), vol. 2, 270, e Korzeniewski (1962), 142.

${ }^{185}$ Korzeniewski (1962), 142s.

${ }^{186}$ Ibid., 143. Anáfora e amplificação com pronome relativo são características formais de ampla difusão nos hinos. Cf. Norden (1913), 163-6, 168-76.
} 
outra, da apóstrofe à frase relativa, reflete-se na transposição do coriambo para o início do verso: ${ }^{187}$
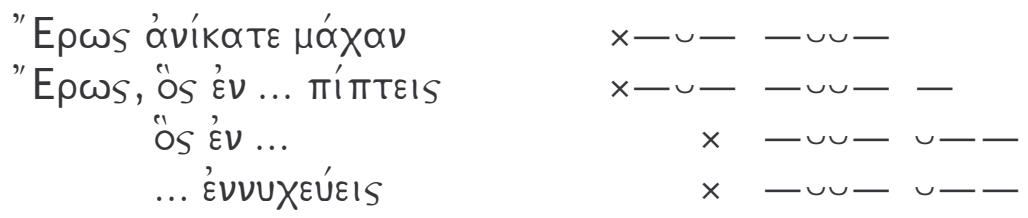

$\mathrm{Na}$ antístrofe, duas frases de construção paralela, iniciadas com où kớ em anáfora, fazem a transição da idéia geral (primeira frase) ao caso concreto (segunda frase), e tal se reflete na métrica com a antecipação do coriambo. ${ }^{188}$ Do amor em geral, capaz de tornar injustos

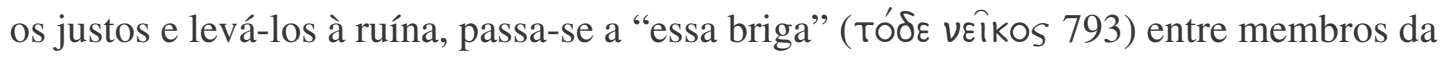
mesma família, ou seja, entre Creonte e Hêmon, cuja causa é o amor deste por Antígone. Tal progressão do geral ao particular já havia sido sugerida na estrofe, na mesma posição métrica: do amor que se abate sobre o rebanho, ${ }^{189}$ sobre as propriedades (782), fecha-se o foco sobre o amor que pernoita nas faces de uma jovem - no caso, Antígone. Tanto mais plausível se torna essa interpretação pelo fato de a referência à jovem ser emoldurada por duas alusões gerais, uma ao mundo animal ( $k т \eta ́ n \propto \alpha \sigma$ ' 'rebanho'), outra ao poder que Eros

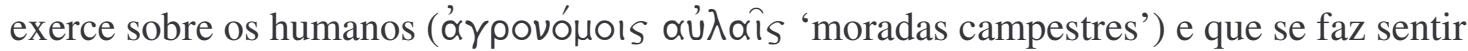
sobre todo o oceano (úrepாóvtios). Destaca-se ainda o caso particular da jovem pelo

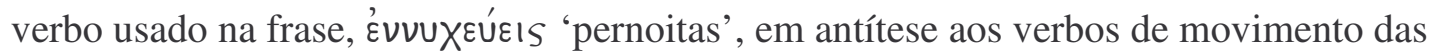

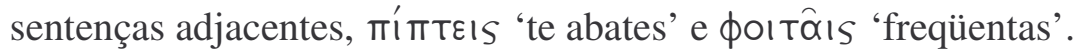

A seção B, portanto, representa uma especificação do caso geral descrito na seção A, fato sublinhado pelo deslocamento do pé coriâmbico no interior do verso. Quanto à seção C, instaura ela uma clara ruptura com as seções anteriores (cf. $\delta^{\prime}$ $785 \sim 795$ ), ${ }^{190}$ expandindo a perspectiva dos poderes de Eros. Frases mais longas são acompanhadas da duplicação dos coriambos; na antístrofe, o $\delta^{\prime}$ (agora explicativo) detalha a razão “dessa

\footnotetext{
${ }^{187}$ Transcrevo, com modificações, o esquema de Korzeniewski (1962), 143.

${ }^{188}$ Korzeniewski (1962), 144.

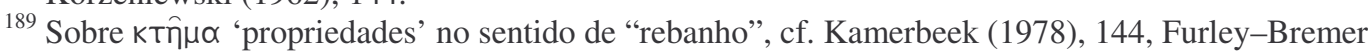
(2001), vol. 2, 270s. Contra: Lloyd-Jones e Wilson (1990), 135s.

${ }^{190}$ Fato notado por Korzeniewski (1962), 144 n.9, sem indicar distinção funcional entre um e outro $\delta$ '́.
} 
briga" entre Creonte e Hêmon: venceu o desejo ${ }^{191}$ que se faz aparente nos olhos da noiva

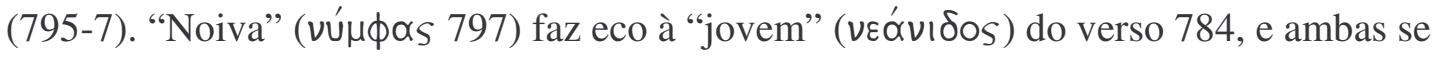
referem ao caso específico de Antígone. Mas aqui o exemplo concreto logo se dissolve

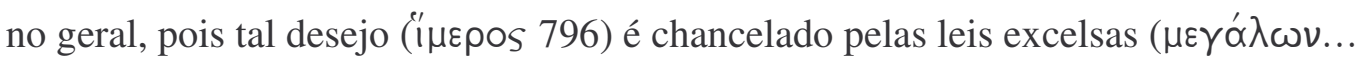
$\theta \varepsilon \sigma \mu \omega \hat{\nu})$, das quais ele é assistente ( $\pi \alpha ́ \alpha \varepsilon \delta \rho \circ \varsigma$ ). Tal como na estrofe, cujo fecho é uma reflexão de cunho universal ("nenhum imortal, nenhum mortal escapa de Eros") ${ }^{192}$, universal é aqui também a ação do desejo. Lá e cá, na estrofe como na antístrofe, os dois últimos versos desaceleram o ritmo dos coriambos e concluem com duas frases em

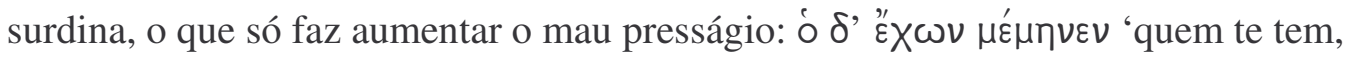

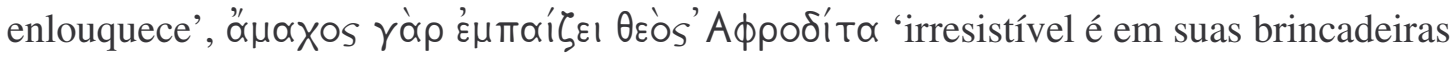
a deusa Afrodite'.

Tais frases são dotadas de um tom funesto porque aludem obliquamente ao caso de Hêmon e Antígone, e isso é sublinhado pelo metro do último verso da seção C (790 = 800), idêntico ao metro dos dois versos da seção B (haguesicóreo) - seção esta, que, como vimos, debruça-se sobre o caso específico do poder universal de Eros. No todo, portanto, há um movimento do geral ao particular e novamente ao geral, o que se reflete não apenas na estrutura métrica, mas ainda no eco vocabular entre início e fim (cf. $\mu \alpha \chi_{\chi} \propto \nu$

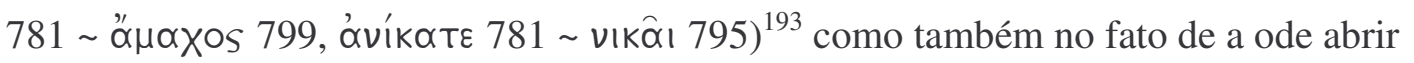

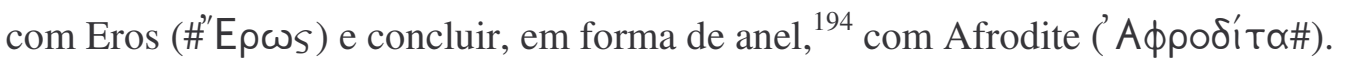

\subsubsection{Aristófanes, Cavaleiros (551-564/581-594)}

Meu segundo exemplo são dois hinos da parábase dos Cavaleiros de Aristófanes (551-564 e 581-594), ${ }^{195}$ o primeiro a Posêidon, o segundo a Atena.

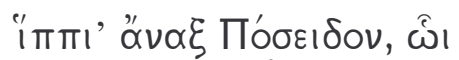
estr.

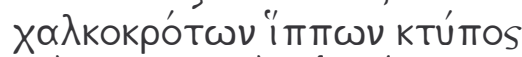

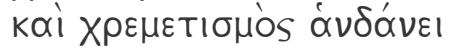

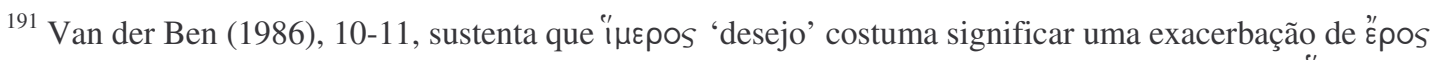
'amor', uma vez que exige a imediata satisfação e não pode ser recusado. Sobre a etimologia de í $\mu \varepsilon \rho \circ$ e

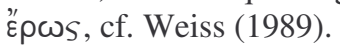

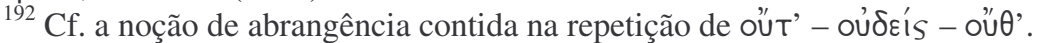

${ }^{193}$ Korzeniewski (1962), 144 n.9.

${ }^{194}$ Como notam Furley-Bremer (2001), vol. 1, 300.

${ }^{195}$ Sobre a paródia de preces, ver Kleinknecht (1937) e Horn (1970).
} 


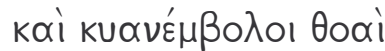

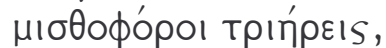

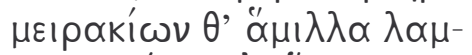

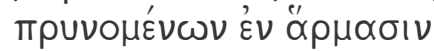

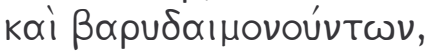

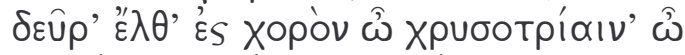

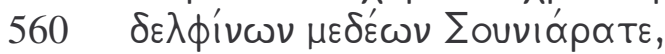

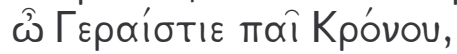

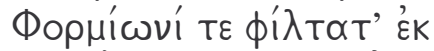

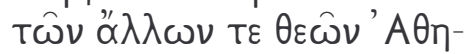

vaíols mpós tò mapeotós.

(Posêidon, senhor dos cavalos, que se compraz com o clangor dos cascos de cavalo tinindo feito bronze, e com seu relinchar, e com os velozes trirremes com seus aríetes azuis e sua equipagem a soldo, e com a disputa de jovens em suas quadrigas, votados à glória ou ao peso da má sorte: vem! junta-te a nossa dança, ó deus do tridente dourado, senhor dos golfinhos de Suníon, filho de Cronos, deus preferido de todos por Fórmio e pelos atenienses nas atuais circunstâncias.)

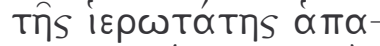

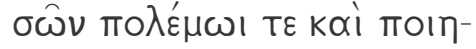

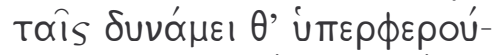

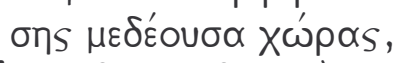

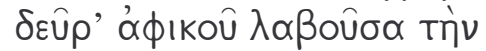

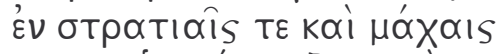

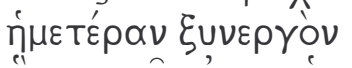

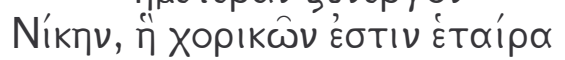

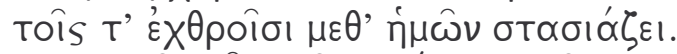

$$
\begin{aligned}
& \text { vUิv oûv } \delta \varepsilon u ̂ \rho o ~ \phi \alpha ́ v \eta \theta_{I} \cdot \delta \varepsilon \hat{\imath}
\end{aligned}
$$

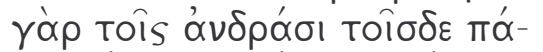

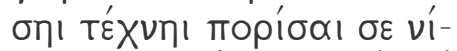

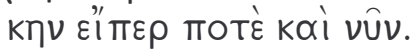

(Palas, guardiã da cidade, senhora da terra mais sagrada de todas e superior na guerra, em poetas e em poder, vem para cá e traze a nossa parceira nas expedições e batalhas, Vitória, que é a nossa companheira em danças corais e toma o nosso partido contra os inimigos. Agora vem, pois, aparece, pois deves de toda a forma conceder a vitória a esses homens - se alguma vez antes, também agora!)

O metro é basicamente eolo-coriâmbico:

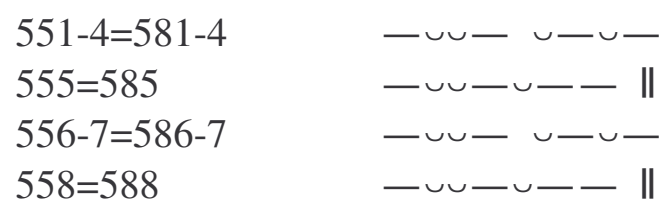

coriambo jambo aristofâneo coriambo jambo aristofâneo 


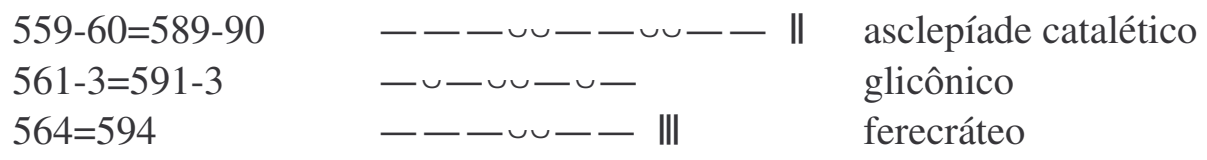

São quatro as seções métricas nas quais se dividem os hinos, separadas acima pelas barras verticais. As duas primeiras assemelham-se: uma seqüência de dímetros coriambo-jâmbicos seguida da sua forma catalética como cláusula, o aristofâneo. Já a terceira seção, como obseva Parker, ${ }^{196}$ destaca-se pelo ritmo e compõe um clímax: "na estrofe há a invocação, na antístrofe a referência à vitória”. Na quarta e última seção repete-se um mesmo cólon (glicônico) seguido, mais uma vez, de sua forma catalética (ferecráteo).

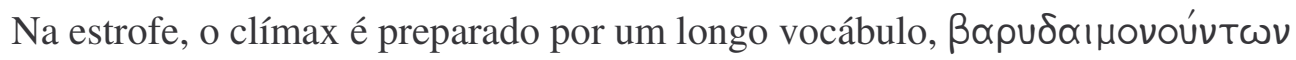
'peso da má sorte' (558), que ocupa praticamente todo o verso e contribui, a par da forma catalética, para transitar ao pedido. Até ali Posêidon fora interpelado como deus afeito a cavalos (551-3), naves (554-5) e competições eqüestres (556-8) - suas esferas genéricas de poder. A regularidade da alternância métrica acompanhara o relato: cavalos e naves preenchem a primeira seção, competições eqüestres, a segunda. Com o pedido para que o deus venha ( $\delta \varepsilon \hat{\rho} \rho$ ' ' $̇ \lambda \theta^{\prime}$ 559), o coro altera o ritmo ao convergir a atenção de Posêidon para o local ao qual deve dirigir-se: a própria orquestra onde o coro executa a sua dança ('̇ร Xopóv 559). Cresce também o envolvimento emotivo do coro: são três $\omega$ seguidos de vocativos, sobre os quais recaem as (duplas) breves que agora se amiúdam para criar uma

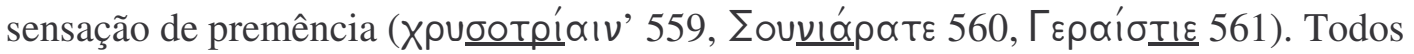
esses vocativos guardam relação com o mar, ${ }^{197}$ e a alusão final a Fórmio, ilustre estratego vitorioso numa série de batalhas navais, ${ }^{198}$ prepara para o último verso, que novamente

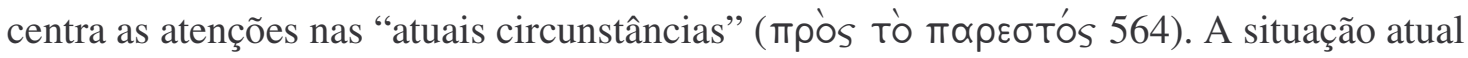
de Atenas, entenda-se, é de guerra - a chamada "guerra de Arquidamas" (Cavaleiros foi composta em 424 a.C., ainda na primeira década da Guerra do Peloponeso). Mas atual é também a situação de disputa na qual está envolvido o coro nessa parábase, "em guerra" com os demais coros em competição. Em vista do pedido endereçado a Posêidon, para

\footnotetext{
${ }^{196}$ Parker (1997), 168, de quem adoto a colometria e a descrição métrica geral da ode.

${ }^{197}$ Suníon, cabo a sudeste de Atenas, é local do famoso templo de Posêidon; Gerestos, além de conter outro célebre templo ao deus (cf. Od. 3,177-8), é um porto de relevância (cf. Tucíd. 3.3,5).

${ }^{198}$ Cf. Tucíd. 1.117,2; 2.69,1 e 3.83-92.
} 


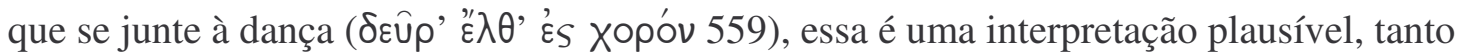
mais porque a antístrofe (o hino a Atena) desenvolve essa tema do vínculo entre guerra e poesia.

$\mathrm{Na}$ antístrofe Atena é interpelada na primeira seção métrica como senhora da terra

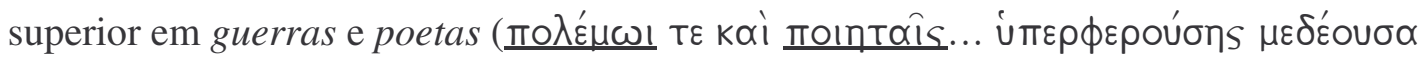
$\left.\chi \omega ́ p \propto \alpha_{S} 583-5\right)$. Na segunda seção, o coro the pede que venha trazendo consigo a parceira

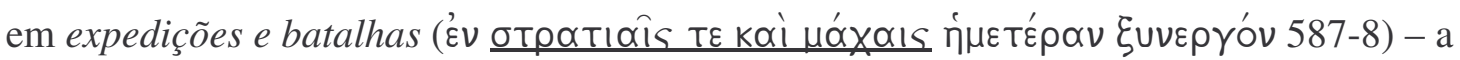
Vitória (Níknv 589). Vitória que, cumpre notar, ganha relevo não apenas pela posição de destaque no verso, mas também pelo clímax rítmico que constitui o novo cólon (terceira

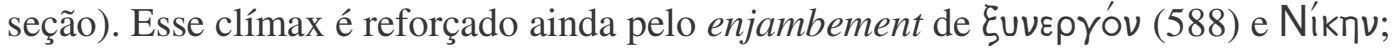

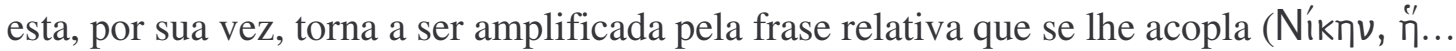
589), na qual se afirma que ela é companheira em danças corais e toma partido contra os

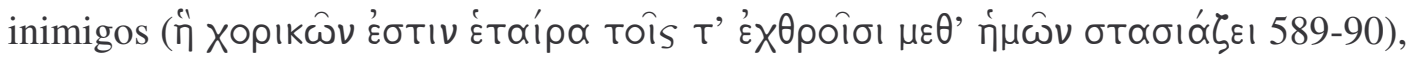
em manifesta alusão à disputa poética entre coros rivais da comédia.

Claras, portanto, são as transições entre as seções métricas da antístrofe, tal como refletidas em seus temas. A primeira trata de guerras e poesia; a segunda, cujo início é

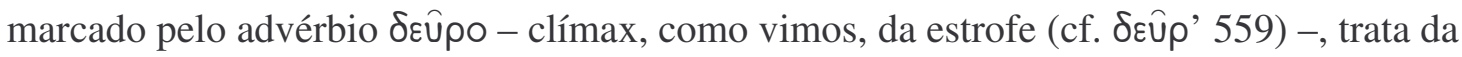
guerra, e a terceira, após a ruptura rítmica, da poesia. Ou em forma esquemática:

\begin{tabular}{|c|c|}
\hline$(581-85)$ & guerra e poesia \\
\hline$(586-88)$ & $\begin{array}{c}\# \delta \varepsilon \cup \bar{\rho} \rho^{\prime} . . . \\
\text { guerra }\end{array}$ \\
\hline$(589-91)$ & $\begin{array}{c}\text { \#Níkпv... } \\
\text { poesia }\end{array}$ \\
\hline
\end{tabular}

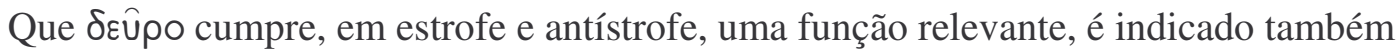

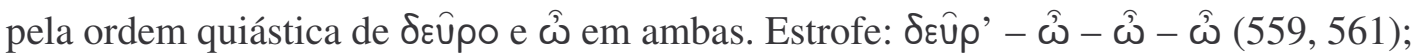

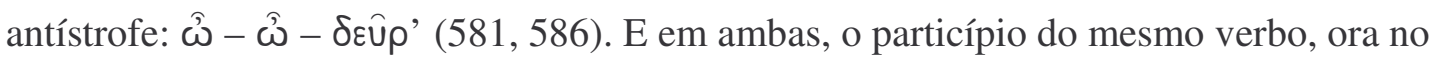
masculino, ora no feminino, sublinha o elemento comum: $\mu \varepsilon \delta^{\prime} \varepsilon^{\prime} \omega \nu \sim \mu \varepsilon \delta^{\prime} \varepsilon_{\text {ov }} \sigma \alpha(560$, $585)$.

Na última seção da antístrofe, o coro faz convergir de vez as atenções de Atena

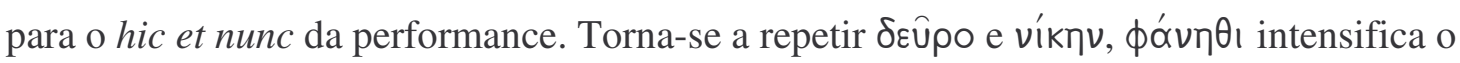

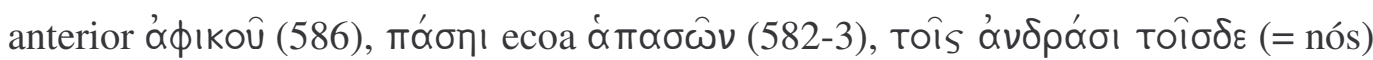


reforça o aspecto dêitico, e a seção, cuja primeira palavra é vûv, em $v \hat{v} \nu$ expressivamente termina. ${ }^{199}$ Guerra e poesia, temas centrais da antístrofe (mas já sugeridos na estrofe), são assim fundidos no instante presente da apresentação do coro.

\subsubsection{Sófocles, Traquínias (205-224)}

Outra passagem hínica que também funde dois temas - agora dois gêneros, peã e ditirambo - e os conduz ao presente é o hino a Apolo e Ártemis das Traquínias de Sófocles (205-224).

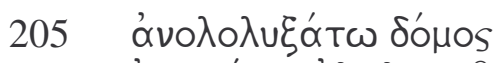

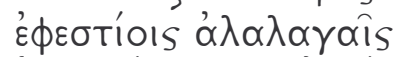

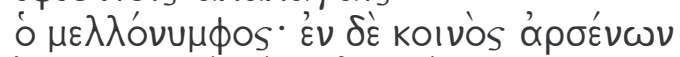
'T

'Ато́ $\lambda \lambda \omega$ тробто́т $\alpha \nu$,

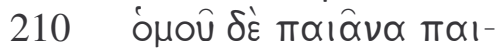

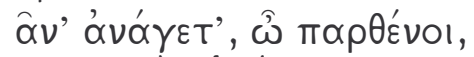
ßoôte tờ ómóortopov

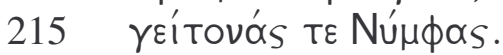

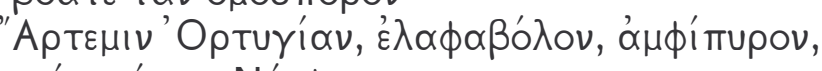

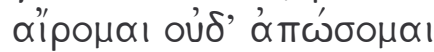

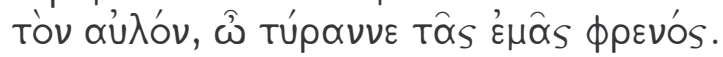

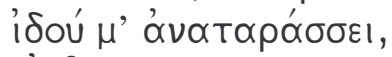
घن่०ิ, ó kıбòs äpтı Bakxíav

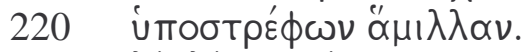

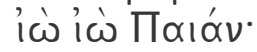

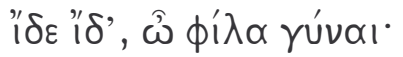

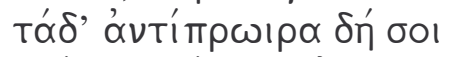

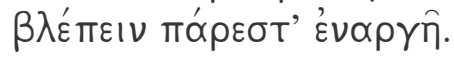

(Que a casa que receberá o noivo dê um grito de alegria, com brados de triunfo vindos do lar. E que se eleve o vozerio conjunto dos homens em honra do deus de fina aljava, Apolo protetor; [210] juntas erguei o peã, o peã, ó donzelas! chamai a sua irmã, Ártemis de Ortígia, que alveja cervos, que carrega tochas, [215] e as ninfas suas vizinhas. Ergo-me, não rejeitarei o aulos (= oboé), ó soberano do meu espírito! Vê, a hera me empolga, evoé! e me põe a rodar [220] na competição báquica! Oh, oh, Peã! Vê, vê, cara senhora! Isso te é dado enxergar diante dos olhos, com toda a clareza.)

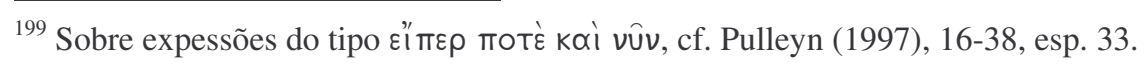


O coro celebra em êxtase a notícia de que Héracles está a caminho de casa, dando

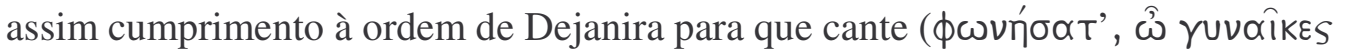
'cantai, ó mulheres' 202). É na presença dela que o coro das traquínias entoa a ode - um peã, a julgar pelas alusões feitas ao gênero em duas passagens: no semi-refrão ic่ i

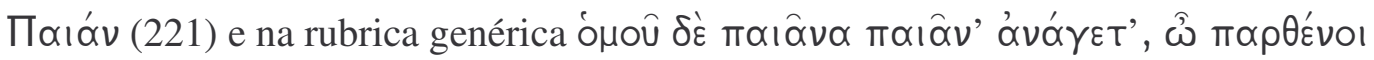
'juntas erguei o peã, o peã, ó donzelas!' (210-11). Somente a primeira parte, porém, trata de Apolo e Ártemis, dois destinatários tradicionais do gênero peã. A segunda, esta, voltase a Dioniso: o coro lança o brado dionisíaco દủoî (219) e fala da hera que o põe a girar,

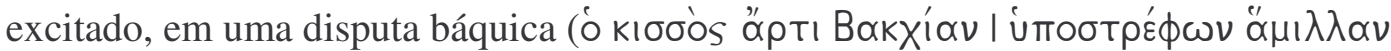
219-20). A disputa báquica ensejada pelo aulos e pela hera, ambos atributos de Dioniso, sugere o ditirambo e a sua dança circular. Como observa Rutherford, ${ }^{200}$ a ode é uma mistura de gêneros ("generic mixture"). Vejamos como se dá essa mistura.

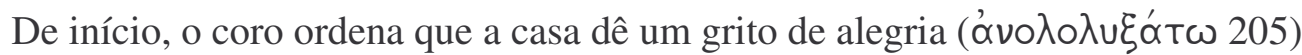

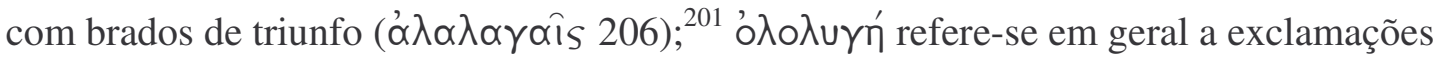
proferidas pelas mulheres, $\alpha^{\prime} \lambda \alpha \lambda \propto \gamma \eta \dot{~ p e l o s ~ h o m e n s . ~}{ }^{202}$ A diversidade de função desses

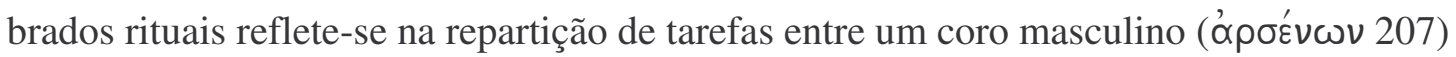
que celebra Apolo e outro, feminino ( $\pi \alpha \rho \theta^{\prime}$ vo 211 ), que exalta Ártemis - mas ambos, é lícito supor, nos moldes peânicos (210-11), e ambos em uníssono (Koıvós 207, ó 210). A transição para o ditirambo dionisíaco é marcada pela afirmação do coro de que

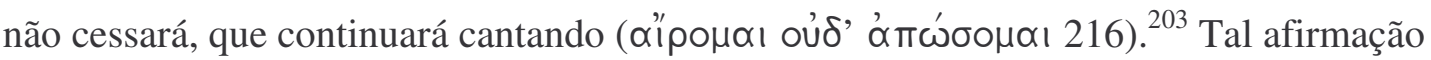
serve de dobradiça entre a primeira e segunda partes da ode, entre peã e ditirambo, e ganha relevo não apenas pelo itifálico em fim de período no verso anterior ( $\gamma$ É Továs TE Nú $\left.\mu \phi \alpha_{S}-\cup-\cup--I\right),{ }^{204}$ mas ainda por ser o ponto final da progressão que leva da

\footnotetext{
${ }^{200}$ Rutherford (2001), 113.

${ }^{201}$ Sobre as diferentes versões dos versos 205-7, cf. Kamerbeek (1978), 71, Lloyd-Jones e Wilson (1990), 156s. e Davies (1991), 101s.

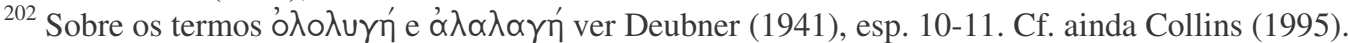

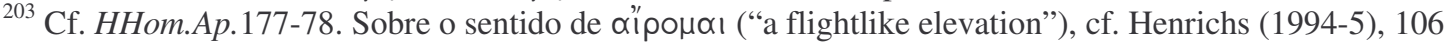
n.105.

${ }^{204}$ Cf. West (1982), 72: "The ithyphallic at the end (= catalectic $E$ ) is not found in Pindar or Bacchylides, but reappears as a D/e clausula in tragedy”. Ver ainda peã de Arífron acima (item 1.1.4), verso 7.
} 


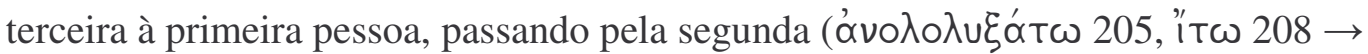

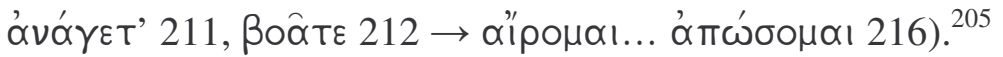

As fronteiras, porém, entre peã e ditirambo são deliberadamente borradas ${ }^{206}$ pelo coro quando reúne no mesmo fôlego a interjeição dionisíaca घủoî (219) e o semi-refrão

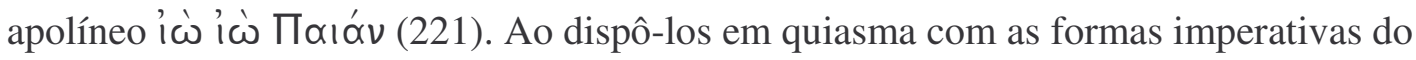
verbo "ver", ele sublinha a equivalência entre os cantos:

\begin{tabular}{|c|c|}
\hline $\begin{array}{l}218 \\
219\end{array}$ & 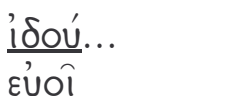 \\
\hline$\ddot{2} 21$ & i் $\Pi \alpha ı \alpha$ \\
\hline 22 & $1 \delta \varepsilon \delta^{\prime} \delta^{\prime} . .$. \\
\hline
\end{tabular}

Por sua vez, a anadiplose de $1 \delta \varepsilon$ (em hiato) transmite o sentido de urgência do coro, que

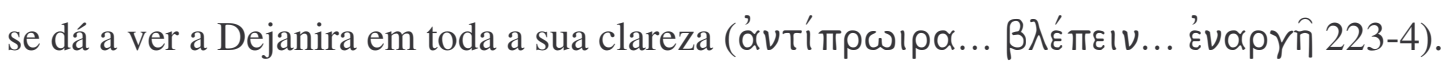
Fundem-se, assim, no momento presente, peã e ditirambo; mescla-se a ação de graças, típica dos peãs, com a excitação própria do ditirambo. Um e outro, fundidos num único canto, exprimem o alívio e júbilo simultâneos do coro, no presente dramático da peça. ${ }^{207}$

\subsubsection{Hino ao Kouros do Monte Dicta}

O hic et nunc a que visa o poeta, contudo, nem sempre sobrevém apenas no final do percurso traçado pelo hino. Certas vezes, é no próprio refrão que o instante atual do

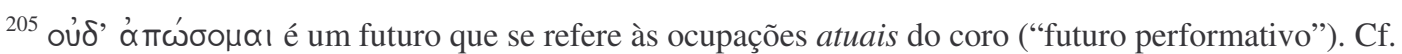
Davies (1991), 104, e Faraone (1995), com bibliografia.

${ }^{206}$ Ambígua é também a transição Apolo/Ártemis-Dioniso pelo fato de manter-se anônimo o "soberano do

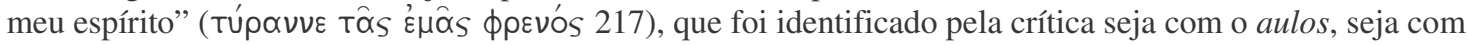
Dioniso, seja com Apolo. Cf. Henrichs (1994-5), 83 e 107 n.112.

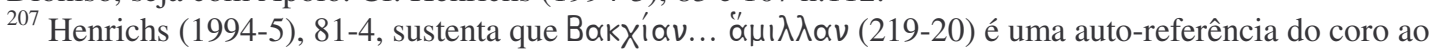
aqui e agora da competição entre coros dramáticos rivais durante a Dionísia Urbana. Além da sua função dramática, a função ritual do coro - como um conjunto que rende homenagem a Dioniso por ocasião do seu festival em Atenas - seria assim evocada. Muitos, lembra Henrichs, tendem a reconhecer em $\propto$ " $\mu \iota \lambda \lambda \propto \nu$ uma simples alusão à rapidez, não à disputa (Lloyd-Jones, por exemplo, em sua edição da Loeb, traduz o termo

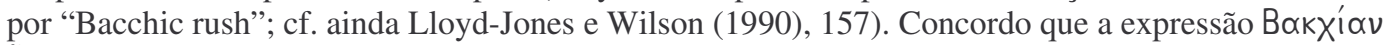
$\propto \dddot{\alpha} \mu \lambda \lambda \chi \propto \nu$ guarda uma acepção agonística e que Kranz (1933), 183, está correto ao traduzi-la por "den bakchischen Wettanz der Füße", mas não vejo por que, nesse caso, Sófocles estaria disposto a ressaltar o papel ritual do coro, ao lado do seu papel dramático. Creio que a expressão não seja mais que uma viva metáfora para a excitação da dança báquica. Outro já é o caso do hino a Dioniso da Antígone de Sófocles (1115-54): lá a aproximação entre as funções dramática e ritual do coro cumpre um propósito literário específico, de fundir Tebas a Atenas para amplificar o impacto dramático buscado pelo autor. Remeto-me à análise desse hino, acima (item 1.1.2), para mais detalhes da minha visão a respeito.
} 
canto celebratório ocupa sua sede natural. Relevo é conferido ao tempo presente do culto não só pela repetição a intervalos fixos, característica do refrão, mas ainda pelo esforço do poeta para integrar esse refrão na seqüência sintática dos demais versos. Tal é o caso, por exemplo, do hino cretense a Zeus do Monte Dicta. ${ }^{208}$

5

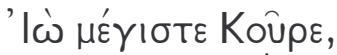

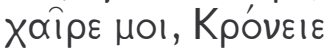

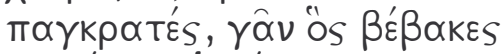

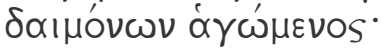

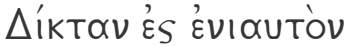

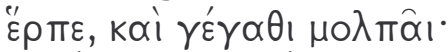

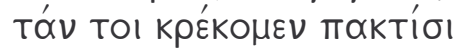

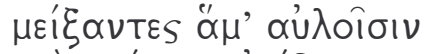

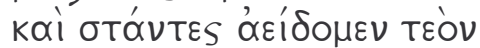

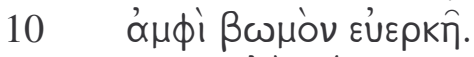

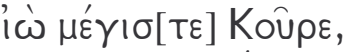

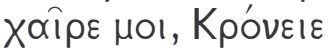

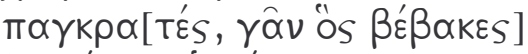

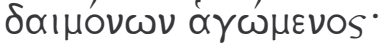

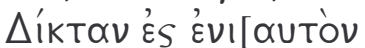

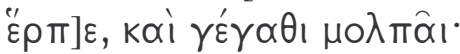

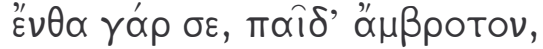
${ }_{\alpha}^{\prime} \sigma \pi, \delta[\ldots \ldots \ldots \ldots . . . \ldots]$

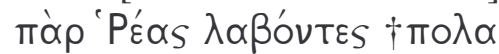

$20 \quad \mathrm{k}[$

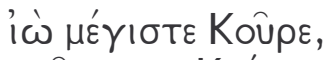

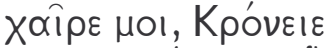

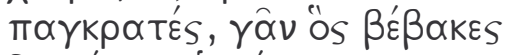

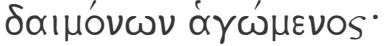

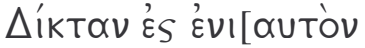

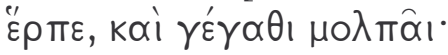

(Faltam três versos.)

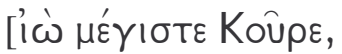

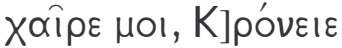

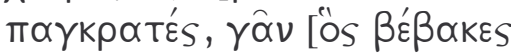

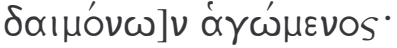

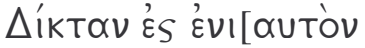

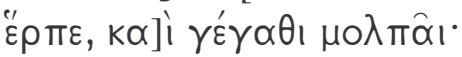

${ }^{208}$ Cito a versão de West (1965), 149-50. Outro exemplo que vale mencionar, mas que não analiso aqui, é o

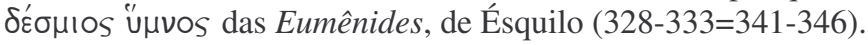


[...........

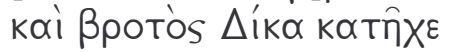
$[\ldots \ldots \ldots \ldots \ldots \ldots] ! \pi{ }^{\prime}{ }_{\varepsilon}^{\prime} \xi \omega$

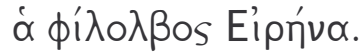

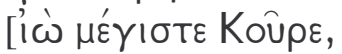

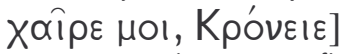

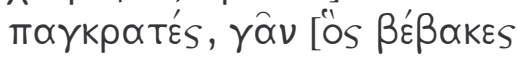

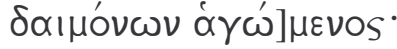

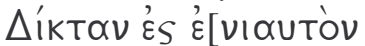
हैр

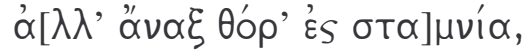

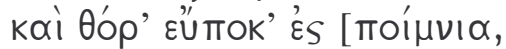

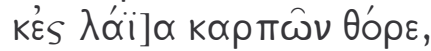

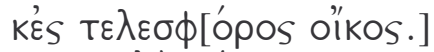

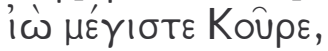

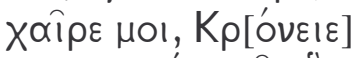

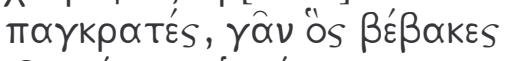

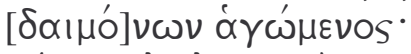

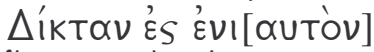

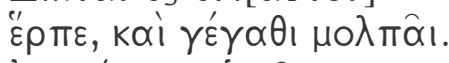

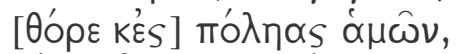

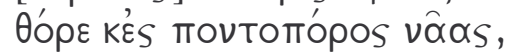

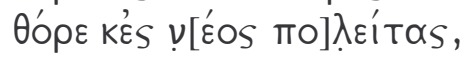

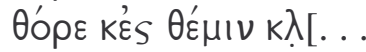

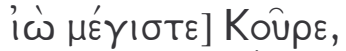

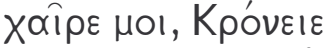

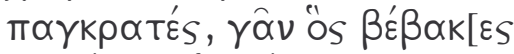

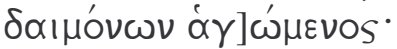

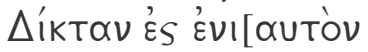

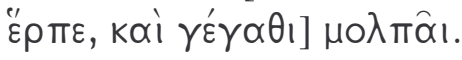

(Io! Poderosíssimo Kouros, salve, filho de Cronos, senhor de tudo, que vieste a essa terra à frente dos deuses, vem ao Dicta nesse ano-novo e deleita-te com nossa música, Que tecemos para ti com harpas e a mesclamos aos oboés e cantamos dispostos ao redor do teu altar bem-murado.

Io! Poderosíssimo Kouros, salve, filho de Cronos, senhor de tudo, que vieste a essa terra à frente dos deuses, vem ao Dicta nesse ano-novo e deleita-te com nossa música. Pois foi aqui que te pegaram, criança imortal, [com seus] escud[os]... das mãos de Réia e...

Io! Poderosíssimo Kouros, salve, filho de Cronos, senhor de tudo, que vieste a essa terra à frente dos deuses, vem ao Dicta nesse ano-novo e deleita-te com nossa música. ... da bela Aurora.

Io! Poderosíssimo Kouros, salve, filho de Cronos, senhor de tudo, que vieste a essa terra à frente dos deuses, vem ao Dicta nesse ano-novo e deleita-te com nossa música. ... pródigas a cada ano, e a Justiça reinava sobre os mortais, ... pela Paz que faz prosperar. 
Io! Poderosíssimo Kouros, salve, filho de Cronos, senhor de tudo, que vieste a essa terra à frente dos deuses, vem ao Dicta nesse ano-novo e deleita-te com nossa música.

Oh! [senhor, pula nas] jar[ras de vinho], e pula [nos rebanhos] lanudos, [e nas plantações de] trigo pula, e n[a casa para que haja] descendentes.

Io! Poderosíssimo Kouros, salve, filho de Cronos, senhor de tudo, que vieste a essa terra à frente dos deuses, vem ao Dicta nesse ano-novo e deleita-te com nossa música.

[Pula em] nossas cidades, pula nos navios mercantes, pula nos j[ovens ci]dadãos, pula na ordem fa[mosa.]

Io! Poderosíssimo Kouros, salve, filho de Cronos, senhor de tudo, que vieste a essa terra à frente dos deuses, vem ao Dicta nesse ano-novo e deleita-te com nossa música.)

A pedra na qual o hino se acha inscrito foi encontrada nas cercanias de um templo arcaico por uma equipe de arqueólogos britânicos durante escavações realizadas entre 1902-1905 na região oriental de Creta, num local hoje chamado Roussolakkos, próximo a Palaikastro, cidade vizinha ao monte Petsofa (antigo Dicta). O templo estava em uso desde o século VII a.C, e o culto a ele relacionado talvez o antedate em cento e cinqüenta anos, mas a inscrição propriamente dita data de meados do século III d.C. - trata-se assim de uma cópia de um original anterior, cuja leitura terá sido prejudicada pela ação do tempo ou por outro tipo de avaria. Tradicional, pois, era o hino para que as autoridades responsáveis pelo santuário mandassem reinscrevê-lo, e tradicional é também a história do filho de Cronos (Zeus) nele narrada. Na verdade, o nome de Zeus não aparece ao longo do hino, sendo ele interpelado como "jovem" (kouros). Mas sabemos, pela tradição mitológica do nascimento de Zeus, da ameaça que representa Cronos, o pai que engole seus filhos ainda bebês, da astúcia da sua mãe Réia, que foge para Creta para dá-lo à luz e para que ele seja criado sob a proteção dos curetes (“jovens”), que abafam os vagidos do recém-nascido com o estrondo das armas de metal percutidas enquanto dançam em sua volta. $^{209}$

Segundo West, ${ }^{210}$ o refrão "evidentemente incorporou algo de uma aclamação de culto tradicional", e é no próprio refrão que se faz referência ao culto, do qual o hino é elemento integrante. Xơipe (2) é uma saudação, como demonstrou Wachter, ${ }^{211}$ que na poesia hínica arcaica grega equivale a um convite à divindade para que receba de bom

\footnotetext{
${ }^{209}$ Cf. Hes. Teog. 468-4, Estrabão 10.46,11, Eur. Ba.120-25, Corina PMG 654 col.1, 12-16, Cal. Hino a Zeus 52-3, ps.-Apolodoro 1.1,6, Higino 139,3. Para essas e outras referências gerais, ver Furley-Bremer (2001), vol. 1, 69-76, e vol. 2, 12.

${ }^{210}$ West (1982), 148.

${ }^{211}$ Wachter (1998) e (2004), esp. 312-3 e 320-1.
} 
grado uma oferenda votiva, sendo essa muitas vezes o próprio hino entoado em sua homenagem. ${ }^{212}$ Ora, tal sentido torna-se explícito no fecho do refrão, ${ }^{213}$ quando se repete, em outros termos, a mesma idéia, com a exortação de que Zeus deleite-se com a música

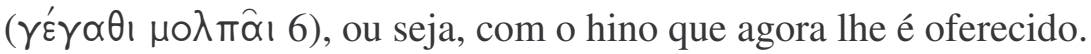

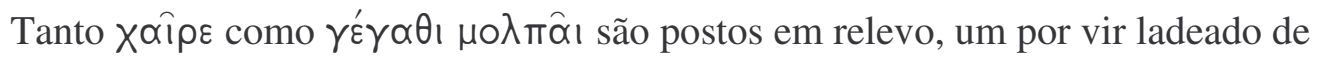

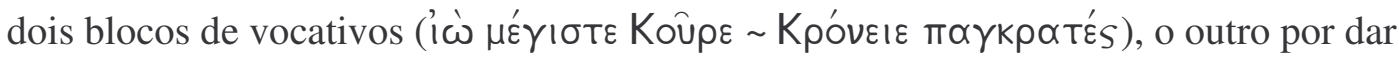
remate ao refrão. Entre ambos, que atuam como uma moldura, o jovem Zeus é trazido para perto em dois estágios: primeiro relata-se que ele veio a esta terra (isto é, Creta) à

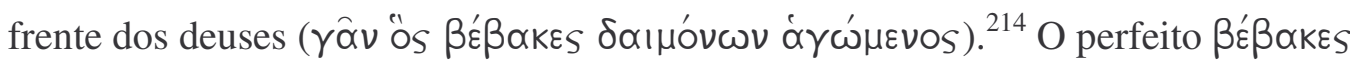
'vieste' exprime a noção de estado, de ponto de chegada após conclusão do movimento: "vieste e aqui estás (na terra)". Uma vez em Creta, o poeta fecha ainda mais o foco e exorta Zeus a vir (" enfático que inaugura nova oração e põe termo ao trajeto, com o acréscimo de mais uma especificação, esta temporal: o kouros deve vir ao Dicta por ocasião do ano-novo ('ยs Ev่ıuTòv), época na qual o hino é recitado.

Os votos para que Zeus deleite-se com a canção ( $\gamma^{\prime} \gamma \alpha \theta$ ı $\left.\mu \lambda \pi \hat{\alpha}_{\imath}\right)$ são assim duplamente sublinhados, tanto por retomarem o $\chi \propto \hat{i} \rho \varepsilon$ inicial quanto por virem ao cabo do breve percurso que leva o deus até Creta e de Creta ao Dicta. E o momento presente das festividades ganha em definitivo o centro das atenções com a continuidade de sentido entre refrão e estrofe, Tóv (7) fazendo a ligação com $\mu \circ \lambda$ กôa. É essa música - o próprio hino que ouvimos -, a forma da sua execução, o local onde ocorre, que ocupam os quatro versos estróficos seguintes (7-10).

Ao final destes, torna o refrão para, mais uma vez, promover a ligação com a estrofe que segue: o $\varepsilon^{\prime} \nu \theta \alpha$ (17) que a introduz refere-se a $\Delta^{\prime} \mid{ }^{\prime}$ T $\alpha \nu$ (15) do refrão, não ao $\beta \omega \mu$ ós (10) da estrofe anterior. A função aqui da continuidade, que não se repetirá no

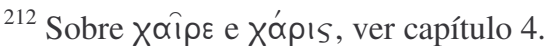

${ }^{213}$ Como notam Furley-Bremer (2001), vol. 2, 5.

${ }^{214} \gamma \hat{\alpha} \nu$ ôs é a leitura de West; na lápide lê-se $\Gamma A N O Y \Sigma$, com um pequeno $Y$ inserido entre $O$ e $\Sigma$. West explica o $Y$ como notação do espírito áspero, mas Furley-Bremer preferem ler $\gamma$ ávos, construindo-o com

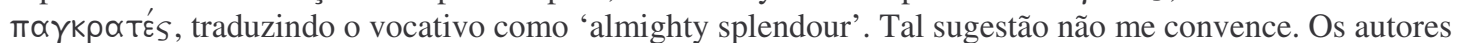
vêem uma deselegante reduplicação da idéia e construção "vir à terra" e "vir ao Dicta", o que tento explicar pela progressiva aproximação - comum na literatura hínica - ao local onde se dá o canto. West (1965), 156, 159, sugere equivocadamente, parece-me, que Zeus dirige-se "para baixo da terra", e aventa a hipótese de um suposto Zeus ctônico que vive permanentemente no mundo inferior.
} 
decorrer do poema, é dar início ao relato mítico, que se estende aparentemente dos versos 17 a 40 e cuja descrição é fundamental para a formulação do pedido. No que resta dessas passagens, Zeus é lembrado do seu local de nascimento, de como Réia transmitiu-o à custódia dos kouretes, de como a seu nascimento seguiu-se uma época de fartura e paz sob o ditame da justiça (37-40). ${ }^{215}$

Concluído o mito, está preparado o terreno para o pedido formulado nas duas últimas estrofes: "assim como teu nascimento, ó Zeus", diz o poeta, "deu ensejo a paz, justiça e prosperidade na terra, vem agora novamente, para que dessa prosperidade possamos usufruir". Tal como ocorreu no passado (cf. os tempos verbais da seção mítica,

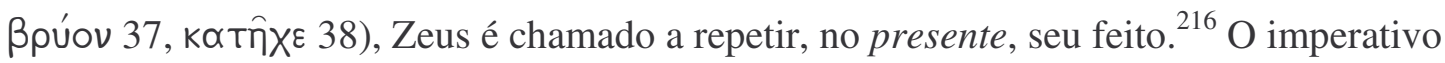
anafórico $\theta o ́ p \varepsilon$ pode referir-se, de acordo com West, ${ }^{217}$ tanto à renovação do nascimento divino quanto à idéia de fertilidade. É essa fertilidade que deverá difundir-se às esferas privada e pública, descritas respectivamente na penúltima e última estrofes.

Vemos assim que há uma distribuição estrutural de funções entre estrofe e refrão. As estrofes 2, 3 e 4 (correspondentes à "seção mítica" ou pars epica) desenvolvem o argumento sobre o qual se baseia o pedido das estrofes 5 e 6: "Ó Zeus, torna a instaurar a época de ouro decorrente do teu nascimento". Quanto ao refrão, ao qual se une (como vimos) intimamente a primeira estrofe, cabe-lhe fixar o local e o momento presentes para

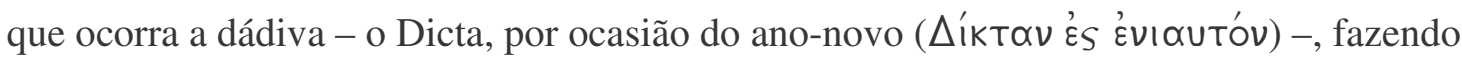

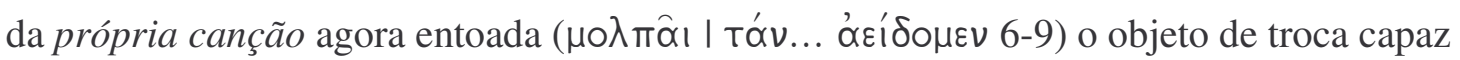
de seduzir a divindade $\left(\chi \propto \hat{\imath} \rho \varepsilon \ldots . \gamma^{\prime} \gamma^{\prime} \propto \theta_{1}\right){ }^{218}$

\footnotetext{
${ }^{215}$ Murray suplementa assim o verso 37: $\Omega \rho \alpha ı$ d’ $\beta$ ]púov ‘As estações eram pródigas...', o que é aceito

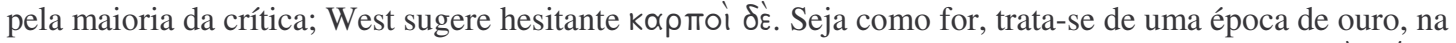
qual justiça e paz concorrem para a prosperidade. Quanto ao verso 39, Wilamowitz suplementa: kåi móv $v$ Ta $\delta 1] \eta ̄ \pi \varepsilon \zeta \hat{\omega}$ ' 'e todos os seres vivos eram governados (pela Paz que faz prosperar)'.

${ }^{216}$ Cf. West (1965), 157, Bremer (1981), 206, Furley-Bremer (2001), vol. 2, 14.

${ }^{217}$ West (1965), 157s.

${ }^{218}$ A relação entre deus e devoto, sacramentada pelo hino, é enriquecida à luz da descoberta por Perlman (1995) de duas inscrições cretenses que revelam notáveis paralelos vocabulares com o hino de Palaikastro. Uma delas trata do juramento a que todos os cidadãos de Itanos deviam submeter-se para obter direitos de plena cidadania: várias palavras e termos afins contidos na inscrição (IC III 4,7) reaparecem nas estrofes 5 e 6 do nosso hino. É como se a esfera de direitos e obrigações relacionados no juramento fosse transferida para o vínculo que une divindade e fiéis, e vice-versa.
} 


\subsubsection{PMG 887}

Vezes há, também, nas quais o caminho que conduz a divindade de longe para perto adapta-se às dimensões reduzidas do poema e às condições de performance, como neste skolion ateniense do início do século V a.C. (PMG 887).

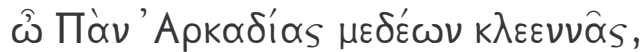

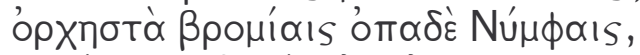

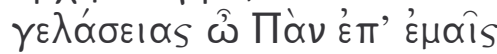

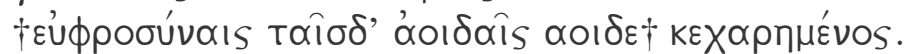

(Ó Pã, senhor da famosa Arcádia, parceiro de dança das ninfas de Brômio, sorri, ó Pã, diante do meu júbilo e deleita-te com as minhas canções.)

De sua sede na Arcádia, terra da qual é senhor, Pã é chamado a "sorrir", a olhar com favor para o entretenimento simpótico e deleitar-se com as suas canções, das quais o hino é um exemplo. ${ }^{219}$ Transita o poema, na exigüidade dos seus versos, da Arcádia para

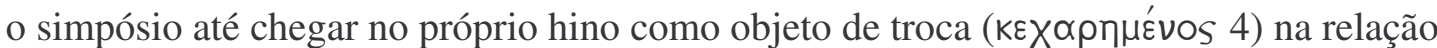
de reciprocidade instaurada com o deus.

Após o vocativo inicial, Pã é interpelado como senhor da Arcádia e acompanhante

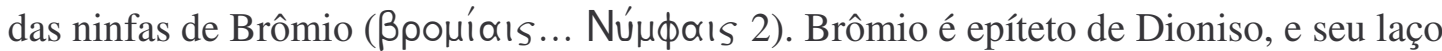
com as ninfas, num contexto simpótico, evoca a mistura de água e vinho, como sugerem Furley-Bremer. ${ }^{220}$ Há um paralelo tardio - mas não menos significativo, em virtude do matiz marcadamente poético da linguagem - para tal metáfora no Misantropo (Duskolos) de Menandro, no qual Dioniso e ninfas também representam a mistura entre água e vinho durante as festividades em honra do mesmo deus Pã (versos 946-48):

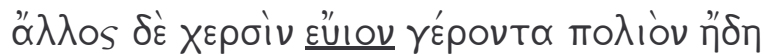

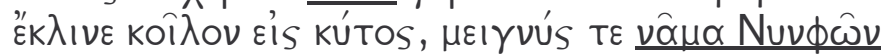

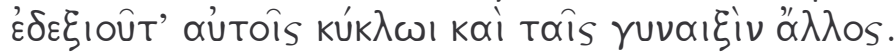

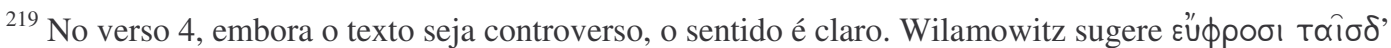

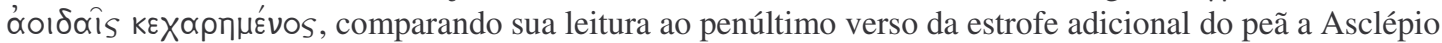

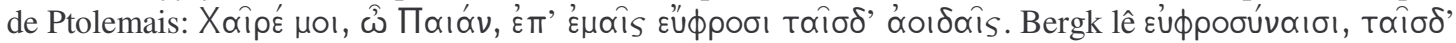
@o

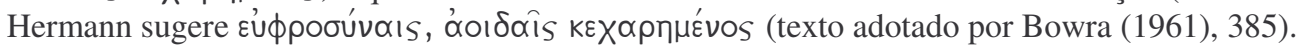

${ }^{220}$ Furley-Bremer (2001), vol. 2, 218s.
} 
(Agora um velho Baco patriarca [= um vinho antigo] foi vertido num vaso côncavo pela mão daquele que o misturou às fontes das ninfas, que então ergueu um brinde aos homens em volta da caverna; outro ergueu um brinde às mulheres.)

Além de companheiro das ninfas, Pã é dançarino ('opxワotó 2), uma das suas atividades tradicionais. ${ }^{221}$ Tal epíteto é retomado logo adiante, quando o poeta convida essa divindade afeita à música e à dança a deleitar-se com as canções (đooıઈốs 4) em seu tributo. A transição definitiva para o instante presente das celebrações é marcada com a repetição do vocativo inaugural ( $\hat{\omega} \Pi \alpha \alpha$ 3), que ocupa posição central no verso (e duas sílabas longas).

${ }^{221}$ Cf. Hino Homérico a Pã, 19-26, Píndaro fr. 95 S.-M. 


\subsection{Quebras de CONVENÇÃo}

Como vimos até aqui, há inúmeras formas de os poetas atraírem as divindades para o aqui e agora, o instante presente em que o hino é cantado. O presente é sempre o ponto de chegada, o foco sobre o qual o cantor faz convergir as atenções - seja do deus, seja do público. Diversos são os expedientes retóricos de que se vale o poeta, dependendo do seu propósito e das suas habilidades, mas o objetivo básico é transformar o hino num ímã para os favores divinos, dos quais ele age como objeto de troca numa relação mútua de reciprocidade. Essa é uma convenção fundamental da literatura hínica, e dela se acham imbuídos poeta, público e divindade. "Todo hino exibe”, afirma Race, ${ }^{222}$ "um movimento do geral ao particular, dos poderes amplos e atemporais dos deuses às necessidades temporais do homem, das ações passadas às expectativas presentes, e, muitas vezes, às esperanças para o futuro". Ora, é justamente por existir tal convenção estilística básica que se torna possível ao poeta jogar com as expectativas do público com relação a ela, a fim de corroborá-las, frustrá-las ou abrir-lhes novos horizontes.

\subsubsection{Píndaro, Olímpica 14}

Mencionarei alguns poucos exemplos de como o poeta hínico incorpora tais expectativas e as remodela em benefício dos seus propósitos laudatórios. O primeiro vem do hino às Graças da Olímpica 14 de Píndaro.

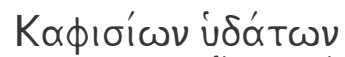

estr.A

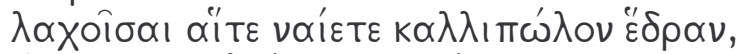

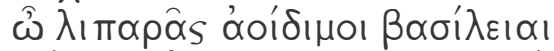

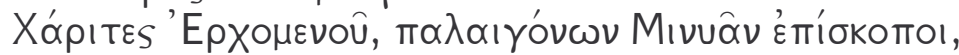

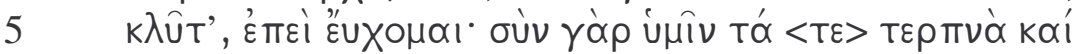

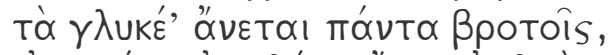

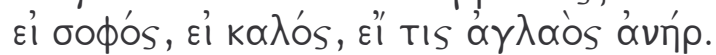

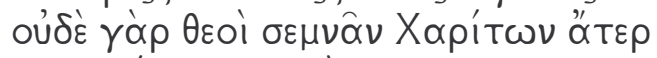

KoIpavÉOVTI XOpOUंS

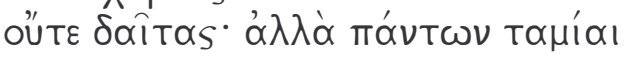

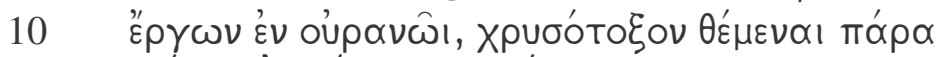

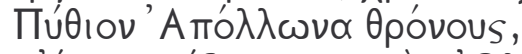

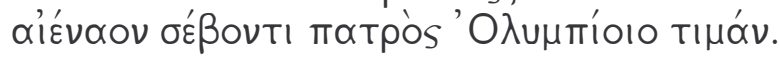

${ }^{222}$ Race (1990), 87. 


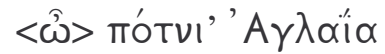

estr.B

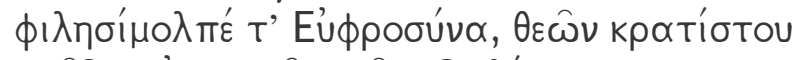

15

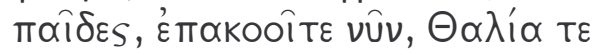

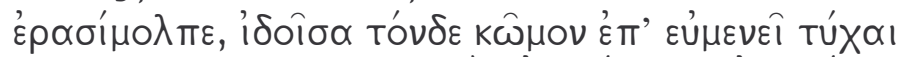

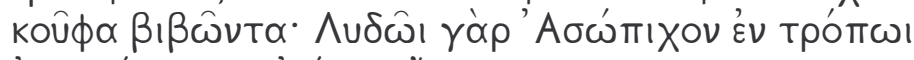

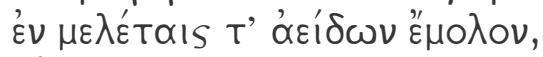

oúvek' 'O

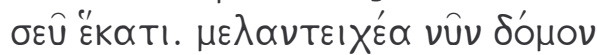

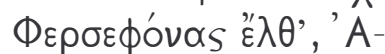

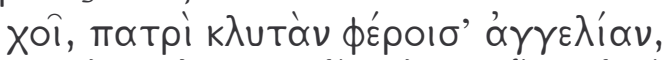

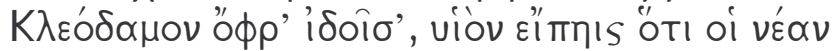

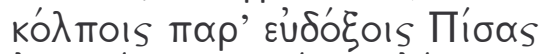

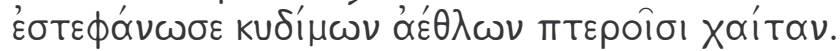

(Vós a quem cabem por lote as águas do Céfisos e que habitais uma terra de belos cavalos, ó Graças, rainhas do brilhante Orcômenos famosas em canto e guardiãs dos antigos Mínias, ouvi a minha prece. Pois convosco tudo quanto há de agradável e doce acontece aos mortais, seja o homem sábio, belo ou ilustre. Nem mesmo os deuses preparam coros ou banquetes sem as augustas Graças; como intendentes de todas as obras no céu, elas têm seus tronos ao lado de Apolo Pítio do arco dourado e reverenciam a majestade inesgotável do pai olímpico. /

Ó senhora Aglaia e Eufrosina amiga da música, filhas do mais poderoso dos deuses, escutai-me agora - e tu, Tália, amante da música, olha com favor esse grupo em festa que celebra a boa fortuna com passos leves. Pois eu vim, cantando Asópico em modo lídio enquanto pratico a minha arte, já que a terra dos mínias é vitoriosa em Olímpia por causa de ti. Vai agora à casa de muros negros de Perséfone, Eco, portando a gloriosa notícia ao pai dele, para que, quando vires Cleodamo, possas dizer que o seu filho coroou a jovem cabeleira no famoso vale de Pisa com as guirlandas aladas dos jogos que trazem renome.)

Primeiro as Graças são interpeladas (1-4) $)^{223}$ como padroeiras da cidade natal do vencedor, com referências específicas à topografia (Céfisos), ao nome da cidade (Orcômenos) e aos seus antigos habitantes (os mínias). Em seguida (5-12) são elas descritas como causa de tudo quanto há de doce e agradável na vida, como indispensáveis às ocasiões festivas. Olhando de forma mais detida, observamos uma escala progressiva de abrangência que leva dos homens aos deuses. A princípio a relação das Graças é com os homens de Orcômenos (1-4), depois (5-7) com os homens em geral (ßротоís 6), a seguir (8-12) com os deuses ( $\theta \varepsilon o i ́$ 8). Tanto para homens como deuses em geral a

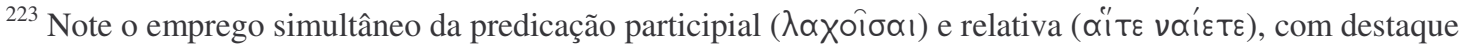

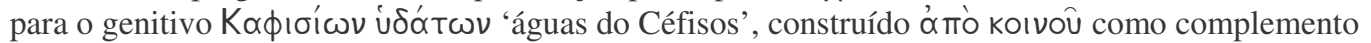
adverbial (do verbo $\left.\lambda \alpha \gamma \chi \alpha \alpha^{\prime} v \omega\right)$ e adnominal (do substantivo $\left.\varepsilon \delta \rho \rho \alpha\right)$ ): cf. Hummel (1993), 117s. Como lembra Verdenius (1979), 17, os três primeiros versos "are a good example of the 'Gesetz der wachsenden Glieder"”.
} 


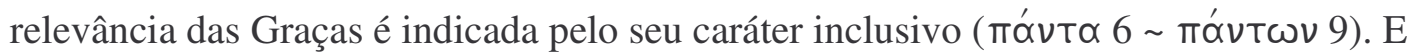
uns, com elas (бúv... únîv 5), são dotados de coisas agradáveis e doces; outros, sem elas

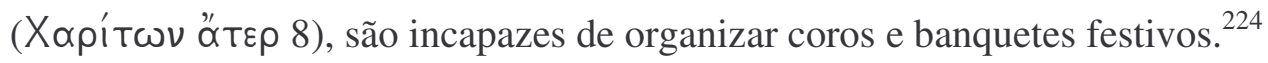

Do Céfisos, em Orcômenos, progride assim a primeira estrofe até o céu ('ُv

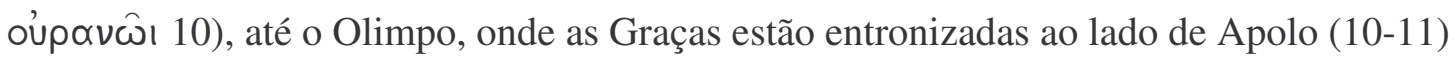
e - remate que alcança o ápice da cadeia hierárquica - onde veneram a majestade do pai olímpico, Zeus (12).

Uma segunda invocação marca o início de uma nova estrofe, que desloca o foco das Graças como coletividade para a natureza individual das suas personalidades. A seqüência em que aparecem é hesiódica, ${ }^{225}$ mas uma série de fatores contribui para emprestar relevo à última delas, Tália, a começar pelos elementos crescentes no verso:226

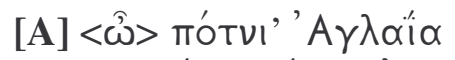

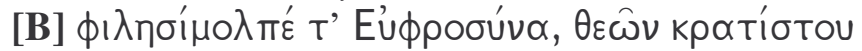
15

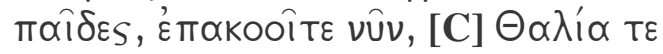

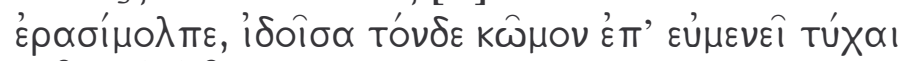

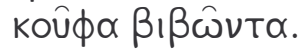

A ordem das palavras e a sintaxe, como observa Miller, ${ }^{227}$ também lhe conferem proeminência. Entre seu nome e o de suas irmãs intervêm a genealogia honorífica $(\theta \varepsilon \hat{\omega} \nu$

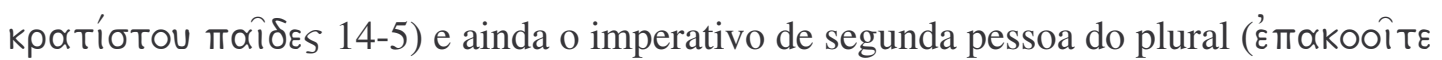
15), mas, aumentando-lhe o isolamento, somente ela é interpelada nos versos que seguem

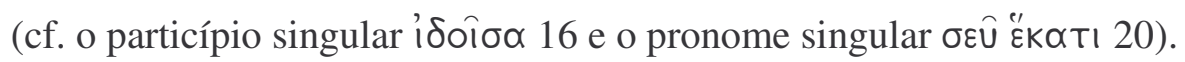

De uma unidade ternária as Graças passam a três individualidades separadas, num movimento análogo, mas contrastante, ao descrito no verso 7. Lá a ação universal (

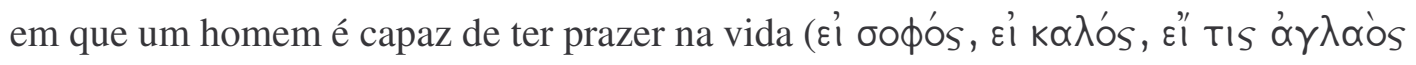
óvíp), conferindo um sentido de abrangência a seu poder: do prazer concedido pelas Graças, o homem logra usufruí-lo "seja ele sábio, seja ele belo, seja ele ilustre” (notar a

\footnotetext{
${ }^{224}$ O caráter antitético e complementar é indicado também pelo uso do "Du-Stil" na parte que se refere aos homens e do "Er-Still" na que se refere aos deuses. A transição é notada por Verdenius (1979), 22, e Dönt (1983), 127.

${ }^{225}$ Cf. Teog. 909.

${ }^{226}$ Fato notado por Race (1990), 100, de quem transcrevo o esquema.

${ }^{227}$ Miller (1977), 226.
} 
tripla anáfora assindética $\varepsilon \hat{\imath}-\varepsilon \hat{\imath}$ - $\varepsilon \dot{l}$, marca de coesão e fator de solidariedade sintagmática). ${ }^{228}$ Aqui, por outro lado, as Graças, a cuja ação conjunta fora atribuída a administração de coro e banquete divinos (9), são cuidadosamente repartidas em três

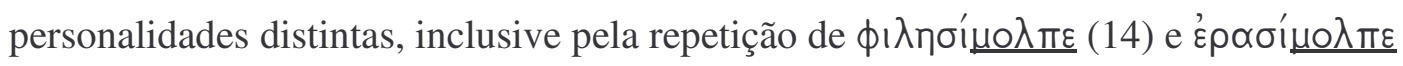
(16), dirigidos a Eufrosina e Tália respectivamente: o elemento constante enfatiza, por contraste, o elemento variável que as separa. ${ }^{229}$

Repartidas as Graças, e somente a terceira delas sendo interpelada de agora em diante, pede-se que Tália olhe com favor ${ }^{230}$ para esse grupo em festa ( $\underline{\text { Tóv } \delta \varepsilon} \kappa \hat{\omega} \mu o v$ 16), mais um aspecto na crescente particularização promovida pela segunda estrofe. ${ }^{231} \mathrm{E}$ do

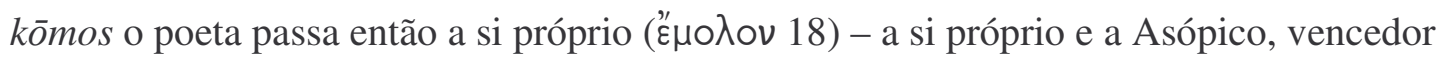
olímpico celebrado pelo epinício, os elos finais nessa cadeia que conduz ao hic et nunc do poema. As três orações com a partícula yó $\rho$ dão testemunho desse movimento oposto e complementar entre primeira e segunda estrofes, entre expansão e convergência do foco

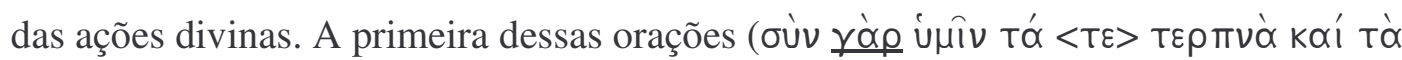

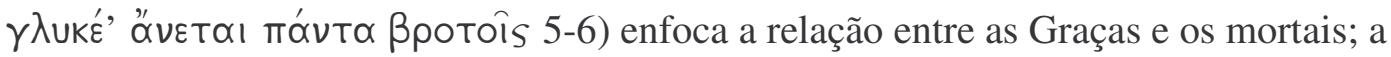

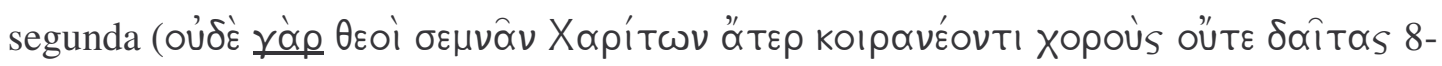

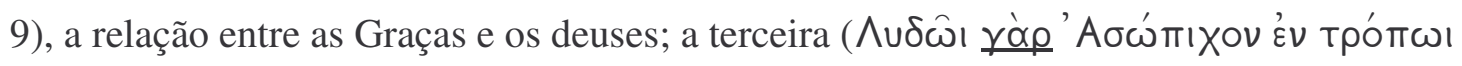

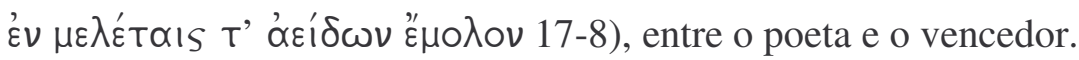

$$
\begin{aligned}
& \text { Graças } \leftrightarrow \text { mortais } \\
& \text { Graças } \leftrightarrow \text { deuses } \\
& \text { poeta } \leftrightarrow \text { vencedor }
\end{aligned}
$$

\footnotetext{
${ }^{228}$ Race (1990), 99s., atenta para divisão, mas a interpreta como um priamel, sendo á $\gamma \lambda \propto$ ós (segundo ele) um gancho para voltar-se o poeta ao vencedor, pois o termo é uma vox propria que descreve o sucesso nas competições: cf. Miller (1977), 228. Mas a amplificação do verso seguinte, dos homens aos deuses, reforça

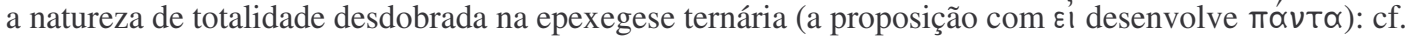
Hummel (1993), 193, 349. Possível é também, contudo, que haja uma alusão velada à complementaridade

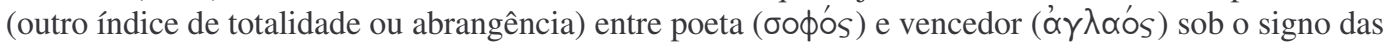
Graças. Cf. Dönt (1983), 132 n.21, com indicação das passagens pindáricas nas quais vencedor e poeta são

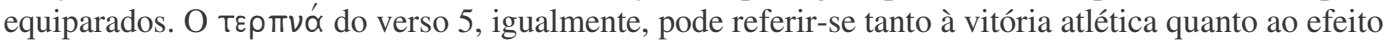
agradável da canção: cf. Verdenius (1979), 19, com citação de paralelos. Não suponho, portanto, como

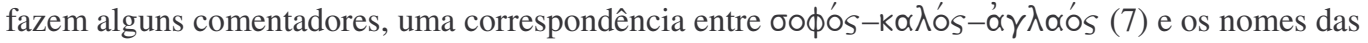
Graças.

${ }^{229}$ Cf. comentários a respeito, sob outro enfoque, de Miller (1977), 230.

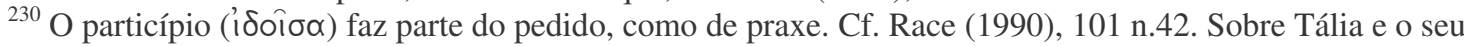
papel nas festividades, e sobretudo sobre sua relação com o $k \hat{\mu} \mu \mathrm{s}$, cf. Miller (1977). Esse segundo pedido

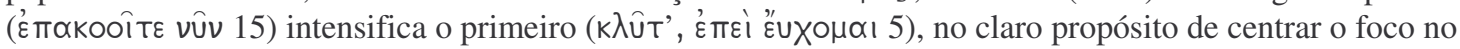
momento presente.

${ }^{231}$ Sobre o dêitico na lírica coral, ver Danielewicz (1990).
} 
Dos mortais em geral passa-se a Asópico, das Graças a Píndaro (cf. os ecos temáticos

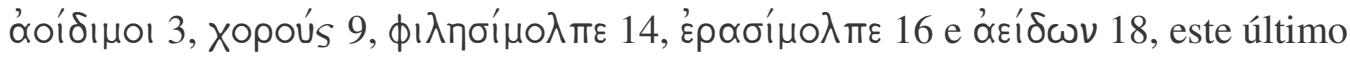
referente ao poeta, os demais termos às Graças). ${ }^{232}$

Recapitulemos o duplo movimento, de expansão e focalização, que percorremos até aqui. Na primeira estrofe, parte-se de Orcômenos, abre-se o foco para os homens em geral, para os deuses em geral, até chegar ao sobreano Zeus; de Zeus então é que parte a

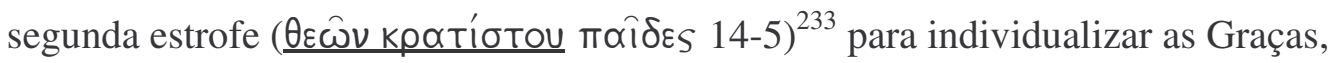
enfatizar uma delas (Tália) e, assim, convergir as atenções para o kōmos, o vencedor, o poeta e por último a sua própria composição. ${ }^{234}$ De Orcômenos partimos e a Orcômenos

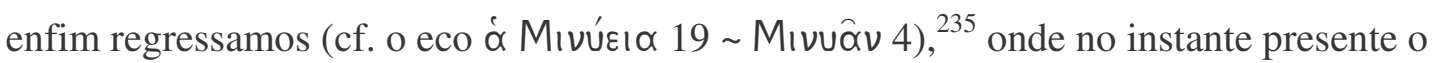
hino figura em destaque.

Parece agora que chegamos ao termo dessa evolução que conduz do particular ao geral para, com tanto mais eficácia, tornar ao particular. Mas então, de modo totalmente inesperado, quando a estratégia retórica do hino parecia completa, tendo sido proclamada a vitória olímpica de Asópico e reconhecida a ação benéfica de Tália, uma abrupta oração assindética ( $\mu \varepsilon \lambda \propto \nu \tau \varepsilon ı \chi^{\prime} \propto \dot{\alpha} \nu \cup \hat{\nu}$... 20) desvia a nossa atenção, das festividades para os nada auspiciosos muros negros de Perséfone, onde se encontra Cleodamo, o (finado) pai do vencedor. Para lá deve dirigir-se Eco, com a notícia da vitória do jovem. Do Olimpo (812), vindo de Orcômenos, o poema torna a deslocar-se para a terra (13-20), e da terra rompendo as convenções hínicas e surpreendendo a platéia - para o Hades (20-24).

Não é só o assíndeto, porém, que sublinha a transição ao mundo inferior; Kurke $e^{236}$ nota que os versos 20-1 exibem peculiaridades sintáticas que, embora encontrem respaldo

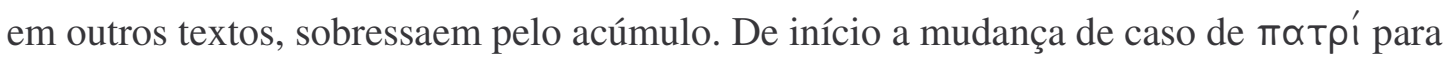

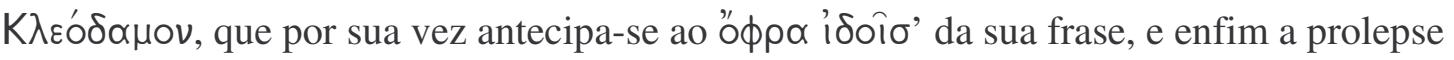

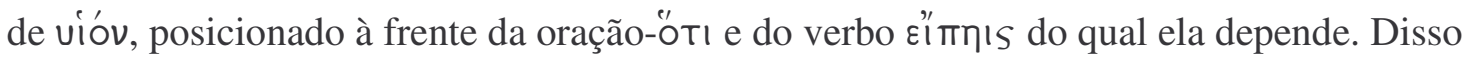

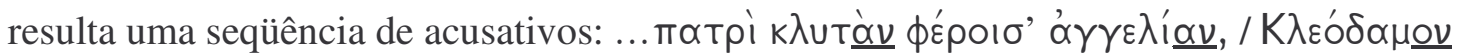

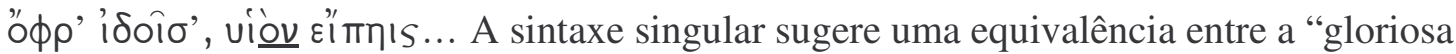

${ }^{232}$ Ecos apontados, em parte, por Dönt (1983), 134s., e Verdenius (1979), 15.

${ }^{233}$ Cf. Dönt (1983), 129, que também nota esse vínculo entre estrofe e antístrofe.

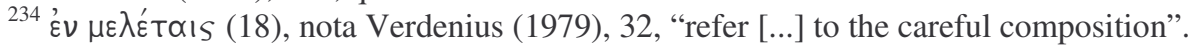

${ }^{235}$ Notado por Race (1990), 101, e Dönt (1983), 129, que chama a atenção ainda o para o paralelismo entre coro e banquete celestes (8-9) e as festividades terrenas (16-7).

${ }^{236}$ Kurke (1991b), 298 s. 


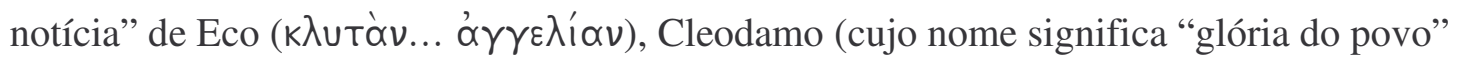
ou "aquele que tem a glória do povo") e o seu filho (vióv). "Cleodamo" parece figurar em aposição a "gloriosa notícia", e o "filho" - todos no acusativo - cumpre o que o nome do pai promete. Só mesmo no Hades, portanto, seria possível rematar o encômio de Asópico, mas com uma ressalva. Dois dativos emolduram a série de acusativos: ratpí e oi. Logo após esse último segue nova referência a Asópico, que coroou em Olímpia a sua “jovem

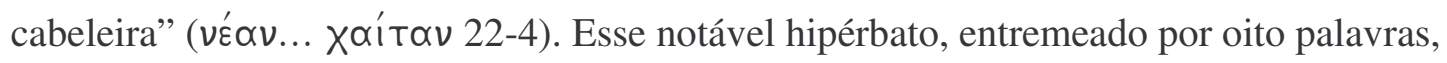
realça a juventude do vencedor e adverte: ele e seu pai podem equivaler-se na seqüência fechada de acusativos dos versos 21-2, mas Asópico é jovem e Cleodamo - Cleodamo já está morto, no Hades.

Ao descer um degrau a mais do que o esperado, o hino às Graças transforma-se em consolo. ${ }^{237}$ No jogo com as expectativas do público, Píndaro expande as fronteiras do gênero e assim enriquece o conteúdo da ode.

\subsubsection{Eurípides, Helena (167-178)}

Meu segundo exemplo vem da Helena de Eurípides. Helena inaugura o párodo antifonário; pouco antes ela fora informada por Teucro das mortes de membros da sua família em Esparta e do desaparecimento de Menelau, que ainda não pisara em terras

\footnotetext{
${ }^{237}$ Cf. Miller (1977), 233s. e Race (1990), 102. As condições de performance original da Olímpica 14 são, é claro, as de um epinício. Mas é plausível supor situações de "re-performance", inclusive por ocasião de festivais religiosos na cidade de Orcômenos (sobre a atividade cultual dedicada às Graças nessa pequena cidade da Beócia, cf. Schachter (1981), 140-4, e Kakridis (1979), 144-6; sobre a re-performance nos epinícios de Píndaro, cf. Currie (2004), Hubbard (2004) e Pfeijffer (1999), 10). Quanto ao vínculo entre epinícios e festivais, ou antes, quanto a epinícios apresentados durante os festivais, cf. Krummen (1990). Seja como for, interessam-me aqui as características formais do poema, e formalmente trata-se sem dúvida de um hino. Valem aqui as palavras de Race (2004), 385, sobre a Olimpica 12 (analisada acima): "[...] the story of Ergoteles [como aqui a de Asópico] is also a part of the whole ode, which is formally a hymn". Cf. ainda Verdenius (1979), 15: "The poem is a hymn to the Charites combined with a victory ode, but in spite of its beauty the balance of the composition is disturbed by the dominance of the first element"; e Deichgräber (1984), 218s., "Das Charakteristische des ganzen Liedes liegt der Absicht des Dichters entsprechend darin, daß der Anruf der Chariten zu einem Hymnus auf sie erweitert ist. Das Lied ist weniger ein Enkomion auf den siegreichen Asopichos als ein Preis der Göttinnen, ein echter Hymnus, deren die Merkmale dieser Liedform bestimmen den größten Teil des Gedichts. Pindar bezeichnet das Siegeslied selbst als Gebet. Es hat die alten Kennzeichen dieser Form der kultischen Huldigung. [...] (220) Pindars Anruf der Göttinnen ist wahrhaft zu einem Preislied auf die Stadtgöttinnen von Orchomenos geworden, zu einem Gebet in kultisch gesetzter Form. [...] (221) Ol. XIV is ein echtes Siegeslied, darüber hinaus [...] ein hymnisches Kultlied auf die Göttinenen, denen der Anruf gilt, die Chariten von Orchomenos". No mesmo sentido, cf. Wilamowitz (1922), 151, Carne-Ross (1975), 187, Bernardini (1991), esp. 93-4, e Athanassaki (2003).
} 
gregas, sendo aliás dado por morto. Abalada pelas notícias, ela entoa um hino às Sereias e a Perséfone (167-178). Vejamos primeiro o texto editado por Kannicht: ${ }^{238}$

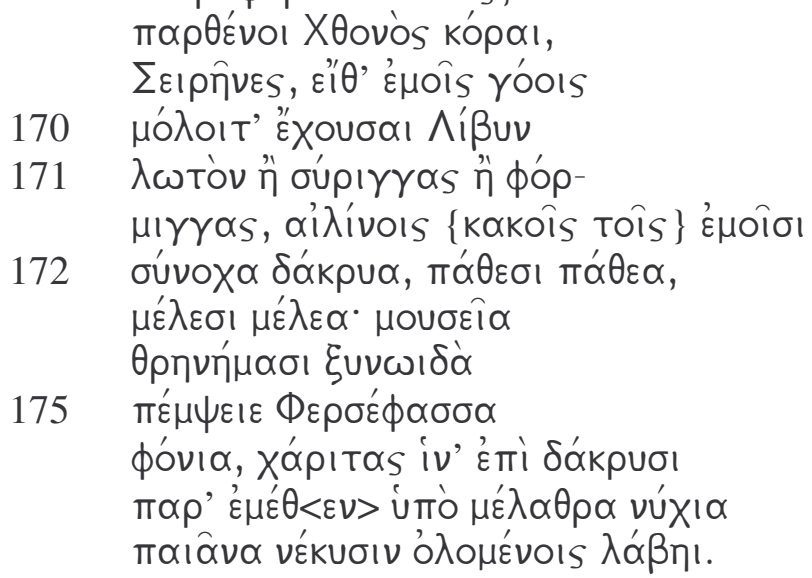

(Jovens aladas, virgens filhas da Terra, Sereias, venham a meus lamentos com oboé líbio ou flautas ou liras, com lágrimas de acordo com os meus ais, pesares de acordo com os meus pesares, cantos de acordo com os meus cantos; envie Perséfone coros de morte em harmonia com as minhas queixas, para que ela receba de mim em troca, além das minhas lágrimas, um peã para os mortos sob a sua morada noturna.)

Kannicht interpreta $\pi \propto \iota \hat{\alpha} v \propto$ (178) como um oxímoro irônico, como uma perífrase para "lamento" (thrēnos), uma vez que a canção de Helena é recebida no Hades e possui como fonte de sua inspiração Perséfone. ${ }^{239}$ Tal juízo é justamente criticado por Käppel ${ }^{240}$ e Rutherford ${ }^{241}$, que defendem o sentido específico do termo peã no contexto dramático: Helena, sentindo-se culpada por tantas mortes, entoa um "peã aos mortos" na vã ilusão de anulá-las, de tornar possível o impossível, embora saiba que agora já é tarde demais.

Para tanto ela invoca primeiro as sereias, a fim de que dela se aproximem e lhe tragam inspiração na forma de oboés, flautas, liras e mesclem sua voz à dela. Num segundo momento, Helena pede a Perséfone que também a inspire e mescle aos dela seus lamentos. A questão está em saber onde termina um pedido e onde começa o outro - e isso é deliberadamente explorado pelo hino. Ambos os pedidos, um às sereias, outro a

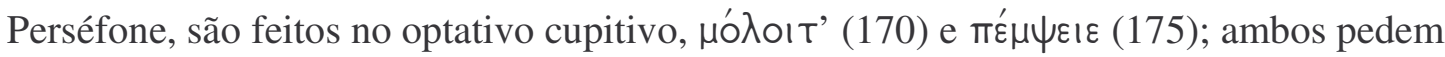

${ }^{238}$ R. Kannicht, Helena, Heidelberg (1969).

${ }^{239}$ Kannicht (1969), vol. 2, 70.

${ }^{240}$ Käppel (1992), 48s.

${ }^{241}$ Rutherford (1994-5), 124. 


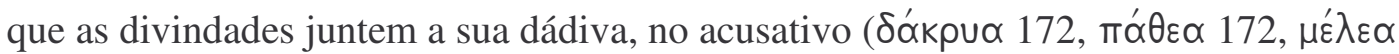

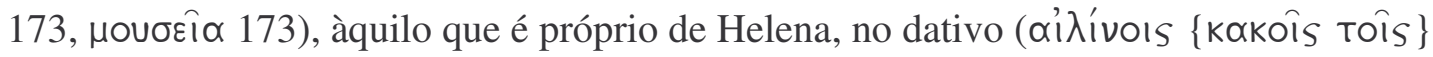

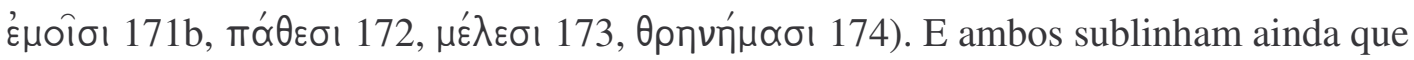

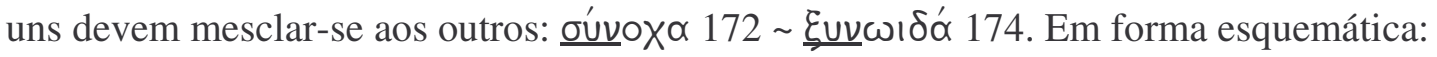

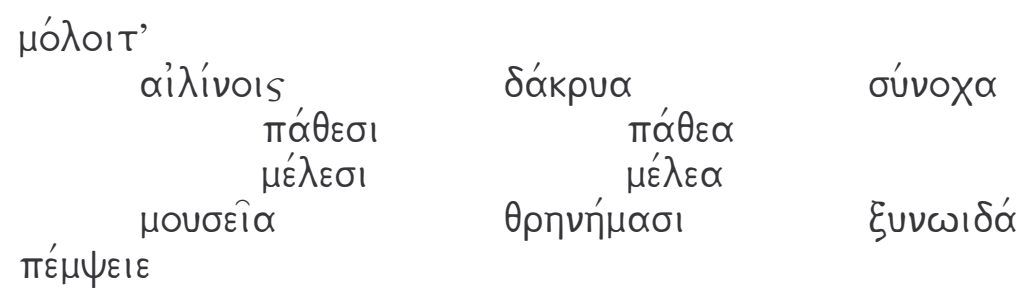

A equivalência é tanto mais saliente porque, dependendo de onde se põe o ponto e vírgula

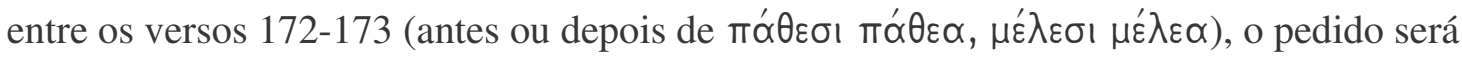
feito ora às divindades do mundo súpero, ora à deusa ctônica - as duas opções são

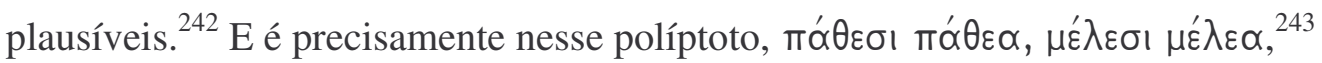
localizado no exato centro do hino, que tal equivalência ou reciprocidade traduz-se em figura de linguagem.

De cima vêm os sons e as lágrimas das sereias que se juntam aos lamentos de Helena; de baixo vêm os coros funestos de Perséfone que se juntam às suas queixas. E os dois, mesclando numa mesma harmonia pesar com pesar, canto com canto, transformamse em um peã - mas um peã dedicado não aos deuses olímpicos, como de costume, e sim

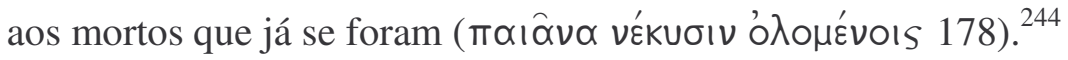

Passemos agora à edição de James Diggle para a Oxford Classial Texts (1994).

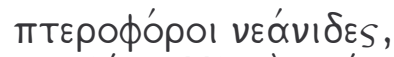

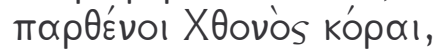

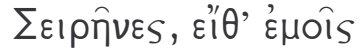

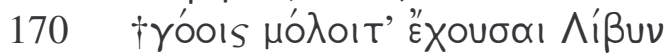

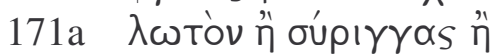

$$
\begin{aligned}
& \text { 171b фópuıryas aìivoıs kakois } \dagger
\end{aligned}
$$

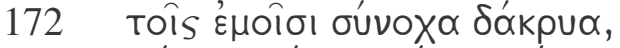

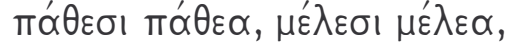

\footnotetext{
${ }^{242}$ Gilbert Murray, por exemplo, na sua edição para a Oxford Classical Texts (1913), exibe o ponto e

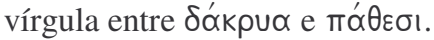

${ }^{243}$ Sobre essa figura retórica, cf. Gygli-Wyss (1966) e Fehling (1969), 221-34.

${ }^{244}$ Rutherford (1994-5), 124: "Lower world invades upper, and then the upper invades the lower". Sobre o sacrifício aos deuses olímpicos e ctônicos, ver Scullion (1994) e (2000).
} 


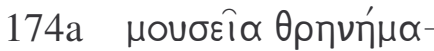

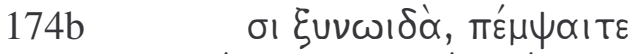

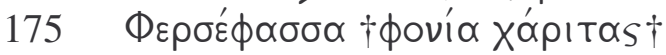

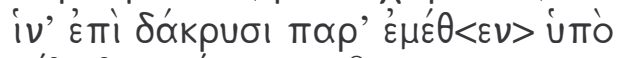

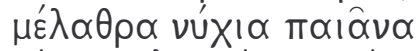

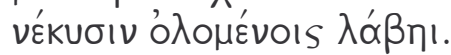

(Jovens aladas, virgens filhas da Terra, Sereias, vinde aos meus lamentos com oboé líbio ou flautas ou liras, com lágrimas de acordo com os meus ais, pesares de acordo com os meus pesares, cantos de acordo com os meus cantos, coros em harmonia com as minhas queixas, enviai-os para que Perséfone receba de mim, além das minhas lágrimas, um peã para os mortos sob a sua morada noturna.)

Diggle adota a correção de Bothe, do singular $\pi \dot{\varepsilon} \mu \psi \varepsilon \varepsilon \varepsilon$ (175) para o plural $\pi \varepsilon \dot{\mu} \psi \alpha ı$ เ $\varepsilon$, que passa a referir-se às sereias. Segundo o texto corrigido, portanto, é exclusivamente às sereias, e não mais a Perséfone, que Helena faz o seu pedido. Após mesclar suas lágrimas às lágrimas delas, o pesar aos pesares, o canto aos cantos em um lamento único, Helena envia a Perséfone o resultado dessa mistura, um peã dedicado aos mortos. O pedido para auxiliar o canto dirige-se às sereias, mas não é às sereias que se oferece o canto de agradecimento (o peã) em troca da ajuda recebida, nem a nenhuma outra divindade olímpica, e sim a Perséfone, nas profundidades da sua morada noturna. Não é para o alto que parte o peã, mas para baixo, para o mundo ctônico.

Na maioria dos hinos que analisamos até aqui, o poeta costuma pedir à divindade que venha até onde ele se encontra; o movimento se dá nos eixos horizontal e vertical, de longe para perto, do alto para baixo. Aqui, no entanto, Eurípides se vale dessa convenção para, ao transgredi-la, conferir densidade ao sofrimento de Helena: do alto $e$ de baixo vêm o auxílio (texto de Kannicht), e para baixo, não para o alto, parte o hino de louvor associado em geral a deuses olímpicos (ambos os textos). ${ }^{245}$ Híbrido de gêneros que é,

\footnotetext{
${ }^{245}$ David Kovacs, em sua edição da Loeb (2002), imprime uma versão próxima da de Diggle, mas com duas interessantes correções. Seguindo as sugestões de Willink, ele acrescenta um $<\delta$ '> no verso $172 \mathrm{e}$

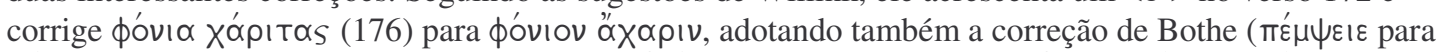

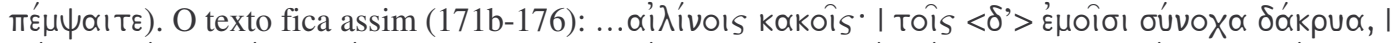

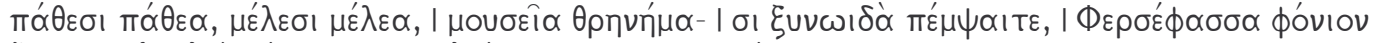

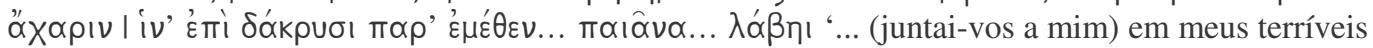
pesares: como cantores em harmonia com meus lamentos, enviai lágrimas de acordo com os meus ais, cantos de acordo com os meus cantos, para que Perséfone receba... com as minhas lágrimas... um peã funesto e sem júbilo'. Também segundo Kovacs, portanto, o movimento é contrário ao de Kannicht. Somente às sereias Helena faz sua prece, no objetivo de que Perséfone receba em sua morada um peã

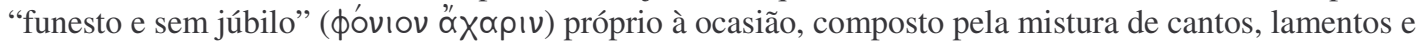


entre o peã e o lamento, esse hino joga com as expectativas do público em benefício do conteúdo dramático da peça, manipula as convenções hínicas para melhor expressar e dar peso às aflições da personagem.

\subsubsection{Eurípides, Hipólito (525-564)}

Outro hino de Eurípides, este mais simples em termos textuais e genéricos, vai no mesmo sentido, embora o seu objetivo seja diverso. Trata-se do hino a Eros e Afrodite do Hipólito (525-564). Tov Tâs 'Aфpodítas

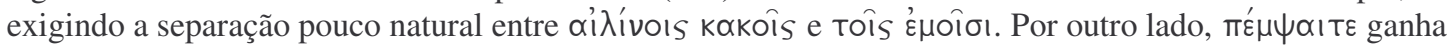
assim maior coesão na sentença, ao contrário do que ocorre no texto de Diggle. Contra Kannicht pode-se

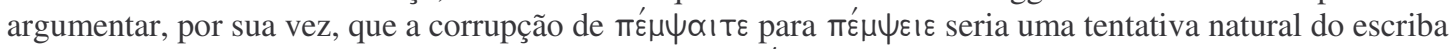
de fazer concordar o verbo com a palavra vizinha, $\Phi \varepsilon \rho \sigma \varepsilon ́ \phi \propto \sigma \sigma \alpha$. Além disso, o hipérbato de $\mu$ фóvia 'coros de morte' soa pouco natural em seu texto (embora a lírica coral de Eurípides esteja longe de

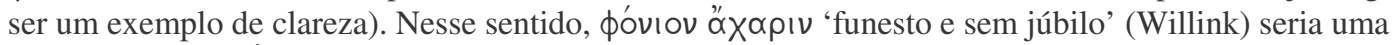
solução atraente. É difícil, pois, decidir entre as edições. A de Kannicht parece preservar uma ambiguidade deliberadamente buscada por Eurípides, as outras duas não. Diggle é mais cauteloso, os trechos entre cruzes são maiores, e não é fácil achar uma solução para o xópı Tas do seu verso 175. A de Kovacs, já pela natureza da edição, é mais ousada, e a segunda metade do hino, com as suas correções, parece fazer mais sentido, embora a junção entre as duas partes seja problemática. Para o meu argumento aqui, obviamente, não é preciso decidir por uma delas. Todas elas comprovam que Eurípides vale-se da transgressão de regras hínicas em prol da sua arte. 


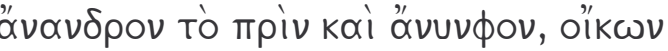

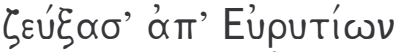

550

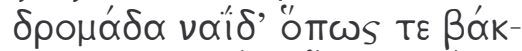

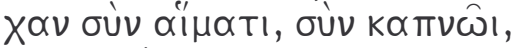

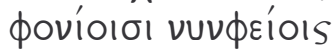

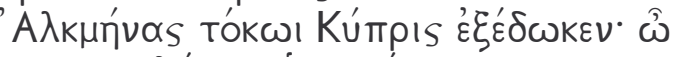

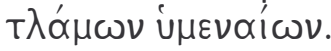

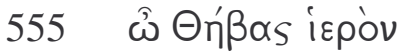

ant.B

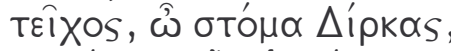

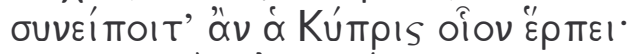

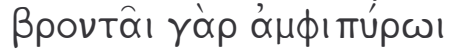

560

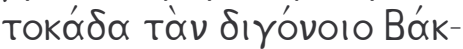

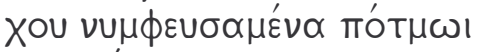

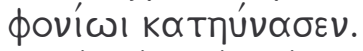

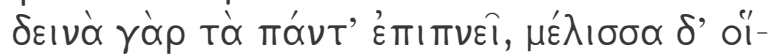

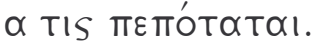

(Eros, Eros, que destilas gotas de desejo sobre os olhos, trazendo doce prazer ao espírito daqueles contra quem moves guerra, não me apareças jamais, peço, para meu mal nem me visites senão em harmonia. Pois nem as flechas do fogo nem das estrelas são mais poderosas que as de Afrodite, que Eros, filho de Zeus, lança de suas mãos. / É em vão, em vão que a Grécia multiplica a matança de bois nas margens do Alfeu e no templo pítio de Apolo, se não veneramos Eros, déspota dos homens, portador das chaves das alcovas mais adoráveis de Afrodite! Ele destrói os mortais e os lança em toda sorte de ruína quando os visita. /

Aquela menina de Ecália, ainda sem o jugo da cama matrimonial, sem marido, sem noivo, Afrodite arrancou-a da casa de Êurito, uma náiade em pânico, uma bacante, em meio a sangue, em meio a fumaça - núpcias sangrentas - e deu-a ao filho de Alcmene. Ah, infeliz em seu casamento! /

Ó sagrada muralha de Tebas, ó fonte da Dirce, podeis confirmar como insinua-se a deusa cipriota. Pois ela deu como noiva ao trovão flamejante a mãe de Baco, o deus duas vezes nascido, e levou-a para cama com o destino fatal. Ela é terrível, seu sopro espalha-se por toda a parte, ela avança feito abelha, esvoaçante.)

A paixão de Fedra pelo enteado Hipólito veio à tona; suspeita-se que a ama, que acaba de deixar a cena, não terá tato suficiente para abordar o casto Hipólito e contar-lhe a respeito, o que trará consequiências funestas para a sua senhora e também para o jovem. As expectativas são altas, e é nesse ponto que o coro de mulheres entoa um hino a Eros e Afrodite, cujo tema é o poder destrutivo de que ambos são capazes e que assume a forma de uma prece para que ele, coro, não seja visitado pela paixão devastadora do amor. Dois pares estróficos cantam, o primeiro, o poder de Eros em termos gerais, e, o segundo, dois exemplos mitológicos específicos da ação deletéria de Afrodite. 
Na primeira estrofe, relevância é dada ao pedido negativo do coro para que o deus

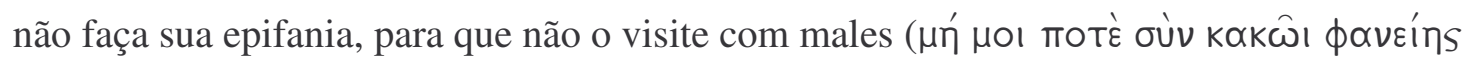

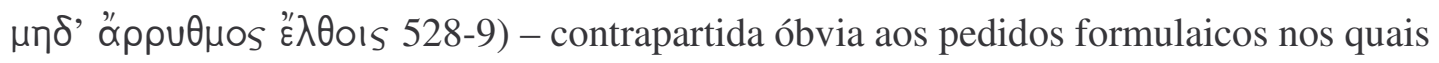

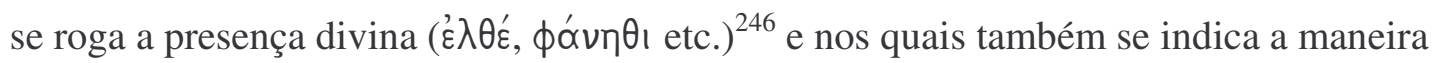

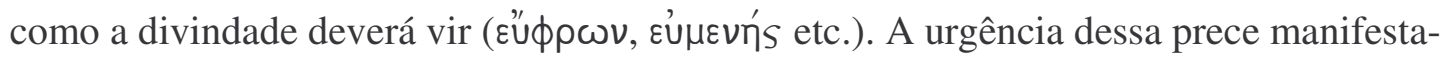
se não só na dupla negativa $\mu \eta \dot{~-~} \mu \eta \delta^{\prime}$, mas ainda no fato de o pedido ser antecipado em relação à sua posição convencional, onde aparece após a invocação e a parte descritiva. Aqui, como observam Furley-Bremer, ${ }^{247}$ a prece é embutida no seio da descrição. Isso se reflete na estrutura formal da estrofe, que emoldura tal pedido com versos honoríficos (525-7, 530-4), conferindo-lhe maior saliência em virtude do contraste obtido. E o último verso ('Epws ò $\Delta$ iòs mốs 534) ${ }^{248}$ fornece um fecho à moldura ecoando os vocativos do

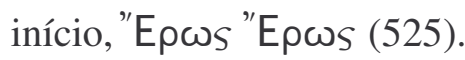

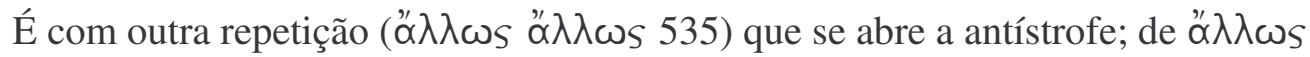
${ }^{\prime \prime} \lambda \lambda \omega s$ até oủ $\sigma \varepsilon \beta i \zeta \zeta o \mu \varepsilon v(540)$ desenrola-se uma única sentença, cujo centro é ocupado

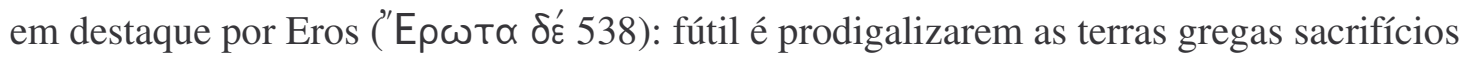
a Zeus e Apolo quando não rendem homenagens a Eros soberano. Os dois últimos versos da antístrofe, em aposição ao objeto da frase anterior, ganham relevo pela separação e ao mesmo tempo alinhavam o período estrófico: ${ }^{\xi} \lambda \lambda \eta$ ı (544), em destaque como termo final

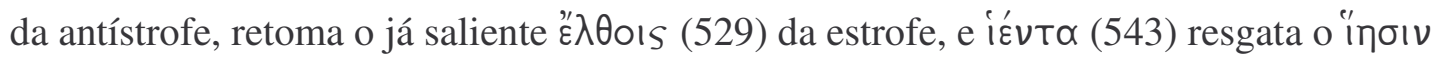
(553) de igual posição métrica. No arco entre esses dois verbos, "vir" e "lançar", revelase o tema de estrofe e antístrofe: a relação entre Eros e os mortais. Pede o coro que Eros não venha (529), pois quando ele vem (544), lança (543) os mortais na ruína lançando (533) as flechas de Afrodite.

Até aqui o coro dedicou-se a reconhecer, louvando-a, a força de Eros em termos gerais, expressando o desejo de que seu poder destrutivo não o atinja. Pelas convenções hínicas, caberia agora descer a detalhes específicos, vincular a idéia geral ao exemplo particular fornecido pelo caso de Fedra. Em vez disso, o segundo par estrófico desdobra

\footnotetext{
${ }^{246}$ Cf. Barrett (1964), 259.

${ }^{247}$ Furley-Bremer (2001), vol. 1, 316.

${ }^{248}$ Barrett (1964), 260, observa que essas palavras são guardadas para o final da sentença, no intuito de lhes amplificar o efeito produzido.
} 
dois exemplos míticos que com Fedra não guardam relação específica: o de Iole (estrofe) e de Sêmele (antístrofe).

Iole, filha de Êurito, rei de Ecália, despertara a paixão de Héracles, que, para tê-la à força, saqueou a cidade e matou pai e irmãos dela. Sêmele, filha de Cadmo, rei de Tebas, foi visitada pelo amante Zeus em toda a sua majestade olímpica, e expirou sob o fulgor do seu raio. Uma e outra põem em evidência a destruição causada por Afrodite, ${ }^{249}$ mas seus exemplos servem apenas para enfatizar o mau pressentimento quanto ao caso de Fedra, cuja ruína é iminente. Iole e Sêmele têm as suas sinas ligadas a Baco e ao sangue fatal, e isso é sublinhado em estrofe e antístrofe, nas quais, no exato centro, figura ora a

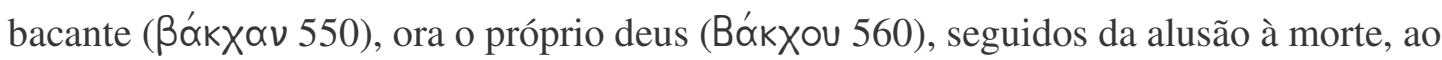

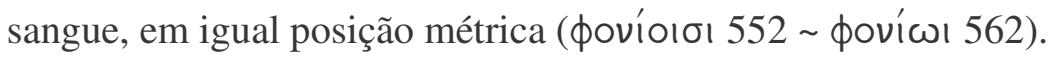

Sob o signo da emoção, o coro passa de um exemplo mítico a outro pela transição de três $\omega$, um na estrofe (553), e dois na antístrofe (555-6). E, para rematar a unidade do hino, os dois versos finais do poema, em frase bem demarcada, fazem eco aos dois versos finais da primeira antístrofe, referindo-se um a Eros que avança destruindo tudo, o outro a

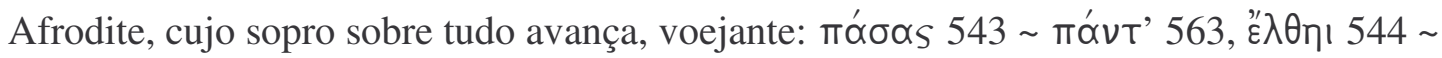

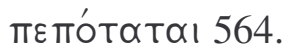

Esse hino de Eurípides, portanto, embora demonstre o mesmo cuidado estrutural que vários outros hinos analisados até aqui, subverte as regras do gênero ao invertê-las, infleti-las a seus objetivos dramáticos. Em vez de atrair o deus para perto, o coro requer que Eros se afaste. Em vez de fechar o foco sobre o momento presente, ele descreve dois exemplos míticos de relação distante com o caso de Fedra - dois exemplos, aliás, cujas heroínas não são mencionadas pelo nome, e sim pela cidade que as viu nascer, Ecália e Tebas, as quais não fazem parte de um catálogo geográfico destinado a conduzir o deus ao local onde se acha o coro, ${ }^{250}$ antes pelo contrário. Trata-se de um hino em tudo oposto ao hino clético - um hino, de fato, apotropaico.

\footnotetext{
${ }^{249}$ No segundo par estrófico, a destruição está a cargo de Afrodite, não de Eros. A transição de um a outro,

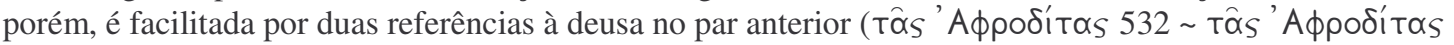
539).

${ }^{250}$ Como é o caso, por exemplo, do Hino Homérico a Apolo, do hino a Dioniso da Antígone de Sófocles e do Hino a Apolo de Calímaco, analisados acima (itens 1.1.1, 1.1.2 e 1.1.3).
} 


\section{CAPÍTULO 2}

\subsection{A ESRUtura do Hino RigVÉdico}

“...l'hymne védique est une pièce composée, un tout dont les parties se suivent avec autant de rigueur qu'on peut l'attendre dans un poème lyrique."

Antoine Meillet

“...den Gedankengang eines Liedes zu verfolgen, um über die Zerlegungen in’s Klare zu kommen, ist oft völlig vergeblich - was kann man in den meisten Vedahymnen überhaupt Gedankengang nennen?"

Hermann Oldenberg

“...aucun enchaînement logique; les images se suivent, les pensées se juxtaposent, se reprennent, roulent sur elles-mêmes sans marquer de progrès, sans esquisser le plus souvent d'architecture."

Louis Renou

À primeira leitura de um hino do Rig Veda, não é raro a pessoa dizer-se perplexa e incapaz de vislumbrar nele uma estrutura global. Algumas vezes, quanto mais se lê um certo hino, mais se tem certeza de que lhe falta qualquer tipo de estrutura: uma estrofe segue a outra naquilo que parece uma seqüência frouxa de idéias, pensamentos isolados limitam-se a uma, duas ou no máximo três estrofes contidas em si mesmas, permitindo pouco mais que um vislumbre de alguma espécie de continuidade, que é repetidamente interrompida tão logo iniciada a estrofe (ou conjunto de estrofes) seguinte. Não é raro o leitor sentir-se tentado a embaralhar estrofes de diferentes hinos endereçados à mesma divindade para verificar se haveria alteração de sentido. Os pedidos nem sempre vêm ao final de um hino, mas podem aparecer espalhados ao longo do poema, feitos mitológicos raramente são narrados em ordem cronológica, ${ }^{251}$ a interpelação direta à divindade ou a declaração do poeta especificando a quem se destina o hino podem ser adiadas aos versos finais, ou, se chegam a aparecer no início, podem muito bem ser repetidas sem nenhum propósito específico. Nesse sentido, os hinos rigvédicos parecem estar nos antípodas da

\footnotetext{
${ }^{251}$ Cf. Jamison (1996), 81: "Though RVic hymns often refer to different actions, belonging to different time periods, these actions are not usually arranged in a plot, even a plot with the links left out. In recounting mythological narratives there is rather a single focused event, to which other mentioned events are related thematically, not chronologically" e 85: “... most RVic narrative is distinctly not chronological, but alludes to events in jumbled and imaginatively reshaped order". Cf. Jamison (2007), 56: "Verses praising a divinity and his deeds and attributes could come in any order. Verses requesting benefits are often interspersed with those of praise. Though the same story may be referred to several times in a hymn, the narrative is seldom chronological, much less complete".
} 
composição clara e precisa que os gregos tanto apreciavam quando se tratava de louvar os seus deuses, com a singela tripartição dos hinos em invocação, argumento e pedido.

De fato, os hinos rigvédicos há muito foram comparados aos epinícios de Píndaro, partilhando ambos uma tendência a transições abruptas, inserções digressivas e riqueza de expressão e imagem. Mas ao contrário dos estudos sobre Píndaro, cujos poemas, tomados individualmente, têm sido há séculos objeto de minucioso exame crítico, muito da história da fortuna crítica do Rig Veda tem-se resignado tacitamente às palavras de Oldenberg e Renou citadas na epígrafe. Supunha-se, e por vezes continua a supor-se, que os hinos rigvédicos constituem a mera soma dos seus versos e estrofes reunidos em um conjunto amorfo, e não um todo de contornos bem delineados. Mesmo a afirmação de Meillet pode ser tomada como uma ligeira desculpa: o rigor composicional que se deve esperar dos hinos é aquele que se costuma encontrar na poesia lírica, que por seu turno é caracterizada pela ação recíproca de alusões no interior de uma moldura apenas esboçada.

Algumas tentativas, é claro, foram feitas para conceber e explicar a estrutura geral dos hinos rigvédicos, mas os resultados, em vista da enorme diversidade do material, são excessivamente genéricos ou perdem-se em detalhes. Tatiana Elizarenkova, por exemplo, sugeriu que todo hino possui duas partes principais que coexistem num certo equilíbrio: uma parte "explicativa" e outra "apelativa". ${ }^{252}$ O poeta pode alterná-las a gosto no curso do seu relato; hinos nos quais prevalece a parte "explicativa" consistem sobretudo de uma narrativa mítica, ao passo que, nos outros, a narração é drasticamente reduzida e a parte "apelativa" - o pedido propriamente dito - prevalece. Bernfried Schlerath ${ }^{253}$ menciona de passagem um princípio estrutural segundo o qual os poetas tendem a unir início e fim de um hino bem como enfatizar os seus versos centrais. Alguns, como Thomas Oberlies, ${ }^{254}$ costumam ressaltar os elementos, os conteúdos dos hinos, mesmo quando discutem a sua estrutura, e com isso borram as distinções de cada poema individual. Outros, como Jared Klein, estão interessados em expedientes retóricos nos horizontes do verso ou da estrofe, e assim perdem de vista como esses artifícios podem ou não contribuir para dar estrutura à composição como um todo. Esforços isolados, como aqueles de Daniele Maggi, para

\footnotetext{
${ }^{252}$ Elizarenkova (1968).

${ }^{253}$ Schlerath (1960), 86, citado por Jamison (2004), 239 n.1.

${ }^{254}$ Oberlies (1998) e (1999).
} 
conceber o hino como unidade nunca foram empenhados em um âmbito mais amplo, ${ }^{255} \mathrm{e}$ possíveis padrões de estrutura poética raramente são propostos.

Esse quadro foi modificado recentemente graças a um breve ensaio da autoria de Stephanie Jamison. ${ }^{256}$ Tomando como ponto de partida a análise de Joel Brereton ${ }^{257}$ sobre o hino Nāsadīya (RV 10.129), na qual ele sugere que a "solução" do enigma proposto pelo poema oculta-se nos seus versos centrais, Jamison avança uma hipótese para descrever uma técnica de estruturação comum a certos hinos "enigmáticos" ou "místicos". Resume-se essa técnica a embutir o enigma principal ou a sua solução mais ou menos no exato centro do poema - uma característica que ela denomina estrutura "omphalos", tomando o nome emprestado de uma figura discutida por Calvert Watkins em seus estudos sobre a sintaxe de Píndaro. ${ }^{258}$ Embora extremamente perspicaz e instigante, seu artigo ocupa-se sobretudo dos hinos "místicos", cujo tema, ela alega, quadra melhor com uma estrutura destinada a codificar numa palavra ou expressão central a chave para a compreensão do hino inteiro.

Meu propósito aqui, longe de ensaiar uma definição abrangente da estrutura média do hino rigvédico, é muito mais humilde - e não poderia ser de outro modo. Tento sugerir certos padrões segundo os quais alguns hinos, com certo grau de plausibilidade, acham-se estruturados. Meu interesse são alguns artifícios formais - parte deles bastante simples - usados por alguns poetas para conferir estrutura à composição como um todo fazendo-a girar de maneira consciente em torno da sua parte central. Como veremos, eles são capazes de fazê-lo de vários modos: coroando o hino com uma estrofe central que representa o seu clímax, tornando conspícua a sua centralidade por intermédio de uma ambigüidade deliberada, ou mediante um grupo de oposições, ou por sobrepor e imbricar as duas partes nas quais se divide o hino, ou ainda concentrando ao redor das estrofes centrais uma série de palavras intimamente relacionadas. ${ }^{259}$

\footnotetext{
${ }^{255}$ Maggi (1975) e (1991).

${ }^{256}$ Jamison (2004). Cf., mais recentemente, Jamison (2007), 51-89, com excelente resumo sobre como a estrutura do hino rigvédico foi compreendida ao longo da história. Para um esboço da estrutura dos hinos do Atharva Veda, cf. Insler (1998).

${ }^{257}$ Brereton (1999).

${ }^{258}$ Watkins (2002a).

${ }^{259}$ Os trechos dos hinos que interessam ao meu argumento estão todos traduzidos; ofereço em apêndice uma tradução integral dos poemas discutidos - uma tradução meramente exemplificativa, sem entrar em detalhes filológicos, baseada em Renou e Geldner.
} 


\subsubsection{Grupo central}

Vamos começar por esse último e mais simples recurso estilístico de reunir em torno da seção central de um hino um grupo de termos relacionados que, pelo seu simples acúmulo, destaca-se do restante da composição. Esses termos podem ser vocábulos iguais ou sinônimos, termos complementares ou constituírem ainda uma seqüência ascendente.

\subsubsection{Repetição simples}

Tomemos como exemplo RV 6.54, um hino a Pūṣan. Referências ao deus não faltam ao longo do poema, mas elas se agrupam de forma inequívoca ao redor do centro.

1 sám pūṣan vidúșā naya yó áñjasānuśăsati | yá evédám íti brávat

2 sám u pūṣnă gamemahi yó grohăm abhisásati | imá evéti ca brávat $\|$

3 pūṣnáś cakrám ná rișyati ná kóśó àva padyate | nó asya vyathate pavíh \|

4 yó asmai havișấvidhan ná tám pūsâẩpi mrṣ̣ate | prathamó vindate vásu

5 pūṣâa gá án ${ }_{u}$ etu nạ̣ pūṣấ rakṣat ${ }_{u}$ árvatah | pūșấ văjaṃ sanotu nạ̣ \|

6 pưșann ánu prá gấ ihi yájamānasya sunvatáh | asmăkam stuvatắm utá ||

7 măkir neśan măkīṃ riṣan mâkīṃ sáṃ śāri kévate | áthắriștāohhir â gahi ||

8 śrṇvántam pūṣánạn vayám íryam ánaștavedasam | 1̂śānaṃ rāyá īmahe \|

9 púșan táva vraté vayáṃ ná riṣyema kádā caná stotăras ta ihá smasi $\|$

10 pári pūṣấ parástād dhástaṃ dadhātu dákșiṇam | púnar no naștám ájatu \|

Nas primeiras quatro estrofes o nome de Pūṣan é espalhado a esmo, sem uma posição métrica fixa no interior do pāda, embora apareça em cada estrofe em um caso diverso: 1 a pūṣan (vocativo), 2 a pūṣnăa (instrumental), $3 a$ pụ̣̄nás (genitivo), $4 b$ pūṣấ (nominativo). Na estrofe 5 o poeta desvia dramaticamente a atenção da multiplicidade aleatória para a unidade metódica de três pūṣăà testa de cada pāda. 
5 pūṣă găán ${ }_{u}$ etu naḥ pūṣă raksat ${ }_{u}$ árvatạ̣ püsạa văjaṃ sanotu nạ̣
'Que Pūșan siga as nossas vacas, que Pūṣan proteja os nossos cavalos, que Pūṣan ganhe butim para nós.

Cada pāda constitui uma sentença completa, cada qual com o seu próprio verbo, sempre no imperativo da terceira pessoa do singular. A estrofe seguinte articula-se a esse conjunto e ao mesmo tempo lhe confere remate satisfatório. Articula-se a ele pela posição enfática do seu vocativo púșan que abre o pāda e prolonga o esquema da estrofe anterior. Mas agora, em vez de três sentenças individuais, temos apenas uma oração unificada que preenche três pāda governada por um único verbo, um imperativo singular de segunda pessoa.

\section{6 pứsann ánu prá gă ihi yájamānasya sunvatáh asmâkaṃ stuvatâm utá}

'Ó Pūṣan, siga as vacas do sacrificador, de quem espreme soma e as nossas também, dos cantores.'

O contraste atingido é acentuado ainda pela ausência - única no poema - do nome divino na estrofe seguinte (7), que representa assim uma ruptura destinada a emprestar relevo às já conspícuas estrofes centrais 5 e 6 . Essa ruptura é tanto mais evidente pela sua tripla repetição da partícula proibitiva mâkiḥ 'nenhum(a)', em oposição ao triplo pūṣă da estrofe 5 .

7 măkir neśan mákịm riṣan mákịm sám śāri kévațe áthârișțābhir ấ gahi
'Nenhuma se perca, nenhuma se machuque, nenhuma caia num buraco: mas para cá vem com as incólumes.

Após a quebra da seqüência na estrofe 7, o nome de Pūṣan recomeça a flutuar tal como fizera na primeira parte, disseminado aleatoriamente pelos pāda e em diferentes casos gramaticais: $8 a$ pūṣánam (acusativo), 9 a pusșan (vocativo) e 10a pūṣăa (nominativo).

\subsubsection{Repetição complexa}

\subsection{Palavras gêmeas}

Em RV 2.16, um hino a Indra, as estrofes centrais 4-6 contêm ao todo dezessete repetições das palavras gêmeas víșan- 'macho' e vrșabhá- 'touro'. 
1 prá vaḥ satấm jyéșṭhatamāya sușțutím agnáv iva samidhāné havír bhare índram ajuryám jaráyantam ukșitám sanấd yúvānam ávase havāmahe ||

2 yásmād índrād brohatáh kím caném rọté víśvān ${ }_{i}$ asmin sámbhrotădhi vīri ${ }_{1} y \bar{a} \mid$ jaṭáre sómam $\tan _{\text {ú }} \overline{1}$ sáho máho háste vájram bhárati šîș̣áṇi krátum \|

3 ná kṣonịibhyām paribh ${ }_{u} v e$ ta indriyám ná samudraíh párvatair indra te ráthaḥ| ná te vájram án $\mathrm{n}_{\mathrm{u}}$ aśnoti káś caná yád āsúbhih pátasi yójanā purú $\|$

4 víśve hí asmai yajatâya dhrșṇáve krátum bháranti vrșabhăya sáścate | ví̛șā yajasva havíșā vidúștarah píbendra sómam vrș̣abhéṇa bhānúnā \|

5 ví̛ș̣ah kóśah pavate mádhva ūrmír vrșabhắnnāya vrș̣abhăya pătave | ví̛șaṇādhvaryú vṛ̛șabhăso ádrayo ví̛șaṇam sómaṃ vṛșabhăya suṣvati ||

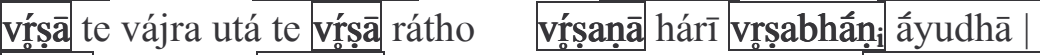
ví̛șno mádasya vroșabha tvám îśsịa índra sómasya vrș̣abhásya troṇuhi \|

7 prá te năvaṃ ná sámane vacasyúvam bráhmaṇā yāmi sávaneșu dấdhṛșị̣| kuvín no asyá vácaso nibódhiṣad índram útsaṃ ná vásunạ̣ sicāmahe \|

8 purấ sambādhăd $\mathrm{abh}_{\mathrm{i}}$ â vavrọtsva no dhenúr ná vatsáṃ yávasasya pipyúșī| sakị́t sú te sumatíbhị̣ śatakrato sám pátnībhir ná vị́ṣaṇo nasīmahi \||

9 nūnám sắ te práti várạ̣ jaritré duhīyád indra dákșiṇā maghónī | śíkșā stotṛ́bhyo mâti dhag bhágo no brohád vadema vidáthe suvírāḥ ||

Além do deus ele próprio, tudo intimamente associado a Indra é chamado de

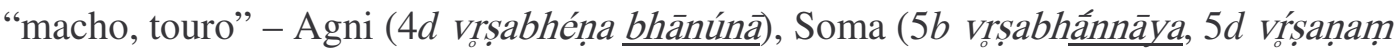
sómaṃ), os dois sacerdotes adhvaryu (5c víș̣anạadhvaryúú), as pedras utilizadas para espremer o líquido soma (5c vrșabhăso ádrayo), a sua clava (6a víșāa te vájra), a sua carruagem ( $6 a$ te vísșa rátho), a sua parelha de cavalos baios ( $6 b$ vísșaṇa hárì), as suas armas (6b vrșabhănị âayudhâa).

4 viśve hí asmai yajatâya dhrș̣náve krátum bháranti vrșabhâya sáścate víșā yajasva havísāa vidúsțtarah píbendra sómaṃ vơșabhéṇa bhānúnā

'Pois todos portam a esse (deus) venerável, audaz, touro que nos acompanha, (seu) pensamento-sacrificial; / como (deus) macho, sacrifica com ajuda da oferenda, tu que sabes mais (que todos os outros), bebe o soma, ó Indra, graças ao brilho (de Agni) (com forma de) touro.' 
'O vaso ritual do (deus) macho, (ou seja), a onda do doce (soma), purifica-se para o touro cujo alimento é o touro (soma); / os dois adhvaryu (são) machos, as pedras (são) touros, elas espremem o macho soma para o touro.'

$6 \quad$ vișsā te vájra utá te viśșā rátho

víșanāa hárī vrș̣abhănị ăyudhā

víș̣no mádasya vrșabha tvám īsișa

índra sómasya vrșabhásya trpṇuhi

'Macho (é) a tua clava e macho a tua carruagem, machos os dois alazães, machos as armas; / da bebida macho que inebria, ó touro, tu és senhor; ó Indra, deleita-te com o soma touro!'

$\mathrm{Na}$ última dessas estrofes centrais, a sexta, o poeta cria um certo sentido de ordem e completude ao aumentar progressivamente as sílabas das palavras ao longo da

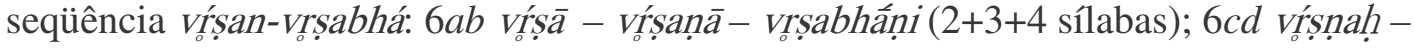
vrșabha - vrșabhásya (2+3+4 sílabas).

Esse acúmulo de palavras com o significado de "touro" e "macho" bem no centro do hino responde a um claro propósito. Não serve ele somente para louvar Indra, cujo poder varonil e fertilizante reflete-se na profusão de palavras víșan-vrșabhá que vicejam pāda após pāda, em seus vários casos (dativo, nominativo, instrumental, genitivo, acusativo, vocativo) e números (singular, dual, plural), fazendo com que tudo à volta dele partilhe da sua natureza. Mas também, e de forma mais relevante no que concerne à estrutura do poema, ele serve para ligar essa seção central à sentença que contém a única outra palavra víșan- no hino localizada fora dos seus limites:

8cd sakŕt sú te sumatíbhị śatakrato sám pátnībhir ná víș̦aṇo nasīmahi
'Que nós de imediato, ó (deus) dos cem poderes, possamos bem nos unir aos teus favores como machos às fêmeas.'

Através do símile o poeta expressa o seu desejo de ser tão varonil quanto Indra, isto é, ser considerado alguém tão próximo da divindade a ponto de participar das suas características. E ele o faz no que é na verdade a última estrofe do poema - a estrofe 9 é 
uma estrofe estereotipada, adicionada a alguns outros hinos do mesmo livro -, unindo a seção central à sua conclusão. ${ }^{260}$

\subsection{Numerais}

Em outro hino a Indra do mesmo livro, RV 2.18, que aliás ostenta a mesma estrofe final do hino que acabamos de analisar, a seção central destaca-se claramente do restante do poema.

1 prātắ rátho návo yoji sásniś cáturyugas trikaśáh saptáraśmị̣ | dásāaritro manușiyaḥ $\mathrm{s}_{\mathrm{u}}$ varșăḥ̣ sá ișțíbhir matíbhī ráṃh $\mathrm{i}$ yo bhūt \|

2 sấsmā áram prathamáṃ sá dvitíyam utó trịtíyam mánuṣạ̣ sá hótā | anyásyā gárbham anyá ū jananta só anyébhiḥ sacate jényo viŕsā $\|$

3 hárī nú kaṃ rátha índrasya yojam āyaí sūkténa vácasā návena| mó sú tvấm átra bahávo hí víprā ní rīraman yájamānāso anyé ||

4 â $\mathrm{d}_{\mathrm{u}} \mathrm{văbhyām} \mathrm{háribhyām} \mathrm{indra} \mathrm{yāh}{ }_{\mathrm{i}}$ á catúrbhir â șaḍbhír hūyámānaḥ | á aștābhír daśábhih somapéyam ayám sutáh sumakha má mị́dhas kạ̣ ||

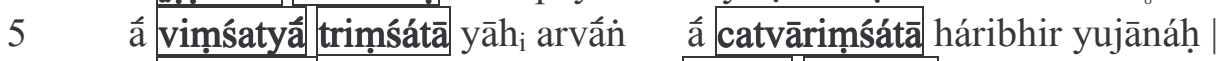
à pañcāsátā suráthebhir indra á șaștiyầ saptatyă somapéyam \|

6 â aśsītyầ navatyấ yāh ${ }_{\mathrm{i}}$ arvắn à śaténa háribhir uhyámānạ̣ | ayám hí te śunáhotreșu sóma índra tvāyă párișikto mádāya \|

7 máma bráhm ${ }_{\mathrm{a}} \mathrm{nd}_{\mathrm{a}} \mathrm{ra}$ yāh $\mathrm{i}_{\mathrm{i}}$ áchā víśvā hárī dhurí dhiṣvā ráthasya

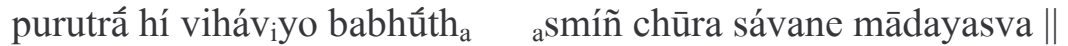

8 ná ma índreṇa $s k_{\mathrm{i}}$ yáṃ ví yoṣad asmábhyam asya dákșiṇā duhīta| úpa jyáyișthe várūthe gábhastau prāyé-prāye jigīvắmsạ̣ $\mathrm{s}_{\mathrm{i}} \mathrm{y} \overline{\mathrm{a}} \mathrm{ma} \|$

9 nūnám să te práti váram jaritré duhīyád indra dákșiṇā maghónī| śíkșā stotṛ́bhyo măti dhag bhágo no brohád vadema vidáthe suvîrāḥ ||

Ao redor do centro, nas estrofes 4-6, agrupam-se repetidos pedidos a Indra para que venha ao ritual do soma com um número crescente de cavalos atrelados a sua carruagem. Pede-se que ele venha com dois, quatro, seis, oito, dez cavalos, com vinte, trinta, quarenta, cinqüenta, sessenta, setenta, oitenta, noventa, cem cavalos.

\footnotetext{
${ }^{260}$ Entre deus e poeta também se sugere um laço através do uso do mesmo adjetivo para ambos, "audaz": $4 a$ dhrṣnáve (Indra) 7 b dádhrșị̣ (poeta). Cf. ainda RV 8.33, um hino a Indra de 19 estrofes: a estrofe 10 (portanto a estrofe central do poema) e as duas seguintes (11 e 12) ostentam acúmulo análogo do vocábulo

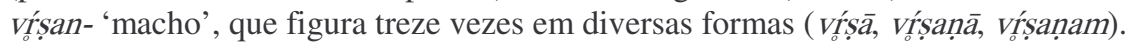


4 â $\boldsymbol{d}_{u}$ văbhyām háribhyām indra yāh $h_{i}$

à catúrbhir â șaḍbhír hūyámānaḥ

ă ${ }_{a}$ șāabhír daśábhị somapéyam

ayám sutáh sumakha mấ mŕdhas kạ̣

5 à vimśatyă trimśátā yāh ${ }_{i}$ arvăin

à catvārimsátátà háribhir yujānáh

à pañcāsátā suráthebhir indr

à șaștiyấ saptatyá somapéyam

6 à asîtyã navatyă yāh $h_{i}$ arvắn

à saténa háribhir uhyámānah

'Vem para cá, ó Indra, com dois cavalos, com quatro, com seis (uma vez) chamado, / com oito, com dez para a bebida do soma. Este (soma) foi espremido, ó generoso, não o despreze! Vem para cá atrelando vinte, quarenta cavalos, cinquienta dotados de belas carruagens, / sessenta, setenta para a bebida do soma.

Vem para cá com oitenta, com noventa, com cem cavalos, sendo conduzido.'

Não é a esmo que esses pedidos sucedem um ao outro, eles aparecem dispostos em arranjo metódico, o sentido de urgência habilmente contido pela dicção ordenada. Do pāda $4 a$ a $6 b$ as palavras obedecem a uma espécie de esquema:

$4 a b \quad a ̊ a+1$ cardinal+instrumental+vocativo+yāhi -2 cardinais(2âa)+particípio

$4 c d \quad a ̊+2$ cardinais+somapéyam - ***

$5 a b \quad a ̆ a+2$ cardinais + yāhi arvắn $-a ̊ a+1$ cardinal+instrumental+particípio

$5 c d \quad a ́+1$ cardinal+instrumental+vocativo - á+2cardinais+somapéyam

$6 a b \quad a ̆+2$ cardinais + yāhi arvắn $-a ̆ a+1$ cardinal+instrumental+particípio

Os vários elementos, em número fixo, são distribuídos ao longo das estrofes; o número de cardinais sempre alterna - quando um cardinal aparece no pāda $a$ ou $c$, o pāda seguinte terá dois cardinais, e vice-versa; seqüências padronizadas, como por exemplo " $a ̂ a+2$ cardinais + somapéyam", podem ser dispostas no pāda $c$ ou $d$, outras acham-se fixadas a um determinado pāda; os particípios podem ser associados a um ou dois cardinais etc. A despeito da relativa flexibilidade, o poeta sinaliza a coerência interna da passagem e lhe confere remate ao repetir em $6 a b$ a mesma sequiência de $5 a b$. Os próprios particípios, repetidos a intervalos regulares (4b hūyámānaḥ, 5 b yujānáh, 6 b uhyámānaḥ), emprestam estrutura ao todo, demarcando os seus limites, especialmente porque entre o primeiro e o último particípio há um eco patente: hūyámānạ̣, uhyámānaḥ. Esse efeito é obviamente explorado pelo poeta, que dessa maneira aponta para eles ao ressaltar-lhes a semelhança de sons associada à divergência de sentido: 
hūyámānaḥ é um particípio médio da raiz hū ‘chamar', uhyámānạ̣ um particípio médio da raiz vah 'conduzir'. Ambos são balizas, postadas no começo e fim da sequiência numérica que compõe o núcleo do hino, e em virtude da sua semelhança fonética eles resumem o tema central do poema - Indra deve ser conduzido graças ao chamado do poeta.

O próprio hino, de fato, é comparado a uma carruagem destinada a conduzir Indra ao sacrifício. Sua descrição, na qual se faz largo uso de numerais, serve para vincular a primeira estrofe à seção central.

1 prātă rátho návo yoji sásniś

cáturyugas trikaśạ saptáraśmị̣

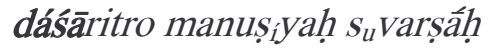

sá iștíbhir matíbhī rámh ${ }_{i}$ yo bhüt

'De manhã a nova carruagem é atrelada, a carruagem vencedora, com quatro jugos, três chicotes, sete rédeas, dez remos, feitas pelos homens, conquistadora do sol: ela é própria para ser posta em movimento por (nossas) buscas, por (nossos) pensamentos poéticos.'

A estrofe 3 não deixa dúvidas quanto à equação entre o chamado do poeta e a condução de Indra:

\section{$3 a b$ hárī nú kam rátha índrasya yojam āyaí sūkténa vácasā návena}

'Eu atrelarei os dois alazões à carruagem de Indra para que ele venha com a ajuda de uma nova palavra bem-proferida.'

O dativo infinitivo āyaí 'vir até aqui' dá o tom e age simultaneamente como um elo catenário com a parte central, à força da sua tripla repetição (também a intervalos regulares) do imperativo â... yāhi ‘vem para cá!' e a presença ubíqua do prevérbio ă, que explicita o movimento na direção de quem fala. E o que é mais, o verbo na verdade emoldura a seção central, com aparições paralelas - os únicos exemplos exteriores ao núcleo do hino - na estrofe 3 (āyaî) e 7, máma bráhma ${ }_{i} n d_{a}$ ra $y_{\bar{a}} h_{i}$ áchā ‘Vem, ó Indra, até a minha fórmula poética'. 


\subsection{Termos afins}

Um último e notável exemplo vem do RV 6.38, um hino a Indra no qual a seção central também é indicada com cuidado. ${ }^{261}$

1 ápād itá úd u naś citrátamo mahím bharṣad dyumátīm índrahūtim | pányasīṃ dhītím daíviyasya yấmañ jánasya rātím vanate sudấnuh \|

2 dūrấc cid á vasato asya kárṇā ghóșād índrasya tanyati bruvāṇáh | éyám enam deváhūtir vavrọān madrag índram iyám rọcyámānā

3 tám vo dhiyă paramáyā purājấm ajáram índram abhy ànūṣi arkaíh | bráhmā ca gíro dadhiré sám asmin mahăṃ̂́ ca stómo ádhi vardhad índre \| 4 várdhād yáṃ yajñá utá sóma índram várdhād bráhma gíra ukthă ca mánma | várdhăhainam uṣáso yắmann aktór várdhān mấsāḥ śarádo dyấva índram || 5 evấ jajñānám sáhase ásāmi vāvṛdhānáṃ rădhase ca śrutâya | mahăm ugrám ávase vipra nūnám á vivāsema vrọtratúríryeșu \|

Já desde o início o poeta anuncia o seu tema, a relação entre Indra e a canção em seu louvor. Um desejo é expresso na primeira estrofe: que o deus tome notícia da "nossa grande e esplêndida invocação" (1 b mahîm... dyumátīm índrahūtim); um outro desejo na estrofe seguinte $(2 c d)$ põe em primeiro plano o próprio poema que está sendo cantado: "que essa invocação (iyám... deváhūtị̣) faça-o voltar-se (â... vavrrtyāt) na minha direção (madríac), a ele, Indra, essa invocação (iyám), cantada em estrofes (r̊cyámānāa)”. Ora, esse desejo é muito mais eficaz que o anterior, uma vez que ele reforça o seu sentido pela meticulosa disposição das suas palavras, como seria natural esperar de uma "invocação cantada em estrofes", uma prece que tem consciência - e o diz - do seu próprio caráter estilizado. O demonstrativo iyám referente à invocação é repetido em $2 c$ and $2 d$, ambas as vezes em contigüidade com referências a Indra: éyám enam 'esse... ele (acusativo)' e índram iyám 'Indra (acusativo)... esse'. Vale observar que o poeta toma cuidado para manter num e noutro caso a mesma sequiência vocálica: $e-a$ (é yám ena $\underline{\text { enm }}$ ), $i-a$ (índrạm iyaám), buscando fortalecer os laços entre Indra e o seu hino. A ordem quiástica faz com que a invocação circunscreva ou abrace, por assim dizer, o deus, e o desejo do poeta de fazê-lo "voltar-se na minha direção" ( vavrtyān madracia é sublinhado por aparecer em enjambement entre os pādas $c$ e $d$.

${ }^{261}$ Sobre o hino, ver Pinault (1994), 50-3. Cf. também Thieme (1952) 


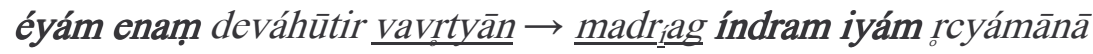

'Que essa invocação o faça voltar-se na minha direção, a ele, Indra, essa (invocação) cantada em estrofes.'

Assim é que o próprio poema passa a ocupar o foco das atenções, e em harmonia com esse fato as duas estrofes seguintes reúnem uma quantidade das mais notáveis de alusões à poesia.

3 tám vo dhiyă paramáyā purājấm ajáram índram abhy ànū $S_{i}$ arkaíh bráhmā ca gíro dadhiré sám asmin mahấnś ca stómo ádhi vardhad índre

4 várdhād yám yajñá utá sóma índram várdhād bráhma gíra ukthă ca mánma várdhăhainam ușáso yămann aktór várdhān mấsāḥ śarádo dyấva índram

'A esse Indra, nascido em tempos imemoriais, impassível de envelhecer, eu gritei para vós com o produto da minha visão poética (dhiyă), ${ }^{262}$ com cantos (arkaíh). As fórmulas (bráhmâ) e elogios (gírạ̣) estão reunidos sobre ele, e o poderoso louvor (stómaḥ) cresce junto a Indra. /

'Indra, a quem o sacrifício e soma farão crescer, (a quem) a fórmula (bráhma), os elogios (gíraḥ), as palavras (ukthă) e os pensamentos poéticos (mánma) farão crescer - faze-o crescer também enquanto a aurora surge da noite - os meses, os outonos, os dias farão Indra crescer.'

A raiz $\operatorname{vodh} /$ vardh 'crescer' torna explícita a reciprocidade subjacente entre Indra e a canção: as canções crescem junto a Indra e devem fazê-lo crescer. No plano formal, o mesmo verbo atua como um elo catenário entre as duas estrofes (note a forma injuntiva vardhat 'cresce' $3 d)^{263}$ e também põe termo à conspícua enumeração de palavras para

\footnotetext{
${ }^{262}$ Sobre essa palavra e termos correlatos, ver Gonda (1963).

${ }^{263}$ Tal forma é tanto mais conspícua em razão do seu sentido intransitivo. Como regra geral, são as formas médias do tema presente várdha- $a$ - que possuem significado intransitivo ou fientivo ("crescer"), cabendo à forma ativa o sentido transitivo ou facientivo ("fazer crescer"). Poucos são os exemplos que fogem a essa norma e conferem uma acepção intransitiva ao tema ativo (além do nosso caso, cf. RV 10.61,26 e 10.50,5). Gotō (1987), 291, tenta a princípio enquadrar o pāda $3 d$ na regra e arrisca a sugestão de que vardhat talvez possa ser concebido como facientivo (“... macht [uns?] bei Indra stark”), mas admite logo em seguida: "Es könnte sich vielleicht in diesen Fällen um Relikte eines aktiven athem. Wz.-Aor. mit intransitiver Bedeutung handeln".
} 
“canção" em $4 c$ com o imperativo auto-exortativo (várdha 'faz com que ele cresça'), em contraste com os dois subjuntivos que abrem os pādas $4 a$ e $b$ (várdhāt 'farão crescer). ${ }^{264}$

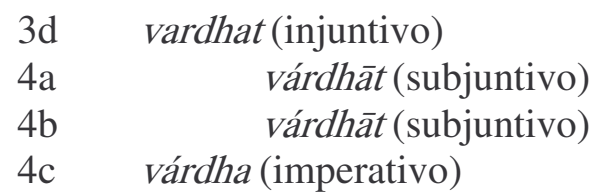

Como podemos ver, o poeta reúne com zelo no centro do hino, dos pādas $2 c$ a $4 b$, as suas múltiplas referências à poesia ritual (8 termos diversos em 10 palavras), num poema no qual o próprio hino ocupa o coração da relação de reciprocidade que o poeta estabelece com o seu deus. Cada referência complementa a outra, levando em conta as diversas facetas da atividade poética - palavra, pensamento, louvor, fórmula. O simples acúmulo dos termos, algo incomum até mesmo para os padrões repetitivos do Rig Veda, dá testemunho da habilidade do poeta em centrar neles a atenção demarcando-lhes a posição central no interior do hino.

\subsubsection{Divisão ao meio}

\subsubsection{Repetição simples}

Outro recurso formal bastante simples é o de repetir uma palavra a fim de dividir a composição em dois ou talvez mesmo sugerir ao público que o poema alcançou o seu centro, a sua metade. Essas palavras são dispostas no geral em posição enfática e de regra aparecem na primeira metade do hino. Mencionarei brevemente três exemplos e passarei então a outro mais complexo, no qual o expediente é empregado para unir ambas as metades da canção. Vamos começar com um exemplo dos mais famosos, o primeiro hino de toda a coleção do Rig Veda.

1 agním īle puróhitạ̣ yajñásya devám rọtvíjam | hótārạ̣ ratnadhătamam \|

2 agníh pưrvebhir ŕșibhir î́diyo nútanair utá sá devắm éhá vakșati \|

\footnotetext{
${ }^{264} 4 d$ várdhān é uma coda, um apêndice que retoma o mesmo verbo dos pādas anteriores para estabelecer um contraste entre esfera humana e mundo natural: de $3 d$ a $4 c$ é a obra poética que faz Indra crescer, em $4 d$ são os meses, os outonos, os dias.
} 
3 agnínā rayím aśnavat póșam evá divé-dive yaśásạ̣ vīrávattamam $\|$

4 ágne yám yajñám adhvarám viśvátah paribhứr ási sá íd devéșu gachati $\|$

5 agnír hótā kavíkratụ satyáś citráśravastamạ̣| devó devébhir â gamat $\|$

6 yád angá dāśúṣe $\mathrm{t}_{\mathrm{u}}$ vám ágne bhadráṃ kariṣyási | távét tát satyám angirạ \|

7 úpa tvāgne divé-dive dóṣāvastar dhiyấ vayám | námo bháranta émasi \|

8 rájantam adhvarănāị gopăm rọtásya dídivim | várdhamānaṃ $\mathrm{s}_{\mathrm{u}}$ vé dáme $\|$

9 sá nạ̣ pitéva sūnávé ạgne sūpāyanó bhava | sácasvā naḥ $\mathrm{s}_{\mathrm{u}}$ vastáye $\|$

Agni é interpelado em quatro casos diversos (acusativo, nominativo, instrumental, vocativo) no início de cada estrofe até a quinta, que é a estrofe central. Depois disso, o poeta toma cuidado para não tornar a pôr o nome divino em posição inicial, à cabeça das estrofes. ${ }^{265}$ A quíntupla repetição poliptótica do nome de Agni na primeira parte contrasta de forma patente com os três exemplos remanescentes na segunda metade, todos eles no vocativo (agne), em posições relativamente neutras $(6 b, 7 a, 9 b)$ - embora os dois vocativos acentuados na abertura dos pādas $6 b$ e $9 b$ talvez sirvam como balizas para sinalizar começo e fim, respectivamente, da segunda parte.

O segundo exemplo vem de outro hino gāyatrī, mas este endereçado a Indra, RV

\section{7.}

1 índram íd gāthíno brhád índram arkébhir arkíṇạ | índram vấnīir anūșata

2 índra íd dháriyoh sácā sámmiśla â vacoyújā índro vajrí hiraṇyáyah \|

3 índro dīrghâya cákșasa â súryam rohayad diví | ví góbhir ádrim airayat \|

4 índra vájeșu no $\mathrm{ava}$ sahásrapradhaneșu ca ugrá ugrábhir ūtíbhị̣ \|

5 índram vayám mahādhaná îndram árbhe havāmahe yújạ̣ vrótréṣu vajrínam \|

6 sá no vrṣann amúm carúm sátrādāvann ápā vrọdhi | asmábhyam ápratiṣkutạ̣ \|

7 tuñjé-tuñje yá úttare stómā índrasya vajrínạạ |

${ }^{265}$ Cf. Toporov (1981), 240-1. 


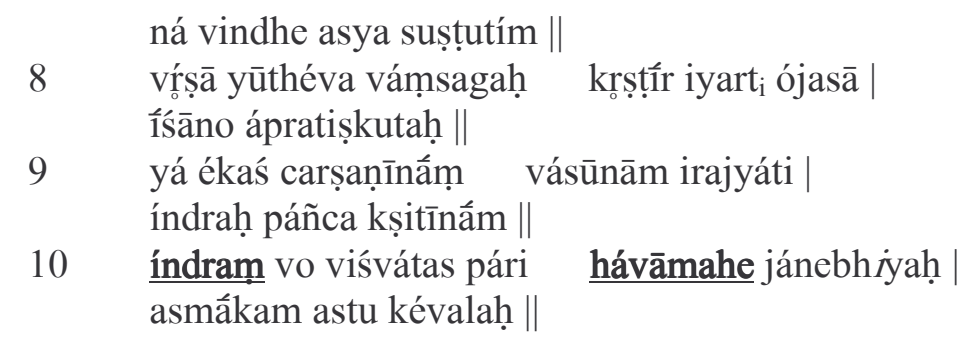

O nome de Indra aparece no início das primeiras cinco estrofes, novamente em vários casos gramaticais - acusativo, nominativo, vocativo. Entre as estrofes 1 e 5 há um certo anel, criando uma sensação de remate que sugere o término da primeira parte do hino. Aqui, e somente aqui, Indra figura no acusativo no começo dos pādas $a$ e $b$ :

$1 a b \quad$ indram íd gāthíno brhád índram arkébhir arkínạ

\section{$5 a b \quad$ índram vayám mahādhaná indram árbhe havāmahe}

'Indra, somente ele, os cantores (clamaram) em voz alta, Indra os que louvam com (seus) louvores.'

'Indra na grande disputa, Indra na pequena nós invocamos.

Pādas $5 a b$, embora ecoem $1 a b$, recebem um toque de acabamento, apropriado a uma sentença de fecho. Além da anáfora comum a ambas as estrofes (índram... índram), a estrofe central destaca-se pela perfeita equivalência silábica entre os termos nos pādas $a$ e $b(2+2+4$ sílabas), em flagrante contraste com sua oposição semântica. Grande e pequena disputa, um merismo para "todas as disputas", são assim postas em oposição e ao mesmo tempo equiparadas dentro da oração.

Não apenas início e conclusão do hino são claramente assinalados, mas também o elo entre o fim e o meio. Na última estrofe Indra reaparece no acusativo, inaugurando o pāda, e o mesmo verbo (havāmahe) é repetido.

10 índram vo viśvátas pári hávāmahe jánebhyạ̣ asmákam astu kévalạ̣
'Indra de toda a parte para vós nós invocamos, de (todas as) tribos. Que ele seja exclusivamente nosso'

Nosso terceiro e último exemplo dessa seção é um hino dedicado a Br̆haspti, RV 10.68. Bṛhaspati é o deus da prece; embora os hinos a ele endereçados não sobressaiam 
pela quantidade, as composições costumam ser muito bem trabalhadas e requintadas, em sintonia com o status divino e a sua esfera de ação, congenial ao ofício dos poetas.

1 udaprúto ná váyo rákșamāṇā văvadato abhríyasyeva ghóṣāh | giribhrájo $\mathrm{n}_{\text {à ù }}$ rmáyo mádanto brónhaspátim abh ${ }_{\mathrm{i}}$ arkă anāvan \|

2 sáṃ góbhir āngirasó nákșamāṇo bhága ivéd aryamáṇạ̣ nināya | jáne mitró ná dámpatī anakti bớhaspate vājáyāśúm̆n ivājaú \|

3 sādh ${ }_{\mathrm{u}}$ varyă atithínīr iṣirấ spārhăḥ suvárṇā anavadyárūpāḥ | bṛ́haspátị párvatebhyo vitúryā nír gâ ūpe yávam iva sthivíbhyah \|

4 āprușāyán mádhuna rtásya yónim avakṣipánn arká ulkăm iva dyóh | bŕchaspátir uddhárann áśmano gấ bhúmyā udnéva ví tvácam bibheda \|

5 ápa jyótișāa támo antárikșād udnáḥ sípālam iva văta ājat | bŕ̛haspátir anumŕśyā valásy a abhrám iva văta â cakra â găh \|

6 yadâ valásya píyato jásum bhéd bớhaspátir agnitápobhir arkaín |

dadbhír ná jihvắ párivișțam ádad āvír nidhímỏr akrṇod usríyānāàm ||

7 bớhaspátir ámata hí tyád āsāṃ năma svaríṇāṃ sádane gúhā yát | āṇdéva bhittvấ śakunásya gárbham úd usríyāḥ párvatasya tmánājat \|

8 áśnápinaddham mádhu páry apaśyan mátsyạ̣ ná dīná udáni kṣiyántam | níṣ țáj jabhāra camasám ná vṛkșấd bớhaspátir viravéṇā vikíntya \|

9 sóșám avindat sá súvah só agním só arkéṇa ví babādhe támāṃsi | bŕ̛haspátir góvapuṣo valásya nír majjănạ̣ ná párvạ̣o jabhāra \|

10 himéva parnấ mușitá vánāni bợhaspátinākrpayad való gấḥ | anānukrtyám apunáś cakāra yắt súryāmăsā mithá uccárātạ̣ \|

11 abhí śyāváṃ ná kr̂śsanebhir áśvạ̣ nákṣatrebhị pitáro dyắm apimśan | rătryāṃ támo ádadhur jyótir áhan bớhaspátir bhinád ádriṃ vidád găh \|

12 idám akarma námo abhriyấya yáh pūrvî́r án ${ }_{\mathrm{u}}$ ānónavīit

bớhaspátị̣ sá hí góbhị̣ só áśvaih sá vīrébhị̣ sá nớbhir no váyo dhāt ||

Boa parte do hino consiste de símiles ou comparações que descrevem o mito da abertura do Vala, segundo o qual as vacas são libertadas do cercado em que se encontram dentro da montanha e as chuvas são assim desencadeadas. Notável nesse hino é a posição do teônimo no esquema métrico. ${ }^{266}$ Ao longo de todo o poema o nome br̆hhaspáti figura uma vez por estrofe abrindo seus diversos pādas, mas numa única ocasião inaugura uma estrofe - a estrofe 7, no exato centro do hino. São doze estrofes nas quais brorhaspáti faz a sua aparição doze vezes em diversos casos: acusativo (bŕrhaspátim), vocativo (bŕhaspate), nominativo (bṛ́̂aspátị̣), instrumental (bṛ́̂aspátină). Elizarenkova ${ }^{267}$ faz notar que, no curso das estrofes 1-7, o nome do deus transita do início do último pāda para o início do

\footnotetext{
${ }^{266}$ Fato observado por Elizarenkova (1995), 159.

${ }^{267}$ Ibid.
} 
primeiro: estrofes 1-2 - pāda $d$; estrofes 3-5 - pāda $c$; estrofe 6 - pāda $b$; estrofe 7 - pāda $a$. Tendo alcançado o teônimo o ápice da estrofe (que corresponde também ao ápice do hino) num progressivo movimento de aproximação, a segunda parte ensaia dois ciclos inacabados de progressão teonímica: estrofes 8-10 - pādas $d, c, b$; estrofes 11-12 - pādas d, c. Em forma esquemática:

$$
\begin{array}{ll}
\text { pādas } d \rightarrow c \rightarrow b \rightarrow a & \text { (estrofes 1-7) } \\
\text { pādas } d \rightarrow c \rightarrow b & \text { (estrofes 8-10) } \\
\text { pādas } d \rightarrow c & \text { (estrofes 11-12) }
\end{array}
$$

Notável também são os ecos vocabulares entre a primeira e última estrofes, ${ }^{268}$ que, em conjunto com o movimento descrito acima, criam uma espécie de composição em anel que salienta ainda mais a estrofe central do hino. A palavra abhríya 'nuvem de tempestade' aparece na estrofe 1 (abhríyasya 1 b) e é retomada na estrofe 12 (abhriyáya

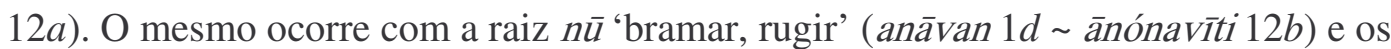
homônimos váyạ̣ ‘pássaros’ (1a) e váyạ̣ ‘força vital' (12d).

\section{1 udaprúto ná váyo rákșamānāā văvadato abhríyasyeva ghósāḥ giribhrájo nórmáyo mádanto bṛ́haspátim $a b h_{i}$ arkă anāvan}

'Como pássaros que nadam na água, alertas, que se fazem ouvir como o estrondeio da nuvem de tempestade, que se inebriam como vagas que rompem montanhas, as canções bramaram na direção de Bronaspati.'

$$
\begin{aligned}
& \text { idám akarma námo abhriyâya } \\
& \text { yáh pūrvî́r ánv ānónavīti } \\
& \text { bŕshaspátịh sá hí góbhị̣ só áśvaịh } \\
& \text { sá vīrébhiḥ sá nŕobhir no váyo dhāt }
\end{aligned}
$$

'Essa homenagem, nós a fizemos ao (deus) das nuvens tempestuosas, que brama fortemente em eco aos muitos (trovões). ${ }^{269}$ É de fato Broshaspati que nos confere a força vital junto com vacas, com cavalos, com heróis e com homens.'

Como observa Schmidt, ${ }^{270}$ na estrofe 1 "são as canções que, feito o bramido das nuvens, bramem na direção de Brohaspati, na estrofe 12 o próprio Brrhaspati assemelha-se

\footnotetext{
${ }^{268}$ Observados por Schmidt (1968a), 223 e n.99.

${ }^{269}$ Renou, EVP 15, 76, sugere ainda: “pūrvíh: ou 'vaches'?”.
} 
a nuvens e brama (feito o trovão)". Canções e Bṛhaspati são assim são assim postos em contato nas estrofes polares do hino: ambos bramem, as canções no imperfeito (anāvan 1d), Brohaspati agora, no presente do indicativo em sua forma intensiva (ánv ā-nónavīti $12 b)^{271}$

\subsubsection{Repetição complexa}

Passemos agora a um exemplo algo mais complexo. Aqui a repetição de uma palavra enfática tem por objetivo dividir a composição em dois, imbricando a primeira e segunda metades.

Vejamos como o poeta o faz tomando como exemplo um hino famoso, RV 9.113,

a Soma Pavamāna.

1 śaryaṇávati sómam índraḥ pibatu vrọtrahấ

bálạ̣ dádhāna ātmáni kariṣyán vīriyam mahád índrāyendo pári srava \|

2 á pavasva diśām pata ārjīkát soma mị̣̣h ${ }_{\mathrm{u}} \mathrm{vah} \mid$ rovākéna satyéna śraddháyā tápasā sutá índrāyendo pári srava \|

3 parjányavrơddham mahiṣám tám sứryasya duhităbharat | tám gandharvăḥ práty agrbhṇan tám sóme rásam ădadhur índrāyendo pári srava $\|$

4 rtám vádann rọadyumna satyám vádan satyakarman | śraddhặ̣́ vádan soma rājan dhātră soma páriṣkrọta índrāyendo pári srava \|

5 satyámugrasya brhatáh sám sravanti saṃsravăh | sáṃ yanti rasíno rásāḥ punānó bráhmanā hara índrāyendo pári srava $\|$

6 yátra brahmấ pavamāna chandasìāị vắcaṃ vádan| grâvṇā sóme mahīyáte sómenānandám janáyann índrāyendo pári srava \|

7 yátra jyótir ájasram yásmim loké súvar hitám | tásmin mấm dhehi pavamān ${ }_{\mathrm{a}} \quad{ }_{\mathrm{a}}$ mớte loké ákșita índrāyendo pári srava $\|$

8 yátra răjā vaivasvató yátrāvaródhanam diváh | yátrāmúr yahvátīr ápas tátra mám amị́tạ̣ $\mathrm{kradh}_{\mathrm{i}}$ indrāyendo pári srava \|

${ }^{270}$ Schmidt (1968a), 223.

${ }^{271}$ Schaefer (1994), 146s., sugere que a função original da forma intensiva era marcar o uso iterativo, que representaria "ein mehrfach wiederholtes Aufbrüllen”, hipótese que, no caso, é corroborada pela presença de pūrvîḥ 'muitos'. 


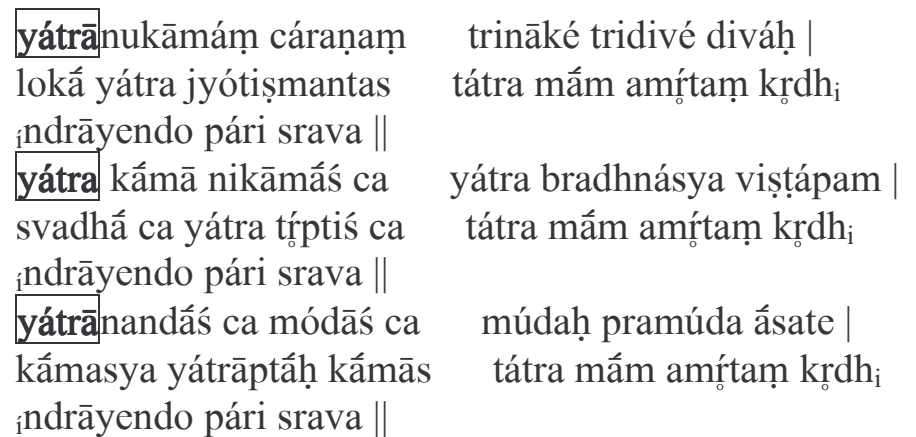

Como se sabe, todo o livro 9 do Rig Veda é composto de canções endereçadas ao deus Soma; soma designa também a planta que é espremida com a ajuda de uma pedra, cujo sumo é então filtrado e ao qual água ou leite são acrescentados. Seu poder inebriante é tremendo, e o processo efetivo da espremedura é repetidamente descrito ao longo dos hinos desse livro. Quanto ao nosso hino, ele exibe uma clara progressão até a sua estrofe central. O poder de Soma é descrito na estrofe inicial, tal como se reflete na força com que Indra é dotado para realizar os seus feitos heróicos após bebê-lo.

\section{1 Śaryanăvati sómam índrạ̣ pibatu vọtrahă bálạ̣ dádhāna ātmáni kariṣyán vīriyam mahád}

'Que Indra, algoz de Vṛtra, beba o soma em Śaryaṇávat, (assim) reunindo em si a força quando queira realizar os seus grandes feitos heróicos.'

Esse tema não é mencionado novamente nas estrofes seguintes, mas empresta uma certa coesão ao todo em virtude do refrão que retorna ao fim de cada uma das onze estrofes: índrāyendo pári srava 'Flui ao redor para Indra, ó gota (de soma)'.

Estrofes 2-4 narram a origem e natureza míticas de Soma, as suas credenciais celestes. Da distância dos céus ele é trazido para a proximidade da terra ao fim da estrofe 4 (dhātrâ soma páriṣkrta 'Foste, ó Soma, todo equipado pelo executor (do rito)'). Isso nos prepara para o clímax do hino, o efetivo processo de purificação que ocorre nas duas estrofes seguintes (5-6). Vejamos como o ritual é descrito:

\section{5 satyámugrasya brhatáh sám sravanti samsravăh sám yanti rasíno rásāḥ}


punānó bráhmanā hara

índrāyendo pári srava

yátra brahmá pavamāna

chandasi yām vắcaṃ vádan

grâvṇā sóme mahìyáte

sómenānandám janáyann

índrāyendo pári srava

'Do (Soma) realmente formidável, sublime, as confluências confluem; juntos avançam os sumos do (soma) sumarento quando és purificado pela fórmula (bráhman-), ó alazão [,]

Flui ao redor para Indra, ó gota (de soma)

Onde o sacerdote (brahmán-), ó Pavamāna, proferindo a palavra melódica, engrandece-se junto ao soma com a pedra espremedora, engendrando alegria pelo soma.

Flui ao redor para Indra, ó gota (de soma).'

Um vínculo estreito entre ambas as estrofes é alcançado porque a oração que tem início em $5 c$ só termina na estrofe 6 , o refrão sendo usado como um parêntese: "Juntos avançam os sumos do sumarento quando és purificado pela fórmula (punānó bráhmaṇā), ... / (fórmula) na qual (yátra) o sacerdote, ó Pavamāna (brahmá pavamāna), proferindo a palavra melódica...'. Este é o único exemplo em todo o hino no qual se cruza a fronteira entre as estrofes. A estratégia é tanto mais notável não somente porque a sentença avança nos estritos limites impostos pelo refrão, mas também por causa da repetição da mesma família de palavras em ordem quiástica - punānó bráhmaṇā 'purificado pela fórmula' e brahmấ pavamāna 'o sacerdote, ó tu que purificas a ti mesmo' - em cada lado da fenda.

O cantor está claramente sinalizando à sua platéia o término de uma seção, impressão que é reforçada pelo efeito de remate causado pelos dois particípios de mesma terminação ao termo dos pādas $6 b$ e $6 d$ : vádan, janáyan 'falando, engendrando'. A prova definitiva é oferecida pela palavra yátra 'onde, no(a) qual', que atua como uma dobradiça entre as estrofes 5-6 e é repetida na mesma posição métrica ao longo da segunda metade (estrofes 7-11). Essa segunda metade, pela qual o hino é famoso, consiste basicamente de preces relacionadas ao mundo celestial ou associadas à vida após a morte, por exemplo a estrofe 7.

yátra jyótir ájasram yásmim̆ loké $S_{u}$ var hitám tásmin mấm dhehi pavamān amŕte loké ákșita
'Onde (há) luz inextinguível, no mundo no qual o sol foi posto, lá me põe, ó Pavamāna, nesse mundo imortal, imperecível.' 
Ou a estrofe 9:

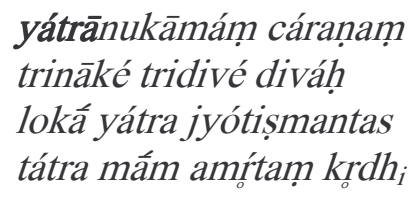

'Onde se pode circular à vontade no triplo firmamento, no triplo céu dos céus, onde (estão) os mundos brilhantes, lá me faz imortal.'

Olhando um pouco mais de perto, contudo, pode-se ver que esse primeiro yátra de $6 a$ não significa exatamente o mesmo que os seguintes. Aqui se faz referência à palavra poética proferida pelo sacerdote-poeta, cuja atividade purificadora é equiparada à efetiva purificação do líquido soma durante o ritual: $5 c d$ sáṃ yanti rasíno rásāḥ punānó bráhmaṇā 'juntos avançam os sumos do sumarento quando és purificado pela fórmula'. E o sacerdote brahmán que 'profere a palavra melódica' (6b chandas $y \bar{a}$ ạ̣ vắcaṃ vádan) empunha "uma pedra espremedora" (grâvṇâ), um objeto ritual que, em outras passagens do Rig Veda, é descrito como algo dotado de canto, voz ou que desempenha um papel invocatório. ${ }^{272}$ Assim como a pedra espremedora produz um som rítmico enquanto extrai o sumo da planta soma, assim também - o poeta parece dizer - o sacerdote purifica o sumo com a sua récita métrica. As demais ocorrências de yátra (estrofes 7 a 11) referemse por sua vez ao mundo celestial pelo qual o poeta revela o seu anseio. ${ }^{273}$

No entanto, e aqui reside a perícia do poeta, tomando cada metade do nosso hino separadamente, tem-se dois hinos perfeitamente autônomos, os quais partilham porém uma única e mesma estrofe, a sexta, situada no centro da canção. O primeiro hino, é lícito argumentar, estende-se das estrofes 1 a 6; o segundo, das estrofes 6 a11. Pela primeira hipótese, estrofes 5 e 6 compõem uma sentença, como acabo de sugerir: "juntos avançam os sumos do sumarento quando és purificado pela fórmula / na qual (yátra) o sacerdote, proferindo a palavra melódica, engrandece-se" etc. Mas se precedência é dada à segunda hipótese, estrofes 6 e 7 constituiriam uma única sentença, a sexta dividindo com a sétima o mesmo imperativo (dhehi 'põe' 7c): "Onde (yátra) o sacerdote... proferindo a palavra melódica, engrandece-se... engendrando alegria pelo soma, / Onde (yátra) há luz inextinguível, no mundo no qual o sol foi posto, lá me põe, ó Pavamāna, nesse mundo

\footnotetext{
${ }^{272}$ Para uma visão polêmica sobre o termo grấvan, cf. Thomson (2001).

${ }^{273}$ Cf. RV 1.108, um hino a Indra de 13 estrofes que exibe uma estrutura formal algo semelhante ao nosso hino: estrofes 7-12 (portanto a segunda metade) iniciam com yád indrāgnī ‘se vós, ó Indra e Agni', sendo rematadas pela última estrofe, que começa com evéndrāgñ̄ ‘desse modo, ó Indra e Agni’.
} 
imortal...". A primeira é mais plausível em termos semânticos, a segunda em seu aspecto formal. $^{274}$

Nosso poeta parece deliberadamente tirar proveito dessa ambigüidade, fazendo as duas metades imbricarem-se, concatenando-as para criar uma unidade superior. No centro ele retrata a sua própria atividade, que em conjunto com a espremedura ritual representa a interseção entre as origens celestes de Soma, tal como são narradas na primeira metade, e os pedidos a ele endereçados relativos ao mundo celestial, tal como expressos na segunda metade. Esses pedidos, de fato, só são possíveis em razão das origens de Soma narradas previamente, e ambos, origens e pedidos, harmonizam-se por intermédio da palavra ritual e purificadora do poeta, descrita metaforicamente no centro do hino.

\subsubsection{Palavra-chave}

Mas não é somente à força da repetição de palavras estrategicamente dispostas que um hino pode revelar a sua estrutura subjacente. Como sugere Jamison, ${ }^{275}$ uma única palavra-chave também pode ser usada como recurso formal a fim de estruturar uma obra.

Vejamos como isso e dá em RV 4.7, um hino a Agni. ${ }^{276}$

1 ayám ihá prathamó dhāyi dhātṛ́bhir hótā yájișțho adhvaréṣu ị̂̂aḥ | yám ápnavāno bhŕ̛gavo virurucúr váneșu citrám vibhúvaṃ viśé-viśe \|

2 ágne kadấ ta ānușág bhúvad devásya cétanam | ádhā hí tvā jagrọhriré mártāso vikṣú ị̂̂am \|

3 rotávānam vícetasam páśyanto dyấm iva stṛ́bhị̣ | víśveșām adhvarănāạm haskartâram dáme-dame \|

4 āsúm dūtám vivásvato víśā yáś carșanî́r abhí | á jabhruḥ ketúm āyávo bhŕgavāṇaṃ viśé-viśe \|

5 tám īṃ hótāram ānuṣák cikitvăṃsạ̣ ní ședire | raṇvám $\mathrm{p}_{\mathrm{a}} \mathrm{V}_{\overline{\mathrm{a}}}$ káśocișạ̣ yájișṭhạ̣ saptá dhămabhị̣ $\|$ 6 táṃ śáśvatịṣu mātr̂́ṣu vána ă vītám áśritam |

\footnotetext{
274 Índice da ambiguidade da estrutura é a hesitação dos tradutores: Renou encerra a estrofe 5 com um ponto final e inicia nova frase na estrofe 6; Geldner também separa a estrofes 5 e 6, mas em vez de unir esta última à estrofe 7 , transforma equivocadamente a estrofe 6 numa unidade autônoma, criando um correlativo inexistente para yátra no refrão: "Woo, o Pavamāna, der Hohepriester in gebundener Rede sprechend mit dem Preßstein (in der Hand) bei Soma sich erhaben fühlt, durch den Soma Wonne wirkend, da fließe usw." (grifos meus). Já Thieme (1964) une ambas as estrofes (5-6) e comenta: "Vers 6 beendet den in Vers 5 begonnenen Satz, in den der Refrain als Parenthese eigeschaltet ist". Eis parte da sua tradução das estrofes 5-6: “ ...zusammen kommen die Säfte... wenn du, Goldener, durch die Dichtung geläutert wirst... / [bei der heiligen Handlung] da der Dichter, du dich Läuternder! die metrische Sprache redend...”.

${ }^{275}$ Jamison (2004), 246.

${ }^{276}$ Cf. Renou (1939), 164.
} 


\begin{tabular}{|c|c|}
\hline & citráṃ sántaṃ gúhā hitáṃ \\
\hline 7 & 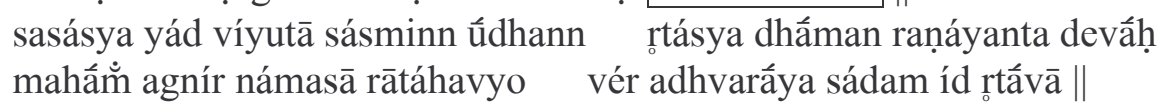 \\
\hline 8 & $\begin{array}{l}\text { vér adhvarásya dūt iyāni vidvấn ubhé antấ ródasī saṃcikitvấn | } \\
\text { dūtá îyase pradíva urānó vidúșțaro divá āródhanāni } \|\end{array}$ \\
\hline 9 & $\begin{array}{ll}\text { krș̣nám ta éma rúśatah puró bhăśs } & \text { carișnú arcír vápușām íd ékam | } \\
\text { yád ápravitā dádhate ha gárbham } & \text { sadyáś cij jātó bhávasî́d u dūtáh } \|\end{array}$ \\
\hline 10 & sadyó jātásya dádrośānam ójo yád asya văto anuvăti socíh | \\
\hline 11 & 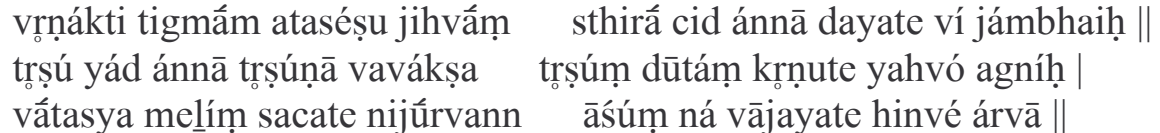 \\
\hline
\end{tabular}

O hino contem 11 estrofes, compostas em três diferentes metros: jagatī na primeira estrofe, anuștubh da segunda à sexta, e triștubh da sétima à décima primeira.

Sua estrofe central, a sexta, situada logo antes da principal mudança de metro, exibe uma notável afirmação de triplo contraste sobre a natureza de Agni baseada em três oposições: Vītám/áśritam 'escondido/sem buscar refúgio', citrám/gúhā 'manifesto/oculto', e suvédam/kūcidarthínam 'fácil de achar/com destino incerto'.

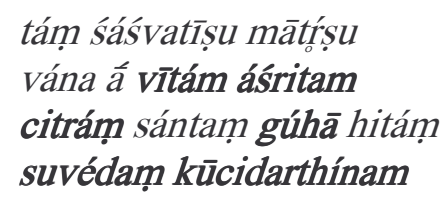

'Ele que está escondido em sucessivas mães, nos bosques, sem (lá) buscar refúgio, que, sendo manifesto, jaz oculto, que é fácil de achar (mas) tem rumo incerto.'

Essa admirável avaliação da essência de Agni, deus do fogo, formulada em termos análogos a uma charada, não surge de forma inesperada no hino, antes é preparada pela estrofe anterior, da qual as oposições servem de complemento e agem como fecho. A estrofe 6 é composta sobretudo de objetos diretos que se referem a um verbo implícito na estrofe anterior, ní ședire ‘eles assentaram, instalaram', e o elo entre ambas as estrofes é salientado pelo mesmo pronome demonstrativo no acusativo em posição inicial enfática:

$\begin{array}{ll}5 a b & \text { tám ìm hótāram ānușák } \\ \text { cikitvămsaṃ ní ședire } \\ \ldots \\ 6 a & \underline{\text { tám... }}\end{array}$

'Ele, instalaram-no como sacerdote hotar de acordo com a seqüência (ritual), sábio que é (...) ele...' 
Entre as estrofes 1 e 5-6, que preenchem a primeira parte do hino, um anel é criado pela repetição do termo hotar associado a verbos praticamente sinônimos, "pôr" (dhā-) e "instalar" (ní sad-):

\section{$1 a b \quad$ ayám ihá prathamó dhāyi dhātróbhir hótā..}

\section{$5 a b \quad$ tám ìṇ hótāram ānuṣák cikitvắṇsaṃ ní ședire}

\author{
'Esse (Agni) foi posto aqui como \\ sacerdote hotar pelos que põem (= \\ executam o rito)...' \\ 'Ele, instalaram-no como sacerdote as \\ hotar de acordo com a sequiência (ritual), \\ sábio que é.'
}

(Notem também ānuṣák 'de acordo com a seqüência ritual' repetido na mesma posição métrica nas estrofes 2 e 5 , as quais estão dispostas simetricamente no interior da primeira parte.) Assim é que o poeta conclui a primeira metade do hino não somente ao alterar abruptamente o metro. Antes, a mudança de metro é um artifício utilizado para sublinhar a ruptura no centro já anunciada pelo efeito em anel e pelo verbo ní ședire em 5 extravasando, por assim dizer, para a estrofe seguinte, a última da primeira parte. Além disso, a estrofe 6 é rematada por intermédio de uma tripla oposição que já mencionamos, engenhosamente disposta em blocos minguantes de palavras em cada grupo de fórmulas contrastantes:

\section{6ab tám sáśvitịṣu mātrísu vána â vītám áśritam(7 palavras); 6c citrám sántam gúhā hitám (4 palavras); $6 d \quad$ suvédam kūcidarthínam (2 palavras).}

Se por um lado kūcidarthínam estabelece um laço com as duas outras oposições

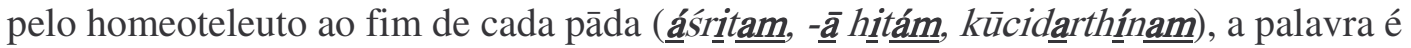
tanto mais conspícua por figurar a cavalo, com as suas cinco sílabas, de ambos os hemistíquios do verso anuștubh octossilábico e por ser de todo incomum - de fato, tratase de um hapax legomenon. Kūcidarthínam (traduzido como "überall strebend", "anderswohin strebend" por Grassmann e Geldner respectivamente), possui uma base interrogativa ku em seu elemento kūcid-, e é precisamente esse elemento que figura a cavalo do hemistíquio ( $\backsim-k \bar{u} \vdots$ cidarthínam), sublinhando o tom de enigma comum à toda estrofe e conferindo-lhe simultaneamente um fecho. Agni desconcerta, diz a nossa 
estrofe, por ocultar-se e ao mesmo tempo ser manifesto, tal como é mais manifesto e ao mesmo tempo oculto na estrofe central desse poema em seu louvor.

A segunda parte, dando início a um novo metro triștubh que cobre as últimas cinco estrofes, não é, como pode parecer à primeira vista, um mero apêndice destinado apenas a preencher o número correto de versos a fim de embutir a sexta estrofe-enigma no centro do hino. Isso porque na própria segunda parte aninha-se outra estrofe de viés enigmático, ela também situada bem no centro, que complementa e alude à primeira pelo posicionamento e tema - a natureza contraditória de Agni.

\section{9 krṣnạám ta éma rúśatạ puró bhâs carișnu arcír vápușām íd ékam yád ápravītā dádhate ha gárbhaṃ sadvás cij jātó bhávasî́ u dūtáh}

\begin{abstract}
'Negro (é) teu caminho, mas tu (és) reluzente; o raio (está) em frente (de nós), mas tua chama (é) móvel: esse (é) um dos milagres, (o outro) que (tua mãe) recebe o embrião sem ser fecundada e tão logo nasces tu viras mensageiro.'
\end{abstract}

De maneira algo mais elíptica, embora chamadas explicitamente de milagres $(9 b$ vápuṣām), quatro oposições que dizem respeito ao caráter desnorteante de Agni tornam a expressar em termos diversos o triplo contraste da estrofe central: krṣnám-rúśatah 'negro-reluzente', puró bhăs- cariṣn nu ‘em frente-móvel', ápravītā-dádhate gárbham 'sem sem ser fecundada-recebe o embrião', sadyáś cij jātáh-dūtáh ‘tão logo nasces-viras mensageiro'. Essa estrofe traz vivamente à lembrança a natureza fluida de Agni tal como expressa na estrofe central do hino não somente pelo seu conteúdo manifesto, mas ainda pelo jogo estrutural que o poeta estabelece entre elas, por assim dizer ocultando-as em sucessivos centros, o do poema e o da segunda parte respectivamente, no propósito de pôlos em evidência tanto maior precisamente porque o faz. Trata-se aqui de um centro secundário, que age de modo a realçar o primeiro e mais central. $\mathrm{O}$ engenho do poeta reside em conferir um fundamento estrutural àquilo que diz, em criar sentido pelo modo como constrói o poema, em louvar a divindade não somente pelo que afirma, mas pela forma como o expressa. ${ }^{277}$

\footnotetext{
${ }^{277}$ Cf. os comentários fundamentais de Jamison sobre a natureza dos hinos rigvédicos: “[...] the way to figure out what the RV (or some parts of it) means is to examine in detail how it means, how the thought unfolds and is verbally embodied. [...] The poem 'means' by dynamically becoming a poem, not through static statements about this belief or that. In other words, what all of the RV shares may be not a unified vision of the cosmos, the forces at play in it, and human's relation to them (i.e., a 'religious system') but a
} 
Outros indícios menores traem o zelo com que o poeta empreende a composição do seu louvor. Em $6 b$ diz-se que Agni acha-se "escondido nos bosques” ( vána ă vītám); na estrofe-enigma gêmea (9), somos informados que sua mãe "recebe o embrião sem ser fecundada" (ápravītā dádhate ha gárbham). Uma afirmação faz eco à outra, e é bem provável que tenham impressionado ouvintes atentos, situadas como estão em ambas as estrofes de cunho enigmático e graças ao jogo entre equivalentes fonéticos de duas raízes verbais diversas, vyā- 'envolver, cobrir' e $v \bar{v}-$ 'voltar-se para' respectivamente ${ }^{278}-$ algo que contribui para aumentar o caráter misterioso dos sucessivos contrastes. Entre elas, nos pādas $7 d$ e $8 a$, dois exemplos da raiz verbal $v \bar{i}$-criam um elo mútuo sugerindo que a repetição não é acidental:

\section{7d [agníh]... vér adhvarâya \\ '(Agni) voltou-se para o sacrifício'}

\section{$8 a \quad$ vér adhvarásya düt tyāni}

'voltaste-te para as funções de mensageiro do sacrifício’

As expressões vér adhvaráya e vér adhvarásya soam bastante semelhantes, e esse aspecto é ressaltado pela repetição epanaléptica no início de dois pādas contíguos (\#vér... \#vér...). Semelhantes embora sejam, o verbo na primeira é todavia complementado por um dativo (adhvaráya), ao passo que na segunda por um acusativo ( $\left.d \bar{u} t_{i} y \bar{a} n i\right)$; e a despeito de possuírem a mesma forma, vér, um conjuga-se na terceira pessoa, "ele voltou-se", ao passo que o outro é conjugado na segunda, "tu voltaste-te". Uma forma sutil, talvez se possa argumentar, de enfatizar por meios morfológicos e sintáticos a natureza ambígua de Agni, ${ }^{279}$ tal como revelada nas duas estrofes-enigmas que emolduram as expressões.

\footnotetext{
shared sense of how to explore the many different possible visions of these matters through imaginative poetic activity" (2001a), 390; "[...] the way the Rig-Veda means is through verbal manipulation and selfconscious artistry; the meaning cannot be reduced to 'concepts' and 'models' divorced from the words that convey them without impoverishing not only its form but also its very message" (2001b), 182-3. Cf. ainda o ensaio de Renou, "Les pouvoirs de la parole dans le Rgveda", in EVP 1, 1-27.

${ }^{278}$ Sobre essa última raiz, cf. Schmid (1968).

${ }^{279}$ Para Malzahn (2002), a terceira pessoa do singular injuntivo véh é uma criação artificial ("Kunstbildung") derivada da segunda pessoa do singular injuntivo do mesmo verbo, cuja formação é regular para um injuntivo presente, ao passo que a forma normal da terceira pessoa seria vét. Segundo a autora, o injuntivo presente de segunda pessoa véh teria sido reinterpretado como um injuntivo aoristo, ensejando assim a homologia das formas de terceira e segunda pessoas.
} 
A composição bem burilada conclui então com uma estrofe cuja imagem é, por assim dizer, um exemplo concreto do hapax kūcidarthínam: um fogo que grassa nos bosques. Sua fúria torna-se audível pelas três formas diversas o adjetivo trasúu- 'ávido', em imitação ao rumor crepitante do fogo à medida que avança acompanhado pelo vento.

\section{1 ab troṣú yád ánnā trọsúnā vavákṣa trșúm dūtám kṛnute yahvó agníh}

'Quando ele cresceu ávido, (consumindo) o alimento com (suas) ávidas (chamas), o jovem Agni faz do ávido (vento) o seu mensageiro.'

Instigado pelo vento, o fogo avança a passos rápidos; a ação ganha velocidade; cavalos vêm à mente como termo de comparação; o hino encerra em ritmo acelerado, em três orações com número decrescente de sílabas: $:^{280}$

\section{1c vătasya melím sacate nijúrvann \\ 11d āśúm ná vājayate \\ hinvé árvā}

'ele junta-se ao rugido do vento, consumindo, / ele como que esporeia o ligeiro (corcel), / aguilhoado está o corredor.'

Todos os verbos das orações principais estão dispostos em posições enfáticas, emprestando vivacidade ainda maior à descrição: krṇute 'faz' e sacate 'junta-se' após a quebra, vājayate 'esporeia' após a (rara) cesura do terceiro pé, hinvé 'aguilhoado’ abrindo a cadência. O último pāda conclui o poema com um quiasma, dois substantivos (āśúm 'cavalo' e árvā 'corredor') servindo de moldura a dois verbos (vājayate 'esporeia' e hinvé 'instigado'). Mais uma vez um contraste é alcançado, em um hino que insiste tanto em estruturar contrastes: a força indômita do fogo tal como surpreendida nas duas últimas estrofes e na sua palavra-chave central (kūcidarthínam) opõem-se às declarações contidas na primeira parte de que Agni foi instalado como sacerdote hotar (estrofes 1 e 5), bem como às imagens recorrentes do sereno fogo sacrificial aceso em cada lar (dáme-dame

\footnotetext{
${ }^{280}$ Em geral, as fronteiras métricas e sintáticas coincidem no Rig Veda, ou seja, verso e sentença são coextensivos. Exceções a essa regra são versos em enjambement e aqueles nos quais há duas ou mais orações no interior de um único verso, como no caso do pāda 11d. Cf. Dunkel (1985).
} 
$3 d$ ), em cada clã ( viśé-viśe $1 d, 4 d$ ), à idéia do fogo como o mais apropriado mensageiro entre homens e deuses. ${ }^{281}$

\subsubsection{Ambigüidade}

Às vezes uma ambigüidade deliberada revela os propósitos estruturantes do cantor e põe em relevo um complexo de relações. Tomemos como exemplo RV 1.10, um hino a Indra.

1 gáyanti tvā gāyatríno a a rcant ${ }_{i}$ arkám arkíṇạ̣| brahmấṇas tvā śatakrata úd vaṃśám iva yemire \|

2 yát sănoḥ sănum áruhad bhứr áspaștạa kárt ${ }_{\mathrm{u}}$ vam | tád índro ártham cetati yūthéna vrș̣ịír ejati \|

3 yukṣvă hí keśínā hárī vị̛șanạa kakșìaprấ | áthā na indra somapā girấm úpaśrutiṃ cara \|

4 éhi stómām̆ abhí svar ${ }_{\mathrm{a}}$ abhí grṇīh $\mathrm{h}_{\mathrm{i}}$ á ruva| bráhma ca no vaso sác ${ }_{\bar{a}} \quad{ }_{i}$ ndra yajñám ca vardhaya $\|$

5 ukthám índrāya śámsyaṃ várdhanam purunișșídhe | śakró yáthā sutéṣu ṇo rāráṇat sakh ${ }_{\mathrm{i}}$ yéșu ca $\|$

6 tám ít sakhitvá īmahe tám rāyé táṃ suvíriye | sá śakrá utá nạ̣ śakad índro vásu dáyamānạ̣ \|

7 suvivị́tam sunirájam índra tvădātam íd yásaḥ | gávām ápa vrajáṃ vrọdhi krṇuṣvá rădho adrivaḥ \|

8 nahí tvā ródasī ubhé rghāyámāṇam ínvatạ̣| jéṣạ̣ súvarvatīr apáḥ sám gá asmábhyaṃ dhūnuhi \|

9 ắrutkarṇa śrudhî hávam nú cid dadhiṣva me gírạ | 10 índra stómam imám máma krósvă yujáś cid ántaram | vŕṣantamasya hūmaha ūtím sahasrasătamām \|

11 ă tú na indra kauśika mandasānáh sutám piba|

12 pári tvā girvaṇo gíra imấ bhavantu viśvátạ̣| vroddháyum ánu ví̛ddhayo júșțā bhavantu júșțayạ̣ \|

A estrofe 7 pode ser compreendida de diversas formas, dependendo de como são construídos os dois termos que compõem o primeiro pāda, suvivíttam sunirájam. Eles

\footnotetext{
${ }^{281}$ Sobre a natureza iterativa e durativa dos āmreditas dáme-dame e višé-viśe cf. Klein (2003), esp. 778s. Para ele, viśé-viśe não possui o valor locativo defendido pelos críticos, mas é um autêntico dativo, como evidenciado pela sua morfologia: "it looks like a dative, behaves like a dative, and translates like a dative" (779 n.19): "to/for clan after clan/every clan" (778).
} 
podem referir-se, e esta é a primeira interpretação possível, ao substantivo neutro yáśas‘distinção' no pāda $b$; os dois primeiros versos constituiriam uma única sentença:

$7 a b \quad$ suvivítam sunirájam índra tvădātam íd yáśạ̣
'Fácil de abrir, fácil de conduzir para

fora é a distinção, Indra, que tu conferes'

Essa solução tem a seu favor o fluxo natural da frase e a unidade sintática que ela supõe para a primeira metade da estrofe; é de presumir que, ao ouvi-la pela primeira vez, a platéia tenha compreendido dessa forma.

Em termos semânticos, como reconciliar "fácil de abrir" (suvivítaṃ) e "fácil de conduzir para fora" ( sunirájam) com "distinção" (yáśaḥ)? Como foi sugerido por Geldner e desenvolvido por Marina Benedetti, ${ }^{282}$ yáśas- 'distinção, honra' bem pode ser uma alusão à dákșịnā, à retribuição ritual a ser dada ao poeta-sacerdote: ${ }^{283}$ uma vez que essa retribuição costuma consistir de vacas, é concebível que o poeta vincule aqui yáśas-, a sua paga em vacas, com o fato de ela ser sunirája-, "fácil de ser conduzida para fora". Por outro lado, no entanto, suvivíta- 'fácil de abrir' teria uma relação no máximo tênue com yáśas- entendida como a vaca da dákșiṇa. ${ }^{284}$

A segunda opção plausível é construir suvivítam sunirájam com o acusativo masculino vrajám 'cercado, estábulo' em $c$, e então $a$ e $c$ constituiriam uma única oração, separada por uma sentença parentética:
suvivítam sunirájam
(índra tvădātam íd yásậh)
gávām ápa vrajám vrọdhi

\footnotetext{
${ }^{282}$ Benedetti (1989), 65. Baseio parte da minha interpretação nos comentários da autora contidos nesse artigo.

${ }^{283}$ Sobre a dákṣiṇā em geral, cf. Heesterman (1959), Pinault (1999-2000), esp. 436-40, e Hintze (2000), esp. 120-32. Cf. ainda Oguibénine (1988), 80-116.

${ }^{284}$ Além disso, se suvivítam é um neutro que concorda com yáśas-, ele tem de ser interpretado como um adjetivo verbal em -ta-, mas o acento seria então anômalo (seria lícito esperar *súvivrta- ou ao menos * suvivirtá-). Para explicar o acento tal como aparece no texto é preciso pressupor um tema consonantal su$v i$ - $v g_{0}$-com alargamento em - $t$-, uma vez que compostos radicais exibem normalmente o seu acento no elemento radical (cf. Wackernagel e Debrunner (1905), II, 1, 221: "Wenn [...] das Hinterglied betont ist, so ist dieses, wenn ohne Formativ oder mit - $t$ - gebildet, notwendig auf der Wurzelsilbe betont z.B. v. paśu-tŕp'Vieh raubend' su-kŕ-t- 'woltuend'”.) Mas se tanto suvivítam quanto sunirájam são construídos a partir de temas consonantais, a sua terminação - am tem necessariamente de ser a de um acusativo. Cf. Benedetti (1989), 62-4.
} 
'(o cercado) que é facilmente aberto, para fora (do qual as vacas) são facilmente conduzidas - (eis) uma distinção conferida somente por ti, ó Indra -, abre esse cercado de vacas (gávāṃ vrajám).'

A objeção erguida contra essa solução é que sunirája- não quadra com vrajá- de maneira tão perfeita quanto se espera. Dado o patente paralelismo explorado pelo poeta entre suvivíta-e sunirája-, ambos deveriam referir-se com igual naturalidade a vrajá-, mas como se pode dizer que um cercado é "fácil de conduzir para fora"? Num caso, tomado com suvivítta-, vrajá- teria uma função acusativa, "cercado fácil de abrir", ao passo que no outro, tomado com sunirája-, teria uma função ablativa, "para fora de cujo cercado as vacas são facilmente conduzidas". Por outro lado, no entanto, essa segunda hipótese faria sentido como uma referência oblíqua às façanhas mitológicas de Indra ao abrir o cercado ou montanha e libertar as vacas, equiparadas assim às chuvas ou à aurora. A par disso, a oração parentética no pāda $b$ ("Indra, esta é uma distinção conferida apenas por ti”) seria uma maneira refinada de entremesclar uma referência às vacas oferecidas ao poeta-sacerdote como contraprestação ritual e a proeza mítica de Indra, uma maneira de identificar - como ocorre tantas vezes ao longo do Rig Veda - as vacas terrestres com as vacas celestes, o rito com o mito.

Uma terceira e última opção seria tomar suvivítame sunirájam como acusativos referentes a um verbo implícito immahe 'nós invocamos', a ser suplementado da estrofe anterior. Indra seria então o objeto da sentença elíptica.

\section{6a tám ít sakhitvá īmahe \\ $6 b \quad$ tám rāyé tám suvîri \\ 7a suvivítam sunirájam}

'Ele (Indra), nós o invocamos para a amizade, ele para a riqueza, ele para homens de elite; '(Ele) que abre bem (o cercado), que conduz para fora bem (as vacas).'

A tripla repetição de tám in $6 a b$, sempre com o pronome em posição métrica enfática (no início de $6 a$, adjacente às fronteiras do hemistíquio em $6 b$ ), assim como o verbo īmahe posicionado antes da quebra, convidariam os ouvintes (razoável é supor) a considerar o grupo assindético suvivịtam sunirájam, com as suas terminações -am de sonoridade idêntica, como complemento natural do verbo na estrofe anterior. Como nomina agentis, os compostos radicais suvivĩt-e suniráj- 'que abre bem', 'que conduz para fora bem' soariam à primeira vista como uma intrigante referência a Indra, mas o 
sentido logo se tornaria perfeitamente claro após o pāda $7 c$, "abre o cercado das vacas" (gávām ápa vrajám vrọdhi). Os pādas remanescentes constituiriam então cada qual uma oração completa.

Para o público, portanto, haveria três possibilidades de compreender o conteúdo da sétima estrofe; as diversas compreensões dependem de como a sentença desdobra-se a cada passo:

a) primeiro, suvivítam sunirájam seriam concebidos como referência a yáśas- 'distinção' (nominativo neutro) no verso seguinte, "fácil de abrir, fácil de conduzir para fora é a distinção, Indra, que tu conferes";

b) à medida, porém, que a estrofe avança, ela parece mudar de conotação: suvivítam sunirájam seriam então construídos com vrajá- ‘cercado’ (acusativo masculino): "abre, ó Indra, esse cercado de vacas que é facilmente aberto, para fora do qual as vacas são facilmente conduzidas ara fora";

c) uma vez que nenhum desses sentidos, embora plausíveis, encaixa-se com precisão no movimento da frase (suvivíta- 'fácil de abrir' tem escassa relação com yáśas-, sunirája- 'fácil de conduzir para fora' reconcilia-se apenas a custo com vrajá-), uma terceira opção teria ocorrido ao ouvinte (fosse deus ou devoto) tão logo terminado o pāda 7c: suvivítam sunirájam têm de ser, ao fim e ao cabo, epítetos de Indra. É preciso refazer os passos para suplementar um verbo da estrofe anterior, ìmahe "nós invocamos', mas ao mesmo tempo o significado pleno de suvivítam sunirájam é alcançado somente depois que todo o trajeto foi percorrido: "invocamos Indra que abre bem o cercado ( vrajám), que conduz para fora bem as vacas (gávām)".

Assim é que podemos ler a nossa estrofe em diversos planos simultaneamente: no plano do mito, no plano do ritual e no plano do próprio poema. $\mathrm{O}$ mito é aquele no qual o deus Indra vence em batalha o adversário Vala e liberta as vacas: suvivítam... gávām ápa vrajám vrdhi 'abre o cercado das vacas que (para ti) é fácil de abrir’. A alusão ritual assume a forma de vacas oferecidas ao poeta a título de dákșināa a recompensa que lhe é devida em troca da sua atividade: sunirájam índra tvădātam íd yáśạ 'fácil de conduzir 
para fora é a distinção (= dákșịnâ) que tu conferes, ó Indra'. O mito, portanto, constitui um modelo para o ritual, ou antes o ritual é a materialização do mito, as vacas oferecidas ao poeta sendo a contrapartida terrestre das vacas celestiais libertadas por Indra. As ações rituais, como resultado, são pertinentemente integradas na ação do mito. E ambos, mito e ritual, encontram um denominador comum nos epítetos de Indra, suvivítam sunirájam 'aquele que abre bem, que conduz para fora bem'.

Esses epítetos contêm in nuce, na sua concisão assindética, a façanha heróica associada por excelência a Indra: a sua vitória sobre Vala, sobre o poder da obstrução, na qual libertou as vacas do mais recôndito centro da montanha. E o poeta empenha-se em enfatizar o conteúdo daquilo que narra ao condensá-lo deliberadamente em dois epítetos incomuns, situados - eles também - bem no centro da composição. Tanto suvivíttaquanto sunirája- são hapax legomena cujo sentido - a libertação das vacas do centro da escuridão por obra e engenho de Indra - é poderosamente sublinhado pelo modo como o poeta o transmite, embutindo-os no centro do hino.

Aqui, de maneira análoga aos exemplos analisados anteriormente, a estrutura do hino é capaz de sustentar e realçar aquilo que o poeta tem a dizer. Seu louvor é tanto mais eficaz pelo laço que estabelece entre o passado mítico e o presente ritual; seu poema, ao chamar a atenção sobre si mesmo, sobre seu centro, faz o elogio de Indra com pertinácia tanto maior ao encerrar em dois epítetos centrais o feito heróico mais glorioso de Indra, a libertação das vacas encerradas por Vala.

Um último detalhe talvez reforce a sugestão de que a obra é conscientemente estruturada. Como vimos, os planos mítico, ritual e poético unem-se para dar realce ao louvor, em cujo centro figura o mito de Vala tal como expresso nos epítetos de Indra. Mas poema e mito são postos em relação ainda mais próxima quando notamos que o próprio hino tem a sua seção central circundada por duas sentenças paralelas, notáveis pela sua admirável paronomásia, uma na primeira estrofe e a outra na última, e ambas relacionadas à atividade poética:

$1 a b$ gáyanti tvā gāyatrínó

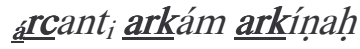

'Os cantores cantam-te, os que louvam $\underline{\text { louvam(-te) com louvores' }}$ 


\section{$12 c d$ vrddhăyum ánu víddhayo júștā bhavantu júsțtayah}

'Que o crescimento (que as canções conferem) sejam con(formes) ao (deus) cuja força vital cresceu, que os prazeres (que elas propiciam) sejam prazerosos.'

Começo e fim destacam assim a reciprocidade entre deus e devoto, da qual o pivô é o próprio hino entoado. Isso resta tanto mais evidente porque a raiz joṣ sobre a qual se baseiam adjetivo e substantivo (júștạḥ - júșțayậ) significa não só "desfrutar, tirar prazer de" (cf. Mayrhofer (1992)), mas também, como sugere Migron, ${ }^{285}$ "escolher, decidir em favor de alguém (em exclusão de outrem)": “[...] júsțtayah em 1.10.12d são os 'favores' (ou seja, preces) que o suplicante oferece à divindade na esperança de que eles, por sua vez, possam ser favorecidos (júștāḥ)".

\subsubsection{Clímax}

Finalmente, tomarei como o meu último exemplo um hino algo mais longo a Ușas, a Aurora (RV 1.113). Aqui o poeta estrutura o seu canto construindo um clímax temático.

1 idáṃ śréșṭham jyótișām jyótir ăgāc citráh praketó ajaniș̣a víbhvā | yáthā prásūtā savitúh savấyam̆ evă rắtrī ușáse yónim āraik \|

2 rúśadvatsā rúśatî śvetiyăgād áraig u kṛṣnạa sádanān $n_{i}$ asyāḥ | samānábandhū amṛ́te anūcí dyâvā várṇaṃ carata āmināné \|

3 samānó ádhvā svás aror anantás tám anyănyā carato deváśiște | ná methete ná tasthatụ suméke náktoṣấsā sámanasā vírūpe \|

4 bhásvatī $\mathrm{n}_{\text {ayi }}$ trí sūnớtānām áceti citrấ ví dúro na āvạ̣ | prărpyā jágad $v_{i} u$ no rāyó akhyad uṣấ aj̄̄gar bhúvanāni víśvā $\|$

5 jihmaśs ${ }_{i} y e$ cáritave maghón ${ }_{\bar{i}}$ ābhogáya iṣtáye rāyá u tvam | dabhrám páśyadbhya urviyă vicákșa ușaá ajīgar bhúvanāni víśvā $\|$

6 kṣatráya tvam śrávase tvam mahīyă iṣtáye tvam ártham iva tvam ityaí | vísadrósaa jīvităbhipracákṣa ușấ aj̄̄gar bhúvanāni víśvā $\|$

7 eșấ divó duhitá práty adarśi vyuchántī yuvatíh śukrávāsāḥ | víśvasyés̄āna părthivasya vásva úṣo adyéhá subhage ví ucha $\|$

8 parāyatīnấm án $n_{u}$ eti pătha āyatīnăm prathamá śáśvatīnām | vyuchántī jīvám udīráyant ${ }_{i}$ ușá mrónạ káṃ caná bodháyantī \|

9 úṣo yád agním samídhe cakártha ví yád ávaś cákșasā sứriyasya | yán mănuṣān yakṣyámāṇām ájīgas tád devéṣu cakṛșe bhadrám ápnah \|

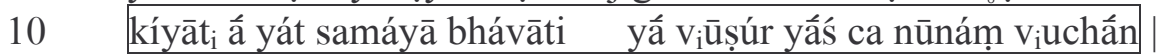
ánu pứrvāḥ kṛpate vāvaśāná pradídhyānā jóṣam anyăbhir eti $\|$

${ }^{285}$ Migron (1988-90), 127, 131. Cf. ainda Klein (2000). 
11 ìyús té yé pưrvatarām ápaśyan $\quad \mathrm{V}_{\mathrm{i}}$ uchántīm uṣásam mártiyāsah |

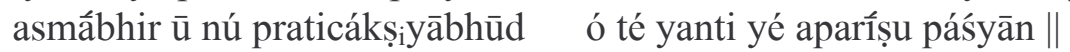

12 yāvayáddveșā rọtapấ riojẩ sumnāvárī sūníntā îráyantī| sumañgalír bíbhratī devávītim ihădyóṣaḥ śréșṭhatamā $\mathrm{v}_{\mathrm{i}} \mathrm{ucha} \|$

13 śáśvat puróșấ $v_{i} u v a ̄ s a ~ d e v_{1}$ átho adyédáṃ $v_{i} \bar{a} v o$ maghónī | átho $v_{i}$ uchād úttarām ánu dyưn ajárāmị́tā carati svadhăbhị $\|$

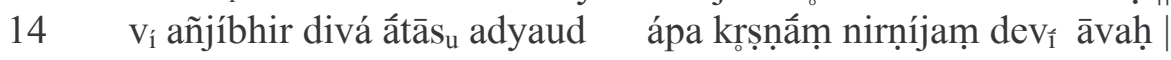
prabodháyantī arunébhir áśvair á ựáa yāti suyújā ráthena \|

15 āváhantī póṣịyā vắrìnāni citráṃ ketúm kṛ̣ute cékitānā $\mid$ ìyúṣiṇām upamă sáśvatīnām vibhātīnăm prathamóṣấ ví aśvait ||

16 úd īrdh ${ }_{\mathrm{u}}$ vaṃ jīivó ásur na ăgād ápa prăgāt táma ă jyótir eti | áraik pánthāṃ yắtave sứriyāy a áganma yátra pratiránta âyuh $\|$

17 syưmanā vācá úd iyarti váhni stávāno rebhá ușáso vibhātîh | adyấ tád ucha grṇaté maghon ${ }_{i} \quad$ asmé áyur ní didīhi prajấvat $\|$

18 yấ gómatīr ușásạ̣ sárvavīrā $\quad v_{i}$ yuchánti dāsúșe márt ${ }_{i} y a ̄ y a \mid$ vāyór iva sūnớtānām udarké tấ aśvadá aśnavat somasútvā $\|$

19 mātă devắnām áditer ánīkạ̣ yajñásya ketúr brọhatî ví bhāhi | praśastikṛ́d bráhmaṇe no $\mathrm{v}_{\mathrm{i}}$ uchă no jáne janaya viśvavāre $\|$

20 yác citrám ápna ușáso váhant ${ }_{i}$ ījānáya śaśamānáya bhadrám| tán no mitró váruno māmahantām áditị̣ síndhuḥ prọthivî utá dyaúḥ \|

A primeira estrofe saúda a chegada da Aurora, que segue a sua irmã Noite num movimento contínuo que se torna explícito nas duas estrofes seguintes.

1 idám śréștham jyótișām jyótir ăgāc citráh praketó ajanișta víbhvā yáthā prásūtā savitúh savâyan̆ evấ rắtrī usáse yónim āraik
'Eis que chegou a mais bela luz das luzes; o sinal brilhante nasceu, difundindo-se. / Assim como a Noite fora impelida pelo impulso de Savitr, assim também ela cedeu o lugar à Aurora.'

A harmonia entre elas é expressa por um conjunto de oposições que é a marca das suas naturezas. Do mesmo modo que a Noite foi impulsionada pelo deus que impulsiona (uma das funções de Savitr, o deus "que impulsiona", é trazer a noite sobre a terra), assim também ela dá lugar à luz da manhã. Já na primeira estrofe podem-se discernir sugestões de um tema que se tornará aos poucos manifesto à medida que o hino avança: a disparidade é contrabalançada pela identidade, ou - como veremos na trca seguinte, estrofes 4-6 - a multiplicidade é contrabalançada pela unidade e vice-versa. Mesmo a aliteração etimológica utilizada para descrever a uniformidade da ação de Savitro ( prásūt tā 
savitúh savâya 1c) $)^{286}$ destaca-se contra o pano de fundo de ambivalência sintática em uma sentença balanceada com correlativos ( yáthā... evâ). Isso porque o sujeito da oração yáthā pode ser a própria Aurora, e não a Noite: "assim como ela, Aurora, é impelida pelo impulso de Savitr, assim também..." Nesse caso, Savitr deve ser identificado ao Sol, ${ }^{287}$ como de fato também é na mitologia védica: a Noite dá lugar à Aurora, que por sua vez dá lugar ao Sol. Tal é uma hipótese sintaticamente correta, embora algo menos provável semanticamente. Ainda assim, fica a dúvida de como construir o dativo savâya, que na frase funciona como um instrumental: "pelo impulso de..." Se quisermos tomá-lo como verdadeiro dativo, a sentença rende ainda outro significado, também sintaticamente possível: "assim como a Noite foi impelida para que Savitr ressurja... (literalmente: para o impulso de Savitr, o deus que impulsiona”). Possível também, como faz Macdonell, ${ }^{288}$ é suprir o verbo da principal (āraik 'cedeu') na oração yáthāe assim justificar o uso do dativo: "do mesmo modo que a Noite cede ao impulso de Savitr, assim também ela cedeu o seu lugar à Aurora”. Seja como for, cabe notar que o jogo entre disparidade e identidade a que aludi acima reflete-se na própria sintaxe ambígua do hino.

Nas três primeiras estrofes nas quais Noite e Aurora aparecem lado a lado, as semelhanças mútuas são sublinhadas pelas divergências, ou, o que dá no mesmo, as suas diferenças são enfatizadas por elas serem de todo parecidas.

'Rutilante, com seu rutilante novilho (= o sol), nívea, ela chegou. A negra (= a noite) cedeu os seus assentos. / De mesma parentela, imortais, seguindo um ao outro, Dia (e Noite) avançam, apagando (um ao outro) a sua cor.'

\footnotetext{
${ }^{286}$ Recorrentes são as passagens nas quais são utilizados termos derivados da raiz $s \bar{u}$ 'impulsionar' lado a lado do teônimo Savitro construído a partir da mesma raiz.

${ }^{287}$ Oldenberg (1917), 64: "Da die Sonne die mächtigste Bewegung im Weltall selbst vollendet und damit alle andere Bewegung beherrscht, steht Savitar natülich zu ihr in besonders enger Beziehung, und es besteht Neigung Attribute des Sonnengottes auf ihn zu übertragen”. Cf. ainda Macdonell (1898), 33. A respeito da paronomásia ou do jogo etimológico com o nome divino, cf. Durante (1976), 153-4.

${ }^{288}$ Macdonell (1932), 352.
} 
Aqui a Aurora, branca (śvetyă $2 a$ ), reluzente na companhia do seu reluzente novilho (rúśadvatsā rúśatîn ${ }^{289}$ é contraposta à "Negra (noite)" (krsṣná) que acaba de lhe ceder os assentos, para então ser equiparada a ela numa fieira de quatro duais femininos ( samānábandhū amíte anūcí dyấvā, esse último um dual elíptico, 'de mesma parentela, imortais, seguindo uma à outra, ambas (as metades do) dia'). E, mais uma vez, diz-se que elas realizam uma ação recíproca, mas oposta: elas "avançam apagando (uma à outra) sua cor" ( várṇaṃ carata āmināné).

samānó ádhvā svásaror anantás tám anyânyā carato devásișțe ná methete ná tasthatuḥ suméke náktoṣâsā sámanasā vírūpe

'Igual é o trajeto das duas irmãs, ilimitado: elas o percorrem uma após a outra, ensinadas pelo deus. / Elas não se chocam nem param, bem firmes que são, Noite e Aurora, de igual coração (embora) de forma diversa.'

No plano morfológico, os pādas $3 c$ e $d$ são um bom exemplo desse vaivém de semelhança e diferença: "elas não se chocam nem param, bem firmes (suméke) que são, Noite e Aurora, de igual coração (embora) de forma diversa (vírūpe)". As terminações aqui parecem reforçar o sentido: náktoṣâsāe sámanasā, dois duais femininos de tema em -as, são emoldurados por dois duais femininos de tema em -a, suméke e vírūpe, cujo sentido - o de separação, de disparidade - contrapõe-se e ao mesmo tempo complementa os termos emoldurados: a unidade de espírito entre Noite-Aurora.

Se as primeiras três estrofes formam uma pequena unidade ao focalizar a relação entre Noite e Aurora, e também pelo uso catenário de verbos unindo as estrofes (1d āraik $\sim 2 b$ áraig, $2 d$ carata $\sim 3 c$ carato), a segunda trca de estrofes destaca-se pelo seu refrão, "Aurora despertou todas as criaturas" (ușâa ajīgar bhúvanāni víśvă). A multiplicidade é o tema central, mas esta é devidamente contrabalançada pelo coroamento que representa o refrão. Estrofes 5 e 6 podem ser vistas como paralelas: em cada uma delas afirma-se que Aurora despertou uma quantidade de pessoas diversas para um dado propósito.

${ }^{289}$ cf. jyótịsāṃ jyótị̣ ‘luz das luzes’ e citráh praketaḥ ‘sinal brilhante’ na estrofe 1. 
jihmaśiye cáritave maghón $n_{\bar{I}}$ ābhogáya iștáye rāyá u tvam dabhrám páśyadbhya urviyă vicákṣa uṣấ ajīgar bhúvanāni víśvā
'Aquele que dorme de través, a generosa (incitou) a andar, um tal outro a buscar sustento ou riqueza; / aos de vista fraca, ela (faz) ver longe. Aurora despertou todas as criaturas.'

Na estrofe 6 o poeta remata a troca ao compor uma seqüência crescente de sílabas relacionadas a quatro partículas distributivas tvam:

\section{$6 a b \quad$ kṣatrầya tvam śrávase tvam mahīyấ} iștáye tvam ártham iva tvam ityaí
'Um tal ao domínio, tal outro à fama, tal outro a buscar grandeza, tal outro a cuidar, por assim dizer, do seus afazeres."

São dois blocos, o primeiro com duas seqüências de 4 sílabas (kṣatráya tvaṃ 'um tal ao domínio' - Śrávase tvam 'tal outro à fama'), o segundo com duas seqüências de 7 sílabas (mahīyă iștáye tvam 'tal outro a buscar grandeza' - ártham iva tvam ityaí 'tal outro a cuidar, por assim dizer, dos seus afazeres'). Remate é dado aos blocos por meio do recurso simples mas eficaz de antecipar o último tvam para antes do infinitivo ityaí para dar fecho às sequiências. A isso o poeta acrescenta uma conclusão geral, na qual os vários tipos de atividades são todas subsumidas sob a ação única da Aurora:

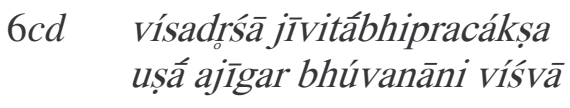

'Para que considerem as diversas (formas de) existência, Aurora despertou todas as criaturas.'

Na estrofe 7 um desenvolvimento cronológico mais claro começa a emergir, em parte por causa da afirmação, repetida a intervalos regulares, de que a Aurora chegou:

1 la idạm śréștham jyótị̦ām jyótir ăgāt

4a bhăsvatī $n_{\text {ayi }}$ trí sūnítānām áceti

7a eṣấ divó duhitâ práty adarśi 'a mais bela luz das luzes chegou'

'guia resplandecente de dádivas, ela mostrou-se'

'essa filha do céu deu-se a ver'

Depois de haver sucedido a sua irmã Noite e ter despertado todas as criaturas nas seis primeiras estrofes, essa aurora que começa a brilhar enquanto o ritual ocorre ganha 
definitivamente o primeiro plano por meio de um dêitico duplo (adyéhá 'hoje aqui') em $7 d$ : úṣo adyéhá subhage $v_{i}$ ucha 'brilha ao longe, ó formosa, hoje aqui sobre nós'. As atenções assim nela são concentradas, porém mais uma vez, tal como ocorrera nas duas primeiras trincas de estrofes, o poeta abranda distinções aguçadas e, na estrofe seguinte, faz a identidade dessa aurora perder-se, por assim dizer, na corrente de auroras passadas e futuras:

\section{$8 a b$ parāyatīnăm án ${ }_{u}$ eti pătha āyatīnám prathamá śáśvatīnām}

'Ela segue o rebanho (de auroras) passadas, ela é a primeira daquelas que vêm em sucessão contínua.'

Embora a última e simultaneamente a primeira das auroras futuras, a divindade agora louvada é engolfada na seqüência infinita daquelas que já passaram e das que ainda estão por vir. Isso é reforçado foneticamente no interior da estrofe pelo eco da terminação das palavras (parāyatīnăm, āyatīnăm, śáśvatīnām, vyuchántī, udīráyanti, bodháyantîn) e sílabas internas (parāyatīnăm, āyatīnám, udīráyanty, bodháyantī).

Até esse ponto, portanto, o poeta sugere um sutil jogo de oposições no qual o movimento é concebido dentro de um círculo recorrente (primeira $\operatorname{trca}$ ), a multiplicidade dentro de uma moldura unitária (segunda trca), e o passado mescla-se ao presente - tudo por obra da deusa Aurora. Nesse sentido, os pādas 10ab talvez soem como mais um elo nessa cadeia, mas agora cifrada numa pergunta formulada enigmaticamente:

$10 a b$ kíyāt $t_{i}$ â yát samáyā bhávāti yấ $v_{i}$ ūsúr yấs ca nūnám viuchân
'Em que ponto, a qual distância (é) que ela estará a meio caminho entre (as) que luziram e irão luzir daqui em diante?'

A pergunta, no entanto, acerca do exato ponto em que a presente Aurora louvada pelo presente hino estará a meio caminho da cadeia infinita de auroras passadas e futuras previamente louvadas e a serem louvadas dali em diante é devidamente realçada por ser feita quando o poeta atingiu o ponto central da sua própria composição. Ela, pergunta, possui um valor expressivo - ou mais, um valor icônico - em relação ao conteúdo da mensagem. Estrofes 10-11, situadas deliberadamente no coração do hino, resumem os temas das estrofes anteriores e dão o tom para o que segue na segunda metade do poema. 
kíyāt $t_{i}$ ấ yát samáyā bhávāti

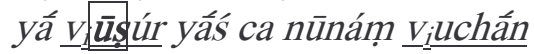
ánu pứrvāh krpate vāvaśānă pradídhyānà jósam anyăbhir eti

11 1yuus té yé pưrvatarām ápaśyan vyuchántīm usásam mártyāsạ̣ asmâbhir ù nú praticákșyāâhūd ó té yanti yé aparîșu páśyān
'Em que ponto, a qual distância (é) que ela estará a meio caminho entre (as) que luziram e irão luzir daqui em diante? Ela conforma-se, mugindo, às anteriores, previdente ela segue de bom grado as outras.

'Eles se foram, os mortais que viram a primeira Aurora brilhar; para nós ela agora tornou-se visível, e eis que vêm aqueles que a verão no futuro.'

Passado e futuro, e com eles a infindável cadeia de auroras e gerações recorrentes, encontram expressão na seqüência de verbos em seus diferentes tempos: além de $v_{i} \bar{u} s u ́ r$ 'luziram' e $V_{i} u c h a ̆ n$ 'luzirão', um perfeito e um subjuntivo combinados de forma típica, a estrofe 11 ostenta uma profusão de formas, a começar pelo perfeito Iy $\underline{\text { ús }}$ 'foram-se' - que ecoa $V_{i} \underline{\underline{u}} \underline{\text { surr }}$ 'luziram' da estrofe anterior e prefigura ușásam 'aurora' do pāda seguinte -, passando pelo imperfeito histórico ápaśyan ‘viram', pelo aoristo de passado recente abhūt 'tornou-se', pelo presente durativo yanti 'vêm', até chegar no subjuntivo prospectivo páśyān 'verão'.

Essas duas estrofes são portanto o clímax temático, a culminação do movimento ascendente descrito pelas séries de oposições cuidadosamente elaboradas na primeira metade do hino. A segunda parte, que não discutirei em detalhes, apenas reforça o tema da infinita sucessão de auroras reutilizando várias sentenças formulares, numa dicção repetitiva que sublinha o próprio tema do poema. Ao perguntar em sua estrofe central a respeito do ponto no qual a aurora estará a meio caminho entre aquelas que luziram e que irão luzir dali em diante, o poeta chama abertamente a atenção para a sua própria obra, para um hino que fala de uma deusa Aurora no centro de uma legião de auroras passadas e futuras e em cujo próprio centro ela figura com toda a proeminência.

\subsection{Hino Grego E "OMphalos"}

É claro que nem todos os hinos rigvédicos exibem uma estrutura geral de fácil identificação. Boa parte deles resume-se a concatenar uma estrofe a outra, ou então a reuni-las em trincas com certa uniformidade temática. Mas alguns deles, pelos exemplos 
sugeridos no capítulo anterior, são deliberadamente estruturados a partir do meio ou da sua seção central.

E quanto aos hinos gregos? É possível vislumbrar neles o mesmo tipo, ou pelo menos um tipo análogo, de organização estrutural?

Embora raro, e de uso incomparavelmente menos difundido que a estratégia de afunilar as atenções da divindade louvada para o momento atual da celebração do poema, tal expediente pode ser encontrado em alguns hinos como forma de codificar a mensagem e reforçar-lhe o sentido. Isso dependerá, sem dúvida, do conteúdo do poema, do fato de ele prestar-se ou não ao realce de sentido propiciado por uma estrutura que salienta a sua mensagem central ao situá-la no centro do hino.

Comecemos com um exemplo sugerido pela crítica. Bing e Uhrmeister, ${ }^{290}$ de quem resumo aqui os argumentos, sustentam que, no Hino a Ártemis, Calímaco ilumina o seu poema do centro para fora. Segundo os autores, a primeira metade do hino traça um um movimento ascendente que conduz Ártemis ao Olimpo. Pouco antes de lá chegar, o narrador descreve duas cidades, uma injusta (122-8), punida com a cólera da deusa, e outra justa (129s.), que por ela é favorecida. Nessa altura, no exato centro do hino, o poeta faz a sua prece para que seja incluído entre os habitantes dessa última cidade (1367). ${ }^{291}$

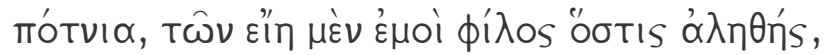

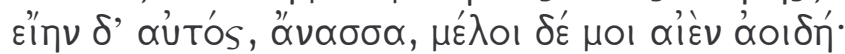

'Senhora, que deles faça parte quem quer que seja meu amigo verdadeiro, que deles eu mesmo faça parte, rainha, e que o canto seja sempre objeto do meu cuidado.'

A proteção de Ártemis, portanto, significa para o poeta a capacidade de entoar o seu canto. Canto esse, aliás, cujo tema ele delineia nos versos seguintes (138-144):

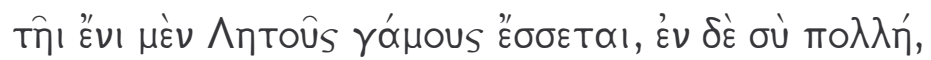

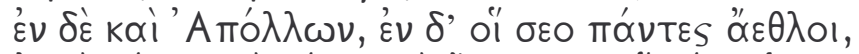

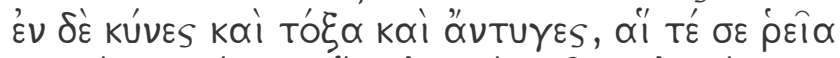

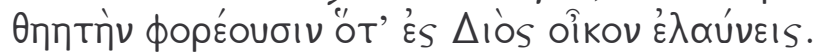

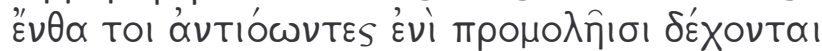

\footnotetext{
${ }^{290}$ Bing e Uhrmeister (1994).

${ }^{291}$ A posição central desses versos já havia sido notada por Bornmann (1968), 68.
} 


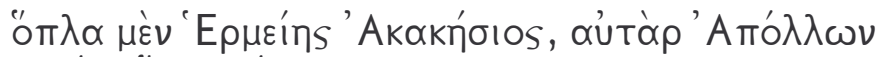

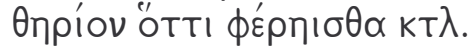

'e nela (= na canção) estará o casamento de Leto, nela estarás tu várias vezes, nela estará Apolo, nela todos os teus feitos, nela os teus cães e o teu arco e a tua carruagem, que facilmente te porta esplendorosa quando te diriges à casa de Zeus. Lá, encontrando-te na entrada, Hermes Akakésios pega as tuas armas e Apolo, qualquer caça que tragas...'

Todos os temas propostos para a canção futura, como lembram os autores, são temas do presente poema; o hino prometido pelo poeta é o próprio Hino a Ártemis que o leitor tem sob a vista. Em suas palavras: "Ora, na medida em que Calímaco foi capaz de escrever esse hino (um poema tal como ele cantaria se apenas Ártemis tornasse possível que ele o fizesse), vemos que ele de fato desfruta do respaldo da deusa. Aquele laço que se almeja entre os dois já é uma realidade: Ártemis permite ao poeta praticar a sua arte, e em troca ele canta um hino (esse hino) a Ártemis". ${ }^{292}$ De um lado, o poema só é possível sob a égide de Ártemis; de outro, é a própria canção que conduz Ártemis até o Olimpo, nas várias etapas pelas quais transita a deusa até o clímax dos versos centrais, passando

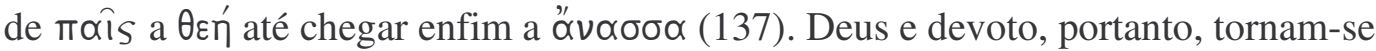
imprescindíveis um ao outro, e de quebra faz-se o elogio da Alexandria de Ptolomeu, a cidade justa que propicia a realização desse ideal de reciprocidade entre fiel e divindade ideal esse que o poeta deliberadamente tematiza nos versos centrais do hino. Neles, a obra transforma-se em seu próprio tema e irradia o seu significado para o restante da composição.

\subsubsection{Anacreonte (PMG 357)}

O significado também pode ser expresso e resumido no centro da obra por meio da posição de palavras que dão estrutura ao todo. Vejamos dois exemplos em hinos de menor porte. Primeiro o pedido de Anacreonte a Dioniso, PMG 357.

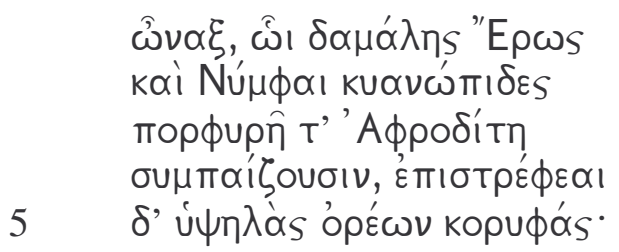

${ }^{292}$ Bing e Uhrmeister (1994), 27. 


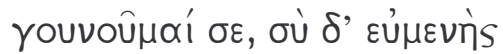

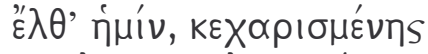

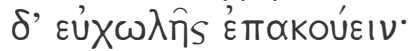

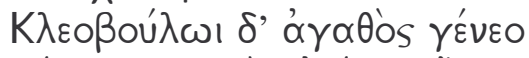

10

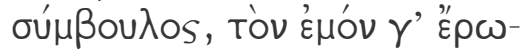

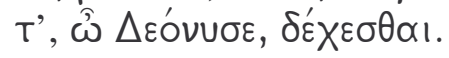

(Ó senhor, com quem brincam Eros domador e as Ninfas de olhos azuis e a radiante Afrodite, tu rondas os cumes elevados das montanhas: eu te peço, vem até nós com boa vontade, escuta e realiza a minha graciosa prece: sê um bom conselheiro a Cleóbulo, para que ele aceite, ó Dioniso, a minha paixão.)

Anacreonte faz uso da forma hínica e da fraseologia religiosa para dar vazão a sentimentos privados; seu anseio amoroso - a sua paixão por Cleóbulo - ganha um brilho todo especial por adaptar-se perfeitamente às convenções do gênero: seu pedido só terá sucesso se a relação de reciprocidade entre fiel e divindade, da qual o hino é o principal objeto de troca, estabelecer-se de modo satisfatório.

A estrutura do poema dá-se a ver de maneira clara. Após a invocação inicial

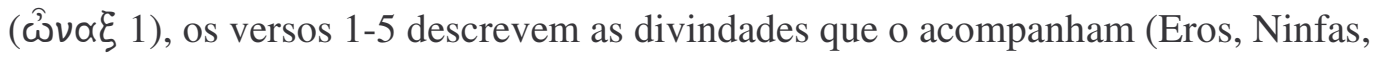

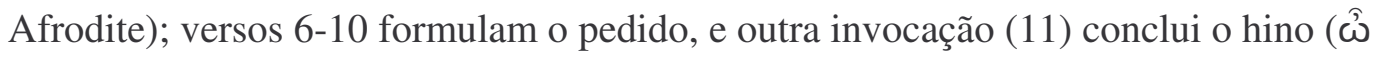
$\left.\triangle \varepsilon^{\prime} \cup \cup \sigma \varepsilon\right)$.

Divide-se assim o poema em duas metades, uma referente à companhia divina, a outra ao pedido do autor. Começo e fim são assinalados com duas invocações, com dois vocativos acrescidos da partícula $َ$, cujo destaque resulta não apenas do paralelismo entre ambos, situados no primeiro e último verso dessa composição em anel, ${ }^{293}$ mas ainda e sobretudo porque o nome do deus é mantido em segredo até fim. Só no último verso ficamos sabendo de qual $\alpha^{\prime} v \propto \xi$, de qual senhor divino é que se trata: Dioniso.

Também a métrica, simples que seja, sublinha a invocação final e a bipartição geral da obra. São dois os metros: glicônicos (1-2, 4-7, 9-10) e a sua forma catalética, o ferecráteo, nos versos 3, 8 e 11. Primeira e segunda partes, portanto, contam com o mesmo número e disposição de cólons, quatro glicônicos (dispostos de dois em dois) entremeados de um ferecráteo, que reaparece no último verso como fecho:

\footnotetext{
${ }^{293}$ Furley-Bremer (2001), vol. 1, 177s., notam também que o anel é realçado pela repetição do substantivo

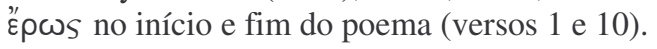




$\begin{array}{ll}\text { versos 1-5 } & 4 \text { gli } \\ & 1 \mathrm{fer} \\ \text { versos 6-10 } & 4 \text { gli } \\ & 1 \mathrm{fer} \\ \text { verso 11 } & 1 \mathrm{fer}\end{array}$

O anel criado pela dupla invocação e a bipartição, temática e métrica, do hino contribuem para pôr em relevo os pronomes localizados bem no centro da composição, precisamente nas duas breves do verso 6: бє бú. Neles a divindade comparece como objeto do pedido do narrador ( $\sigma \varepsilon$ acusativo) e como sujeito capaz de realizar-lhe o pedido ( oú nominativo). Para instigá-lo a tanto, o próprio hino serve como moeda de troca, e o poeta de fato o diz: ao qualificar sua prece de $\kappa \varepsilon \chi \propto \rho ı \mu \varepsilon^{\prime} \nu \eta$ (7), Anacreonte salienta num adjetivo proléptico a relação de reciprocidade ( $\chi \alpha ́$ ós) entre ele e Dioniso, que se reflete

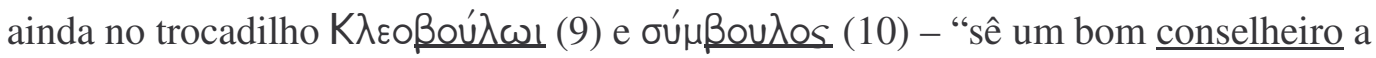
Cleóbulo, àquele que é famoso por seu conselho" - e que está contida em germe, na brevidade de dois pronomes pessoais ( $\sigma \varepsilon \leftrightarrow \sigma u ́$ ), no exato centro do hino.

Em outro hino, este extremamente breve, a colocação das palavras ganha destaque à força das repetições. Vejamos rapidamente o Hino Homérico a Apolo $\left(\mathrm{n}^{\mathrm{0}} 21\right)$.

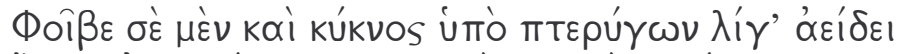

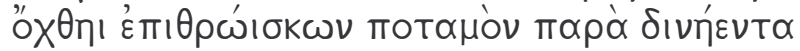

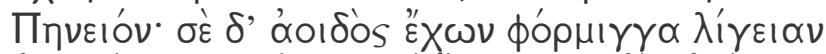

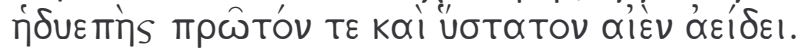

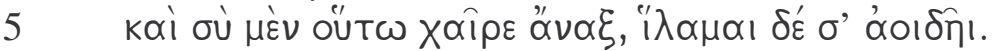

(Febo, também o cisne te canta em tons claros batendo as asas quando pousa na margem ao lado dos redemoinhos do rio Peneio; e o cantor com a sua lira de tons claros e versos doces canta-te sempre em primeiro e último lugar. Salve, senhor; eu busco teu favor com o meu canto.)

Esse hino a Apolo é peculiar entre as obras que compõem a coleção dos Hinos Homéricos sobretudo por causa da sua abertura. O poeta dos hinos homéricos costuma iniciar a sua composição de duas formas diversas: ${ }^{294}$

a) afirmando que cantará ou começará a cantar a divindade:

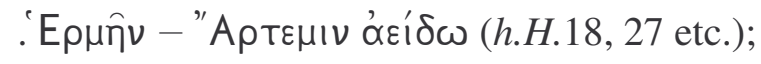

${ }^{294}$ Cf. Race (1992), esp. 19-22. 


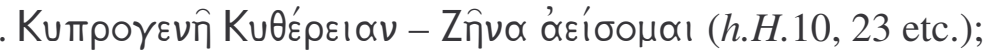

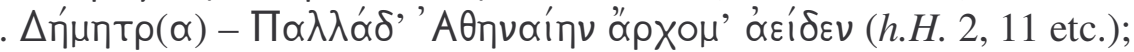

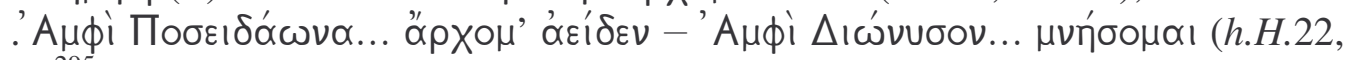
7). ${ }^{295}$

b) pedindo à Musa que cante a divindade louvada:

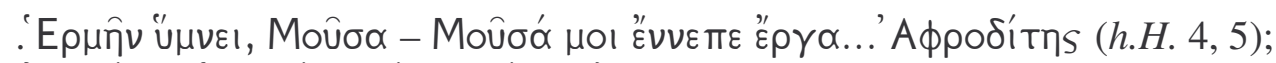

.'A

Em ambos os casos a divindade costuma figurar no acusativo ("Er-Stil"), um traço distintivo dos hinos que parte da crítica denomina "rapsódicos", em oposição aos "cultuais", que em geral interpelam diretamente a divindade na parte invocatória ("DuStil"). Além do nosso, dois outros hinos que integram a coleção dirigem-se na segunda

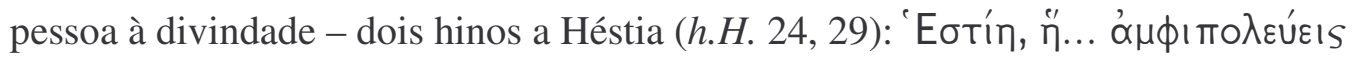

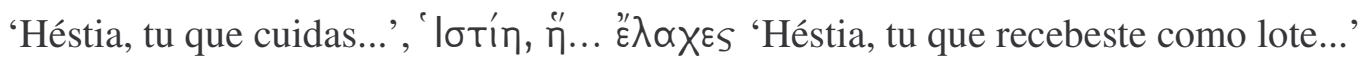
Mesmo nesses casos, a ruptura com o padrão tradicional não é tão severa, pois em ambos

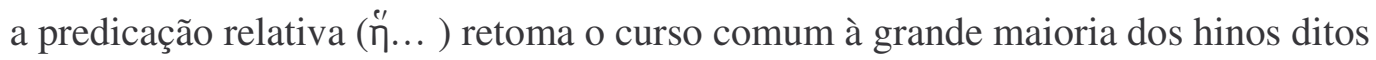
homéricos. ${ }^{296}$ Já se cogitou tratar-se de um hino cujo início perdeu-se durante o processo de transmissão, mas não há razão suficiente para tanto. Nem só porque nosso hino foge às regras que parte da crítica moderna convencionou chamar de "rapsódicos" deve-se considerá-lo incompleto ou espúrio: trata-se de um hino hexamétrico que adota características formais dos hinos ditos "cultuais" e que é legítimo considerar como um todo coeso preservado pela tradição. ${ }^{297}$

Permanece, porém, o fato de que, pela razão mesma de frustrar as expectativas, esse breve hino Apolo chama tanto mais a atenção para o inusitado da sua forma. A apóstrofe inicial (Фоіß $\varepsilon$ ) dita o tom dos demais versos, estruturados em uma frase $\mu \varepsilon^{\prime} v-$

\footnotetext{
${ }^{295}$ Variante dessa abertura com o verbo "lembrar" figura no Hino Homérico a Apolo (n ${ }^{\circ} 3$ ), na qual o deus

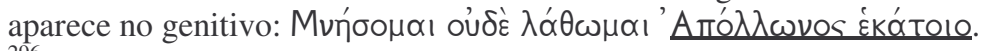

${ }^{296}$ As exceções (ou seja, os hinos que não apresentam predicação relativa) são: hino 1 a Dioniso (estado fragmentário, início não documentado), hino 8 a Ares (não faz parte, como reconhece a crítica, dos Hinos Homéricos: é obra provável do neoplatônico Proclo, e terá migrado inadvertidamente da sua coletânea de hinos para a coleção de Hinos Homéricos, que na Idade Média eram transmitidos em conjunto com mais duas outras coleções, a dos hinos órficos e os hinos de Calímaco; cf. West (1970) e Gelzer (1987), para quem o hino é da autoria de Porfírio ou seu círculo, portanto anterior a Proclo); hino 13 a Deméter (parece tratar-se de um fragmento); hino 25 às Musas e a Apolo (outro que parece indicar um estado fragmentário: versos 2-5 são emprestados à Teogonia de Hesíodo (94-7) e pouco fazem sentido da forma como foram transmitidos).

${ }^{297}$ Contra: Càssola (1975), 379, para quem “è possibile [...] che l'intero componimento sia um congedo".
} 


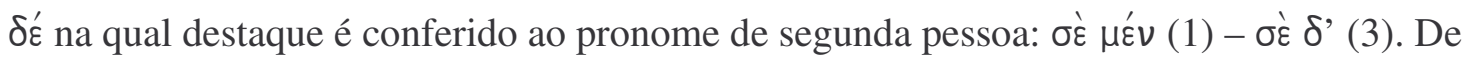
um lado é o cisne que canta Apolo ( $\left.\sigma \dot{\varepsilon} \mu \mu^{\prime} v\right)$, de outro, o bardo ( $\left.\sigma \dot{\varepsilon} \delta^{\prime}\right)$ - o poeta, é claro, busca captar a benevolência de Apolo ao aproximar-se da ave que lhe é congenial. O tom claro no qual canta o cisne ao final do verso 1 ( $\lambda_{i}^{\prime} \gamma$ ’ $\left.\alpha^{\prime} \varepsilon_{\delta} \delta \varepsilon\right)$ é retomado "verticalmente" nos versos 3-4, agora referindo-se ao aedo:

$$
\begin{aligned}
& 1 . . . \lambda i \gamma^{\prime} \alpha^{\prime} \varepsilon i \delta \varepsilon ı \# \\
& \text {... } \\
& 3 \quad . . \lambda i \gamma \varepsilon \varepsilon ı \alpha \# \\
& 4 \text {... } \propto \varepsilon^{\prime} \delta \varepsilon \varepsilon \#
\end{aligned}
$$

O canto, comum a ambos - cisne e aedo (e obviamente também a Apolo $)^{298}$-, ecoa pelo

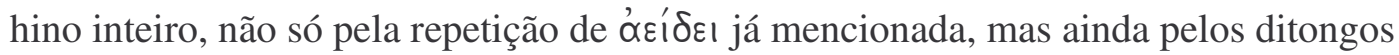

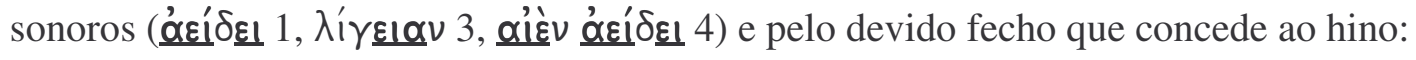

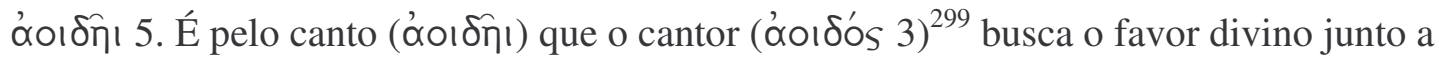
Apolo, citando o cisne como termo de comparação:

$$
\begin{aligned}
& 1 \quad \ldots \underline{\sigma \varepsilon \dot{\varepsilon} \mu \dot{\varepsilon}^{\prime}} \ldots \text { KúkVOS... }
\end{aligned}
$$

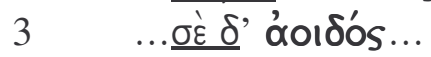

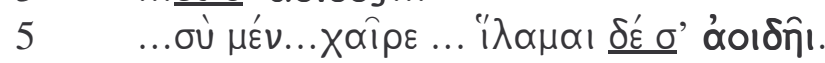

'Aoı́ós 'cantor', referência ao próprio poeta, é o ponto central dessa breve narrativa cujo elemento comum é o canto e cujos pólos são o cisne e Apolo. E é no exato centro do hino, de fato, que ele figura, em posição enfática antes da cesura trocaica, na proximidade

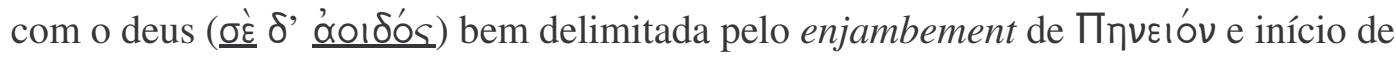
nova frase:

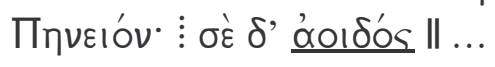

\footnotetext{
${ }^{298}$ Sobre os cisnes como pássaros de Apolo dotados de canto, cf. Krappe (1942), Williams (1978), 20, e Mineur (1984), 206.

${ }^{299}$ Cf. a posição métrica de destaque conferido aos termos "cantor", "canto" e "cantar" no Hino Homérico a Dioniso, $\mathrm{n}^{\circ} 1$ D (codex M), 8-10, na versão de West (2003):

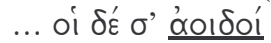

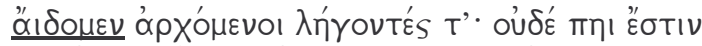

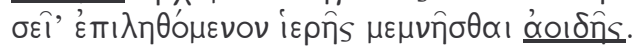
'os cantores te cantamos no princípio e no fim, não há como esquecer-se de ti e lembrar-se do sagrado canto.'
} 
O hino, na verdade um proêmio como os demais Hinos Homéricos, é portanto oferecido como uma dádiva em troca de outras dádivas divinas por um poeta que se põe, com a devida consciência, no centro dessa relação. Nas palavras de Böhme: "Que o proêmio seja utilizado como introdução não resulta do seu sentido, isso faz parte da sua essência. [...] Ele é que primeiro proporciona a salvação, que chama e vincula os deuses. [...] E esses deuses estão vinculados pela linguagem (pela linguagem poética) e têm nos limites dela também os seus limites". 300

\subsubsection{Arístono, Hino a Héstia}

Forma e estrutura também reforçam o tema de outro hino, este em homenagem a Héstia, da autoria de Arístono de Corinto. A obra foi encontrada em 1903 no tesouro público de Delfos, junto com um peã a Apolo do mesmo autor, ${ }^{301}$ datados um e outro do terceiro quartel do século IV a.C. ${ }^{302}$

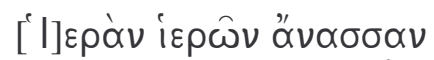

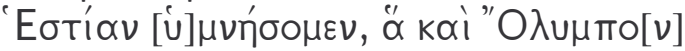

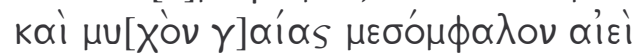

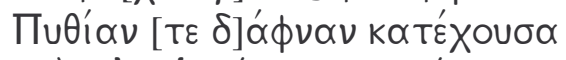
5 vaov ơv'

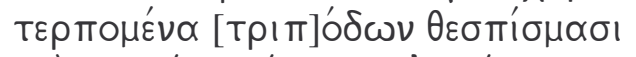

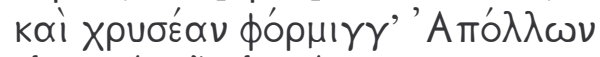

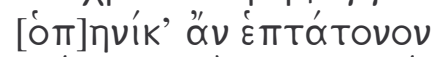

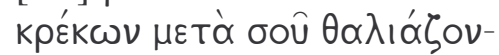

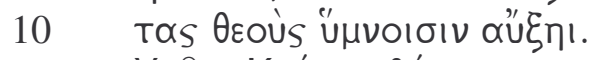

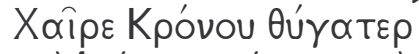

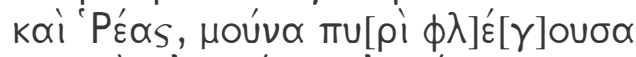

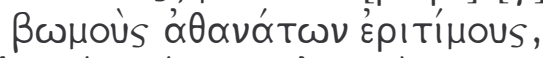

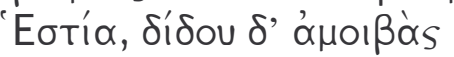

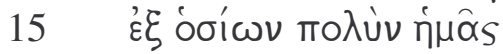

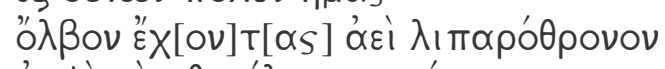

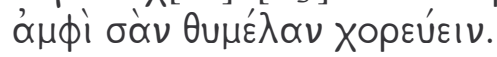

(Sagrada rainha das coisas sagradas, nós te cantamos em hino, Héstia, tu que habitas o Olimpo e o umbigo central da terra e o loureiro pítico e danças em torno do templo de Apolo com as suas torres eminentes, deleitando-te com as palavras mânticas do tripé e quando Apolo tange as sete cordas da sua lira dourada e contigo enaltece em canções os

\footnotetext{
${ }^{300}$ Böhme (1937), 68.

${ }^{301}$ Veja capítulo 4, item 4.1.

${ }^{302}$ Cito a edição de Furley-Bremer (2001), vol. 2, 38.
} 
deuses que festejam. Salve, filha de Cronos e Rea, que sozinha faz arder o fogo nos altares sagrados dos imortais, Héstia: recompensa a nossa prece, confere riqueza obtida com honestidade, para que nós dancemos sempre ao redor do teu altar-trono cintilante.)

Héstia é a deusa do fogo instalado no centro do lar; quando animais sacrificiais

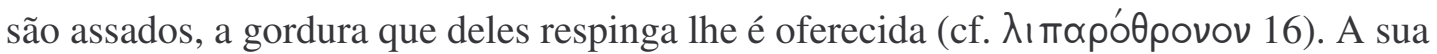
posição central é explicitada em várias esferas, do lar doméstico ao ponto focal (público) da cidade até o centro do mundo. Cito um exemplo de cada uma delas.

Hino Homérico a Afrodite ( $\left.{ }^{0} 5\right), 30$ :

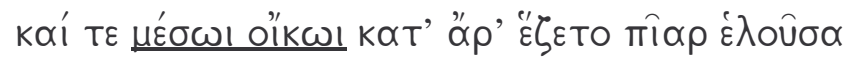

'e ela sentou-se no meio da casa e recebeu gordura'.

Baquílides 14b, 1-6:

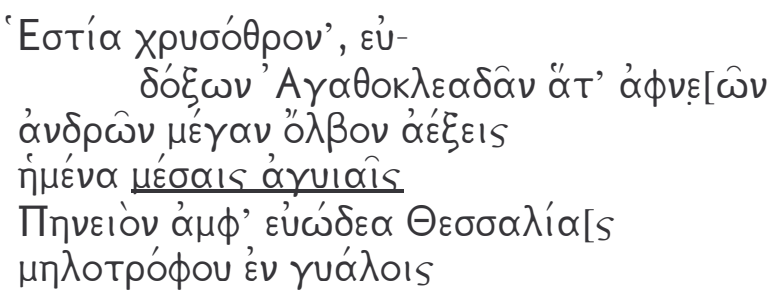

'Héstia do trono de ouro, tu que promoves a grande prosperidade dos gloriosos Agatóclidas, homens de posses, sentada no centro da cidade ao lado do aromático Peneio nos vales da Tessália, criadora de ovelhas'.

Referência é feita aqui à cidade de Larissa, na Tessália, em cujo centro Héstia está publicamente instalada. Seu posto também pode localizar-se em Delfos, o lar central do mundo para os gregos, como no Íon de Eurípides (452-471):

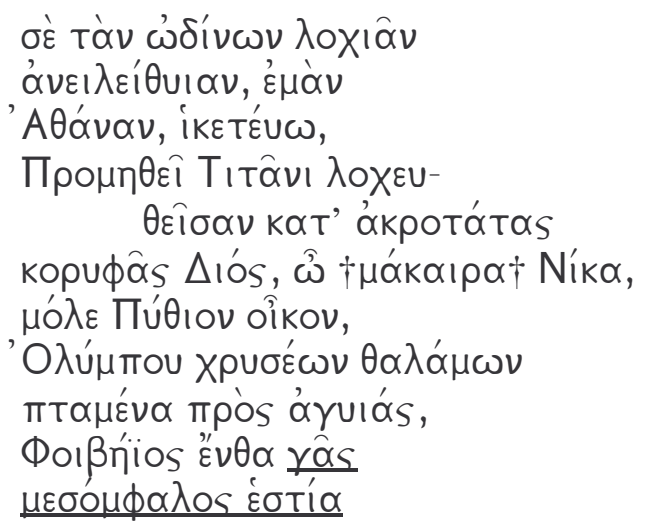




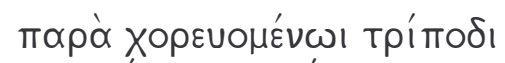

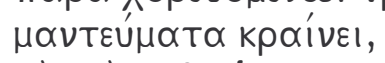

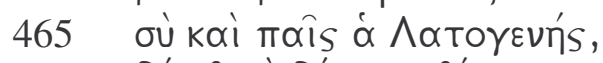

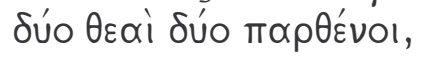

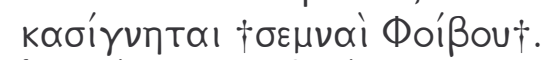

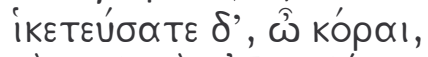

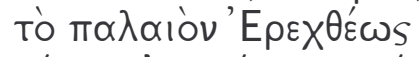

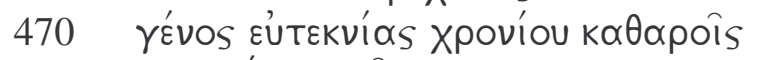

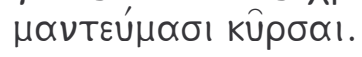

(Alheia às dores do parto, minha Atena, eu te rogo, que vieste à luz pelo Titã Prometeu do topo da cabeça de Zeus, abençoada Vitória, vem à casa de Pito, voando dos aposentos dourados do Olimpo até essas vias onde o apolíneo lar central da terra profere os seus oráculos em meio à dança ao redor do tripé; tu e a filha de Leto, duas deusas, duas virgens, irmãs veneráveis de Apolo. E vós, mulheres, rogai a elas que seja concedida à antiga tribo de Erecteu uma clara promessa mântica de fertilidade, embora extemporânea.)

Aqui Delfos, o lar central da terra, tem a sua posição geográfica sublinhada por localizar-se no centro desse hino a Atenas e Ártemis. As duas divindades, aliás, ladeiam o centro da obra, sendo a primeira invocada na primeira metade (452-60), a segunda na segunda (465) - duas deusas cujo elo que as une em dupla a Apolo é expresso na anáfora

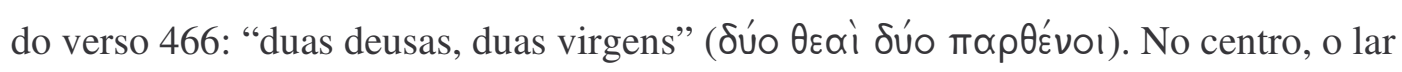

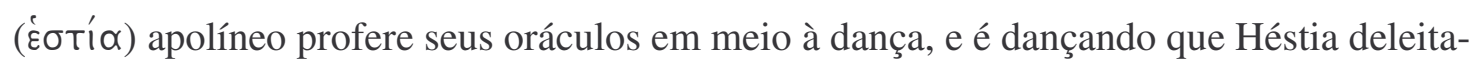
se com os oráculos de Apolo no hino de Arístono (5-6), que terá talvez sido influenciado por Eurípides. $^{303}$

Arístono divide claramente em duas partes o seu hino a Héstia. Versos 1-10 compõem a narrativa, enquanto os versos 11-17 saúdam a deusa ( $\chi \propto \hat{\imath} \rho \varepsilon$ 11) e expressam

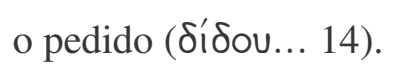

A dança circular de Héstia em volta do templo em Delfos, no centro do mundo (5), ganha destaque por figurar no centro dessa primeira parte (1-10). Diz o poeta que a

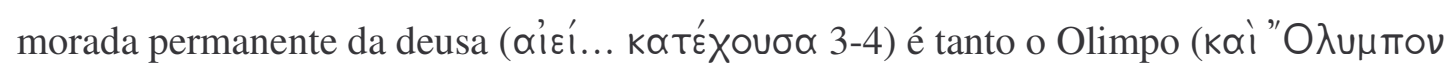

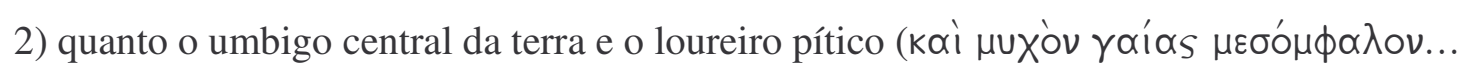

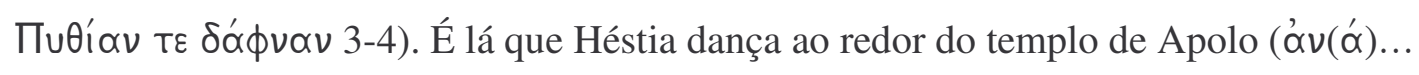
Хорєúદıs 5) e deleita-se com os seus oráculos. A frase seguinte (7-10) é de sintaxe

\footnotetext{
${ }^{303}$ Cf. Furley-Bremer (2001), vol. 1, 117, e vol. 2, 40s.
} 
complexa. ${ }^{304}$ Espera-se um complemento dativo que faça avançar a oração anterior

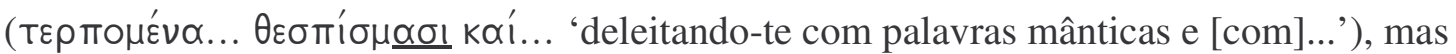

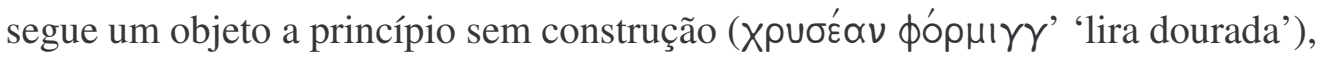
sucedido de um sujeito ('Aтó $\lambda \lambda \omega \nu$ ), uma conjunção posposta (ómqvík' 'quando'), um particípio (

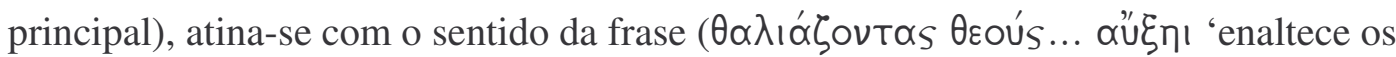
deuses em festa'). Os deuses em festa ao som da lira de Apolo figuram por último, em uma sentença cuja sintaxe retorcida ali os posiciona; só agora podemos perceber que, da terra, onde deleita-se com os oráculos apolíneos, Héstia transitou com Apolo ao Olimpo,

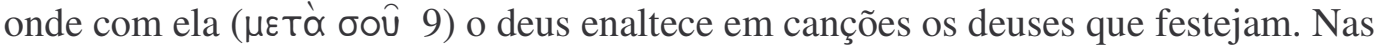
palavras de Furley-Bremer: ${ }^{305}$ "Primeiro se diz que Héstia aprecia os oráculos proferidos por Apolo em Delfos (isto é, na terra); depois, que ela se compraz com a sua música quando ele 'exalta os deuses que banqueteiam' (9-10): trata-se da cena no Olimpo vivamente invocada, por exemplo, no Hino Homérico a Apolo, 186ss. (no qual se diz especificamente que Apolo deixa Delfos rumo ao Olimpo a fim de tocar para os deuses). [...] Héstia, que freqüenta o principal templo de Apolo na terra, deleita-se com os seus oráculos e a sua música quando ele entretém os deuses olímpicos". Mas não é só isso.

Vemos, nessa primeira parte, que a referência à dança circular de Héstia no centro da terra é circundada por duas alusões ao Olimpo, primeiro como uma das moradas da

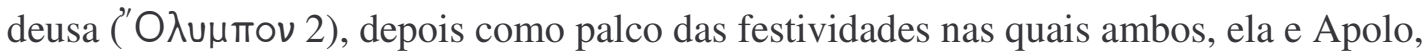
cantam o louvor dos deuses (7-10). Essa última alusão é tanto mais marcante por resultar de uma sentença cuja sintaxe corrobora, conscientemente, o movimento que leva da terra ao Olimpo. Flanqueada pelas referências olímpicas e situada no centro dos versos que a

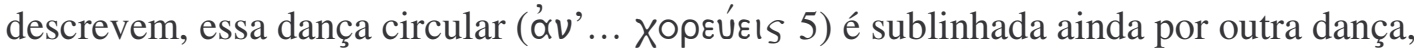
também circular, para a qual serve de modelo: a dança dos devotos mencionada no verso

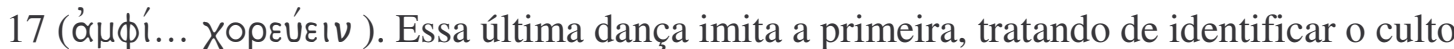
rendido pelos homens e a atividade típica da divindade louvada. Héstia dança ao redor do

\footnotetext{
${ }^{304}$ Detalhes notados por Furley-Bremer (2001), vol. 2, 42.

${ }^{305}$ Ibid.
} 
templo de Apolo, e o prazer que ela tira dessa atividade será transmitido - assim deseja o poeta - à dança humana ao redor do seu altar em Delfos. ${ }^{306}$

Fechando o hino, essa dança circular ilumina por contraste a outra, divina, situada no centro dos versos da sua seção, e conclui ela própria o segundo grupo de versos (11-7)

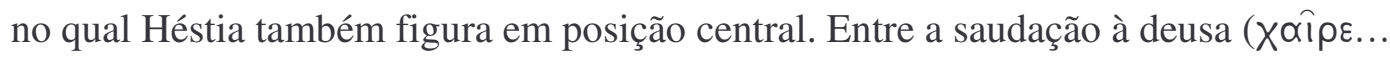

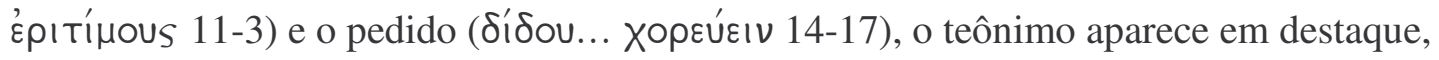
abrindo o verso 14 (Eøría), no exato centro dessa segunda parte.

Desse modo, Arístono logra fazer com que o tema do hino, o posto central de Héstia como deusa do lar em Delfos (o lar central do mundo), reflita-se na própria forma do poema, posicionando Héstia no centro das duas partes que o compõem.

\subsubsection{Eurípides, Ifigênia em Táuris (1234-1258)}

Vejamos agora um hino da tragédia, uma ode a Apolo entoada pelo coro de cativas gregas no último estásimo da Ifigênia em Táuris de Eurípides. Enquanto o coro canta o seu hino, Ifigênia, de quem as cativas são cúmplices, encabeça uma procissão do templo de Ártemis (da qual ela é sacerdotisa) até o mar, acompanhada por Orestes e Pílades. Esses dois, segundo o costume de Táuris, deverão ser sacrificados a Ártemis Tauropolos, mas Ifigênia convenceu o rei Toas a purificá-los no mar junto com a estátua de Ártemis antes do sacrifício. Trata-se na verdade de um estratagema para que ela fuja com o irmão e Pílades portando a imagem, tal como Orestes fora instruído por Apolo. A procissão não retorna ao templo para consumar o ritual e os três escapam por pouco. Um mensageiro, terminada a ode, retorna ao palácio para dizer ao rei que este fora ludibriado por Ifigênia. E, a julgar pelo conteúdo do hino, não só por ela, mas também pelas cativas, cuja ode narra realidades distantes - o nascimento de Apolo e a sua conquista do oráculo délfico -, em tudo alheias às maquinações do presente. Do estásimo, reproduzo somente a estrofe, versos 1234-1258.

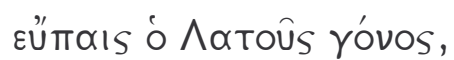

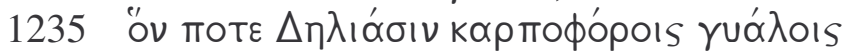

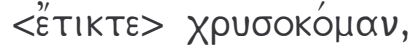

\footnotetext{
${ }^{306}$ Vamvouri (2004), 87, observa que "représenter les effets agréables du chant constitue em quelque sorte um talisman légitimant le plaisir présent de la divinité".
} 


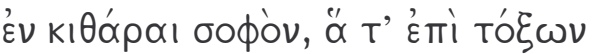

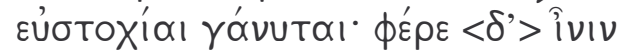

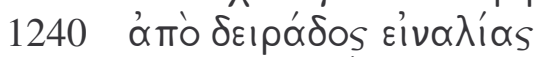

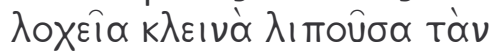

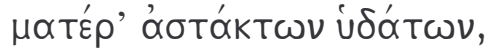

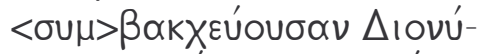

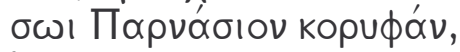

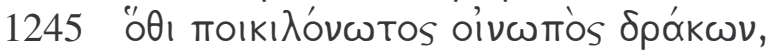

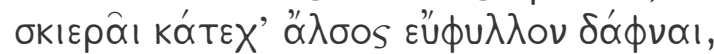

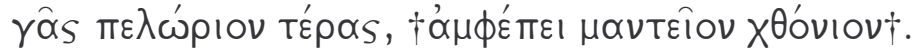

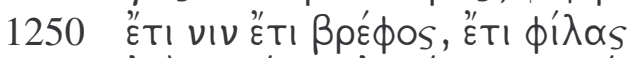

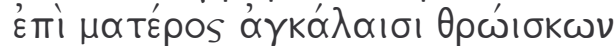

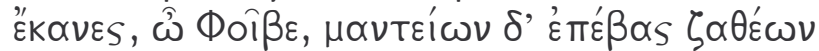

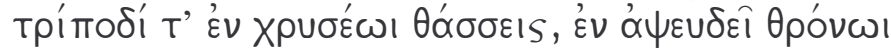

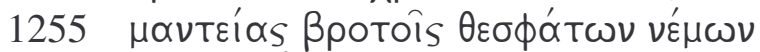

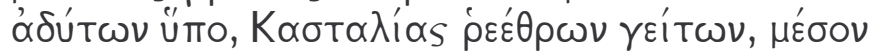

$\gamma \hat{\alpha}_{S}{ }^{\prime} X \omega \nu \mu \dot{\varepsilon} \lambda \alpha \theta \rho o v$.

(Que filhos maravilhosos Leto deu à luz na terra frutífera de Delos: ele de cabelos dourados, versado na lira, e ela que se delicia com a mira infalível do seu arco. Ela levou o seu filho, da pedra junto ao mar, deixando o famoso local de nascimento, até a mãe das águas em jorro, o cume do Parnaso, que dança feito bacante com Dioniso. Ali um dragão de faces negras e lombo malhado mantinha sob seu poder o frondoso bosque sombreado por loureiros - um monstruoso portento surgido da Terra - e guardava o oráculo terreno. Ainda bebê, ainda nos braços da tua mãe, tu pulaste e o mataste, ó Febo, e puseste os pés no sagrado oráculo, e agora tens o teu assento no tripé de ouro, do teu trono infalível tu fazes profecias de decretos divinos aos mortais em teu aposento mais recôndito, vizinho às correntes da Castália, com o teu altar no centro da terra.)

Abre o hino ${ }^{307}$ com uma breve descrição dos nascimentos de Apolo e Ártemis em Delos (1234-8). Em seguida, menção é feita do trajeto percorrido pela mãe, Leto, com o seu filho Apolo: de Delos ela segue na direção do Parnaso (1349-1244). Trata-se de um movimento ascendente, bem demarcado por verso e métrica. Da pedra junto ao mar (á iò

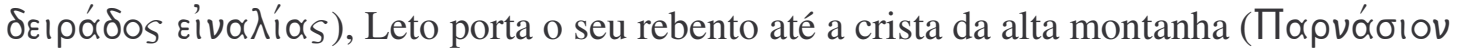
kopuфóvv). Sua chegada é marcada pelo advérbio de lugar ö $\theta_{1}$ 'onde' em destaque (1245).

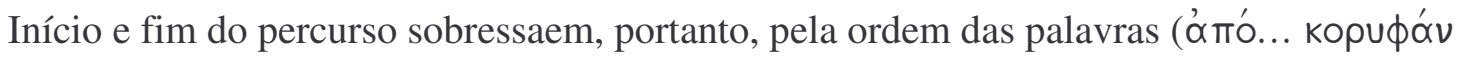
1240-4), sendo o começo do percurso devidamente assinalado pelos anapestos de marcha do verso 1240:

\footnotetext{
${ }^{307}$ O poema não possui invocação introdutória nem prece final, mas é composto apenas da pars media - a narrativa dos feitos de Apolo -, como notam Furley-Bremer (2001), vol. 1, 332-6. Os autores sugerem que se trata de um "nomo", aparentado, por exemplo, aos Persas de Timóteo. Sobre o nomo citaródico e a sua relação com os hinos (homéricos), cf. Koller (1956).
} 


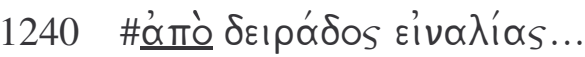

(prosódio)

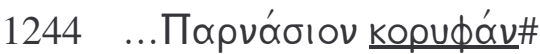

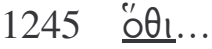

$\mathrm{O}$ advérbio de lugar interrompe o movimento e inaugura um conjunto de cinco versos (1245-9) marcados pela estática. Neles se descreve o dragão que mantém sob seu domínio o sítio oracular. Os verbos sublinham a inércia, o obstáculo representado pelo

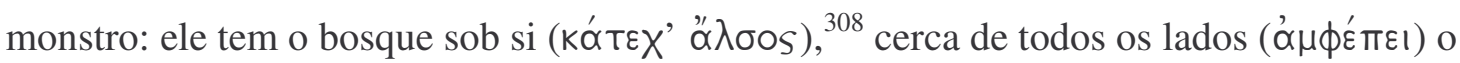
oráculo terreno. ${ }^{309}$ Oráculo, aliás, situado no centro da terra, como o próprio hino faz questão de frisar (1258), e guardado pelo dragão nos versos que ocupam o exato centro do hino. Reforça o poeta a sua mensagem, portanto, fazendo uso da estrutura do poema. A magnitude do obstáculo que representa o dragão para a carreira de Apolo é sugerida não só pela viva descrição que se faz do monstro ameaçador, mas ainda pelo lugar em que ela ocorre na seqüência da narrativa.

Não se trata apenas, obviamente, de lançar os versos no centro do relato, mediante simples cálculo aritmético que divida a obra em duas metades. É preciso antes demarcálos, sublinhá-los aos ouvintes, chamar-lhes a atenção através de balizas formais. Já vimos como o poeta o faz na primeira metade, contrapondo o movimento ascendente dos versos 1240-4 à estática da seção central (1245-9). A transição desse miolo central para a seção seguinte é tanto mais nitidamente indicada pela brusca mudança para a interpelação direta ("Du-Stil") nos versos 1250ss., em oposição ao "Er-Stil" (terceira pessoa) prevalecente

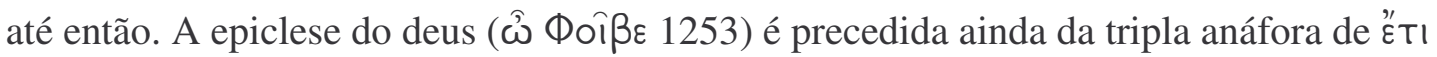
(1250) imprimindo um sentido de urgência ao relato após a menção do adversário. O coro amiúda o fôlego, as sílabas breves rolam umas sobre as outras em dois jambos com forte resolução:

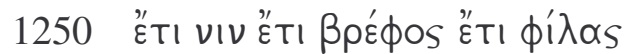

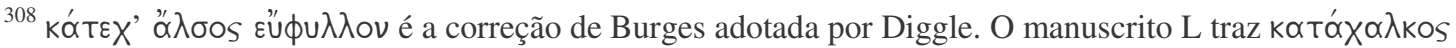

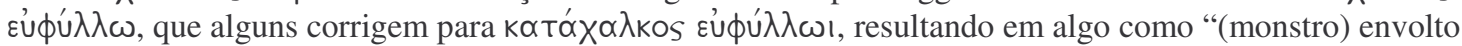
em armadura (= escamas) na sombra da folhagem do loureiro". Desaparece o verbo, portanto, segundo essa hipótese, mas o sentido permanece o mesmo.

${ }^{309}$ Entre cruzes no texto de Diggle, $\propto \alpha \mu \phi^{\prime} \pi \varepsilon$ । (presente) costuma ser corrigido para o imperfeito $\propto$ ’ $\mu \phi \varepsilon \pi \varepsilon$. O sentido também permanece o mesmo.
} 
Mas Apolo, deus precoce, ${ }^{310}$ deixa os braços da mãe para dar cabo do monstro e instaurar a ordem que vigora até hoje. Do passado (iniciado com o ő

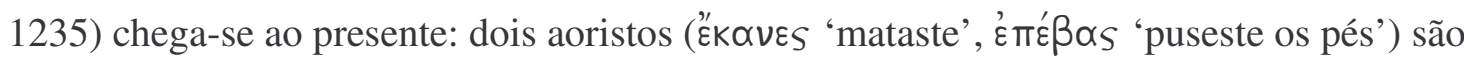

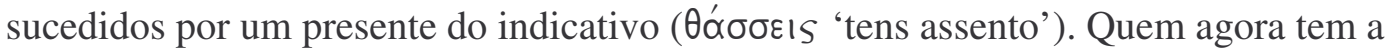

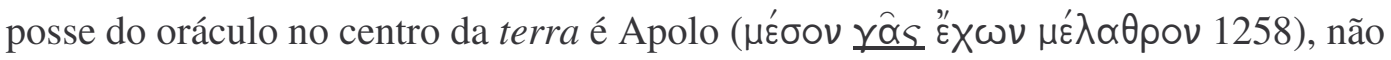

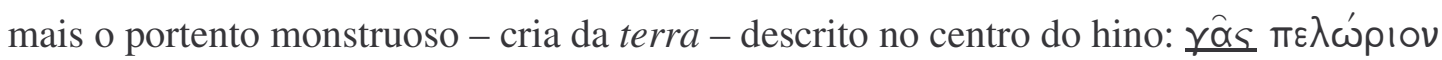
Tépas (1248).

O deus estabelece assim as suas credenciais e desbanca o dragão que ocupara um posto central, tanto na terra quanto no poema.

\subsubsection{Calímaco, Hino a Delos}

Outra maneira de que se vale o poeta para salientar a seção central de uma obra e aqui chego ao meu último exemplo - é estruturá-la segundo uma clara simetria. Para alcançá-la, são exploradas semelhanças temáticas e repetições verbais que emolduram o centro da composição em círculos concêntricos. Citarei um dos exemplos mais patentes, mas nele não me deterei mais do que o necessário porque ele já foi objeto de um estudo minucioso por parte da crítica, sobretudo num artigo Robert Schmiel ao qual me remeto para maiores detalhes. ${ }^{311}$ Trata-se do Hino a Delos de Calímaco.

Consiste o hino, e isso já havia sido notado há muito pela crítica, de um longo relato do nascimento de Apolo flanqueado por uma introdução e conclusão cujo tema é a ilha de Delos. O mérito de Schmiel reside em ter apontado uma profusão de ecos, tanto temáticos quanto (sobretudo) vocabulares, que acabam por tecer uma estrutura simétrica ao redor do centro do poema, no qual sobressai a famosa profecia de Apolo a respeito de Ptolemo Filadelfo. Dou aqui, em forma resumida, um esquema por ele proposto.

\footnotetext{
${ }^{310}$ Sobre a precocidade de bebês divinos, cf. HHom.Atena $\left(\mathrm{n}^{\mathrm{o}} 28\right)$, que nasce da cabeça de Zeus trajando “armadura de batalha de ouro resplandecente (5-6 по

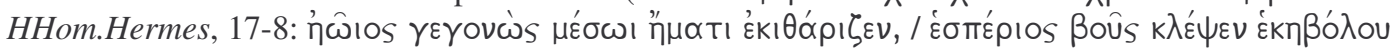
'A то́ $\lambda \lambda \omega \nu$ os 'nascido de manhã, ao meio-dia ele tocava lira e à noite roubou o gado de Apolo que atira longe'. Sobre o próprio Apolo, cf. HHom.Apolo, 127ss., e os vaticínios feitos pelo embrião divino no útero da sua mãe no Hino a Delos de Calímaco, 88-98 e 162b-195: ver a respeito Bulloch (1984), 216-20 e 22830, e Fröhder (1994), 79s.

${ }^{311}$ Schmiel (1987). Cf. ainda Ukleja (2005).
} 
A1 (1-50) Canção para Delos

A1 a (1-10) Eu cantarei Delos

A1 b (11-27) Descrição de Delos

A1 c (28-50) Origem da ilha flutuante, Delos (Astéria)

B1 (51-99) Cólera de Hera põe as terras etc. em fuga

B2 (100-152) Peneio oferece hospitalidade; Ares ameaça; Leto rejeita

B3 (153-202) Profecia de Apolo

B3 a1 (153-162a) Leto recusada

B3 b (162b-195) profecia

B3b $\propto 1$ (162-64) Apolo rejeita Cós

B3b $\beta 1$ (165-70) Ptolomeu haverá de nascer ali

B3b $\gamma$ (171-87) Invasão dos Celtas

B3b $\propto 2$ (188-90) Ptolomeu louvará Apolo no futuro

B3b $\beta 2$ (191-95) Apolo escolhe Delos

B3 a2 (196-202) Leto recebida

B4 (203-248) Leto em Delos; Hera com raiva

B5 (249-274) Nascimento de Apolo; Delos responde

A2 (275-326) Origem dos ritos délicos

A2 a (275-99) Cidades enviam coros e levam oferendas

A2 b (300-15) Música e dança para Delos (Astéria)

A2 c (316-27) Descrição de Delos e despedida

São inúmeros, como dito, os paralelos verbais posicionados em seções simétricas, mas para os meus propósitos aqui circunscrevo-me a enfatizar aqueles relacionados à noção de movimento circular ou à idéia de rodear, cercar ou cingir, também notados por Bing. ${ }^{312} \mathrm{Na}$ introdução (A1), Delos é descrita como circundada pelo mar (13-4 ó $\underline{\alpha \mu \phi}$

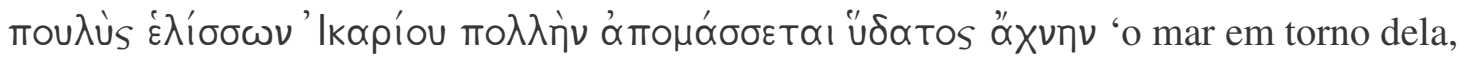
rolando intenso, enxuga a espuma sem fim das águas de Ícaro’) e protegida pelo poder

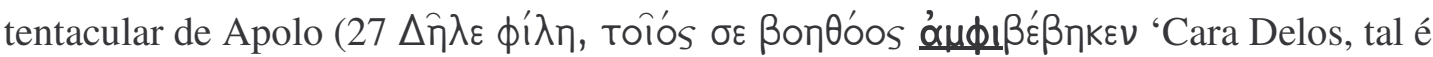
o protetor que te cerca de cuidados'). Na pergunta aporética do verso seguinte, mais uma imagem ligada ao círculo: "se canções sem-número te circundam, qual irei entrelaçar-te?"

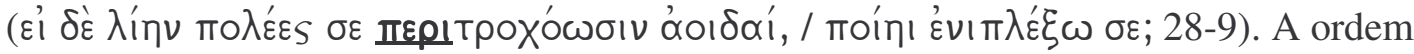
das palavras nesses dois versos (27-28) realça o conteúdo da mensagem; em ambos, o pronome referente à ilha $(\sigma \varepsilon)$ é ladeado ora por quem a protege (Apolo), ora por aquilo

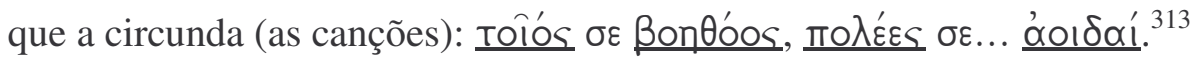

\footnotetext{
${ }^{312}$ Cf. Bing (1988), 125s.

${ }^{313}$ Mineur (1984), 77, chama a atenção para o fato, embora se mostre algo cético a respeito: "this could just as well be accidental".
} 
Situados no oposto simétrico da introdução, os versos da conclusão (A2) levam adiante esse tema ao narrar como Delos desfruta dos dízimos e das primícias que lhe são

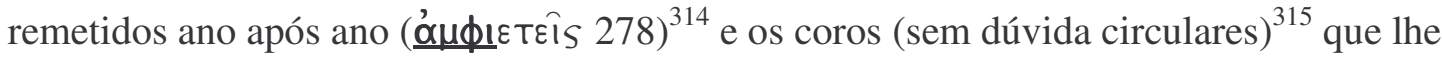

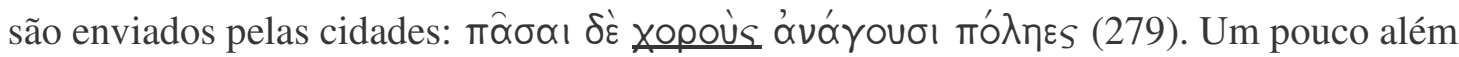
(300-2), o aition do nome das Cíclades - a sua etimologia - é devidamente apresentado:

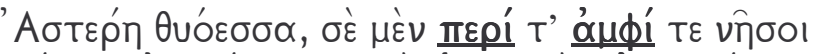

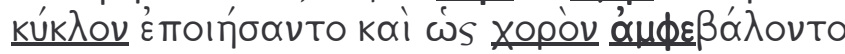

'Astéria perfumada, ao teu redor as ilhas fizeram um círculo ${ }^{316}$ e formaram como se fosse um coro à tua volta.'

Das Cíclades que dançam ao redor de Delos passa-se às festividades noturnas que animam a ilha: Héspero olha de cima a ilha que ressoa por todos os lados ( ${ }^{\alpha} \lambda \lambda^{\prime} \alpha \varepsilon^{\prime} i^{\prime} \sigma \varepsilon$

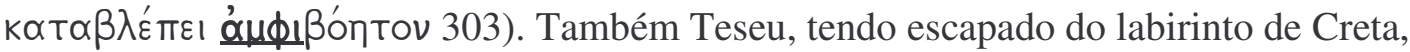
executou pela primeira vez em torno do altar em Delos o celebrado yépavos ou dança do grou:

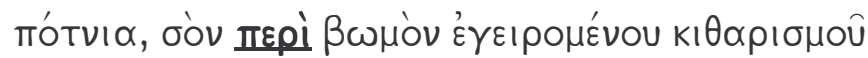

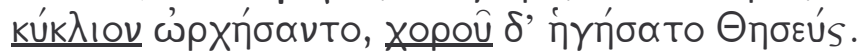

'Ao som da cítara, senhora, eles dançaram em círculo ao redor do teu altar, e Teseu guiou o coro.'

Não só Teseu, mas também os simples marinheiros aportam na ilha e só tornam a

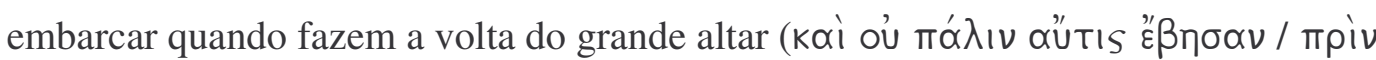

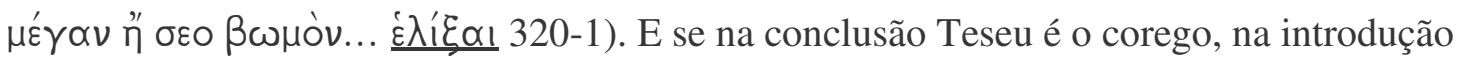

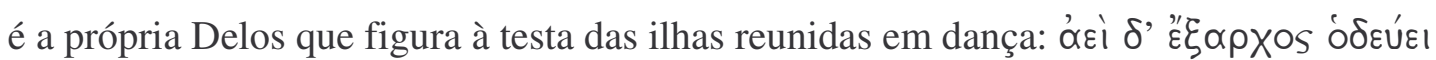
$18 .^{317}$

A insistência no tema da dança coral, do círculo que se forma ao redor de Delos nos planos real e metafórico, tal como expressos nas preposições ơ $\mu \phi i ́$ e пєрí repetidas

\footnotetext{
${ }^{314}$ O termo é uma inovação de Calímaco, cf. Lanzara (1990), ad loc. Schmitt (1970), 122 n.73, apud Mineur (1984), ad loc., sugere o sentido "auf beiden Seiten das Jahr habend".

${ }^{315}$ Sobre o coro circular como a forma mais comum de dança cultural, cf. Calame (1977), 77s. et passim.

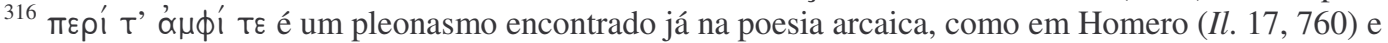
Hesíodo (Teog. 848), mas Mineur (1984), 235, observa o inusitado da anástrofe: "the postposition here is remarkable" - um fator a mais que confere relevo aos já proeminentes ơ $\mu \phi i ́$ e пєрí ao longo do hino.

${ }^{317}$ Cf. Schmiel (1987), 49 n.10.
} 
em seções simétricas do poema, tem o seu reflexo, como aponta Schmiel, numa palavra altamente sugestiva situada no centro da profecia do feto Apolo que compõe o centro do

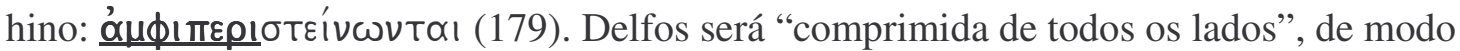
hostil, pelo invasor celta. Trata-se de um composto verbal único, criação de Calímaco, que já pela sua extensão ${ }^{318}$ atrai para si as atenções do ouvinte e concretiza num só verbo a idéia recorrente de um centro cingido por todos os lados. E no centro do hino figura a profecia de Apolo feita ainda no útero da mãe, na qual ele a adverte a não demorar-se em

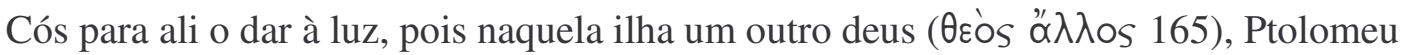
Filadelfo, haveria de nascer. Os dois, Apolo e Filadelfo, continua a profecia, haveriam de dar combate ao inimigo gaulês, um em Delfos, o outro no Egito (alusão ao fato histórico da invasão da Grécia pelos gauleses, sua derrota em Delfos em 279/8 a.C., sua passagem ao Egito como mercenários e posterior rebelião sufocada por Ptolomeu). Leto por fim é instruída pelo feto a levá-lo a uma pequena ilha flutuante, à deriva no mar, pois ali ela irá encontrar acolhida - em Delos.

O vaticínio, que interrompe a narrativa do nascimento e a sua progressão lógica, constitui assim o ponto focal do hino; nele são equacionadas as repetições temáticas e verbais, nele a estrutura simétrica da obra ganha pleno sentido. Como afirma Schmiel, ${ }^{319}$ "a profecia de Apolo, central em posição e importância por causa da sua extensão e do seu conteúdo, possui uma função estrutural básica no poema. [...] ela marca o ponto de inflexão no hino, da rejeição e fracasso à aceitação e sucesso, do ser evitado ao ser procurado, da peregrinação ao repouso". A virtuosidade técnica do poeta, que situa Delos no centro das várias atividades descritas no hino, serve portanto para multiplicar o louvor da ilha, estruturando para tal a sua composição em círculos concêntricos no foco dos quais figura proeminente a própria Delos, local privilegiado do nascimento de Apolo e termo das andanças de Leto.

\footnotetext{
${ }^{318}$ Mineur (1984), 173: "an impressive word, filling the first colon completely”. Cf. Schmiel (1987), 52.

${ }^{319}$ Schmiel (1987), 54.
} 


\section{CAPÍTULO3}

\subsection{Pares Contrastantes}

Vimos até aqui como o poeta hínico, entre os inúmeros recursos retóricos à sua disposição, lança mão de duas estratégias básicas para atrair a divindade e com ela estabelecer um laço de reciprocidade no qual o próprio hino age como objeto de troca: a) fechar o foco sobre o momento presente da celebração; b) estruturar o hino a partir do seu centro, nele situando o núcleo da mensagem. Outro artifício comum é contrastar passado e presente a fim de que este ganhe estatura e sentido à luz daquele. Busca-se reativar no instante presente do canto as forças latentes que têm o seu fundamento no passado - um passado mítico ou histórico, no qual se põe em evidência o contato prévio e íntimo entre divindade louvada e devoto, seja na figura do próprio cantor ou da cidade da qual ele é legítimo representante.

Não há, é claro, exemplos "puros" desta ou daquela estratégia, uma acaba inevitavelmente se valendo de rudimentos da outra para maximizar o efeito que o canto visa a ter sobre o destinatário divino, mas entre elas uma costuma prevalecer, e em torno dela as demais se agrupam. Vejamos alguns exemplos de composições hínicas que ressaltam a oposição entre presente e passado para infundir legitimidade e vigor ao instante atual em que o canto é celebrado.

\subsubsection{Alternância passado - presente: Limênio, Peã a Apolo}

Começo por um hino epigráfico, um dos célebres peãs com notação musical dedicado a Apolo, inscrito no muro sul do Tesouro público ateniense em Delfos e encontrado por arqueólogos franceses no final do século XIX. Seu autor é Limênio, filho de Teno. $^{320}$

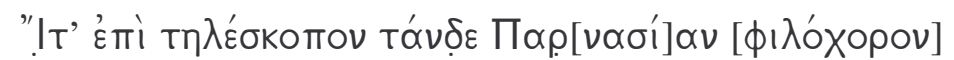

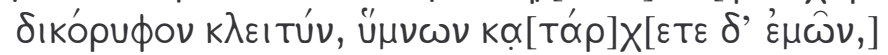

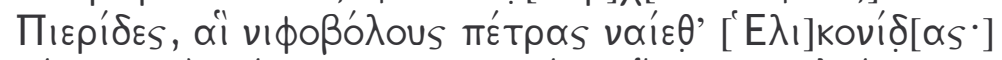

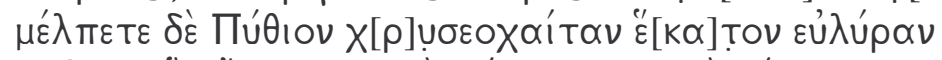

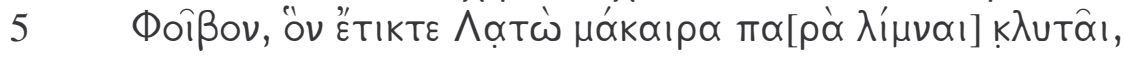

\footnotetext{
${ }^{320}$ Edição de Furley-Bremer (2001), vol. 2, 92ss.
} 


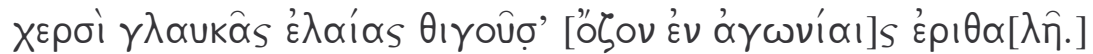

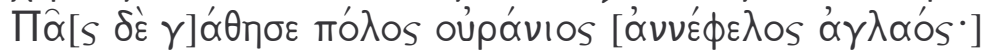

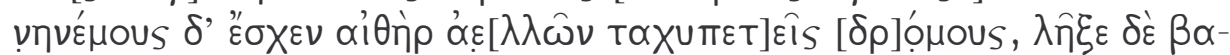

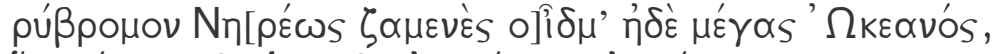

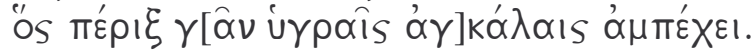

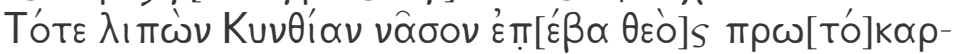

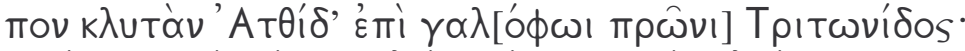

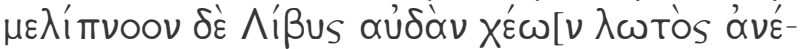

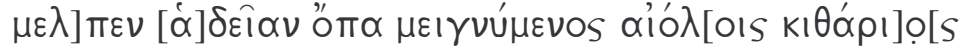

15

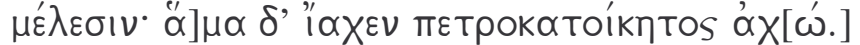

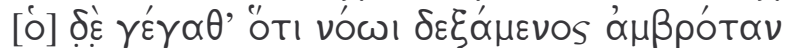

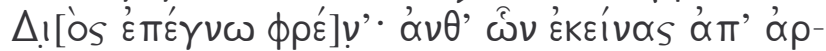

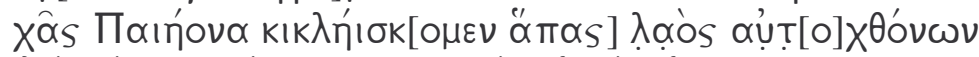

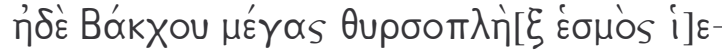

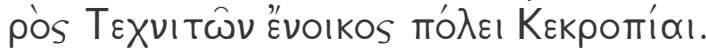

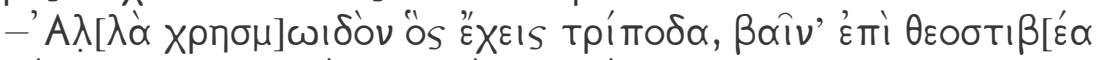

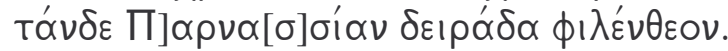

'А

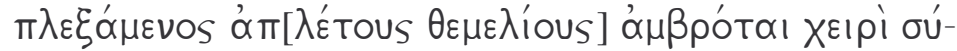

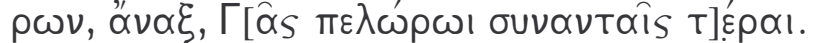

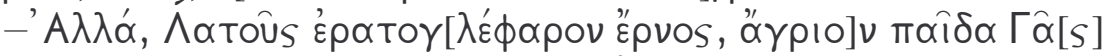

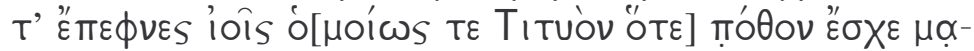

тро̀ $[\ldots . . .$.

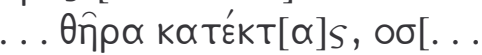

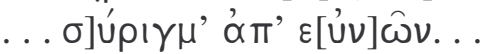

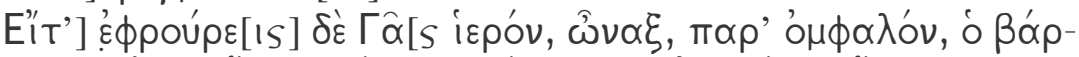

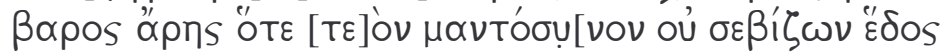

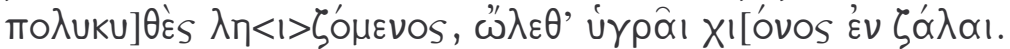

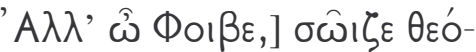

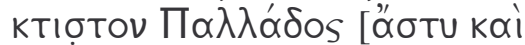

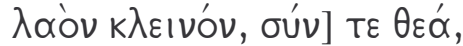

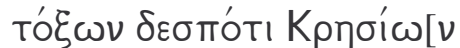

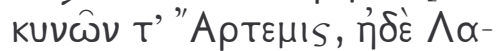

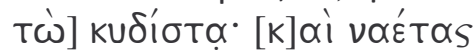

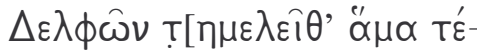

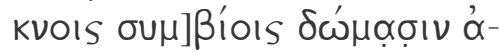

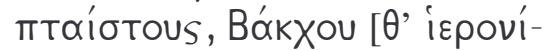

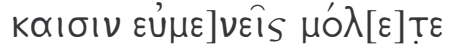

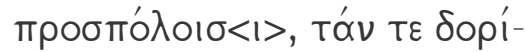

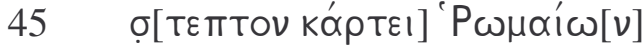

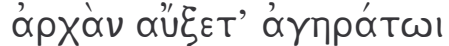

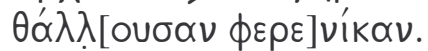


(Vinde até esse famoso Parnaso de dois picos que domina a região e é afeito à dança para conduzir os meus hinos, ó Musas de Piéria, que habitais as rochas cobertas pela neve. Cantai Apolo Pítio de cabelos dourados, deus que atira longe e é versado [5] na lira, a quem a bem-aventurada Leto deu à luz junto ao lago famoso, agarrando com as mãos um ramo vicejante da oliveira cinzenta durante o parto. Todo o eixo celeste alegrou-se em glória sem nuvens e o éter conteve as rajadas impetuosas do vento; as vagas poderosas de Nereu acalmaram seu estrondo, e assim também o vasto Oceano [10] que circunda a terra num abraço líquido. Deixando a ilha do Cintos, o deus aportou na Ática, famosa pela primeira espiga, na encosta rochosa de Tritão; a melodiosa flauta líbia vertia doce a sua voz, mesclando-a às melodias [15] da cítara enquanto um eco, latente na rocha, ressoava. E ele alegrou-se porque compreendeu que tal era a vontade imortal de Zeus. Desde então nós, toda a população nativa de Atenas, clamamos ao deus Peã, tal como faz a companhia sagrada [20] dos Cantores de Baco fulminados pelo tirso e que habita a cidade de Cécrops. Ora, tu que deténs o tripé divinatório, vem a esse sagrado Monte Parnaso, caro aos deuses. Tendo coroado o teu cabelo luzidio com louro, enquanto erguias pedras colossais com a tua mão imortal, tu desafiaste, senhor, [25] o enorme monstro nascido da Terra. Mas tu, rebento de Leto dos olhos amáveis, tu mataste o filho selvagem da Terra a flechadas, e também a Títios, quando este teve desejos pela tua mãe... tu mataste a fera... [30] um assobio vindo da cova... Então, senhor, tu protegeste o umbigo sagrado da Terra, quando um exército estrangeiro saqueou tua abastada sede profética de forma sacrílega, mas pereceu em uma tempestade de granizo.

Ó Febo, salva a cidade [35] de Atena fundada pelos deuses e sua gente famosa, com a ajuda de Ártemis, senhora dos arcos e dos cães cretenses, e também da famosíssima Leto. E protegei os cidadãos [40] de Delfos e os seus filhos em suas casas, longe do perigo, vinde de boa vontade até os cantores de Baco que competem pelo prêmio, dai ao Império [45] Romano, coroado de espadas, força eterna através da vitória.)

Duas são as seções métricas nas quais se divide o hino, a primeira em metro crético-peônico (1-33), a segunda em glicônicos (34-47). O peã propriamente dito corresponde à primeira seção, sendo a segunda um prosódio, tal como vem designado no título da inscrição: "Peã e p[rosó]dio ao [deus que] Limêni[o, filho do ateniense T]eno

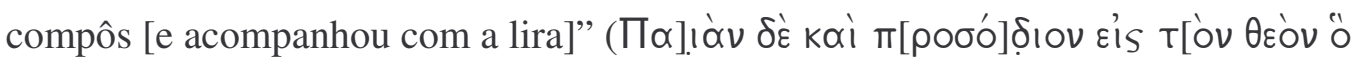

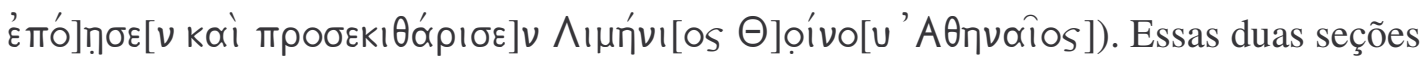
métricas estão intimamente relacionadas ${ }^{321} \mathrm{e}$ formam um conjunto apresentado pela primeira vez no festival Puthais em 128 a.C. Esse festival consistia em uma embaixada sagrada - uma $\theta \varepsilon \omega p i ́ \alpha$ - ateniense enviada a Delfos para homenagear Apolo. Trata-se, portanto, de uma obra de cunho nacional, um peã "estatal" encomendado a profissionais, no caso os Tekhnìtai de Dioniso, dos quais o compositor Limênio era membro integrante. As inscrições do Tesouro ateniense em Delfos registram quatro embaixadas (nos anos de

${ }^{321}$ Schröder (1999), 74-5. 
138, 128, 106 e 98 a.C.) a esse festival realizado a intervalos irregulares, ${ }^{322}$ conforme fossem observados ou não relâmpagos sobre o monte Parnes em certos dias do ano por oficiais especialmente designados para tanto, postados junto ao altar de Zeus Astrapaios. Um dos objetivos originais do festival, que teve início após a batalha de Platéia, era pegar em Delfos fogo novo e transportá-lo a Atenas, onde os invasores persas haviam poluído os fogos (ou lares) domésticos.

Aspecto fundamental do hino é o elo que o poeta estabelece entre Apolo e Atenas, a cidade que o reverencia. Vejamos como isso se dá em nosso peã.

A tradicional invocação das Musas estabelece logo de saída um local específico para que elas venham e conduzam os hinos do poeta: o monte Parnaso, realçado pelo dêitico que o acompanha - "esse Parnaso" ( $\underline{\alpha \alpha ́ v \delta \varepsilon} \Pi \alpha \rho v \alpha \sigma i ́ \alpha v 1)$. Fixa-se assim o local e instante presentes para que as deusas venham e cantem Apolo, introduzido pelo relativo (óv 5) que marca o início do relato do seu nascimento (5-10). Leto o deu à luz em Delos, apoiada a uma oliveira em pleno viço, junto ao famoso lago circular da ilha (5-6). Aqui a epifania do deus, desencadeada pela sua vinda ao mundo, faz expandir o foco da

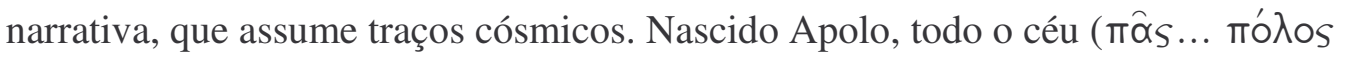

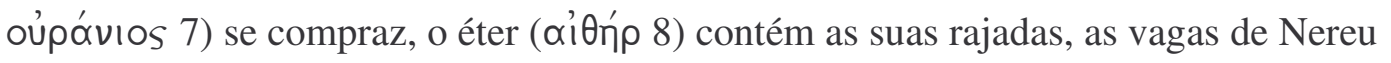

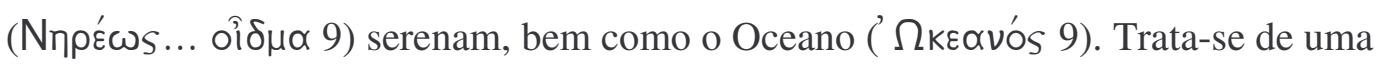
característica típica da epifania divina, o momento de silêncio que lhe segue. ${ }^{323}$ Tal ocorre também ao cabo dos abalos provocados no cosmos pelo nascimento de Atena em um dos Hinos Homéricos a ela dedicados ( $\left.{ }^{\circ} 28\right)$ :

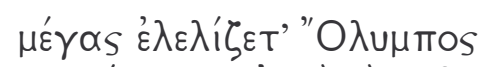

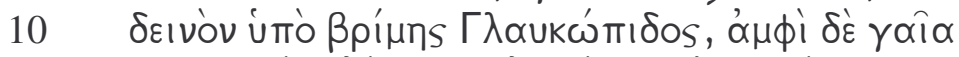

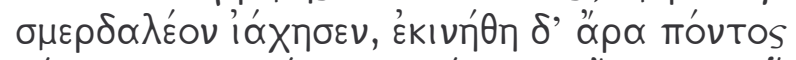

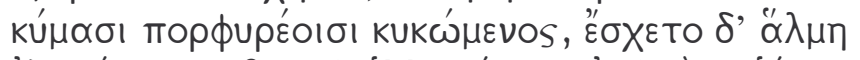

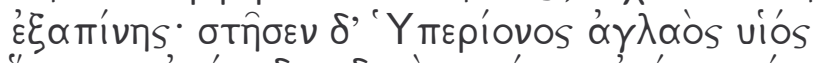

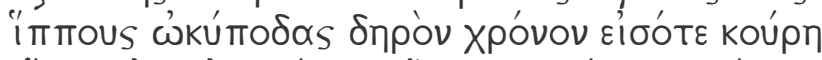

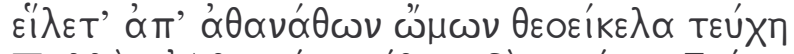

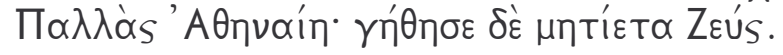

\footnotetext{
${ }^{322}$ Sobre o festival, ver Nilsson (1955), vol. 2, 84ss., Deubner (1932), 203s., Tracy (1975), Furley-Bremer (2001), vol. 1, 132s., e Rutherford (2004), 76-9.

${ }^{323}$ Cf. Pfister (1924), 318.
} 
(Um tremor imenso correu o Olimpo frente ao poder da deusa de olhos cinzas, a terra ressoou terrivelmente de fora a fora, e o mar agitou-se na confusão de ondas revoltas. Mas de repente as águas detiveram-se, e o filho do esplêndido Hipérion conteve os seus cavalos de pés ligeiros por muito tempo, até que a virgem, Palas Atena, tirou a armadura divina dos seus ombros imortais, e Zeus perspicaz alegrou-se.)

Mal vem à luz, Atena desencadeia uma reação em cadeia que se alastra pelos quadrantes do mundo. O Olimpo treme, a terra ressoa, o mar revolve-se - mas súbito as águas serenam e os corcéis de Hélio estacam passo. Os enjambements dos versos 9-13 imprimem dinâmica ao relato, as palavras que fecham o hexâmetro explicitam o sentido descendente que assume o movimento, que se propaga do Olimpo até as águas do mar

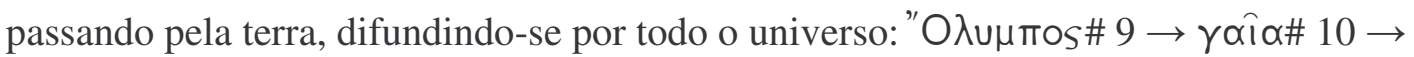

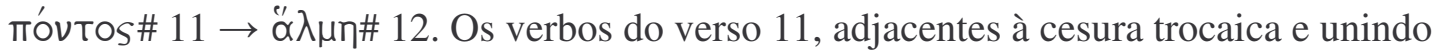

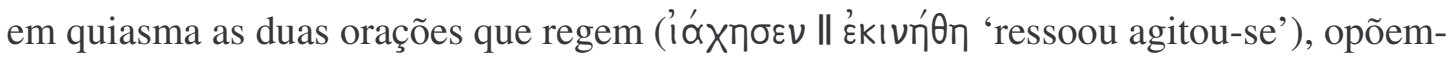
se com eficácia aos dois verbos seguintes que barram o movimento, situados um após a

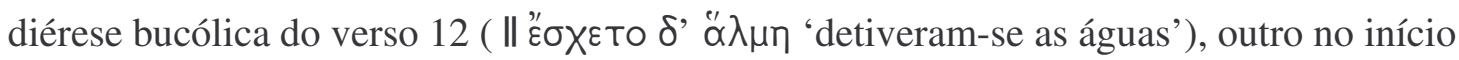

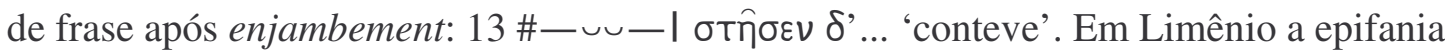
divina difunde-se igualmente do alto para baixo, do eixo celeste até o oceano passando pelo éter e as ondas de Nereu. Lá e cá o resultado é o silêncio reverencial dos próprios elementos naturais.

No Hino Homérico a Atena, esse resultado é tanto mais marcante devido a fatores formais. O poema consta de 18 versos; na primeira parte (1-9a), antes de narrar os reflexos que o nascimento de Atena causa no universo, o poeta relata esse próprio nascimento em duas seções cuidadosamente demarcadas:

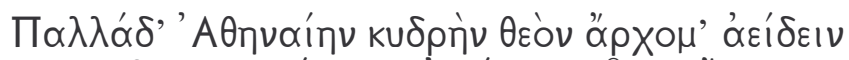

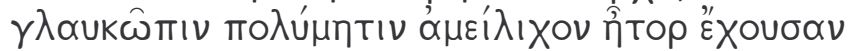
тар日⿱一⿻上丨

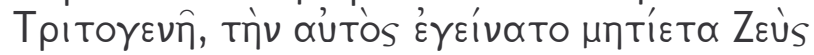

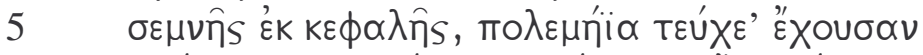

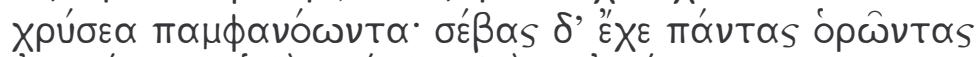

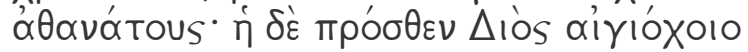

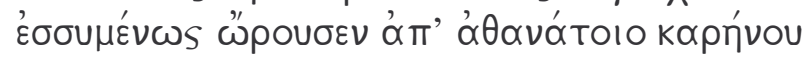
$9 \mathrm{a}$

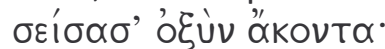

'Primeiro eu canto Palas Atena, deusa gloriosa, de olhos cinzentos, engenhosa e de coração implacável, virgem venerável, salvadora da cidade, robusta, Tritogênia, a quem 
Zeus perspicaz ele mesmo deu à luz da sua augusta cabeça, trajando ela armadura de batalha dourada, resplandecente: todos os imortais assistiram com espanto quando diante de Zeus que detém a égide ela pulou veloz da sua cabeça imortal brandindo sua lança afiada.'

Começo e fim da primeira dessas seções são delimitados pelos dois atores

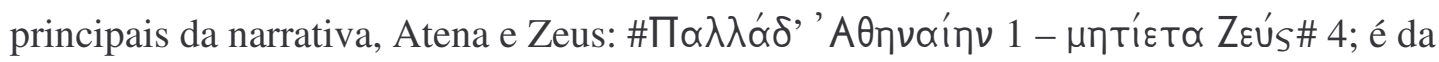
sua cabeça que ela vem ao mundo, e ela, a cabeça divina de Zeus, ganha destaque no

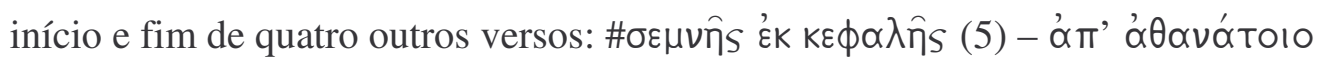
kapívou\# (8). Do alto da cabeça, palavra que conclui o hexâmetro, passa-se então ao Olimpo no fecho do verso seguinte ( 9 "O $\mathrm{O} \cup \mu$ mos\#, citado acima), que inaugura o movimento descendente até as águas do mar. O Olimpo, note-se, ponto culminante do qual se irradiam as reações da natureza ao seu nascimento, situa-se no exato centro do hino. E Palas e Zeus, que marcam respectivamente início e fim da primeira seção (1-4), unem-se como fecho da parte narrativa, antes dos versos finais (17-8) que compõem a despedida formular à deusa:

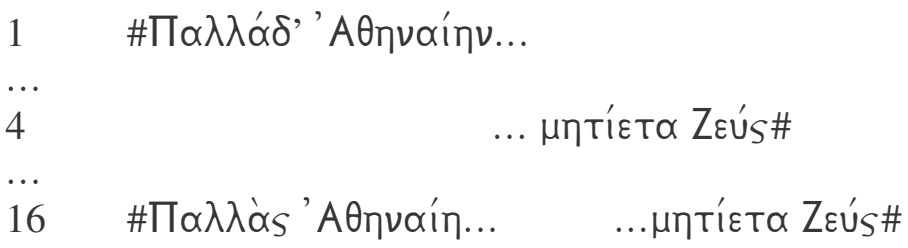

Zeus e Atenas, além disso, aproximam-se em virtude dos seus epítetos, Zeus

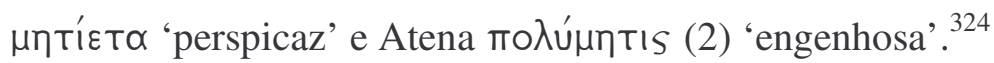

Mas voltemos ao peã de Limênio. Ao nascimento de Apolo segue então a sua viagem de Delos à Ática em nosso peã (11-17a). Lá ele é recebido ao som da flauta líbia (13) e da música local, em contraste com o silêncio anterior, e um eco latente na pedra ressoa - ressoa, obviamente, ao peã ou refrão peânico entoado pela gente de Atenas. ${ }^{325}$

\footnotetext{
${ }^{324}$ Cf. Fröhder (1994), 225: “Am Anfang und Ende seines erzählenden Teils preist er [o poeta] den

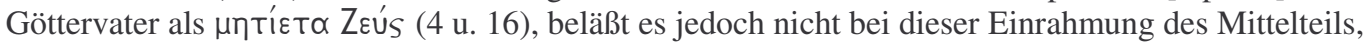
sondern ehrt auch Athena gleich zu Beginn des Hymnus mit dem entsprechenden schmückenden Beiwort

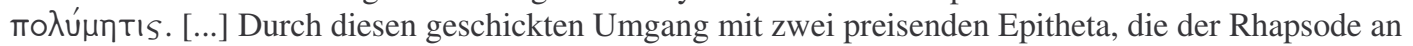
prägnanten Stellen des Hymnus einsetzt, läßt er Athena по入ú Zzús werden".

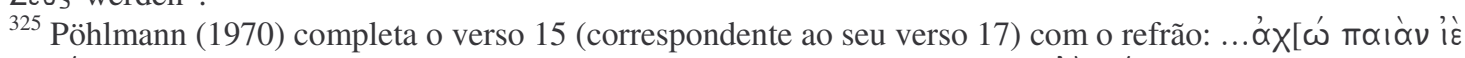

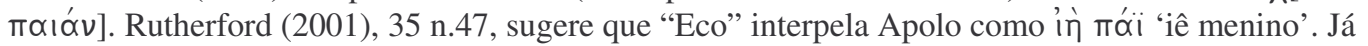
Furley-Bremer (cuja edição eu sigo) preferem não restituir o refrão (... $\chi x\left[\omega \omega^{\prime}\right]$ ).
} 
Pelo menos isso é o que resta claro do aition que preenche os versos seguintes (17b-20): nele é fornecida a razão pela qual o povo ateniense chama Apolo de Peã - o povo ateniense e, mais especificamente, os Cantores de Dioniso ou Tekhnītai de Baco (19-20), grupo que se incumbe, no presente momento, de celebrar o deus em canto no festival de Delfos.

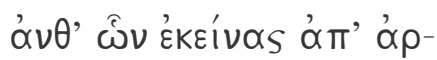

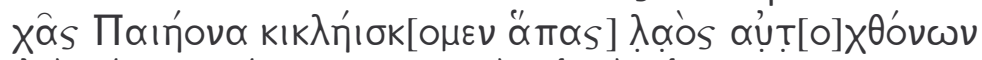

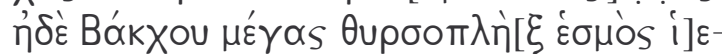

'Desde então nós, toda a população nativa de Atenas, clamamos ao deus Peã, tal como faz a companhia sagrada dos Cantores de Baco fulminados pelo tirso e que habita a cidade de Cécrops.'

O aition, como aliás todo aition, estabelece uma ligação entre passado e presente, ou antes, diz como práticas presentes resultam de fatos passados: ${ }^{326}$ no nosso caso, como Apolo ainda é chamado de Peã por ter sido recebido em terras áticas ao som do peã ou do refrão peânico após o seu nascimento em Delos. ${ }^{327}$ Fecha-se assim o círculo e a narrativa torna ao momento presente do qual partira. Às Musas pede-se que venham a este Monte Parnaso onde ocorre a celebração para que cantem Apolo, a quem Leto deu à luz e cujo nascimento silenciou céu, terra e mar. De Delos Apolo transita diretamente para a Ática, onde é recebido com festa ao som de peãs pelo povo nativo e pela companhia de cantores que o celebra agora, no monte Parnaso, por ocasião do festival Puthais.

\footnotetext{
${ }^{326}$ Hopkinson (1984b), 141: “Aetiologizing, especially in mythological contexts, was more than a learned game: it provided a link between past and present highly valued in Greek society. Within a hymn, its importance is even greater: aetiology points to visible manifestations of divine activity, rationalizes ritual, accounts comfortably for existence, dispels doubts by producing final causes; its deep appeal should not be underestimated". Cf. ainda Hunter (1996), 52: “[...] hymns look to the past for the validation of the present order; the linking of the past to the present is not only a central structuring mode of such poems, but also to some extent their very purpose".

${ }^{327}$ Atenas, da qual os Tekhnītai são representantes oficiais, assume especial relevo nesse relato por ser nela que tem origem o nome "Peã" relacionado a Apolo, e não em Delfos. Cf. Rutherford (2001), 35: "Note that, according to Limenios, Apollo receives the name 'Paieon' before he reaches Delphi, so that the Pythoctonia aetiology is pre-empted". O "nexo ateniense" já havia sido sugerido versos antes (6), quando da narrativa do parto de Leto, durante o qual ela apóia-se numa oliveira, e não numa palmeira, como tradicionalmente ocorre (cf. Hino Homérico a Apolo, 117). Cf. Vamvouri (1998), 51: "Qui dit olivier dit Athéna et donc Athènes, la cité protégée de la déesse”, e Furley-Bremer (2001), vol. 2, 95.
} 


$\begin{array}{ll}(1-5 a) & \text { presente (Musas) } \\ (5 b-10) & \text { passado (nascimento) } \\ (11-17 a) & \text { passado (viagem) } \\ (17 b-20) & \text { presente (aition) }\end{array}$

Os dois versos seguintes (20-1) servem tanto de conclusão a essa primeira parte quanto de introdução à parte seguinte. De um lado, esses versos inauguram uma seção na qual o poeta deixa de referir-se à divindade louvada na terceira pessoa ("Er-Stil”) e passa a interpelá-la diretamente ("Du-Stil"), e assim prossegue até o final da composição. ${ }^{328}$ De outro, o poeta retoma o pedido antes dirigido às Musas para que Apolo venha até esse Monte Parnaso onde transcorre o culto, unindo, por assim dizer, as duas pontas da obra:

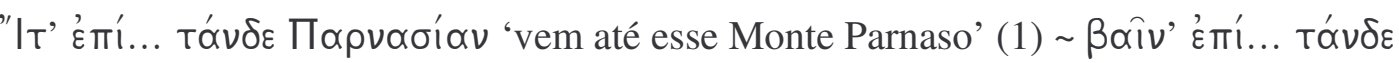

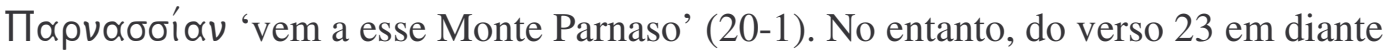
Limênio abandona o tempo presente e torna ao passado da narrativa.

Tal narrativa desdobra-se por sua vez em duas etapas, uma referente ao passado mítico (23-30), outra ao passado histórico (31-3). Enquanto lança as fundações do seu templo oracular, Apolo, a cabeça coroada com a guirlanda de louros, desafia o portento nascido da terra, Píton (23-5). O deus o mata a flechadas, como também a Títios (se aceitarmos a conjetura oferecida por Moens para o verso 27), quando este tentou violentar Leto. Do mito o poeta transita para a história e narra em seguida a derrota do exército gaulês (31-2 ó ßópßopos ớp)s) ocorrida cerca de 150 anos antes e ainda viva na memória. Em 278 a.C., um destacamento celta sob o comando de Breno invadiu a Fócida na tentativa de pilhar o oráculo délfico. Sua tentativa foi frustrada por um regimento liderado pelos etólios, mas ficou na história como uma vitória pessoal de Apolo, que teria descido do céu, deslocado uma rocha sobre os gauleses e sobre eles lançado uma feroz tempestade de granizo. ${ }^{329}$

Terminado o relato, o poeta avança para o pedido propriamente dito, retornando assim ao tempo presente no prosódio (34-47). Nele se pede que Apolo, com a ajuda de Ártemis e Leto, salve a cidade de Atenas (34-5), mantenha longe do perigo os cidadãos de Delfos (39-40) e venha com benevolência até os cantores de Baco (42-3), além de dar

\footnotetext{
${ }^{328}$ Moens (1930) sugere uma divisão estrófica da obra na qual os versos 21-2 marcam o início da segunda tríade.

${ }^{329}$ Cf. Paus. 10.15,2; 16,4; 18,7; $22-4$
} 
força ao exército romano (44-7). A referência aos Tekhnītai de Dioniso no final do hino faz eco a alusão semelhante no fim da primeira parte (19-20), na qual, também lá, a auto-

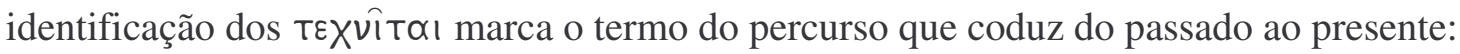

$$
\begin{array}{ll}
(21-22) & \text { presente (pedido) } \\
(23-30) & \text { passado (mito) } \\
(31-33) & \text { passado (história) } \\
(34-47) & \text { presente (pedido) }
\end{array}
$$

Na primeira parte (1-20) certa ênfase foi dada ao aspecto espacial, não só pela ressonância causada no cosmos com o nascimento de Apolo, mas sobretudo pela progressão divina de Delos a Atenas até chegar definitivamente a Delfos ${ }^{330}$ nos versos 21-2, que agem como uma dobradiça no poema. Já na segunda parte (21-47) o acento desloca-se para o aspecto temporal, uma vez estabelecido Delfos como o palco das ações. Mito e história fornecem a matéria para o poeta formular o seu pedido. Em ambas as partes, no entanto, o presente alterna-se com o passado e imprime uma dinâmica peculiar ao hino.

\subsubsection{Acontecimento único - atividade atemporal: Hesíodo, Teogonia (1-115)}

A alternância de dois momentos contrastantes pode assumir formas análogas para conferir estrutura à obra. Não apenas a oposição entre passado e presente, mas ainda entre acontecimento único e atividade atemporal é capaz de, em sua sucessão, dotar o hino de um sentido específico. Vejamos como isso se dá no proêmio da Teogonia de Hesíodo (1$115)$.

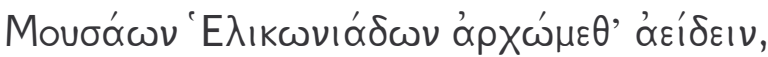

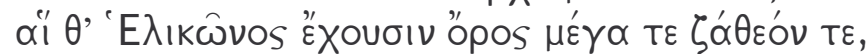

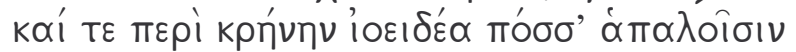

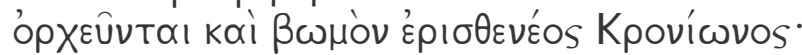

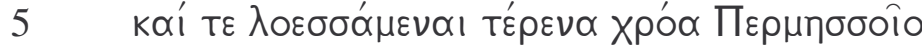

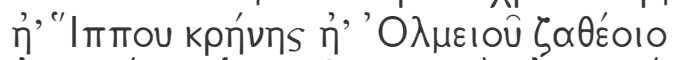

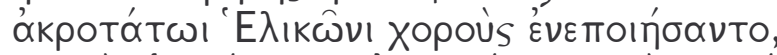

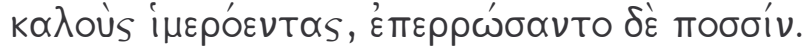

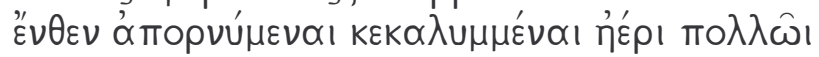

\footnotetext{
${ }^{330}$ Rutherford (2004), 81, nota que a segunda parte da viagem de Apolo (de Atenas a Delfos) corresponde precisamente à theōria que os Tekhnittai acabaram de empreender.
} 


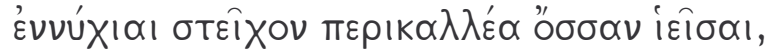

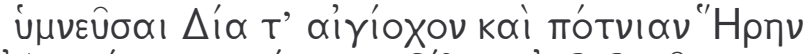

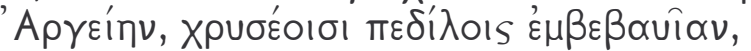

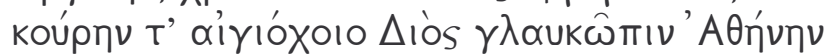

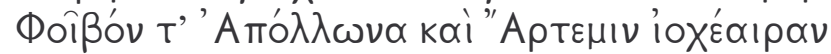

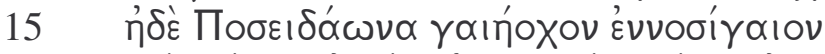

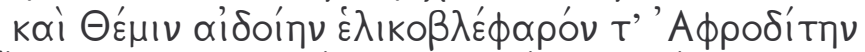

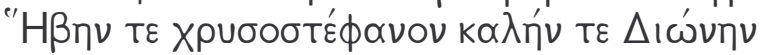

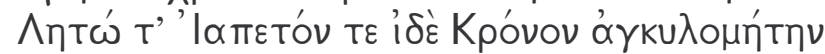

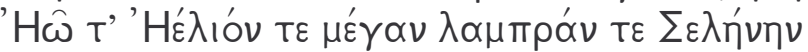

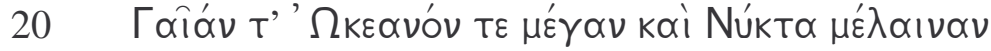

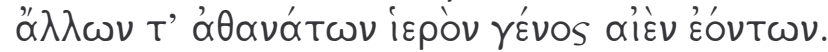

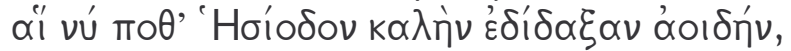

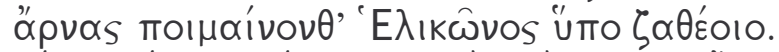

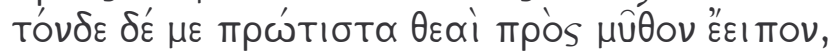

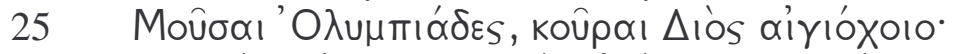

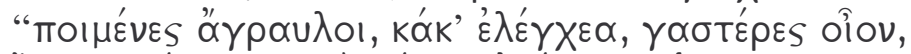

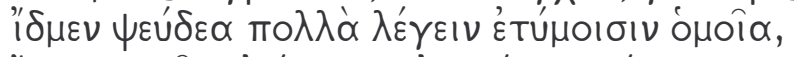

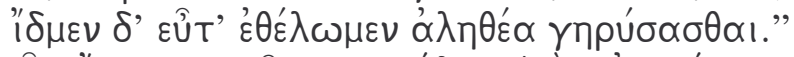

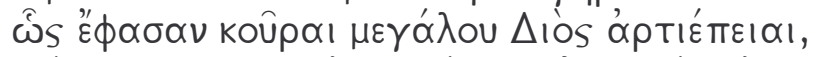

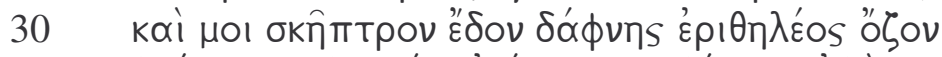

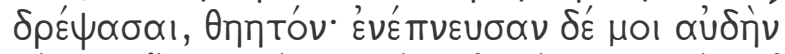

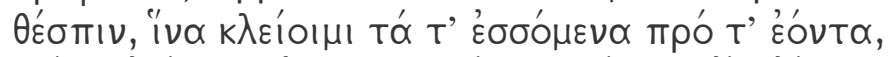

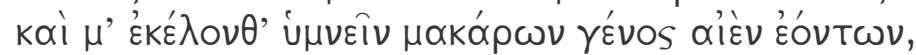

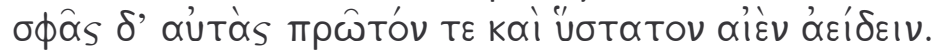

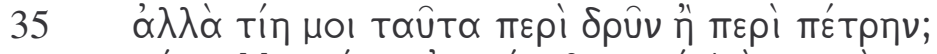

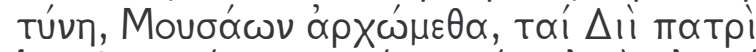

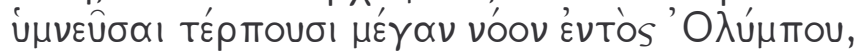

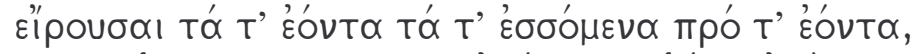

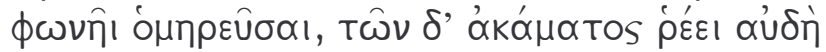

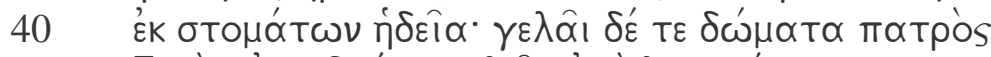

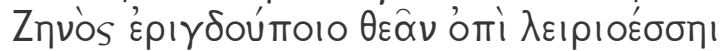

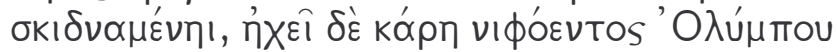

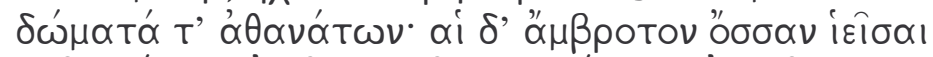

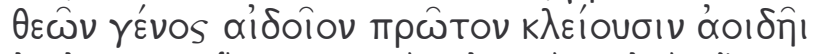

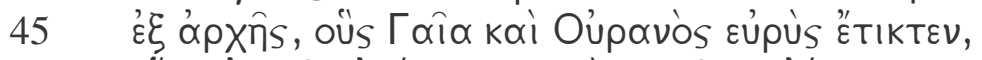

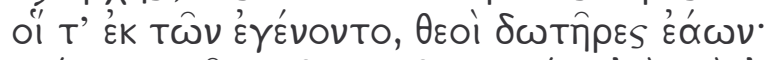

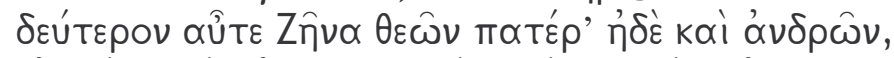

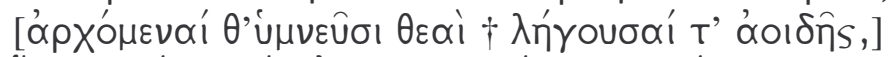

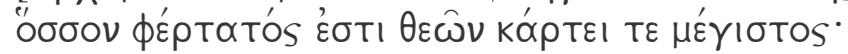

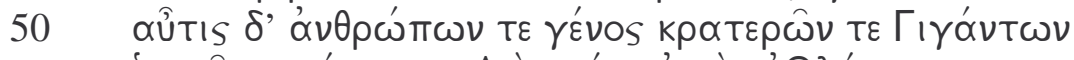

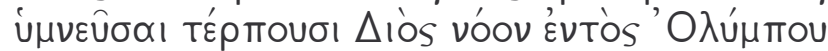

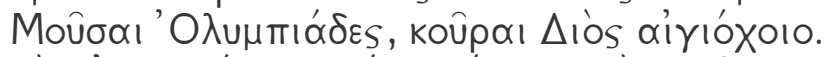

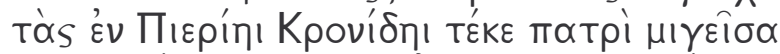

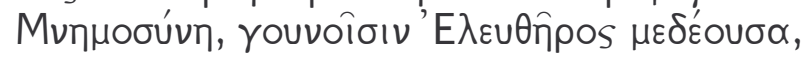

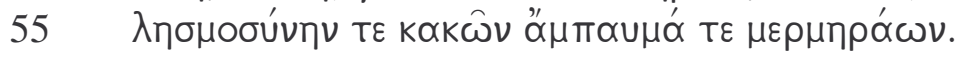




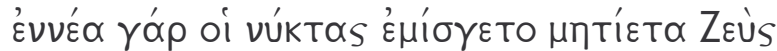

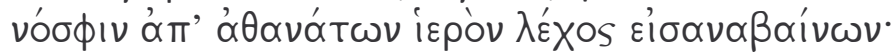

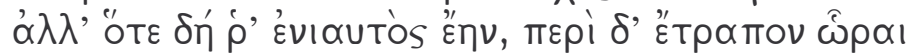

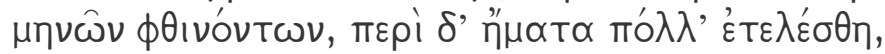

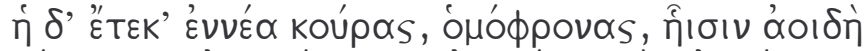

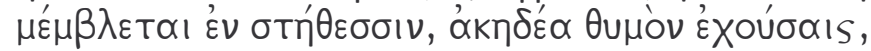

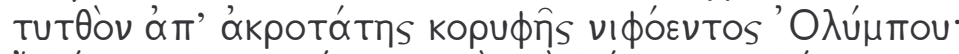

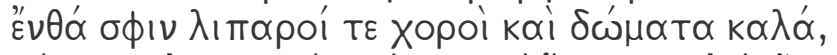

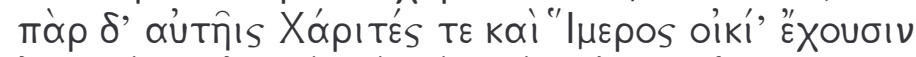

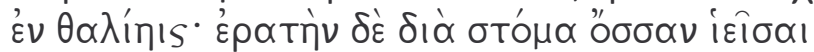

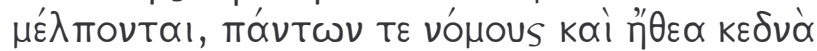

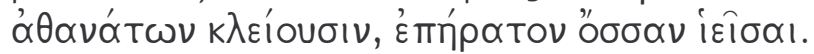

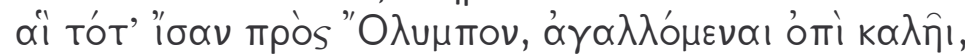

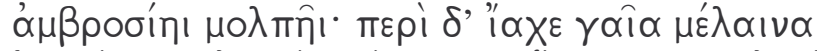

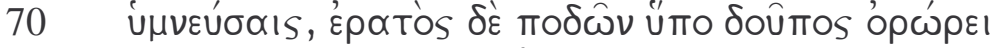

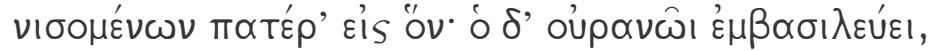

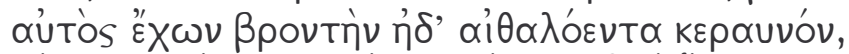

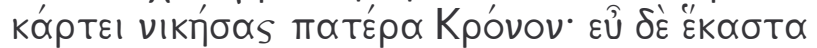

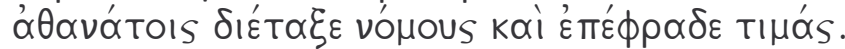

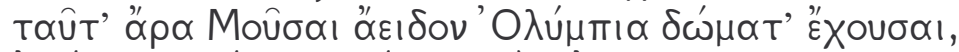

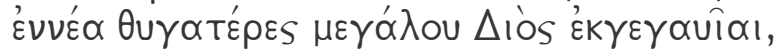

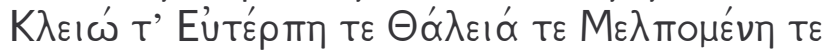

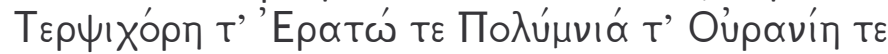

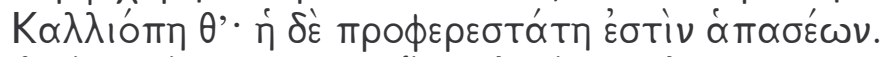

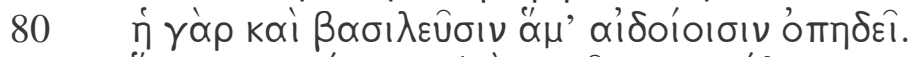

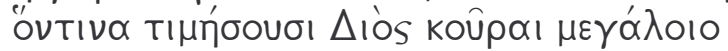

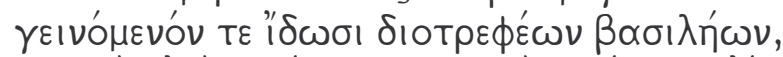

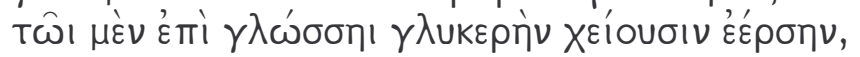

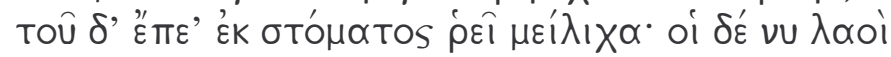

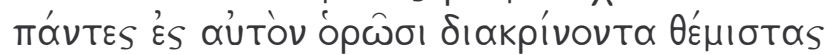

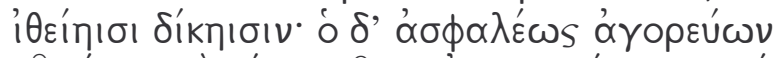

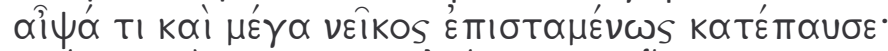

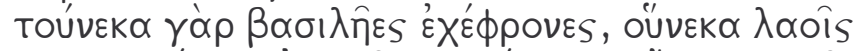

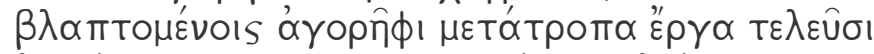

90 ṕ

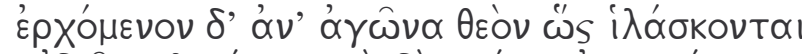

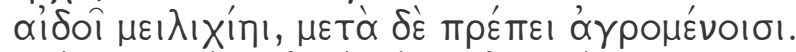

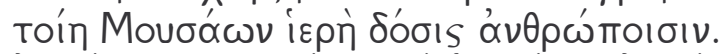

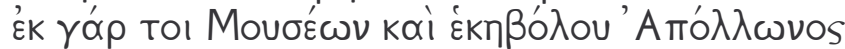

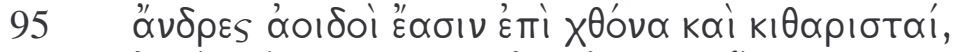

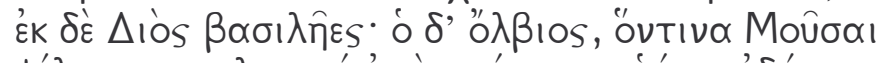

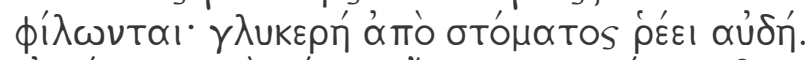

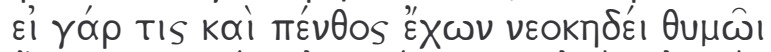

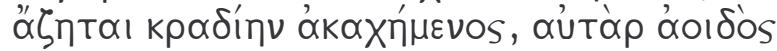

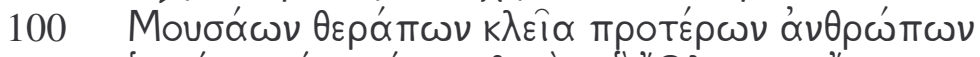

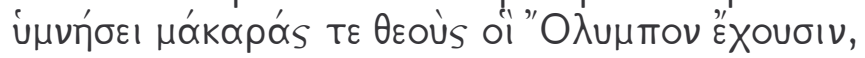




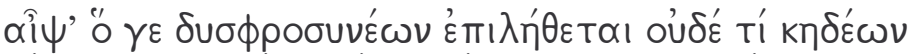

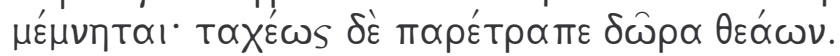

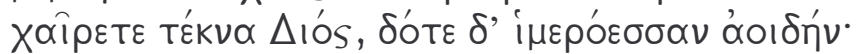

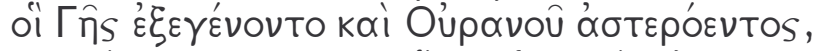

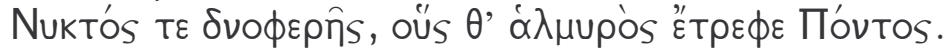

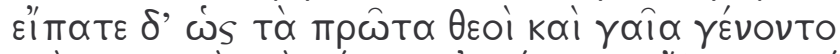

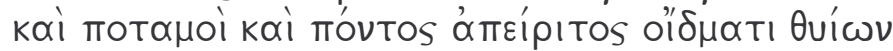

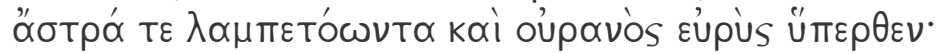

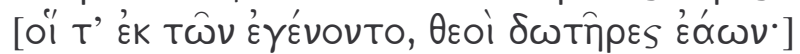

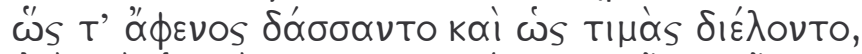

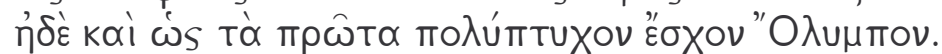

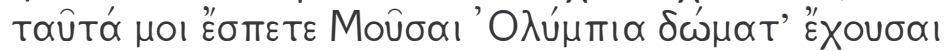

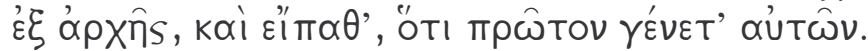

(A partir das Musas do Hélicon comecemos o nosso canto, as quais freqüentam a grande e sagrada montanha do Hélicon, e dançam com pés macios ao redor da fonte violeta e do altar do poderoso filho de Cronos. [5] E após banharem a sua delicada pele no Permessos, ou na Fonte do Cavalo, ou no sagrado Olmêios, no cume do Hélicon elas fazem as suas danças, belas e adoráveis, ao ritmo de passos lépidos. De lá elas seguem, veladas em espessa névoa, [10] e andam à noite, declamando em bela voz, cantando Zeus que porta a égide e a senhora Hera de Argos, que caminha com sandálias de ouro, e a filha de Zeus que porta a égide, Atena de olhos cinzentos, e Febo Apolo, e Ártemis a arqueira, [15] e Posêidon cuja carruagem é a terra e que a terra sacode, e a sagrada Têmis, e Afrodite de cílios recurvos, e Hebe do diadema dourado, e a bela Dione, Leto, Iapeto e Cronos das maquinações tortuosas, a Aurora, o grande Sol e a Lua brilhante, [20] a Terra, o grande Oceano e a Noite escura e o restante da sagrada família dos imortais que são para sempre. E certa vez elas ensinaram a Hesíodo o belo cantar, enquanto ele pastoreava as suas ovelhas sob o sagrado Hélicon. Eis o que as deusas me disseram primeiro, [25] as Musas Olímpicas, filhas de Zeus que porta a égide: "Pastores que acampam em solo agreste, vergonha que sois, meras barrigas: sabemos contar muitas mentiras que soam como verdades, mas sabemos cantar a realidade quando queremos". Assim disseram as filhas do poderoso Zeus, cujas palavras são seguras, [30] e deram-me um ramo de loureiro verdejante para arrancar as folhas e usar como cetro, objeto admirável, e insuflaram em mim uma voz maravilhosa, para que celebrasse as coisas do futuro e do passado, e ordenaram-me que cantasse a família dos bem-aventurados que são para sempre, e que cantasse sempre elas próprias em primeiro e último lugar.

[35] Mas que faço eu às voltas com árvore e pedra? Eia, a partir das Musas comecemos, as quais com o seu canto deleitam o poderoso espírito de Zeus pai no Olimpo ao narrarem as coisas do presente e do futuro e do passado, as vozes em uníssono, as palavras fluindo doces, sem cansar, [40] das suas bocas; os aposentos do seu pai, Zeus que troveja alto, deleitam-se com a voz clara que se espalha, e a crista do nevoento Olimpo ecoa, e as mansões dos deuses. Declamando em voz imortal elas primeiro celebram em sua canção a augusta família dos deuses, [45] do início, aqueles que a Terra e o vasto Céu conceberam, e os deuses que deles nasceram, dispensadores de dádivas. Em segundo lugar elas cantam Zeus, pai dos deuses e dos homens, o quanto ele é superior aos demais 
deuses em força e sublime em poder. [50] E em seguida, ao cantarem a família dos homens e dos poderosos Gigantes elas deleitam o espírito de Zeus no Olimpo, essas Musas Olímpicas, filhas de Zeus que porta a égide.

Elas nasceram em Piéria, da união entre Memória, rainha dos contrafortes de Elêuterai, e o pai, filho de Cronos - [55] oblívio dos males e trégua das preocupações. Nove noites o perspicaz Zeus deitou-se com ela, subindo em seu leito sagrado longe dos imortais. E quando chegou a hora, à medida que os meses minguavam e as estações giravam, e a longa sequiência de dias completou-se, [60] ela deu à luz nove filhas - um único espírito em todas elas, os despreocupados corações em seus peitos devotados à canção -, bem perto do pico mais alto do nevoento Olimpo.

Lá elas têm o seu cintilante local de dança e as suas belas mansões, ao lado delas habitam as Graças e o Desejo, [65] em festa. Adorável é o som que elas produzem das suas bocas ao cantar e celebrar as ordens e os bons costumes de todos os imortais, declamando em voz adorável.

Elas dirigiram-se então ao Olimpo, exultantes em suas belas vozes, em seu canto imortal. A terra negra ecoou ao redor [70] enquanto cantavam, e dos seus pés ergueu-se um adorável estampido ao dirigirem-se à casa do seu pai. Ele reina no céu, dele são o trovão e o raio fumegante, tendo vencido em força seu pai Cronos; ele determinou aos imortais cada uma das regras, em detalhes, e designou-lhes os privilégios. [75] Isso é o que cantaram as Musas, que habitam o Olimpo, as nove filhas nascidas do poderoso Zeus, Clio e Euterpe e Tália e Melpômene, Terpsícora e Érato e Polínia e Urânia e Calíope, que é líder entre todas elas; [80] isso porque ela cuida até dos reis augustos.

Quem quer que as filhas do poderoso Zeus privilegiam entre os reis que Zeus favorece, e para quem voltam os seus olhos ao nascerem, na língua dele vertem doce orvalho, e da boca dele as palavras fluem melífluas; e todo [85] o povo dirige-lhe a vista quando ele decide o que deve vigorar mediante os seus juízos corretos. Sua palavra é segura, e habilmente ele põe termo rápido até mesmo a uma grande disputa. Eis por que há reis prudentes: quando as pessoas são prejudicadas em seus negócios, eles as compensam [90] com facilidade, persuadindo-as com suaves palavras. Quando ele mistura-se à gente reunida, buscam seu favor com dócil reverência, como se ele fosse um deus, e ele sobressai entre a multidão.

Tal é a dádiva sagrada das Musas aos homens.

Pois é graças às Musas e a Apolo que atira longe [95] que os homens são cantores e citaristas na terra, mas graças a Zeus que são reis: feliz daquele que é benquisto das Musas - da sua boca flui doce a voz. Embora o coração de alguém definhe com a tristeza de uma perda recente, se um cantor, [100] servo das Musas, canta os célebres feitos de homens do passado e dos deuses bem-aventurados que habitam o Olimpo, logo ele esquece os seus pesares e não pensa mais nas agruras familiares, rapidamente distraído pelas dádivas divinas.

Salve, filhas de Zeus, e concedei-me um canto deleitável. [105] Celebrai a família sagrada dos imortais que são para sempre, aqueles que nasceram da Terra e do Céu estrelado e da Noite escura e aqueles que o Mar salobro criou; narrai como os deuses e a terra surgiram em primeiro lugar, e os rios e o mar sem fim com as suas vagas furiosas [110] e as estrelas brilhantes e o vasto firmamento acima; e como eles partilharam os seus bens e como dividiram os seus privilégios, e como em primeiro lugar apoderaram-se das 
numerosas escarpas do Olimpo. Narrai-me isso desde o início, Musas que habitam o Olimpo, [115] e dizei o que entre elas veio primeiro.)

O hino às Musas que consta do proêmio da Teogonia de Hesíodo, assim como o hino a Zeus que inaugura os Trabalhos e os Dias, são, como se sabe, hinos compostos desde o início em conjunto com as obras que prefaciam, ao contrário dos Hinos Homéricos, cuja récita costumava preceder poemas épicos como a Ilíada e a Odisséia, dos quais a tradição manuscrita não preservou os hinos introdutórios. Inicia o nosso hino às Musas com uma descrição de algumas das suas atividades características (1-21): elas cantam e dançam em horas noturnas no Monte Hélicon. Alguns críticos, perplexos com

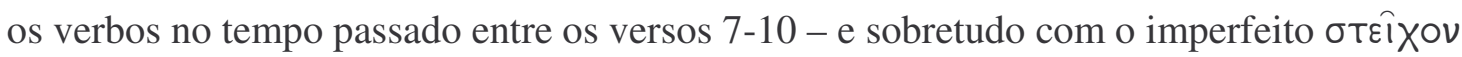
(10) -, negam que se trate de uma cena recorrente, que se repita indefinidamente no diaa-dia das divindades. ${ }^{331}$ A combinação de verbos no presente ('o

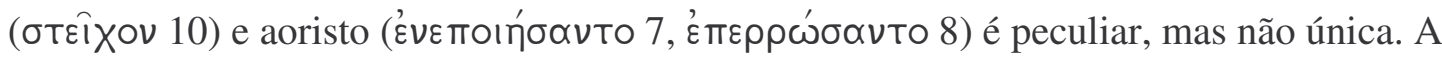
mesma seqüência ocorre em outra passagem cuja explicação já fez correr muita tinta por parte da crítica: a abertura do Hino Homérico a Apolo.

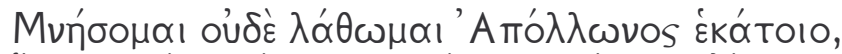

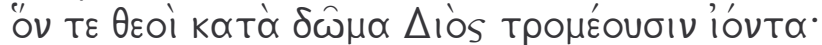

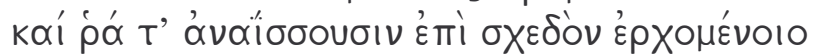

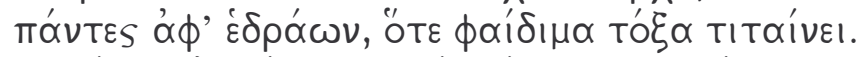

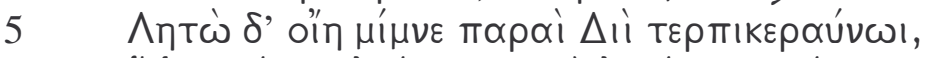

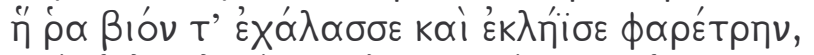

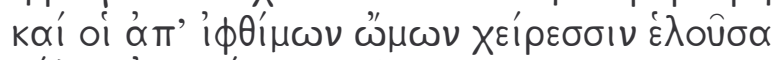

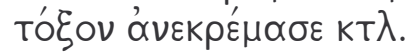

'Que eu me lembre e não me esqueça de Apolo que atira longe, diante da chegada de quem tremem os deuses na casa de Zeus. Todos se erguem num pulo dos seus assentos quando ele distende o seu arco brilhante. Somente Leto permanece ao lado de Zeus cuja diversão é o raio; ela afrouxa-lhe o arco e fecha-lhe a aljava, e após retirar o arco dos seus ombros fortes ela os pendura...'

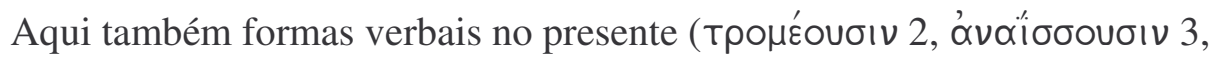

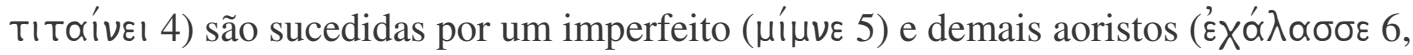

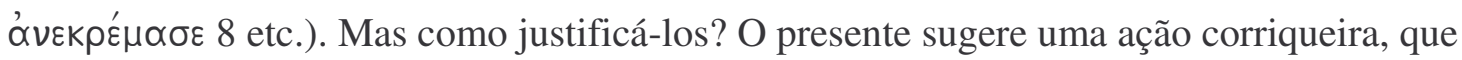

\footnotetext{
${ }^{331}$ Janko (1981), 20s., afirma por exemplo: "The past tenses in 7-10 are required by the fact that they [as Musas] cannot always be singing this particular song. [...] Thus I do not accept West's assertion (ad. loc.) that these past tenses are timeless [...]".
} 
faz parte da rotina divina; o aoristo conjugado com o imperfeito, uma ação única. Terá sido inadvertência do poeta que, tendo iniciado a narrativa de atividades rotineiras, deu-se conta a meio caminho de que impossível seria conceber a ação como freqüente - os deuses, salvo melhor juízo, não se ergueriam assustados a cada vez que Apolo fizesse o seu ingresso na casa de Zeus ${ }^{332}$ - e julgou melhor alterar o tempo verbal para o passado?

A solução do problema parece ter sido descoberta por Martin West em um breve artigo no qual sustenta que o imperfeito utilizado nessas passagens e noutras análogas um imperfeito sempre sem aumento, precedido de verbos no presente - é uma relíquia de uma forma verbal indo-européia: o injuntivo. Trata-se de uma forma sem aumento derivada dos temas presente e aoristo com terminações secundárias, neutra com relação a tempo e modo. ${ }^{333}$ Segundo West, formas injuntivas de tema presente (ou imperfeitos sem aumento) são usadas para "descrever atividades habituais (atemporais) dos deuses ou demais seres sobrenaturais". ${ }^{334}$ Esse é um uso semelhante ao verificado no Rig Veda, o que sugere o arcaísmo da forma. Ou seja, o injuntivo nessas passagens, assim como as demais formas pretéritas empregadas ao seu lado, ${ }^{335}$ não são índice de uma ação ocorrida no passado, mas significam antes um fato atemporal, seja ele uma atividade característica, como é mais comum (este é o caso do proêmio à Teogonia de Hesíodo), seja uma ação divina única (como no início do Hino Homérico a Apolo). ${ }^{336}$

Após essa descrição introdutória das atividades habituais da Musa no Monte Hélicon, Hesíodo transita para a narrativa da sua consagração como poeta pelas Musas

\footnotetext{
${ }^{332}$ Contra, Clay (1989), 29: “[...] the opening scene in the Hymn to Apolo portrays both the first epiphany of the god [...] and his eternally repeated entrance into his father's house".

${ }^{333}$ West (1989). Cf. ainda Kiparsky (1968), esp. 35-41, Clay (1997), 494, e Bakker (2002), esp. 73-7. Sobre o injuntivo no Rig Veda, ver Renou (1928), Hoffmann (1967) e Kiparsky (2005).

${ }^{334}$ West (1989), 135. "Only in the special context of poetry about the gods and their typical activities did the present-stem injunctive, or augmentless imperfect, survive in occasional use into historical times" (137).

${ }^{335}$ Nos primeiros 44 versos do Hino Homérico a Afrodite, por exemplo, também eles voltados à exposição de fatos atemporais, o tempo presente alterna com o perfeito e o aoristo.

${ }^{336}$ Cf. Faulkner (2005), 56: "[...] one might say 'omnitemporal' rather than 'timeless', as the question of time is not altogether absent in these propositions". Quanto aos aoristos no contexto do louvor hínico em geral, afirma o autor que eles conferem "some historic reference to what is essentially a statement of permanent fact” (57). Cf. ainda Sicking (1991). Já sobre o uso do imperfeito (com aumento) para expressar "a timeless statement" a respeito da existência de certa entidade, cf. Hooker (1992), esp. 64-5. Em apoio à

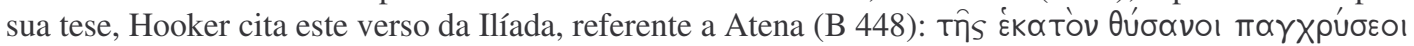

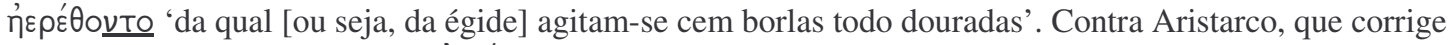

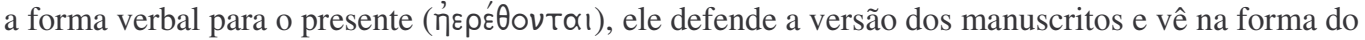
imperfeito "an allusion to a timeless attribute of the goddess" (64). Cf. também Koller (1951) e McKay (1986).
} 
(22-35). O início da sua famosa Dichterweihe é marcado pelo relativo seguido de потє ( ai vú поӨ’ 22) sinal de que deixamos a esfera das atividades típicas para ingressar no relato de um acontecimento único e pontual no qual elas estiveram envolvidas. ${ }^{337} \mathrm{~A}$ epifania delas a Hesíodo, na qual ordenam ao poeta que cante a família dos deuses e elas

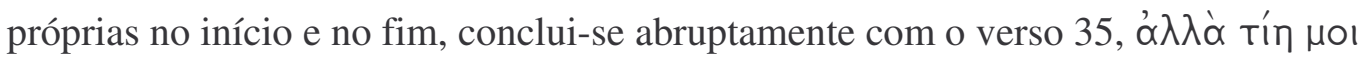

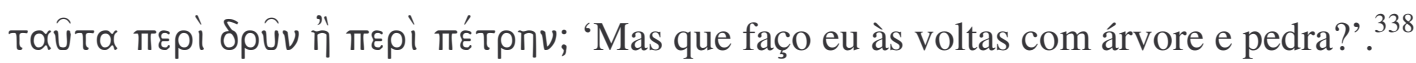
Tornam então os versos seguintes (36-52) às ações habituais das Musas: elas cantam para Zeus no Olimpo.

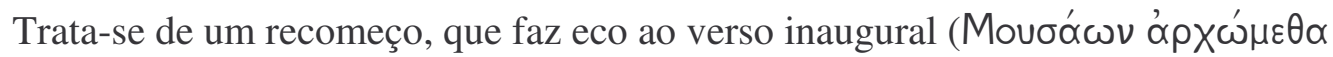

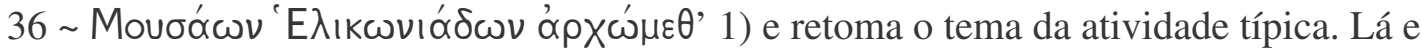
cá, como é natural, as Musas cantam, ${ }^{339}$ lá e cá a descrição tem início com relativos (đoi 2 Tớ i 36), mas agora começo e fim da seção são claramente delimitados por meio de uma repetição que se aproxima de um quiasma:

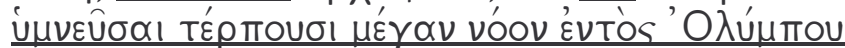

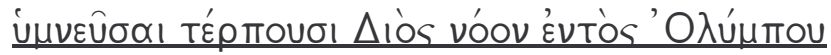

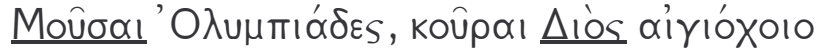

Friedländer ${ }^{340}$ chama esses dois últimos versos de "dobradiça” cujo propósito é possibilitar a transição para a seção seguinte (53-62), que outra vez abandona a descrição dos atributos típicos das deusas e retorna à narrativa de uma ocorrência única - a história do seu nascimento no Olimpo. Também aqui a nova seção é inaugurada por um relativo ( Tós 53), e mesmo nela a relação habitual das Musas com o canto é mencionada em uma frase cuja moldura constitui o acontecimento único do nascimento:

60

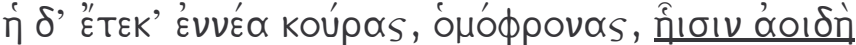

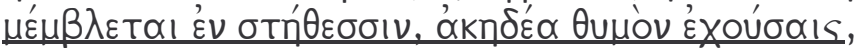

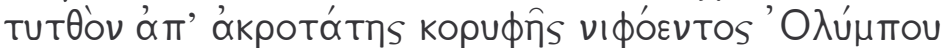

\footnotetext{
${ }^{337}$ Cf. West (1966) ad 22: "the relative (demonstrative) and потє are characteristic of the transition to a historical digression in epic, as of that to the myth in choral lyric".

${ }^{338}$ Sobre tal expressão, cf. Janda (1997).

339 Sobre o conteúdo do canto das Musas e a sua relação com o canto de Hesíodo, cf. Clay (1988).

${ }^{340}$ Friedländer (1914), 6: "Diese Verse dienen als Scharnir, das es ermöglichen soll, ein neues relativisch oder quasirelativisch eingeleitetes Stück, die Geburtsgeschichte, anzufügen".
} 
'ela (a Memória) deu à luz nove filhas - um único espírito em todas elas, os despreocupados corações em seus peitos devotados à canção -, bem perto do pico mais alto do nevoento Olimpo.'

Indicado o local onde nasceram, o poeta utiliza-o como gancho (" mais uma vez, passar ao relato das suas ações habituais em uma breve seção (63-67). No Olimpo as Musas têm as suas moradas e vivem em festa, a cantar.

Outro relativo (åi Tót’ 68) marca então o retorno à narrativa, que dá seqüência à história do nascimento com a ascensão das deusas ao Olimpo. ${ }^{341}$ Para lá elas seguem, já adivinhamos, a cantar e dançar - para a casa de Zeus. Zeus reina no céu empunhando trovão e raio, tendo imposto as suas ordens e repartido os privilégios entre os imortais (71-4). À primeira vista resvalamos aqui imperceptivelmente da narrativa à descrição, da ascensão das Musas ao fato estabelecido. Porém logo se esclarece que da narrativa ainda se trata: tudo isso é o que as Musas cantam em sua marcha montanha acima, é o conteúdo

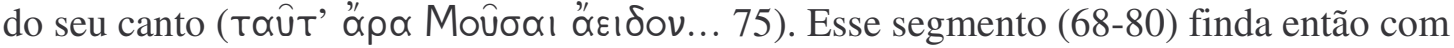
um catálogo de transição com o nome das Musas. ${ }^{342}$

Façamos um resumo esquemático do trajeto percorrido até aqui pelo poema, em sua alternância entre atividade típica das Musas (= descrição) e acontecimento singular (= narrativa) no qual elas tomam parte:

$\begin{array}{ll}(1-21) & \text { descrição (canto e dança no Hélicon) } \\ (22-35) & \text { narrativa (epifania a Hesíodo) } \\ (36-52) & \text { descrição (canto a Zeus no Olimpo) } \\ (53-62) & \text { narrativa (nascimento) } \\ (63-67) & \text { descrição (morada) } \\ (68-80) & \text { narrativa (ascensão ao Olimpo) }\end{array}$

Da narrativa Hesíodo retorna então às ações da Musas e os seus efeitos nos versos seguintes (81-104), que narram o poder benéfico que elas exercem sobre reis e cantores. O fio da narrativa não é dos mais claros, as transições para o tema dos reis (80ss.) e dos

\footnotetext{
${ }^{341}$ A ascensão ao Olimpo de divindades recém-nascidas é tema típico dos Hinos Homéricos: cf. HHom.Hermes ( ${ }^{\circ}$ 4), 322ss., HHom.Afrodite ( $\mathrm{n}^{\circ}$ 6), 15, HHom.Pã ( ${ }^{\circ}$ 19), 42.

${ }^{342}$ Sobre o catálogo de nomes usado como transição, cf. Walcot (1966), 44.
} 
cantores (94ss.) soam forçadas. ${ }^{343}$ Friedländer ${ }^{344}$ fornece um bom resumo da passagem: “O 'rei' a quem as deusas olham com favor durante o nascimento possui o poder da fala e dele faz uso nas disputas em praça pública. Essa é a dádiva das Musas, pois muito embora os cantores provenham de Apolo e das Musas e os 'reis' [não delas, mas] de Zeus, concedem as Musas [a todos, inclusive aos 'reis' que provêm de Zeus] o poder da palavra. [E tal é o poder das Musas:] Quando certa pessoa é assaltada por preocupações, o cantor a consola". É legítimo, no entanto, perguntar por que os reis são mencionados e a razão pela qual transita-se em seguida para os poetas.

Alguns críticos enxergam nessa seção do proêmio uma moldura que, juntamente com uma primeira parte (1-35), relata os efeitos das divindades sobre os mortais primeiro sobre Hesíodo, depois sobre os reis e poetas em geral. O hino ostentaria assim uma estrutura tripartite balanceada, geométrica mesmo. ${ }^{345}$ Outros já sugerem uma estrutura bipartite, ${ }^{346}$ uma conjunção de dois hinos (1-35 e 36-104): um tradicional (o segundo), o outro inovador, com a consagração poética na qual Hesíodo refere-se a si próprio. Há também aqueles que, céticos quanto a um suposto esquema fixo adotado no proêmio, sustentam que o fio narrativo obedece basicamente a associações de idéias. ${ }^{347}$ Para justificar a menção a reis e poetas, parece-me que ainda vale a sugestão de West (proposta primeiro por Wade-Gery) sobre a ocasião na qual o poema foi composto. A Teogonia, ou uma versão dela, teria sido recitada nos jogos de Anfidamas na Cálcida,

\footnotetext{
${ }^{343}$ West (1966), 181: "Calliope is the most important of the Muses, because she has tutelage of kings. But for the rest of the section, the kings owe their advantages to the Muses as a body. At the end (94ff.) there is an even more awkward transition from kings to singers".

${ }^{344}$ Friedländer (1914), 10.

${ }^{345}$ Exemplos dessa corrente crítica: Walcot (1957), Schwabl (1963) e (1966), Minton (1970). Ver ainda Bradley (1966).

${ }^{346}$ Friedländer (1914), Janko (1981).

${ }^{347}$ Cf. Verdenius (1972). O perigo dessa hipótese, embora me pareça mais convincente que as anteriores, é enxergar uma associação de idéias em qualquer transição no texto, por mais abrupta que ela soe: fosse o texto diverso, dotado de outras transições, o crítico estaria igualmente habilitado a justificá-las como idéias livremente associadas. Não me convence a explicação de Verdenius sobre tal seqüência (259s.): "The movement of the Muses from Helicon to Olympus reminds him of the place where he had met them; the influence exercised by them on his own life induces him to describe their influence on the gods; the place of their main activity suggests their birth-place; the birth-place suggests the dwelling-place; the dwellingplace suggests their companions, and these suggest the quality of their voice; the later suggests a return to

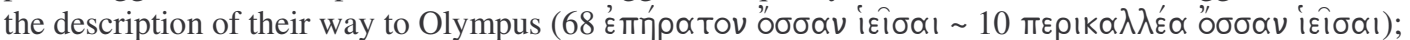
Olympus suggests Zeus, and Zeus suggests (1) the main subject of the Theogony, (2) the names of his children; the last name suggests the Muses' influence on kings; this influence manifests itself in the influence exercised by the kings on their audience; a similar influence is exercised by poets celebrating great men and the gods (100-1 k $\lambda \varepsilon \hat{\imath} \alpha .$. ú $\mu \nu \eta \dot{\sigma \varepsilon 1)}$; Hesiod will now concentrate on celebrating the gods, for which he needs the help of the Muses (105 к $\lambda \varepsilon i \varepsilon \tau \tau \varepsilon) "$. Cf. ainda Verdenius (1960).
} 
aos quais se faz alusão nos Trabalhos e os Dias (654-9). ${ }^{348}$ Segundo West, a eulogia dos reis e os versos que lhe seguem (98-103) sobre a tristeza de uma perda recente ( $\pi \dot{\varepsilon} v \theta 0 s . .$.

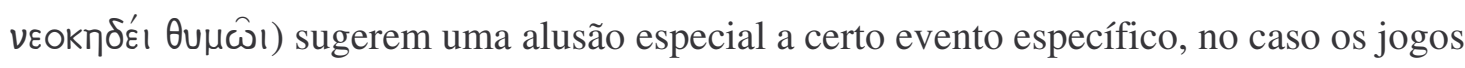
funerais de Anfidamas promovidos pelos seus filhos. Ou seja, essa seção do hino começa por descrever a ação das Musas no contato com os reis e termina por fechar o foco sobre

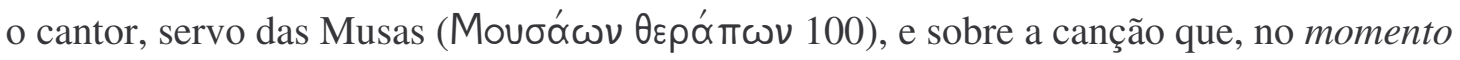
atual (acontecimento único), ele entoa em homenagem ao finado rei na presença dos seus filhos. Tal canto é que lhes servirá de consolo.

(81-103) descrição $\rightarrow$ narrativa (reis e poetas $\rightarrow$ ocasião da performance)

Finalmente, em uma passagem de transição para a parte central da Teogonia, o poeta despede-se das Musas e lhes diz o que elas devem cantar (104-15).

Vemos assim que, no vaivém entre narrativa e descrição, o poema assume um movimento peculiar, cuja unidade é fornecida pelo tema do canto; este, como notamos, perpassa cada uma das seções alternadas. Louvando as Musas, Hesíodo - cujo nome pode estar relacionado à arte de cantar ${ }^{349}$ - engrandece a si próprio, primeiro ao narrar a sua consagração como poeta, depois ao aludir em tom enaltecedor ao próprio canto que ele entoa naquele instante.

Verdenius, ${ }^{350}$ ao final das suas notas sobre o hino às Musas, emite a opinião de que "a unidade do proêmio não reside na interdependência das suas partes, mas na continuidade do seu progresso". Ora, tentamos sugerir que é justamente na continuidade do seu progresso (na alternância entre narrativa e descrição) que o proêmio alcança, ao adotar o tema do canto como fio condutor, uma verdadeira unidade e interdependência das suas partes.

\footnotetext{
${ }^{348}$ West (1966), 44s.

${ }^{349}$ Cf. Bader (1992), esp. 115s. A autora sugere que o nome de Hesíodo, assim como o de Homero, não é um nome individual, é uma designação do poeta-cantor que ele confere a si mesmo. O nome, segundo ela, remonta à raiz * $s h_{2^{-}}$'ligar, atar', cuja relação com o fazer poético é extensa (veja artigo), acrescido de -০ঠos, na metáfora comum que faz da poesia uma via ("canto-caminho"). A forma primitiva seria *seh ${ }_{2}$-tioঠos. Sobre a metáfora do canto como caminho, cf. Becker (1937) e Durante (1976), 123-34.

${ }^{350}$ Verdenius (1972), 260.
} 


\subsubsection{Planos temporais no Rig Veda}

A alternância entre dois planos temporais distintos, um atual e outro anterior, também é explorada para efeitos poéticos e religiosos em pelo menos dois hinos do Rig Veda, que comento brevemente. Trata-se, no primeiro caso, de uma alternância simples (presente-passado-presente), no segundo de uma alternância múltipla, como nos poemas gregos analisados acima. O primeiro é um hino a Ușas, a Aurora (RV 7.76).

1 úd u jyótir amṛ́tạ̣ viśvájanyạ̣ viśvắnarah savită devó aśret | krátvā devấnām ajanișța cákșur āvír akar bhúvanaṃ víśvam ușăḥ ||

2 prá me pánthā devayănā adróśrann ámardhanto vásubhir íṣkrtāsaḥ| ábhūd u ketúr ușásạ̣ purástāt pratīcy âgād ádhi harmyébhyạ̣ \||

3 táníd áhāni bahulány āsan yấ prācínam úditā súryasya | yátah pári jārá ivācáranty úṣo dadrokṣé ná púnar yatíva \|

4 tá íd devấnām sadhamấda āsann rốvānaḥ kaváyạ̣ pūrvyấsạ̣ | gūlhám jyótiḥ pitáro ánv avindan satyámantrā ajanayann ușásam ||

5 samāná ūrvé ádhi sámgatāsaḥ sám jānate ná yatante mithás té | té devănāṃ ná minanti vratấny ámardhanto vásubhir yấdamānāḥ ||

6 práti tvā stómair īlate vásișṭā uṣarbúdhạ̣ subhage tușțuvấṃsạ̣| gávāṃ netrí văjapatnī na uch ${ }_{\mathrm{a}}$ ự̦ạ̣ sujāte prathamá jarasva $\|$

7 eșá netrî rắdhasaḥ sūnóntānām uṣấ uchántī ribhyate vásiṣthaiḥ | dīrghaśrútam rayím asmé dádhānā yūyám pāta svastíbhih sádā nạ̣ \|

(1 Para o alto Savitr erigiu a luz imortal própria a todos os humanos, ele, o deus próprio a todos os homens de prol. / O olho dos deuses nasceu segundo a sua força de inspiração. A Aurora tornou manifesto o universo inteiro.

2 Os caminhos que levam aos deuses tornaram-se visíveis para mim, os (caminhos) impecáveis, munidos de bens [ou: preparados pelos deuses]. / O sinal luminoso da Aurora apareceu no oriente, ela veio ao nosso encontro vinda das suas habitações.

3 Numerosos, de fato, foram aqueles dias que (surgiram) outrora, ao erguer do sol, na sequiência dos quais tu te mostraste, / Aurora, aproximando-se como de um amante, não como alguém que se vai.

4 Eles eram de fato os comensais dos deuses, os poetas antigos votados à verdade. / Os pais descobriram a luz escondida; proferindo as fórmulas, eles engendraram a Aurora.

5 Reunidos em torno do local de encontro, eles estão de acordo, eles não se opõem obstáculos mútuos; / eles não violam as ordens dos deuses, (os pais? os Vasișțhas?) impecáveis que se unem aos deuses.

6 Os Vasișțhas invocam-te através dos seus cantos de louvor, ó bem-aventurada, eles que despertam na aurora, louvando-te. / Condutora de vacas, senhora dos prêmios, brilha para nós, Aurora bem-nascida, seja a primeira a despertar.

7 Eis a condutora de bens, de liberalidades, a Aurora que brilha é cantada pelos Vasișțhas, / dando-nos a riqueza amplamente famosa. Vós, protegei-nos com bênçãos eternamente.) 
Ao contrário dos vinte hinos dedicados à Aurora no Rig Veda, que obedecem em geral a uma sequiência cronológica pertinente à natureza da divindade - à noite segue-se a aurora, à aurora segue-se o sol ${ }^{351}$-, esse poema inova ao transitar do presente ao passado e do passado de volta ao presente. Estrofes 1-2, a exemplo de vários desses hinos, celebra a aparição da aurora no mesmo instante que o poema é entoado, e os verbos nela contidos são todos aoristos com aumento, próprios para designar o presente/passado imediato, como nota Jamison: ${ }^{352} 1 \mathrm{~b}$ aśret 'erigiu', 1c ajanișta 'nasceu', 1d akar 'tornou', 2a adrrśran 'tornaram-se visíveis', 2c ábhūt 'apareceu', 2d ăgāt 'veio'. Já as estrofes 3-4 tornam ao passado mítico, o que se reflete nos seus verbos, quatro imperfeitos com aumento ( $3 \mathrm{a} / 4 \mathrm{a}$ āsan 'foram/eram', 4c avindan 'descobriram', 4d ajanayan 'engendraram') e um perfeito (3d dadrkssé 'tu te mostraste'). Enfim, estrofes 5-7 contêm somente presentes do indicativo (5b sám jānate... yatante 'estão de acordo... opõem', 5c minanti 'violam', 6a İlate 'invocam', 7b ribhyate 'é cantada') e imperativos (6c ucha 'brilha', 6d jarasva 'desperta').

Trata-se, à primeira vista, de uma simples contraposição entre o passado mítico (estrofes 3-4) e o presente da celebração (estrofes 1-2 e 5-7), este último servindo de moldura ao primeiro. O contraste é sublinhado ainda pelo paralelismo na abertura das estrofes 3-4 (3a tâníd... āsan 'aqueles foram de fato...' 4a tá íd... āsan 'aqueles eram de fato...') e pela repetição de ámardhantạ̣ 'impecáveis' (2b e 5b) nas estrofes contíguas. O quadro se complica, porém, quando passado e presente se fundem na estrofe 5. Menção é feita na estrofe 4 aos primeiros poetas (os "pais") e ao seu papel de destaque no mito de Vala; na estrofe 6, os protagonistas são os Vasiṣṭhas, autores do hino agora entoado; entre uma e outra, que marcam respectivamente o tempo passado e o presente do culto, inserese - no presente do indicativo - uma estrofe cujo sujeito sintático é ambíguo, podendo acomodar tanto os Vasișțhas, poetas atuais, quanto os pais do mito, poetas do passado. Mas ambos, note-se, ocupam-se da mesma tarefa, o que sugere uma aproximação dos pais mitológicos aos poetas que entoam o presente hino, sendo os últimos engrandecidos tacitamente no processo: os pais atuam na libertação original da aurora (4cd), mantida em

\footnotetext{
${ }^{351}$ Cf. Renou, EVP 3, 2: "La présence du phénomène naturel est mieux affirmée qu'un aucun autre ensemble hymnique du RV".

${ }^{352}$ Jamison (2007), 85s., que nota o esquema verbal do poema, a semelhança das aberturas das estrofes 3 e 4 , a repetição de ámardhantah (2b e 5d) e a estrutura "omphalos" do hino.
} 
cativeiro por Vala, e o mesmo mito fornece o modelo para a regeneração diária da aurora, pela qual são responsáveis - através desse hino - os Vasișțhas. Claramente repartidos segundo os tempos verbais das estrofes, passado e presente perdem assim suas fronteiras nítidas em proveito do presente do culto, que ganha a magnitude do passado mitológico.

Vejamos o segundo exemplo, de alternância múltipla, contido em um hino a Indra

(RV 1.174).

1 tvám răjā ${ }_{i} \mathrm{nd}_{\mathrm{a}}$ ra yé ca devấ rákșā n⿳̛̣n pāh $\mathrm{h}_{\mathrm{i}}$ asura tvám asmấn | tváṃ sátpatir maghávā nas tárutras $\mathrm{t}_{\mathrm{u}}$ váṃ satyó vásavānaḥ sahodăḥ $\|$

2 dáno víśa ind ${ }_{\mathrm{a}}$ ra mrdhrávācaḥ saptá yát púrạ̣ śárma sááradīr dárt | rnór apó anavady a árnāa yúne vọtrám purukútsāya randhị \|

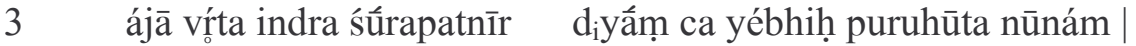
rákṣo agním aśúșạ̣ túrvayāṇam sị̣hó ná dáme ápāṃsi vástoḥ \|

4 séșan nú tá ind ${ }_{a}$ ra sásmin yónau práśastaye pávīravasya mahnấ|

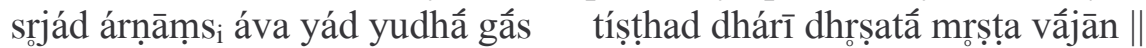

5 váha kútsam ind ${ }_{\mathrm{a}}$ ra yásmiñ cākán syūmanyú rijá vătasya ásvā prá súraś cakráṃ vrọhatād abhíke abhí spŕ̛dho yāsișad vájrabāhuh \|

6 jaghanvấm ind ${ }_{\mathrm{a}}$ ra mitrérūñ codápravroddho harivo ádāsūn | prá yé páśyann aryamáṇaṃ sácāyós tváyā suūtá váhamānā ápatyam \|

7 rápat kavír ind $\mathrm{a}_{\mathrm{a}} \mathrm{a}_{\mathrm{a}}$ rkásātau kṣăm dāsấyopabárhaṇị̣̄ kaḥ| kárat tisró maghávā dănucitrāa ní duryoné kúyavācam mrọdhí śret \|

8 sánā tấ ta ind ${ }_{a}$ ra návyā ăguh sáho nábho áviranāya pūrvíh | bhinát púro ná bhído ádevīr nanámo vádhar ádevasya pīyóh \|

$9 \quad \mathrm{t}_{\mathrm{u}}$ váṃ dhúnir ind $\mathrm{a}_{\mathrm{a}}$ ra dhúnimatīr rnór apáh sīră ná srávantīh $\mid$ prá yát samudrám áti suūra párși pāráyā turváśaṃ yáduṃ $\mathrm{s}_{\mathrm{u}}$ astí ||

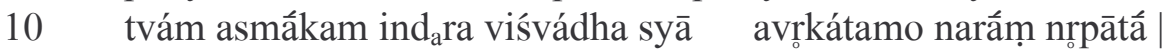
sá no víśvāsāṃ sprdhắm sahodấ vidyămesám vịjánaṃ jīrádānum ||

(1 Tu, ó Indra, (és) rei (dos homens) e daqueles que (são) deuses; zela pelos senhores, ó Asura, tu, protege-nos! / Tu (és) senhor do que existe, bondoso, nosso salvador, tu o verdadeiro possuidor de bens, doador de força superior.

2 Tu reprimiste, ó Indra, as tribos de palavra hostil quando esmagaste as sete fortalezas outonais, o refúgio (deles). / Tu fizeste fluir as águas em torrentes, ó (deus) irrepreensível; tu entregaste Vṛtra ao jovem Purukutsa.

3 Conduze os exércitos, ó Indra, para quem (és) um senhor heróico, e aqueles com quem, ó (deus) de muitas invocações, (conquistarás) agora o céu. / Protege Agni, Aśúșa, Túrvayāṇa, (tu que és) como um leão na casa, (protege) os ritos (executados) na alvorada!

4 Que eles repousem assim, esses (inimigos), ó Indra, num mesmo útero, para glória do raio-clava em sua grandeza! / Quando (Indra) fez fluir as correntes, as vacas, graças ao combate, ele montou nos dois alazães (e) com ousadia arrebatou os prêmios. 
5 Conduze Kutsa, ó Indra, a quem te afeiçoaste, (atrela) os dois cavalos de Vāta que obedecem às rédeas! / Arranca a roda do sol no instante decisivo! Que (o deus) que segura o raio na mão marche contra o inimigo.

6 Tendo matado os Mitrerus ímpios, ó Indra, senhor dos alazães, fortalecido por Coda, / (esses inimigos) que viam diante (deles) Aryaman junto com Âyu, esmagados por ti quando carregavam seus descendentes...

7 O poeta, ó Indra, tomou a palavra quando do (combate para) a conquista do sol: "Tu fizeste da terra uma almofada para o dāsa! / O (deus) bondoso fez três (rios) brilharem com água; ele precipitou Kuyavāc num útero funesto, na privação".

8 São estes, ó Indra, os teus antigos (feitos); novos (feitos? hinos?) vieram: muitas vitórias para a insatisfação dos inimigos! $!^{353}$ / Racha como fortalezas as rachaduras inimigas; verga a arma mortal do ímpio que odeia.

9 Tu, ó Indra, (deus) torrencial, tu fizeste correr as águas torrenciais como rios caudalosos. / Se tu atravessas o oceano, ó herói, faz atravessar Turváśa e Yádu em segurança.

10 Que tu possas, ó Indra, ser sempre para nós o mais seguro protetor de homem dos homens! / Assim, (seja) o doador de força superior sobre todos os nossos inimigos! Que nós encontremos um círculo de (senhores) generosos, cujas dádivas sejam vivazes!)

Embora a compreensão do hino seja dificultada em seus detalhes pela referência a acontecimentos históricos de significado obscuro, a estrutura geral é clara: a narrativa dos eventos mitológicos alterna-se com pedidos endereçados à divindade. O presente alternase com o passado mítico, com os feitos heróicos de Indra, os quais são chamados na estrofe 8 de "antigos" ( sánā $8 a$ ). Dou um resumo esquemático dessa alternância até esse ponto:

$\begin{array}{ll}\begin{array}{l}\text { estrofe 1 } \\ \text { estrofe 2 }\end{array} & \begin{array}{l}\text { presente } \\ \text { passado } \\ \text { estrofe 3 }\end{array} \\ \text { estrofe 4 (pādas } a b) & \text { prente } \\ \text { presente } \\ \text { (pādas } c d \text { ) } & \text { passado } \\ \text { presente } \\ \text { estrofe 5 } & \text { passado } \\ \text { estrofe 6 } & \text { passado } \\ \text { estrofe 7 } & \text { presente } \\ \text { estrofe 8 } & \end{array}$

\footnotetext{
${ }^{353}$ sáhas $(8 d)$ também pode ser um subjuntivo do aoristo radical atemático do verbo de raiz sah 'dominar'; sigo a sugestão de Oldenberg (1909) ad. loc., que interpreta sah- como um substantivo no nominativo plural feminino ("vitórias"), e reproduzo a tradução sugerida por Gotō (1987), 325, que entretanto alerta: "der Vers ist auf jeden Fall ganz unklar".
} 
A interpelação direta à divindade é expressa em geral no imperativo (rákșā 'zela' $1 b$, pāhy 'protege' $1 b$, ájā 'conduze' $3 a$ etc.), ao passo que as façanhas mitológicas são narradas num modo verbal do qual falamos há pouco - o injuntivo (dánạ̣ 'reprimiste' $2 a$, dárt 'esmagaste' $2 b, k a h$ 'fizeste' $7 b$, ní... śret 'precipitou' $7 d$ etc.). Tal forma, porém, é usada (como lembramos) para relatar acontecimentos em cujos horizontes a idéia de tempo acha-se ausente: trata-se de fatos alheios à dinâmica temporal e cujas nuanças modais são definidas exclusivamente pelo contexto. É lícito inferir, alcançada a estrofe 8, que tais feitos praticados pelo deus ocorreram antes do instante no qual o hino é entoado (cf. sánā 8a), mas a forma injuntiva prevalecente por exemplo nas estrofes 2 e 7, as quais narram as ações de Indra, rouba-lhes simultaneamente a moldura temporal que permitiria precisar quando os eventos descritos ocorreram (em diferentes contextos, tais formas podem assumir tanto um sentido presente quanto passado ou mesmo futuro).

Passado e presente perdem assim as suas delimitações precisas; os feitos do deus podem ter ocorrido antes do momento da celebração, mas os imperativos das estrofes $3 \mathrm{e}$ 5 pedem a Indra que execute essas mesmas ações agora. Como nota Elizarenkova, ${ }^{354}$ "os feitos heróicos de Indra são enumerados, enquanto quase simultaneamente ele é rogado a praticar esses feitos". O uso generoso de formas injuntivas atemporais para descrever as ações divinas, aliado aos imperativos e optativos ${ }^{355}$ que expressam o desejo atual do poeta em relação a essas mesmas ações, acabam por arrancá-las do passado e aproximálas do presente. Tais feitos também costumam ser narrados por meio de formas pretéritas como o imperfeito, o aoristo ou mesmo o perfeito; a ausência delas (ou antes: das suas formas finitas) nas passagens mitológicas do nosso hino (estrofes 2, $4 c d, 6$ e 7), conjugada à ausência de verbos no indicativo, ${ }^{356}$ parecem ser um artifício consciente do

\footnotetext{
${ }^{354}$ Elizarenova (1995), 189, cujas observações serviram de inspiração ao meu comentário.

${ }^{355}$ Cf. estrofe 5: yāsiṣat 'que ele marche'; estrofe 10: syās 'sejas', vidyăma 'encontremos'. Sobre os imperativos na estrofe 3, Geldner (ad loc.) comenta: "Die Imperative in lebhafter Vergegenwärtigung des Mythos wie in 5"; e sobre a forma pāráyā 'faze atravessar' (9d): "Ist wieder Imperativ (wie in Str. 3. 5) im Sinn des hilfesuchenden Turvaśa und Yadu gedacht oder mit Übertragung der mythologischen Sprache auf die Gegenwart".

${ }^{356}$ Uma possível exceção é ăgụh ‘ele/as vieram’ (8a), embora a morfologia seja ambígua. A forma (ă $\left.+g \bar{a}-\right)$ pode ser analisada tanto como ă aguḥ (indicativo), como faz o Padapātha, ou como ă guḥ (injuntivo). Já kárat (7c) pode ser interpretado como um aoristo radical subjuntivo, mas o mais provável é que seja um injuntivo, em razão do contexto (faz par com $k a h ̣ 7 b$ ). O verbo de segunda pessoa do singular párși (9c) não é um indicativo porque o verbo par- 'atravessar' possui apenas formas reduplicadas no presente. Tais formas, isoladas, são em geral usadas como imperativos (os chamados "imperativos em -si"), embora estes,
} 
poeta para sugerir que tais ações repetem-se cada vez que ele entoa o seu canto e pede a Indra que ponha novamente em prática, no instante atual, as suas façanhas cosmogônicas atemporalmente válidas.

\subsubsection{Passado mítico / passado histórico e presente}

Até aqui pudemos ver como, no vaivém entre dois planos temporais diversos, concebidos em termos gerais como passado e presente, o poeta logra fazer o elogio da divindade e aproximá-la à força desse próprio movimento traçado pelo hino. Mas não é só por meio da alternância entre os planos que se alcança o objetivo de progressivamente apagar as fronteiras que os separam. Estratégia mais simples é resgatar a divindade do passado mítico ou histórico no qual se acha entronizada para que ela faça valer outra vez, no presente, os benefícios pelos quais ela se destacou em ocasião anterior.

Vimos como no peã de Limênio (3.1.1) Apolo é trazido retoricamente em duas etapas até o presente da celebração, primeiro através da narrativa de um dos seus feitos míticos, a destruição da serpente (vv. 23-30), e a seguir através do relato de um dos seus feitos no passado histórico, a vitória sobre o invasor gaulês em Delfos nos anos 279/8 a.C. (vv. 31-3). Muito próximo é o recurso usado em outro peã com notação musical também encontrado no muro sul do Tesouro público de Delfos e que exibe inúmeras semelhanças com o de Limênio. O nome do seu autor é provavelmente Ateneu, e também aqui transita-se do mito à história (os mesmos, vale dizer), até chegar ao presente. Cito os versos relevantes: $:^{357}$

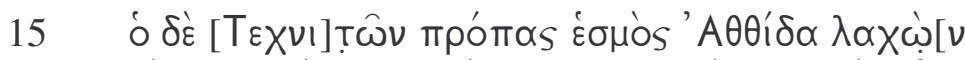

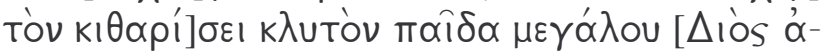

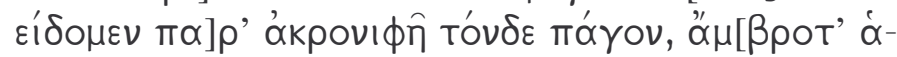

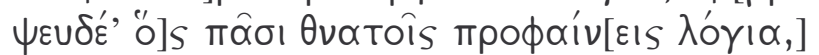

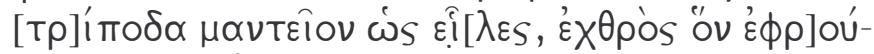

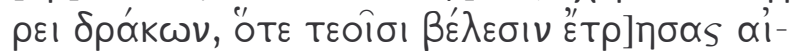

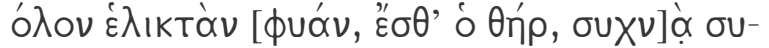

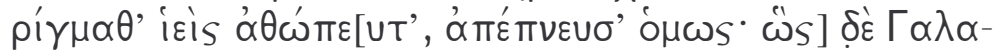

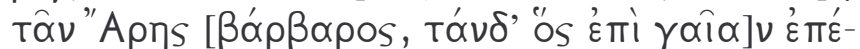

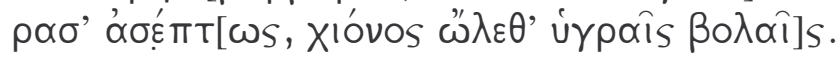

como aqui, raramente apareçam em frases subordinadas, com valor subjuntivo. Cf. Elizarenkova (1995), $183 \mathrm{~s}$.

${ }^{357}$ Edição de Furley-Bremer (2001), vol. 1, 85. Cf. Bélis (1992) e West (1992), 288-93. 


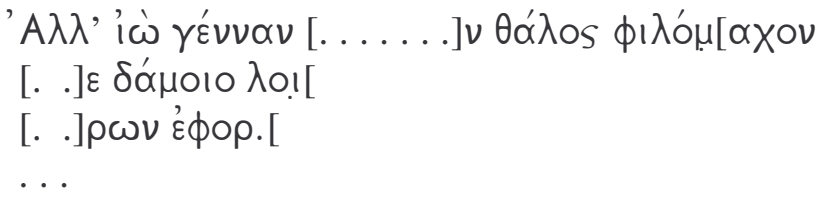

(A companhia inteira dos artistas de Atenas, ao lado desse pico coberto de neve, celebramos o famoso citarodo, filho do poderoso Zeus, que proferes oráculos infalíveis, imortais, a todos os humanos, (cantamos) como te apoderaste do tripé profético que uma serpente hostil guardava, quando perfuraste com flechas a criatura coleante, luzidia, até que a fera, com sibilos mil, expirou. Do mesmo todo, a horda estrangeira dos gauleses que atacaram brutalmente essa terra morreu nas tempestades de neve durante o inverno. Salve, filho de...)

Versos 19-22 narram o mito da pitoctonia, os seguintes (22-4) a expulsão dos bárbaros, ao passo que a apóstrofe final é introduzida por $\alpha \lambda \lambda \alpha \alpha^{\prime}(25) .{ }^{358}$ Essas duas etapas reforçam uma a outra e fornecem o fundamento, tanto mítico quanto histórico, sobre o qual se baseará o pedido. Vezes há, ainda, em que somente um desses fundamentos é mencionado a fim de captar a atenção divina e fazer com que, em virtude de uma ação que realizou no passado, o deus ou deusa ouça com benevolência o que lhe roga o devoto. Começo pelo exemplo histórico - os hinos dos embaixadores ateniense e espartano para ratificar o tratado de paz na Lisístrata de Aristófanes.

\subsubsection{Aristófanes, Lisístrata (1247-1294)}

Durante a Guerra do Peloponeso, as mulheres gregas forçam os seus maridos a um acordo de paz negando-lhes sexo até que se decidam a firmá-lo. Os termos de paz são assentados nas cenas finais da peça, e uma vez estabelecidos, primeiro o embaixador ateniense, depois o lacedemônio cantam hinos celebratórios para comemorar o desfecho.

$1250 / 1$

$$
\begin{aligned}
& \triangle \mathrm{AKE} \triangle \mathrm{AIMONI} \Omega \mathrm{N} \text { TPE } \Sigma \mathrm{BEYTH} \Sigma
\end{aligned}
$$

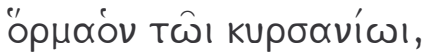

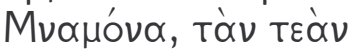

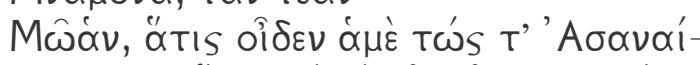

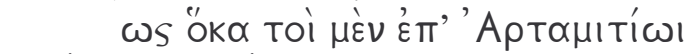

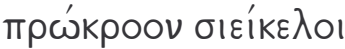

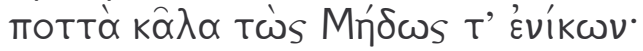

\footnotetext{
${ }^{358}$ Denniston (1954), 14: "' $\propto \lambda \lambda \alpha^{\prime}$ in commands and exhortations expresses a break-off in the thought, a transition from arguments for action to a statement of the action required". Cf. ainda Adami (1900), 234, Ausfeld (1903), 537 e Meyer (1933) 18, 34s.
} 


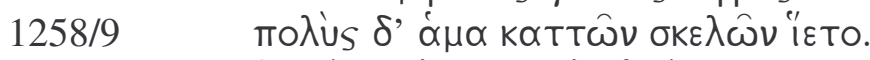

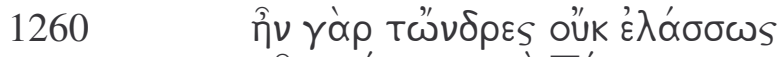

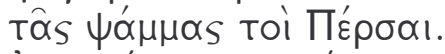

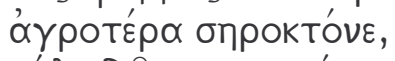

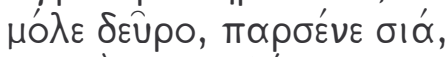

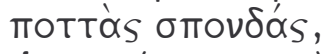

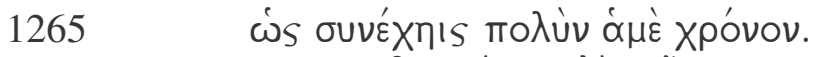

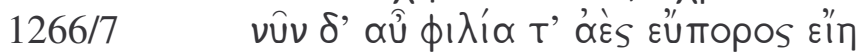

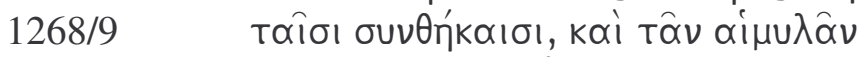

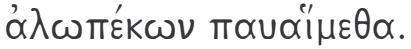

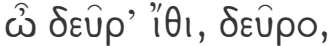

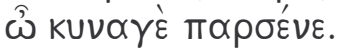

\section{A $\Theta H N A I \Omega N$ TPE $\Sigma$ BEYTH $\Sigma$}

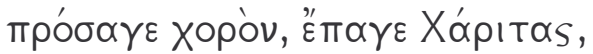

$1280 \quad \varepsilon \pi i \delta^{\prime} \varepsilon$ ká $\lambda \varepsilon \sigma o v$ "А

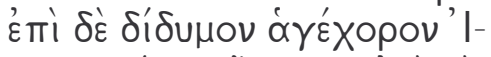

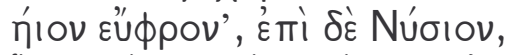

$1283 / 4$

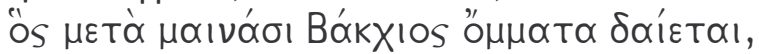

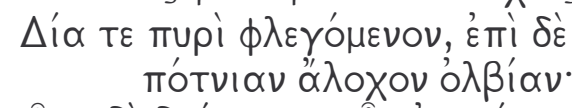

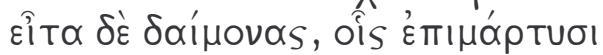

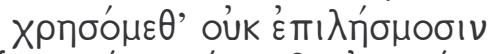

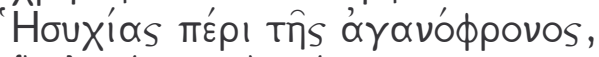

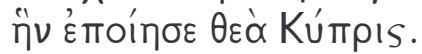

\section{XOPOS}

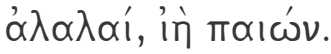

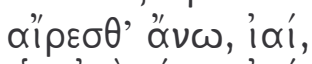

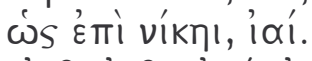

\section{(Embaixador espartano:}

Memória, expede a esse rapaz (= a mim) a sua própria Musa, que sabe a nosso respeito, quando naquele dia em Artemísion eles içaram velas feito deuses contra a esquadra e derrotaram os Medas; enquanto nós, nós éramos liderados por Leônidas, feito javalis a rangerem os dentes, de nossos queixos corriam rios de espuma, de nossas pernas também. O inimigo não era menos numeroso que as areias da praia, os persas. Senhora das selvas, algoz das feras, vem para cá, deusa virgem, testemunhe o nosso tratado, e nos mantenha unidos por muito tempo. Que a amizade agora flua abundante, sempre, sobre o nosso acordo, e paremos com essa história de trapacear um ao outro como raposas. Vem para cá, ó deusa virgem, para cá! 


\section{Embaixador ateniense:}

Dá início à dança, inclua as Graças, e convida Ártemis, e o seu irmão gêmeo, o benévolo curandeiro, e o deus de Nisa (= Dioniso) cujos olhos cintilam báquicos entre as mênades, e Zeus com a sua chama incandescente, e a afortunada senhora sua esposa, e ainda os poderes divinos a que rogamos testemunhar solenemente e não esquecer essa Paz bem intencionada que Afrodite arquitetou.

Coro:

Alalai, iê peã! Mexei-vos, iai! Rumo à vitória, iai! Evói evói, evai evai!)

Duas são as menções explícitas a fatos históricos na canção do embaixador espartano, que ensaia os passos da dipodia enquanto entoa o hino. Ambas referem-se à guerra contra os persas: a primeira à batalha naval de Artemísion, na qual os atenienses declararam-se vitoriosos (1249-53), a segunda à resistência heróica de Leônidas em Termópilas (1254-9), na qual forças espartanas rechaçaram por três dias as investidas persas e acabaram dizimadas. Trazer esses dois acontecimentos à memória é tarefa que o embaixador transfere à Musa, filha de Memória (1247-9), a qual impõe assim o seu aval divino à seção narrativa do canto. Tal seção é encerrada com um símile de tom grave, no qual prevalecem os espondeus (1260-1), mas a transição para o pedido propriamente dito é facilitada pela apóstrofe a Ártemis Agrotera (1262), que alude a outro fato histórico - a batalha de Maratona. ${ }^{359}$

A canção do embaixador ateniense expande a lista das divindades chamadas a comparecer à celebração e fecha progressivamente o foco sobre o momento presente. A anáfora quádrupla de $\varepsilon$ 'mi $\delta \dot{\varepsilon}(1280-5)$ e a freqüente resolução do metro trocaico-dactílico desse segundo canto imprimem maior premência ao pedido e refletem a excitação com a magnitude do evento. ${ }^{360}$ Os deuses - Ártemis e Apolo, Dioniso, Zeus e Hera - são invocados, como nota Henderson, "em ordem crescente de importância, com Afrodite no final". ${ }^{361}$ Sua relevância é sublinhada ainda porque entre o convite aos deuses e a menção a ela intercala-se o chamado aos poderes ( $\delta \alpha i ́ \mu o v \propto s$ 1287) para que testemunhem a paz alcançada por Cípris. Foi ela, afinal, que logrou reconciliar maridos e mulheres através do desejo mútuo, tal como narrado na peça.

Ao clímax que representa a referência a Afrodite, cujo epíteto dá fecho aos cantos antifônicos dos embaixadores, segue-se então um refrão do coro. O foco agora converge

${ }^{359}$ Cf. Henderson (1987), ad loc.

${ }^{360}$ Cf. Furley-Bremer (2001), vol. 2, 339 (ad 1281), e vol. 1, 349.

${ }^{361}$ Henderson (1987), 216. 
de vez sobre o instante atual: o enredo mistura-se à realidade na exortação para que o

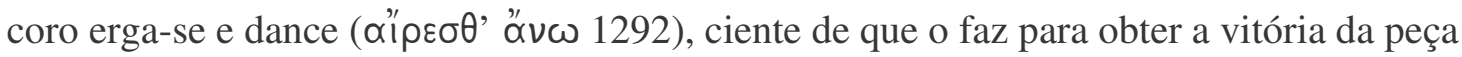

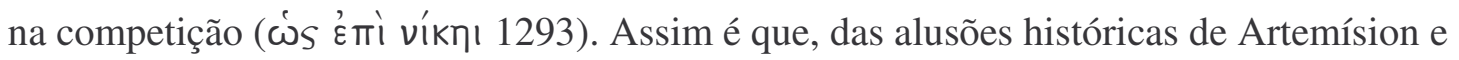
Termópilas, o canto transita à invocação dos deuses a começar por Ártemis, que conjuga em si outra referência histórica, à Maratona, e segue com o catálogo divino até atingir seu ápice na imagem de Afrodite, deusa cuja ação foi decisiva para o desfecho específico da peça. Esta, por sua vez, assume o foco das atenções no refrão do coro, no qual a platéia é lembrada da competição dramática de que é testemunha. ${ }^{362}$

O passado histórico é utilizado aqui para, ao ser mencionado, desencadear os seus efeitos benéficos sobre o presente. Também o passado mítico pode sê-lo, e de maneira tão direta e singela como no seguinte exemplo.

\subsubsection{Teógnis $773-782^{363}$}

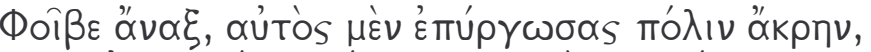

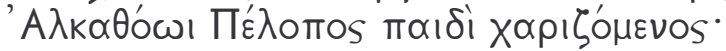

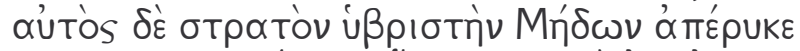

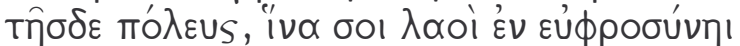

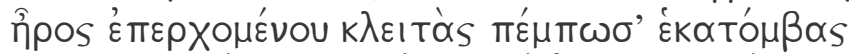

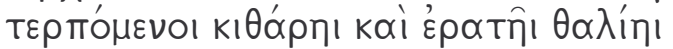

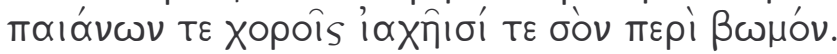

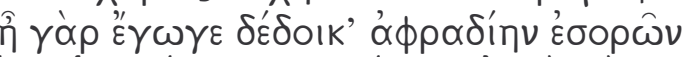

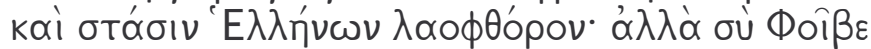

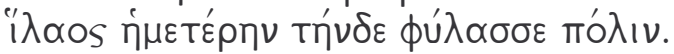

(Senhor Febo, tu que construíste a eminente cidadela como um favor a Alcato, filho de Pélops, mantém agora longe dessa cidade a agressão do exército meda para que, chegada a primavera, as pessoas possam enviar-te gloriosas hecatombes em meio a festividades, deleitando-se com a cítara e o adorável banquete e com as danças de peãs e os brados em volta do teu altar. Porque eu de fato receio quando vejo a luta dos gregos, uma luta brutal e que destrói o povo. Mas tu, Febo, protege indulgente essa nossa cidade.)

\footnotetext{
${ }^{362}$ Calame (2004), 169: “[...] this movement from the fictional action dramatized on stage to the cultic circumstances of its enunciation operates precisely in a song of ritual type, performed by a group of Athenian choreutai directed by a protagonist who, having been master of ceremonies, becomes its xopirós".

${ }^{363}$ West (1974), 65, seguindo uma sugestão de Carrière, aventa a autoria, não de Teógnis, mas de um certo Filíadas, poeta megarense.
} 
Apolo é chamado a tomar partido da cidade de Megara contra a invasão de Xerxes em 480 a.C. E a justificativa para que o faça reside no mito segundo o qual Alcato foi por ele auxiliado ao construir a cidadela.

Por si só enfática, a anáfora do pronome oưtós ‘tu mesmo' referente a Apolo é salientada ainda porque situada em duas frases contrastantes $\left(\mu \varepsilon^{\prime} \nu \ldots \delta^{\prime} \varepsilon_{\ldots} .\right)^{364}-$ a primeira constata um fato (o deus murou a cidadela de Megara), a segunda formula o pedido

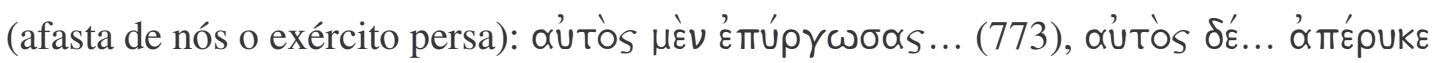
(775). O foco da ação presente também ganha destaque pela tripla repetição da palavra

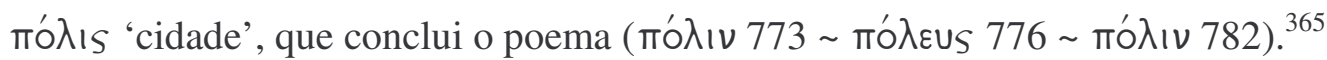

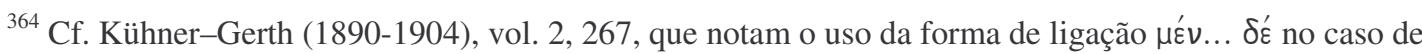
"Wiederholung (Anaphora) desselben [...] Wortes in zwei verschiedenen Sätzen, indem durch das trennende und das entgegenstellende $\mu \mu^{\prime} \nu . . . \delta^{\prime}$ der beiden Sätzen gemeinsame Begriff gleichsam räumlich auf zwei verschiedene Seiten gestellt, und dadurch die Bedeutsamkeit desselben hervorgehoben wird". Não se trata aqui, portanto, de um uso anafórico de $\mu \varepsilon^{\prime} \nu . . . \delta^{\prime} \varepsilon$ como simples ligação a fim de melhor repartir e acomodar o conteúdo da frase para assim lhe facilitar a compreensão, como ocorre por vezes em Heródoto

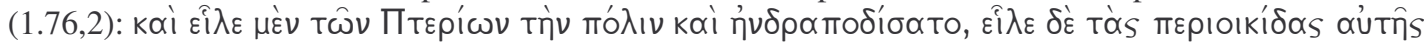

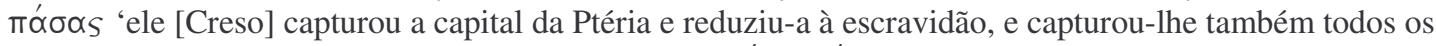
povoados vizinhos'. Acerca desse aspecto da ligação $\mu \varepsilon^{\prime} v$... $\delta^{\prime}$, contra o qual se destaca o uso que dele faz Teógnis (ou Filíadas), comenta Fehling (1969), 192: "Ferner ist für die Form charakteristisch die retorisch sehr schwache Verwendungsweise, die sie an vielen Stellen kaum als echte pointierte Wiederholungsfigur, sondern fast nur als besondere Art der Satzverbindung erscheinen läßt”. Cf. ainda Slings (1997), esp. 17192, para uma tentativa de delimitar quando a anáfora é figura de linguagem e quando é artifício natural para compartimentar as informações contidas na frase.

${ }^{365}$ West (Iambi et Elegi Graeci, Oxford, 1989) une os versos acima a este outro segmento, tornando-os um poema único, ao contrário do que costumam fazer outros editores:

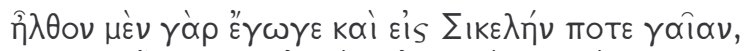

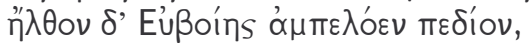

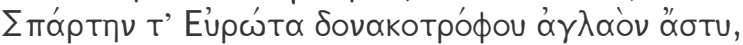

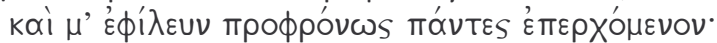

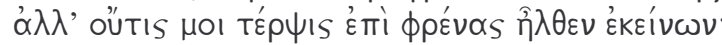

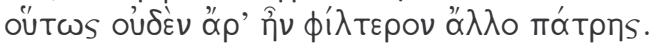

'Pois eu fui certa vez à terra da Sicília, fui à planície rica em vinhas da Eubéia e a Esparta, a esplêndida cidade do Êrotas que nutre caniços, e todas elas trataram-me com cordial amizade ao chegar. Mas nenhum prazer veio ao meu coração por causa delas, tão certo é afinal que nada é mais caro a alguém do que a sua pátria.'

Obviamente é possível combinar os versos, tanto mais que as duas partes exibem paralelismos

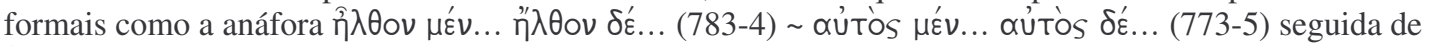

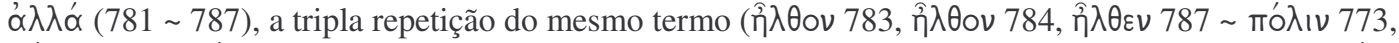

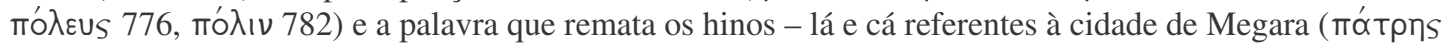

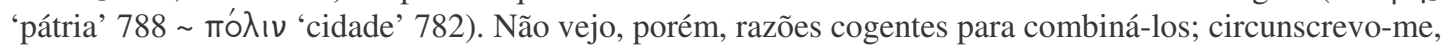
portanto, aos versos 773-82 e os considero como um conjunto autônomo. Cf. porém Faraone (2006), que sugere uma estrutura de estrofes alternadas (geralmente cinco ou seis) na elegia arcaica grega. Os seus exemplos são Tirteu, Calino e Xenófanes, os quais alternariam a intervalos regulares estrofes de exortação e meditação. No nosso exemplo - para quem toma os versos 773-88 como um segmento único -, talvez se 
Assim, da menção de um fato mitológico ( aủiòs $\mu$ źv... ) passa-se no mesmo fôlego (aưtós $\delta^{\prime} \varepsilon$... ) a imperativo que clama a ajuda divina diante do perigo iminente. Esse breve hino é na verdade a junção de dois tipos de prece comuns na tradição grega. Versos 773-6 correspondem ao tipo da quia dedisti: ${ }^{366}$ porque Apolo ergueu a muralha da cidade, que então expulse dela o perigo persa. Já os versos 776-9 mudam o enfoque com a promessa de uma hecatombe em meio a festividades; trata-se agora do tipo da ut dem, ou mesmo da ut dare possim: se Apolo mantiver longe a ameaça, será brindado ao som da cítara com um adorável banquete. Certa ansiedade - contida na frase "porque eu de fato receio quando vejo a luta dos gregos, uma luta brutal e que destrói o povo" (780-1) implica veladamente que, caso o inimigo não seja rechaçado, não haverá sacrifício. ${ }^{367} \mathrm{~A}$ mesma idéia é expressa na famosa prece de Teano a Atenas na Ilíada (6, 305-10):

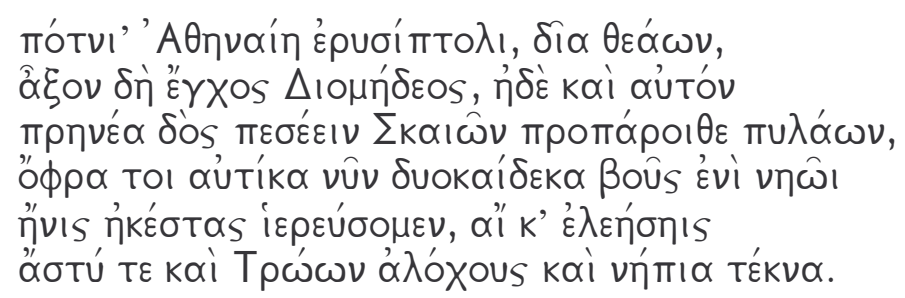

(Senhora Atena, guardiã da cidade, brilhante entre as deusas, rompe a lança de Diomedes e concede que ele próprio caia de cabeça diante dos portões Esqueus, de modo que possamos sacrificar agora de imediato a ti em teu templo doze novilhos de um ano, não domesticados, se tiveres piedade da cidade e das mulheres dos troianos e dos seus filhos pequenos.)

Sugere-se aqui também que os mortos não rendem homenagens aos deuses. ${ }^{368} \mathrm{O}$ sacrifício futuro é condicionado a uma ação divina iminente, na falta da qual o vínculo de reciprocidade será rompido.

\footnotetext{
possa argumentar que as cinco primeiras estrofes (773-82) correspondem à exortação (cf. os imperativos

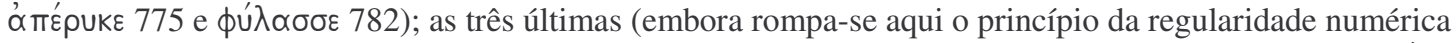
na alternância), à meditação (introduzida, como nos exemplos citados pelo autor, através da partícula yáp). ${ }^{366}$ Sobre esse e outros tipos de prece, cf. Bremer (1981), 196, e Pulleyn (1997), 17ss. et passim.

${ }^{368}$ Lang (1975) opina que a prece é rejeitada por ser demasiado brusca: esse não seria um modo adequado de tratar com a deusa, por intermédio de uma barganha. Já Morrison (1991) interpreta a negativa em termos de economia narrativa: a idéia inicial de Heleno, ao enviar Heitor a Tróia a fim de providenciar a prece, era apenas sustar a investida de Diomedes; Atena não teria como negar esse pedido à sua laboriosa sacerdotisa, mas o relato seria prejudicado, se a prece fosse aceita; Homero furta-se a tal dilema fazendo com que Teano peça não somente que Diomedes seja contido, mas que seja morto - algo absurdo, rejeitado com boa razão pela deusa. Cf. Pulleyn (1997), 27s.
} 
Seja como for, o poema de Teógnis inicia com uma alusão ao passado mítico e avança para uma promessa de tributo futuro ao deus. O eixo sobre o qual giram ambas as referências é o momento presente - a cidade sob ameaça estrangeira. Porque no passado Apolo foi benéfico a Megara (ele é de fato o patrono da cidade), que a ajude agora, nesse momento de crise, e assim poderá deliciar-se no futuro com as festividades em sua honra.

O passado também pode desaguar no presente ao cabo de um detalhado catálogo, e não através de uma simples menção como em Teógnis. No hino à ninfa Tebas que abre a Ístmica 7, Píndaro arrola momentos e figuras marcantes na história pregressa da cidade epônima.

\subsubsection{Píndaro, Ístmica 7, 1-22}

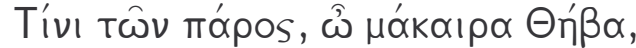
estr.A

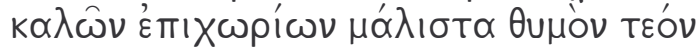

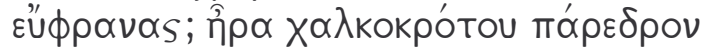

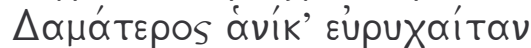

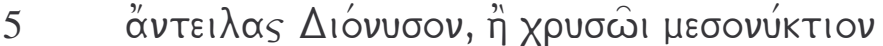

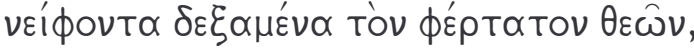

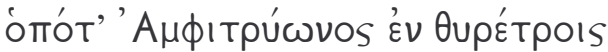

ant.A

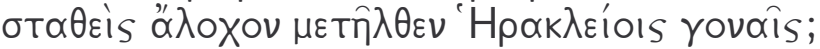

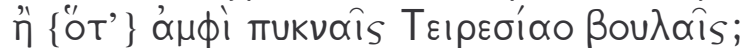

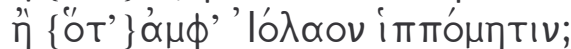

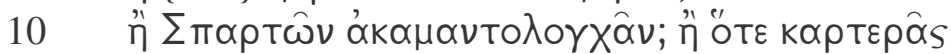

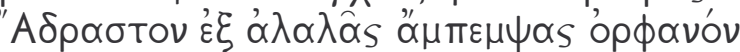

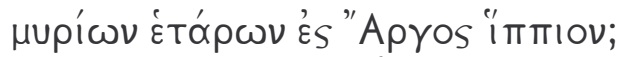
ep.A

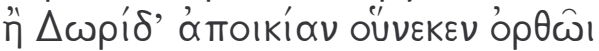

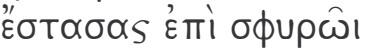

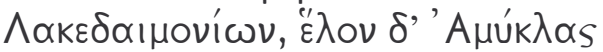

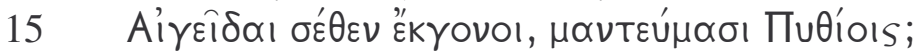

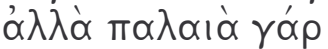

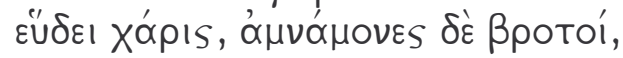

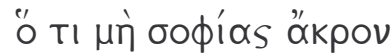

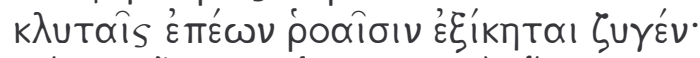

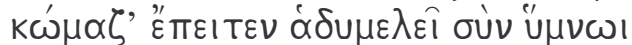

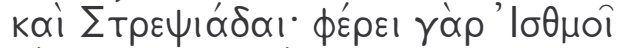

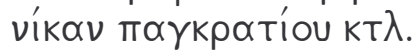

(Em qual das glórias passadas da tua terra, ó bem-aventurada Tebas, o teu coração mais se compraz? Foi quando criaste Dioniso da basta cabeleira para ser companheiro de 
Deméter do bronze que ressoa? Ou quando, em uma nevasca de ouro à meia-noite, tu recebeste o maior dos deuses, /

quando ele parou diante da porta de Anfitrião e foi ter com a mulher dele para conceber Héracles? Ou por causa de Tirésias dos conselhos argutos? Ou por causa de Iolaos, hábil cavaleiro? Ou em razão dos espartanos das espadas incansáveis? Ou quando mandaste Adrastos de volta da batalha renhida privado /

de inúmeros companheiros para Argos, terra de cavalos? Ou porque estabeleceste em bases firmes a colônia dórica dos lacedemônios, e teus descendentes, os Egidas, tomaram Amiclas de acordo com os oráculos píticos? Mas a glória antiga dorme e os homens esquecem / o que não atinge o primoroso ápice da sabedoria poética, jungido a renomadas correntes de versos. Celebra, portanto, em um hino de doce melodia também Estrepsíadas, pois ele foi vencedor no Istmo competindo no pancrácio...)

Pode-se dizer que toda essa passagem constitui um longo priamel para introduzir a figura do vencedor Estrepsíadas. Mas trata-se de um priamel especial, no qual a cadeia disjuntiva de perguntas, característica da dicção hínica, ${ }^{369}$ é utilizada simultaneamente no propósito de louvar a ninfa Tebas e mapear a história gloriosa da cidade. Pergunta-se a Tebas qual entre as glórias passadas é a que mais lhe enche de orgulho; seguem-se sete alternativas de temas em potencial, as três últimas referentes à força militar tebana. Estas compõem um crescendo, ${ }^{370}$ pondo em destaque a bravura defensiva na invasão dos Sete (10-11) e a proeza ofensiva do clã dos Egidas ao ajudarem os espartanos a tomar Amiclas e consolidar o poder dórico, em harmonia com o oráculo délfico (12-15). Na gnoma que segue (16-19), o progressivo movimento que começa a delinear-se rumo ao presente é sustado; os feitos anteriores, descritos como "antigos" ( $\pi \propto \lambda \propto \iota^{\prime} \alpha$ 16), ${ }^{371}$ são contrapostos à glória mais recente de Tebas - a vitória de Estrepsíadas. Bundy observa que Píndaro tem em mente aqui "a constante necessidade de renovar a tradição a fim de manter aceso o verdadeiro sentido das formas ideais criadas pelo passado". ${ }^{372}$ A lógica seria mais ou menos esta: se tu te compraz, ó Tebas, com todos esses feitos passados que acabo de

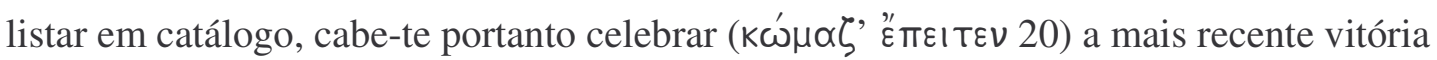
atlética que lhes dá o devido remate. É essa vitória, aliás, a par do seu canto celebratório, que ilumina, no presente, o restante das glórias passadas da cidade.

\footnotetext{
${ }^{369}$ Cf. Hino Homérico a Apolo, 207-16 e Teócrito, 22, 23-6, com nota de Sens (1997) ad loc.

${ }^{370}$ Cf. Race (1990), 36s. e 116.

${ }^{371}$ Race (1990), 117 n.86: " $\pi \propto \lambda \propto \iota \alpha ́$ provides a summary and intensification of $\tau \hat{\omega} \nu$ mópos (1), which established the context of the priamel in the first place". No mesmo sentido, Bundy (1972), 65.

${ }^{372}$ Bundy (1972), 66 n.72. Cf. ainda Willcock (1995), 62-5.
} 
O jogo entre o passado mítico e o presente no qual o hino é celebrado pode também assumir feições surpreendentes, como no poema 17 de Baquílides.

A narrativa tem início in medias res, com indicações alusivas do cenário no qual se desenrolará o episódio principal. O navio com Teseu a bordo transporta sete jovens e sete virgens a Creta, como tributo sacrificial pago por Atenas a título de compensação ao rei Minos pela morte do seu filho. Minos, também a bordo, não consegue porém conter o desejo por uma das virgens, Eríboia, e toca-lhe as faces brancas. A moça grita por ajuda, Teseu ouve e repreende Minos, pedindo que se contenha. A fala de Teseu é respeitosa; Minos é interpelado como "filho de Zeus" (20), como "herói” (23); mas se Minos é filho de Zeus, ele, Teseu, é filho de Posêidon, e portanto lhe é dado ordenar a Minos que dê cobro a sua insolência e largue mão da jovem; do contrário eles chegariam às vias de fato

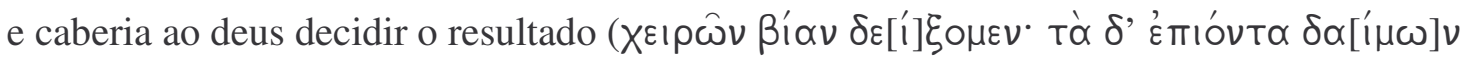
кคIVEิ 45-6).

Minos aceita o desafio: desconsiderando seu ato insolente, restringe-se à questão da ascendência, e a resposta vem na forma de uma prece a Zeus. Se ele é de fato o seu filho, diz, que Zeus lhe envie um sinal na forma de um raio; quanto a Teseu, para provar que foi por Posêidon concebido, que mergulhe agora nas profundezas do mar e traga-lhe de volta este anel que ele, Minos, lança às águas. O rei mostra-se confiante, irônico - ele

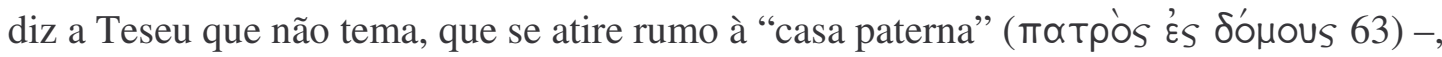
e de fato Zeus ouve a sua prece emitindo-lhe um raio. Em glória, Minos reitera o desafio que Teseu dê provas de que Posêidon é seu progenitor. Teseu não se apequena; da popa salta ao mar, que lhe acolhe indulgente. Minos, receoso, ordena que o navio siga no seu curso, impelido pelo vento norte; o grupo de jovens treme e verte lágrimas pelo seu herói, temendo pelo pior.

Debaixo d'água, contudo, golfinhos levam-no à casa do pai; lá ele admira-se com o fulgor emitido pelos corpos das Nereidas, que se divertem dançando com pés líquidos. Lá também se encontra Anfitrite, a esposa do seu pai, por quem é presenteado com um manto púrpura e uma guirlanda que recebera de Afrodite quando do seu casamento com o deus dos cavalos.

O retorno à superfície e à narrativa principal é feito através de uma gnoma: "nada

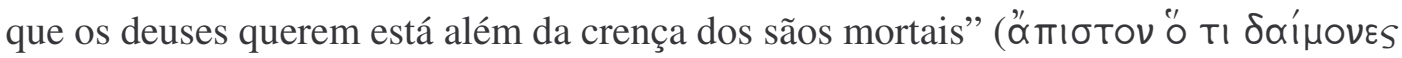




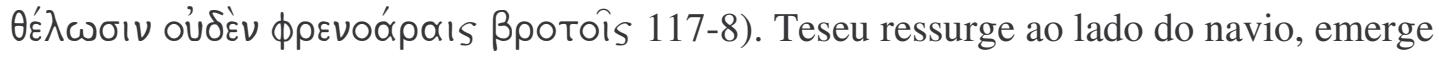
do mar sem ter-se molhado, um milagre para todos - e as dádivas divinas brilham em seu

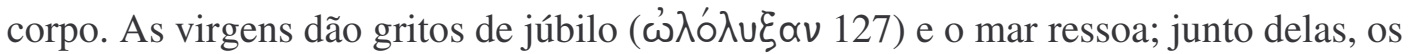

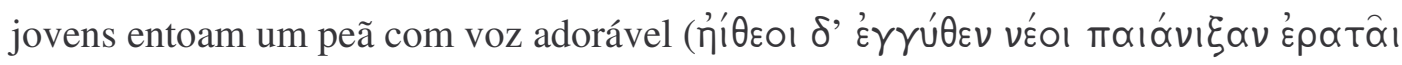
ơrí 128-9).

É então que o relato dá uma guinada final imprevista.

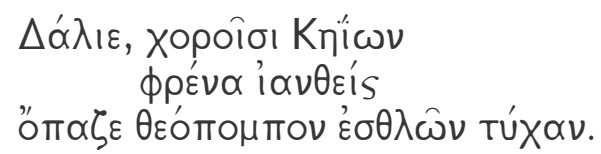

'Deus de Delos, deleita-te em teu coração com os coros dos habitantes de Ceos e concede uma fortuna de bênçãos enviada pelos deuses.'

A epiclese $\Delta \alpha^{\prime} \lambda_{1 \varepsilon}$ (130) parece reproduzir o canto dos jovens atenienses a bordo do navio, mas esse peã mítico logo se transforma no pea ${ }^{373}$ do coro real que, naquele momento, interpela Apolo no contexto específico de uma performance. Ou melhor, o peã do coro mítico é ao mesmo tempo o canto que o coro dos habitantes de Ceos entoa em uma situação real, na ilha de Delos. Os dois coros, o mítico e o real, entremesclam as suas vozes de maneira peculiar. "Os n’îعoı”, diz Käppel, ${ }^{374}$ "revelam-se subitamente como o coro dos habitantes de Ceos, ou por outra: o público reconhece na suspensão da

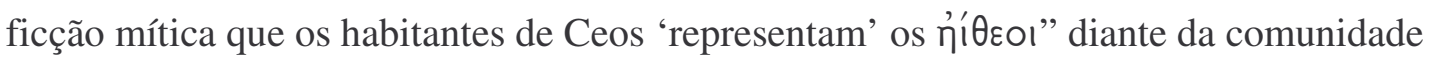
dos délios reunida em festa.

O passado mítico irrompe assim de imprevisto, nos três versos finais, em meio ao presente da celebração cultual. Os dois coros dão-se a conhecer como um só; um e outro, passado e presente, têm as suas fronteiras anuladas, e com isso o mito exerce o seu poder e peso benéficos sobre a ocasião na qual o canto é apresentado. A estratégia de encurtar a distância entre passado e presente, ou antes, de trazer o passado até o presente a ponto de torná-los indistinguíveis não é exclusividade da ode 17 de Baquílides. Outros hinos se valem do mesmo recurso, e ecos desse artifício também podem ser distinguidos em certos epinícios pindáricos. É o que veremos no próximo item.

\footnotetext{
${ }^{373}$ Sobre a questão do gênero do poema de Baquílides - se peã ou ditirambo -, cf. Schröder (2000), Schmidt (1990), Käppel (1997), 156-89, esp. 183-9, Burnett (1985), 36, e Snell (1980), 95s.

${ }^{374}$ Käppel (1997), 183.
} 


\subsection{UNIÃO DE OPOSTOS}

Durante séculos - pelo menos desde Baquílides até Plutarco - vigorou em Delfos o costume de homenagear Dioniso nos três meses de inverno com a apresentação de ditirambos. No restante do ano, a começar da primavera, peãs eram entoados em honra de Apolo. ${ }^{375} \mathrm{O}$ acentuado contraste de gêneros entre ditirambo e peã já figura implícito na abertura do poema 16 de Baquílides, um ditirambo composto no século V a.C. para ser apresentado em Delfos. Nele, o poeta refere-se à própria canção, ao próprio ditirambo que ele entoa naquele momento, como obra levada a público no período que antecede o retorno de Apolo a Delfos, quando então o deus é saudado com peãs:

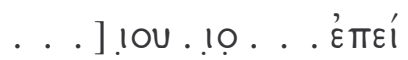

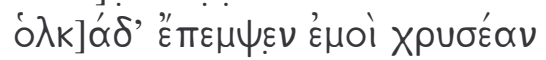

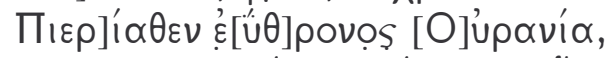

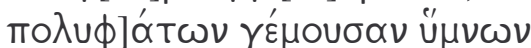

5 . . . . ] veııाı

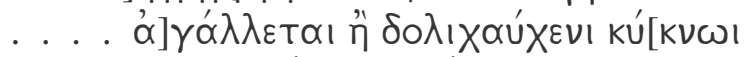

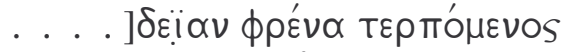

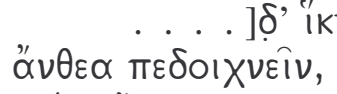

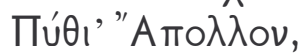

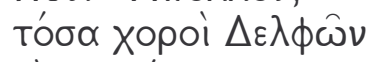

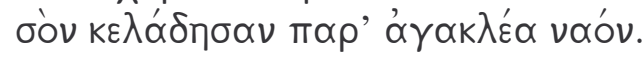

$\pi \rho i ́ \nu \gamma \varepsilon k \lambda \varepsilon^{\prime} \circ \mu \varepsilon \nu \lambda_{I} \pi \varepsilon \hat{\imath} \nu$

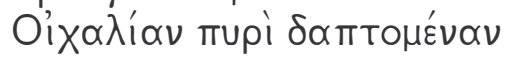

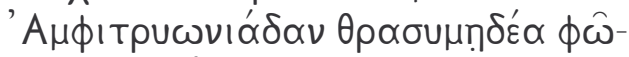

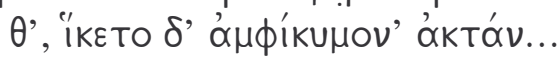

(... uma vez que Urânia do belo trono enviou-me de Piéria um navio de carga repleto de canções gloriosas ... [5] junto ao rio Hebro em flor ele rejubila-se [com...?] ou com o cisne de longo pescoço ... contentando o seu coração ... tu vens, [10] Apolo Pítio, em busca das flores dos peãs - tantas quantas os coros dos délfios bradam ao lado do teu famoso templo. I

Mas antes disso, cantamos como o filho de Anfitrião, [15] o ousado mortal, deixou Ecália em chamas e veio até a praia banhada por ondas...)

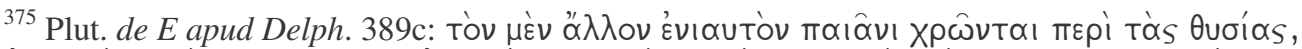

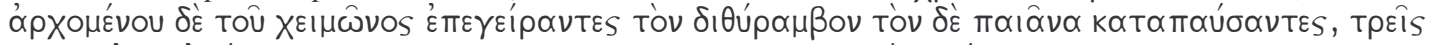

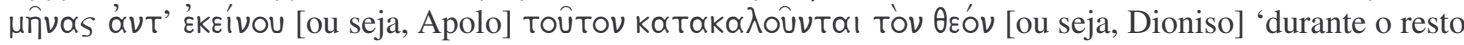
do ano eles usam o peã para acompanhar sacrifícios, mas quando começa o inverno eles despertam o ditirambo, pondo de lado o peã, e invocam este deus (Dioniso) em vez daquele (Apolo)'.
} 
A compreensão dos oito primeiros versos é prejudicada pelo caráter fragmentário do papiro, mas Baquílides parece propor-se cantar a história de Héracles, Dejanira e Nesso (13ss.) na forma de ditirambo antes que, chegada a primavera, Apolo retorne da sua temporada entre os Hiperbóreos. Jebb ${ }^{376}$ fornece um bom resumo da passagem: "Apolo acha-se ausente, no norte, divertindo-se nas margens do Hebro, até que chegada seja a hora de ele retornar ao seu lar pítico e, assim, deleitar-se mais uma vez com os peãs dos coros délficos".

Em meados do século IV a.C., contudo, um peã da autoria conjunta de Filodamo de Escarféia e os seus irmãos põe em xeque esta clara repartição cultual délfica entre peã e ditirambo, Apolo e Dioniso, inverno e restante do ano. O peã de Filodamo, dedicado a Dioniso, foi composto para a inauguração do sexto templo em Delfos (provavelmente em 340/339 a.C.) e destinava-se à apresentação no festival da Teoxenia, durante a primavera. Doze são as estrofes do poema, quatro delas hoje ilegíveis $(4,6-8)$, sendo provável que as seis primeiras narrassem o nascimento de Dioniso e os vários sítios sagrados pelos quais passou até chegar ao Olimpo; as últimas seis giram em torno do estabelecimento do culto a Dioniso em Delfos, onde ele e o seu irmão Apolo terão igual parcela nas honrarias. Mas vamos ao peã. ${ }^{377}$

\subsubsection{União de gêneros: Filodamo, Peã a Dioniso}

[. . . . . . ] $\triangle 1 \theta u ́ p \propto \mu \beta \varepsilon, B^{\prime} \alpha \chi \chi^{\prime}$

estr.I

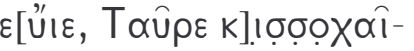

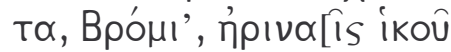

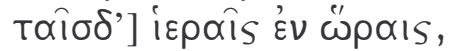

5

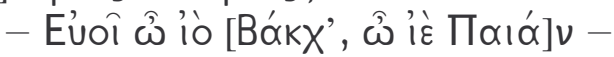

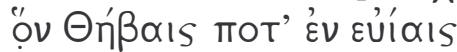

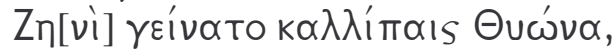

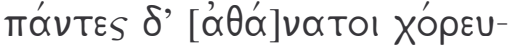

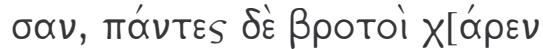

10

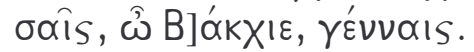

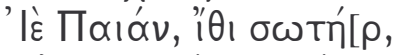

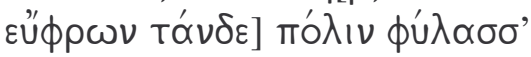

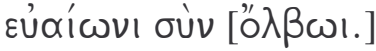

\footnotetext{
376 Jebb (1905), 221.

377 O texto é de Furley-Bremer (2001), vol. 2, 53ss., com a correção de algumas gralhas.
} 


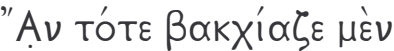

estr.II

$15 \chi \chi \theta \omega \dot{\omega}[\nu \ldots . . . . ..] \tau \varepsilon K^{\prime} \alpha \delta_{-}$

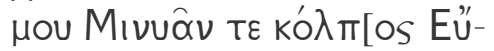

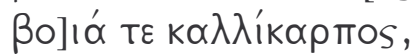

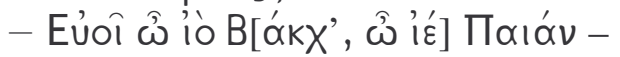

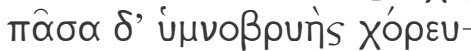

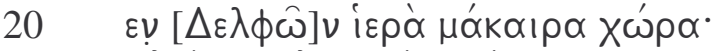

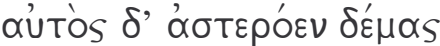

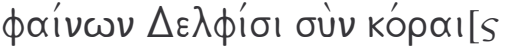

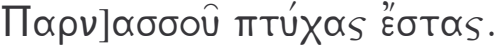

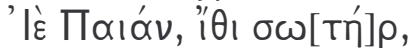

25

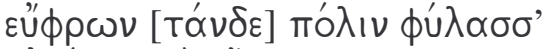

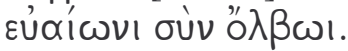

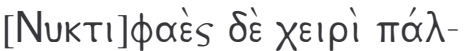

estr.III

$\lambda \omega \nu \sigma\left[\varepsilon^{\prime} \lambda\right] \alpha_{S} \varepsilon^{\prime} \varepsilon \theta^{\prime} \dot{\varepsilon}$ ols [. . . . . . .]

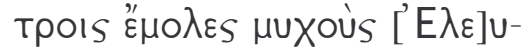

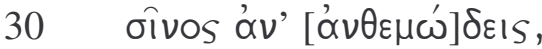

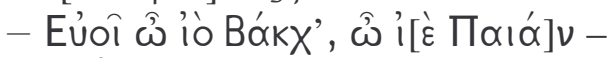

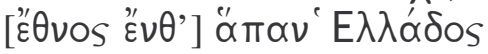

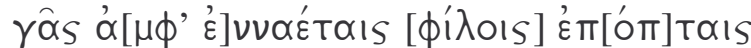

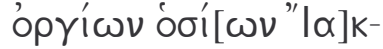

35

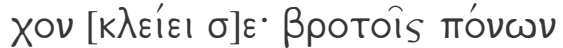

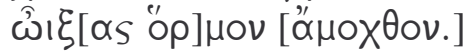

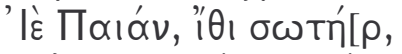

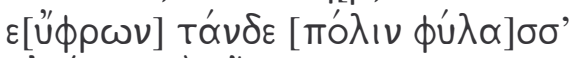

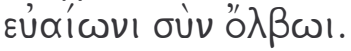

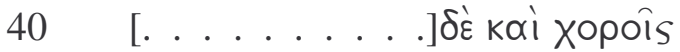

estr.IV

$\gamma[\ldots . . .$.$] . . . Is$

$[\ldots \ldots \ldots . \ldots . \ldots k \mathrm{k} \gamma$

$[\ldots \ldots \ldots . \ldots]_{S}$

$[. ..] \cup \theta \ldots$. . up[

. $\lambda$. то...v[....]

50

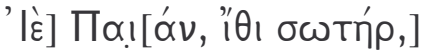

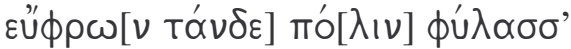

$\varepsilon[\dot{u} \alpha i \omega v ı$ б]نे[v" ò $\lambda \beta \omega ı$.

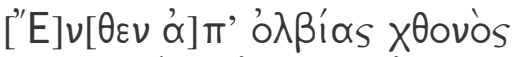

estr.V

$\Theta \varepsilon \sigma\left[\sigma \alpha \lambda \alpha^{\prime} \alpha_{S}\right]$ है $\varepsilon \varepsilon \lambda \sigma \alpha \alpha_{S}{ }^{\prime \prime} \sigma-$

55

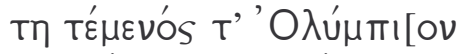

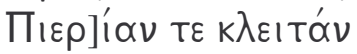

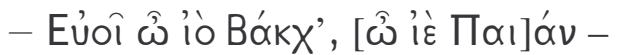

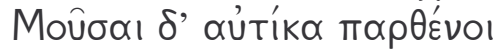




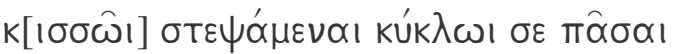

60

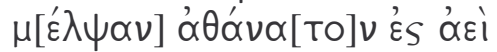

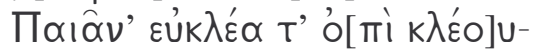

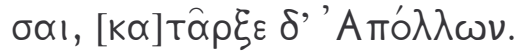

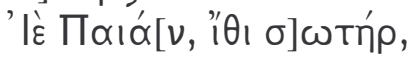

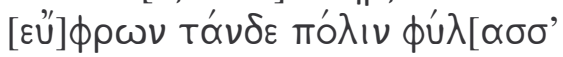

65

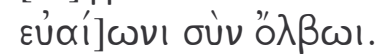

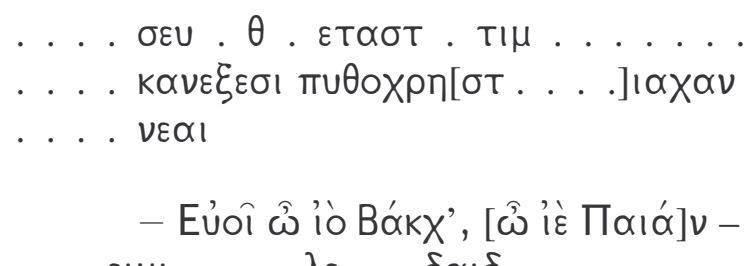

$\ldots \varepsilon ı \mu ı \ldots . \lambda \varepsilon \ldots \delta \alpha ı \delta \ldots . . . . . \pi$. . . . . . .

$[\ldots . . . . .]. v \phi \circ$

estr.VI

$\pi \propto \lambda[$

$\rho \omega \nu \phi 1 \lambda[$

estr.VII

$\omega \nu \pi \rho \circ \phi \eta[$

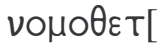

$\pi \alpha \lambda \lambda . k[$

$\omega \sigma[$

$v \propto \pi \varepsilon \mu \pi \varepsilon[$

estr.VIII

OІбєßОu[

$\omega \sigma \delta \cup \sigma \alpha \nu T[$

бІV $\varepsilon \times \rho \theta \theta \pi \circ[$

. $\varepsilon \chi \omega \rho \propto \nu \varepsilon \lambda \varepsilon$

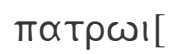

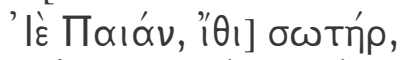

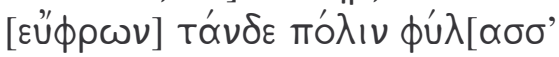

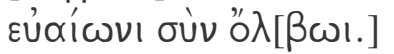

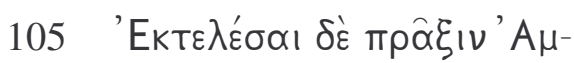

estr.IX

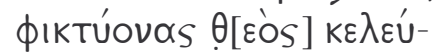

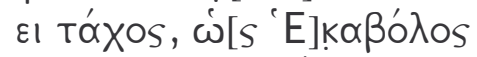

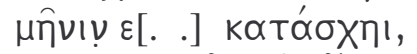

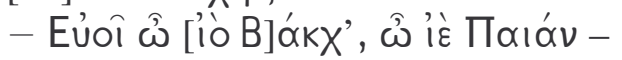

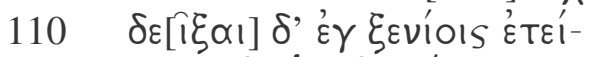

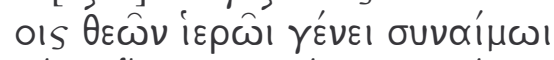

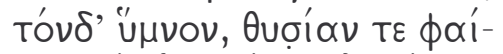

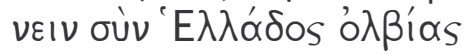

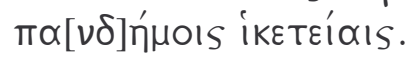

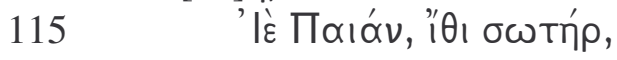




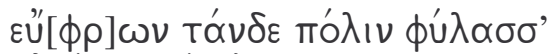

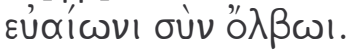

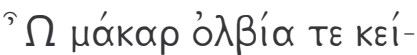

estr.X

120 $\nu \omega \nu \gamma \varepsilon[v \varepsilon \dot{\alpha}] \beta \rho o t \omega \hat{\nu} \alpha^{\alpha} \gamma \eta^{-}$

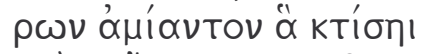

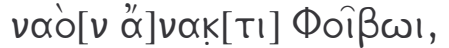

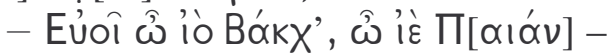

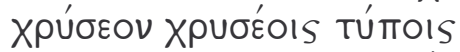

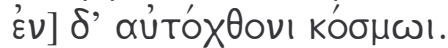

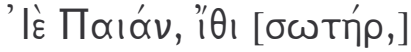

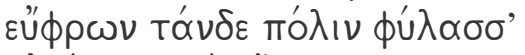

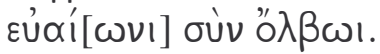

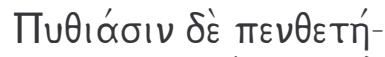

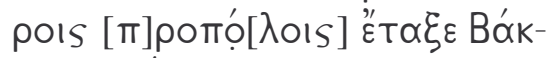

estr.XI

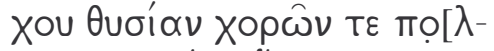

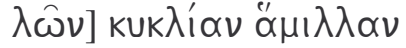

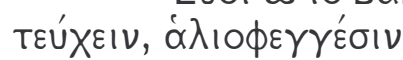

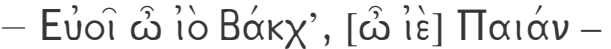

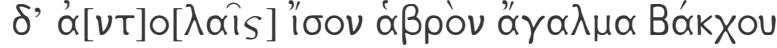

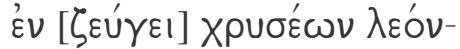

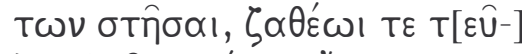

$140 \xi \alpha$ छ $\theta \varepsilon \omega \hat{~}$

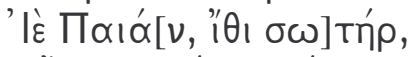

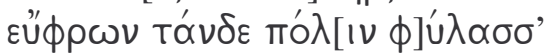

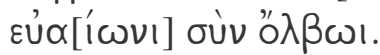

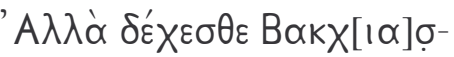

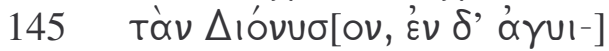

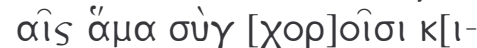

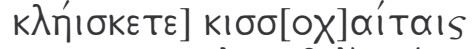

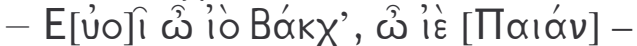

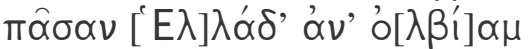

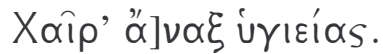

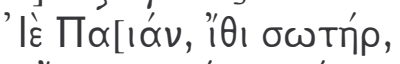

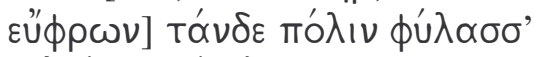

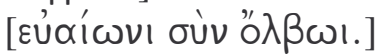


([I] ... ó Ditirambo, Baco, deus do êxtase, Touro com uma guirlanda de hera nos cabelos, Bramador, vem para cá nessa sagrada estação da primavera - evoé, ó iô Baco, ó iê Peã! -, a quem um dia na extática Tebas Tiona do belo filho deu à luz, sendo Zeus o pai. Todos os imortais puseram-se a dançar, todos os mortais em júbilo pelo teu nascimento, ó Baco. - Iê Peã, vem Salvador, protege de bom grado essa cidade com próspera fortuna.

[II] Naquele dia a terra de Cadmo saltava feito bacante, e o vale dos mínios também e a fértil Eubéia - evoé, ó iô Baco, ó iê Peã! -. Pejada de hinos, toda a sagrada e abençoada região de Delfos dançava, enquanto tu, tu revelaste o teu corpo estrelado, tomando posição nos penhascos do Parnaso na companhia das donzelas de Delfos. - Iê Peã, vem Salvador, protege de bom grado essa cidade com próspera fortuna.

[III] Brandindo a tocha nas tuas mãos - luz na escuridão da noite -, tu chegaste em teu entusiasmo aos recantos de Elêusis cobertos de flores - evoé, ó iô Baco, ó iê Peã! -, onde toda a nação da terra grega, em volta das testemunhas nativas dos mistérios sagrados, invoca-te como Íaco: tu abriste aos mortais um porto contra os males, livre de pesares. Iê Peã, vem Salvador, protege de bom grado essa cidade com próspera fortuna.

[IV] ... e com coros ... - Iê Peã, vem Salvador, protege de bom grado essa cidade com próspera fortuna.

[V] Daquela terra abençoada tu aportaste nas cidades da Tessália, nos recintos sagrados do Olimpo e na famosa Piéria - evoé, ó iô Baco, ó iê Peã! -, e as Musas, coroando-se de pronto com hera, cantaram e dançaram todas em círculo para a tua honra, proclamando-te imortal para sempre e famoso Peã, e quem liderava a dança era Apolo. - Iê Peã, vem Salvador, protege de bom grado essa cidade com próspera fortuna.

$[\mathrm{VI}] ? ? \ldots$

[VII] ??...

[VIII] ... - Iê Peã, vem Salvador, protege de bom grado essa cidade com próspera fortuna.

[IX] O deus ordena aos anfictiões executarem a ação com rapidez, para que o deus que atira longe contenha a sua ira - evoé, ó iô Baco, ó iê Peã! - e apresentarem esse hino para o sagrado rebento fraterno (= Dioniso) por ocasião do banquete anual dos deuses, e fazerem um sacrifício público quando das súplicas pan-helênicas da abençoada Hélade. Iê Peã, vem Salvador, protege de bom grado essa cidade com próspera fortuna.

[X] Oh, feliz e afortunada a geração daqueles mortais que constrói ao senhor Apolo um templo que não envelhece, que não se corrompe, um templo - evoé, ó iô Baco, ó iê Peã! de ouro com estátuas de ouro [onde] as deusas rodeiam [Peã], o seu cabelo luzente com marfim, adornado com uma guirlanda nativa. - Iê Peã, vem Salvador, protege de bom grado essa cidade com próspera fortuna. 
[XI] Aos organizadores do quadrienal festival pítico, o deus deu ordem de instaurar em honra de Baco um sacrifício e uma competição de vários coros circulares (= ditirambos) evoé, ó iô Baco, ó iê Peã! - e de erigir uma formosa estátua de Baco igual aos raios do sol nascente, sobre uma carruagem puxada por leões dourados, e de fornecer uma gruta conveniente ao santo deus. - Iê Peã, vem Salvador, protege de bom grado essa cidade com próspera fortuna.

[XII] Pois bem, acolhei Dioniso, deus das bacantes, e clamai por ele nas vossas ruas com coros coroados de hera: - evoé, ó iô Baco, ó iê Peã! -. Por toda a abençoada Hélade ... Salve, senhor da Saúde! - Iê Peã, vem Salvador, protege de bom grado essa cidade com próspera fortuna.)

Filodamo inova não somente por estender o culto dionisíaco primavera adentro

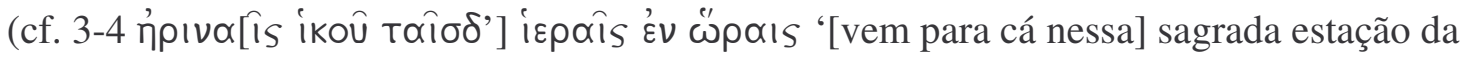
primavera'), mas sobretudo por celebrar Dioniso como Peã, "um título cultual reservado normalmente a Apolo ou Asclépio". ${ }^{378}$ E mais: ao celebrá-lo como Peã, Filodamo chama a atenção para o próprio gênero da canção na qual exalta Dioniso: não um ditirambo, mas justamente um peã. Isso porque uma canção só é digna do nome moı́óv se a divindade à qual ela se dedica puder ser invocada como $\pi \propto \iota^{\alpha} \nu$. O principal artifício de que lança mão o poeta para frustrar as expectativas da platéia e tornar Dioniso o legítimo destinatário da epiclese "peã" são o meshumnion

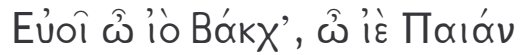

'evoé, ó iô Baco, ó iê Peã!’

e o ephumnion

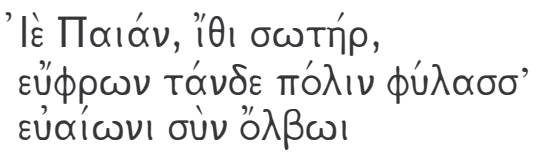

'Iê Peã, vem Salvador, protege de bom grado essa cidade com próspera fortuna' que preenchem respectivamente os versos 5 e 11-13 de cada uma das doze estrofes do hino.

\footnotetext{
${ }^{378}$ Furley-Bremer (2001), vol. 1, 127. Cf. ainda Käppel (1997), 207-84, cujos comentários servem de guia e inspiração para a análise que segue.
} 
Na primeira estrofe, o meshumnion ${ }^{379}$ ganha nitidez por separar claramente duas semi-estrofes distintas. Se nos versos 1-4 Dioniso é interpelado inicialmente com uma seqüência de pelo menos seis vocativos ${ }^{380}$ rematados por um apelo para que a divindade compareça ao instante presente no qual o hino é apresentado (o festival de primavera da Teoxenia), os versos posteriores ao meshumnion já mudam, por sua vez, de enfoque, a começar pela predicação relativa que inaugura o verso 6 ("o

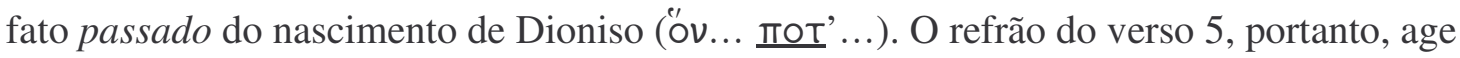
como divisor de águas entre a Delfos do presente e a Tebas do passado, onde a vinda ao mundo do filho de Zeus e Tiona pôs os deuses a dançar e encheu de júbilo os mortais (6$10)$.

Dioniso, note-se, não é aqui chamado pelo nome, mas a dupla apóstrofe BókX’ (1) e Bók $\chi ı$ (10) - uma na primeira semi-estrofe, a outra na segunda ${ }^{381}$ - contribui para criar um sentido de coesão com o meshumnion, no qual também figura o epíteto ( O alinhave, todavia, não se dá apenas entre as duas primeiras semi-estrofes, mas estendese ainda à estrofe seguinte, com o verbo inaugural em tmese $\alpha^{\prime} v[\alpha] \ldots \beta \propto \alpha \chi i \propto \zeta \varepsilon$ 'dançar, pular em êxtase' (14). Na verdade, o elo entre as duas estrofes é mais elaborado e serve para integrar meshumnion e ephumnion ao fluxo da narrativa, ao mesmo tempo que lhes confere destaque como elemento articulador do relato. O nascimento do deus desencadeia um movimento de expansão que anima deuses e mortais na primeira estrofe e galvaniza, na segunda, a própria natureza. Todos os deuses, diz Filodamo, puseram-se a dançar,

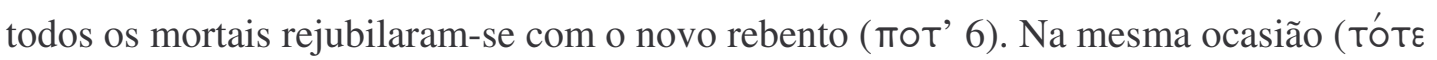
14) o mundo natural, representado por três paisagens terrenas em forma de catálogo, foi tomado pelo êxtase (14-7). Esse breve catálogo, além disso, descreve em linhas gerais

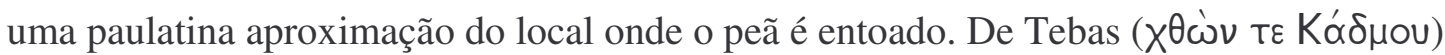

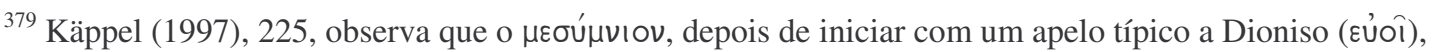
congrega e aplica ao deus dois elementos contrários mas paralelos, um próprio do ditirambo (

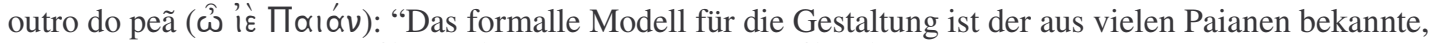

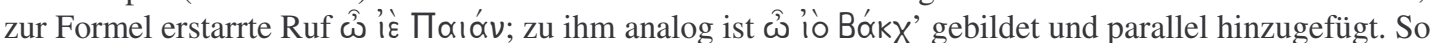
entsteht insgesamt ein Vers, der in seiner Form ein Gattungsmerkmal des Paian aufnimmt und in eine neue Funktion - den Anruf an Dionysos - überführt". Käppel sugere ainda (222-32 et passim) que as duas semiestrofes ao longo do hino obedecem em geral a uma divisão de conteúdo, a pimeira marcada por aspectos característicos de Dioniso, a segunda por alusões mais congeniais a Apolo.

${ }^{380}$ Ou talvez sete, caso a lacuna inicial seja suplementada com $\Delta \varepsilon u \hat{\rho}$ ' 'óva 'vem para cá, senhor', como sugere Weil.

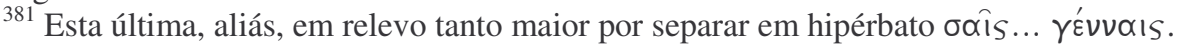




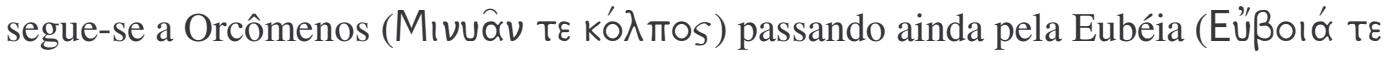

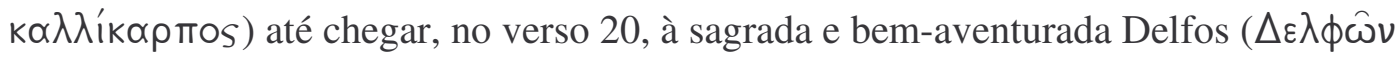

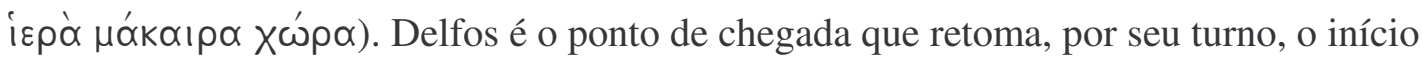
desse movimento de expansão. Se antes as esferas divina e humana uniram-se em um único conjunto através da anáfora $\pi \alpha^{\prime} \nu T \varepsilon S \delta^{\prime} \sim \pi \alpha{ }^{\prime} \nu T \varepsilon S \delta^{\prime} \varepsilon$ (8-9), agora é também toda a região de Delfos ( $\pi \widehat{\alpha} \sigma \alpha \delta^{\prime}$ 19) que, carregada de canções, ensaia os seus passos de dança.

Esse arco que leva do mundo animado ao inanimado, de todos os deuses e mortais à toda a região de Delfos, é sublinhado ainda por outro fator. A referência a Delfos figura ao cabo do catálogo com três sítios naturais, do qual ela é o fecho: são três locais ligados

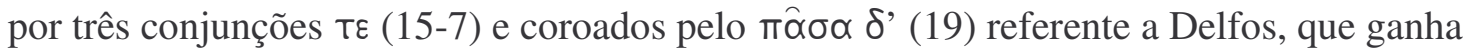
destaque por ocorrer logo após a quebra representada pelo refrão, no início do verso. Mas toda essa expansão, habilmente combinada pelo poeta com a simultânea convergência do foco sobre o sítio délfico, atua por sua vez como contraste para a epifania de Dioniso (213). Aos dois verbos de movimento conjugados no imperfeito, relativos ao entusiasmo que

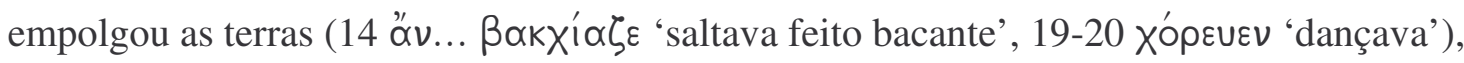
segue-se um verbo de estado no aoristo a fim de marcar, mediante a oposição, o ápice do

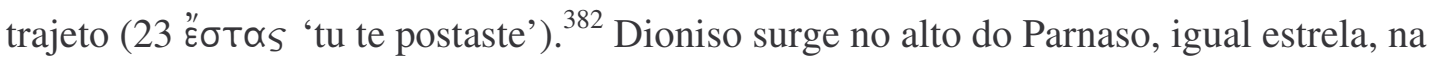
companhia das donzelas de Delfos. Para sublinhar o contraste, o relato passa da terceira para a segunda pessoa; ao $\mu \mu^{\prime} v$ do verso 14 responde o $\delta$ ' do verso 21: de um lado dançam extáticas as nações, de outro Dioniso em pessoa ( đữòo $\delta$ ') faz a sua epifania. ${ }^{383}$

As seções narrativas (versos 1-4 e 6-10 de cada estrofe) acham-se metricamente delimitadas em relação aos refrões pela catalexe ao final dos versos 4 e $10 .{ }^{384}$ No entanto, é evidente o esforço do poeta para integrá-las aos refrões, e isso tanto no interior de cada uma delas quanto entre as estrofes. O meshumnion, como vimos, serve como divisor entre presente e passado, entre Delfos e Tebas na estrofe I, ao passo que o ephumnion encadeia as reações que o nascimento de Dioniso provoca entre deuses, mortais e natureza (cf. a

\footnotetext{
${ }^{382}$ Cf. Furley-Bremer (2001), vol. 2, 67.

${ }^{383}$ Sobre a correlação $\mu \mu^{\prime} \nu$ - $\delta^{\prime} \varepsilon$ dos versos 14 e 21, cf. Käppel (1997), 233, n.109. Versos 21-3 sobressaem

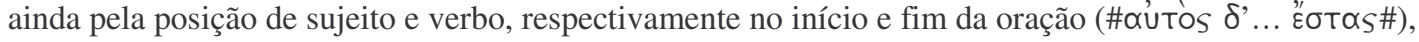
sendo a frase delimitada ainda pela pausa retórica ao final do verso 20 - um verso, a propósito, catalético.

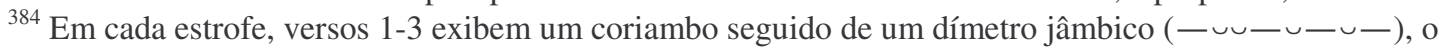

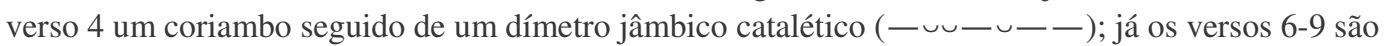
preponderantemente glicônicos $(-x-\cup \cup-\cup-)$, enquanto o verso 10 representa a sua forma catalética, o ferecráteo $(-\times-\cup \cup--)$. (Exceção é o verso 7: glicônico seguido de báquico $-\times-\cup \cup-\cup-\cup-\longrightarrow)$.
} 
correlação пот' 6 то́тє 14). Já o ephumnion da estrofe II leva adiante esse movimento de expansão sobre o mundo natural, mas amplifica a importância de Delfos ao apartá-la das demais localidades, preparando assim o terreno para a epifania de Dioniso no monte Parnaso. Ao serem integrados ao relato, os refrões lhe conferem estrutura e, sobretudo, atraem a atenção para seu conteúdo e propósito peculiares - legitimar Dioniso como deus Peã, a quem um peã é endereçado.

O clímax desse desenvolvimento coincide com o ponto alto da narrativa, quando Dioniso chaga ao Olimpo na estrofe V. Até ali a divindade percorrera várias estações correspondentes aos seus sítios de devoção: de Tebas na primeira estrofe ele transitara a Delfos na segunda, e dali seguira para Elêusis (29-30) na terceira, onde a Hélade inteira o invoca como Íaco e onde ele permanece provavelmente durante toda a estrofe IV. É de lá então, dessa terra abençoada (Elêusis?), que ele aporta nas cidades tessálias, nos recintos sagrados do Olimpo e na famosa Piéria no início da estrofe seguinte (53-6), a quinta.

Tais versos destacam um conjunto geográfico que se contrapõe não só à marcha de cidade a cidade descrita em cada estrofe (Tebas, Delfos, Elêusis), mas também ao catálogo contido na primeira metade da estrofe II (14-8). Lá, como vimos, o propósito era convergir o foco sobre Delfos à força do deslocamento topográfico entre regiões diversas (Tebas, Orcômenos, Eubéia), cada uma delas um marco individual da reação suscitada pelo nascimento de Dioniso. Aqui, ao contrário, trata-se de um trajeto descrito ao redor de um mesmo ponto geográfico, o Olimpo. As cidades da Tessália, os recintos olímpicos e a Piéria não indicam, como nota Käppel, ${ }^{385}$ "três locais distintos e independentes entre si, nos quais Dioniso fez a sua aparição e sobre os quais agiu em momentos diversos, mas representam o percurso do deus na vizinhança imediata de um único lugar, que agora é o seu destino final". O Olimpo ganha assim em vulto pelo contraste obtido, e é nele que se dará um fato crucial não somente para a narrativa do hino, mas sobretudo para justificar o hino como peã.

Uma vez na Piéria, as Musas coroam a si mesmas com hera e dançam e cantam à volta de Dioniso, chamando-o Peã; à frente delas, quem lidera a dança é Apolo. É nesse ponto do relato mítico que Dioniso, interpelado como Peã pelas Musas, torna-se legítimo destinatário de um hino que o interpela como Peã em ambos os refrões. A Filodamo, em

${ }^{385}$ Käppel (1997), 243s. 
suma, é lícito chamar Dioniso de Peã porque as Musas o fazem, e com o aval de ninguém menos senão Apolo - o deus Peã por excelência. A chancela de Apolo e das Musas ao novo estatuto de Dioniso como Peã é tanto mais saliente por vir expressa em uma frase (58-62) emoldurada por meshumnion e ephumnion, na qual Musas e Apolo ocupam os

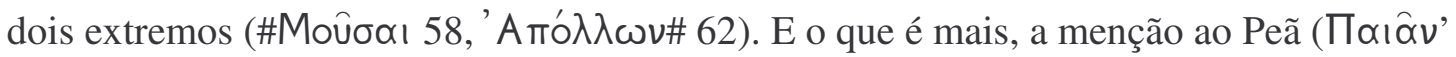

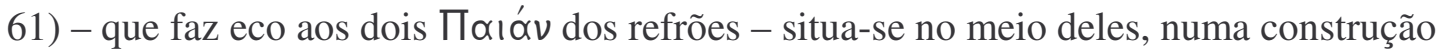
ámò Koıvoû que atrai em definitivo a atenção da platéia para o novo estatuto de Dioniso:

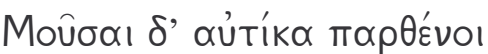

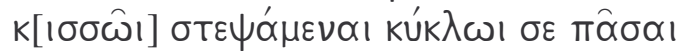

60

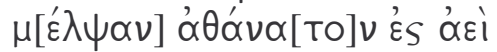

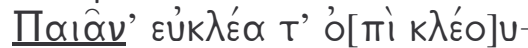
$\sigma \alpha ı,[k \alpha] \tau \hat{\alpha} \rho \xi \varepsilon \delta$ ' 'A $A{ }^{\prime} \lambda \lambda \omega \nu$.

'e as Musas, coroando-se de pronto com hera, cantaram e dançaram todas em círculo para a tua honra, proclamando-te imortal para sempre e famoso Peã, e quem liderava a dança era Apolo.'

O "Peã" do verso 61 ( $\Pi \propto \propto$ เôv') descreve o conteúdo da canção das Musas e pode ser tomado igualmente como complemento de $\mu \dot{\varepsilon} \lambda \psi \propto \alpha \nu$ 'cantaram, dançaram' como do

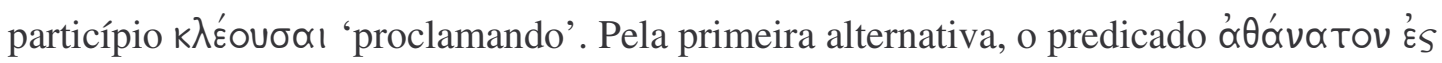

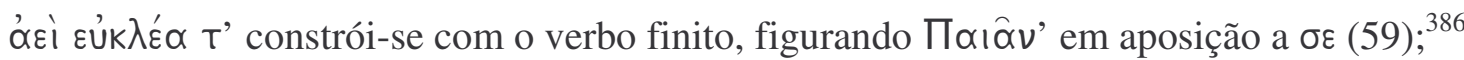
pela segunda, o mesmo predicado une-se ao particípio: ora as Musas cantam e dançam ao redor do Peã imortal e famoso, ora proclamam imortal e famoso o Peã - sendo que o T',

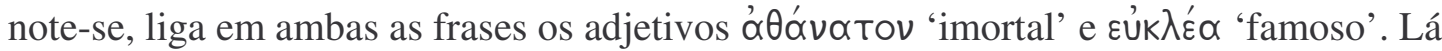
e cá, porém, o termo $\Pi \propto$ ıิôv' aplicado a Dioniso encontra-se no centro sintático da oração ambígua, refletindo a posição central por ele ocupada como tema do hino. Um exemplo análogo, no qual o nome divino ocupa o coração de uma sentença ambígua, talvez seja a seguinte frase de Sófocles que abre o primeiro estásimo das Traquínias (497):

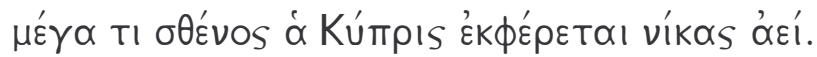

'Com grande força, Cípris sempre se sai com vitórias.'

${ }^{386}$ Cf. Käppel (1997), $246 s$. 
Também aqui a sentença muda de direção a meio caminho. ${ }^{387}$ A primeira metade ( $\mu$ É $\gamma \alpha$ Tı бӨ'́vos á Kúmpıs) pode ser tomada como um todo completo, embora a expressão com

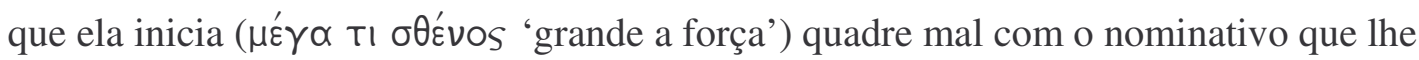
segue ( $\propto$ Kúmpıs). É que ao adjetivo neutro oӨ'́vos 'força' costuma suceder algum termo que deixe claro a quem pertence a força, como por exemplo um genitivo (cf. oO'́vos

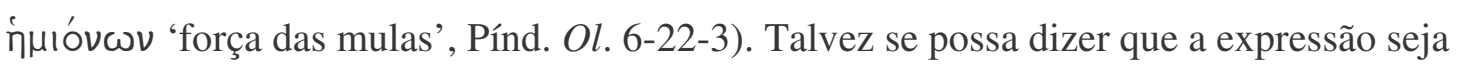
equivalente ao adjetivo $\mu \varepsilon \gamma \propto \sigma \sigma \varepsilon v \eta \dot{s}$, o que renderia à frase um sentido próximo a "Cípris é muito forte". Porém o nominativo ó Kúmpıs acoplado a $\sigma \theta^{\prime} \varepsilon$ vos, que pode ser tanto um nominativo ou um acusativo, mantém a construção em suspenso, e é natural supor que a platéia aguardasse o desenrolar da oração para certificar-se do sentido.

A segunda metade, no entanto, não esclarece as dúvidas, uma vez que ela própria é melhor compreendida como uma oração completa em si mesma, da qual o sujeito seria

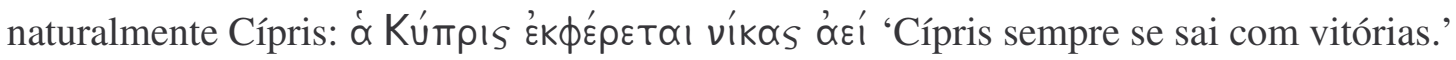

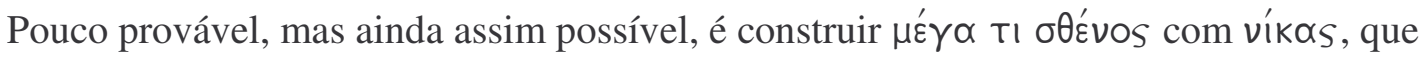
formariam assim uma unidade equivalente a $\mu \varepsilon \gamma \propto \sigma \theta \varepsilon v \eta \tilde{~ \tau ı v \propto ~ v i ́ k \eta v ~-~ e m ~ u m a ~ t r a d u c ̧ a ̃ o ~}$ aproximada: "grandes e poderosas vitórias".

Diversas, portanto, são as formas de compreender o verso. Para o público que a

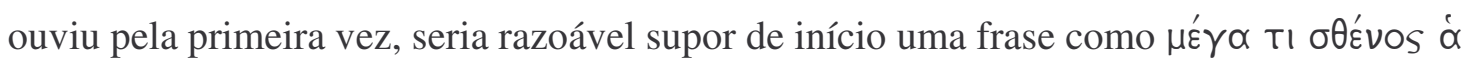
Kúmpıs 'Cípris é muito poderosa', para depois alterar o arranjo dos termos e conceber

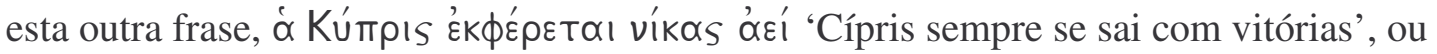

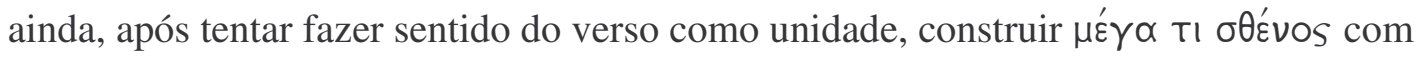
víkas: 'Cípris sempre se sai com vitórias grandes e poderosas'. ${ }^{388}$ Comum a todas essas alternativas, no entanto, é a posição de destaque conferida a Cípris: localizada bem no centro, ela produz efeitos à direita e à esquerda, como fecho ou início de frase, ou ainda na condição de pivô do verso, flanqueada pelos seus predicados.

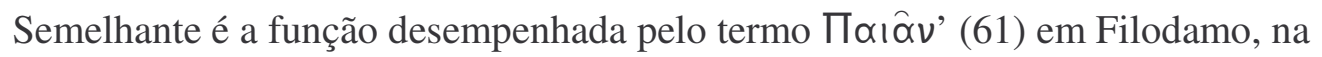
interseção de uma sentença que pode ser compreendida nos dois sentidos e em cujos pólos figuram significativamente as divindades responsáveis pela concessão da epiclese a

\footnotetext{
${ }^{387}$ Cf. a análise de Budelmann (2000), 45-7, e Ferrari (1983), 43-4, dos quais adoto parte do comentário e das referências.

${ }^{388}$ Possível ainda, claro, é supor uma pontuação após Kúmpıs, como fazem H. Lloyd-Jones e N.G. Wilson na sua edição, ou mesmo julgar o verso corrupto, a exemplo de Dawe.
} 
Dioniso: as Musas e Apolo. Deus do ditirambo (cf. $1 \Delta, \theta u ́ p \propto \mu \beta \varepsilon$ ), Dioniso recebe das mãos de quem mais de direito um título inusitado, Peã. Agora a ele, Dioniso, é justo endereçar, não um ditirambo, mas precisamente um peã apolíneo, uma de cujas marcas é o refrão (“peã!") com que se interpela a divindade assim concebida. Não é só Dioniso, no entanto, que recebe novas credenciais que o habilitam a ser chamado de Peã, é o próprio peã composto por Filodamo que, por meio da narrativa mítica, legitima a sua obra como um verdadeiro peã. Isso se dá com a hábil inserção, nessa estrofe, do ephumnion no corpo do relato.

Até ali, nas estrofes anteriores, os refrões ditaram o descompasso entre o relato mítico da seção narrativa e a exclamação (de coro ou poeta) neles contida, impondo uma ruptura - de resto trivial - entre ficção e realidade, entre mito e situação real de performance. ${ }^{389} \mathrm{O}$ refrão repetia-se de forma inorgânica, sem relação sintática nem de conteúdo com a narrativa a seu redor. Eram blocos estanques, cujos parâmetros serviam, é certo, para emprestar estrutura e realce ao relato (e assim continuarão nas estrofes seguintes, como veremos), mas o elo com as partes narrativas era tênue. Aqui, porém, a situação é diversa; aqui são as Musas que, lideradas por Apolo, assim celebram Dioniso como Peã: “- Iê Peã...” (58-65). O ephumnion do peã de Filodamo é o mesmo que as Musas entoam. Agora o refrão passa a integrar a narrativa, sem no entanto perder o seu estatuto próprio, como refrão de um peã real em louvor de Dioniso. Entre o peã das Musas e Apolo e o peã de Filodamo caem momentaneamente as barreiras que os distinguem; fundem-se mito e realidade na canção entoada dentro da canção, com o que o poeta legitima a sua escolha inovadora: a Dioniso ele dedica um peã porque como Peã Dioniso é celebrado pelas Musas. Significa isso, de outro lado, que é através desse próprio peã, no qual as Musas celebram Dioniso, que ele torna-se Peã e com um peã pode então ser celebrado. Passado mítico e presente da celebração movem-se assim, em breve intervalo, num círculo fechado.

A referência a Apolo que conclui a semi-estrofe serve de gancho para a segunda parte do hino. A despeito do caráter fragmentário das estrofes VI-VIII, é possível afirmar que Apolo, destinatário tradicional do peã e deus Peã por prerrogativa natural, distribui (a partir da estrofe IX) ordens a respeito da situação em Delfos do novo deus Peã, Dioniso.

${ }^{389}$ Cf. Käppel (1997), 248s. 
Trata-se das honras que a ele devem ser destinadas, e também aqui os refrões preservam o seu poder de estruturar o relato, sempre, vale lembrar, no simultâneo propósito de pôr em evidência o tema específico do hino - Dioniso como Peã, como um segundo Apolo.

Ordem é dada, na primeira metade da estrofe IX, para que os anfictiões concluam o mais rápido possível as obras no templo délfico ${ }^{390}$ e ao mesmo tempo, por ocasião do festival da Teoxenia (segunda metade), recebam Dioniso - o irmão de Apolo (111) - com

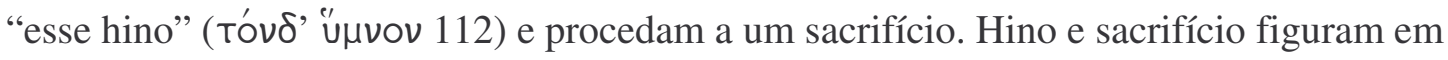

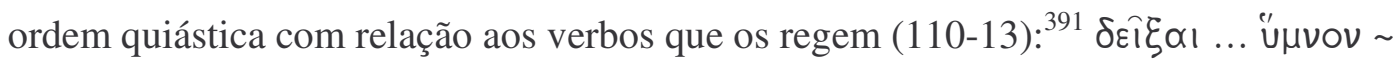

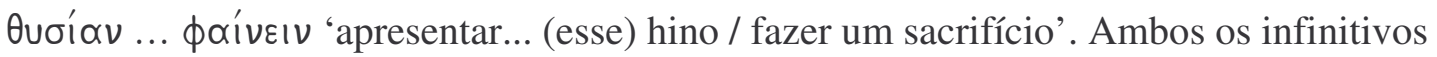
ganham assim certo relevo, tanto mais porque a estrofe é composta de três infinitivos

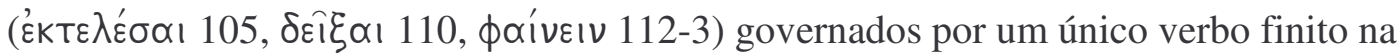

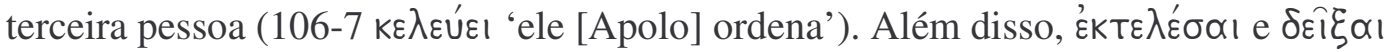
ocupam posição de destaque, um no início da estrofe, outro na abertura da segunda semiestrofe, logo após o meshumnion. Que esta seja uma disposição deliberada do poeta para inserir o refrão no fluxo narrativo é sugerido na estrofe XI, cujo tema e colocação verbal espelham a estrofe IX. Nela também se trata, não da Teoxenia, mas de outro festival, os Jogos Píticos (ПuӨıóoııv 131). Nela também um único verbo finito na terceira pessoa

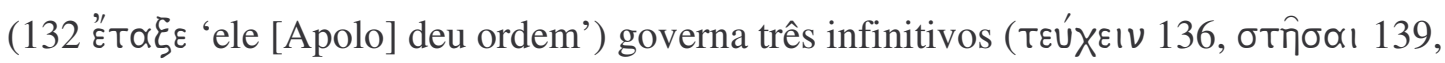
$\tau \varepsilon \hat{\cup} \xi \propto ।$ 139-40), o primeiro deles em realce, inaugurando a segunda semi-estrofe tal como $\delta \varepsilon i \xi \alpha ı ~(110)$ o fizera na estrofe IX. Lá e cá a sintaxe da frase abraça o refrão, sobre ele faz correr a sentença, que por sua vez é sublinhada pela pausa que ele representa e ao mesmo tempo o integra ao seu sentido. Na estrofe XI, por exemplo, ao adiar o infinitivo TعÚXદıv 'instaurar' para depois do meshumnion, o poeta o separa do seu complemento - o sacrifício e a competição ditirâmbica em louvor a Baco (132-4) - e com isso alinhava o refrão à frase. Esta só se completa, só se torna inteligível após o infinitivo final (тعúXદıv), mas antes disso já nos é dado discernir um eco dos brados lançados (“Evoé, ó iô Baco!”) durante a disputa entre os vários coros circulares nas pitíadas quadrienais. ${ }^{392}$

\footnotetext{
${ }^{390}$ Para uma discussão a respeito, cf. Furley-Bremer (2001), vol. 2, 74-7, e Käppel (1997), 255-9.

${ }^{391}$ Cf. Käppel (1997), 268.

392 Käppel (1997), 254 n.185: "So hört der Rezipient des vorliegenden Gedichts gleichsam in Antizipation die im Dithyrambenagon erklingenden Euoi-Rufe an den nunmehr dem Apollon gleichgestellten Dionysos".
} 


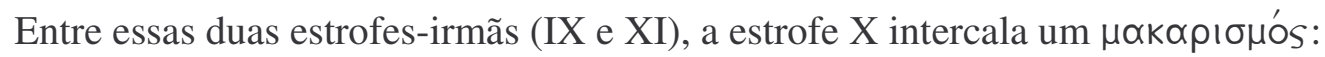
"Feliz daquele que construir um templo a Apolo" (118-21). A frase, completa em si mesma ao final do verso 121, continua todavia na semi-estrofe seguinte, após a quebra do

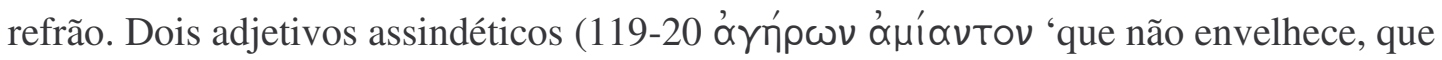
não se corrompe') já haviam qualificado o templo, porém mais outro, à testa do verso

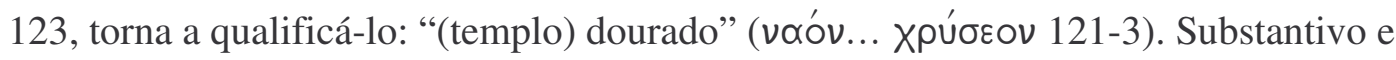
adjetivo são posicionados a cavaleiro do refrão, abrindo os versos que o emolduram, e a oração iniciada na primeira semi-estrofe continua na estrofe seguinte: "templo... dourado

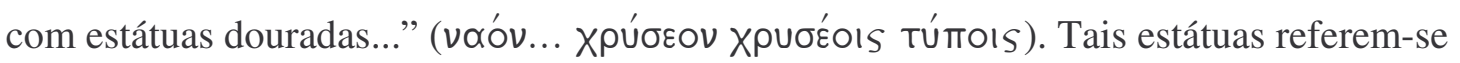

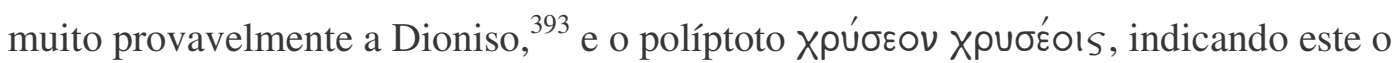
ouro das estátuas de Dioniso, aquele o ouro do templo de Apolo, faz com que os adjetivos repitam, postados que estão no início do verso após o meshumnion, a bipartição neste

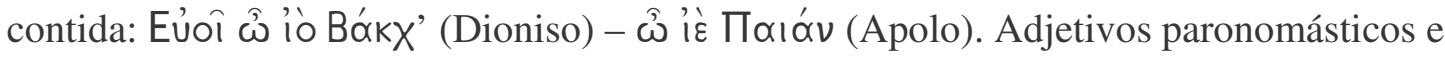
refrão exprimem a equivalência que agora reina em Delfos entre os dois irmãos divinos, sem que nenhum deles perca entretanto a sua individualidade - inclusive em termos de prosódia. É que Filodamo altera expressivamente a quantidade das sílabas em Xpúøєov

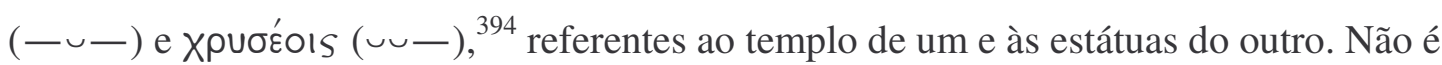
fato tão raro a disparidade prosódica em vocábulos geminados, ${ }^{395}$ mas a sua utilização aqui para fins expressivos lembra esta passagem de Aristófanes nas Tesmoforiantes (1202):

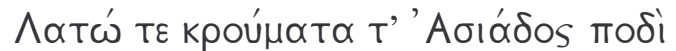

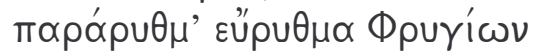

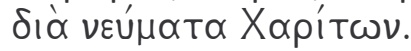

'[Cantai...] E Leto e os passos de dança dentro e fora do ritmo segundo o compasso das Graças Frígias.'

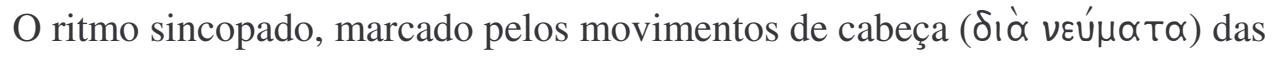
Graças, é mimetizado em sua irregularidade pela diferença de quantidade nos termos

\footnotetext{
${ }^{393}$ Cf. Furley-Bremer (2001), vol. 2, 79-80, e Käppel (1997), 260-1.

${ }^{394}$ Fato notado por Käppel (1997), 260 n.212a, e Furley-Bremer (2001), vol. 2, 80.

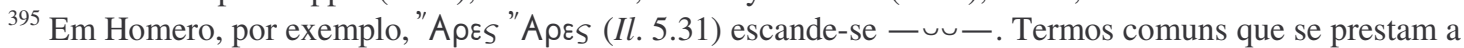
tanto são kaגós e íoos: cf. Fehling (1969), 178s.
} 


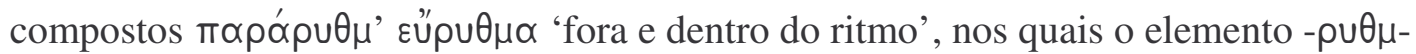
ora ostenta uma sílaba longa (pararūthma), ora uma sílaba breve (eurŭthma). ${ }^{396}$

É na última estrofe, contudo, que a integração do refrão à seção narrativa torna-se mais óbvia. Assim como a transição da primeira para a segunda estrofes fora marcada pela tripla repetição de termos relativos a Baco, em nítido eco ao Bó́kX’ do refrão, assim também na transição da penúltima para a última estrofe vocábulos ligados a Baco são repetidos três vezes, à parte o vocativo do meshumnion, em uma espécie de composição em anel:

\begin{tabular}{|c|c|}
\hline estr.I & 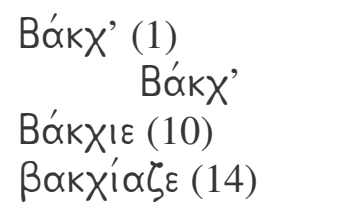 \\
\hline estr.XI & 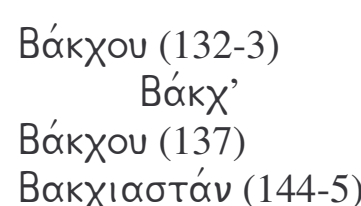 \\
\hline
\end{tabular}

Trata agora essa estrofe, a última, de um apelo à comunidade dos fiéis para que recebam Dioniso e, em meio a danças, clamem por ele da seguinte maneira: "Evoé, ó iô

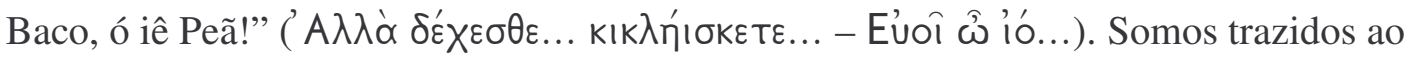
instante presente, ao hic et nunc do canto, e ao cabo desse caminho Dioniso pode ser

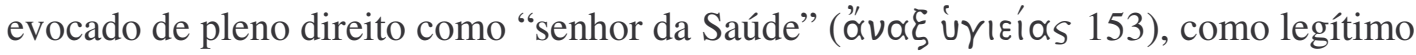
deus Peã de ambos os refrões.

\subsubsection{Presente da celebração}

À platéia que esperava um ditirambo em honra de Dioniso, Filodamo apresentalhes um peã, frustrando-lhes as expectativas e elevando Dioniso a um novo patamar na história religiosa de Delfos, em igualdade de condições com Apolo. E o faz tornando o

\footnotetext{
${ }^{396} \mathrm{Cf}$. Wilamowitz (1886), 156s. Outros exemplos nos quais a mesma palavra recebe tratamento métrico

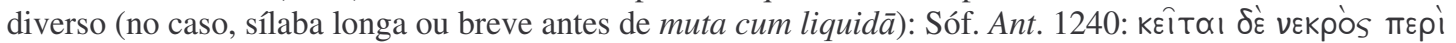

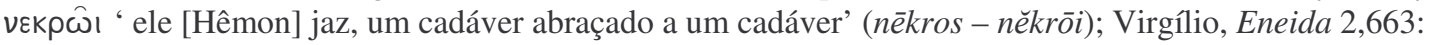
nātum ante ōra patris, patrem quī obtruncat ad āras '[Pirro] que assassina o filho perante a vista do pai, e o pai junto aos altares' (pătris - pātrem).
} 
próprio Apolo o responsável pela mercê, não somente em virtude das determinações referentes a seu culto contidas na segunda parte do poema (uma espécie de lex sacra), mas sobretudo por afiançar Dioniso como justo destinatário de um peã, gênero que não lhe pertence por tradição. Ao termo de um percurso que se estende por toda a primeira parte do hino, partindo de Tebas e passando por Orcômenos, Eubéia, Elêusis, Tessália, Olimpo até chegar a Piéria, são as Musas que, lideradas por Apolo, celebram em canto

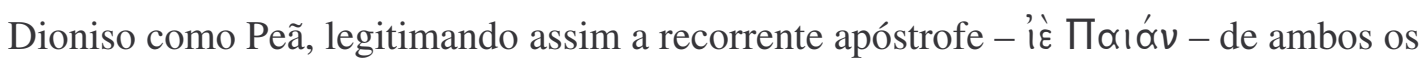
refrões. É ali, porém, na estrofe V, que ocorre outra guinada decisiva: do deslocamento geográfico, no eixo do espaço, o poeta transita para o eixo temporal, fazendo com que no ephumnion mesclem-se indissoluvelmente a exclamação das Musas no passado mítico e o clamor atual dos fiéis em Delfos, durante o festival da Teoxenia, ocasião na qual o hino foi entoado pela primeira vez.

Tivemos oportunidade de observar acima, de passagem (item 1.1.3), um artifício semelhante no Hino a Apolo de Calímaco. A começar pelo verso 72, o poeta, cujo hino mimetiza uma celebração real à divindade (cf. vv. 1-31), traça um percurso que leva de Esparta a Tera, e de Tera a Cirene. Narra Calímaco como Apolo foi conduzido nesses três estágios até Cirene, onde um sacrifício anual lhe é instituído e onde ocorre, no presente, a suposta celebração. Um templo fora erigido ( $77 \delta \varepsilon \hat{\imath} \mu \varepsilon$ : aoristo) em sua homenagem, nele estatuiu-se (78 $\theta \hat{\eta} \mathrm{k} \varepsilon$ : aoristo) um sacrifício ${ }^{397}$ no qual touros em quantidade caem sobre os próprios flancos (79 mímrovoıv : presente). De Esparta rumamos a Cirene, do passado (aoristo) ao presente do culto, e agora já nos é impossível dizer se a exclamação do verso

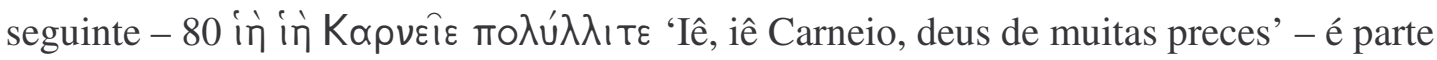
dos gritos rituais que acompanham a hecatombe ou compõe antes o cenário descrito no começo e fim do hino, no qual o próprio hino acha-se inserido. Trata-se de um cenário ritual, que busca recriar a expectativa candente com a iminência da chegada de Apolo ao festival da Carnéia. ${ }^{398} \mathrm{O}$ loureiro agita-se, toda a sua morada estremece; a palmeira délica inclina-se docemente e o cisne canta nos ares; que os jovens, diz o poeta, preparem seus

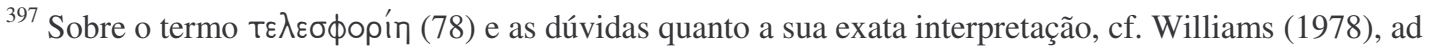
loc.

${ }^{398}$ Alusões à performance, no caso de Calímaco, tentam compensar a ausência de performance real. No que diz respeito ao Hino a Apolo, remota é a possibilidade que ele tenha sido composto, não para a leitura, mas para a performance no festival cirenaico da Carnéia.
} 
cantos, que façam ressoar seus passos de dança, e que a cítara não permaneça calada. ${ }^{399}$ Tal pedido, ao que parece, é prontamente atendido: "Parabéns aos jovens", aplaude a voz

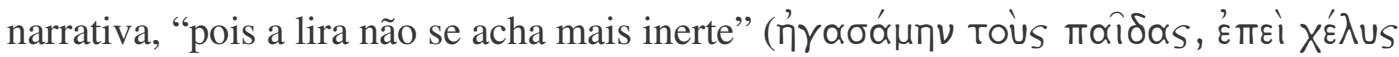

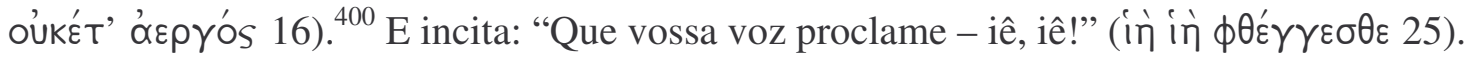

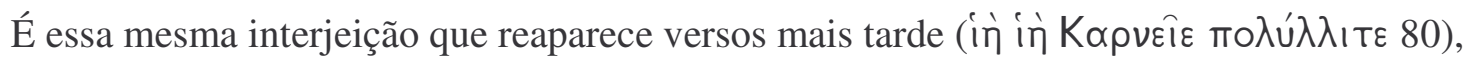
sem que agora possamos afirmar ao certo quem a profere, se os jovens do ritual presente ou os responsáveis pelo mesmo festival no passado. A Carnéia, esse festival que se repete anualmente ( repetição; passado e presente unem-se num mesmo instante e num mesmo verso, e se foi em Delfos que o brado ritual in in maıñov teve a sua origem - no passado mítico da pitoctonia (cf. vv. 103-4) -, é esse mesmo brado que ecoa na Carnéia do presente (97 ì

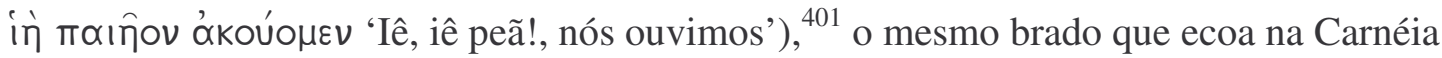

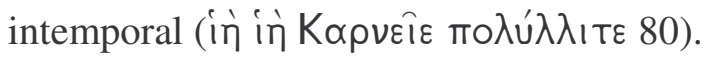

Outro poema que, tendo Cirene igualmente como pano de fundo, converge em um único instante três níveis temporais - passado mítico, passado histórico e presente - é a Pítica 5 de Píndaro. Aqui um evento ritual que se desenrola no presente reflete, ou antes reencena, um acontecimento mítico. Vejamos os versos 54-93 (epodo 2 a epodo 3).

\subsubsection{Píndaro, Pítica 5, 54-93}

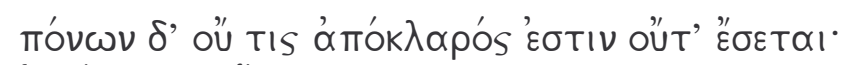

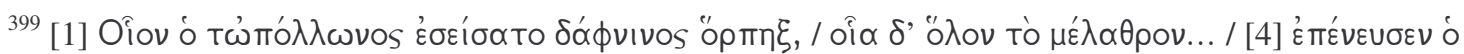
$\Delta \eta^{\prime} \lambda ı$ IO

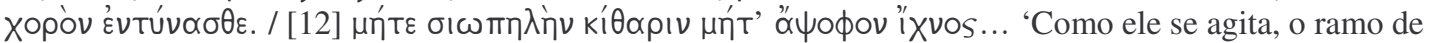
loureiro de Apolo, como toda a sua morada estremece... A palmeira délica acaba de inclinar-se docemente, o cisne canta bonito nos ares... Vós, jovens, preparai vossos cantos e danças... que nem a cítara mantenhase calada nem os passos deixem de ressoar..."

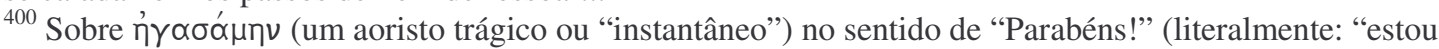
cheio de admiração"), cf. Lloyd (1999), esp. 38 e 40, para quem essa passagem de Calímaco é um eco erudito da dicção trágica. Segundo o crítico, tais aoristos não são mais "instantâneos" nem mais vigorosos que os presentes a ele equivalentes; sua função é antes distanciar quem fala da sua própria afirmação, tornar uma expressão menos imediata e portanto mais educada. (Rijksbaron adota essa interpretação de Lloyd na $3^{\mathrm{a}}$ edição do seu livro (2002), 30).

${ }^{401}$ Tal verso pode muito bem ser um sinal indicativo de que o poema de Calímaco - mesmo tendo sido composto em hexâmetros e por outra razão que não a performance - pertence ao gênero peã, como sugere Rutherford (2001), 130. Cf. ainda vv. 17-21. Burnett (1998), 514-5, sugere que o mesmo artifício de unir passado e presente em um único brado ritual é utilizado também no sexto peã de Píndaro (vv. 121-2). 


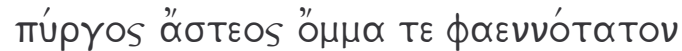

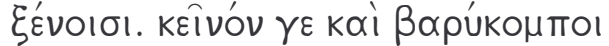

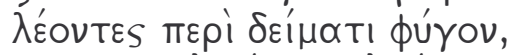

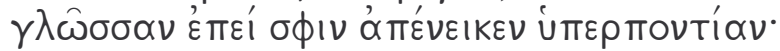

60

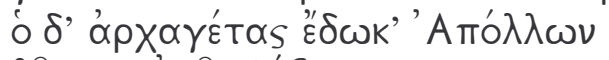

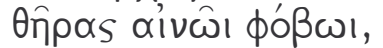

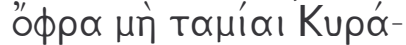

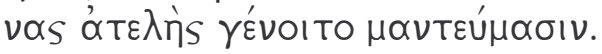

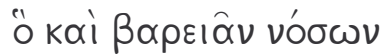

estr.3

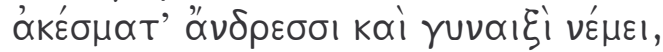

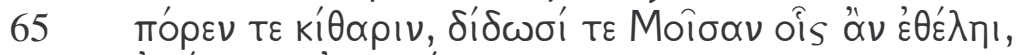

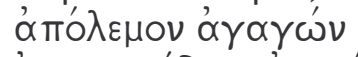

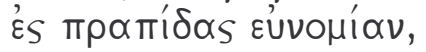

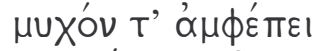

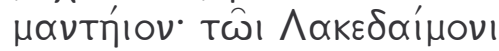

$70 \quad \varepsilon \nu$ "А

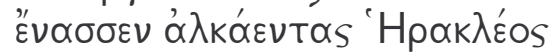

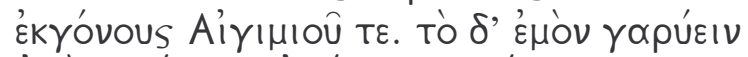

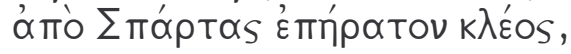

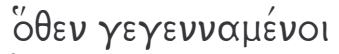

ant.3

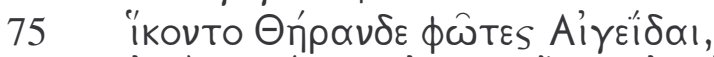

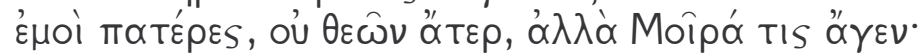

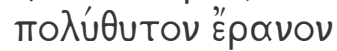

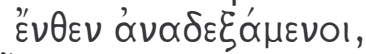

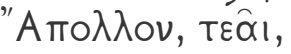

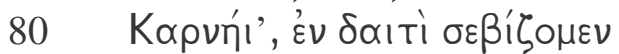

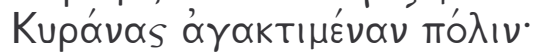

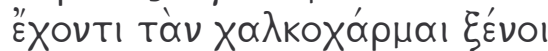

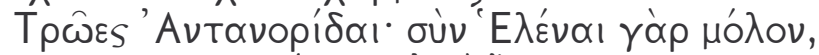

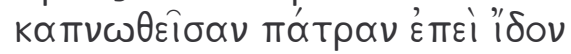

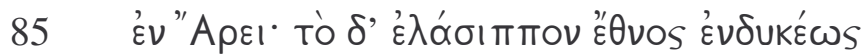

ep.3

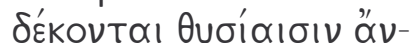

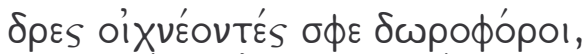

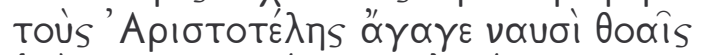

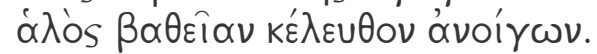

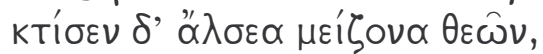

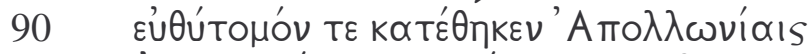

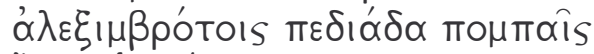

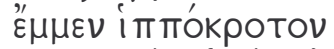

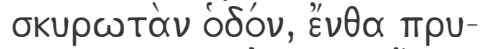

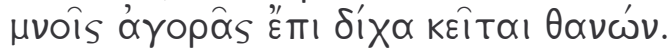

(Ninguém está livre do seu quinhão de labuta, nem estará. [55] Mas a antiga prosperidade de Battos permanece, a despeito de tudo, conferindo ora isso, ora aquilo, bastião da 
cidade e luz mais esplêndida aos estrangeiros. Dele até mesmo leões que rugem grosso fugiram de medo, quando ele lhes comunicou sua fala exótica. [60] Foi ele, Apolo o fundador de colônias, que entregou as feras ao pânico, para que não ficassem sem cumprimento seus oráculos a respeito do intendente de Cirene (= Battos). /

Ele também confere remédios contra doenças atrozes a homens e mulheres; [65] ele forneceu a cítara e concede a Musa a quem quer que queira, após infundir bom governo nos seus espíritos; e ele reina sobre o seu sítio oracular, pelo qual estabeleceu na Lacedemônia [70] e em Argos e na sagrada Pilos os bravos descendentes de Héracles e Egímio. E a mim cumpre proclamar a adorável glória que vem de Esparta, /

De onde homens nascidos [75] como Egidas, meus antepassados, chegaram a Tera, não sem o favor divino, mas uma certa Moira (= destino) os conduziu. De lá, tendo recebido o banquete público com os seus muitos sacrifícios, nós veneramos em tua festa, ó Apolo [80] Carneio, a cidade de Cirene de sólidas construções, da qual os filhos de Antenor, estrangeiros troianos que se regalam com as armas de bronze, são os detentores, pois eles vieram com Helena após verem a sua pátria em chamas /

[85] Durante a guerra. E aquela raça de condutores de carruagem (= os antenoridas) é recebida calorosamente com sacrifícios por homens que deles se aproximam portando presentes, os homens que Aristóteles (= Battos) trouxe em navios velozes, abrindo o caminho profundo da água do mar. Ele fundou santuários mais amplos aos deuses [90] e assentou o pavimento de uma estrada reta e plana, para que ela ecoasse com cascos de cavalos em procissões que homenageiam Apolo e trazem amparo aos mortais. E lá, na extremidade da praça pública, ele jaz à parte desde a sua morte.)

Tem início no verso 69 a história da fundação de Cirene, vertida na forma de um catálogo geográfico. Trata-se a princípio do estabelecimento dos dórios no Peloponeso, ou seja, dos descendentes de Héracles e Egímio na Lacedemônia, em Argos e em Pilos (69-72a). Do Peloponeso, ou mais especificamente de Esparta, o relato segue para a ilha de Tera, para onde emigram com glória os Egidas, conduzidos que são pelo destino (72b76). O passo seguinte é a chegada a Cirene, mas aqui a história de fundação confunde-se com o festival da Carnéia lá realizado, e com um agravante: até ali o relato ativera-se aos tempos verbais no passado, sublinhando a transição de uma para outra localidade com o

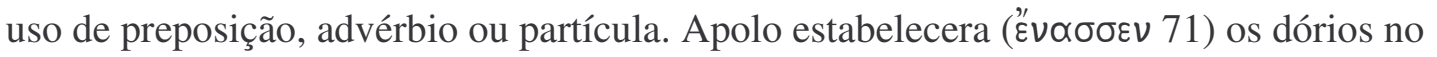

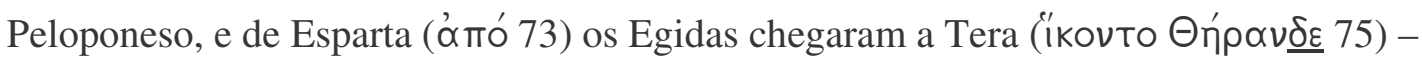

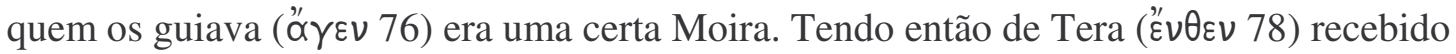
( $\propto \dot{v} \propto \delta \varepsilon \xi \xi^{\alpha} \mu \varepsilon v o$ । 78) o banquete público - ou seja, a Carnéia trasladada de Esparta a Tera e de Tera a Cirene -, nós veneramos, ó Apolo, diz o poeta, a cidade de Cirene construída

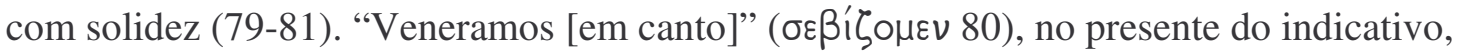


marca a alteração do tempo verbal bem no instante em que a narrativa toca solo cirenaico, e nos versos seguintes (80-6) é no presente que permanecemos. ${ }^{402}$

Em resumo: os versos 69-76 giram em torno da história de fundação de Cirene, e o tempo verbal utilizado é o passado; na sequiência, a história de fundação continua como tema, porém mescla-se à Carnéia, festival no qual o poema muito provavelmente foi

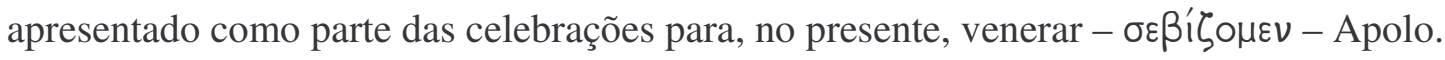
Marca o verbo, agora flexionado na primeira pessoa, o instante atual da canção do poeta, entoada nessa Carnéia específica. E é no presente que tem seguimento a narrativa, ao ser

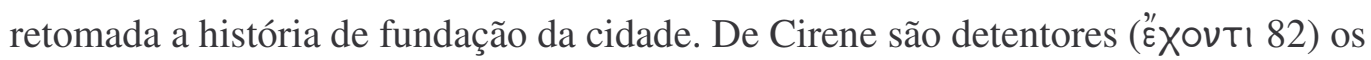
filhos de Antenor, troianos vindos com Helena após a destruição da pátria. São eles, os antenoridas, essa raça de condutores de carruagem (85), quem os homens conduzidos por

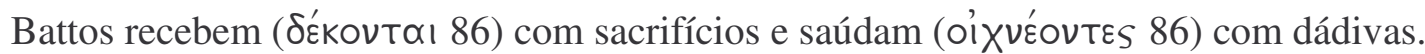

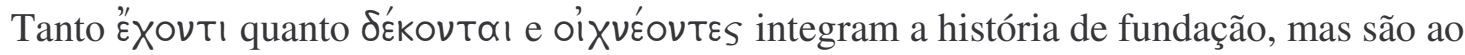
mesmo tempo parte do presente - do presente cultual em que se insere o poema. ${ }^{403}$ Planos temporais diversos são comprimidos em uma mesma sentença:

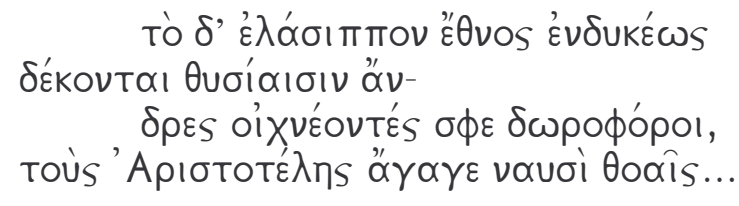

'E aquela raça de condutores de carruagem é recebida calorosamente com sacrifícios por homens que deles se aproximam portando presentes, os homens que Aristóteles trouxe em navios velozes...'

A raça dos condutores de carruagem são os antenoridas do passado mítico, os homens trazidos por Battos são os habitantes de Tera do passado histórico - ambos têm em Cirene o seu destino. Alusão é feita aos colonos de Tera mediante um pronome, toús

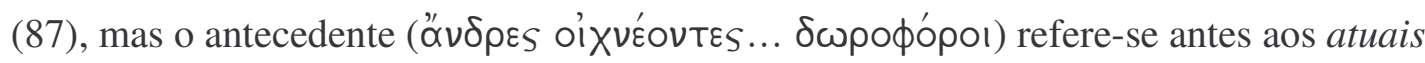

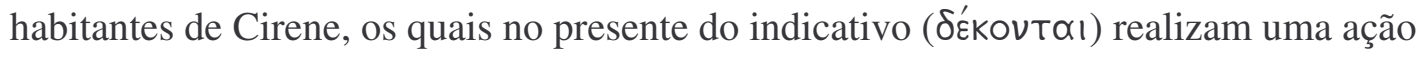

\footnotetext{
${ }^{402}$ Cf. Krummen (1990), 114s.: "[...] der Wechsel der Tempora [erfolgt] in dem Augenblick, in dem die Erzählung inhaltlich kyrenäischen Boden erreicht". No que segue, adoto em linhas gerais os comentários e as análises da autora.

${ }^{403}$ Cf. Krummen (1990), 120: "Sie [i.e., esses tempos verbais no presente] sind somit Gründungsgeschichte und gleichzeitig Gegenwart, was hinwiederum bedeutet, daß es sich hier um einen kultischen Vorgang handelt, da diese Gegenwart religiös determiniert ist".
} 


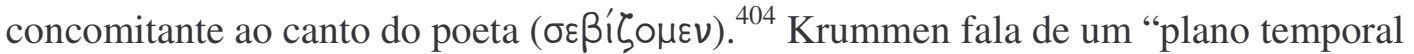
duplo", ${ }^{405}$ no qual presente e passado (mítico e histórico) intersectam-se para formar uma unidade. Os cireneus, portanto, recebem os antenoridas por ocasião da Carnéia - festival, aliás, teoxênico - durante a qual o nosso poema é apresentado, e desse modo reencenamlhes o advento mitológico, quando aportaram na cidade fugidos de Tróia.

Início e fim dessa seção pautada por verbos no presente, em cujo centro encontrase Cirene e seu festival, são sinalizados por dois verbos no passado que se espelham. De Esparta a Tera, os Egidas foram conduzidos por uma certa Moira (Moîpó TIS @ِ $\underline{\gamma \varepsilon v ~ 76) ; ~}$

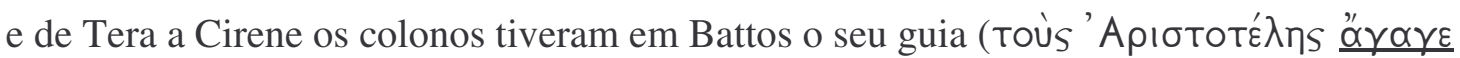
87). A Battos torna então a narrativa que com ele iniciara: versos 87-93, nos quais ele é o protagonista, rematam a história da fundação de Cirene, assim como versos 55-62 servem de introdução, não já à história de fundação da cidade, mas ao elogio a Apolo no qual ela está inserida (63-88). Tal elogio é claramente caracterizado pela dicção hínica. ${ }^{406}$ Apolo é louvado pelos seus poderes medicinais, musicais e divinatórios (63-9); são esses últimos que agem como um estopim para a história de fundação de Cirene: reina Apolo sobre seu

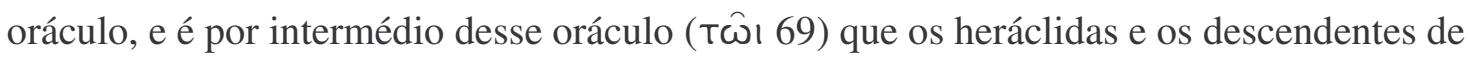
Egímio firmaram pé no Peloponeso etc.

Cirene e a sua fundação, assim como a Carnéia e o próprio poema de Píndaro, são parte assim de um conjunto maior, o elogio a Apolo, que por sua vez é emoldurado pela história de Battos. ${ }^{407}$ De um a outro, de Battos a Apolo, interpõe-se a clara transição dos versos 60-2, nos quais Apolo assume a frente do palco. ${ }^{408}$ Ao fim do seu elogio, ou seja, ao cabo da história de Cirene, os versos 87-8 fazem nova transição, agora a Battos e seus méritos.

\footnotetext{
${ }^{404}$ Cf. Krummen (1990), 117ss. e Rutherford (2001), 413.

${ }^{405}$ Krummen (1990), 115, 120, 124 (“doppelte Zeitebene”).

${ }^{406}$ Cf. Krummen (1990), 138.

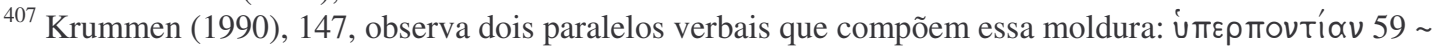

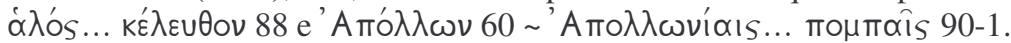

${ }^{408}$ Versos 55, 63 e 60 (que marcam respectivamente a seção referente a Battos, a seção relativa a Apolo e a transição de um a outro) distinguem-se pelo uso quase demonstrativo do artigo, sempre em início de verso: dois deles retardam a menção do substantivo (ó Bátтou... ö $\lambda \beta$ os 55 ó... A Áó $\lambda \lambda \omega \nu$ 60), o outro mantém o sujeito inexpresso, embora manifesto pelo contexto: ó kói... (63). Sobre esse uso peculiar do artigo grego e o emprego sintático análogo do seu cognato sá no sânscrito védico, cf. Watkins (2002b).
} 
- Battos (55-62)

- transição $(60-62)$

- Apolo (63-88)

- fundação de Cirene (69-88)

- passado (69-76)

. heráclidas e egimidas no Peloponeso (69-72)

. egidas: Esparta $\rightarrow$ Tera (73-76)

o presente: Tera $\rightarrow$ Cirene (Carnéia) (77-86)

- transição (87-88)

- Battos (89-93...)

No festival da Carnéia, contemporâneo à récita do poema pindárico, o passado mítico e histórico é reencenado no presente e nele se entrelaça. Trata-se de um presente cultual, no qual "o epinício”, como nota Krummen, 409 "e a história de fundação de Cirene transformam-se (...) em canção de louvor a Apolo, sem que no entanto ele jamais deixe de ser um epinício".

Outro poema, esse um peã, que também sugere a fusão entre o instante atual em que se desenrola o culto e o passado mitológico por ele descrito é o Peã 15 de Píndaro.

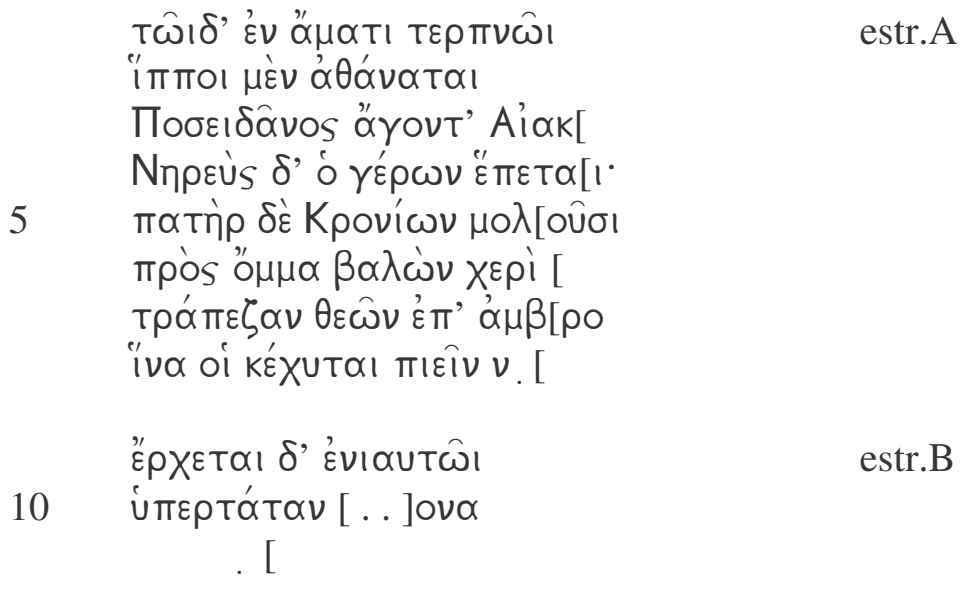

(Nesse dia agradável as éguas imortais de Posêidon conduzem ... Éaco ... e o velho Nereu segue. Zeus pai ... vêm ... voltando os seus olhos, com a sua mão ... para a mesa imortal dos deuses, onde [néctar?] se acha servido para beber. No final do ano lá vem ... maior ...)

O adjetivo dêitico $\tau \hat{\omega} ı \delta \varepsilon$ que abre o poema e o uso do tempo presente ao longo do fragmento circunscrevem a ação ao instante atual da apresentação da obra. Tal ação, no entanto, refere-se a um acontecimento mítico, provavelmente o casamento de Éaco com

${ }^{409}$ Krummen (1990), 151. 
Psamatéia, filha de Nereu. Fundem-se com isso o tempo mítico e o tempo real do culto; o mito é reencenado no rito, ${ }^{410}$ ou por outra, concebe-se que o evento sagrado descrito pelo poeta acontece no presente da performance, sendo concomitante ao canto. É nesse dia de

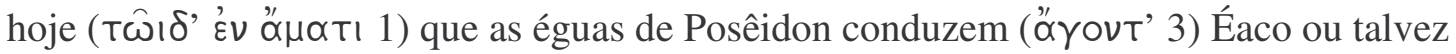
Psamatéia, que Nereu as segue ("ُ algo para Zeus beber, que sobrevém (" uma epifania divina: transpõe-se para o presente do relato a narrativa mitológica, que nele então se desdobra como no plano sagrado.

Por outros meios, Calímaco obtém resultado análogo em seu Hino a Apolo. Nele, como sugere Erbse, ${ }^{411}$ a narrativa também serve de veículo para a epifania. Antes de dar início à narrativa propriamente dita, o narrador ordena aos jovens circunstantes lançarem gritos de "iê iê" (in in $\phi \theta \varepsilon \gamma \gamma \gamma \varepsilon \sigma \theta \varepsilon$ 25); ao concluí-la, diz ouvir efetivamente tais brados

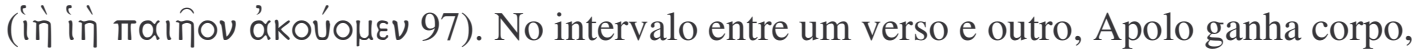
torna-se presente. Ao chegarmos no verso 97, clímax do relato, ele aparece em toda a sua estatura; a breve etiologia do brado ritual (97-104) sugere que o júbilo daqueles que agora tomam parte na apresentação compara-se ao dos habitantes de Delfos, testemunhas que foram da morte da odiosa serpente. "No instante em que o poeta diz ouvir o brado in in

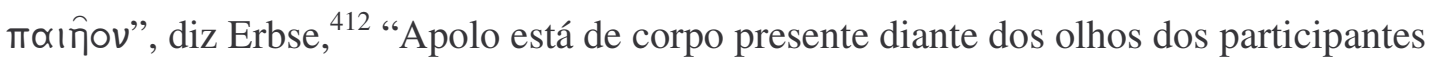
(entre eles o leitor), está no meio deles - não um deus abstrato com atributos de difícil compreensão, mas Apolo com suas qualidades claramente definidas na figura do Carneio de Cirene."

E como Carneio, de fato, Apolo é interpelado em uma apóstrofe (80) que faz a costura entre os brados rituais (in iń) contidos nos versos de moldura 25 e 97 : in ì

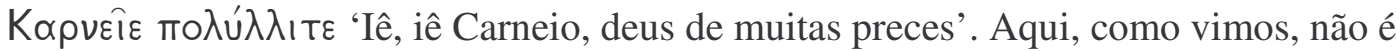
possível dizer se a voz que ouvimos pertence aos personagens da narrativa, aos jovens a que se dirige o narrador no início do poema ou até mesmo ao próprio poeta. Trata-se, de

\footnotetext{
${ }^{410}$ Cf. Rutherford (2001), 412, e D’Alessio (2004), 293, o qual chama a atenção ainda para a raiz cultual dessa prática, que remonta ao período arcaico.

${ }^{411}$ Erbse (1955). Sobre a epifania e os Hinos Homéricos, cf. García (2002).

${ }^{412}$ Ibid., 422. Cf. ainda Calame (1993), Bing (1993), 192ss., e Williams (1978), 56: "the poem as a whole is set in the context of an expected epiphany". A mesma interpretação é estendida ao Hino 5 de Calímaco por Heath (1988), 89s.: "The telling of the tale is the epiphany: we have seen the goddess through the medium of poetry".
} 
toda a maneira, de uma exclamação hínica que irrompe no interior do hino e estabelece uma relação complexa entre narrativa e narrador, tal como nos versos 130-2 da ode 17 de Baquílides, no ephumnion da quinta estrofe do peã de Filodamo a Dioniso (versos 63-5) ou ainda nos versos 121-2 do sexto peã de Píndaro. ${ }^{413}$ Vezes há, porém, em que não é só um refrão ou uma frase de teor hínico que no hino é intercalada, mas insere-se todo um hino dentro do hino, com resultados peculiares. Vejamos o exemplo do Hino Homérico a $P \tilde{a}\left(\mathrm{n}^{\mathrm{o}} 19\right)$.

\subsubsection{Hino dentro do hino: Hino Homérico a Pã}

'A

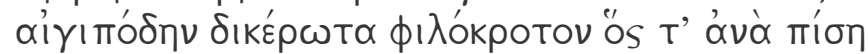

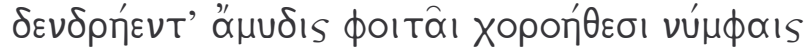

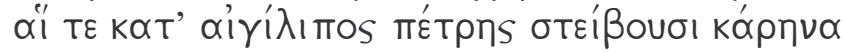

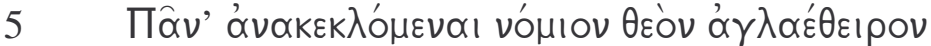

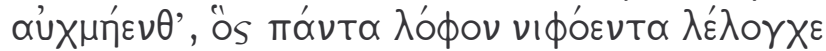

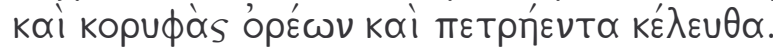

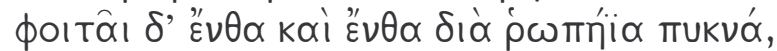

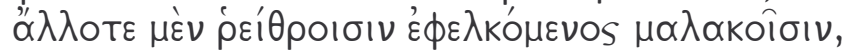

10 'а

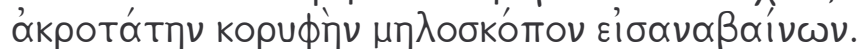

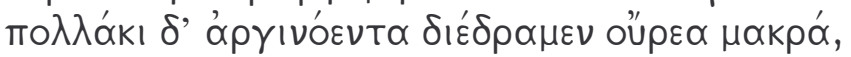

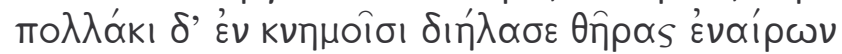

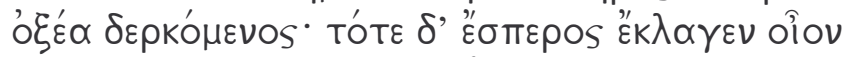

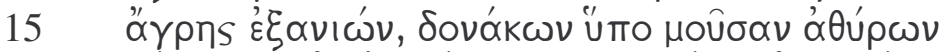

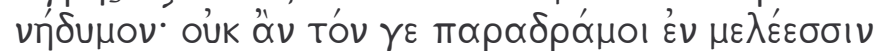

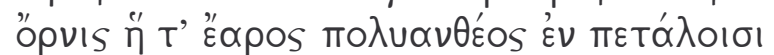

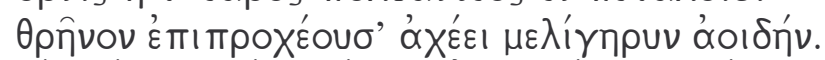

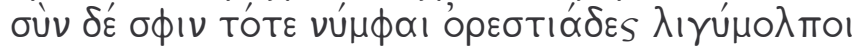

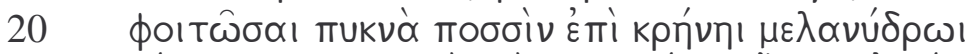

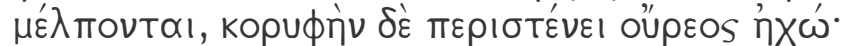
$\delta \alpha i ́ \mu \omega \nu$ ' '

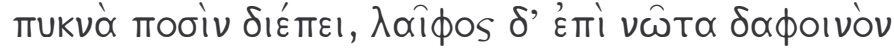

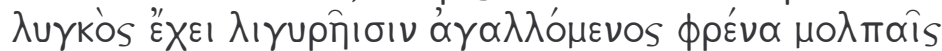

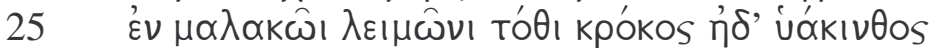

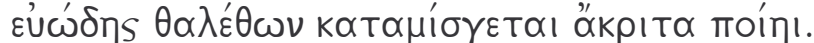

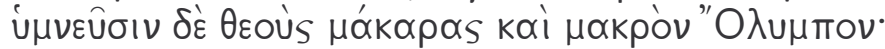

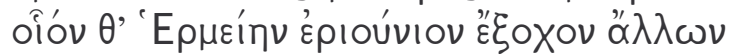

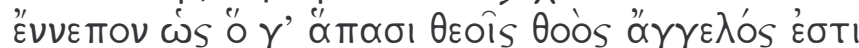

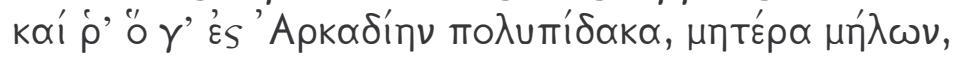

${ }^{413}$ Ver respectivamente itens 3.1.4.3 in fine, 3.2.1 e 1.1.12. 


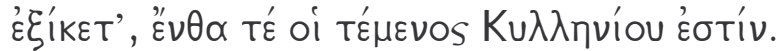

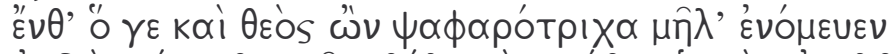

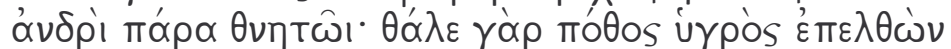

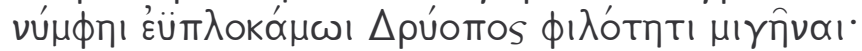

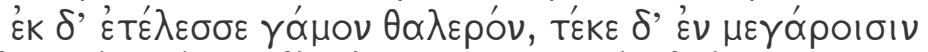

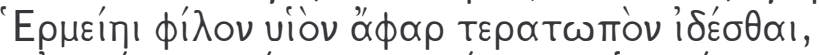

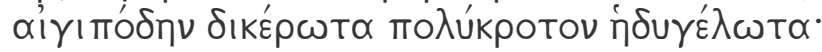

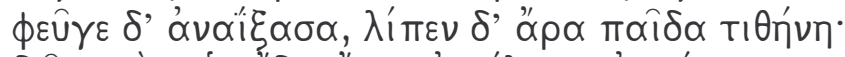

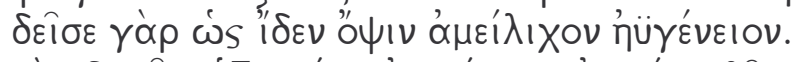

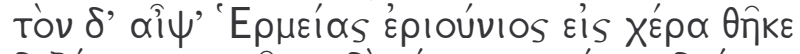

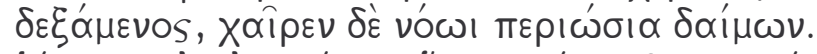

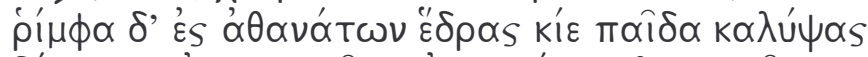

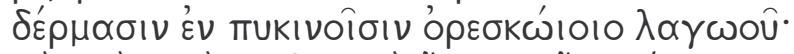

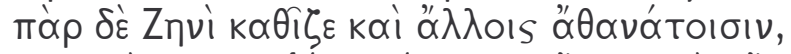

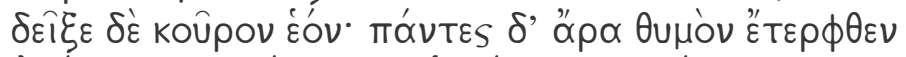

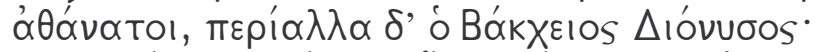

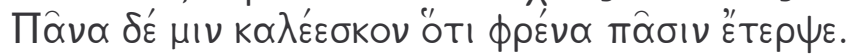

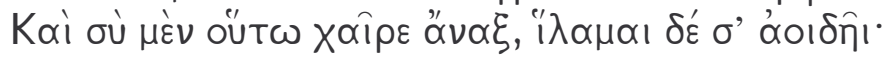

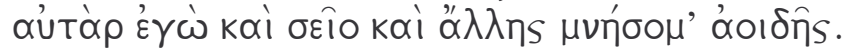

(Conta-me sobre o querido filho de Hermes, Musa, com os seus pés de cabra, seus dois chifres, amigo do barulho, que vagueia pelos campos cobertos de bosques junto com as ninfas acostumadas à dança, as quais pisam nos cumes à beira de pedras em precipício, [5] chamando por Pã, deus das pastagens com esplendorosa cabeleira crestada, a quem coube por lote todos os picos nevados e as cristas das montanhas e as sendas pedregosas. Aqui e ali ele vagueia entre o matagal cerrado, às vezes é atraído até os suaves riachos, [10] às vezes de novo atravessa pedras em precipício ao escalar até o pico mais alto para vigiar o rebanho. Muitas vezes ele corre pelas longas montanhas brancas, muitas vezes ele toca as feras pelos vales, matando-as, a vista aguçada. Lá pela noite seu som solitário é ouvido [15] ao regressar da caça, tocando música doce e profunda em suas flautas de caniço; as suas melodias não seriam superadas por aquele pássaro que, na primavera em flor, despeja entre as folhas o seu lamento em uma canção com voz de mel (= rouxinol). Com ele então as ninfas das montanhas de clara voz, [20] com passos ágeis junto a uma fonte escura, cantam e dançam; o eco geme ao redor do topo da montanha, enquanto o deus, movendo-se de um lado a outro do círculo de dança, ou ainda no meio, dá passos de dança intrincados, uma pele marrom de lince nas costas, deleitando-se com o canto claro e agudo, [25] em uma campina delicada, onde o açafrão e o aromático jacinto florescem misturados indissoluvelmente à relva. Eles celebram os abençoados deuses e o extenso Olimpo; e contam a respeito de um deus acima de todos, Hermes o corredor, como ele é o veloz mensageiro de todos os deuses [30] e como chegou à Arcádia de muitas fontes, mãe dos rebanhos; é lá que ele tem seu sítio sagrado como Hermes Cilênio. Lá, deus embora, ele pastoreou rebanhos de pelagem desgrenhada ao lado de um mortal, pois um desejo em onda viera sobre ele para unir-se em amor com a ninfa de belas tranças, filha de Dríops. [35] Ele consumou o frutífera união, e a Hermes ela pariu na casa um filho querido, de imediato um prodígio de se ver, pés de cabra, dois chifres, barulhento, risonho. Ela deu um pulo e fugiu, a ama abandonou a criança, pois teve medo quando viu a sua cara pouco 
atraente toda barbada. [40] Mas Hermes o corredor logo o tomou nos braços, e o espírito do deus alegrou-se enormemente. Rápido ele foi até a morada dos imortais, enrolando a criança em grossas peles de lebre montanhesa, e sentou-se ao lado de Zeus e dos demais deuses [45] e exibiu o seu filho. Todos os imortais deleitaram-se, sobretudo o báquico Dioniso; e passaram a chamar-lhe Pã, porque ele os deleitou a todos. Assim é que eu te saúdo, senhor; busco o teu favor com a minha canção. E lembrar-me-ei tanto de ti quanto de outra canção.)

Quanto aos temas de que trata, o hino reparte-se em duas metades. A primeira centra-se nas ações típicas da divindade - no caso, as atividades pastorais de Pã e o seu gosto pela dança, que ele divide com as ninfas; a segunda gira em torno da sua história de nascimento e do seu advento no Olimpo. Entre a ação típica e o relato do nascimento há, porém, um elemento comum que serve como elo de ligação: o tema do canto. As ninfas entram em cena durante a descrição das ações típicas de Pã e louvam, em sua canção, o nascimento do deus. Cada uma das metades articula-se, na verdade, em outras duas. ${ }^{414} \mathrm{Na}$ primeira, Pã figura como deus pastor e senhor das montanhas (8-18); na segunda, como dançarino e companheiro das ninfas (19-26); já a terceira abandona o terreno das ações típicas e narra um acontecimento único na vida da divindade, o seu nascimento (27-39), do qual a recepção no círculo dos olímpicos (40-47) representa o devido fecho. O relato do nascimento e o advento no Olimpo que compõem a segunda metade inserem-se, cabe notar, no canto das ninfas, introduzido na primeira metade.

O papel central das ninfas manifesta-se já nos versos introdutórios (1-7), nas três frases relativas em que se subdividem. Pã, à diferença dos demais hinos da coleção, não é de início interpelado diretamente pelo nome, mas como filho do seu pai Hermes. ${ }^{415}$ Pede o poeta à Musa (1) que lhe conte a respeito dele, e estende a frase por intermédio de uma relativa (os... 2) na qual descreve o local por onde vagueia Pã na companhia das ninfas. Estas, por sua vez, também ganham uma relativa (điı... 4), e é somente então, pela boca

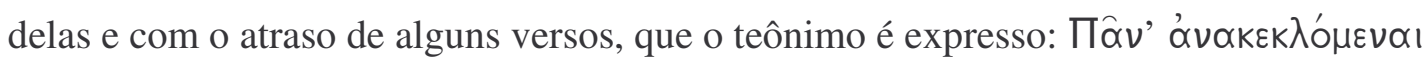
(5). ${ }^{416} \mathrm{O}$ deus remata então com mais outra relativa ("Ó... 6) esses versos de abertura, nos quais as duas frases relativas referentes ao deus ladeiam a relativa dedicada às ninfas (ós - đi - Ǒs). As ninfas acham-se aqui no centro, como no centro também se encontram na

${ }^{414}$ Cf. Fröhder (1994), 334.

${ }^{415}$ Ibid., 307 e 309.

${ }^{416}$ Cf. Schwabl (1969), 6 n.4. 


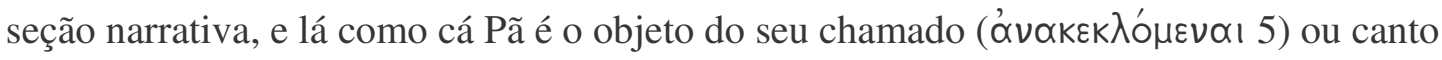

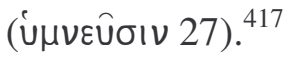

$\mathrm{O}$ artifício de inserir um canto dentro de um canto, um hino dentro de um hino, reaparece em outro poema da coleção, o Hino Homérico a Ártemis ( $\left.\mathrm{n}^{\mathrm{o}} 27\right)$. Também aqui descreve-se uma transição semelhante à do nosso poema, da caça à dança. Dedica-se a deusa às suas duas atividades típicas, a caça na primeira metade, a dança na segunda, esta última em companhia das Musas e das Graças, cujos movimentos ela organiza. Saciada da caça, Ártemis dirige-se à morada do seu irmão Apolo (16-20):

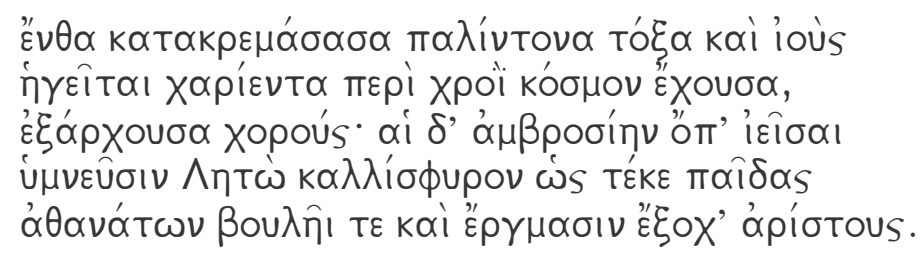

'Lá ela pendura o seu arco recurvo e as suas flechas e toma a frente, seu corpo coberto de belos ornamentos, liderando as danças; e com vozes divinas elas celebram Leto de belos tornozelos, como ela deu à luz filhos que sobressaem entre os imortais em conselho como em ação.'

Aqui, como no hino a Pã, a história de nascimento (no caso, de Ártemis e Apolo) insere-se no canto das deusas, que é uma atividade típica. ${ }^{418}$ Mas os desdobramentos são aqui sumários: a dois versos resume-se o hino entoado no interior do hino, ao contrário da canção que relata o nascimento de Pã e a sua ascensão ao Olimpo no hino a ele dedicado. Esta canção prolonga-se por quase metade da obra, em meio à dança das ninfas. Sob um prisma diverso, aliás, pode-se dividir o poema de acordo com as duas atividades típicas de Pã - a dança e o pastoreio. Como tema do canto que acompanha a dança, narra-se o nascimento divino e a acolhida pelos seus pares.

- deus pastor (8-18)

- deus dançarino e as ninfas (19-47)

- nascimento (27-47) . filho de Hermes (27-39) . cena no Olimpo (40-47)

\footnotetext{
${ }^{417} \mathrm{O}$ destaque conferido a Hermes na história de nascimento da segunda metade já é sugerido no primeiro verso, no qual ele assume o papel convencionalmente assegurado ao deus a quem se dedica o hino.

${ }^{418}$ A poesia é tematizada na poesia e a canção torna-se objeto da canção também em outros hinos, como Hes. Teog. 36-74, HHom.Ap. 158ss. e duas vezes no HHom.Her., vv. 57ss. e 427ss. Sobre esse último, ver Clay (1989), 95-151.
} 
O hino entoado dentro do hino, portanto, faz parte das ações típicas das ninfas que

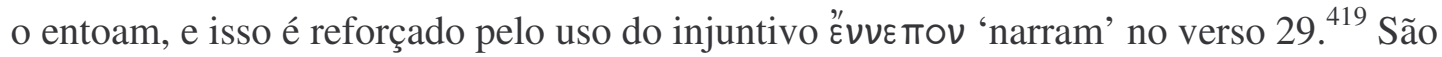

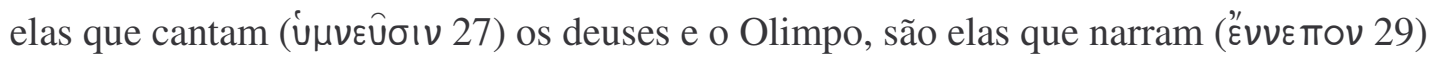
como Hermes é o veloz mensageiro de todos os deuses etc. Ao chegarmos, entretanto, ao verso 32, as duas vozes - a das ninfas e a do poeta - tornam-se indistinguíveis. ${ }^{420} \mathrm{O} \dot{\omega} s$ do verso 29 marca o discurso indireto, que se estende pelo menos até o verso 31; a partir daí, pode-se interpretar que a narrativa segue no mesmo estilo e reproduz o conteúdo do canto das ninfas, ou então que é a voz do poeta que assume o relato. Nessa ambigüidade entre vozes, o poeta faz aderir seu discurso ao das ninfas, com dois resultados principais: primeiro, ele partilha da natureza atemporal do canto das ninfas e de Pã - um atributo particular dos seres mais elevados, cuja natureza reflete-se no uso de um tempo verbal peculiar, o injuntivo; segundo, ele logra assumir, na companhia das ninfas, a posição central por elas ocupada no seu próprio poema. O canto, portanto, não é apenas o tema que une as duas metades do hino, mas o vínculo que une as vozes de poeta, ninfas e divindade, abreviando as diferenças entre o canto mítico atemporal e o canto do poeta, situado no presente.

A duplicação da voz poética, note-se, tem o seu paralelo na estrutura mesma da obra. Se a segunda metade, como vimos, é um hino dentro de um hino, o início dela é

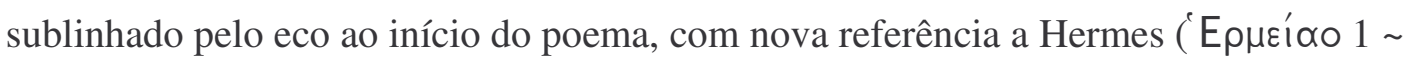

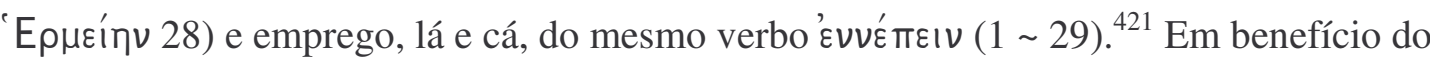
canto, o poeta obtém assim o aval não só das Musas, chamadas que são a lhe afiançarem o enredo da história (cf. v. 1), mas também das próprias ninfas, de quem a sua voz tornase inseparável. As Musas inspiram o poeta, cujo hino narra a história de Pã e das ninfas, que por sua vez entoam um hino no qual as suas vozes confundem-se com a do poeta. Já é ocioso perguntar a quem cabe a narrativa - se às Musas, a Pã, às ninfas ou ao próprio aedo, pois na voz deste, de forma ambígua, as demais se resumem.

\footnotetext{
${ }^{419}$ Sobre o injuntivo, ver item 3.1.2 e West (1989).

${ }^{420}$ Cf. Vamvouri (2004), 149: "La voix du dieu se superpose à celle du locuteur-aède au point d'en être indissociable", e Germany (2005), 193: "[...] we cannot quite discern whether we are listening to the inspired Homeric hymnist, the Muse herself, Pan and his nymphs, or the particular nymph, Echo".

${ }^{421}$ Paralelo notado por Germany (2005), 191.
} 
A ambigüidade é justamente um outro artifício retórico utilizado pelo poeta hínico para fazer cair barreiras - seja a barreira existente entre deuses, seja sobretudo a existente entre deuses e mortais, como veremos nos breves exemplos a seguir.

\subsubsection{Ambiguiidade}

Apolo parece ter sempre desempenhado papel de eminência no culto a Asclépio, mas em nenhum poema esse estreito laço entre as divindades traduz-se tão bem quanto no peã eritreu a Asclépio, que data do primeiro terço do século IV a.C. Além da versão eritréia, que é a mais antiga, três outras acham-se preservadas: de Ptolemais no Egito (do ano de 97 d.C.), de Atenas (século I ou II d.C.) e de Díon na Macedônia, que remonta ao século II d.C. Esse rico testemunho é praticamente único na história do gênero, e o arco das atestações, que se estende por quase 600 anos, revela o quanto a obra era estimada pelos fiéis. O texto de Eritréia está inscrito em uma lápide de mármore com instruções a respeito do ritual, que envolvia a repetição, por três vezes, de um peã a Apolo em torno do seu altar. ${ }^{422}$ No reverso, lêem-se dois textos: o primeiro, fragmentário, parece conter um outro peã a Apolo, diverso daquele inscrito na frente da lápide; o segundo exibe este peã a Asclépio.

\subsubsection{Peã Eritreu}

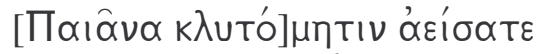

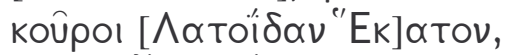

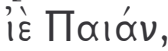

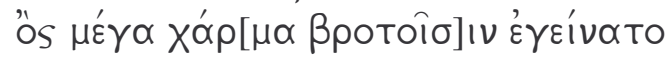

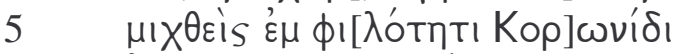

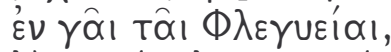

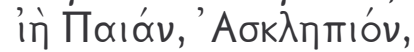

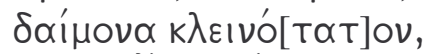

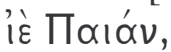

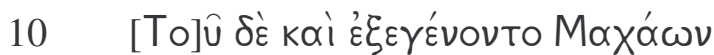

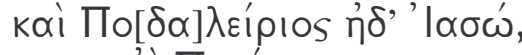

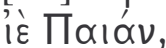

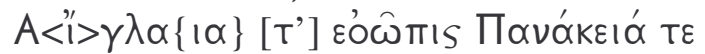

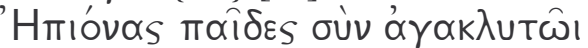

15 દoa

${ }^{422}$ Cf. Graf (1985), 250ss. Adoto o texto de Furley-Bremer (2001), vol. 2, 161s. 


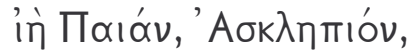

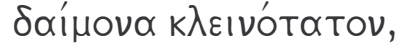

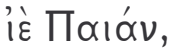

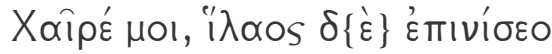

20

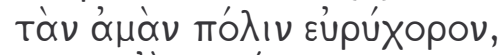

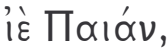

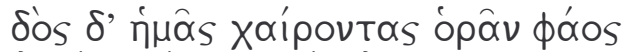

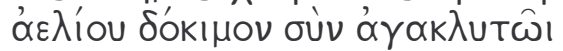

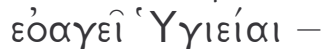

25

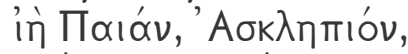

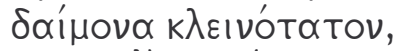

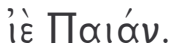

(Cantai, jovens, o Peã famoso por sua perícia, filho de Leto, deus que atira longe - iê Peã! -, que gerou grande alegria aos mortais unindo-se em amor com Corônis na terra de Flêgias - iê Peã! -, Asclépio, famosíssima divindade - iê Peã! /

De quem por sua vez foram gerados Mácaon, Podalírio e Íaso - iê Peã! -, e Aigla de belos olhos e Panacéia, filhas de Epione, com a pura Higiéia de vasta fama - iê Peã! -, Asclépio, famosíssima divindade - iê Peã! /

Eu te saúdo: vem com indulgência à nossa cidade com o seu amplo local de dança - iê Peã! -, concede que vejamos felizes a estimada luz do sol com a pura Higiéia de vasta fama - iê Peã! -, Asclépio, famosíssima divindade - iê Peã!)

São três as estrofes em dáctilos líricos interrompidos pelo refrão médio ('ì Taı́áv) e pelo dímetro jâmbico do primeiro verso do refrão final $(7,16,25)$. À divisão estrófica corresponde a repartição de conteúdo, em três estágios: da exortação ao coro de jovens para que cante Apolo, genitor de Asclépio, passa-se à progenitura deste último, e dela ao pedido de saúde em benefício da cidade. Na terceira estrofe, a do pedido, transitase para o "Du-Stil", em contraste com a narrativa em terceira pessoa que vigora nas duas primeiras estrofes. Nestas, elemento comum é o tema genealógico: Apolo gerou Asclépio e este, por sua vez, gerou outros tantos descendentes. É como genitor destes, justamente, que Asclépio é chamado a dispensar saúde à cidade. Afinal, ele é pai dos dois médicos míticos da Ilíada, Mácaon e Podalírio, e sua mulher e demais filhas são etimologicamente

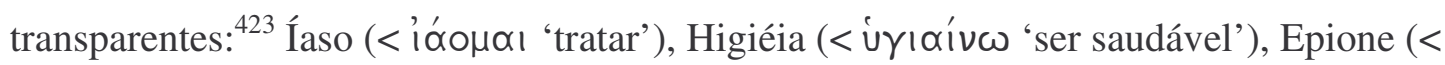

${ }^{423}$ Cf. Bremer (1981), 209, e Käppel (1997), 195s. 


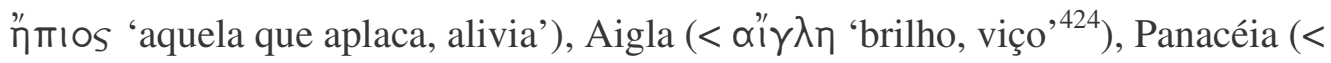

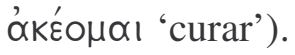

A linguagem é singela, a estrutura é clara, marcada pela extrema simplicidade, o que transforma o poema em objeto de pronto uso, quase um peã de bolso para qualquer eventualidade. ${ }^{425}$ Para tanto, evitam-se referências particulares que caracterizem os fiéis como pertencentes a esta ou aquela localidade: os "jovens" exortados a cantar (2) podem ser quaisquer jovens; a "nossa cidade" (20) beneficiária da graça divina pode ser qualquer cidade. Ainda assim, cabe ao poema o mérito de traduzir em linguagem poética o estreito vínculo entre Apolo e seu filho Asclépio, cujo culto parece jamais estar separado do culto devido a seu pai. ${ }^{426}$ A primeira estrofe volta-se de início a Apolo, objeto da canção que o coro é incitado a entoar. Seu louvor prolonga-se de forma característica por intermédio de uma frase relativa ("ó ... 4), não sem antes soar o meshumnion "iê Peã!" (3). Peã refere-se

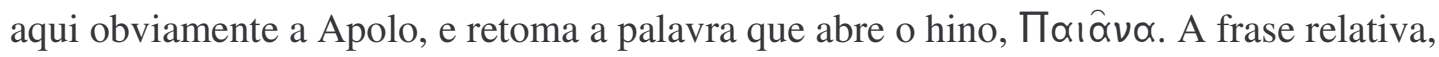
por sua vez, promove a transição de Apolo a Asclépio - do objeto da primeira estrofe ao destinatário do hino. ${ }^{427}$ E agora, no ephumnion, Asclépio mencionado no acusativo (7) é integrado sintaticamente à relativa que o precede, em aposição a "grande alegria" ( $\mu$ ź$\gamma \alpha$

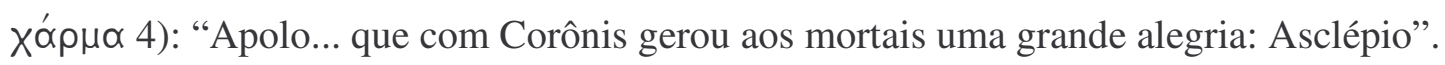

Nesse refrão que fecha a primeira estrofe, porém, antes da menção a Asclépio, há

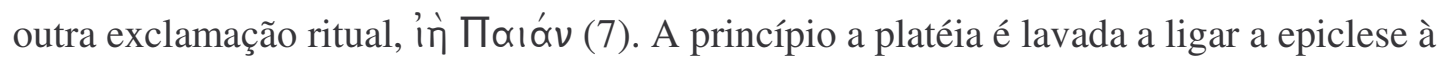
figura de Apolo, sujeito da relativa, mas a palavra que segue imediatamente, Asclépio no acusativo integrado à frase, faz pender a balança em favor desse último. Tanto mais que

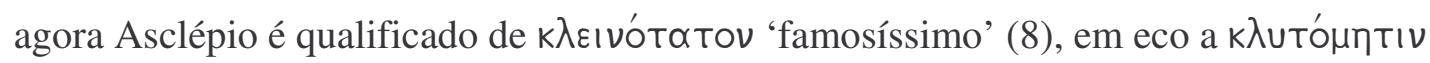
(1) 'famoso por sua perícia', adjetivo concedido a Apolo. Ao termo da estrofe e do refrão,

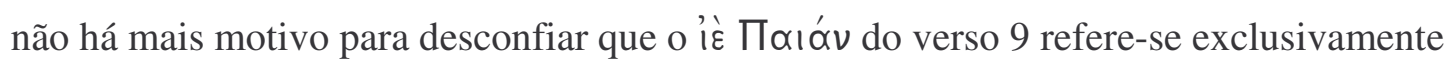
a Asclépio, a divindade que se acha no ápice do movimento estrófico e que lhe domina a cena. Dele, de fato, é que parte a segunda estrofe, com outro relativo ( Toû $\delta^{\prime} \varepsilon . .10$ ).

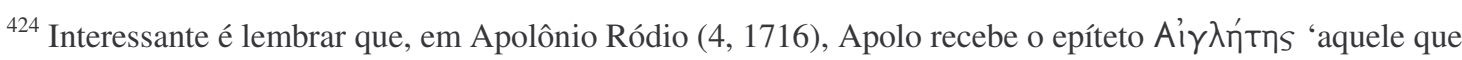
brilha', o que evidencia a sua associação com Asclépio em Anafe. Cf. Bremmer (2005).

${ }^{425}$ West (1982), 141, inclui-o na categoria de peãs "subliterários".

${ }^{426}$ Graf (1985), 250: "Mit dem Kult Apollons ist auch in Erythrai, wie an vielen anderen Orten der antiken Welt, derjenige des Asklepios verbunden, und wie anderswo, trug vielleicht auch Apollon schon vorher die Züge eines Heilers". Cf. ainda Furley-Bremer (2001), vol. 1, 213.

${ }^{427}$ Cf. Käppel (1997), 194.
} 
Vejamos num esquema como se dá a passagem de uma divindade a outra através do emprego de um mesmo termo, "Peã":

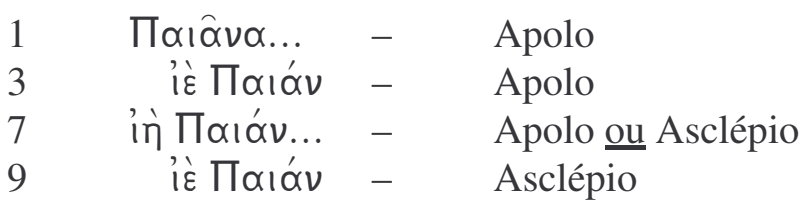

Ambos, meshumnion e ephumnion, são assim inseridos na sintaxe, e de um deus a outro somos conduzidos com certa elegância. Nas estrofes seguintes, cabe notar, o nome de Asclépio contido nos refrões finais continua a figurar no acusativo, embora agora sem

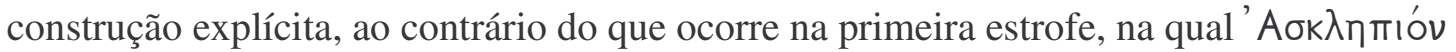

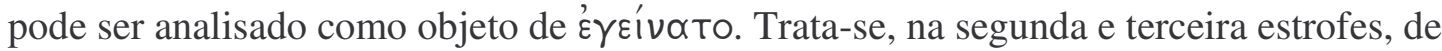

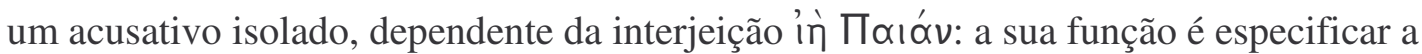
divindade louvada por meio da exclamação. ${ }^{428}$ Mesmo que a interjeição o governe, o acusativo ligado ao nome de Asclépio traz à lembrança, ao longo do hino, essa passagem crucial de Apolo a Asclépio - dois deuses Peãs - contida na primeira estrofe. Nas demais versões do peã, tardias, o acusativo do refrão final das duas últimas estrofes é corrigido

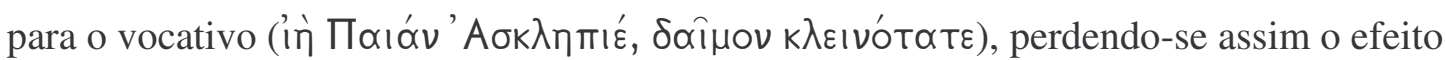
em surdina ${ }^{429}$ do uso reiterado do acusativo.

Do Peã Apolo, de quem parte o hino, ao Peã Asclépio, a quem se faz o pedido de saúde e prosperidade, o poeta mimetiza as circunstâncias reais de culto, nas quais o deus Asclépio costuma ser venerado ao lado do deus Apolo. Borra-se, nesse propósito, a linha divisória entre um e outro, para louvor tanto maior de ambos e mérito do próprio poema, que promove tal junção.

\subsubsection{Píndaro, Olímpica 4, 1-16}

Ambígua também pode ser a referência, não apenas a duas divindades, mas ainda a um deus e um mortal, tendo como o pivô da relação a figura do poeta. Este é o caso do hino a Zeus que inaugura a Olímpica 4 de Píndaro.

\footnotetext{
${ }^{428}$ Cf. Rutherford (2001), 317, e Kühner-Gerth (1890-1904), vol. 1, 329-31 (“absoluter Akkusativ").

${ }^{429}$ Para exemplos concretos de tal recurso, cf. Spitzer (1970).
} 


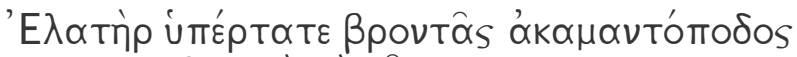

estr.

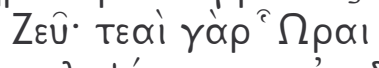

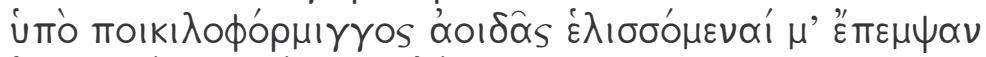

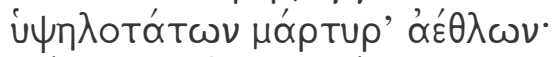

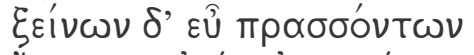

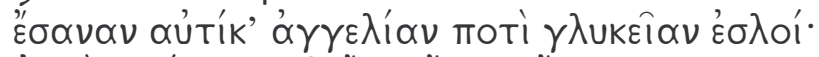

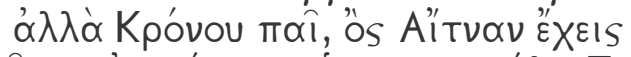

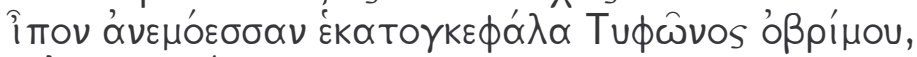

Oủ $u \mu \pi$ TIOvíkav

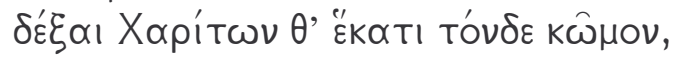

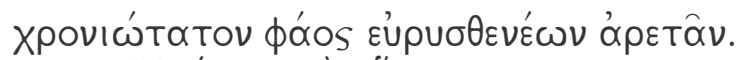

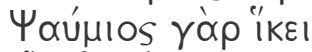

ox

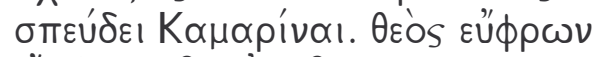

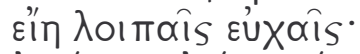

દ̇

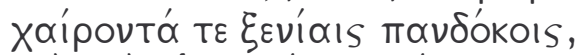

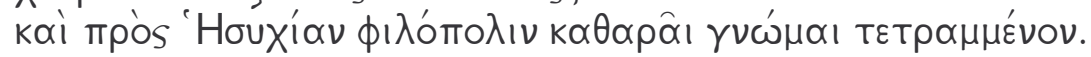

ant.

(Condutor mais sublime do trovão de pés incansáveis, Zeus: [eu te invoco] pois as Horas, em suas rondas circulares, enviaram-me acompanhado da canção com os tons variados da lira, como testemunha dos jogos mais excelsos; e quando os anfitriões têm sucesso, os homens de bem imediatamente se alegram com as doces notícias. Mas filho de Cronos, tu que reinas sobre o Etna, fardo tempestuoso para o poderoso Tifos de cem cabeças, recebe um vencedor olímpico e, com a ajuda das Graças, essa celebração, /

luz de mais longa duração para os feitos de grande força. Pois ela chega em honra da carruagem de Psaumis, que, coroado com a oliveira de Pisa, está ansioso por despertar glória para Camarina. Que o deus olhe com favor as preces futuras, pois eu o louvo, um criador de cavalos dos mais zelosos, que se deleita com atos de hospitalidade que a todos recebe, e devotado à Hesíquia (= paz) com espírito arejado.)

Píndaro duplica aqui o movimento do universal ao particular que observamos nos vários exemplos do primeiro capítulo. São duas as partes, divididas em invocação e reinvocação, que conduzem do deus louvado à ocasião específica na qual ele é chamado a prestar os seus favores. Em ambas, o caminho que leva da divindade ao vencedor atlético é expressamente mediado pelo poeta.

Abre o hino com uma elaborada invocação de Zeus, na qual o teônimo é retido até

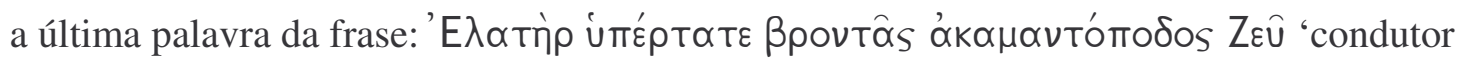
mais sublime do trovão de pés incansáveis, Zeus' (1). Os quatro termos que o precedem ganham assim certa proeminência, que será explorada na sequiência do poema. Destaque também é dado ao Tعơi que lhe segue, cuja função é análoga aos pronomes relativos que 


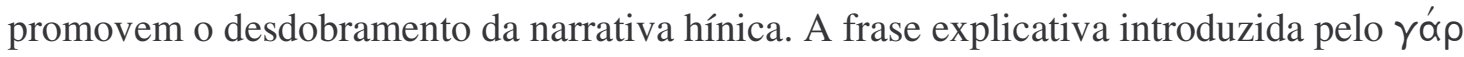
(1), com a elipse do verbo subentendido, fornece um elo entre Zeus e as divindades que o acompanham: “(Eu te invoco) pois foram as tuas Horas...” Estas, por sua vez, servem de ponte para que o poeta entre em cena. Foram elas que o enviaram ( $\left.\mu^{\prime} \varepsilon^{\prime} \pi \varepsilon \mu \psi \alpha \nu 2\right)$ como testemunha - e aqui nova passagem, agora do poeta ao vencedor -, dos jogos olímpicos.

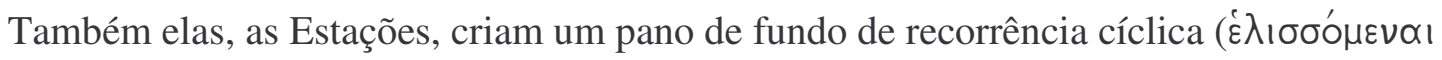
2) contra o qual se destaca a vitória na presente Olimpíada. ${ }^{430}$ De Zeus passamos assim às suas divindades satélites, as Horas, e delas ao poeta, cuja missão é dar notícia da vitória em uma competição atlética. O elo entre deus, poeta e vencedor reflete-se na ordem das

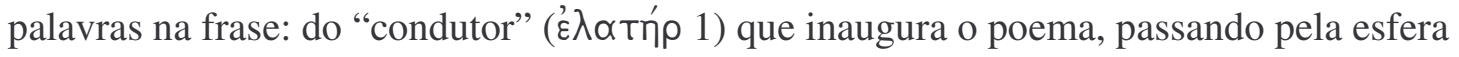

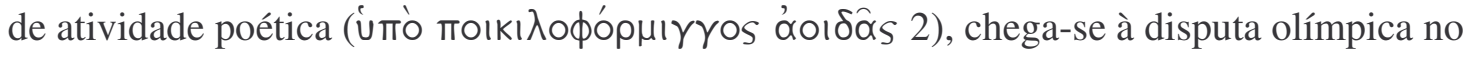

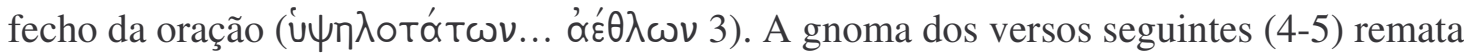
esse trajeto e ao mesmo tempo prepara para nova seqüência de versos (6ss.), na qual se repetirá o mesmo esquema (deus $\rightarrow$ poeta $\rightarrow$ vencedor), mas agora de forma mais ambígua e elaborada.

A partícula $\alpha \lambda \lambda \alpha^{\prime}$ (6) marca uma nova invocação de Zeus, cuja vitória sobre Tifos

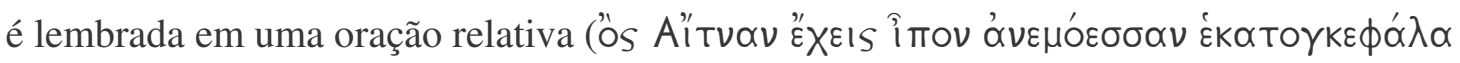

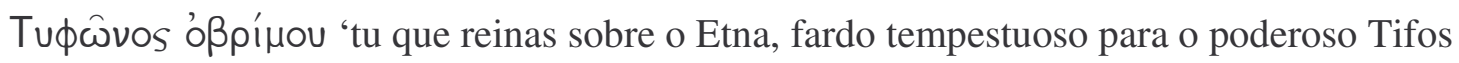
de cem cabeças' 6-7). Tal re-invocação de certo modo retoma e desdobra a primeira, pois foi com o raio ${ }^{431}$ (cf. ßpovtôs 1) que ele triunfou sobre o monstro. O imperativo ( $\delta_{\varepsilon}^{\prime} \xi \alpha$ । 9), já antecipado pelo ó $\lambda \lambda \alpha_{\alpha}$ que costuma sinalizá-lo, efetua então a passagem ao poeta e ao vencedor: pede-se a Zeus que receba de bom grado o vencedor e esse poema que lhe é entoado. Sublinha o poeta a referência à própria obra através de uma oração preposicional

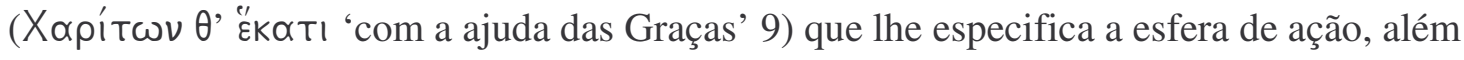
de explicitar o seu poder de imortalizar conquistas de relevo: ela é a "luz de mais longa

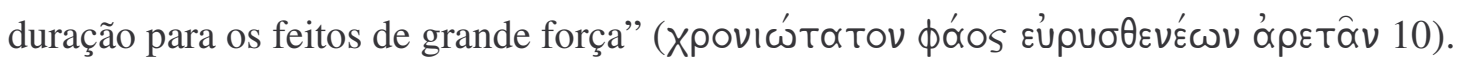

Parece aqui encerrar-se novamente o caminho que leva do deus ao poeta e deste ao vencedor. Mas a princípio, como nota Race, ${ }^{432}$ tais "feitos de grande força" referem-se tanto à conquista atlética de Psaumis quanto, num sentido mais amplo, à vitória de Zeus

\footnotetext{
${ }^{430}$ Cf. Race (1990), 92, cujos comentários gerais sobre o hino eu sigo de perto.

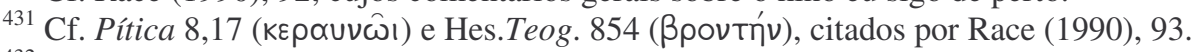

${ }^{432}$ Race (1990), 94.
} 
sobre Tifos, narrada nos versos precedentes (6-7). Até ali permaneceram vagas as alusões à vitória olímpica; o nome e a cidade do vencedor, elementos formais básicos do epinício, ainda restam em aberto. Após a re-invocação, ressalta a imagem vitoriosa de Zeus, e nada mais natural que relacionar também a ele, não só ao atleta, tais façanhas de grande monta. A ambigüidade parece dissipar-se, porém, nos versos seguintes (10b-12). Em uma frase explicativa ( $\gamma \alpha ́ \rho . .$.$) , na qual nome e cidade do atleta situam-se enfaticamente no começo$

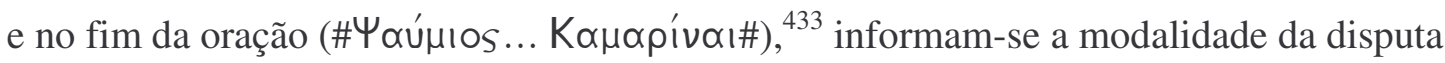

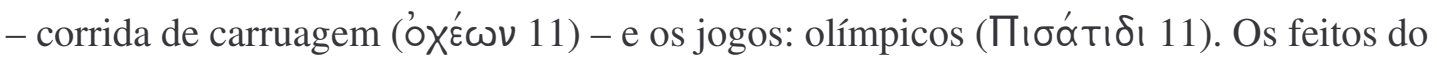
verso 10 diriam respeito, portanto, à conquista de Psaumis na corrida de cavalos, naquela Olimpíada específica do ano de 452 a.C. Aqui, todavia, uma vez fornecida a informação sobre a modalidade cuja vitória é celebrada, torna à lembrança o início enfático da ode -

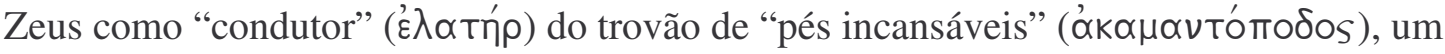
atributo metafórico que equipara, presumivelmente, o rolar do trovão ao estampido dos cascos eqüestres. Entre Zeus e Psaumis estabelece-se com isso um elo subliminar: ambos são condutores, um de carruagem, outro de trovões que a cavalos equivalem; ambos conquistaram vitórias, um no vale de Pisa, outro sobre o mítico Tifos no Etna (vulcão, aliás, situado na Sicília, onde se localiza também Camarina, cidade do vencedor); ambos, enfim, têm sua grandeza reconhecida em superlativos, sendo um dito "o mais sublime"

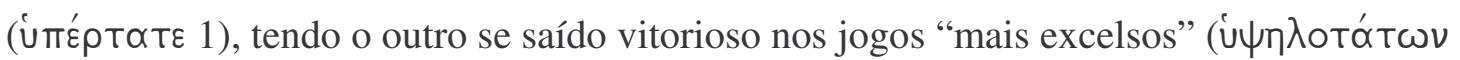
$3)$.

Se na primeira invocação o poeta servira de laço entre deus e vencedor, agora, na re-invocação, ele surge como pivô de referências cruzadas entre um e outro. Mesmo no

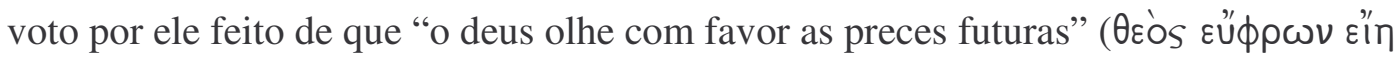

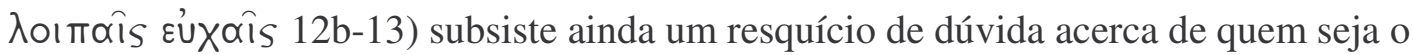
verdadeiro sujeito de tais preces. Natural é supor que seja Psaumis, que sejam as suas preces futuras pelas quais o poeta intercede com o seu pedido junto à divindade. Tanto

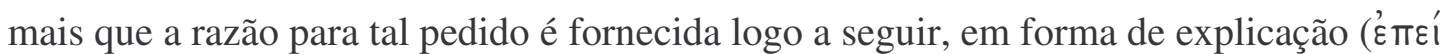
14): "pois eu o louvo..." Pede-se que o favor divino continue no futuro por causa das virtudes de Psaumis. As عủ đấs seriam aqui as suas preces por mais vitórias. Mas nada impede, de outro lado, que essas preces sejam as do próprio poeta. No verso 10 , como

${ }^{433}$ Ibidem. 
vimos, sua ode é descrita como a luz capaz de conferir extrema longevidade aos feitos de grande força. Tal descrição, porém, está inserida num pedido a Zeus, para que ele receba ( $\left.\delta^{\prime} \xi \xi \propto । 9\right)$ de bom grado o poema, o que a torna uma espécie de esperança proléptica ${ }^{434}$ de que o aval divino assegure essa permanência. Ora, como os feitos de grande força aludem também aos atos de Zeus, pode-se compreender aqui que o poeta pede à divindade que seja favorável a suas preces, que tenha prazer ( $\varepsilon \cup ̋ \phi \rho \omega v \varepsilon l \eta \eta)$ com os seus hinos futuros, dos quais ele, Zeus, é o destinatário e o objeto. A indeterminação, aliás, avança mesmo na frase explicativa: de início não está absolutamente claro a quem se refere o pronome

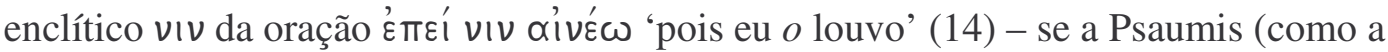
seqüência da frase deixará manifesto), ou ao próprio Zeus.

Deus e vencedor, respectivamente o pólo universal e particular do louvor poético, são assim unidos em suas características, cada qual dentro da sua respectiva esfera. Aqui o poeta, por meio retórico, esfuma os limites entre atleta e divindade, assim como no peã Eritreu abreviara a distância que separa os dois deuses, Apolo e Asclépio. Vezes há em que a própria canção, ao explorar o sentido dúbio de uma frase, mescla as suas fronteiras ao âmbito divino. Nunca isso ocorre de forma mais singela e concisa do que na invocação ritual de Dioniso pelas mulheres de Élis (PMG 871):

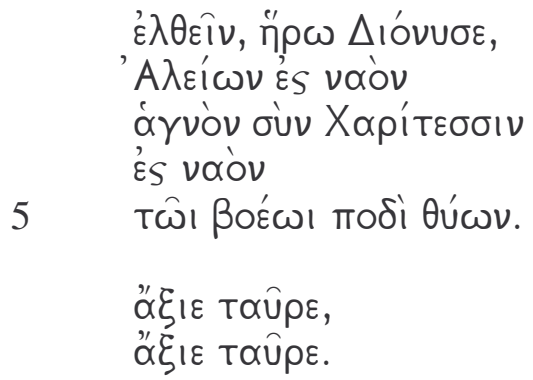

(Vem, senhor Dioniso, para o templo sagrado da gente de Élis, acompanhado das Graças, para o templo, em disparada com teus pés de boi. Touro de valor, touro de valor.)

A associação entre Dioniso e o touro é corrente nos documentos gregos. ${ }^{435}$ Aqui, o mais provável, como sugerem Furley-Bremer, ${ }^{436}$ é que as mulheres de Élis interpelem simultaneamente o animal conduzido ao sacrifício e o deus em pessoa. Touro e divindade

${ }^{434}$ A expressão é de Race (1990), 94.

${ }^{435}$ Para referências, cf. Furley-Bremer (2001), vol. 1, 369-72.

${ }^{436}$ Ibid., 372. 
tornam-se um só à luz do ritual - o animal diviniza-se, o deus assume feição teriomórfica. Dioniso é invocado como touro à medida que este é levado ao sacrifício a realizar-se no templo de Élis. Local e modo são assim fixados para o advento divino - o templo e seus pés bovinos -, e pede-se ainda que ele venha na companhia das Graças, nesse caso as divindades satélites que cercam o destinatário principal do poema, um aspecto comum da narrativa hínica. ${ }^{437}$ Tais Graças, porém, e aqui reside a ambigüidade da expressão, são ao

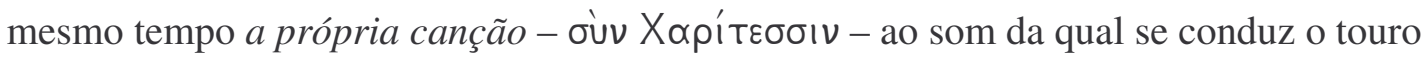
para sacrifício no templo. ${ }^{438}$ Pode-se igualmente interpretar a expressão como um dativo comitativo, caso no qual as Graças são compreendidas como deusas, ou como um dativo instrumental, com o que se faz referência ao canto dotado de graça e charme por meio do qual se pretende atrair Dioniso ao culto. ${ }^{439}$ São dois vetores opostos que se encontram em um mesmo ponto - as deusas Graças que vêm de fora para supostamente infundir charme ao canto, e o próprio canto cujo charme atrai Dioniso de longe para perto.

\subsubsection{Hino matinal a Aclépio}

Outro exemplo bastante simples de como o fiel faz mesclar sua atividade ao poder divino é uma canção matinal para Asclépio, contida na mesma lápide (hoje em Kassel) na qual se acha inscrito o peã a Higiéia de Arífron. ${ }^{440}$

\footnotetext{
${ }^{437}$ As Graças cumprem aqui o papel de figura complementar ou de séquito que iluminam, por contraste, o personagem principal, como é corriqueiro nos hinos. "Dionysos", nota Fröhder (1994), 83, "hält sich gerne im Thiasos der Mänaden auf, Aphrodite läßt sich von den Horen ankleiden und schmücken. Der Hirtengott Pan pflegt sich Nymphen anzuschließen, mit denen auch Artemis anzutreffen ist, solange sie in der freien Natur jagt. Betritt sie jedoch als Tänzerin Apolls heiligen Hain in Delphi, ist sie von Musen und Chariten umringt".

${ }^{438}$ Cf. Furley-Bremer (2001), vol. 1, 372 n.8.

${ }^{439}$ Cf. Kühner-Gerth (1890-1904), vol. 1, 430-7, e Smyth (1920), 346-50. Ambigüidade análoga é a dos

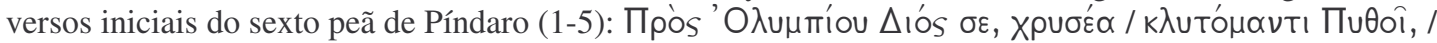

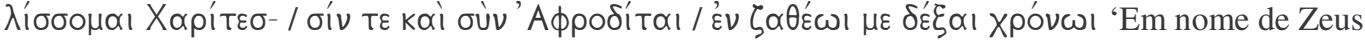
Olímpio, rogo-te, Pito dourada, famosa pela profecia, com as Graças e Afrodite recebe-me, porta-voz das Piérides, famoso pelo canto, nesse tempo sagrado'. É lícito interpretar que Píndaro faça sua súplica a Pito e conjuntamente às Graças (dativo comitativo) ou então que afirme serem as Graças e Afrodite atributos da

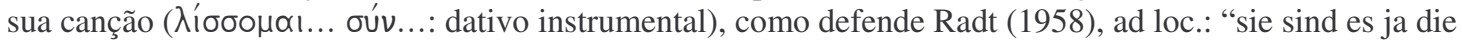
dem Lied, um dessen Aufnahme Pindar die Pytho bittet, Anmut verliehen haben, und stehen daher bei einer solchen Bitte auf seiner Seite". Para o uso metonímico das "Graças" para denotar "canção", cf. o peã de Arífron (PMG 813), 9 (item 1.1.4), e Aristóf. Tesm. 121-2.

${ }^{440}$ Ver acima, item 1.1.4. O texto da canção a Asclépio é de Dittenberger IG III.1,171 (1878) e Kaibel, Epigrammata Graeca, 1027 (1878).
} 


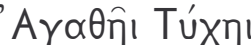

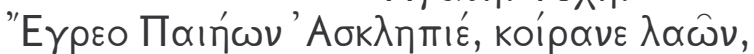

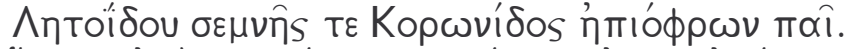

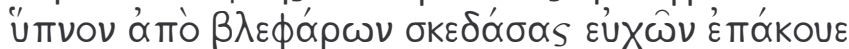

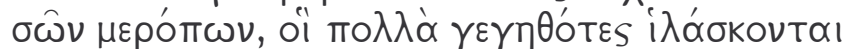

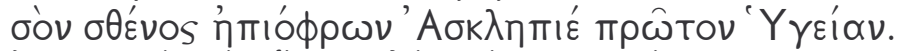

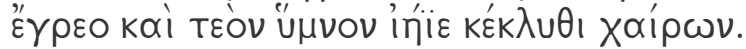

(Acorda, Peã Asclépio, senhor dos povos, filho de terno coração do rebento de Leto e da augusta Corônis. Sacode o sono dos teus olhos, escuta a prece dos teus devotos, que em júbilo suplicam, ó Asclépio de terno coração, pela tua força primeira: a saúde. Acorda e, com prazer, dá ouvidos a teu hino, ó Peã!)

Esse breve hino encabeça os textos sagrados gravados na pedra; é provável que a ordem de inscrição obedecesse a propósitos cultuais, cada hino sendo cantado ao longo do rito diário na seqüência em que foi registrado, como sugere Maas. ${ }^{441}$ Trata-se aqui de uma prece matutina (talvez a primeira do dia), na qual se roga ao deus que desperte e dê atenção ao canto dos seus fiéis.

Não é sem alguma habilidade que o poeta desincumbe-se da genealogia divina em um único verso hexamétrico. De maneira concisa, a informação genealógica envolve não só Apolo e Corônis, pais de Asclépio, mas ainda Leto, presente na forma do matronímico $\wedge$ ^тої́оou. Duplica-se, assim, a seqüência mãe $\rightarrow$ filho: Leto $\rightarrow$ Apolo, Corônis $\rightarrow$ Asclépio

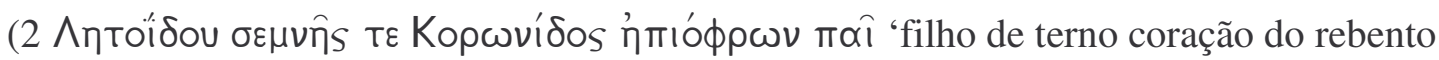
de Leto e da augusta Corônis'). A técnica espelha um bom hinodista e traz à memória um outro poema a Asclépio, o peã de Sófocles ( $P M G 737)$ :

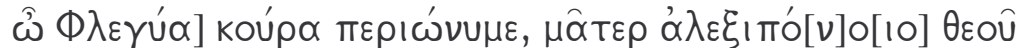

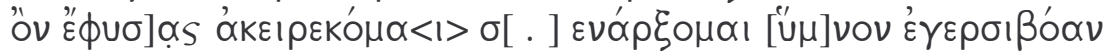

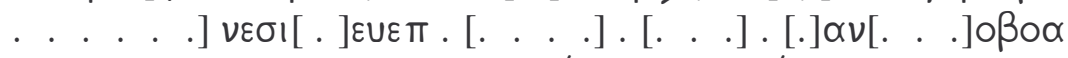

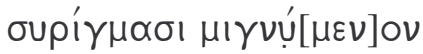

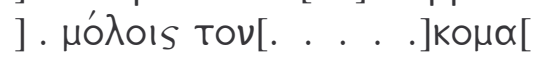

]v auTOv[

'Filha de Flêgias, amplamente famosa, mãe do deus que afasta a dor, (o qual tu geraste) ao deus de cabelos intonsos... dou início ao hino que desperta o brado... misturado com as flautas... ajudante dos cecrópidas... vem!...'

${ }^{441}$ Maas (1933), 154-5. Cf. ainda Furley-Bremer (2001), vol. 1, 268. 
A Corônis é endereçado o poema, e a menção a ela permite incluir com brevidade

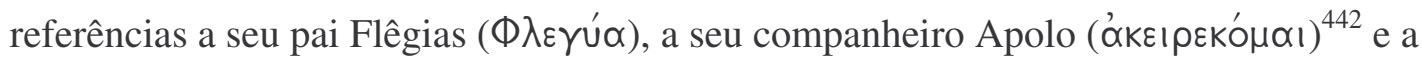

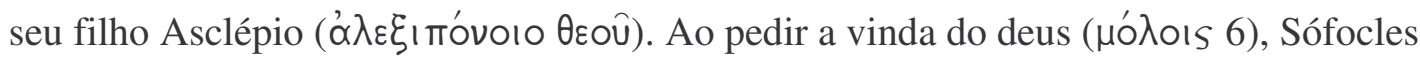

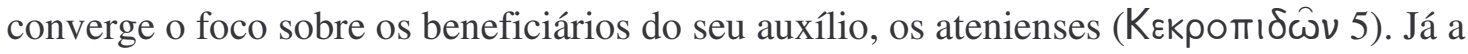
estratégia do poeta da prece matinal a Asclépio para aproximar fiel e divindade é outra. Seu hino também possui o poder de despertar, não somente o brado como no de Sófocles

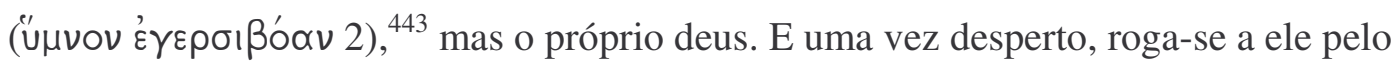

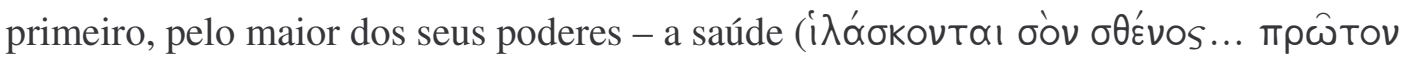
'Y Yeíav 4-5). Prōton é usado aqui como predicativo e qualifica son sthenos, mas nada nos impede interpretar o termo - e nisso radica a ambigüidade - como advérbio ${ }^{444}$ que modifica hilaskontai: "(teus devotos) suplicam por saúde primeiro, em primeiro lugar”, ou seja, é a primeira coisa que fazem no dia. Isso quadra bem com o fato de o hino estar inscrito à frente dos demais na lápide de Kassel, sendo muito provavelmente o primeiro do horário litúrgico a ser cantado.

Ato ritual e poder divino encontram como que um denominador comum: o favor primeiro de Asclépio (a saúde) é aquilo pelo que primeiro suplicam os mortais em suas preces. Uma certa reciprocidade, aliás, entre deus e devotos é sugerida pelo júbilo mútuo que caracteriza ambos: estes suplicam alegres ( $\gamma \varepsilon \gamma \eta \theta$ ótes 4) a graça divina, e aquele há

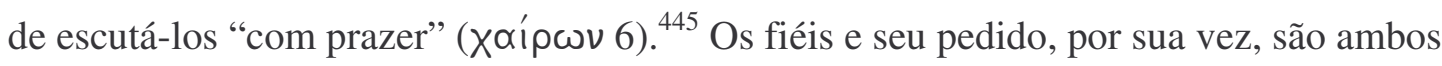

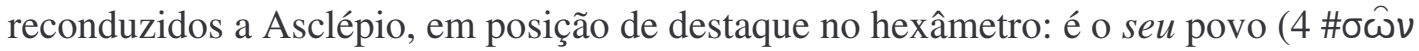

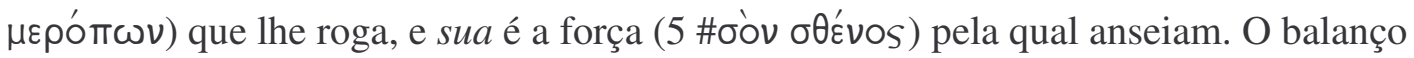
também é alcançado pela repetição de palavras-chave em quiasma, no começo e fím do poema:

\footnotetext{
${ }^{442}$ Tal como se encontra inscrito, o termo dá margem a várias interpretações: pode ser tanto um nominativo

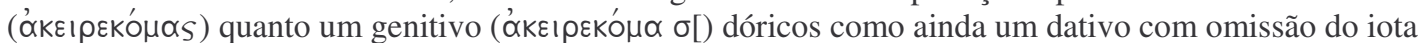
final. Em qualquer uma dessas hipóteses, porém, é inegável a alusão a Apolo.

443 'E $\gamma \varepsilon i ́ p \omega$ 'despertar' é usado com frequiência no sentido metafórico, tendo por objeto a canção, a lira, a música etc. (cf. referências no $L S J$ ). No sânscrito védico, a raiz budh- 'despertar, atentar' (tanto em seu tema primário bódha- quanto no causativo bodháya-) também é empregada no contexto em que o fiel desperta a divindade. Cf. RV 7.21,1cd: bódhāmasi tvā hariaśva yajñaír/ bódhā na stómam ándhaso mádeșu 'Nós te despertamos, ó (senhor) dos cavalos baios, com sacrifícios. Atenta para o nosso louvor em (tua) embriaguez de soma'; RV 8.44,1ab: samídhāgním duvasyata/ ghrtaír bodhayatătithim 'Com lenha ritual venerai Agni, com manteiga líquida despertai o hóspede'.

${ }^{444}$ Furley-Bremer (2001), vol. 2, 235.

${ }^{445}$ Xóípwv significa aqui, como de costume, não só o prazer da divindade com o hino que lhe é oferecido, mas sugere ainda sua predisposição a retribuir a dádiva. Cf. o próximo capítulo.
} 


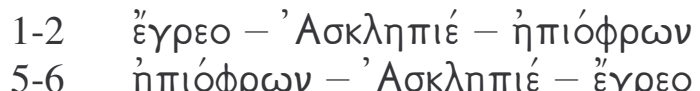

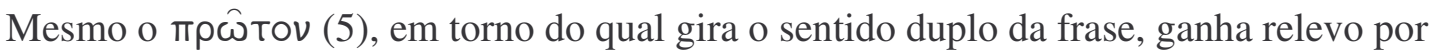
inserir-se nessa seqüência, assim como a elaborada genealogia da invocação inicial.

O louvor à divindade mescla-se assim ao pedido dos mortais a ela endereçado, um recurso retórico para aproximar a ambos também utilizado, sob outro prisma, nesta frase proferida por Ágaton nas Tesmoforiantes de Aristófanes (111-13):

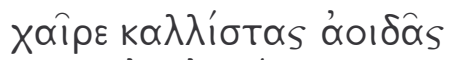

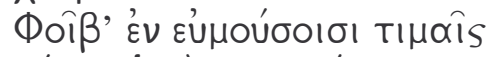

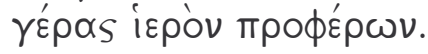

'Salve, Febo, tu que exibes a dádiva sagrada da mais bela canção nas honras musicais.'

Eurípides dirige-se a Ágaton para pedir-lhe que espione as mulheres que, na peça, tramam contra ele, Eurípides. Mal encontra Ágaton, este entoa uma canção (101-29) que exalta Apolo, Ártemis e Leto à maneira tradicional, mas com liberdades métricas que o caracterizam como um inovador em termos musicais. Idealiza-se uma situação na qual o poeta instrui, na condição de ${ }^{\prime} \xi \propto \rho \chi 0 \varsigma$, um coro de jovens mulheres: ele sugere um tema, o coro responde na forma de prece em louvor à trindade délica. $\mathrm{O}$ mais provável é que Ágaton recite e cante não só as suas falas, mas também as do coro, monodicamente. A frase reproduzida acima cabe às jovens; Ágaton as incita a venerar Apolo, deus do arco dourado; elas respondem com uma alusão a outro dos seus atributos, a música.

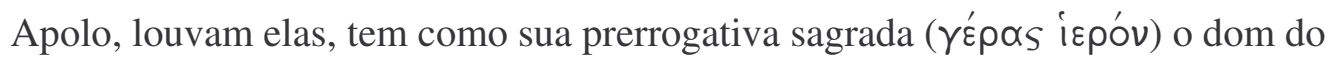

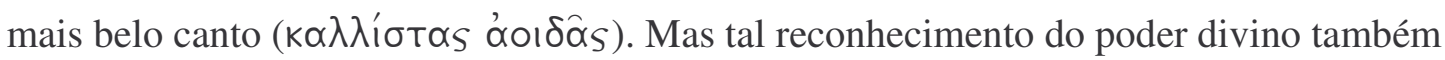
pode ser interpretado em outro sentido, como pedido para que o deus receba com deleite

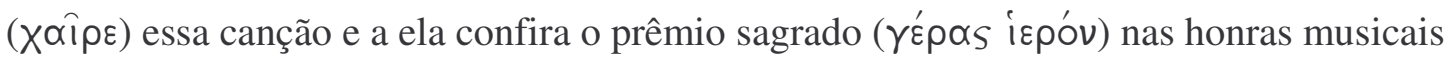

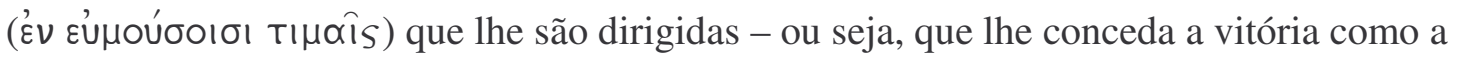

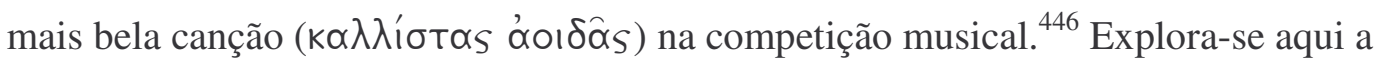

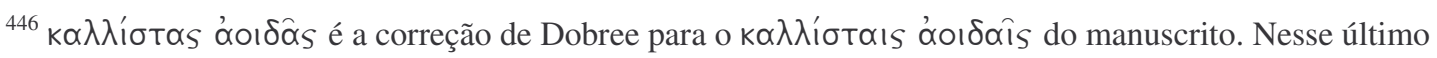

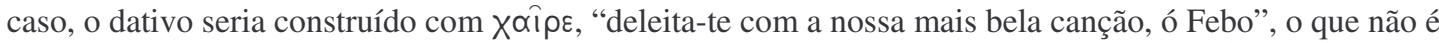
de modo algum indefensável, embora eu ainda prefira o texto corrigido, construindo $k \alpha \lambda \lambda i ́ \sigma \tau \alpha s$ 'oo, $\delta \hat{\alpha}_{S}$

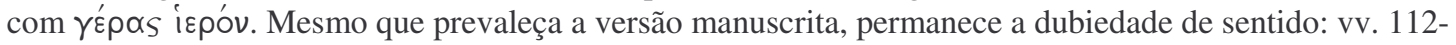


imprecisão semântica das palavras para favorecer esta ou aquela interpretação: $\gamma \varepsilon \rho^{\prime} \alpha_{S}$ pode ser tanto a prerrogativa divina (o foro privilegiado da sua esfera de atuação) quanto

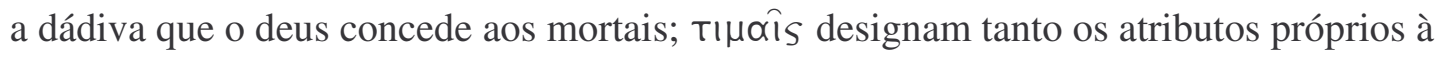
divindade quanto as honrarias que lhe prestam os fiéis, tais como a presente canção.

Ao referir a si próprio ao mesmo tempo que exalta as prerrogativas musicais de Apolo, o coro de jovens (ou Ágaton) une a celebração humana ao poder divino. De tal recurso também se vale um hino de matriz bastante diversa - e aqui chego a meu último exemplo. Trata-se de um texto dos papiros mágicos, um hino a Apolo cuja récita destinase a quem pretenda receber visões proféticas. ${ }^{447}$

\subsubsection{Hino mágico a Apolo}

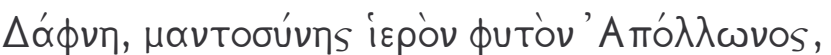

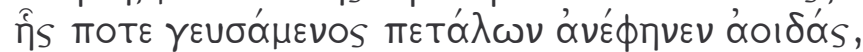

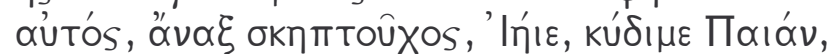

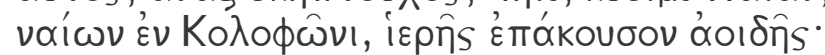

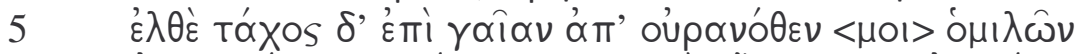

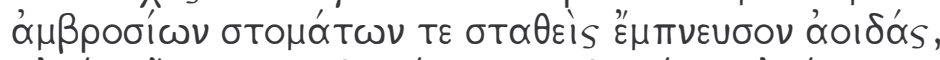

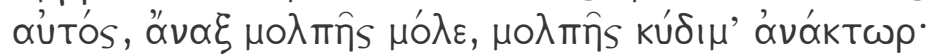

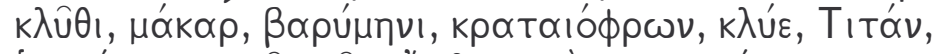

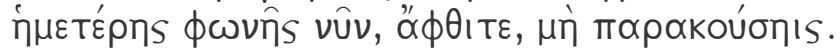

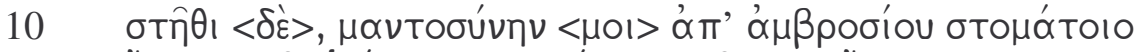

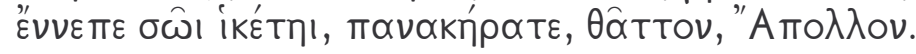

(Loureiro, planta sagrada do dom profético de Apolo, cujas folhas ele saboreou certa feita e revelou canções - tu mesmo e ninguém mais, senhor que empunha o cetro, Iêio, nobre Peã que habita Colofonte, dá ouvidos à canção sagrada; [5] vem rápido, baixa do céu sobre a terra e junta-te a mim, põe-te a meu lado e insufla-me canções da tua boca imortal, tu mesmo e ninguém mais, senhor da canção, vem!, nobre senhor da canção. Escuta, bem-aventurado, deus de pesada fúria e espírito poderoso, escuta, Titã! Não ignores agora a minha voz, ó deus imperecível! [10] Põe-te a meu lado, declara a profecia da tua boca imortal ao teu suplicante, rápido, imaculado Apolo!)

A estratégia de persuasão dos hinos mágicos é semelhante àquela dos hinos de culto. ${ }^{448}$ Aqui, no objetivo de obter inspiração divina, o mágico começa por narrar o

\footnotetext{
13 podem ser compreendidos tanto como "tu que exibes o privilégio sagrado da honraria musical" quanto como "tu que concedes a dádiva sagrada nas honras musicais (a ti devidas)".

${ }^{447} \mathrm{O}$ texto é de K.Preisendanz, E.Heitsch e A.Henrichs, Papyri Graecae Magicae. Die griechischen Zauberpapyri, vol. 2 (Stuttgart, 1974), 245, hino $\mathrm{n}^{\circ} 11$. Reproduzo apenas os onze primeiros versos. ${ }^{448}$ Cf. Graf (1991).
} 
episódio no qual Apolo recebeu poderes visionários após mascar folhas de loureiro em

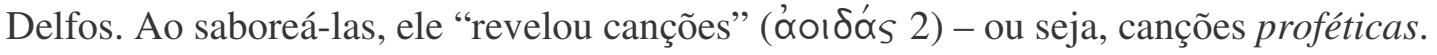
Uma vez estabelecido o paradigma mítico, narrado em terceira pessoa ("Er-Stil"), passa o poeta diretamente ao pedido, marcado pelo anacoluto do pronome enfático oútós (3): do loureiro e sua predicação relativa ( $\hat{\eta}_{S} \ldots$... 2) transita-se a Apolo e sua predicação participial (vơíwv... 4). E é sobre a própria performance que chama a atenção o pedido, pois o poeta

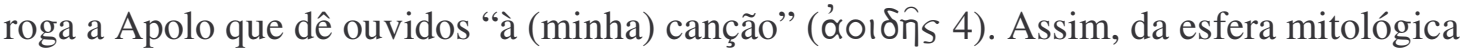
ao hic et nunc do rito, a mesma palavra, em acepções diversas, serve como elo de ligação: aoidē.

Segue então a prece para que o deus baixe do céu à terra e, junto a ele, usuário da

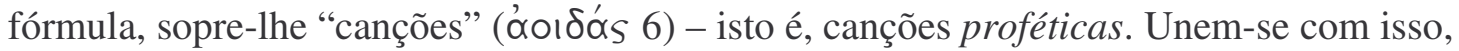
em definitivo, as duas espécies de canto; a intervalos regulares, fechando o hexâmetro, a canção profética de Apolo (’ooı óas 2 6) e a própria canção que o mágico entoa naquele instante ('ơ ôñs 4) ganham certa equivalência: porque Apolo revelou canções proféticas no passado (потє 2), que agora insufle ao usuário as mesmas canções, dando ouvidos no

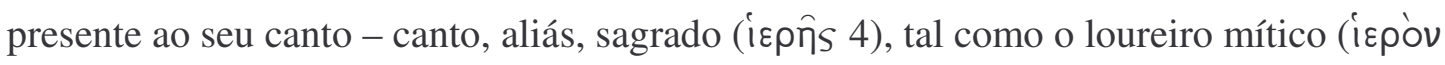
1) que serviu de inspiração ao deus. As duas menções ao canto profético emolduram a auto-referência ao hino, ${ }^{449}$ e a afinidade entre ambos, hino e canto profético, é ressaltada no verso seguinte (7), sob a figura de Apolo. Apolo é, afinal, o "senhor da canção", com poder de dar origem e apreciar um e outro canto. ${ }^{450} \mathrm{O}$ quiasma de $\alpha{ }^{\prime} \nu \propto \xi \mu \mathrm{\jmath} \lambda \pi \hat{\eta} s$ e

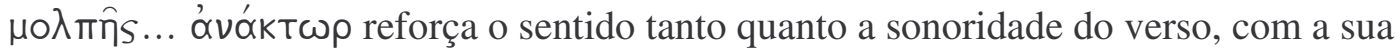
profusão dos fonemas /a/, /o/ e /m/ e o acúmulo dos /e/ no centro (onde se destaca, de forma icônica, o imperativo $\mu$ ó $\lambda \varepsilon$ 'vem!').

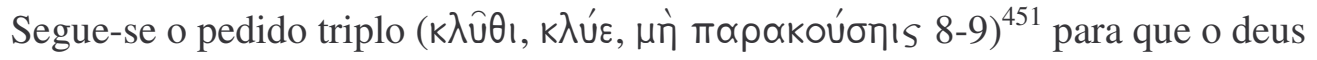

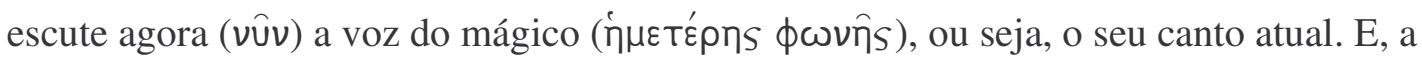

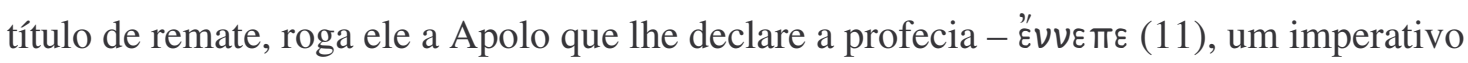

\footnotetext{
${ }^{449} \mathrm{O}$ uso de um mesmo termo-chave em acepções diversas, no intuito de sublinhar o que os une e separa, lembra a repetição concentrada da palavra " $\rho^{\prime} \rho \gamma \propto$ (6 vezes nos 15 primeiros versos) do Hino Homérico a Afrodite $\left(\mathrm{n}^{\circ} 5\right)$. Ver a respeito Porter (1949), esp. 251-4.

${ }^{450}$ Cf. Furley (1995), 40: "There is an element of sympathetic attraction in that the speaker invites Apollo to listen to his sacred invocation $(4,9)$ because Apollo is the originator and lord of holy chants $(1-2,7) . "$

${ }^{451}$ Sobre a fórmula tripla e o número três na religião grega, cf. Usener (1903); sobre o uso retórico corrente da afirmação positiva seguida da contra-afirmação negada, cf. Humbach (1959) e Tzamali (1997).
} 
associado em geral ao pedido por inspiração poética feito às Musas. ${ }^{452}$ Fecha-se assim a prece que busca criar uma empatia entre si própria como canto de louvor e o seu pedido por um canto de inspiração profética, unindo celebração ritual e atributo divino.

${ }^{452}$ Cf. Il.2,761, Od.1,1 etc. 


\section{Capítulo 4}

\subsection{RECIPROCIDADE COMO TEMA}

O ideal de reciprocidade entre deuses e mortais serve de base a toda prática cultual grega e permeia, sem exceção, todos os hinos que analisamos até aqui. Trata-se, de fato, de um ideal, pois boa parte das estratégias retóricas do poeta hínico devota-se a transformar uma relação desigual, na qual os mortais subordinam-se aos deuses, em uma relação de coordenação, marcada pela troca recíproca de bens mutuamente necessários: no caso dos hinos, louvores em forma de palavra e canto são trocados por dádivas, e viceversa. ${ }^{453}$ Cria-se, por assim dizer, a ficção de que entre devoto e divindade existe um laço de benefício recíproco por intermédio do hino ofertado. Mas além de ser um fundamento comum a todo canto de louvor aos deuses, o ideal de reciprocidade pode ser ele próprio enfatizado ao longo do hino, seja como tema, seja como expediente retórico que reforça e estrutura a mensagem central. Tal como os demais recursos estilísticos, porém, também esse costuma mesclar-se a vários outros. Nos hinos até agora analisados, tivemos ocasião de apontar aqui e ali como certos aspectos retóricos contribuem para sublinhar a natureza recíproca das prestações entre deuses e humanos; no que segue, traço o caminho inverso: escolho alguns poucos hinos nos quais a própria reciprocidade é tematizada e assume um viés retórico, cujo propósito é sublinhar justamente a relação de reciprocidade que subjaz à composição.

\subsubsection{Arístono, Peã a Apolo}

Além de um hino a Héstia, que pudemos analisar em outro contexto, ${ }^{454}$ Arístono de Corinto compôs também um peã a Apolo, ambos preservados na mesma lápide. ${ }^{455}$

$$
\begin{aligned}
& \text { ПuӨíav iepóktıтov }
\end{aligned}
$$

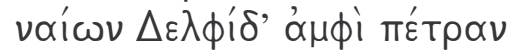

\footnotetext{
${ }^{453}$ Sobre a reciprocidade em geral na religião grega e nos seus hinos, ver Parker (1998), Bremer (1998) e, sobre os Hinos Homéricos em particular, Calame (1995), esp. 11s. ("Contrats de réciprocité"). Cf. ainda Hunter (1996), 73: "Power, particularly when it is power over us, is an uncomfortable poetic subject, because praise of the powerful can never be simply praise - it always contains a recognition of our vulnerability and an attempt to protect that vulnerability by 'buying off' the powerful with praise". ${ }^{454}$ Cf. capítulo 2, item 2.2.2.

${ }^{455}$ Edição de Furley-Bremer (2001), vol. 2, 45-7.
} 
ó

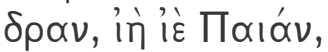

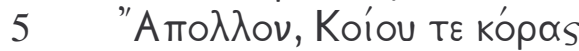

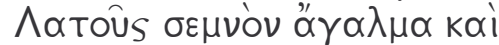

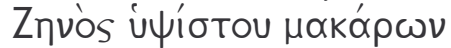

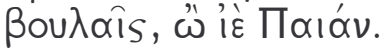

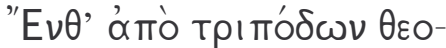

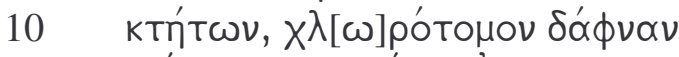

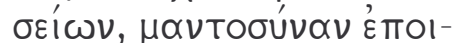

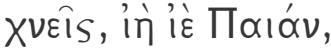

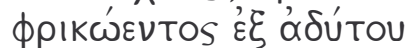

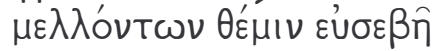

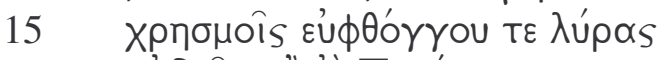

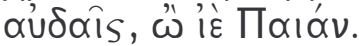

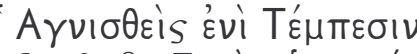

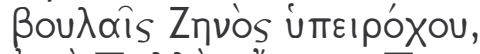

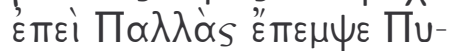

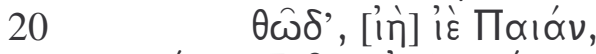

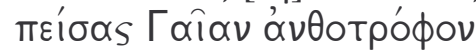

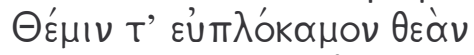

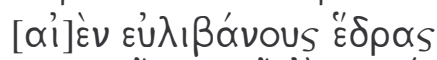

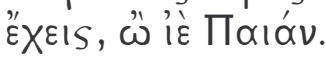

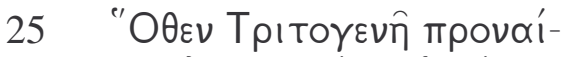

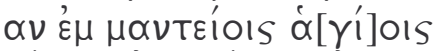

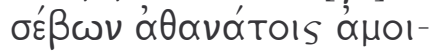

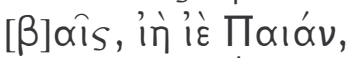

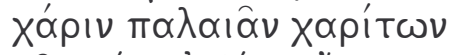

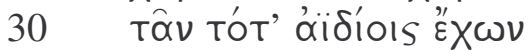

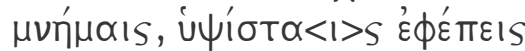

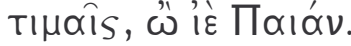

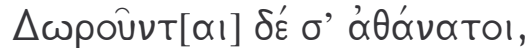

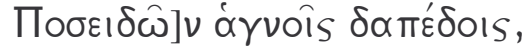

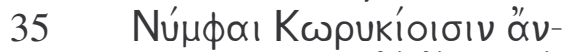

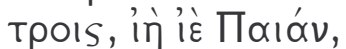

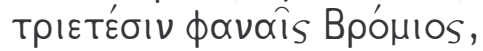

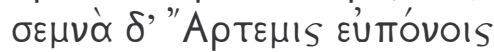

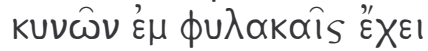

40 Tómous,

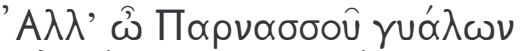

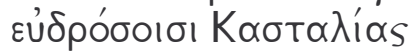

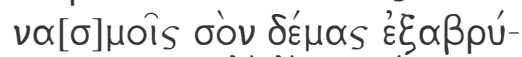

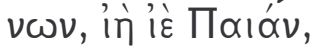


(Residente eterno da pedra délfica, sede profética do oráculo pítico de sagrada fundação, iê iê Peã, [eu te invoco] [5] ó Apolo, venerável objeto de orgulho de Leto, filha de Ceos, e pela vontade de Zeus, supremo entre os deuses, ô iê Peã. /

Onde dos tripés forjados pelos deuses [10], brandindo galhos de loureiro recém-colhidos, tu exerces a arte profética, iê iê Peã, daquela parte do templo que, sendo a mais recôndita, inspira calafrios: leis pias que governam o futuro ao som de [15] oráculos e da voz da lira de língua melodiosa, ô iê Peã. /

Purificado no vale de Tempe pela vontade de Zeus sublime, depois do que Palas te conduziu a Pito, [20] iê iê Peã, tu deténs a eterna sede perfumada após haver persuadido Gaia, nutriz de flores, e Têmis de bela cabeleira, ô iê Peã. /

[25] Daí, retribuindo Tritogênia com recompensas imortais, tu lhe conferes um local de privilégio no limiar do teu templo sagrado, iê iê Peã; em gratidão a graças passadas [30] que tu sempre manténs na memória, a ela tu concedes sem cessar honras sublimes, ô iê Peã. /

Os deuses te dão presentes, Posêidon um terreno sagrado, [35] as ninfas uma gruta corícia, iê iê Peã, Dioniso folias à luz de tochas, e a venerável Ártemis patrulha a região com a sua matilha de cães bem treinados, [40] ô iê Peã. /

Sendo assim, tu que adorna o teu corpo nas torrentes da Castália que descem as vertentes do Parnaso, iê iê Peã, [45] recebe esse nosso hino e nos dá para sempre fortuna fundada no decoro, e também nos protege sem cessar, ô iê Peã.)

Nas seis estrofes em que se divide, esse peã do século IV a.C. segue de forma tradicional o esquema tripartite comum aos hinos e preces gregos. Da invocação inicial, o poeta transita para uma seção média que congrega descrição (o oráculo délfico como principal atributo do poder de Apolo) e narrativa (eventos do passado mítico tais como a sua peregrinação a Tempe, a avocação da sede oracular, os presentes dos deuses), para então concluir o poema com a prece final. A rigidez da composição é reforçada ainda pelo caráter estanque das estrofes, cada qual delimitada por um único período extenso, balizado por meshumnion e ephumnion. Cada um desses períodos, por sua vez, acha-se contido em unidades métricas de dois quartetos fixos, compostos de três glicônicos e um ferecráteo (sua forma catalética). ${ }^{456}$

A arte de Arístono consiste justamente em transcender tal rigidez ao encadear as estrofes para fazê-las culminar no pedido. Na invocação que preenche a primeira estrofe,

${ }^{456}$ Sobre o metro, cf. West (1982), 141, e Furley-Bremer (2001), vol. 2, 47. No poema, a forma anaclástica do glicônico (oo-×- $-\backsim-)$ é tratada como um glicônico comum. 
por exemplo, já se faz alusão à área de poder que será descrita, na segunda estrofe, como o principal atributo do deus. Não é Apolo que abre o hino, mas a sede oracular de Delfos, que figura nos quatro primeiros versos até o meshumnion. É nela que a divindade tem a

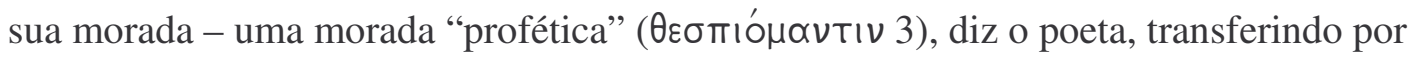
metonímia $^{457}$ uma qualidade da voz divina ao local sagrado. Invoca-se o deus, mas ao mesmo tempo a sede do seu poder assume o primeiro plano e adota um aspecto que lhe é próprio. Apolo só aparece após o refrão interno, mas tanto a elipse do verbo de invocação quanto a menção genealógica sublinham a primazia do oráculo, que será o tema das estrofes seguintes. Leto é sua mãe e Zeus o progenitor, mas a alusão à "vontade de Zeus,

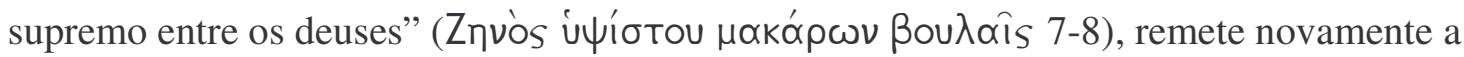
Delfos, onde Apolo exerce as suas prerrogativas mânticas com a chancela do pai. ${ }^{458}$

E é ali ( $\varepsilon \nu \theta^{\prime}$ 9), em Delfos, que Apolo empunha um ramo de loureiro e profere os seus oráculos enquanto dedilha a sua lira na segunda estrofe. Da descrição o poema passa a uma breve narrativa (terceira estrofe) de como Apolo ascendeu ao poder oracular. Há um corte para o passado, e ficamos sabendo que Apolo instalou-se em Delfos depois de persuadir Gaia e Têmis, detentoras originais do sítio oracular, após ser conduzido a Pito por Atena (19-24). A estrofe seguinte, a quarta, retorna ao presente atemporal do mito, que contrasta com o acontecimento único da estrofe anterior. Grato a Atena, Apolo lhe concede as mais sublimes honrarias, a título de recompensa (’’uoıßœî 27-8) pela ajuda prestada. Se Apolo é pródigo em dádivas a Atena, os deuses, por seu turno, não poupam presentes a Apolo, em júbilo pela sua chegada a Delfos - Posêidon lhe dá o solo sagrado, as ninfas a gruta corícia, Dioniso as tochas das festividades e Ártemis os cães de guarda (33-40). Na sexta e última estrofe, passamos do plano divino ao humano. A aproximação foi progressiva: do acontecimento único no passado chegamos ao presente atemporal do tempo mítico e, deste, ao presente da celebração do próprio hino, todos marcados pela reciprocidade das trocas. Agora, após mencionar a troca de dádivas divinas, o poeta faz seu pedido, também ele baseado na mutualidade: que Apolo aceite de bom grado esse nosso hino, diz, e dê em contrapartida fortuna conquistada com decoro, além de proteção eterna (45-8).

\footnotetext{
${ }^{457}$ Cf. Furley-Bremer (2001), vol. 2, 47.

${ }^{458}$ Cf., por exemplo, Ésq. Eum. 620, e Sourvinou-Inwood (1987).
} 
A relação de reciprocidade que o poeta tenta estabelecer com a divindade espelhase, portanto, na representação que fornece das dádivas mútuas no plano divino. Uma série de paralelos verbais dá sustentação a tal correspondência entre os dois universos, divino e humano. ${ }^{459}$ Da mesma maneira que, em reconhecimento pelo auxílio de Atena (Xópı

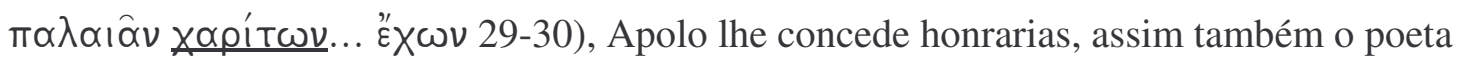

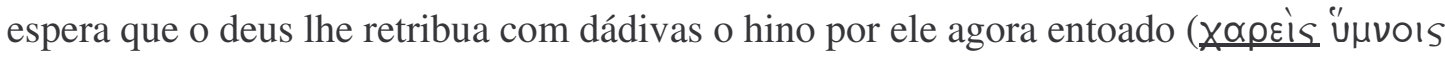
$\grave{\eta} \mu \varepsilon$ TÉpoıs 45). Nesse sentido, a troca entre Apolo e Atena é paradigmática também em outro aspecto: o termo referente às recompensas recebidas pela deusa, $\alpha \mu$ oıß $\alpha_{1}$ s (27-8), designa em outros contextos a bênção que os deuses concedem aos mortais em troca dos seus atos de devoção. ${ }^{460}$ Em uma pequena estátua votiva datada do século VII a.C., por exemplo, as coxas da figura que representa um guerreiro estão gravadas com a seguinte inscrição (CEG 1.326): ${ }^{461}$

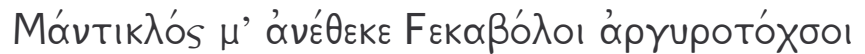

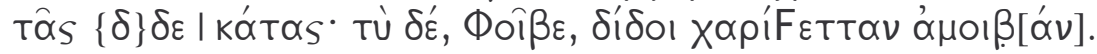

'Mânticlo me dedicou ao deus do arco de prata que atira longe, como parte do dízimo. Quanto a ti, Febo, dá uma recompensa deleitável.'

Apolo é chamado a aceitar de boa vontade a estatueta a ele dedicada e dar em troca aquilo que agrade ao fiel. ${ }^{462}$ Ambas, a figura votiva e a bênção divina, são entendidas como xápıs, termo que estabelece o elo entre deus e devoto com base na agradável reciprocidade. O mesmo ocorre em uma passagem análoga da Odisséia $(3,58)$, na qual Atena, disfarçada de Mentor, oferece uma libação a Posêidon e lhe pede em contrapartida uma recompensa deleitável ( habitantes de Pilos. Aqui também se pede que o deus conceda Xópıs aos fiéis em troca da Xópıs que o ritual lhe propicia.

\footnotetext{
${ }^{459}$ Paralelos notados por Vamvouri (2004), 95s., que oferece uma excelente análise do hino.

${ }^{460}$ Fato observado por Vamvouri (2004), 95, sem no entanto oferecer paralelos.

${ }^{461}$ Sobre essa famosa inscrição e a análise do termo xápıs nela contido, cf. Day (2000) e Parker (1998), esp. 110s.

${ }^{462}$ Cf. Henrichs (2003), 48: "[...] the reciprocal principle of mutual gift giving as an exchange of favors between god and mortal is here formulated for the first time outside epic literature with an aplomb and immediacy that illustrate the ease with which Greeks could talk to, and interact with, their gods, at least within the relative safety of cult".
} 
No peã de Arístono, além disso, o mesmo verbo é empregado para indicar as honras que Apolo confere a Atenas, de um lado, e, de outro, a proteção que o poeta pede

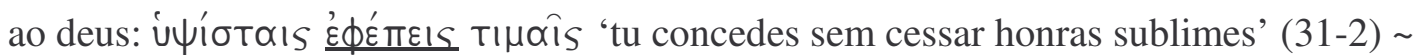

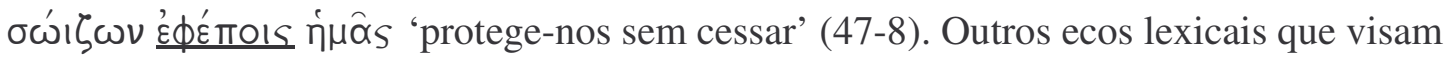
a promover uma correspondência entre as transações divinas e a troca que o poeta busca

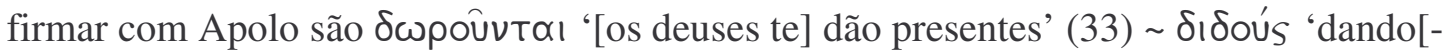
nos fortuna]' (46) e a noção de eternidade que caracteriza tanto a esfera divina quanto as

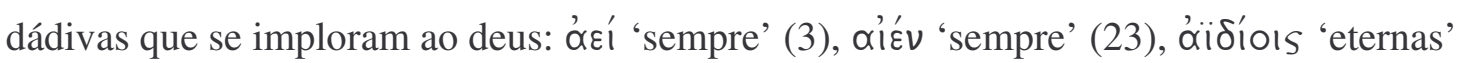
(30) 'óí 'sempre' (47). ${ }^{463}$

O mundo dos deuses constitui assim o paradigma da relação de reciprocidade na qual o poeta pretende inserir os homens. Não se trata, porém, de elevar os mortais ao patamar divino, mas antes de assimilar a relação entre deuses e mortais àquela que os mortais mantêm entre si. Uma relação que foge necessariamente ao controle humano é com isso trazida para limites razoáveis, nos quais o poeta pode influenciar a divindade a quem requisita os seus favores. E o objeto que exerce tal influência é o próprio hino bem burilado, capaz de ser reconhecido em suas qualidades pelo deus a que se dirige o louvor - afinal Apolo é representado no próprio peã como um músico que adorna seus oráculos com a "voz da lira de língua melodiosa" (15-6).

\subsubsection{Macedônico, Peã a Apolo e Asclépio}

Outro poema que se vale da repetição vocabular para sugerir uma proximidade entre a divindade e seus devotos é o peã de Macedônico a Apolo e Asclépio. A inscrição foi encontrada no final do século XIX no Asclepiéion de Atenas. ${ }^{464}$

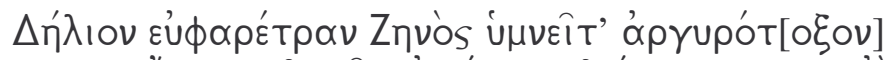

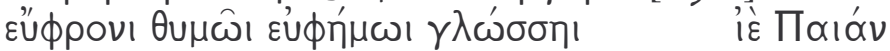

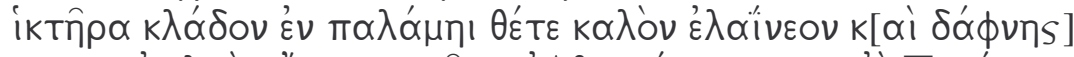

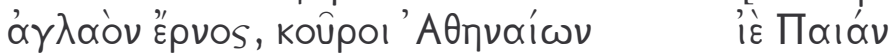

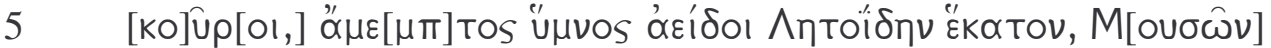

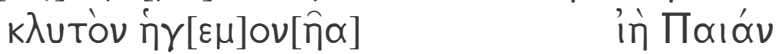

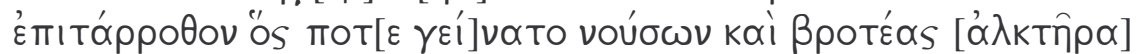

\footnotetext{
${ }^{463}$ Acerca do uso de ớí na dicção hínica, cf. Keyssner (1932), 39-45; o advérbio, segundo o autor, é um dos elementos que compõem o "estilo hiperbólico", tão marcante nos hinos gregos.

${ }^{464}$ Edição de Furley-Bremer (2001), vol. 2, 228-9.
} 


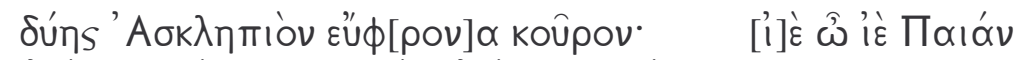

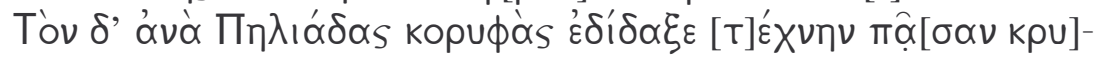

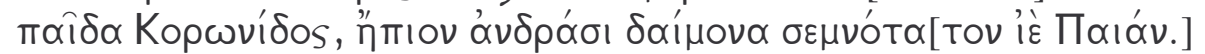

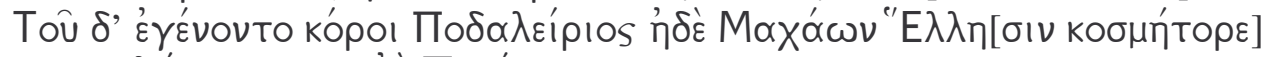

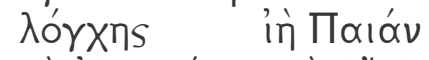

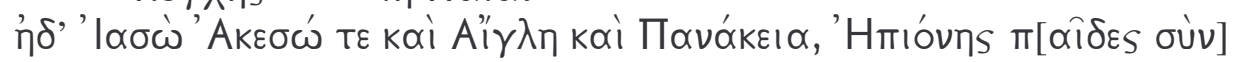

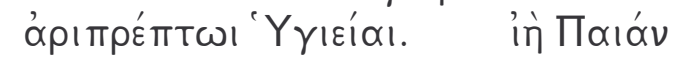

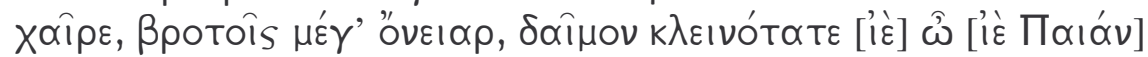

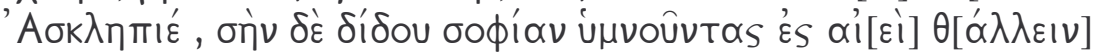

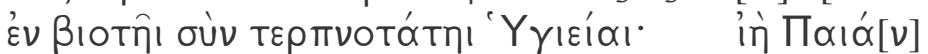

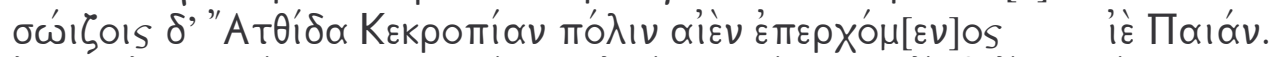

"ᄁாı

(Louvai em hino o délio filho de Zeus do arco de prata com corações alegres e vozes de bom augúrio - iê Peã! Ponde o ramo de súplica nas mãos, luzente rebento da bela oliveira e do loureiro, jovens atenienses - iê Peã! [5] Jovens, que ressoe o vosso impecável hino para o filho de Leto que atira longe, famoso líder das Musas - iê Peã! -, o salvador que outrora gerou aquele que cura doenças e misérias, Asclépio, deus jovem e alegre - iê ô iê Peã! - a quem nos picos do Pélion o centauro ensinou toda a arte secreta da medicina, [10] o antídoto da dor - iê Peã! -, filho de Corônis, gentil com os homens, deus venerável - iê Peã! Dele descendem Podalírio e Mácaon, generais-de-campo dos gregos - iê Peã! -, e Íaso e Aqueso e Aigla e Panacéia, filhos de Epione, [15] junto com a ilustríssima Higiéia - iê Peã! Salve, grande ajudante dos mortais, deus famosíssimo - iê Peã! Asclépio, concede a nós, que cantamos a tua sabedoria, florescer para sempre na vida com a deleitável Higiéia - iê Peã! Protege Atenas, cidade de Cécrops, com a tua eterna presença - iê Peã! [20] Sê gentil, senhor, e nos defende das nefastas doenças - iê ô iê Peã!)

O conteúdo do poema é notavelmente próximo do peã Eritreu. ${ }^{465}$ Ambos tratam da descendência de Asclépio e promovem a transição do louvor de Apolo ao elogio do seu filho, a quem o poeta faz o seu pedido. Aqui, porém, a transição de Apolo a Asclépio é mediada pelos fiéis que lhe cantam o hino, através da repetição marcada de vocábulos idênticos que dizem respeito ora aos deuses, ora aos mortais.

O hino, em linhas gerais, divide-se em três partes, e destinava-se a uma cerimônia na qual um coro de jovens atenienses, empunhando ramos de oliveira e loureiro em sinal de súplica (3-5), entoa o peã composto por Macedônico de Anfípolis "sob as instruções do próprio deus", como diz o título da inscrição. ${ }^{466}$ Na primeira parte (1-8), exorta-se ao coro que celebre Apolo, pai do deus Asclépio; na segunda (9-15), na qual sobressai o uso

\footnotetext{
${ }^{465}$ Cf. capítulo 3, item 3.2.4.

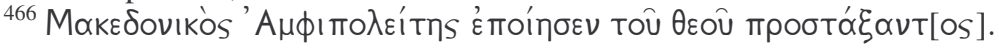


enfático dos pronomes tóv (9) e toû (12) em início de frase, narra-se, de um lado, o aprendizado das artes médicas às quais Asclépio foi introduzido pelo centauro Quíron e, de outro, a descendência de Asclépio; na terceira e última parte (16-20), o poeta faz a sua prece por saúde e fecha o foco sobre Atenas, sobre a qual deve recair a bênção divina: as instruções para compor o hino bem podem ter vindo da boca do próprio deus, mas foi do bolso de Atenas que saiu o dinheiro para que a obra, com certeza encomendada, fosse gravada na pedra e assumisse um caráter público. ${ }^{467}$

De Apolo a Asclépio a transição é simples. Apolo ocupa a atenção do autor, e a ele dirigem-se naturalmente os refrões ("Peã!"), nos primeiros sete versos; daí em diante, o pai cede ao filho seu lugar e seus refrões por meio de um recurso de linguagem banal:

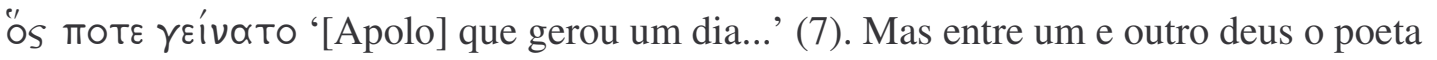
intercala a presença do coro de jovens atenienses, no propósito de fazê-los participar das virtudes do jovem deus Asclépio. Ao coro ele pede expressamente que cante de coração

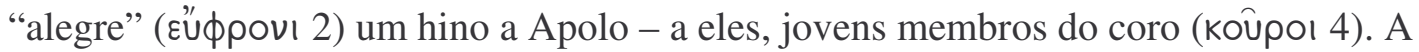
juventude do coro é sublinhada pela epanalepse do termo no verso seguinte (Koûpoı 5). ${ }^{468}$ E tanto a juventude quanto a alegria são justamente as qualidades que caracterizam o

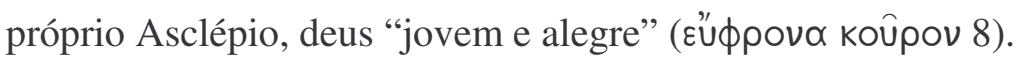

Assim, os mesmos termos designam tanto o coro de jovens que entoam seu louvor quanto o jovem deus louvado. ${ }^{469}$ Cabe notar que esse papel de mediação assumido pelo coro reflete-se na estrutura mesma do poema: em sua primeira parte (1-8), somos levados

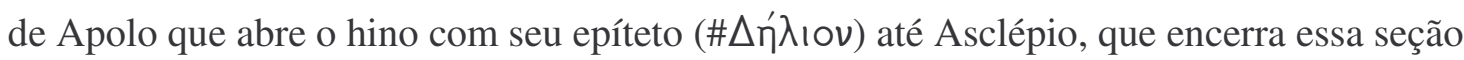
da obra também com um epíteto (koûpov\# 8). Nesse arco estendido entre a primeira e última palavras, o coro dos jovens, à força da repetição vocabular, atua como elo de ligação. ${ }^{470} \mathrm{O}$ coro é alegre como Asclépio, e além disso jovem, não só como Asclépio,

\footnotetext{
${ }^{467}$ Cf. Furley-Bremer (2001), vol. 2, 233.

${ }^{468}$ [Ko] $u$ p[ol] é a restituição de Peek para o texto fragmentário. Pardo (1984) prefere o suplemento alternativo de Peek, $[\delta \varepsilon] \cup \tilde{\rho} \rho$ ' [i T'] 'vem para cá', sugestão rejeitada com acerto por Furley-Bremer (2001), vol. 2, 231: nesse hino clético, o próprio deus é chamado, não o coro que o celebra.

${ }^{469} \mathrm{O}$ paralelo léxico foi notado por Vamvouri (2004), 101.

${ }^{470}$ Não é só na primeira parte do hino que se nota certo cuidado com a estrutura e a disposição das palavras. Os versos dedicados à descendência de Asclépio (12-15) iniciam com o pronome toû 'dele' (12), relativo a

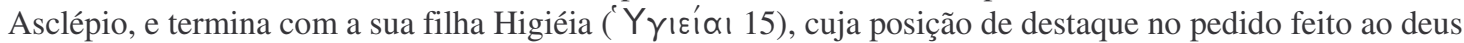
é sublinhada pela sua repetição três versos adiante ( $Y$ Yı $\varepsilon^{\prime} \alpha_{\curlywedge}$ 1 18), outra vez em posição final. No primeiro caso, Higiéia ganha relevo por aparecer, não em seqüência com os demais filhos, mas após a quebra representada pelo nome da mãe: "de Asclépio nasceram A, B, C, D, filhos de Epione, e também Higiéia". E
} 
mas também como Apolo, o deus jovem por excelência. E a atividade a que ele, coro, se dedica - o canto de louvor - é expressamente designada como objeto de troca na relação de reciprocidade entre homem e deus. Por duas vezes a voz narrativa exorta o coro a

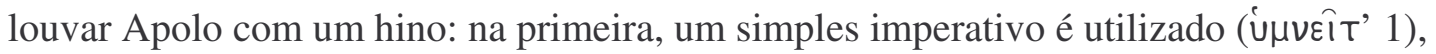
já na segunda o poeta faz questão de salientar a excelência do seu próprio hino que o coro

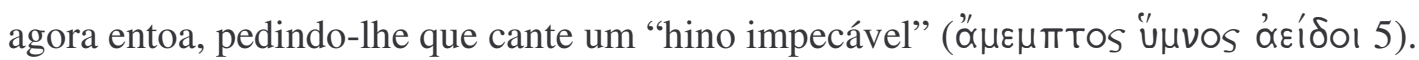
Como sugerem Furley e Bremer, ${ }^{471}$ a noção que está por trás do caráter impecável do hino é a de que "oferendas aos deuses tinham de ser irrepreensíveis para serem aceitas". Ao fazer o seu pedido a Asclépio, Macedônico volta mais uma vez ao tema para lhe dar o alinhave final. Aqui o hino ocupa a posição focal nessa relação de toma-lá-dá-cá entre deus e devoto, na qual um oferece o poema e o outro faz a sua contraprestação em forma

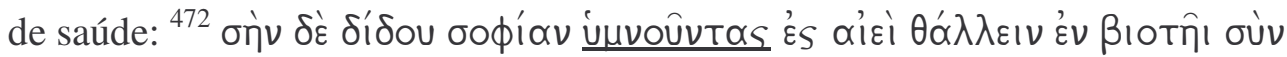

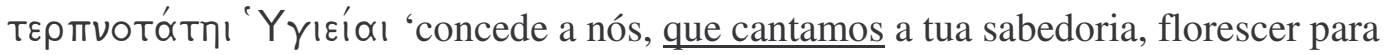
sempre na vida com a deleitável Higiéia' (17-8). O particípio úuvoûvтðs, além de fazer

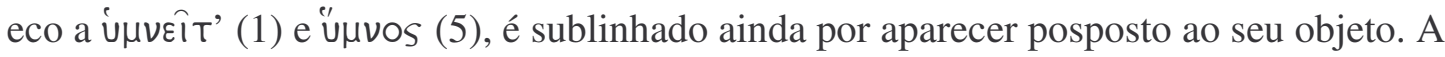
quem escuta a frase, é lícito supor de início que ờv бoфíav 'a tua sabedoria' seja objeto

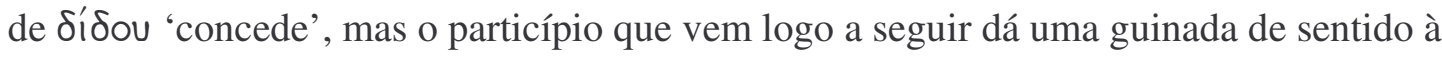
frase e faz da "sabedoria" o seu objeto sintático: "concede-nos saúde eterna em troca desse hino que canta a tua sabedoria". 473

O peã de Macedônico é portanto a moeda de troca que o coro de jovens atenienses oferece a dois deuses eternamente jovens, Apolo e Asclépio. A reciprocidade, assim, não se manifesta apenas nas palavras do canto, mas no próprio rito que lhe serve de base, pelo

tanto num como noutro caso, a ordem dos termos é a mesma: бúv + superlativo + Higiéia (dativo). Outra

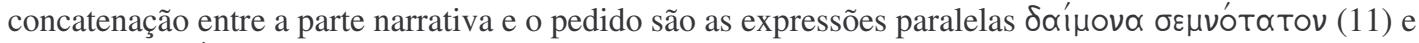

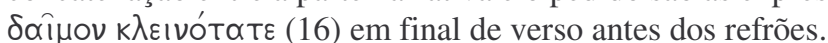

${ }^{471}$ Furley-Bremer (2001), vol. 2, 231.

${ }^{472}$ Não se trata, obviamente, de uma pura relação comercial ou contratual por meio da qual se compram os favores divinos; não há um cálculo de valores que possa aferir a qualidade dos bens trocados, não há preço. Nas palavras de Parker (1998), 118s., a troca recíproca de kharites "is an exchange of favours, a voluntary, if socially prescribed, expression of a relationship of friendship". Sobre tal tipo de reciprocidade, ver Festugière (1976), Wees (1998), Seaford (1994), 13-25, Pulleyn (1997), 16-38, , e sobretudo o ensaio até hoje fundamental de Mauss (1924).

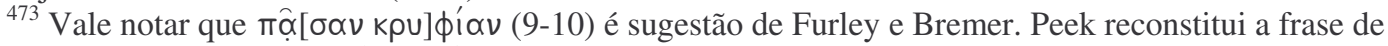

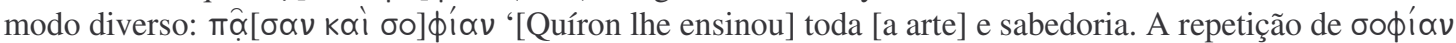
no verso 17 constituiria assim um elemento a mais, se seguirmos o suplemento de Peek, para aumentar a ambigüidade. 
qual a dança dos jovens busca assimilá-los a Apolo - deus que é a epítome da juventude e da força - e a seu filho Asclépio, que partilha das suas virtudes. É na dança conjunta dos jovens que se celebra a força e coesão da comunidade, inclusive em face da ameaça de

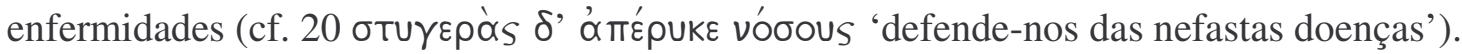
Como observa Rutherford, ${ }^{474}$ "o canto-dança peânico representa a organização e exibição da força coletiva dos adultos de sexo masculino, especialmente aqueles em idade militar, apresentando-os de tal modo a enfatizar sua relação com a divindade Peã/Apolo, que era um guardião e um ícone desse grupo. O canto-dança peânico era percebido como forma de promoção da segurança e estabilidade da polis, que tinha uma particular dependência desse grupo. [...] A invocação do Peã/Apolo concomitante ao canto-dança peânico pode ser construído como uma projeção externa do jovem forte do sexo masculino - o cidadão ideal".

Calímaco fornece outro exemplo em que a relação de reciprocidade figura como tema do canto; nele, não apenas a reciprocidade entre os deuses serve de paradigma para a relação que o fiel pretende instaurar com a divindade, como no caso de Arístono, mas ainda, como em Macedônico, os próprios humanos (no caso o poeta) inscrevem-se nessa relação pelo intermédio do hino entoado. Vejamos os dez primeiros versos que compõem a invocação do seu Hino a Delos.

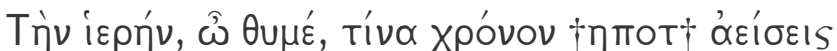

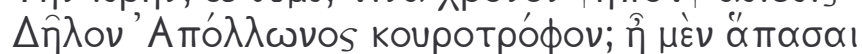

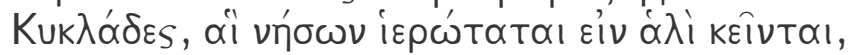

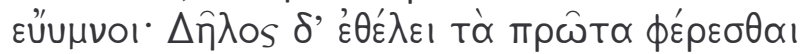

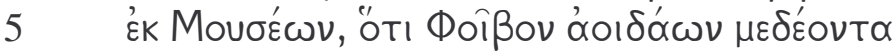

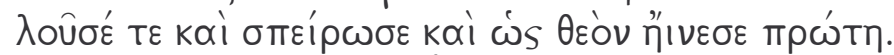

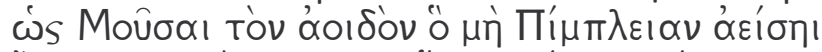

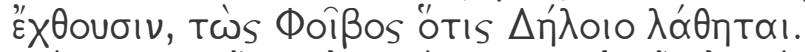

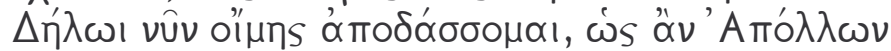

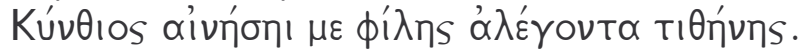

(Em que tempo, ó coração, cantarás a sagrada Delos, nutriz de Apolo? É verdade que todas as Cíclades, as ilhas mais sagradas que existem no mar, são bem providas de hinos, mas Delos quer a primazia das dádivas que vêm [5] das Musas, pois foi ela a primeira que banhou Febo, mestre dos cantos, e que lhe pôs cueiros e o louvou como deus. Assim como as Musas odeiam o poeta que não canta Pimpléia, assim também Febo odeia aquele

${ }^{474}$ Rutherford (1994-5), 115-6. Cf. ainda Rutherford (2001), 89. 
que esquece de Delos. A Delos eu consagro agora o meu canto, para que Apolo [10] Cíntio louve o meu zelo pela sua cara nutriz.)

Como já notado por Bing, ${ }^{475}$ esse proêmio insiste na perfeita reciprocidade entre Delos e Apolo: ambos são mencionados quatro vezes cada (Delos, além disso, em quatro casos diversos) $;{ }^{476}$ o epíteto de um tem a sua origem no outro, e vice-versa (Delos é

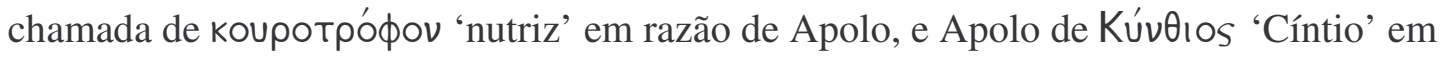
razão de Delos); o vínculo entre o deus e a sua ilha traduz-se na estrutura dos dois versos

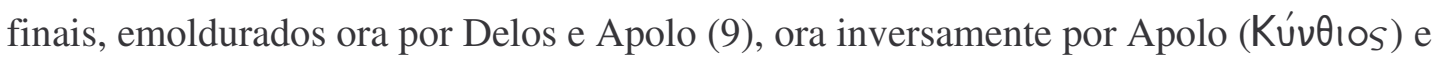

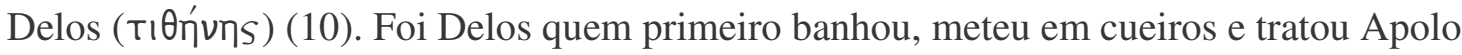
como deus; em sinal de retribuição, Apolo odeia quem se esquece de Delos em seu canto.

Ao expor as qualidades de Delos na sua relação a Apolo, o poeta apresenta as suas próprias credenciais, no objetivo de inserir-se nessa troca mútua de favores que vigora entre a divindade e a ilha que o viu nascer. Entre as Cíclades, todas elas bem providas de

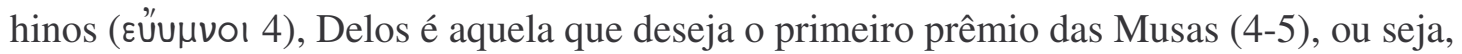
que aspira à primazia de lhe ser destinado o melhor de todos os hinos - no caso, o Hino a Delos que lhe canta agora o poeta. O narrador alude assim à sua excelência e à qualidade sublime do seu poema, em cuja origem, aliás, está o próprio Apolo, pois dizer que o deus "odeia quem se esquece de Delos" (8) equivale a uma injunção para glorificá-la por meio do poema. E o hino que o poeta lhe consagra agora ( $V U \hat{V}$ 9) é entoado na expectativa de

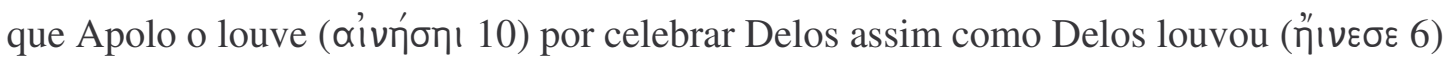
Apolo, conquistando a sua gratidão. ${ }^{477}$

\subsubsection{Louvor e pedido: Hino Homérico a Gaia}

Se é verdade que os hinos gregos obedecem em geral a uma estrutura tripartite, na qual a invocação é seguida pelo argumento e pelo pedido, não menos certo é que parte do esforço do poeta hínico, como já tivemos oportunidade de notar em vários dos poemas

\footnotetext{
${ }^{475}$ Bing (1988), 110s.

${ }^{476}$ Sobre' Aтó $\lambda \lambda \omega \cos$ (v. 2), Mineur (1984), 53, observa: "placed immediately after $\Delta \hat{\eta} \lambda$ ov, the name is programmatic: the part Apollo has to play in the Hymn is hardly inferior to that of Delos herself".

${ }^{477}$ Cf. Vamvouri (2004), 48: "Le poète établit explicitement un contrat d'échange avec le dieu, du type do ut des. Il entonne un chant en l'honneur de Délos pour être, en retour, loué et honoré par Apollon. Ce contrat d'échange est d'autant plus motivé qu'il se dédouble au niveau divin entre Délos et Apollon".
} 
analisados até aqui, destina-se a fundar o seu pedido tanto nos louvores da parte narrativa quanto nos epítetos laudatórios da invocação. Raro é que a prece final se dê no vazio, sem lastro com aquilo que a precede. Faz parte da estratégia natural dos poetas, para aumentar a eficácia da sua prece, mobilizar no seu elogio aquelas mesmas qualidades divinas que são necessárias ao cumprimento daquilo que rogam à divindade. Elogio e pedido se dão nos horizontes de uma troca recíproca entre deus e devoto: os poderes cujo benefício o poeta reclama para os mortais são aqueles que ele oferece previamente como elogio aos deuses.

Tal estratégia é largamente difundida nos hinos da tradição grega; tomo aqui um exemplo meramente ilustrativo, o Hino Homérico a Gaia $\left(\mathrm{n}^{0} 30\right)$ :

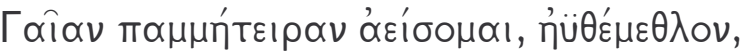

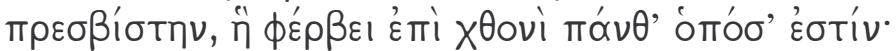

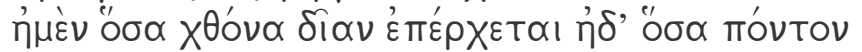

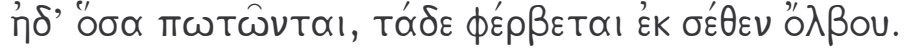

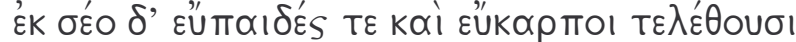

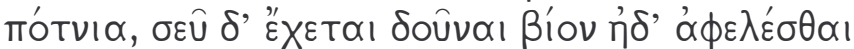

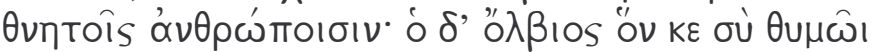

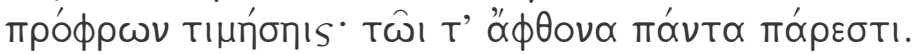

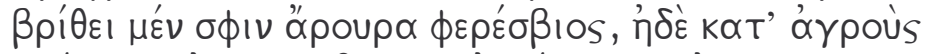

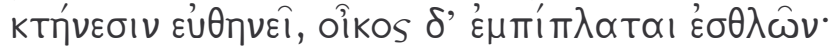

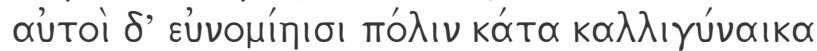

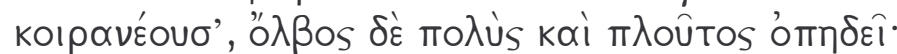

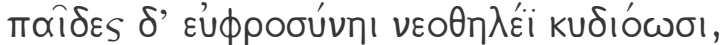

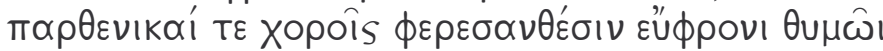

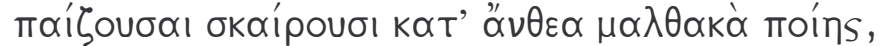

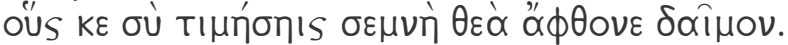

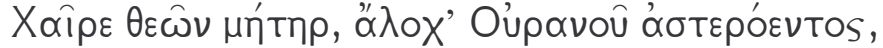

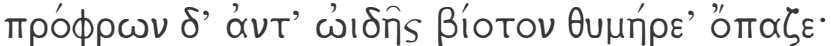

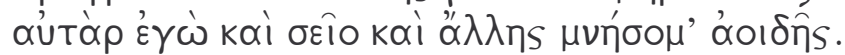

(Cantarei Gaia, mãe universal, a bem-fundada, a mais velha, que alimenta tudo o que há na terra; tudo aquilo que se move sobre a terra divina e no mar e tudo aquilo que voa é alimentado pela tua munificência. [5] De ti eles tornam-se férteis em filhos e em colheitas, senhora, e depende de ti dar sustento ou tirá-lo dos mortais. Feliz é aquele que o teu coração favorece e privilegia, e tudo lhe pertence em abundância. A sua terra pesa com frutos que dão vida, nos campos [10] ele é próspero em rebanho, e a sua casa enchese de bens. Tais homens são senhores de cidades nas quais a lei e a ordem vigoram e as mulheres são belas, e muita fortuna e riqueza os acompanha; os seus filhos exultam no vigor da juventude e da alegria, e as suas filhas [15] brincam contentes em danças florais entre as suaves flores do prado - assim acontece com aqueles que tu privilegias, deusa 
augusta, divindade generosa. Salve, mãe dos deuses, esposa do céu estrelado: concede de bom grado confortável sustento em troca do meu canto. E eu me lembrarei tanto de ti quanto de outro canto.)

A tripartição da obra é manifestamente clara e sublinha, por contraste, o vínculo que as une. Primeiro e segundo versos inauguram a invocação (1-4) de forma solene, com espondeus que prevalecem até a cesura. ${ }^{478}$ Entre os três epítetos conferidos a Gaia, todos

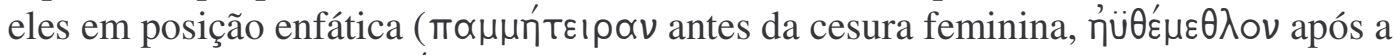

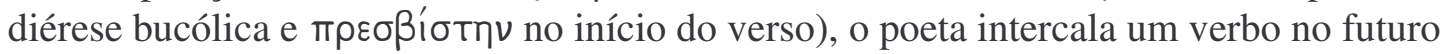

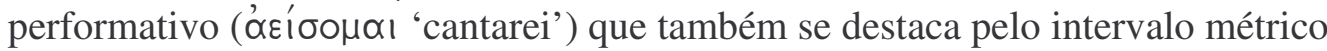
ocupado, entre a cesura e a diérese (o tema do canto será retomado no pedido). Tudo o que há na terra, no mar e no ar é alimentado por Gaia: terra, mar e ar formam um tricólon

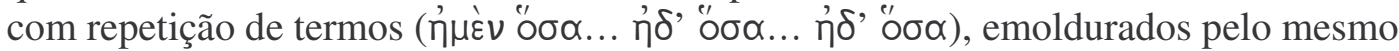
verbo, "alimentar", ora na voz ativa, ora na passiva, em duas expressões posicionadas ora antes, ora depois da cesura:

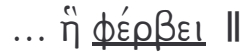

4

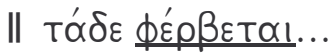

O termo que fecha a invocação, o’入ßou 'munificência', prefigura a parte narrativa (5-16), na qual a palavra reaparece outras duas vezes, ${ }^{479}$ e as suas ressonâncias se farão sentir também no pedido. Da invocação à parte central a transição é suave, marcada pelas

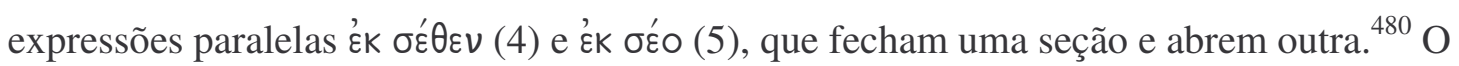
verso 5 é programático em sua bipartição: é graças a Gaia, diz o poeta, que todos são bem dotados de filhos ( $\varepsilon \cup ̋ \pi \alpha ı \delta \varepsilon S)$ e colheitas ( $\varepsilon \cup ̈ \kappa \alpha \rho \pi o ı)$. Esses dois temas, filhos e colheitas em abundância, são então desenvolvidos nos versos seguintes, em quiasmo - ilustram-se

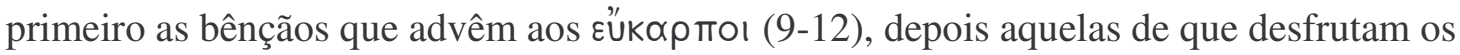

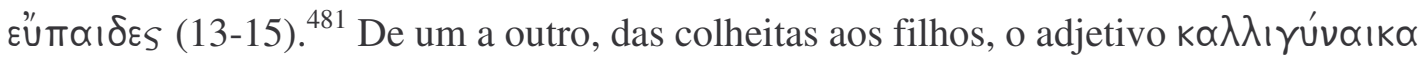
‘de belas mulheres' (11) serve como elo de ligação.

\footnotetext{
${ }^{478}$ Sobre as "invocações espondaicas", cf. West (1982), 55s.

${ }^{479}$ Cf. vv. 7 e 12. Fröhder (1994), 135: "Mit dem Ausdruck ö $\lambda \beta o s$ ist ein Schlüsselwort genannt, das auf den Hauptteil vorausweist, in dem es mehrmals in modifizierter Form wieder auftaucht".

${ }^{480}$ ¿́ $\sigma^{\prime} \theta \varepsilon \nu$ marca ainda a passagem para o "Du-Stil" que prevalecerá no restante do hino, em oposição ao "Er-Stil" dos dois primeiros versos.

${ }^{481}$ É possível que essa forma de estruturar o hino - primeiro fornecer uma sinopse da situação para depois repeti-la descrevendo os detalhes - não seja apenas uma herança que, como sugere Fröhder (1994), 136, o rapsodo tenha tomado de empréstimo a Homero. Em duas aberturas hínicas dos seus epinícios, Píndaro se vale de recurso análogo: primeiro esboça dois tipos de enredo, para a seguir ilustrar um deles. Um desses

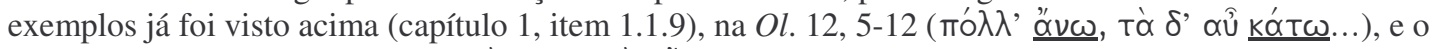

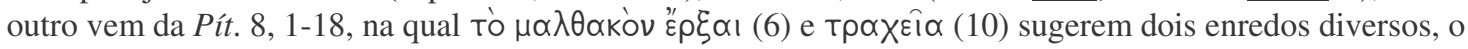
segundo ilustrado pela ruína de Tifo e Porfírio. Cf. Race (2004), 383 n.31.
} 
As diversas seções nas quais se divide o poema, que se delimitam com cuidado não menor do que se encadeiam, contribuem para criar um sentido de totalidade à ação da deusa Gaia, mãe de todos e que a todos alimenta, em terra, mar e ar, propiciando-lhes filhos e colheitas. Essa totalidade reflete-se na forma como o rapsodo dá fecho à seção narrativa, resumindo o conteúdo do hino até ali e antecipando o pedido. Quem por Gaia é favorecido, a ele nada falta, tudo lhe sobra, dizem os vv. 7-8. O mesmo raciocínio conclui a seção, criando um paralelismo pela repetição de termos-chave: ${ }^{482}$

7

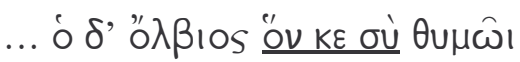

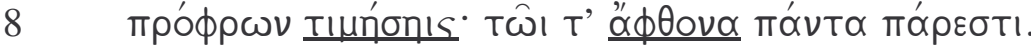

$\cdots$

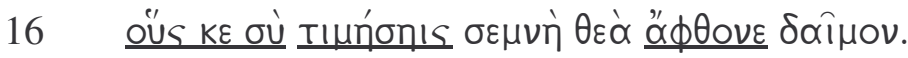

O verso 16, que com os versos 7-8 compõe uma moldura ao redor dos exemplos ilustrativos (9-15), é tanto mais notável por figurar em flagrante anacoluto (oüs KE oú em complemento a đữoí $\delta ’ 11)$. Se antes eram as dádivas concedidas aos humanos que se

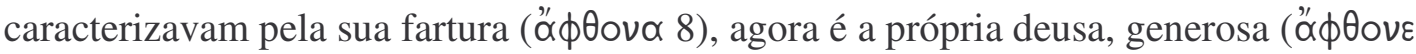
16), que foge a todo $\phi \theta$ óvos divino em sua relação com os homens; inversamente, é a munificência ("ôßßou 4) de Gaia que transita ao longo do hino à esfera humana: feliz

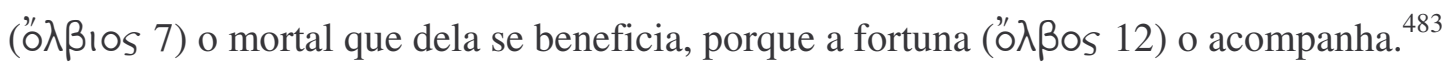
Os limites que separam Gaia dos homens são assim permeáveis às mesmas qualidades, que ora têm a sua sede num plano, ora noutro. Tal reciprocidade torna-se explícita no pedido. O poeta, tendo mapeado em sua canção a abrangência do poder da divindade, que a todos sustenta, pede-lhe que em troca dessa mesma canção ('óv ' lhe confortável sustento, tal como descrito ao longo do hino. ${ }^{484}$

\subsubsection{Paronomásia}

Muitas vezes, sobretudo em preces e em hinos breves, o nexo de reciprocidade resume-se a uma simples paronomásia entre o nome do deus (ou uma de suas qualidades)

\footnotetext{
${ }^{482}$ Cf., no mesmo sentido, Fröhder (1994), 141s.

${ }^{483}$ Fröhder (1994), 137: "War anfangs von Gaias o’ $\lambda \beta \circ$ s die Rede, liegt jetzt die Betonung auf dem Wohlstand der Menschen".

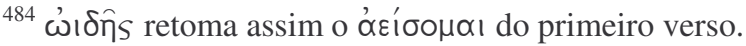


e uma palavra central do poema. O exemplo mais famoso são talvez dois decassílabos ${ }^{485}$ atribuídos a Terpandro (PMG 698):

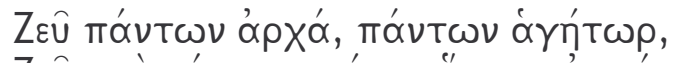

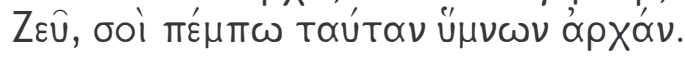

'Zeus, começo de tudo, líder de tudo, Zeus, a ti envio esse começo dos meus hinos.'

Em função da prece, os próprios epítetos divinos podem ser concebidos, e não o

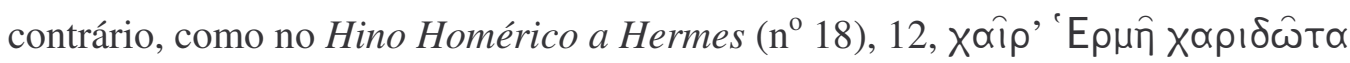

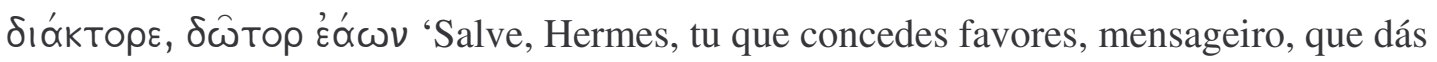
bens' ${ }^{486}$ Aqui, como em tantas outras passagens dos hinos gregos, a Xópıs resume os atos de dar e receber, e portanto a relação de reciprocidade firmada entre o deus e o seu fiel, na qual ambos estão obrigados por prestações opostas e complementares. Ao deus se

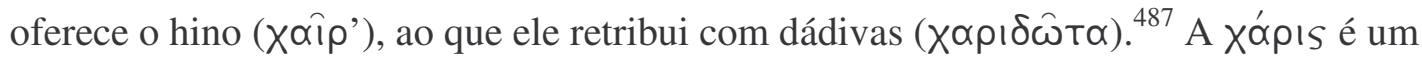
dos conceitos centrais, se não o conceito central em que se baseia a hinologia grega; tratase de uma palavra de sentido duplo, que reflete os dois lados da relação entre deus e devoto. Furley e Bremer observam que "de um lado, charis expressa aquela atitude de grata adoração que caracteriza idealmente o devoto, mas denota também a graça e o favor do deus obtidos por meio dessa adoração. Os dois lados se complementam: ao venerar uma divindade com palavras de louvor e agradecimento, o fiel espera que o destinatário se disponha a retribuir concedendo-lhe o seu favor". ${ }^{488}$

Essa natureza dupla da Xópıs emerge claramente de outro Hino Homérico, este a Dioniso $\left(\mathrm{n}^{\mathrm{o}} 26\right), 11-2$ : $^{489}$

\footnotetext{
${ }^{485}$ Compostos exclusivamente de sílabas longas (cf. $P M G$ 941).

${ }^{486}$ Mais exemplos em Durante (1976), 153 n.17. Cf. ainda Gygli-Wyss (1966), 79 ("Beiname eines Gottes und entsprechende Bitte"), 103 n.3, e Fehling (1969), 228. Sobre a dinâmica dos epítetos nos hinos órficos, cf. Hopman-Govers (2001) e Morand (2001).

${ }^{487}$ Sobre $\chi \propto$ \îp como um imperativo para que a divindade aceite o presente - no caso, o hino - que lhe é ofertado, cf. Wachter (1998).

${ }^{488}$ Furley-Bremer (2001), vol. 1, 61s. Cf. Parker (1998), 108: “Kharis words [...] are applied to both sides of the relationship. Motals seek to bring gifts or sacrifices which are kharienta or kekharismena to the gods, and request a return which is in itself khariessa; in later texts the relation can be presented quite explicitly as one in which kharites are exchanged". Sobre kharis e reciprocidade, ver ainda Furley (1995), 32, Bremer (1998), Depew (2000), 60, Day (2000), 47, Scheid-Tissinier (2000), 219-30, e MacLachlan (1993), passim.

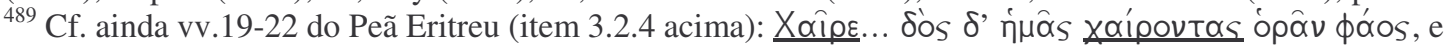
Race (1982), esp. 8-10.
} 


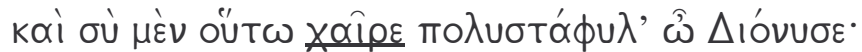

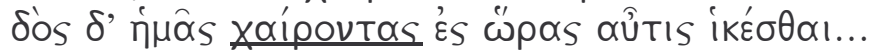

'Eu te saúdo, Dioniso dos muitos cachos de uva: concede a nós, que te saudamos [com um hino], retornar no devido tempo...'

Virtude divina e pedido dirigido à divindade são reunidos de forma banal, mas não menos eficaz, pela mera repetição paronomástica de termos-chave, como neste Hino Homérico a Afrodite $\left(\mathrm{n}^{\mathrm{o}} 10\right)$ :

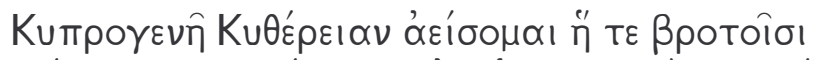

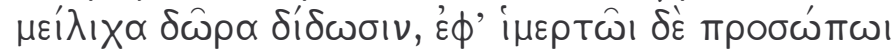

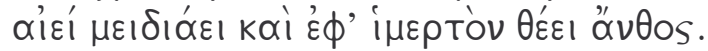

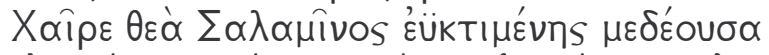

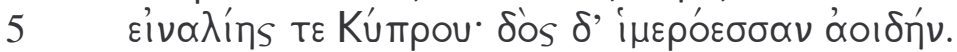

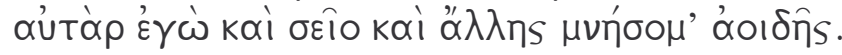

(Cantarei Citérea nascida em Chipre, a qual dá aos mortais presentes melífluos; em seu rosto adorável ela está sempre rindo, e uma flor adorável sempre corre sobre ele. Salve, deusa, rainha da bem-cultivada Salámis [5] e de Chipre rodeado pelo mar: concede-me um canto adorável. E me lembrarei tanto de ti quanto de outro canto.)

Afrodite tem um rosto adorável (i

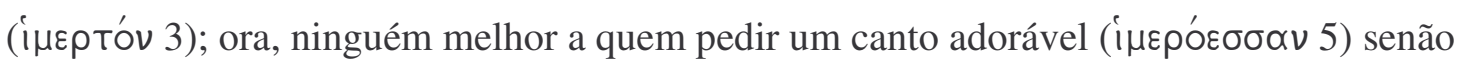
a própria deusa, que atua assim como avalista da canção - dessa canção, que sem dúvida é adorável aos seus ouvidos e que ela mesma terá inspirado. ${ }^{490}$ Por vezes, o epíteto divino - tal como concebido pelo poeta - implica a sua capacidade de agir segundo os desejos dos mortais; implícita ao atributo que lhe é dirigido a título de louvor está a informação a respeito das dádivas que o devoto dele espera. Um exemplo simples, contido em um hino de dicção igualmente simples e clara, são estes versos das Tesmoforiantes de Aristófanes (1136-37):

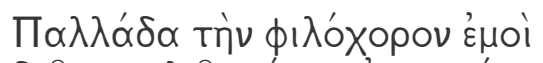

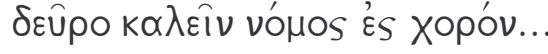

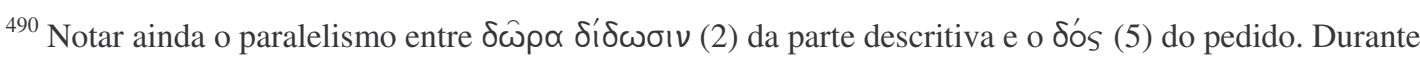
(1976), 132, comenta que "se la poesia è istituzione divina, come dicono in modi diversi l' antica formula

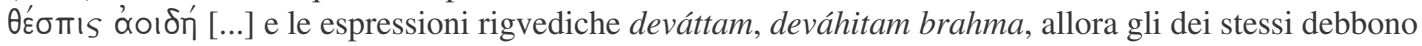
essere eccellenti poeti o musici e cantori, altrimenti non potrebbero ispirare gli uomini”.
} 
' $O$ costume requer de mim invocar a presença de Palas, amante da dança, nessa dança coral.'

Aqui, a fluidez entre descrição laudatória e apelo à divindade é tanto mais óbvia

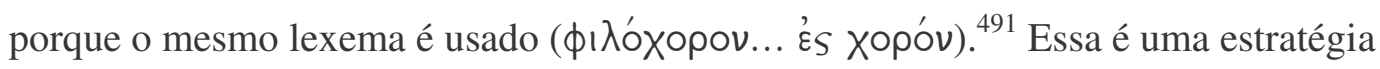
relativamente comum nos hinos do Rig Veda, como por exemplo: sá tváṃ na ūrjasana úrjaṃ dhā 'assim, dá-nos vigor, ó (deus) que ganha vigor' (6.4,4c), ránam krạhi rạ̣akrt ‘cria alegria (de batalha), ó criador de alegria!' (10.112,10c), úrukrd urú ṇas krdhi ‘ó criador de espaço, cria espaço para nós!' (8.75,11c), bhúridā bhứri dehi 'ó tu que dás abundância, dá-nos abundância!' (4.32,20a), sá tvám no vīra vīryàya codaya 'assim, impele-nos, ó herói, a feitos heróicos!' (9.110,7c), śagdhy ù sú śacīpata (8.61,5a) 'mostra o teu poder, senhor do poder!', índrāvaruṇā sutapāv imám sutám / sómam pibatam mádyaṃ dhrtavratā 'ó Indra e Varuṇa, vós que bebeis (soma) espremido, bebai esse inebriante soma que vos foi espremido!' (6.68,10ab), śáviṣtham na á bhara śūra śáva 'traze-nos, ó poderoso herói, o mais poderoso poder heróico!' $(6.19,6 \mathrm{a})$, vrtrănịi vṛtrahañ jahi ‘ó destruidor de Vrrtra/obstáculos, destrói obstáculos! (8.17,09c), tápā tapiștha tápasā tápasvān 'queima, ó (deus) que mais queima, com a tua queimadura, tu que tens o poder de queimar $(6.5,4 \mathrm{~d}),{ }^{492}$ ómāsaś carșaṇīhhrto / víśve devāsa ă gata / dāśvấmso dāśúṣaḥ sutám 'ó vós que ajudais, protetores dos povos, ó todos os deuses, vinde para cá, em honra ao soma daquele que vos honra!' $(1.3,7)$. Nesse último exemplo, o particípio perfeito de dās 'honrar' é usado para designar tanto uma ação dos deuses em relação aos mortais ( dâśvămạsas 'em honra') quanto uma ação dos mortais em relação aos deuses (dâśúșas 'aquele que honra, devoto'). A idéia de uma troca entre deus e fiel ganha contornos léxicos ainda mais óbvios nesta outra passagem, na qual reaparece a mesma

\footnotetext{
${ }^{491}$ Furley-Bremer (2001), vol. 2, 361: "[...] because Athena is dance-loving she will come now to the women's dance; because she comes, the chorus' dance will be inspired by the divine presence. It is the two sides of Xópıs once again: a god lends grace to the human worship by his/her beneficence; humans thank the god through this very worship". Cf. ainda Aristóf. Tesm. 980-3.

${ }^{492}$ Cf. Gonda (1959a), caps. 8 e 11, e (1959b), 202-5, Elizarenkova (1995), 167s., e West (2007), 324s. A paronomásia pode vincular não apenas deus e devoto, mas ainda devoto e patrono, como em RV 6.48,20:

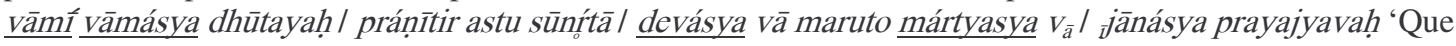
tenhamos uma adorável liderança de um ser adorável, ó (Maruts, deuses) agitadores, a sua generosidade, / seja a de um deus ou a de um mortal que sacrifica (= patrono), ó (deuses) a quem sacrificamos de frente". O termo vāmá- 'desejável' (cuja raiz é van- 'desejar', cognata do latim uenus 'amor'), lembra o pedido de um "canto adorável" no Hino Homérico à Afrodite ( ${ }^{\circ}{ }^{10}$ ) citado acima. Cf. Mayrhofer (1992-6), vol. 2, sob $V A N^{I}$-, e Gotō (1987), 283-6.
} 
raiz verbal: só apratîni mánave purựṇ ${ }_{i}$ indro dāśad dāśúṣe hánti vrtrám 'em benefício do homem, ele, que não tem igual, (mata) numerosos (inimigos); Indra honra (dāsat) aquele que o honra (dāsúșẹ); ele mata Vrrtra' $(2.19,4 a b)$.

Tal como no caso da Xápıs grega, cujo sentido varia conforme esteja associada à divindade ou ao seu devoto, servindo tanto para referir os favores divinos quanto o favor (o hino ou outro objeto votivo) que o fiel lhe oferece em troca, os dois últimos exemplos védicos utilizam palavras de mesma raiz que adquirem um traço semântico específico de acordo com a esfera (divina ou humana) na qual se acham inseridos. Trata-se de um vasto estrato léxico de sentido "conversível", como lhe chama Elizarenkova, ${ }^{493}$ que muda de direção e ênfase conforme o contexto e incluem verbos, substantivos, adjetivos, palavras primárias e compostos.

Essa "conversibilidade" obedece a uma estratégia retórica que os hinos do Rig Veda possuem em comum com a hinologia grega - a de criar um vínculo mútuo entre deuses e mortais, sendo o ato de um o reverso da moeda do outro. Em um fragmento das Carmina Popularia, por exemplo, lê-se (PMG 849):

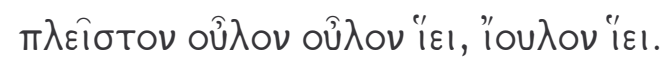

'Envia um grande feixe, um feixe (oulos), envia um feixe (ioulos).'

Ateneu, em cuja obra o verso foi preservado, comenta que, segundo Semus, autor de um trabalho sobre peãs, ouloi e iouloi eram tanto os feixes de cevada quanto os hinos em homenagem a Deméter, deusa que inventou o grão, ela própria chamada às vezes Ioulo ${ }^{494}$ Hinos e grãos são a prestação e contraprestação entre divindade e devoto, ambas designadas pelo mesmo termo, que sintetiza a natureza mútua da troca. Deméter é requisitada a enviar não somente os grãos de que é a patrona, mas os próprios hinos com que os mortais lhe rendem devoção. ${ }^{495}$ Que a divindade inspire o fiel na composição de

\footnotetext{
${ }^{493}$ Elizarenkova (1995), 41-67.

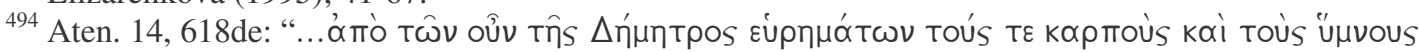

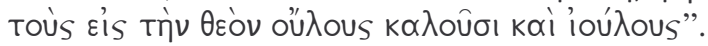

${ }^{495}$ No Hino a Deméter de Calímaco (v. 19), o poeta propõe-se cantar como a deusa foi a primeira a cortar

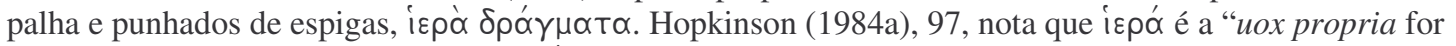
Demeter's gifts, perhaps because the $\delta \rho \alpha \gamma \gamma \mu \alpha \tau \alpha$ were offered as first fruits". Ou seja, o punhado de espigas de trigo é "sagrado" tanto porque Deméter foi a primeira a ceifá-lo como porque os mortais oferecem-no à
} 
hinos para que, através desses mesmos hinos, o fiel lhe retribua a dádiva é uma noção que vigora também nos hinos do Rig Veda e que talvez seja resumida da maneira mais lapidar na expressão devyấ dhiyă 'por intermédio de uma intuição poética divina', como em RV 10.176,2ab: prá devám devyă dhiyă / bháratā jātávedasam 'portai avante o deus Jātavedas (= Agni) por intermédio de uma divina intuição poética' ${ }^{496}$ Dhť-é o próprio poema, ${ }^{497} \mathrm{o}$ próprio hino entoado, cuja inspiração é fornecida pela divindade que é o seu destinatário.

Resultado inevitável dessa busca de um elo recíproco é a proximidade que se pretende estabelecer entre os dois planos, e aqui voltamos ao início do nosso estudo, no qual se procurou expor o modo pelo qual o poeta hínico tenta aproximar deus e devoto em um mesmo ponto no tempo e no espaço. A proximidade que me interessa aqui, e que passo a analisar brevemente como fecho ao trabalho, é aquela refletida na justaposição dos pronomes.

\subsubsection{Justaposição de pronomes}

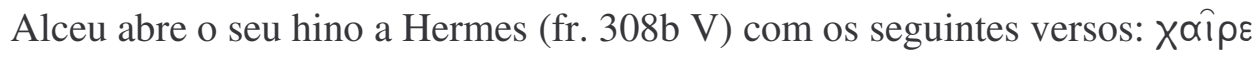

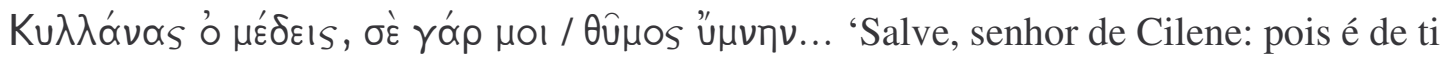
que o meu coração deseja cantar...' Os pronomes $\sigma \varepsilon ́$ e $\mu$ ol, que fecham o hendecassílabo sáfico, destacam-se não só pela posição métrica, mas ainda pela sua óbvia adjacência. $\mathrm{O}$ poeta sublinha assim, pela ordem das palavras, o laço que deseja entreter com o deus 498

deusa a título de primícias. No primeiro sentido, trata-se de um presente da deusa aos mortais; no segundo, de uma oferenda dos mortais à deusa - ambos, porém, são "sagrados".

${ }^{496}$ Cf. também RV 8.27,13cd.

${ }^{497}$ Geldner traduz: "unter göttlicher Dichtung”. Sobre o conceito de dhî-, cf. Gonda (1963), que comenta sobre esse verso e passagens análogas (166): "The force of devi-must, in these cases, be that the 'concept' expressed by the substantive is more than human, that it is beyond the power and understanding of ordinary man, that it is engendered or set in motion by divine powers".

${ }^{498}$ Ao aportar em Ítaca com um navio carregado de bens preciosos, Odisseu ignora o seu paradeiro e dirige estas palavras a Atena, que, embora disfarçada de jovem pastor, ele sem dúvida reconhece e interpela como

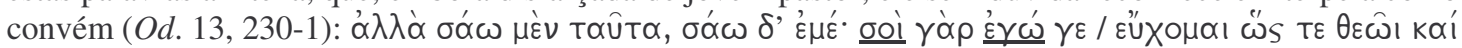

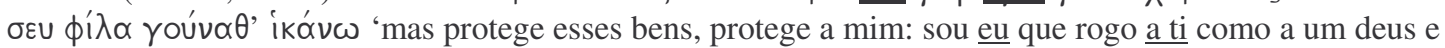
abraço os teus joelhos como suplicante'. Tal como em Alceu, a adjacência dos pronomes é reforçada pela posição que ocupam no metro (após a diérese bucólica e em enjambement com o verso seguinte). Também Anquises, ao deparar-se com Afrodite e tomá-la por uma deusa ou uma ninfa, promete-lhe construir um

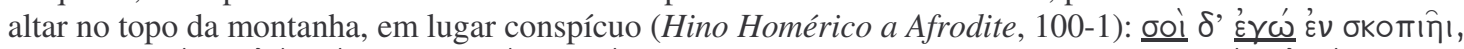

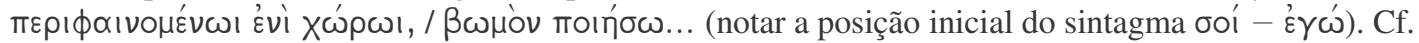

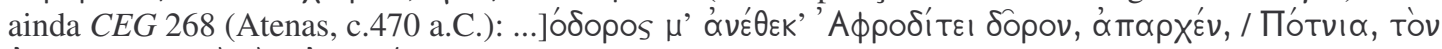

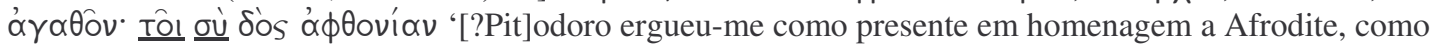

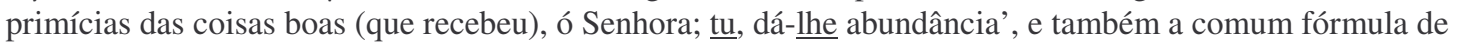


através do hino. O mesmo se dá, como vimos, ${ }^{499}$ no peã a Higiéia de Arífron: $\underline{\sigma u} \delta^{\prime} \varepsilon \underline{\mu O}$

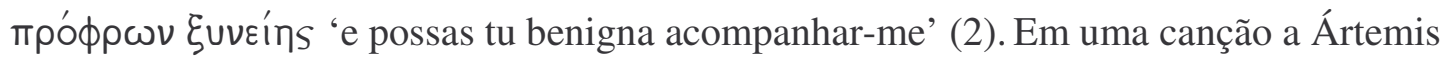
entoada por mulheres, embora o texto preservado em Ateneu encontre-se extremamente corrompido, notamos fenômeno análogo (PMG 955): "A

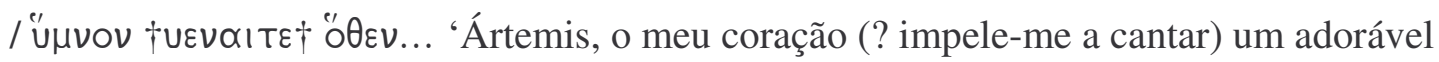
hino para ti...'

Justapor os pronomes de devoto e divindade no esforço de uni-los pela retórica da palavra também é um recurso difundido no Rig Veda, como Elizarenkova ${ }^{500}$ teve ocasião de observar. Cabe lembrar que, em grego como em védico, é opcional o uso de pronomes pessoais com verbos finitos, cuja inflexão já traz implícitas as informações sobre pessoa e número do sujeito. Seu uso, portanto, costuma ser explorado de maneira expressiva pelo poeta, que se vale das diversas categorias de pronomes de primeira e segunda pessoas em geral relativos a fiel e divindade, respectivamente - para multiplicar a força simbólica da sua composição. Vejamos alguns exemplos pontuais.

(1) a) 1.94,1-14d ágne sakhyé mâa riṣāmā vayám táva 'ó Agni, que em tua amizade nós não soframos danos'

b) 8.61,14cd tám tvā vayám maghavann indra girvạ̣ạ̣/ sutấvanto havāmahe 'ó generoso Indra, sequioso de canções, nós que esprememos o soma te invocamos' (literalmente: 'invocamos um tal [como] ti')

c) 7.32,27cd tváyā vayám pravátạ̣ śáśvatīr apó / âti suüra tarāmasi 'que contigo nós ultrapassemos todos os desfiladeiros, todas as águas, ó herói’

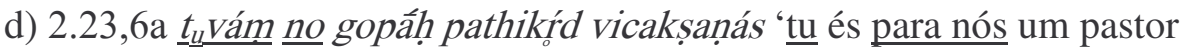
que abre caminhos e enxerga longe'

A seqüência tvā vayám (1b) aparece tanto no começo dos pādas de 8, 11 e 12 sílabas ${ }^{501}$ quanto no final do pāda de 8 sílabas, quando então, pela prosódia, pronuncia-se

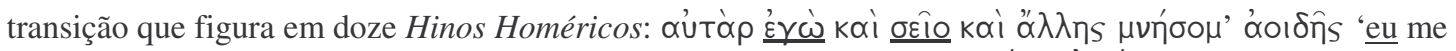

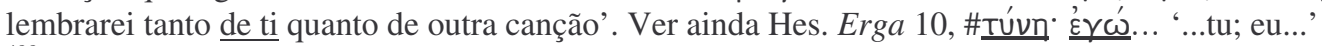

${ }^{499}$ Capítulo 1, item 1.1.4.

${ }^{500}$ Elizarenkova (1995), 179, com exemplos.

${ }^{501}$ Oito sílabas: tám tvā vayám havāmahe 'nós te invocamos' (8.43,23a); onze sílabas: mấ tvā vayám sahasāvann avîrā / mấpsavaḥ pári șadāma mấduvaḥ 'que nós não nos sentemos ao teu redor, ó poderoso, sem filhos, sem gado, sem favor' (7.4,6cd). A oitava maṇulala é particularmente rica em exemplos de $t v \bar{a}$ 


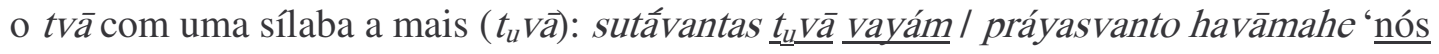
que esprememos o soma e oferecemos libações te invocamos $(8.65,6 \mathrm{ab}){ }^{502}$ Também a seqüência tváyā vayám (1c) ocupa as posições enfáticas de início e fim do pāda: víśvā utá tváyā vayám / dhấrā udanyà̃ iva / áti gāhemahi dviṣaḥ ‘e que nós superemos contigo todas as hostilidades como (superamos) torrentes de água $(2.7,3) .{ }^{503}$ Muito comum é a dupla tvám naḥ (1d) em posição inicial, como no exemplo citado, ${ }^{504}$ mas pode-se encontrá-la também no fim: ă gómati vrajé bhajā tvám nah ‘ ‘u dá-nos um quinhão do rebanho de vacas' $(7.27,1 \mathrm{c}) .{ }^{505}$ É possível ainda inverter a ordem dos termos em (b) e (d): vayám $\underline{\underline{t} \underline{\underline{v}} \underline{\bar{a}}}$ vavrmahe 'nós te escolhemos' (1.187.2b); abhí khyạ̣ pūṣan pŕtanāsu nas tvám 'tu Pūṣan, olha por nós nas batalhas' $(6.48,19 \mathrm{c}){ }^{506}$ A vizinhança por si só marcante entre os pronomes referentes ao fiel e à divindade são, portanto, sublinhadas pela posição ocupada no metro e pela esporádica inversão da sua ordem formular usual.

Às vezes, os pronomes acoplados vinculam-se à menção do próprio canto, como nos exemplos de Alceu e da canção a Ártemis citados acima: tvám no asyá vácasaś cikiddhi 'tu , compreende essa nossa palavra' (4.4,11c); sá tvám na na indra dhiyasānó arkaír 'tu, ó Indra, com a atenção chamada pelo nosso canto...' (5.33,2a); sá tvám $\underline{\text { no }}$ maghavann indra girvaṇo / venó ná śrṇudhī hávam 'tu, ó generoso Indra, sequioso de canções, escuta o nosso chamado como um amante' (8.3,18cd); eșá stóma indra túbhyam

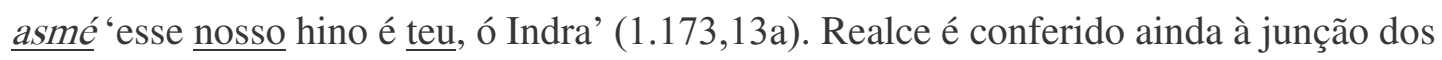
pronomes quando entre eles se intercala uma partícula enfática: tvám tư na indra tám rayím dā ‘tu, pois, Indra, dá-nos essa riqueza' (1.169,4a); vayám u tvāa śatakrato / gấvo ná yávaseṣv ăl ukthéșu rạ̣ayāmasi 'quanto a nós, ó (deus) das cem forças, nós te fazemos feliz com canções como vacas com o pasto' $(8.92,12) .{ }^{507}$ Além da ênfase que a partícula empresta, o elo entre deus e mortal pode receber o reforço do paralelismo na construção:

vayám adjacentes em versos de doze sílabas: além do exemplo (b), cf. 8.43,23a; 8.51,6c; 8.52,4c; 8.53,2c; $8.65,7 \mathrm{c}$ e ainda $1.60,5 \mathrm{a}$.

${ }^{502}$ Cf. $1.82,3 \mathrm{a}(=10.158,5 \mathrm{a}) ; 1.130 .1 \mathrm{~d} ; 1.44,5 \mathrm{a}$ (tvắm ahám).

${ }^{503}$ Outros exemplos de tváyā vayám em início de verso: 1.132,1a; 1.178,5a; 4.4.14a; 4.20,3d; 7.43,5b; $10.38,3 \mathrm{~d}$.

${ }^{504}$ Cf. (com e sem sá-figé inicial): 2.23.6a; 3.16.3a; 3.19.5a; 4.1.4a/5a; 6.4.4c; 6.12.6a; 6.16,30a = 7.15,15a; $6.45 .17 \mathrm{c}=8.80,2 \mathrm{c} ; 6.46,9 \mathrm{a} ; 8.16,12 \mathrm{a} ; 8.23,12 \mathrm{a} / 29 \mathrm{~b} ; 8.61,16 \mathrm{a} ; 8.70,10 \mathrm{a} / 12 \mathrm{a}$.

${ }^{505} \mathrm{Cf}$. (com e sem enjambement) 3.1,22a; 7.37,6a; 10.83,3d.

${ }^{506}$ Cf. $10.86,8 \mathrm{c} ; 10.128,6 \mathrm{~b} ; 10.141,1 \mathrm{~d}$.

${ }^{507}$ Cf. ainda 8.33.1a (vayám gha tvă), 8.21,1a (vayám u tvắm) e 6.15.19a (vayám u tvă), este último citado por Elizarenkova (1995), 179. 
(2) a) 8.64,6ab vayám u tvā dívā suté/ vayám náktaṃ havāmahe 'quanto a nós, nós te invocamos de dia, nós de noite junto ao soma'

b) 3.15,2ab tuvám no asyă uṣáso vyùștau / t tuám sưra údite bodhi gopạḥ 'tu, sê o nosso protetor no raiar dessa aurora, tu quando o sol está no alto'

c) $6.15,12 \mathrm{ab}(=7.4,9 \mathrm{ab}) t_{u}$ Vám agne vanuṣyató ní pāhil t tuvám u nạ̣ sahasāvann avadyắt 'tu, ó Agni, protege(-nos) do invejoso, sim, tu, ó (deus) da força, (protege-)nos do erro'

\section{d) 2.9,2ab tuvám dūtás tuám u nạ̣ paraspấs / t tuám vásya ă vrșabha}

prạ̣etã 'tu (és) o mensageiro, (és) tu também (que) nos protege de longe, tu (és), ó touro, um condutor para o melhor-estar'

O primeiro exemplo (2a) reúne anáfora do pronome de primeira pessoa (vayám), elipse do verbo no primeiro pāda (havāmahe) e paralelismo antitético (dívālnáktam 'de dia/de noite'). ${ }^{508}$ Conjugados, tais elementos contribuem para dar relevo ao par vayám $u$ tvā, por si só saliente. A sucessão natural entre noite e dia põe em evidência não apenas o zelo do devoto, mas alude ainda à complementaridade entre ele e o seu deus. Análoga é a passagem (2b): paralelismo entre a aurora e o pleno dia, anáfora do pronome (tvám) e verbo copular ( bodhi) elidido no primeiro pāda. Em (2c) os pronomes anafóricos, sempre em posição inicial, são acompanhados da elipse do imperativo ní pāhi 'protege' e do paralelismo daquilo contra o que o poeta pede a proteção divina - vanuṣyatáh 'invejosos' e avadyăt 'erro', um e outro no ablativo. Já o quarto exemplo (2d) é formado por três orações nominais. Trata-se de um tricólon cujos membros se acham dispostos em ordem crescente (Behaghel), cada qual correspondente a uma oração: o primeiro cólon ocupa a abertura do verso triṣtubh, o segundo a quebra e a cadência, e o terceiro o segundo pāda inteiro.

Nos itens (2c) e (2d), observamos uma certa progressão na repetição pronominal. Primeiro é usado o pronome referente à divindade ( $t$ vám), depois o mesmo pronome ladeado do pronome referente ao devoto ( tvám... nạh). Isso pode se dar no interior do

\footnotetext{
${ }^{508}$ Klein (1999), 123: "The threefold complex of anaphora, non-overt representation of the verb, and parallelism has been elevated in the Rigveda almost to a compositional principle".
} 
mesmo pāda (2d), em pādas diversos no interior da mesma estrofe (2c) ou ainda entre estrofes consecutivas de um mesmo hino, como em RV 1.91,5-8:

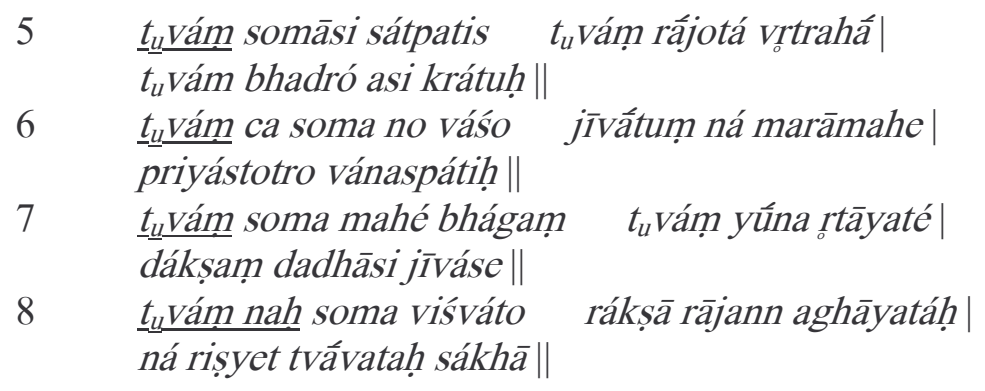

([5] Tu, ó Soma, és o senhor da verdade, tu (és) rei e algoz de Vritra. / Tu és a feliz força de inspiração.

[6] Se tu, ó Soma, quer que vivamos, nós não morremos. / És amigo do elogio, senhor da floresta.

[7] Tu, ó Soma, (dás) ao adulto a sorte, tu (a dás) ao jovem que segue a verdade. / Tu dás a força para que (eles) vivam.

[8] Tu, ó Soma, protege-nos de todos os lados, ó rei, daquele que nos quer mal! Que o amigo de alguém como ti não sofra danos.)

Aqui a seqüência tríplice de tvám seguido de tvám nạ̣ constitui um crescendo "vertical" entre as estrofes; os demais tvám em início de pāda (5b, 5c, 7b) fazem eco a esse movimento, bem como o adjetivo tvăvataḥ (literalmente: 'tão como tu') em 8c. ${ }^{509}$

A simples repetição dos pronomes combinados em pādas sucessivos também serve para reforçar o sentido. Tal repetição ocorre tanto no interior da estrofe (p.ex. RV 8.48,15a-15c \#tvám nạ̣... \#tváṃ nạ̣...; 8.66,14a-14c \#tvám nạ̣... \#tváṃ nạ̣...) quanto no início de estrofes adjacentes (p.ex. RV 1.129,9a-10a \#tvám na indra... \#tváṃ na indra...; 2.23,9a-10a \#tváyā vayám... \#tváyā vayám...; 10.25,7a-8a-9a \#tvám nạ̣... \#tváṃ nạ̣... \#tvám nạ̣...), ou ainda como encadeamento estrófico (RV 6.1):

\section{6cd tám tvā vayám dáma â dīdivămịsam úpa jñubădho námasā sadema 7ab tám tvā vayám sudhyò návyam agne sumnāyáva ìmahe devayántạ̣|}

([6] Enquanto tu brilhas na casa, nós queremos te servir, de joelhos dobrados, com veneração. [7] Assim, nós te abordamos de novo, que temos bons pensamentos, que queremos o teu favor, ó Agni, que adoramos os deuses.)

${ }^{509}$ Cf. RV 1.121,12-14, com uma progressão semelhante: 12a tvám..., 13a tvám..., 14a tvám naḥ... 
Tal concatenação é tanto mais notável porque, além de ser única no hino, com as suas aberturas de pāda idênticas, ela marca a transição para a estrofe central, a sétima, nesse hino de treze estrofes. A moldura dessa estrutura "omphalos" é fornecida pela repetição, igualmente única, de palavras que abrem os pādas $a$ e $c$ da primeira e última estrofes: 1a tvám... 1c tvám... 'tu' 13a purúnịi 13c purưni ‘muitos'.

Ainda mais explícita é a reciprocidade quando há inversão de pronomes em pādas adjacentes.
a) $7.37,4 \mathrm{a}$

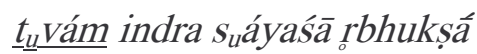
b Văjo ná sādhúr ástam eși ŕkvā/

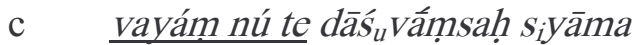
d bráhma krṇvánto harivo vásișthāh

'Tu, ó Indra, que és um Rbhukșan cuja fama é espontânea, tu retornas para casa como um Vāja feliz, rico em estrofes. Quanto a nós, que sejamos os teus devotos, capazes de criar uma fórmula poética, ó deus dos alazães, nós os Vasiștha!'

\section{b) $8.32,7 \mathrm{a} \quad$ vayám ghā te ápi șmasi \\ b stotâra indra girvaṇah̆/ \\ c $\quad \underline{t}_{u}$ vám no jinva somapāh}

'Nós cantores temos em ti um refúgio, ó Indra sequioso de canções. Tu, que bebes soma, aviva-nos!'

\begin{tabular}{|c|c|}
\hline c) $1.91,10 \mathrm{a}$ & imám yajñám idám váco \\
\hline $\mathrm{b}$ & jujuṣāṇá upăgahi i \\
\hline c & sóma tvám no vrdhé bhava \\
\hline $11 \mathrm{a}$ & sóma gīrbhís ț $\underline{u}_{u}$ vā vayám \\
\hline $\mathrm{b}$ & vardháyāmo vacovídaḥ / \\
\hline c & sumrg̣īkó na â viśa \\
\hline
\end{tabular}

'[10] Tirando prazer desse sacrifício, dessa palavra, aproxima-te, ó Soma, sê tu propício ao nosso crescimento! [11] Ó Soma, nós te fazemos crescer pelo canto, tu que sabes as palavras: entra em nós (como alguém) que se compadece!'

Nos dois primeiros exemplos (3a-3b), a passagem do "tu" ao "nós", e vice-versa, ocorre dentro da mesma estrofe; no terceiro (3c), sublinha o elo inter-estrófico. Em (3a), há uma progressão simples com pronomes invertidos: tvám $\rightarrow$ vayám te; nos demais, o 
poeta cria um movimento basculante, com dupla inversão pronominal: vayáṃ te $\rightarrow$ tváṃ nạ̣ (3b) e tvám nạ̣ $\rightarrow$ tvā vayám (3c).

Nem sempre, porém, o esquema restringe-se a estrofes contíguas, como em RV $8.93,19 / 21$ :

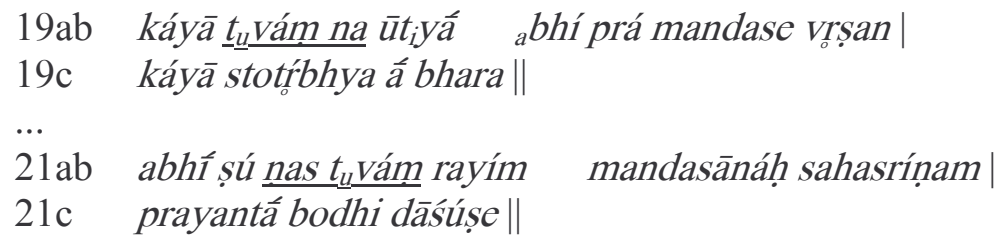

'[19] Com qual ajuda tu te alegras conosco, ${ }^{510}$ ó touro, com qual delas trazes (algo) ao cantor? (...) [21] Tendo-te alegrado, (traze-)nos tu bens às centenas, sê um doador ao devoto!'

O par antifônico composto pelas estrofes, que se unem quase como pergunta e resposta, é marcado pelo eco de mandase 'alegras-te' (19b) mandasānáh 'tendo-te alegrado' (21b) e pela repetição quiástica dos pronomes adjacentes tvám nạ̣(19a) nas tvám (21a). Com que ajuda, com que objeto de devoção (káyā... ūtyă), pergunta o poeta a Indra, tu te alegras conosco (tvám nạ̣)? A resposta implícita é o próprio hino: tendo-te alegrado com ele, hino, que tu, Indra, traga bens às centenas para nós (nas tvám).

Certas vezes, a geminação dos pronomes de deus e devoto recebe o reforço de termos afins que se agrupam ao seu redor - geralmente os mesmos pronomes, em casos diversos ou não.

\section{(4) a) 4.4,14ab tváyā vayám sadhanyàs $\underline{t}_{u}$ vótās / táva pránịt $t_{i}$ aśi} "nós somos conduzidos em comum por ti, somos por ti favorecidos: que sob a tua condução alcancemos os prêmios'

\begin{tabular}{|c|c|}
\hline b) $2.20,2 \mathrm{a}$ & $\underline{t}_{u}$ vám na ind ${ }_{a}$ ra $\underline{t}_{u}$ văbhir ùttí \\
\hline $\mathrm{b}$ & $\underline{t}_{u}$ vāyató abhiștipăsi jánān / \\
\hline $\mathrm{c}$ & 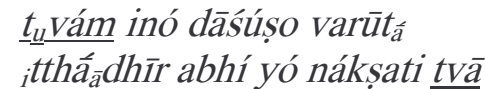 \\
\hline
\end{tabular}

\footnotetext{
${ }^{510}$ Sigo aqui a análise de Gotō (1987), 236 n.520, que considera o presente temático mandase como intransitivo ("sich an jn. (Akk.+abhî) sehr erfreuen"), ao contrário de Geldner. Cf. Mayrhofer (1992-6), vol. 2, sob $M A D$-. A confusão entre o sentido intransitivo e transitivo do verbo, vale notar, deve-se em parte à ambigüidade semântica de $\bar{u} t i$ - 'ajuda', que pode designar tanto o auxílio que os deuses conferem aos homens quanto a "ajuda", em forma de libações ou do próprio hino, que os homens ofertam aos deuses.
} 
'Graças às tuas ajudas, ó Indra, tu és quem velas sobre gente como nós, que nos votamos a ti. / Tu és o poderoso protetor do devoto, que se aproxima de ti com essa visão poética' ${ }^{511}$

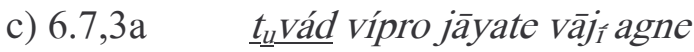
b t $\quad$ tuvád vīráso abhimātiṣăhạ
c vaíśvānara țuám asmấsu dhehi
d Vásūni rājan sprhayấy

'De ti nasce o orador inspirado, que ganha prêmios, ó Agni, de ti os homens que vencem os pensamentos adversos. Tu, ó Vaíśvānara, confere-nos bens a serem invejados'
d) $7.31,3 \mathrm{a}$
tulvám na indra vājayús
b $\quad \underline{t}_{u}$ vám gavyúh śatakrato
c $\quad \underline{t}_{u}$ vám hiranyayúr vaso
4a vayám indra $\underline{t}_{u}$ vāyávo
b abhí prá ṇonumo vrșan
c viddhí tú àsyá no vaso

'[3] Tu, ó Indra, conquista prêmios por nós, tu conquista gado, ó (deus) das cem forças, tu conquista ouro, ó bondoso. [4] Nós, que a ti nos votamos, clamamos por ti, ó touro Indra, dá atenção a esse nosso (chamado), ó bondoso'

Em (4a), a parelha tváyā vayám é reforçada pela dupla repetição do pronome de

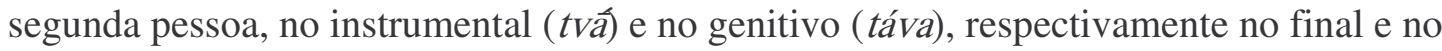
início do pāda. ${ }^{512} \mathrm{O}$ par pronominal tvám nạ̣ também abre a estrofe em (4b), e a seguir é ecoado pelo possessivo tvăbhis 'teu', referente ao deus, e pelo adjetivo tvāyatás 'votados a ti', referente aos devotos. A oração que preenche os dois pādas seguintes $(2.20,2 \mathrm{c}-\mathrm{d})$ é então emoldurada pelo nominativo \#tvám e pelo acusativo enclítico tvä\#. No exemplo (4c), o par tvám asmâsu é sublinhado pela anáfora do pronome ablativo tvád, que por sua vez ressalta da construção paralela com elipse verbal dos pādas 6.7,3a-b. O esquema progressivo $t$ vád $\rightarrow$ tvád $\rightarrow$ tvám asmâsu assemelha-se àquele de RV 1.91,5-8 que vimos acima: tvám $\rightarrow$ tvám $\longrightarrow$ tvám $\longrightarrow$ tvám naḥ. Em (4d), a sequiência de três tvám 'tu' em início de pāda (inaugurada pelo par tvám nạ̣) culmina com o vayám 'nós' da estrofe seguinte, ele próprio qualificado por aquilo que o une ao deus Indra interpelado: eles são tvāyávas

\footnotetext{
${ }^{511}$ Sobre o composto itthădhī-, cf. Gonda (1963), 113.

${ }^{512}$ A raiz $n \bar{T}-$ 'conduzir' amplifica esse eco, comparecendo num e noutro pāda: sadhanías, pránīti.
} 
'votados a ti'. O pronome referente aos devotos (vayám) assume assim a posição métrica reservada nos pādas anteriores ao pronome divino ( $t v a ́ m$ ), no claro objetivo de aproximar um e outro. ${ }^{513}$

Essa substituição métrica do pronome do deus pelo dos mortais que lhe rendem louvor costuma ocorrer em posição de destaque no verso, no início do pāda ou da estrofe, como em RV 5.10,2-4:

\section{2 țuvám no agne adbhuta krátvā dákṣasya maṃhánā tuvé asuryàm ấruhat krāṇă mitró ná yajñíyaḥ \|

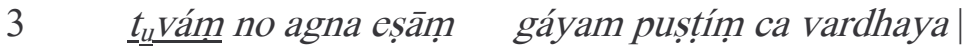 yé stómebhị̣ prá sūráyo náro maghăn $n_{i}$ ānaśúh $\|$ \\ 4 yé agne candra te gírạ śumbhánt ${ }_{i}$ ásvarādhasạ̣| śúșmebhị̣ śuṣmiṇo náro ～diváś cid yéșām brhát sukītír bódhati tmánā||}

'[2] $\underline{\mathrm{Tu}}$, ó Agni extraordinário, com o teu poder, com a generosidade do teu pensamento em ti ergueu-se a natureza de asura - com o teu concurso em nosso favor, tu és digno de sacrifício como Mitra. [3] Tu, ó Agni, aumenta o curso de vida e a prosperidade desses senhores, nossos patronos, que com (as nossas) canções de louvor alcançaram riquezas ao longe. [4] Eles que, ó Agni, (deus) luminoso, enfeitam cantos para ti ao fazerem dádiva de cavalos, os senhores, ardorosos com seu ardor, cujo elevado renome (é mais alto) que o próprio céu (e) assinala-se por si mesmo.'

Os pādas 2a, 2c e 3a iniciam com o pronome referente ao deus, com o detalhe de que 2c (\#tvé... 'em ti...') é uma frase parentética com uso expressivo do pronome em primeira posição para acompanhar a seqüência. Em 3c, o relativo yé 'os quais', referente aos devotos, assume a posição antes reservada a Agni. Destaque ainda maior é conferido ao pronome relativo pelo fato de se transferir o antecedente ao qual ele se refere (no caso, os "senhores patronos") da oração principal para a subordinada: eșām... yé... sūráyo nárạ̣ 'desses... os quais... senhores patronos'. O demonstrativo genitivo eșām 'desses' da principal só ganha sentido pleno na frase subordinada, após menção dos sūráyo nárạ̣ 'senhores patronos', cujo caso (nominativo) é assimilado ao relativo yé.

E é com o mesmo yé que se inicia novamente o pāda 4a, um indício de que a sua utilização anafórica não é fortuita. A rigor, ambos os relativos referem-se aos patronos, mas o poeta é hábil o suficiente para inserir-se nesse nexo entre patrono e divindade

\footnotetext{
${ }^{513}$ Elizarenkova (1995), 173, comenta que "this device brings the worshipper closer to his deity or, in terms of magic, grants the worshipper power over his deity".
} 
louvada, criando uma relação triangular: os patronos alcançam riquezas por meio de canções (stómebhịh 3c), compostas afinal pelo poeta; e se enfeitam (śumbhánti 4b) tais cantos (uma ação de que, em geral, os poetas se incumbem), só o fazem na medida em que são pródigos em cavalos (áśvarādhasah 4b) - uma alusão à retribuição ritual paga aos poetas pelos patronos em troca do hino. ${ }^{514}$

Os papéis também podem inverter-se: ao deus reserva-se o pronome relativo, ao fiel o pronome pessoal, ambos em posição enfática, como no famoso hino a Indra, RV 2.12. Cada uma das suas estrofes, com exceção da última (15), termina em um refrão: sá janāsa índraḥ 'esse, ó gentes, é Indra'. Ao refrão precede, em cada caso, uma descrição de um traço ou feito peculiar do deus, vinculada ao refrão final através de uma estrutura fixa, segundo o esquema relativo/correlativo. Todas as estrofes contêm pelo menos um pronome relativo yá-(referente a Indra) correlacionado ao sá do refrão, e algumas delas exibem uma profusão de tais pronomes, como a estrofe 7:

\subsection{2,7 yásyấs vāsaḥ pradísi yásya găvo yásya grămā yásya víśve ráthāsaḥ| yáh sưriyam yá uṣásam jajăna yó apăm netá sá janāsa índraḥ\|}

'Aquele sob o comando de quem (estão) os cavalos, de quem as vacas, de quem a soldadesca, de quem todas as carruagens, / que engendrou o sol, que (engendrou) a aurora, que (é) o guia das águas - esse, ó gentes, é Indra.'

Trata-se de um dispositivo sintático comum, uma frase relativa ser resolvida por uma oração principal, mas a sua repetição ao longo do hino, no qual o relativo figura em diversos casos (yáh, yám, yásya, yásmād, yéna) e ocupa, com poucas exceções, posição inicial nos pādas $a$ e $c$, faz com que sua ausência na última estrofe, como nota Jamison, ${ }^{515}$ chame tanto a atenção quanto sua presença:

\subsection{2,15 yáh sunvaté pácate dudhrá ă cid Vaăjam dárdarṣi sá kílāsi satyáh | vayám ta indra viśváha priyăsạ̣ suvîrāso vidátham ă vadema\|}

'(Tu) que, mesmo diante de um (inimigo) obstinado, faz irromper o prêmio de vitória para aquele que espreme (e) cozinha - tu és de fato verdadeiro. / (Que) nós sempre (sejamos) caros a ti, ó Indra. Tendo bons heróis, que anunciemos a cerimônia.'

\footnotetext{
${ }^{514}$ Sobre essa relação triangular entre deus, poeta e patrono, na qual o poeta louva o deus, o deus retribui ao patrono, que por sua vez paga ao poeta para louvar o deus, cf. Wilden (2000), 12-66, Hintze (2000), 30140, e (2004), esp. 28-30, Watkins (1995), 68-84, e Oguibénine (1988), 58ss.

515 Jamison (2007), 69.
} 
Falta aqui o refrão, mas o relativo que abre a estrofe é mais uma vez retomado no correlativo ao final do pāda b (yáḥ... sá kílāsi satyáh ‘[tu] que... tu és de fato verdadeiro). Logo após essa quebra na seqüência de refrões, que surpreende o ouvinte por antecipar a correlação que até ali fechara as estrofes com o teonímico em posição final de destaque ( sá janāsa índrah), o pronome referente aos devotos ( vayám 'nós') abre o pāda seguinte, assumindo assim o posto métrico preenchido anteriormente pelo relativo divino. "Após um hino inteiro", comenta Jamison, ${ }^{516}$ "em que o deus figurava na terceira pessoa e seus fiéis eram um público silencioso na segunda, o próprio Indra aparece agora na segunda pessoa, e os fiéis na primeira". E o laço entre ambos torna-se tanto mais explícito pela contigüidade final dos seus pronomes: vayám te...

Outro exemplo marcante, esse já analisado por Elizarenkova, ${ }^{517}$ é RV 2.1, um hino a Agni. O poema é composto de dezesseis estrofes, as quatorze primeiras iniciadas por tvám 'tu' em seus diversos casos (nominativo, acusativo, genitivo, locativo), seguido do vocativo agne 'ó Agni’: tvám agne..., tvăm agne..., távāgne..., tvé agne... A maioria dos pādas restantes também inicia com uma das formas do mesmo pronome: tvám, tvắm, tváyā, táva, tvé. Elipse verbal e paralelismo mitigam um pouco da saturação causada pelo acúmulo pronominal, como por exemplo na primeira estrofe:

\section{tvám agne dyúbhis tvám āśuśuksáṇis tvám adbhiyás tuvám áśmanas pári|}

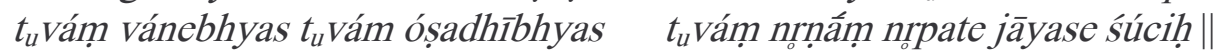

'Tu, ó Agni, (nasces) com os dias, tu que brilhas com intensidade, tu das águas, tu da pedra, / tu das árvores, tu das plantas, tu, ó senhor de homens entre os homens, nasces puro.'

Na penúltima estrofe, uma estrofe de transição, o poeta descontinua a sequiência observada até ali na abertura estrófica ("tu”+agne) e desmembra o sintagma: "tu" aparece no primeiro pāda, agne no segundo (15a \#tvám..., 15b \#ágne). A última estrofe promove então a inversão métrica dos pronomes de deus e devoto:

$$
\begin{aligned}
& \text { yé stotŕbhyo góagrām áśvapeśasam ágne rātím upasrjánti sūráyạ̣| } \\
& \text { asmẫn ca tâmós ca prá hí néși vásya ă brhád vadema vidáthe suvî́rāh } \|
\end{aligned}
$$

\footnotetext{
${ }^{516}$ Idem, 70.

${ }^{517}$ Elizarenkova (1995), 172s.
} 
'Os patronos que vertem sobre os cantores, ó Agni, um bem que culmina em vacas, tendo cavalos por enfeite, / a nós e a eles conduze para o melhor-estar! Tendo bons heróis, que falemos alto na cerimônia ritual.'

O pronome relativo yé, referente aos patronos, figura na posição até ali cativa do pronome divino. Já por si enfática, a inversão é salientada ainda pelo contraste entre os dois primeiros pādas das últimas estrofes:

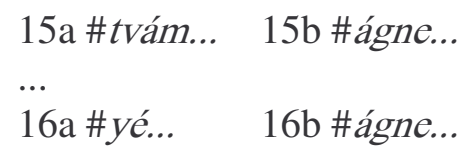

Sūráyaḥ 'patronos' (16b), antecedente a que se vincula o relativo yé, figura como último termo da oração e do pāda (\# yé... ...sūráya!̣\#), em notável hipérbato. No arco entre um e outro, menção é feita ao poeta (stotŕchhyah 16a) e ao próprio deus a quem se faz o pedido (ágne 16b) - um artifício para mesclar, através da sintaxe, os três pólos da relação (poeta, patrono e divindade louvada).

Outro caso evidente de inversão pronominal expressiva é RV 6.26, um hino de oito estrofes a Indra. O pronome tvám 'tu' abre as estrofes 2 a 6 , tanto no nominativo quanto no acusativo (tvám..., tvắm...), e o mesmo acontece em alguns dos demais pādas (2c, 2d, 3b, 3c, 4c, 4d, 6c). Nas duas últimas estrofes a ordem inverte-se, e o pronome referente a Indra cede lugar ao pronome dos fiéis:
7 ahám caná tát sūríbhir ānaśyām
táva jyâya indra sumnám ójạ̣| tváyā yát stávante sadhavīra vīrăs trivárūthena náhușā śaviștha 8 vayám te asyấm indra dyumnáhūtau sákhāyaḥ syāma mahina préșthāḥ| prătardanị̣ kṣatraśrír astu śréștho ghané vợtrănāạm sanáye dhánānām\|

'[7] Quanto a mim, possa eu também alcançar com os patronos esse teu poderoso favor e força, ó Indra, / que os heróis, ó companheiro dos heróis, sejam por ti louvados, tu que és um triplo Nahus, ó (deus) mais poderoso. [8] Que nesse chamado flamejante, ó excelso Indra, nós sejamos os teus mais caros amigos. / Que o filho de Pratardana, que faz brilhar o domínio, seja quem mais brilhe ao matar o inimigo para obter riquezas.'

Aqui, ao contrário do hino anterior (RV 2.1), não há transição: os pronomes de segunda pessoa acumulados ao longo do poema à cabeça da estrofe (2a-6a) cedem lugar a dois pronomes de primeira pessoa, um referente ao poeta (ahám 'eu' 7a), o outro a ele e a 
seu patrono juntos ( vayám 'nós' 8a). Mortais e imortais dividem assim o mesmo espaço no metro, e a sua proximidade ressalta ainda pelo entrelace, nessas duas últimas estrofes, dos pronomes de um e outro: ahám ‘eu' (7a), táva 'de ti' (7b), tváyā 'por ti’ (7c), vayám te 'nós... de ti' (8a). E o favor que se roga a Indra é serem os heróis por ele louvados ( tváyā... stávante 7c), não o contrário - uma inversão de papéis que confunde as esferas de deus e poeta, já que stu- 'louvar' designa obviamente o ato de veneração dos humanos em relação à divindade.

O jogo de pronomes, o zelo em dispô-los de modo a sugerir um elo estreito entre quem louva e é louvado, espelha toda uma concepção religiosa que supõe a reciprocidade entre os dois pólos da relação - uma reciprocidade enunciada de modo simples e lapidar no ligeiro zeugma deste pāda gāyatrī de um hino a Indra (RV 8.92,32c): tvám asmákaṃ táva smasi 'tu (és) nosso, nós somos de ti'. Ao propor a Zeus que ambos cedam de parte a parte, Hera - também na forma de pronomes - ecoa essa noção de um laço mútuo que, se vigora entre os deuses, os homens desejam estabelecer com os imortais (Ilíada 4,63): бoi

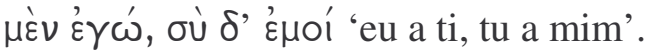




\section{CONCLUSÃO}

Se é de fato na reciprocidade que se baseia a troca mútua de dádivas entre deus e mortais, é natural que a relação só se sustente quando a bênção divina seja conquistada com a oferta de um bem que lhe esteja à altura. Tais bens podem consistir de sacrifícios, objetos votivos ou ainda hinos de louvor. Day ${ }^{518}$ já apontou a semelhança entre hinos e epigramas votivos, e não é raro encontrar, em um e outro gênero, menção à própria obra como moeda de troca fundamentada no vínculo mútuo. Entre tantos exemplos que podem ser citados, escolho apenas dois - primeiro um epigrama, depois uma passagem hínica. Em uma inscrição de meados do século V a.C. descoberta na acrópole ateniense lê-se $(C E G 275):^{519}$

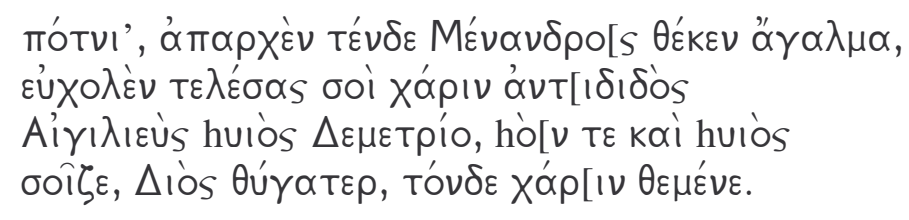

'Senhora, essas são as primícias que Menandro erigiu, uma estátua pelo cumprimento de um voto; ele, filho de Demétrio de Egília, retribui a ti um favor. Filha de Zeus, salva a ele e a seu filho, retornando-lhe essa dádiva.'

Na parte final do Hino a Zeus de Cleantes (403-6), o poeta estóico faz seu pedido: 405

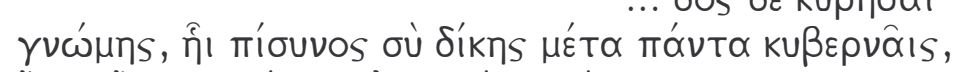

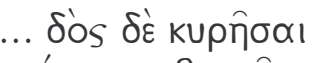

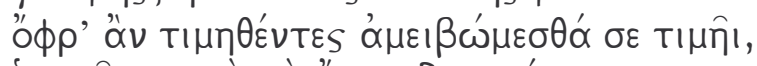

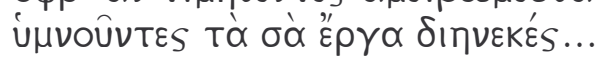

'...dá-nos alcançar o bom discernimento, em obediência ao qual tu governas tudo com justiça, para que, assim honrados, possamos retribuir-te com honras, cantando tuas obras eternamente...'

Em ambos os exemplos, prestação e contraprestação são expressas nos mesmos

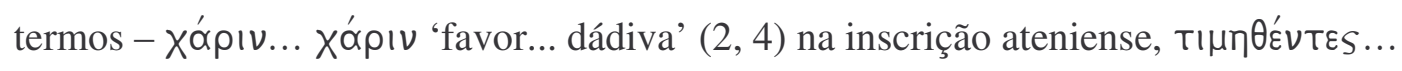

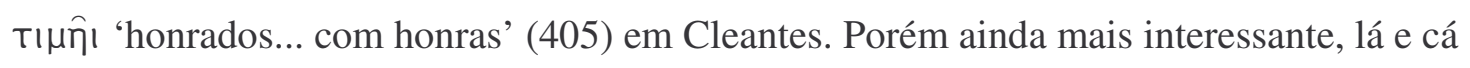
o objeto de devoção ofertado é ao mesmo tempo resultado da bênção divina e meio para

\footnotetext{
${ }^{518}$ Day (2000). Cf. também Bremer (1998), 134 n.11.

${ }^{519}$ Suplementos de Hansen.
} 
perpetuá-la. A inscrição é simultaneamente um agradecimento pela dádiva alcançada

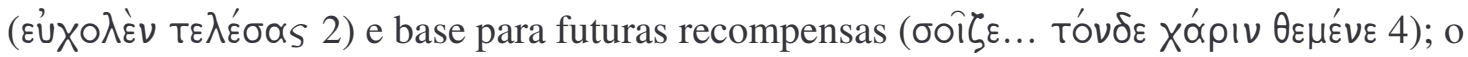
hino, além de pedir a Zeus o discernimento necessário para cantar as suas obras e assim honrá-lo, é ele próprio fruto desse discernimento previamente obtido, pois é nesse mesmo hino que se presta homenagem a Zeus cantando-lhe as obras. Inscrição e hino são o pivô de uma reciprocidade que se estende do passado ao futuro.

Que os hinos sejam uma oferenda, de natureza análoga não só a objetos votivos, mas aos próprios sacrifícios, é algo a que se alude de maneira esparsa nos documentos gregos. A idéia do sacrifício da poesia ${ }^{520}$ aparece, por exemplo, em Píndaro, fr. 86a S.-M.

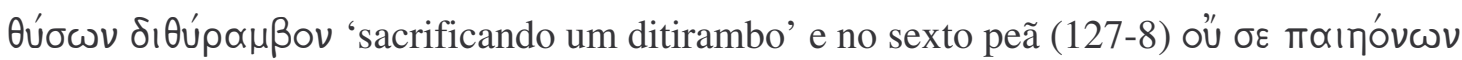

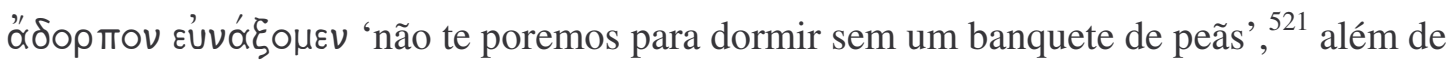
constar de uma anedota biográfica helenística sobre o poeta:

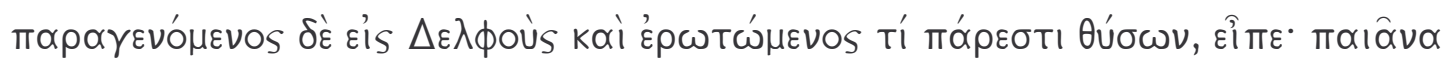
'chegando a Delfos e sendo perguntado o que sacrificaria ali, disse: um peã' (Schol. Pind. Drach. 1,3,18). ${ }^{522}$

Calímaco também menciona a idéia, que parece ter tido certa voga na época

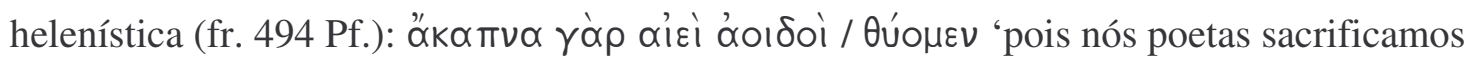
sempre oferendas sem fumaça'. 523

Séculos mais tarde, Menandro Retor (II, 17 Пєрі $\Sigma \mu ı v \theta ı \alpha$ koû 437, 25-7) insiste na mesma tecla:

\footnotetext{
${ }^{520}$ Cf. Svenbro (1988), Pulleyn (1997), 49s., Rutherford (2001), 324 n.75, e (2004), 71.

${ }^{521}$ Svenbro (1988), 233: “Come il plurale 'inni' può aver il significato di 'inno' al singolare nella poesia di Pindaro, il plurale 'peani' non è altro qui che una maniera enfatica di dire 'peana'; il 'pranzo' (dorpos) siamo ai Teoxenia, festa di commensalità fra dèi e uomini a Delfi - consiste dunque nel peana stesso [...]."

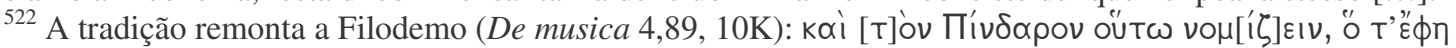

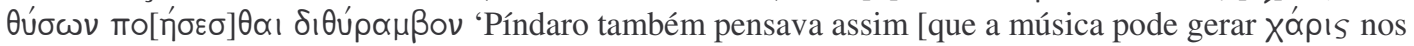
deuses] ao dizer que comporia um ditirambo como sacrifício'. Cf. ainda Eustácio, Prooem. comm. Pind. 31 (Schol. vet. Pind. 3, 302, 15 Drachmann). Rutherford (2001), 324 n.75, menciona outro paralelo de Delfos

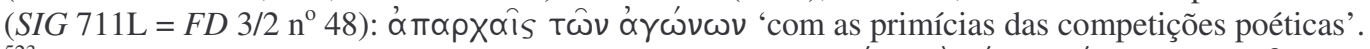

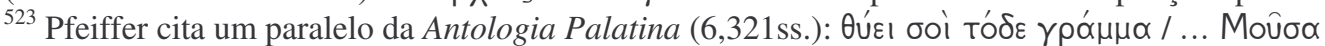

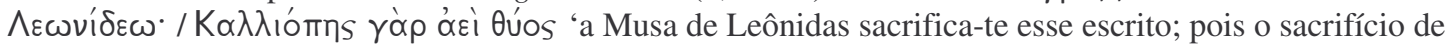
Calíope é sempre isento de fumaça'. Eustácio, referindo-se provavelmente à época de Calímaco, diz ao

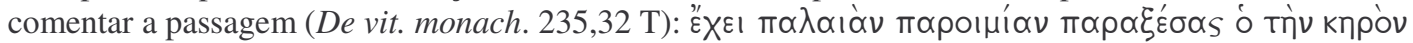

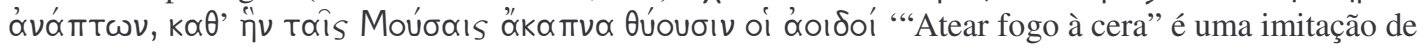
um antigo provérbio, segundo o qual os poetas fazem sacrifícios sem fumaça às Musas'.
} 


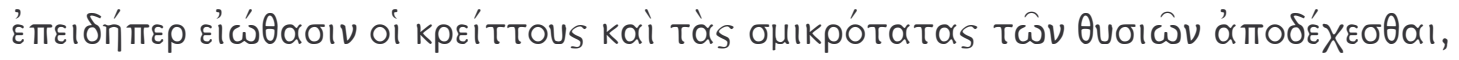

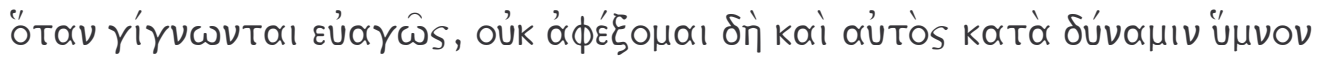

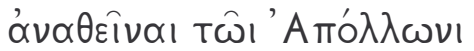

'uma vez que os poderes superiores costumam aceitar até mesmo o menor dos sacrifícios quando feitos com piedade, não me furtarei eu próprio a dedicar um hino a Apolo tão bem quanto puder'.

Noção análoga é expressa em uma estrofe de um hino a Agni do Rig Veda:

\subsection{6,47 â te agna rộa havír hroấ taștám bharāmasi} té te bhavant u uṣ̣ána r rṣabhăso vaśă utá ||

'Ó Agni, nós te portamos com o canto uma oferenda confeccionada com o coração; que esses sejam os teus bois, touros e vacas! ${ }^{524}$

Aqui o poema equipara-se à vítima destinada ao sacrifício e o ato verbal substituise ao objeto material. ${ }^{525}$ Também as libações são comparadas aos hinos, que, como elas, podem ser vertidos em homenagem à divindade:

\subsection{1,18 imấ bráhma sarasvati jușásva vājinīivati} yă te mánma grtsamadă ritāvari priyă devéșu júhvati $\|$

'Deleita-te, Sarasvati rica em dádivas, com essas fórmulas poéticas, com os pensamentos caros aos deuses que os Grintsamadas vertem para ti, ó (deusa) verdadeira. ${ }^{526}$

Denominador comum a todos - a vítimas sacrificiais, objetos votivos, libações e também aos hinos - é serem oferendas propiciatórias aos deuses; nunca é demais lembrar, embora isso possa soar um truísmo, que os hinos não são menos dignos de figurar como objetos de troca por serem bens imateriais, à diferença das demais oferendas que firmam

\footnotetext{
${ }^{524}$ Geldner traduz: "Wir bringen dir, o Agni, mit einem Vers ein Opfer, das mit dem Herzen gedichtet ist, denn das sollen deine Ochsen, Stiere und Kuhe sein", e comenta: "Der Sinn ist jedenfalls: Das Lied soll ein Ersatz für das Tieropfer sein". Cf. ainda Renou, EVP 13, 51.

${ }^{525}$ Cf. Lazzeroni (1983), 50s., e Oguibénine (1988), 14 n.3. A tese deste último, entretanto, é de que, embora a poesia religiosa védica seja ela mesma uma forma de sacrifício, somente nos hinos a Ușas as libações e vítimas sacrificiais são substituídas exclusivamente pelo sacrifício da palavra.

${ }^{526}$ Kurke (1989) demonstrou que se trata de uma imagem compartilhada pelas tradições indiana, grega e latina - a de verter preces; cf. por exemplo RV 8.39,3; 1.110,6; 2.27,1; Pínd. Íst. 8,56a-58, Ésq. Coé. 448-9, Supl. 630-1, fr. 36 N; Od. 19, 521-2; HHom. 19, 17-8; Hor. Epod. 17,53; Virg. En. 6,55-8; 5,233-8. A equiparação rigvédica entre hino ritual e libações já havia sido observada por Lüders (1959), 55ss. e 559, e Bergaine (1878), 283-5, 312s. Cf. ainda Thieme (1968), esp. 204-23.
} 
com os imortais o nexo de reciprocidade. Que o hino, aliás, seja uma oferenda em troca da qual se roga a bênção divina é algo dito explicitamente nos Hinos Homéricos, para me restringir ao exemplo mais óbvio:

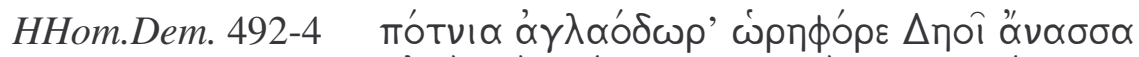

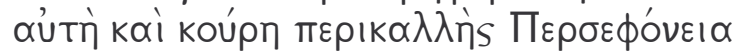

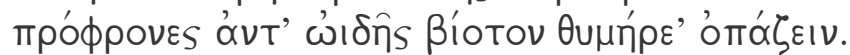

'Senhora, que trazes dádivas resplandecentes na devida estação, rainha Deo, tu e a tua filha, a belíssima Perséfone: concedei de bom grado confortável sustento em troca da minha canção.'

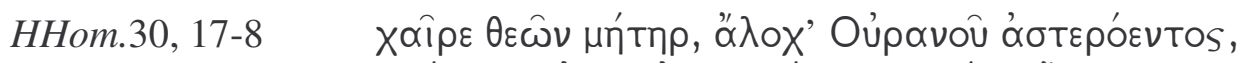

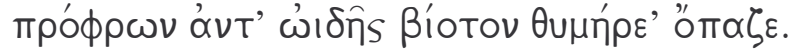

'Salve, mãe dos deuses (= Gaia), esposa do céu estrelado: concede de bom grado confortável sustento em troca do meu canto.'

Nesse último caso, como é corriqueiro na conclusão desses poemas, o pedido à divindade é precedido do imperativo $x \propto \hat{\imath} p \varepsilon,{ }^{527}$ que aparece em quase todos os 33 hinos da coleção. Não se trata apenas, como notou Wachter, ${ }^{528}$ de uma fórmula de despedida ou de um simples apelo para que a divindade se alegre, mas antes de um pedido para que ela aceite de bom grado e desfrute uma oferenda. Tal oferenda pode ser uma libação ou ainda o próprio hino, como também ocorre no paralelo por ele citado do Rig Veda:

\section{$5.54,15 \mathrm{~cd}$ idám sú me maruto haryatā váco yásya tárema tárasā satám hímāḥ}

'Tirai bom proveito, ó Maruts, desse meu poema, através de cujo poder de superação possamos superar cem invernos.'

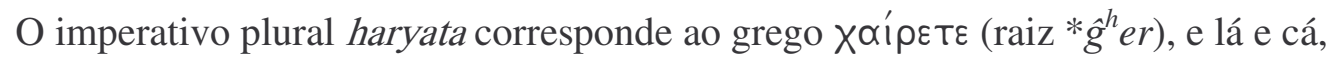
a oferenda é o próprio hino de louvor entoado - uma noção amplamente difundida nos

${ }^{527}$ HHom.6,19-20; 10,4-5; 11,5; 13,3; 15,9; 22,6-7; 25,6; 26,11-3; 31, 17.

${ }^{528}$ Wachter (1998). Cf. ainda Latacz (1966), 20-127. 
hinos rigvédicos e que encontra pelo menos mais um eco explícito na coleção de Hinos Homéricos: ${ }^{529}$

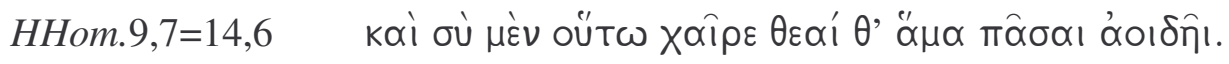

'Eu te saúdo, a ti e a todas as deusas, em minha canção', ou mais exatamente 'Aceita e tira proveito desse meu canto, tu junto com todas as deusas. ${ }^{, 530}$

Nisso talvez resida a principal diferença entre hino e prece: enquanto as preces costumam remeter a uma libação, a um objeto votivo ou a um sacrifício oferecidos no presente ou no passado, ou ainda a serem oferecidos no futuro, os hinos, como sugere Pulleyn, são oferendas capazes elas próprias de gerar $\chi \alpha ́$ pıs e servir de moeda de troca na relação com os deuses ${ }^{531}$ - ou seja, os hinos contêm em si mesmos o meio de suscitar a boa vontade do deus e obter seu favor ou auxílio, ao passo que a prece costuma depender de outro ato de veneração, que lhe é externo. É claro que os fatos da realidade, tanto aqui como em geral, não se adaptam perfeitamente ao rigor da distinção teórica: as preces também podem conter louvor, e os hinos acompanham com freqüência os sacrifícios. ${ }^{532}$ Os hinos bem podem ter influenciado as preces, que se tornaram assim mais elaboradas, ou talvez as preces sejam a forma mais primitiva dos hinos, que terão acrescentado a parte laudatória à mera invocação e pedido. Não há como decidir qual surgiu primeiro, se prece ou hino, nem qual terá sido o vetor da influência: trata-se antes de formas complementares de louvor cujas fronteiras por vezes se sobrepõem. Resta porém o fato de que, se as preces (insisto) costumam acompanhar atos de devoção capazes, eles sim,

\footnotetext{
${ }^{529}$ Sobre a estrutura da troca que marca a maioria desses hinos, cf. Bremer (1981), 196s., Calame (1995), 812, (1997), esp. 119, e (1994-95), 396s.: “[...] chanter une divinité, c’est bien lui rendre un honneur susceptible de payer en retour ses propres faveurs. [...] La réciprocité du do ut des peut donc être assurée dans les Hymnes par le chant hymnique lui-même. [...] L'exécution du chant [...] représente une offrande; elle représente le contre-don proposé au dieu en échange de la faveur demandée [...]".

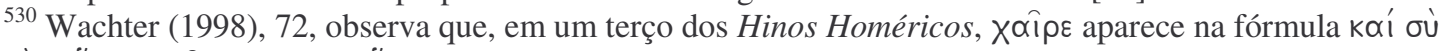

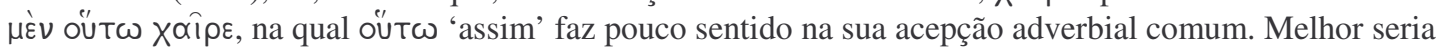
interpretá-lo, sugere, em sua possível função pré-histórica como complemento instrumental ou ablativo:

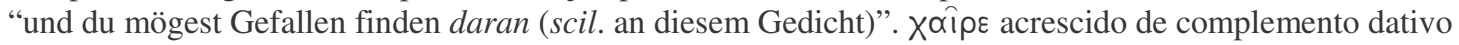
com função instrumental e dirigido, tal como no nosso exemplo, a uma divindade, tem paralelos, citados por Wachter, na Ilíada (10,462ss.) e na Odisséia (13,356ss). Cf. ainda Scheid-Tissinier (2000), 219, que

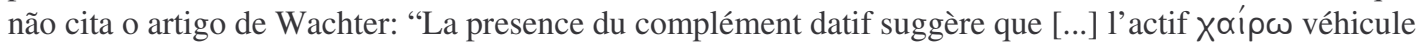
non seulement l'idée du plaisir mais aussi celle de l'acceptation hereuse de ce qui est offert”.

${ }^{531}$ Pulleyn (1997), 55: "[...] the most significant functional difference between a hymn and a prayer is that the former is a sort of negotiable " $\alpha \gamma \alpha \lambda \mu \alpha$ which generates $\chi \alpha$ ó

${ }^{532}$ Cf. Furley (1999-2000), 184 n.4, e Furley-Bremer (2001), vol. 1, 4.
} 
de serem trocados por dádivas divinas, já os hinos nunca se prestam a uma função meramente ancilar. Em uma e outra tradição hínica, a rigvédica e a grega, as descrições do ritual são vagas e em boa parte poéticas, não pontuais ou segundo a estrita ordem ditada pelos atos de culto. Ainda que sirvam de acompanhamento a ações rituais ${ }^{533}$ como certamente o fazem em ambas tradições, os hinos dela se desprendem para assumir estatuto autônomo: são uma oferenda a par das demais oferendas prestadas pelos fiéis, como fica explícito nesta passagem rigvédica:

\subsection{3,1 prá punānáya vedháse sómāya váca údyatam bhrtím ná bharā matíbhir jújoṣate \|}

'Ao soma purificado, ordenador (do rito), apre(sento) a palavra ofertada. / Trago(-a) com os poemas como uma oferenda; que ele se deleite! ${ }^{534}$

Dádiva feita na expectativa de obter em troca uma dádiva contrária, o hino - e foi isso que o presente trabalho procurou mostrar - tem de ser burilado, tem de ser urdido com os meios retóricos à disposição do poeta, para que possa assim tornar-se um objeto digno do apreço da divindade a quem é ofertada a palavra.

\footnotetext{
${ }^{533}$ Sobre as exceções que confirmam essa regra no Rig Veda, cf. Jamison (2007), 71ss. Sobre duas interessantes análises sobre a relação entre hino e rito nos Hinos Homéricos, cf. Parker (1991) e Johnston (2002).

${ }^{534}$ Cf. ainda RV 2.31,7a; 8.101,7a; 10.50,6d. Os hinos rigvédicos, além do serem explicitamente uma oferenda, adotam por vezes um caráter cosmogônico, de recriação do universo pela palavra: cf. Kuiper (1960). Quanto aos hinos gregos, cf. Depew (2000), 63s.: "It is this functioning as an offering, shared alike by texts that might be called 'cultic' for their use in a god's recurring festival, and by texts such as the corpus of 'Homeric Hymns', whose performance may have been tied more closely to competition or even to quasi-sympotic occasions, that I would argue unifies the genre of Greek hymn".
} 


\section{APÊNDICE}

RV 6.54

1. Ó Pūṣan, conduze(-nos para nos juntar) com uma (pessoa) que saiba, que indique corretamente (o caminho), que diga: "É este!"

2. Que possamos nos encontrar com Pūṣan, que nos indicará onde é a casa e dirá: "É esta!"

3. A roda de Pūṣan não sofre danos, a caixa (da carruagem) não cai, nem vacila a trava dessa (roda).

4. Aquele que rendeu homenagem a esse (deus) com uma oferenda, Pūṣan não o esquece; ele é o primeiro a encontrar um bem.

5. Que Pūṣan siga as nossas vacas, que Pūṣan proteja os nossos cavalos, que Pūṣan ganhe butim para nós.

6. Ó Pūṣan, siga as vacas do sacrificador, de quem espreme soma e as nossas também, dos poetas.

7. Nenhuma se perca, nenhuma se machuque, nenhuma caia num buraco, mas retorna com as (vacas) incólumes.

8. Pūṣan que escuta, (deus) alerta, que não perde nenhum bem, senhor da riqueza nós (o) invocamos.

9. Ó Pūṣan, possamos em tua lei jamais sofrer danos. Somos aqui os teus laudadores.

10. Que Pūșan, do outro lado, ponha o seu braço direito ao nosso redor. Que ele nos traga o (gado) perdido.

RV 2.16

1. Ao melhor entre vós que existis, eu apresento o bom louvor como uma oferenda no fogo inflamado. Indra que não envelhece, que faz envelhecer (os outros), que cresceu de velha data (e no entanto) é jovem, nós o invocamos para que (nos) ajude.

2. Indra, sem o qual, (deus) poderoso, não há nada, todas as forças viris estão concentradas nele. Em seu ventre ele carrega o soma, em seu corpo a força, o poder, em sua mão o raio, em sua cabeça o poder espiritual.

3. Teu poder indraico não pode ser cercado pelos dois mundos, nem pelos oceanos, (nem) pelas montanhas, ó Indra, a tua carruagem. Ninguém alcança o teu raio, quando com os velozes (cavalos) tu voas muitas léguas.

4. Pois todos portam a esse (deus) venerável, audaz, touro que nos acompanha, (seu) pensamento-sacrificial; como (deus) macho, sacrifica com ajuda da oferenda, tu que sabes mais (que todos os outros), bebe o soma, ó Indra, graças ao brilho (de Agni) (com forma de) touro.

5. O vaso ritual do (deus) macho, (ou seja), a onda do doce (soma), purifica-se para o touro cujo alimento é o touro (soma); os dois adhvaryu (são) machos, as pedras (são) touros, elas espremem o macho soma para o touro. 
6. Macho (é) a tua clava e macho a tua carruagem, machos os dois alazães, machos as armas; da bebida macho que inebria, ó touro, tu és senhor; ó Indra, deleita-te com o soma touro!

7. Eu (envio) para ti adiante, como um navio, (um canto) eloqüente para a competição, vou valente com a fórmula enquanto o soma é espremido. Sem dúvida ele dará atenção a essa nossa palavra. Haurimos Indra como uma fonte de riquezas.

8. Para evitar (que caiamos em) apuros, vira para nós como a vaca leiteira pejada de leite (vira) para seu novilho. Que nós de imediato, ó (deus) dos cem poderes, possamos bem nos unir aos teus favores como machos às fêmeas.

9. Agora, que essa tua recompensa generosa, ó Indra, verta como leite para o cantor, a seu bel-prazer. Presta a tua ajuda aos que louvam! Que a sorte não passe para além de nós! Tendo bons heróis, que falemos alto na cerimônia ritual.

RV 2.18

1. De manhã a nova carruagem é atrelada, a carruagem vencedora, com quarto jugos, três chicotes, sete rédeas, dez remos, feitas pelos homens, conquistadora do sol: ela é própria para ser posta em movimento por (nossas) buscas, por (nossos) pensamentos poéticos.

2. Esse (Agni?), o hotar de Manu, está pronto para esse (Indra?) uma primeira vez, ele uma segunda e terceira vez; recém-nascido de uma (fêmea), são outros (sacerdotes) que o engendraram, com outros (deuses) ele associa-se, (deus) íntimo, (deus) macho.

3. Eu atrelarei os dois alazães à carruagem de Indra para que ele venha com a ajuda de uma nova palavra bem-proferida. Que os outros sacrificadores - pois são muitos os oradores - não te detenham (no seu trajeto) para cá.

4. Vem para cá, ó Indra, com dois cavalos, com quarto, com seis (uma vez) chamado, com oito, com dez para a bebida do soma. Este (soma) foi espremido, ó generoso, não o despreze!

5. Vem para cá atrelando vinte, quarenta cavalos, cinqüenta dotados de belas carruagens, sessenta, setenta para a bebida do soma.

6. Vem para cá com oitenta, com noventa, com cem cavalos, sendo conduzido (por eles)! Pois esse soma (é) teu na casa dos Śunáhotra, ó Indra; para o teu benefício ele foi vertido ao redor, para a ebriedade.

7. Vem, ó Indra, à minha fórmula, põe no timão da carruagem todas as parelhas de alazães! Pois (já que) tu és próprio para ser chamado de muitos lados, inebria-te, ó herói, com esse soma (que te é) espremido.

8. Que a minha amizade com Indra não desatrele! Que a sua recompensa ritual para nós possa ser ordenhada! Que possamos, sob a tua proteção mais poderosa (e) sob a tua mão, a cada nova empreitada, ser sempre vencedores!

9. Agora, que essa tua recompensa generosa, ó Indra, verta como leite para o cantor, a seu bel-prazer. Presta a tua ajuda aos que louvam! Que a sorte não passe para além de nós! Tendo bons heróis, que falemos alto na cerimônia ritual. 
RV 6.38

1. Dela (da taça) ele bebeu, e que o mais maravilhoso escolha a nossa grande e esplêndida invocação. O melhor poema como dádiva ao gênero celeste é o que deseja o generoso (Indra) em sua viagem.

2. Mesmo de longe os seus ouvidos estão próximos: que ele ouça! Aquele que se devota a Indra clama com voz de trovão. Que essa invocação faça-o voltar-se na minha direção, a ele, Indra, essa invocação, cantada em estrofes.

3. A esse Indra, nascido em tempos imemoriais, impassível de envelhecer, eu gritei para vós com o produto da minha visão poética, com cantos. As fórmulas e elogios estão reunidos sobre ele, e o poderoso louvor cresce junto a Indra.

4. Indra, a quem o sacrifício e soma farão crescer, (a quem) a fórmula, os elogios, as palavras e os pensamentos poéticos farão crescer - faze-o crescer também enquanto a aurora surge da noite - os meses, os outonos, os dias farão Indra crescer.

5. Assim, queremos invocar o (deus) nascido para o poder e crescido para a famosa dádiva, (o deus Indra), grande, majestoso, agora, ó vidente, a fim de que nos ajude nas batalhas.

\section{RV 1.1}

1. Invoco Agni (como) preposto (ao culto), deus do sacrifício, oficiante, hotar que confere os tesouros por excelência.

2. Agni que é digno de ser invocado pelos poetas antigos assim como pelos de agora: que ele conduza os deuses para cá!

3. Graças a Agni, possa (o sacrificador) alcançar a riqueza (e) a prosperidade dia após dia, (riqueza e prosperidade) honráveis, abundantes em homens de elite.

4. Ó Agni, o sacrifício, o rito que tu abraça de todos os lados, somente esse segue para os deuses.

5. Agni, hotar que possui a força espiritual de um poeta, (Agni) real com renome esplendoroso, deus (ele próprio), que ele venha com os deuses!

6. De fato, quando tu decidires, ó Agni, beneficiar o devoto, é a ti (que retornará o mérito) real, ó Añgiras.

7. Nós nos aproximamos de ti dia após dia, ó Agni, graças à visão poética, ó tu que iluminas durante a noite, nós mesmos, trazendo-te homenagem.

8. Tu que coordenas os ritos (como) guardião da verdade, (deus) esplendoroso, que cresce em sua própria casa.

9. Assim sendo, sê-nos de fácil acesso como um pai para o filho, ó Agni, põe-te ao nosso lado para (nossa) salvação. 
1. Indra, somente ele, os cantores (clamaram) em voz alta, Indra os que louvam com (seus) louvores, para Indra as palavras melodiosas ressoaram.

2. É Indra que está associado aos dois alazães; que Indra, (deus) do raio, cor de ouro, (suba nos alazães) que a palavra atrela!

3. Indra fez erguer o sol no céu para que o vejamos ao longe; ele abriu a montanha com as vacas (presas).

4. Ó Indra, ajuda-nos para os prêmios e quando mil coisas estão em jogo, (deus) formidável com (tuas) ajudas formidáveis.

5. Indra na grande disputa, Indra na pequena nós invocamos, (para que ele esteja) associado nos combates contra os inimigos, (esse deus) do raio.

6. Assim sendo, ó (deus) macho, ó tu que dás sempre, destampa para nós (a tampa) desse caldeirão, tu a quem não se pode resistir.

7. Os louvores que, investida após investida, (vão sempre) mais altos... desse Indra que porta o raio eu não falto com o elogio.

8. Como o touro macho (põe em marcha) a tropa, (Indra) põe em marcha os povos com a sua força, (deus) poderoso, impossível de resistir.

9. Somente ele comanda as populações, as riquezas, Indra, (que comanda) os cinco povos.

10. Indra de toda a parte para vós nós invocamos, de (todas as) tribos. Que ele seja exclusivamente nosso.

\section{RV 10.68}

1. Como pássaros que nadam na água, alertas, que se fazem ouvir como o estrondeio da nuvem de tempestade, que se inebriam como vagas que rompem montanhas, as canções bramaram na direção de Bŗhaspati.

2. (O deus) proveniente dos Angiras, que se aproxima, conduziu (estes) para junto das vacas, como Bhaga (conduziu) Aryaman; tal como o amigo no grupo (consagra) os dois mestres da casa, (assim também Bronaspati) unta (os Angiras e a vacas, dizendo:) "ó Bṛhaspati, espora(-os) como corcéis (que se lançam) na competição".

3. (As vacas) amigáveis, hospitaleiras, ativas, desejáveis, dotadas de belas cores (e) formas irrepreensíveis... Brihaspati, tendo-as feito passar através das montanhas, verteu (essas) vacas para fora como (se verte) o trigo para fora dos cestos.

4. Aspergindo com o doce (líquido) a sede natal da verdade como um relâmpago que precipita a tocha do céu, Brọhaspati, tendo extirpado as vacas do rochedo, fendeu a pele da terra como com uma torrente.

5. Com a luz ele expulsou as trevas para fora do espaço mediano como o vento (expulsa a planta) śípāla para fora da água. Brọhaspati, agarrando por trás as vacas de Vala, tocou-as adiante como o vento as nuvens.

6. Quando Bŗhaspati rompeu a prisão de Vala, (essa criatura) hostil, graças ao seus cantos que possuem a força flamejante de Agni, ele apoderou-se (dele) como a língua com os dentes a (comida) servida; ele lançou à luz os tesouros das vacas (da aurora). 
7. De fato, Brhaspati invocou o nome célebre dessas (vacas) que ressoam, (nome mantido) em segredo na sede (suprema). Como o pássaro recém-nascido, depois de ter fendido o ovo, (assim também) ele conduziu por si mesmo para fora da montanha as vacas (da aurora).

8. Ele espiou ao redor a doce bebida (proveniente das vacas) encerradas pela rocha como um peixe que repousa na água baixa. Brhaspati extraiu essa (bebida) como (se extrai) da árvore (aquilo com que se fabrica) um copo, destruindo (a pedra) com seu bramido.

9. Foi ele que descobriu a aurora, ele o sol, ele Agni: ele que expulsou as trevas graças ao canto. Brhaspati extraiu (as vacas) de Vala, que se enfeitava com vacas, como (se extrai) a medula da articulação.

10. Como as árvores (choram) as folhas roubadas pelo gelo, (assim também) Vala chorou as vacas (roubadas) por Brhaspati. (Esse deus) fez (algo de) inimitável, irreversível, enquanto o sol e a lua se levantem alternadamente.

11. Os pais adornaram o céu com constelações como (se adorna) um cavalo negro com pérolas; eles puseram as trevas na noite, a luz no dia. Brhaspati fendeu o rochedo, descobriu as vacas.

12. Essa homenagem, nós a fizemos ao (deus) das nuvens tempestuosas, que brama fortemente em eco aos muitos (trovões). É de fato Bṛhaspati que nos confere a força vital junto com vacas, com cavalos, com heróis e com homens.

RV 9.113

1. Que Indra, algoz de Vritra, beba o soma em Śaryanấvat, (assim) reunindo em si a força quando queira realizar os seus grandes feitos heróicos. Flui ao redor para Indra, ó gota (de soma)!

2. Clarifica-te, ó mestre dos pólos, ó Soma generoso (que emana) de Ārjīka, que é espremido com a ajuda da palavra sagrada, do real, da confiança, da ascese! Flui ao redor para Indra, ó gota (de soma)!

3. Invigorado por Parjanya, a filha do sol conduziu (à terra) esse búfalo (= soma). Foi ele que os Gandharva receberam, foi esse sabor que eles puseram no soma. Flui ao redor para Indra, ó gota (de soma)!

4. Tu que falas (segundo) a verdade, ó Soma, que brilhas (segundo) a verdade, tu que falas (segundo) o real, ó tu cujos atos são reais, ó rei; foste, ó Soma, todo equipado pelo executor (do rito). Flui ao redor para Indra, ó gota (de soma)!

5. Do (Soma) realmente formidável, sublime, as confluências confluem; juntos avançam os sumos do (soma) sumarento quando és purificado pela fórmula, ó alazão [,] Flui ao redor para Indra, ó gota (de soma)!

6. Onde o sacerdote, ó Pavamāna, proferindo a palavra melódica, engrandece-se junto ao soma com a pedra espremedora, engendrando alegria pelo soma. Flui ao redor para Indra, ó gota (de soma)!

7. Onde (há) luz inextinguível, no mundo no qual o sol foi posto, lá me põe, ó Pavamāna, nesse mundo imortal, imperecível. Flui ao redor para Indra, ó gota (de soma)! 
8. Onde é rei o filho de Vivasvant, onde (está) a fortaleza do céu, onde (estão) aquelas águas juvenis, lá me faz imortal. Flui ao redor para Indra, ó gota (de soma)!

9. Onde se pode circular à vontade no triplo firmamento, no triplo céu dos céus, onde (estão) os mundos brilhantes, lá me faz imortal. Flui ao redor para Indra, ó gota (de soma)!

10. Onde (estão) os desejos (abertos) e os desejos secretos, onde está a abóbada do sol, onde o repasto fúnebre e a saciedade, lá me faz imortal. Flui ao redor para Indra, ó gota (de soma)!

11. Onde as felicidades e os prazeres e os deleites e as delícias estão instalados, onde se alcançam os desejos do desejo, lá me faz imortal. Flui ao redor para Indra, ó gota (de soma)!

RV 4.7

1. Esse (Agni) foi posto aqui como sacerdote hotar pelos que executam o rito, hotar, (deus) mais apto a sacrificar, digno de ser invocado nos ritos, ele que Apnavāna (e) os Bhŕgu inflamaram, ele que se assinala nos bosques, que se manifesta em cada tribo.

2. Ó Agni, quando terá lugar, segundo a seqüência (ritual), a tua manifestação, deus que és? Pois foi de ti que os mortais lançaram mão (como deus) digno de ser invocado nas tribos.

3. Considerando (esse Agni) que sustenta a verdade, (deus) perspicaz, como (vemos) o céu (noturno) graças às estrelas, (esse deus) que para todos os ritos em cada casa cria (como) um riso...

4. Rápido mensageiro de Vivasvant, que (reina) sobre todas as populações. Os Āyu o trouxeram, ele flama, ele Bhrgavāna, a cada tribo.

5. Ele, instalaram-no como sacerdote hotar de acordo com a seqüência (ritual), sábio que é, (deus) alegre com a chama purificadora, que sacrifica melhor (que todos os outros) segundo as sete posições (sacrificiais).

6. Ele que está escondido em sucessivas mães, nos bosques, sem (lá) buscar refúgio, que, sendo manifesto, jaz oculto, que é fácil de achar (mas) tem rumo incerto.

7. Quando os deuses se deleitaram em separar o alimento (que estava) em um mesmo úbere, no sítio original da verdade, o grande Agni, a quem se oferece a oblação com homenagem, voltou-se para o sacrifício, para sempre, (esse deus) que sustenta a verdade.

8. Voltaste-te para as funções de mensageiro do sacrifício, (ó Agni), tu que sabes, que compreendes todas (as coisas) entre os dois mundos. Do fundo dos dias tu avanças, tendo sido escolhido mensageiro, tu que conheces melhor (que nenhum outro) os meios de subir aos céus.

9. Negro (é) teu caminho, mas tu (és) reluzente; o raio (está) em frente (de nós), mas tua chama (é) móvel: esse (é) um dos milagres, (o outro) que (tua mãe) recebe o embrião sem ser fecundada e tão logo nasces tu viras mensageiro.

10. Mal nasce, sua força se faz ver, quando o vento sopra atrás da sua chama; ele volteia a sua língua afiada nos arbustos; os alimentos, mesmo (os mais) sólidos, ele os esmigalha com a sua mandíbula. 
11. Quando ele cresceu ávido, (consumindo) o alimento com (suas) ávidas (chamas), o jovem Agni faz do ávido (vento) o seu mensageiro; ele junta-se ao rugido do vento, consumindo, ele como que esporeia o ligeiro (corcel), aguilhoado está o corredor.

RV 1.10

1. Os cantores cantam-te, os que louvam louvam(-te) com louvores. Os sacerdotes te ergueram como uma viga de telhado, ó (deus) dos cem poderes.

2. Quando (o sacrificador) subiu de planalto em planalto (e) viu o número (de coisas) a fazer, então Indra repara no seu projeto: ele se põe em marcha (como) o carneiromestre com a tropa.

3. Atrela, pois, os dois alazães de crinas, (cavalos) machos que enchem as cintas! Então, ó Indra, ó (deus) que bebe o soma, avança para escutar os nossos cantos!

4. Vem ao nosso elogio, faz eco (a ele), canta (com ele), esbraveja! E fortalece, ó Vasu, nossa fórmula poética como também (nosso) sacrifício!

5. O hino deve ser recitado (como) fortalecimento a Indra, (deus) de numerosas recompensas, de modo que (esse deus) poderoso deleite-se com o soma que esprememos e com as nossas amizades.

6. É ele que invocamos para a amizade, ele para a riqueza, ele para homens de elite; ele (é) o poderoso; que ele exerça, pois, o seu poder para nós, Indra, repartindo a riqueza.

7. Invocamos Indra que abre bem o cercado, que conduz para fora bem as vacas - (eis) uma distinção conferida somente por ti, ó Indra -, abre esse cercado de vacas!

8. Não, os dois mundos não te abalam quando tu faz ameaças: conquista as águas acompanhadas do sol; sacode juntas as vacas para nós!

9. Ó tu cujas orelhas escutam, escuta o (nosso) apelo! Aceita os meus cantos! Ó Indra, esse meu elogio, faze (com que ele se torne) mais próximo que um companheiro!

10. Pois nós te conhecemos (como) o mais macho (dos deuses), (como) aquele que escuta o apelo pelos prêmios; nós invocamos, do (deus) mais macho, o auxílio que faz ganhar mil (bens) por excelência.

11. Ó Indra, ó (deus) de Kuśika, bebe o nosso (soma) espremido, inebria-te! Prolonga a nossa vida, (para nos dar) uma nova, faz com que o poeta ganhe mil (bens)!

12. Que esses cantos te envolvam de todos os lados, ó (deus) que ganhas os cantos (para o homem)! Que o crescimento (que as canções conferem) sejam con(formes) ao (deus) cuja força vital cresceu, que os prazeres (que elas propiciam) sejam prazerosos!

\section{RV 1.113}

1. Eis que chegou a mais bela luz das luzes; o sinal brilhante nasceu, difundindo-se. Assim como a Noite fora impelida pelo impulso de Savitr, assim também ela cedeu o lugar à Aurora. 
2. Rutilante, com seu rutilante novilho (= o sol), nívea, ela chegou. A negra (= a noite) cedeu os seus assentos. De mesma parentela, imortais, seguindo um ao outro, Dia (e Noite) avançam, apagando (um ao outro) a sua cor.

3. Igual é o trajeto das duas irmãs, ilimitado: elas o percorrem uma após a outra, ensinadas pelo deus. Elas não se chocam nem param, bem firmes que são, Noite e Aurora, de igual coração (embora) de forma diversa.

4. Guia luminosa das liberalidades, ela mostrou-se: cintilante, ela nos abriu as portas. Após ter incitado avante o mundo animado, ela nos revelou riquezas: a Aurora despertou todas as criaturas.

5. Aquele que dorme de través, a generosa (incitou) a andar, um tal outro a buscar sustento ou riqueza; aos de vista fraca, ela (faz) ver longe. Aurora despertou todas as criaturas.

6. Um tal ao domínio, tal outro à fama, tal outro a buscar grandeza, tal outro a cuidar, por assim dizer, do seus afazeres. Para que considerem as diversas (formas de) existência, Aurora despertou todas as criaturas.

7. Essa filha do céu deu-se a ver, brilhando ao longe, jovem com o vestido branco. Tu que reinas sobre todo o bem terrestre, Aurora formosa, brilha ao longe hoje aqui sobre nós.

8. Ela segue o rebanho (de auroras) passadas, ela é a primeira daquelas que vêm em sucessão contínua, a Aurora brilhando ao longe que anima aquilo que vive, (mas) não desperta jamais aquele que está morto.

9. Aurora, que tu tenhas feito acender o fogo, que tenhas brilhado ao longe pelo olhar do sol, que tenhas despertado os humanos que devem sacrificar: eis um belo mérito que conquistaste entre os deuses.

10. Em que ponto, a qual distância (é) que ela estará a meio caminho entre (as) que luziram e irão luzir daqui em diante? Ela conforma-se, mugindo, às anteriores, previdente ela segue de bom grado as outras.

11. Eles se foram, os mortais que viram a primeira Aurora brilhar; para nós ela agora tornou-se visível, e eis que vêm aqueles que a verão no futuro.

12. Rechaçando a hostilidade, guardando a verdade, nascida dentro da verdade, rica de favores, suscitando liberalidades, boa em presságios, portando o convite aos deuses: aqui mesmo hoje, Aurora, brilha ao longe, tu que és a mais bela de todas.

13. No passado, de forma contínua, a Aurora divina brilhou ao longe; hoje ainda a generosa brilhou ao longe, e brilhará ao longe durante os dias por virem. Sem envelhecer, sem morrer, ela procede segundo as suas próprias leis.

14. Com seus enfeites, ela brilhou nos pórticos do céu; ela afastou brilhando a roupa negra, a deusa. Despertando (as criaturas), a Aurora chega com seus cavalos rosas, sobre a sua carruagem fácil de atrelar.

15. Trazendo dádivas desejáveis, ela deposita o sinal cintilante, ela que se assinala ao longe. Última das (auroras) passadas, primeira daquelas que resplandecem em sucessão contínua, a Aurora brilhou.

16. Erguei-vos! O espírito de vida veio até nós, as trevas se foram ao longe, a luz chega. Ela cede lugar para que o sol avance. Chegamos ao ponto em que (os homens) prolongam as suas vidas. 
17. Pelas rédeas do discurso, o guia (dos ritos), o cantor que louva suscita as auroras fulgurantes. Brilha, pois, hoje para aquele que canta, ó generosa! Faze cintilar sobre nós uma vida cheia de filhos!

18. Essas auroras que brilham ao longe, detentoras de vacas, de todos os homens valentes, doadoras de cavalos para o mortal venerador, que aquele que espreme o soma possa alcançá-las quando surgem as suas liberalidades, como (as) de Vāyu!

19. Mãe dos deuses, face de Aditi, sinal do sacrifício, reluze, tu que és alta! Conferindo fama a nossa prece, brilha ao longe, engendra-nos na raça (humana), ó tu que deténs todas as coisas desejáveis!

20. O mérito fulgurante que trazem as auroras, o belo (mérito) a quem sacrifica e dá-se ao trabalho, queiram Varuṇa e Mitra assegurá-lo a nós, e Aditi e o rio e o céu e a terra! 


\section{BIBLIOGRAFIA}

ADAMI, F. (1901), "De poetis scaenicis graecis hymnorum sacrorum imitatoribus", Jahrbuch für classische Philologie, supl. 26, 213-262.

Allen, T., W. Halliday e E. SiKes (eds.) (1936), The Homeric Hymns, Oxford.

Aloni, A. (1980), "Prooimia, Hymnoi, Elio Aristide e i cugini bastardi", QUCC 4, 23-40.

(1989), L'aedo e i tirani: ricerche sull'Inno omerico a Apollo, Roma.

(1990), "Proemio e funzione proemiale nella poesia greca arcaica", in Lirica greca e latina. Atti del convegno di studi polacco-italiano, Poznań 2-5 maggio 1990, Roma, 99-130.

Athanassaki, L. (2003), "A Divine Audience for the Celebration of Asopichus' Victory in Pindar's Fourteenth Olympian Ode", in G.W. Bakewell e J.P. Sickinger (eds.), Gestures. Essays in Ancient History, Literature, and Philosophy Presented to Alan L. Boegehold, Exeter, 3-15.

Aubriot-SÉvin, D. (1992), Prière et conceptions religieuses en Grèce ancienne jusqu'à la fin $d u V^{e}$ siècle av. J.-C., Lyon.

AUSFELD, K. (1903), "De Graecorum precationibus quaestiones", Jahrbuch für classische Philologie 28, 505-547.

BADER, F. (1992), "Liage, peausserie, et poètes-chanteurs", in F. Létoublon (ed.), La langue et les texts en grec ancien: actes du colloque Pierre Chantraine (Grenoble, 5-8 septembre 1989), Amsterdã, 105-118.

BAKKER, E. J. (2002), "Remembering the God's Arrival", Arethusa 35, 63-81 (reimpresso com acréscimos em E.J. Bakker, Pointing at the Past. From Formula to Performance in Homeric Poetics, Cambridge, Mass./Londres, 2005, 136-153).

Baltes, M. (1982), "Die Kataloge im homerischen Apollonhymnus", Philologus 125, 2543.

BARRETT, W. S. (1964), Euripides, Hippolytus, Oxford.

BeARD, M. (1985), "Writing and Ritual. Diversity and Expansion in the Arval Acta", PBSR 53, 114-162.

BECKER, O. (1937), Das Bild des Weges und verwandte Vorstellungen im frühgriechischen Denken, Berlim.

BÉLIS, A. (1992), Les Hymnes à Apollon, Corpus des Inscriptions de Delphes, Paris.

BenedeTti, M. (1989), "Vedico suvivítam sunirájam (RV I 10, 7)”, SSL 29, 61-76.

Benveniste, E. (1966), "La phrase nominale", in E. Benveniste, Problèmes de linguistique générale, Paris, 151-167.

Bergaine, A. (1878), La Religion Védique d'après les Hymnes du Rig-Veda (vol. 1), Paris

(1881), "Quelques observations sur les figures de rhétorique dans le Rig Veda", Mémoires de la Société Linguistique 4, 96-137. (1886), "La Saṃhitā primitive du Rig-veda", Journal Asiatique 8, 193-271.

BERNARDINI, P. A. (1991), "L'inno agli dei nella lirica corale greca", in AION 13, L'inno tra rituale e letteratura nel mondo antico. Atti di un colloquio, Napoli 21-24 ottobre 1991, Roma, 85-94.

BIERL, A., (1989), "Was hat die Tragödie mit Dionysos zu tun? Rolle und Funktion des Dionysos am Beispiel der Antigone des Sophokles", WüJbb 15, 43-57. 
(1991), Dionysos und die griechische Tragödie. Politische und

“metatheatralische” Aspekte im Text, Classica Monacensia, Tübingen.

BING, P. (1988), The Well-Read Muse, Göttingen.

(1993), "Impersonation of Voice in Callimachus' Hymn to Apollo", TAPA

123, 181-198.

e V. Uhrmeister (1994), "The Unity of Callimachus' Hymn to Artemis”, JHS 114, 19-34.

BöHME, R. (1937), Das Prooimion: Eine Form sakraler Dichtung der Griechen,

Bausteine zur Volkskunde und Religionswissenschaft 15, Bühl Bader.

Bornmann, F. (1968), Callimachi Hymnus in Dianam, Florença.

BowIE, E. (1985), resenha de R. JANKO (1982), Homer, Hesiod and the Hymns:

Diachronic Development in Epic Diction, CR 35, 240-242.

Bowra, C. M. (1938), “Aristotle's Hymn to Virtue”, $C Q$ 32, 182-189.

(1961), Greek Lyric Poetry (2 ${ }^{\mathrm{a}}$ ed.), Oxford.

Bradley, E. (1966), "The Relevance of the Proemium to the Design and Meaning of Hesiod's Theogony", SO 41, 29-47.

Bremer, J. M. (1981), "Greek Hymns", in H.S. Versnel e F.T. van Straten (eds.), Faith, Hope and Worship, Leiden, 193-215.

(1995), "Menander Rhetor on hymns", in J.G.J. Abbenes, S.R. Slings e I.

Sluiter (eds.), Greek Literary Theory After Aristotle, Amsterdã, 259-274.

(1998), "The reciprocity of giving and thanksgiving in Greek worship", in

C. Gill, N. Postlethwaite e R. Seaford (eds.), Recipocity in Ancient Greece,

Oxford, 127-137.

Bremmer, J. N. (2005), “Anaphe, Aeschrology and Apollo Aiglētēs: Apollonius Rhodius 4.1711-1730", in A. Harder e M. Cuypers (eds.), Beginning from Apollo. Studies in Apollonius Rhodius and the Argonautic Tradition, Leuven, 18-34.

BRERETON, J. P. (1985), "Style and Purpose in Rgveda 2.11”, Indo-Iranian Journal 28, 237-262.

(1999), "Edifying Puzzlement: Rgveda 10.129 and the Uses of Enigma", Journal of the American Oriental Society 119, 248-60.

Budelmann, F. (2000), The Language of Sophocles, Cambridge.

Bulloch, A. W. (1984), "The Future of a Hellenistic Illusion. Some Observations on Callimachus and Religion", $M H$ 41, 209-230.

Bundy, E. (1972), “The 'Quarrel between Kallimachos and Apollonios', Part I, The Epilogue of Kallimachos's Hymn to Apollo", CSCA 5, 39-94.

(1986), Studia Pindarica, Berkeley.

Burkert, W. (1979), "Kynaithos, Polycrates, and the Homeric Hymn to Apollo", in G.W. Bowersock, W. Burkert e M. Putnam (eds.), Arktouros: Hellenic Studies Presented to Bernard M. W. Knox on occasion of his $65^{\text {th }}$ Birthday, Berlim, 53-62. (1985), Greek Religion, Cambridge Mass.

(1987a), "The Making of Homer in the Sixth Century B.C.: Rhapsodes versus Stesichoros", in Papers on the Amasis Painter and His World, Malibu, 4362.

(1987b), "Offerings in Perspective: Surrender, Distribution, Exchange", in T. Linders e G. Nordquist (eds.), Gifts to the Gods: Proceedings of the Uppsala Symposium 1985, Uppsala, 43-50. 
(1994), "Griechische Hymnoi”, in W. Burkert e F. Stolz (eds.), Hymnen der alten Welt im Kulturvergleich, Göttingen, 9-17.

BurnetT, A. P. (1985), The Art of Bacchylides, Cambridge, Mass.

(1998), "Spontaneity, Savaging, and Praise in Pindar's Sixth Paean", AJP 119, 493-520.

Burton, R. W. B. (1980), The Chorus in Sophocles' Tragedies, Oxford.

CALAme, C. (1977), Les Chœurs de jeunes filles en Grèce archaïque, 2 vols., Roma. (1993), "Legendary Narration and Poetic Procedure in Callimachus' Hymn to Apollo", in M.A. Harder, R.F Regtuit e G.C. Wakker (eds.), Hellenistica Groningana. Callimachus, Groningen, 37-55.

(1994-95), "Les Hymnes Homériques. Modalités énonciatives et fonctions", Metis 9-10, 391-400.

(1995), "Variations énonciatives, relations avec les dieux et fonctions poétiques dans les Hymnes homériques", $M H$ 52, 2-19.

(1997), "L’Hymne homérique à Déméter comme offrande: Regard rétrospectif sur quelques catégories de l'anthropologie de la religion grecque", Kernos 10, 111-133.

(2004), "Choral Forms in Aristophanic Comedy: Musical Mimesis and Dramatic Performance in Classical Athens" in P. Murray e P. Wilson (eds.), Music and the Muses: The Culture of 'Mousikè' in the Classical Athenian City, Oxford, 157-184.

CAMPAnILE, E. (1977), Ricerche di cultura poetica indoeuropea, Pisa.

CARne-Ross, D. S. (1985), Pindar, New Haven/Londres.

CASABONA, J. (1966), Recherches sur le vocabulaire des sacrifices en Grèce ancienne, Aix-en-Provence.

CASSIO, A. C. e G. CERRI (eds.) (1991), L'inno tra rituale e letteratura nel mondo antico (atti di un coloquio) Napoli 21-24 ott. 1991, Annali dell'Istituto Universitario Orientale di Napoli [AION], Sez. filol-lett. 13, Roma.

CÀssola, F. (ed.) (1975), Inni Omerici, Milão.

Clay, J. S. (1988), "What the Muses sang: Theogony 1-115", GRBS 29, 323-333.

(1989), The Politics of Olympus: Form and Meaning in the Major Homeric Hymns, Princeton.

(1997), "The Homeric Hymns", in I. Morris e B. Powell (eds.), A New Companion to Homer, Leiden/Nova York/Colônia, 489-507.

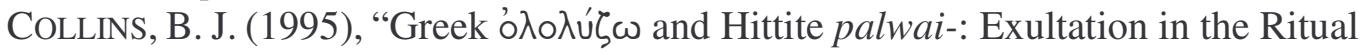
Slaughter of Animals", GRBS 36, 319-325.

CuRRIE, B. (2004), "Reperformance Scenarios for Pindar's Odes”, in C.J. Mackie (ed.), Oral Performance and its Context, Leiden, 49-69.

Dale, A. M. (1968), The Lyric Metres of Greek Drama, Cambridge.

D'Alessio, G. B. (1997), "Pindar's Prosodia and the Classification of Pindaric Papyrus Fragments", ZPE 118, 23-60.

(2004), "Past Future and Present Past: Temporal Deixis in Greek Archaic Lyric", Arethusa 37, 267-294.

DANIElEWICZ, G. (1974), "De Elementis Hymnicis in Sapphus Alcei Anacreontisque Carminibus Obuiis Quaestiones Selectae", Eos 62, 23-33.

DANIELEWICZ, J. (1990), “Deixis in Greek Choral Lyric”, QUCC 63, 7-17. 
DAvies, M. (1991), Sophocles, Trachiniae, Oxford.

DAwE, R. D. (1978), Studies on the Text of Sophocles, Leiden.

DAY, J. W. (2000), "Epigram and Reader: Generic Force as (Re-)Activation of Ritual", in

M. Depew e D. Obbink (eds.), Matrices of Genre. Authors, Canons, and Society, Cambridge, Mass., 37-57.

DEICHGRÄBER, K. (1984), "Die Chariten als Göttinnen der glanzvollen Schönheit: von Homer über Pindars Charitenhymnus zu Aischylos", in H. Gärtner, E. Heitsch e U. Schindel (eds.), K. Deichgräber. Ausgewählte Kleine Schriften, Zurique/Munique, 207-225.

Denniston, J. D. (1954), Greek Particles (2a ed.), Oxford.

DEPEW, M. (1997), "Reading Greek Prayers", CA 16, 229-262.

(1998), "Delian Hymns and Callimachean Allusion", HSCP 98, 155-182. (2000), "Enacted and Represented Dedications: Genre and Greek Hymn", in

M. Depew e D. Obbink (eds.), Matrices of Genre. Authors, Canons, and Society, Cambridge, Mass., 59-79.

Des Places, E. (1969), La religion grecque, Paris.

DEUBNER, L. (1932), Attische Feste, Berlim.

(1941), Ololyge und Verwandtes, Abhandlungen der Preussischen Akademie der Wissenschaften I, Berlim.

Devlin, N. G. (1995), The Hymn in Greek Literature, tese inédita de Oxford.

DöNT, M. (1983), “Zur 14. olympischen Ode Pindars”, RhM 126, 126-135.

DORNSEIFF, F. (1921), Pindars Stil, Berlim.

(1933), Die Archaische Mythenerzählung. Folgerung aus dem homerischen Apollonhymnos, Berlim/Leipzig.

DORSCH, K.-D. (1983), Götterhymnen in den Chorliedern der griechischen Tragiker. Form, Inhalt und Funktion, Münster.

DRERUP, E. (1937), "Der homerische Apollonhymnos: Eine methodologische Studie", Mnemosyne 5, 81-134.

DunKel, G. E. (1985), "Verse-Internal Sentence Boundary in the Rg-Veda: a Preliminary Overview", in B. Schlerath (ed.) Grammatische Kategorien:

Funktion und Geschichte - Akten der VII. Fachtagung der Indogermanischen Gesellschaft, Berlin 20-25 Februar 1983, Wiesbaden, 119-133.

(1993), "Periphrastica Homerohittitovedica", in B. Brogyanyi e R. Lipp (eds.), Comparative-Historical Linguistics - Indo-European and Finno-Ugric. Papers in Honor of Oswald Szemerényi III, Amsterdã/Filadélfia, 103-118.

Durante, M. (1976), Sulla preistoria della tradizione poetica greca. Parte seconda: Risultanze della comparazione indoeuropea, Roma.

EASTERLInG, P. E. (1993), "Tragedy and Ritual”, in R. Scodel (ed.) Theatre and Society in the Classical World, Ann Arbor, 7-23. e J. V. MuIR (eds.) (1985), Greek Religion and Society, Cambridge.

EliZARENKova, T. J. (1968), "An Approach to the Description of the Contents of the Rgveda", in Mélanges d'indianisme à la mémoire de Louis Renou, Paris, 255-268. (1995), Language and Style of the Vedic Rsis, Nova York.

ERBSE, H. (1955), “Zum Apollonhymnus des Kallimachos”, Hermes 83, 411-428.

FAIRBAnKS, A. (1900), A Study of Greek Paean, Cornell Studies in Classical Philology 12, Ithaca. 
FALIVENE, M. R. (1990), “La mimesi in Callimaco: Inni II, IV, V e VI”, QUCC 36, 103-128.

FANTUZZI, M. e R. HunTER (2004), Tradition and Innovation in Hellenistic Poetry, Cambridge.

FARAONE, C. A. (1995), “The 'Performative Future' in Three Hellenistic Incantations and Theocritus' Second Idyll', CP 90, 1-15. (2006), "Exhortation and Meditation: Alternating Stanzas as a Structural Device in Early Greek Elegy", CP 100, 317-336.

FAUlKner, A. (2005), The Homeric Hymn to Aphrodite. Introduction, Text and Commentary on Lines 1-199, tese inédita de Oxford.

FEHLING, D. (1969), Die Wiederholungsfiguren und ihr Gebrauch bei den Griechen vor Gorgias, Berlim.

FERRARI, F. (1983), Ricerche sul testo di Sofocle, Pisa.

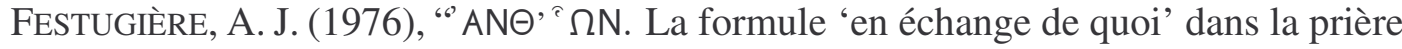
grecque hellénistique”, Revue des Sciences Philosophiques et Théologiques 60, 389-418.

FORDERER, M. (1971), Anfang und Ende der abendländische Lyrik: Untersuchungen zum homerischen Apollonhymnus und zu Anise Koltz, Amsterdã.

FÖRSTEL, K. (1979), Untersuchungen zum homerischen Apollonhymnos, Bochum.

Friedländer, P. (1914), "Das Proömium von Hesiods Theogonie", Hermes 49, 1-16.

FRIEDRICH, R. (1996), "Everything to Do with Dionysos? Ritualism, the Dionysiac, and the Tragic", in M.S. Silk (ed.), Tragedy and the Tragic, Oxford, 257-283.

FRÖHDER, D. (1994), Die dichterische Form der Homerischen Hymnen untersucht am Typus der mittelgroßen Preislieder, Hildesheim/Zurique/Nova York.

FuRLEY, W. D. (1981), "Types of Greek Hymns", Eos 81, 21-41. (1995), "Praise and Persuasion in Greek Hymns", JHS 115, 29-46. (1997), "Hymnos, Hymnus", in Der neue-Pauly: Enzyklopädie der Antike Altertum, s.v., Stuttgart. (1999-2000), "Hymns in Euripidean Tragedy", in M. Cropp, K. Lee, D. Sansone (eds.), Euripides and Tragic Theater in the Late Fifth Century, YCS 2425, 183-197.

e J. M. Bremer (2001), Greek Hymns. Selected Cult Songs from the Archaic to the Hellenistic Period (2 vols.), Tübingen.

García, J. F. (2002), "Symbolic Action in the Homeric Hymns: The Theme of Recognition", CA 21, 5-39.

Geldner, K. F. (2003), Der Rig-Veda. Aus dem Sanskrit ins Deutsche übersetzt und mit einem laufenden Kommentar versehen, Harvard Oriental Series 63, Cambridge, Mass.

Gelzer, T. (1987), "Bemerkungen zum Homerischen Ares-Hymnus (Hom.Hy.8)", MH 44, 150-167.

Germany, R. (2005), "The Figure of Echo in the Homeric Hymn to Pan", AJP 126, 187-208.

Gonda, J. (1959a), Stylistic Repetition in the Veda, Amsterdã. (1959b), Epithets in the Rgveda, 's-Gravenhage. (1960), Brachyology and Other Forms of Brevity in Speech in the Rgveda, Amsterdã. 
(1963), The Vision of the Vedic Poets, Amsterdã.

(1964), “'Gifts' and 'giving' in the Rgveda”, Vishveshvaranand Indological Journal 2, 9-30 (= 1975b, 122-143).

(1975a), Vedic Literature (A History of Indian Literature), vol. 1, fasc. 1, Wiesbaden.

(1975b), Selected Studies, vol. 4: History of Ancient Indian Religion, Leiden.

Gotō, T. (1987), Die “I. Präsensklasse” im Vedischen. Untersuchung der vollstufigen thematischen Wurzelpräsentia, Viena.

GRAF, F. (1985), Nordionische Kulte, Roma.

(1991), "Prayer in Magic and Religious Ritual", in C.A. Faraone e D.

Obbink (eds.), Magika Hiera: Ancient Greek Magic and Religion, Nova York/Oxford, 188-213.

GRONINGEN, B. A. VAN (1948), La composition littéraire archaïque grecque, Amsterdã.

Gygli-Wyss, B. (1966), Das nominale Polyptoton im älteren Griechisch, Göttingen.

HARDER, M. A. (1992), "Insubstantial Voices: Some Observations on the Hymns of Callimachus” CQ 42, 384-394.

, R. F. ReGTUIT e G. C. WAKKeR (eds.) (1993), Hellenistica Groningana: Callimachus, Groningen.

Harvey, A. E. (1955), "The Classification of Greek Lyric Poetry”, CQ 5, 157-175.

HAubOLD, J. (2001), "Epic with and end: an interpretation of Homeric Hymns 15 and 20", in F. Budelmann e P. Michelakis (eds.), Homer, Tragedy and Beyond. Essays in Honor of P. E. Easterling, Londres, 23-41.

Heath, J. R. (1988), "The Blessings of Epiphany in Callimachus' Bath of Pallas", CA 7, 72-90.

HEESTERMAN, J. C. (1959), "Reflections on the Significance of the dákșinăa', IndoIranian Journal 3, 241-258.

HENDERSON, J. (1987), Aristophanes, Lysistrata, Oxford.

Henrichs, A. (1990), "Between Country and City: Cultic Dimensions of Dionysus in Athens and Attica", in M. Griffith and D.J. Mastronarde (eds.), Cabinet of the Muses. Essays of Classical and Comparative Literature in Honor of Thomas G. Rosenmeyer, Atlanta, 257-277.

(1994-5), “'Why should I dance?': Choral Self-Referentiality in Greek Tragedy", Arion 3.1, 56-111.

(1996a), "Dancing in Athens, Dancing in Delos: Some Patterns of Choral Projection in Euripides", Philologus 140, 48-62. (1996b), "Warum soll ich denn tanzen?" Dionysisches im Chor der griechischen Tragödie, Stuttgart/Leipzig.

(2003), "Writing Religion: Inscribed Texts, Ritual Authority, and the Religious Discourse of the Polis", in H. Yunis (ed.), Written Texts and the Rise of Literate Culture in Ancient Greece, Cambridge, 38-58.

HeubecK, A. (1972), "Gedanken zum homerischen Apollonhymnus", in Festschrift für Konstantinos J. Merentitis, Atenas, 131-146.

HINTZE, A. (2000), "Lohn” im Indoarischen. Eine semantische Studie des Rigveda und Avesta, Wiesbaden. 
(2002), "On the Literary Structure of the Older Avesta", Bulletin of the School of Oriental and African Studies 65, 31-51.

(2004) " "Do ut des': Patterns of Exchange in Zoroastrianism”, Journal of the Royal Asiatic Society, 14, 27-45.

HofFMANN, K. (1967), Der Injunktiv im Veda, Heidelberg.

HoOKER, J. T. (1992), "Some Uses of the Greek Imperfect", in B. Brogyanyi e R. Lipp (eds.), Historical Philology - Greek, Latin, and Romance. Papers in Honor of Oswald Szemerényi II, Amsterdã/Filadélfia, 47-65.

Hopman-Govers, M. (2001), "Le jeu des épithètes dans les Hymnes orphiques", Kernos 14, 35-49.

Hopkinson, N. (1984a), Callimachus, Hymn to Demeter, Cambridge. (1984b), "Callimachus' Hymn to Zeus", CQ 34, 139-148.

HorN, W. (1970), Gebet und Gebetsparodie in den Komödien des Aristophanes, Nurembergue.

Houben, J.E.M. (2000), "The Ritual Pragmatics of a Vedic Hymn: The 'Riddle Hymn' and the Pravargya Ritual", Journal of the American Oriental Society 120, 499-536.

Hubbard, T. K. (2004), “The Dissemination of Epinician Lyric: Pan-Helenism, Reperformance, Written Texts", in C.J. Mackie (ed.), Oral Performance and its Context, Leiden, 71-93.

HumbaCH, H. (1959), “Aussage plus negierte Gegenaussage”, Münchener Studien zur Sprachwissenschaft 14, 23-33.

Hummel, P. (1993), La syntaxe de Pindare, Louvain/Paris.

HunTER, R. L. (1996), Theocritus and the Archeology of Greek Poetry, Cambridge.

INSLER, S. (1998), "On the Recension of the Atharva Veda and Atharvan Hymn Composition”, Wiener Zeitschrift für die Kunde Südasiens 42, 5-21.

JACOBY, F. (1933), Der homerische Apollonhymnos, Berlim.

JACQUINOD, B. (1989), Le double accusative en grec d'Homère à la fin du $V^{e}$ siècle avant J.-C., Louvain-la-Neuve.

JAMison, S. (1996), Sacrificed Wife / Sacrificer's Wife: Women, Ritual, and Hospitality in Ancient India, Oxford. (2001a), resenha de T. OBERLIES (1998), Die Religion des Rgveda. Erster Teil: Das religiose System des Rgveda, History of Religions 40, 387-390. (2001b), resenha de T. OBERLIES (1999), Die Religion des Rgveda. Zweiter Teil: Kompositionsanalyse der Soma-Hymnen, History of Religions 41, 180-183. (2004), "Poetry and Purpose in the Rgveda: Structuring Enigmas", in A. Griffiths e J.E.M. Houben (eds.), The Vedas. Texts, Language \& Ritual (Proceedings of the $3^{\text {rd }}$ International Vedic Workshop, Leiden, 2002), Groningen, 237-249.

(2007), The Rig Veda Between Two Worlds. Quatre conférences au Collège de France en mai 2004, Paris.

JANDA, M. (1997), Über "Stock und Stein": die indogermanischen Variationen eines universalen Phraseologismus, Dettelbach.

(2000), Eleusis: das indogermanische Erbe der Mysterien, Innsbruck.

JANKO, R. (1981), "The Structure of the Homeric Hymns: A Study in Genre”, Hermes $109,9-24$. 
(1982), Homer, Hesiod and the Hymns: Diachronic Development in Epic

Diction, Cambridge.

JeBB, R. C. (1888), Sophocles. The Plays and Fragments. Antigone. Cambridge.

(1905), Bacchylides. The Poems and Fragments, Cambridge.

Johnston, S. I. (2002), "Myth, Festival, and Poet: The Homeric Hymn to Hermes and its Performative Context", CP 97, 109-132.

KAHN, C. H. (1973), The Verb 'Be' in Ancient Greek, Indianápolis/Cambridge.

KAKRIDIS, J. T. (1937), "Zum homerischen Apollonhymnos”, Philologus 92, 463-477.

(1979), "Die 14. Olympische Ode. Ein Beitrag zum Problem der Religiosität Pindars", in Serta Philologica Aenipontana 3, 141-147.

KAMERBEEK, J.C. (1978), The Plays of Sophocles. Antigone, Leiden.

KANNICHT, R. (ed.) (1969), Euripidis Helena, Heidelberg.

KäPPEL, L. (1997), Paian. Studien zur Geschichte einer Gattung, Berlim/Nova York.

KeMMER, E. (1903), Die polare Ausdrucksweise in der griechischen Literatur, Würzburg.

KEYSSNER, K. (1932), Gottesvorstellung und Lebensauffassung im griechischen Hymnus, Würzburger Studien zur Altertumwissenschaft 2, Stuttgart. (1933), "Die Hygieiahymnen des Ariphron und des Likymnius", PW 53, 1289-1296.

KiPARSKy, P. (1968), “Tense and Mood in Indo-European Syntax”, Foundations of Language 4, 30-57.

(2005), "The Vedic Injunctive: Historical and Synchronic Implications", in http://www.stanford.edu/ kiparsky/Papers/injunctive.article.pdf.

KLEIN, J. S. (1985), Toward a Discourse Grammar of the Rigveda, Volume. 1: Coordinate Conjunction, Part 1: Introduction, $\underline{c a}$, utá, Heidelberg.

(1999), "A Triadic Structure Feature of Nominal Anaphora in the Rigveda", in J. Habisreitinger, R. Plath e S. Siegler (eds.), Gering und doch von Herzen: 25 indogermanische Beiträge - Bernhard Forssman zum 65. Geburtstag, Wiesbaden, 119-134.

(2000), "Polyptoton and Paronomasia in the Rigveda", in A. Hintze e E.

Tichy (eds.) Anusantatyai. Festschrift für Johanna Narten zum 70. Geburtstag, Dettelbach, 133-155.

(2002), "Responsion in the Rigveda", Journal of the American Oriental Society 122, 311-317.

(2003a), "Āmreditas and Related Constellations in the Rigveda", Journal of the American Oriental Society 123, 773-802. $7-45$.

(2003b), "Phrasal Repetition in the Veda", Bulletin des Études Indiennes 21,

KLEINKNeCht, H. (1937), Die Gebetsparodie in der Antike, Stuttgart/Berlim.

KÖHNKEN, A. (1971), Die Funktion des Mythos bei Pindar, Berlim.

Koller, H. (1951), "Praesens historicum und erzählendes Imperfekt", $M H$ 8, 63-99. (1956), "Das kitharodische Prooimon: Eine formgeschichtliche

Untersuchung", Philologus 100, 159-206.

KoRZENIEWSKI, D. (1962), "Zum Verhältnis von Wort und Metrum in sophokleischen

Chorliedern", RhM 105, 142-152.

KranZ, W. (1933), Stasimon, Berlim. 
(1961), "Sphragis: Ichform und Namensiegel als Eingangs- und

Schlußmotiv antiker Dichtung", $R h M$ 104, 3-46/97-124.

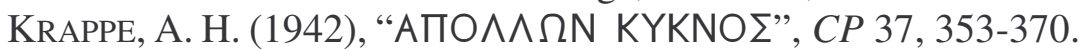

KRUMMEN, E. (1990), Pyrsos Hymnon. Festliche Gegenwart und mythisch-rituelle Tradition bei Pindar (Isthmie 4, Pythie 5, Olympie 1 und 3), Berlim/Nova York. (1998), "Ritual und Katastrophe. Rituelle Handlung und Bildersprache bei Sophockles und Euripides", in F. Graf (ed.), Ansichten griechischer Rituale:

Geburtstag Symposium für Walter Burkert, Castelen bei Basel, 15. bis 18. März 1996, Stuttgart, 296-325.

KÜHNER, R. e B. GERTH (1890-1904), Ausführliche Grammatik der griechischen Sprache (2 vols.), Hannover.

KuiPER, F. B. J. (1960), "The Ancient Aryan Verbal Contest”, Indo-Iranian Journal 4, 217-281.

KURKE, L. (1989), "Pouring Prayers: a Formula of IE Sacral Poetry?", Journal of Indo-European Studies 17, 113-125. (1991a), The Traffic in Praise. Pindar and the Poetics of Social Economy, Ithaca/Londres.

(1991b), "Fathers and Sons: a Note on Pindaric Ambiguity", AJP 112, 287-300.

Lang, M. (1975), "Reason and Purpose in Homeric Prayers", Classical World 68, 309314.

LanZara, V. G. (1990), Callimaco, Inno a Delo, Pisa.

LATACZ, J. (1966), Zum Wortfeld 'Freude' in der Sprache Homers, Heidelberg.

LAtTKe, M. (1991), Hymnus: Materialen zu einer Geschichte der antiken Hymnologie, Novum Testamentum et Orbis Antiquus 19, Göttingen.

LAZZERONI, R. (1983), "Oggetto materiale e atto verbale nella cultura vedica", in E. Campanile (ed.), Problemi di Lingua e di Cultura nel Campo Indoeuropeu, Pisa, 47-52.

(1991), "Per l'esegesi dell'inno vedico: architettura e cultura", in AION 13, L'inno tra rituale e letteratura nel mondo antico. Atti di un colloquio, Napoli 2124 ottobre 1991, Roma, 73-84.

Lloyd, G. E. R. (2003), In the Grip of Disease. Studies in the Greek Imagination, Oxford.

Lloyd, M. (1999), "The Tragic Aorist", CQ 49, 24-45.

Lloyd-Jones, H. e N. G. Wilson (1990), Sophoclea. Studies on the Text of Sophocles, Oxford.

(1997), Sophocles: Second Thoughts, Göttingen.

Lonsdale, S. H. (1993), Dance and Ritual Play in Greek Religion, Baltimore/London. Lubotsky, A. (1997), A Rgvedic Word Concordance (2 vols.), New Haven.

LÜDERS, H. (1959), Varuṇa. Vol. 2: Varuṇa und das Rta (ed. L. Alsdorf), Göttingen.

LudwICH, A. (1908), Homerischer Hymnenbau nebst seinen Nachahmungen bei Kallimachos, Theokrit, Vergil, Nonnos und Anderen, Leipzig.

MAAS, P. (1933), Epidaurische Hymnen, Halle.

MACDONELl, A. A. (1898), Vedic Mythology, Estrasburgo.

(1932), "The Ușas Hymns of the Rgveda", JRAS, 345-371.

Maclachlan, B. (1993), The Age of Grace. Charis in Early Greek Poetry, Princeton. 
MAGGi, D. (1975), "Sull'unità dell'inno rigvedico: sollecitazione a un problema. 'Come è fatto' RV X, 104", SSL 15, 52-101. (1991), "L'inno vedico: le ragioni della forma", in AION 13, L'inno tra rituale e letteratura nel mondo antico. Atti di un colloquio, Napoli 21-24 ottobre 1991, Roma, 33-54.

Malzahn, M. (2002), “Auf der Spur von AI. véṭ’, Indo-Iranian Journal 45, 197-204.

MAuss, M. (1924), Essai sur le don, Année sociologique, Nouvelle série I, Paris.

MAYRHOFER, M. (1992-1996), Etymologisches Wörterbuch des Altindoarischen. Erster Teil: Ältere Sprache (2 vols.), Heidelberg.

MCKAY, K. L. (1986), “Aspectual Usage in Timeless Contexts in Ancient Greek”, in A. Rijksbaron, H. Mulder e G.C. Wakker (eds.), In the Footsteps of Raphael Kühner, Amsterdã, 193-208.

MeILlet, A. (1925), Trois conférences sur les Gâthâ de l'Avesta, faites à l'Université d'Upsal, Paris.

Meyer, H. (1933), Hymnische Stilelemente in der frühgriechischen Dichtung, Diss. Köln, Würzburg.

Migron, S. (1988-1990), "Rgvedic jús- and joștín-, Old Persian dauštar-: a Semantic Investigation", Die Sprache 34, 124-135.

Miller, A. M. (1977), “Thalia Erasimolpos: Consolation in Pindar's Fourteenth Olympian", TAPA 107, 225-234.

(1979), "The 'Address to the Delian Maidens' in the Homeric Hymn to Apollo: Epilogue or Transition?”, TAPA 109, 173-186.

(1986), From Delos to Delphi: A Literary Study of the Homeric Hymn to Apollo, Leiden.

Mineur, W. H. (1984), Callimachus, Hymn to Delos, Leiden.

Minton, W. W. (1970), "The Proem-Hymn of Hesiod's Theogony", TAPA 101, 357-377.

Moens, P. W. (1930), De twee delphische Hymnen met muzieknoten, Purmerend.

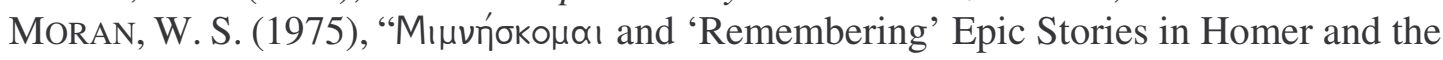
Hymns", QUCC 20, 195-211.

MorAnd, A.-F. (2001), Études sur les Hymnes orphiques, Leiden.

Morrison, J. (1991), "The Function and Context of Homeric Prayers: A Narrative Perspective", Hermes 119, 145-157.

MÜLlER, G. (1967), Antigone. Heidelberg.

Murray, O. (1990), "Sympotic History", in O. Murray (ed.), Sympotica. A Symposium on the Symposion, Oxford, 3-13.

NAGy, G. (1990), Greek Mythology and Poetics, Ithaca.

NiLSSON, M. P. (1955), Geschichte der griechischen Religion ( $2^{\mathrm{a}}$ ed.), Munique.

NoRDEN, E. (1913), Agnostos Theos. Untersuchungen zur Formgeschichte religiöser Rede, Leipzig/Berlim.

Oberlies, T. (1998), Die Religion des Rgveda. Erster Teil: Das religiose System des Rgveda, Viena.

(1999), Die Religion des Rgveda. Zweiter Teil: Kompositionsanalyse der Soma-Hymnen des Rgveda, Viena.

OguiBÉnine, B. (1988), La Deésse Ușas. Recherches sur le sacrifice de la parole dans le Rgveda, Louvain/Paris. 
OLDENBERG, H. (1884), "Rgveda-Samhitâ und Sâmavedârcika", ZDMG 38, 439-480 (=Kleine Schriften I, Wiesbaden, 1967, 513-554). (1888), Metrische und textgeschichtliche Prolegomena zu einer kritische Rgveda Ausgabe, Berlim. (1907), "Rgveda 6, 1-20”, ZDMG 55, 267-330 (= 1967, 726-789). (1909-1912), Rgveda: Textkritische und exegetische Noten (2 vols.),

Abhandlungen der Königlichen Gesellschaft der Wissenschaften zu Göttingen, Philologisch-Historische Klasse, Berlim. (1917), Die Religion des Veda ( $2^{\mathrm{a}}$ ed.), Stuttgart. (1967), Kleine Schriften, herausgegeben von Klaus Janert, vol. 1.

OTTERLO, W. A. A. VAN (1944), "Untersuchungen über Begriff, Anwendung und Entstehung der griechischen Ringkomposition", Mededeelingen der Koninklijke Nederlandse Akademie van Wetenschappen, Afd. Letterkunde, 7/3, 131-176.

PAGE, D. (1955), Sappho and Alcaeus, Oxford.

PARDO, F. P. (1984), "El pean de Macedonico a Apolo y a Asclepio, un nuevo hallazgo epigrafico", Corolla Londiniensis 4, 101-129.

PARKER, L. (1997), The Songs of Aristophanes, Oxford.

PARKER, R. (1991), "The Hymn to Demeter and the Homeric Hymns", G\&R 38, 1-17. (1996), Athenian Religion: A History, Oxford. (1998), "Pleasing Thighs: Reciprocity in Greek religion", in C. Gill, N.

Postlethwaite e R. Seaford (eds.) Reciprocity in ancient Greece, Exeter, 105-125. (2005a), Polytheism and Society at Athens, Oxford. (2005b), "Law and Religion", in M. Gagarin e D. Cohen (eds.), The Cambridge Companion to Ancient Greek Law, Cambridge, 61-81.

PEeK, W. (1980), Attische Versinschriften, Leipzig.

Perlman, P. J. (1995), "Invocatio and Imprecatio: the Hymn to the Greatest Kouros from Palaikastro and the Oath in Ancient Greece", JHS 115, 161-167.

Peters, M. (1993), "Beiträge zur griechischen Etymologie", in L. Isebaert (ed.), Miscellanea linguistica Graeco-Latina, Namur, 85-113.

PFEIJFFER, I. L. (1999), Three Aeginetan Odes, Leiden.

PFISTER, F. (1924), "Epiphanie", in Paulys Realencyclopädie der classischen Altertumswissenschaft, Supplementband IV, 277-323.

PinAult, G.-J. (1994), "Le genre de l'éloge dans les hymnes védiques", in N. Balbir (ed.), Genres littéraires en Inde, Paris, 35-67. (1999-2000), "Le nom primitive de la rétribution rituelle en védique ancient", Bulletin des Études Indiennes 17-18, 427-476.

Pöhlmann, E. (1970), Denkmäler der altgriechischen Musik, Nurembergue.

PORTER, H. N. (1949), "Repetition in the Homeric Hymn to Aphrodite", AJP 70, 249272.

Powell, J. U. (ed.) (1925), Collectanea Alexandrina, Oxford.

Prestagostini, R. (1991), "Rito e letteratura negli inni 'dramatici' di Callimaco", in AION 13, L'inno tra rituale e letteratura nel mondo antico. Atti di un colloquio, Napoli 21-24 ottobre 1991, Roma, 253-263.

Pulleyn, S. (1997), Prayer in Greek Religion, Oxford.

RACE, W. H. (1982a), "Aspects of Rhetoric and Form in Greek Hymns", GRBS 23, 5-14. (1982b), The Classical Priamel from Homer to Boethius, Leiden. 
(1990), Style and Rhetoric in Pindar's Odes, Atlanta.

(1992), "How Greek Poems Begin", YCS 29, 13-39.

(2004), "Elements of Plot and the Formal Presentation in Pindar's Olympian 12", CJ 99, 373-394.

RADT, S. L. (1958), Pindars zweiter und sechster Paian. Text, Scholien und Kommentar, Amsterdã.

ReneHAN, R. (1969), "Conscious Ambiguity in Pindar and Bacchylides”, GRBS 10, 217 228.

(1982), "Aristotle as Lyric Poet: the Hermias Poem", GRBS 23, 251-274.

RenOU, L. (1928), "Les formes dites d'injonctif dans le Rgveda”, in Etrennes de linguistique E. Benveniste, Paris, 53-89.

(1939), “L’ambigüité du vocabulaire du Rgveda", Journal Asiatique 231, $161-235$

(1942), La poésie religieuse de l'Inde antique, Paris.

(1949), "Langue et réligion dans le Rgveda", Die Sprache 1, 11-17.

(1952), Grammaire de la langue védique, Lyon.

(1955-1969), Études védiques et pāṇinéennes [EVP], tomos I-V, VII-X, XII-

XVII, Paris.

(1958), Études sur le vocabulaire du Rgveda. Première série, Pondichéry.

(1966), "Sur l'utilisation linguistique du Rgveda", Bulletin de la Société

Linguistique de Paris 61, 1-12.

Richardson, N. J. (1974), The Homeric Hymn to Demeter, Oxford.

RijksBaron, A. (2002), The Syntax and Semantics of the Verb in Classical Greek: an Introduction ( $3^{\mathrm{a}}$ ed.), Chicago.

Risch, E. (1962), "Der göttliche Schlaf bei Sappho. Bemerkungen zum Ostrakon der Medea Norsa", MH 19, 197-201.

RoHDICH, H. (1980), Antigone. Beitrag einer Theorie des sophokleischen Helden, Heidelberg.

RouX, G. (1965), "Sur deux passages de l'Hymne homérique à Apollon”, REG 77, 1-22.

RudHARDT, J. (1978), “À propos de l'hymne homérique à Déméter", $M H$ 35, 1-17. (1992), Notions fondamentales de la pensée religieuse et actes constitutifs du culte dans la Grèce classique ( $2^{\mathrm{a}}$ ed.), Paris.

Russell, D. A. e N. G. WILSON (eds.) (1981), Menander Rhetor, Oxford.

RUTHERFORD, I. (1994-1995), "Apollo in Ivy: the Tragic Paean”, Arion 3.1, 112-135. (1997), "For the Aiginetans to Aiakos a Prosodion": an Unnoticed Title at

Pindar, Paean 6, 123, and its Significance for the Poem", ZPE 118, 1-21. (2001), Pindar's Paeans. A Reading of the Fragments with a Survey of the Genre, Oxford.

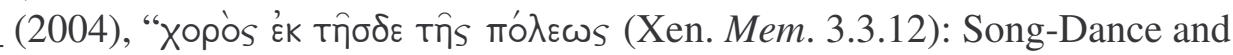

State-Pilgrimage at Athens", in P. Murray e P. Wilson (eds.), Music and the

Muses: The Culture of 'Mousikē' in the Classical Athenian City, Oxford, 67-90.

SANSONE, D. (1984), "On Hendiadys in Greek", Glotta 62, 16-25.

SCHACHTER, A. (1981), Cults of Beotia, suplemento 38 do BICS (vol. 1), Londres.

SCHAEFFER, C. (1994), Das Intensivum im Vedischen, Göttingen. 
SCHEID-TissinieR, E. (2000), "Recevoir des dieux, donner aux dieux. Aspects de la relation avec le divin dans la poésie grecque archaïque", Revue de Philologie 74, 199-230.

SCHLERATH, B. (1960), Das Königtum im Rig- und Atharvaveda, Wiesbaden. (1974), "Gedanke, Wort und Werk im Veda und im Avesta", in Antiquitates Indogermanicae. Gedenkschrift für Hermann Gündert, Innsbruck. (1985), "Beobachtungen zum Wortfeld 'singen, preisen, rufen, verkunden’ im Rigveda”, Münchener Studien zur Sprachwissenschaft 44, 191214.

SCHMID, W. P. (1968), "Die Wurzel vī-im Rgveda", in Mélanges d'indianisme à la mémoire de Louis Renou, Paris, 613-624.

SCHMidT, D. A. (1990), "Bacchylides 17 - Paean or Dithyramb?", Hermes 118, 18 31.

SCHMIDT, H.-P. (1968a), Brhaspati und Indra. Untersuchungen zur vedischen Mythologie und Kulturgeschichte, Wiesbaden.

(1968b), "Die Komposition von Yasna 49", in J.C. Heesterman, H.Shokker e V.I. Subramoniam (eds.) Pratidānam: Indian, Iranian, and Indo-European Studies Presented to Franciscus Bernardus Jacobus Kuiper on his $60^{\text {th }}$ Birthday, Haia/Paris, 170-192.

(1974), "Associative Technique and Symmetrical Structure in the Composition of Yasna 47", in R. Frye (ed.), Neue Methodologie in der Iranistik, Wiesbaden, 306-352.

(1985), Form and Meaning of Yasna 33, New Haven.

SCHMIEL, R. (1987), "Callimachus' Hymn to Delos: Structure and Theme", Mnemosyne 40, 45-55.

SCHMITT, R. (1967), Dichtung und Dichtersprache in indogermanischer Zeit, Wiesbaden. (1970), Die Nominalbildung in den Dichtungen des Kallimachos von

Kyrene. Ein Beitrag zur Stellung seines Wortschatzes innerhalb des Griechischen, Wiesbaden.

SCHRÖDER, S. (1999), Geschichte und Theorie der Gattung Paian, Leipzig/Stuttgart. (2000), "Das Lied des Bakchylides von der Fahrt des Theseus nach

Kreta (C. 17 M.) und das Problem seiner Gattung”, RhM 143, 128-160.

Schwabl, H. (1963), "Aufbau und Struktur des Proömions des hesiodischen Theogonie”, Hermes 91, 385-415.

(1966), Hesiods Theogonie. Eine unitarische Analyse, Viena. (1969), "Der homerische Hymnus auf Pan", WS 3, 5-14.

SCHWARTZ, M. (1998), "The Ties that Bind: on the Form and Content of Zarathustra's Mysticism", in F. Vajifdar (ed.), New Approaches to the Interpretation of the Gāthās. Proceedings of the First Gāthā Colloquium Held in Croydon, England $\left(5^{\text {th }}-7^{\text {th }}\right.$ November 1993) under the Auspices of the World Zoroastrian Organization, Londres, 127-197.

SCullion, S. (1994), "Olympian and Chthonic", CA 13, 75-119. (1998), "Dionysos and Katharsis in Antigone", CA 17, 96-122. (2000), "Heroic and Chthonian Sacrifice: New Evidence from Selinous", ZPE 132, 163-171. 
(2002), "'Nothing to Do with Dionysus': Tragedy Misconceived as Ritual”, CQ 52, 102-137.

SEAFORD, R. (1994), Reciprocity and Ritual: Homer and Tragedy in the Developing CityState, Oxford.

SEgal, C. (1981), Tragedy and Civilization. An Interpretation of Sophocles, Cambridge, Mass.

SEnS, A. (1997), Theocritus: Dioscuri (Idyll 22). Introduction, Text, and Commentary, Göttingen.

Sicking, C. M. J. (1991), "The Distribution of Aorist and Present in Greek", Glotta 69, 14-43/154-170.

Simondon, M. (1982), La Mémoire et l'oubli dans la poésie grecque jusqu'à la fin du $V^{e}$ siècle av. J.-C., Paris.

SLATER, W. J. (1969a), Lexicon to Pindar, Berlim. (1969b), "Futures in Pindar", CQ 19, 86-94.

SLINGS, S. R. (1997), "Figures of Speech and their Lookalikes: Two Further Exercises in the Pragmatics of the Greek Sentence", in E.J. Bakker (ed.), Grammar as Interpretation. Greek Literature in its Linguistic Contexts, Leiden/Nova York/Colônia, 169-214.

Sмyтh, H. W. (1900), Greek Melic Poets, Londres. (1920), Greek Grammar, Cambridge, Mass.

SNELl, B. (1980), Die Entdeckung des Geistes (3 ${ }^{\mathrm{a}}$ ed.), Hamburgo.

SourvinOu-INwOOD, C. (1987), "Myth as History: The Previous Owners of the Delphic Oracle", in J. Bremmer (ed.), Interpretations of Greek Mythology, Londres, 215241.

(2003), Tragedy and Athenian Religion, Lanham/Oxford.

SowA, C. A. (1984), Traditional Themes and the Homeric Hymns, Chicago.

SPITZER, L. (1970), "L'effet de sourdine dans le style classique: Racine", in L. Spitzer, Études de style, Paris, 208-335.

StAROBINSKI, J. (1971), Les mots sous les mots. Les anagrammes de Ferdinand de Saussure, Paris.

Stehle, E. (2004), "Choral Prayers in Greek Tragedy: Euphemia or Aischrologia?", in P. Murray and P. Wilson (eds.), Music and the Muses, Oxford, 121-155.

STROHM, H. (1944), TYCHE: Zur Schicksalauffassung bei Pindar und den frühgriechischen Dichtern, Stuttgart.

SvenBro, J. (1988), "Il taglio della poesia: Note sulle origini sacrificali della poetica greca", in C. Grottanelli e N.F. Parisi (eds.), Sacrificio e società nel mondo antico, Roma/Bari, 231-252.

TARAgna, S. N. (1979), "Lingua e stile dell'inno tragico in Sofocle, Ant. 1115-1152", RFIC 107, 131-141.

Thalmann, W. G. (1984), Conventions of Form and Thought in Early Greek Epic Poetry, Baltimore.

THIEME, P. (1949), Untersuchungen zur Wortkunde und Auslegung des Rigveda. Halle/Saale.

(1952), "Bráhman", Zeitschrift der Deutschen Morgenländischen Gesellschaft 102, 91-129 (= 1971, 100-138). 
(1964), Gedichte aus dem Rig-Veda. Aus dem Sanskrit übertragen und erläutert, Stuttgart.

(1968) "Vorzarathrustisches bei den Zarathustriern und bei Zarathustra", in R. Schmitt (ed.), Indogermanische Dichtersprache, Darmstadt, 204-41 (publicado originalmente em Zeitschrift der Deutschen Morgenländischen Gesellschaft 107, 67-96.

(1971), Kleine Schriften (ed. Georg Buddruss), Wiesbaden.

Thompson, G. (1997), "The Brahmodya and Vedic Discourse", Journal of the American Oriental Society 117, 13-37.

Thomson, K. (2001), "The Meaning and Language of the Rigvedic grâvan as a Case Test", Journal of Indo-European Studies 29, 295-349.

Thummer, E. (1957), Die Religiosität Pindars, Innsbruck.

TichY, E. (1994), "Indoiranische Hymnen", in W. Burkert e F. Stolz (eds.), Hymnen der alten Welt im Kulturvergleich, Göttingen, 79-95.

Toporov, V. N. (1981), "Die Ursprünge der indoeuropäischen Poetik", Poetica 13, 189251.

TraCY, S. V. (1975), "Notes on the Pythais Inscription", $B C H$ 99, 185-218.

TZAmali, E. (1997), "Positive Aussage plus negierte Gegenaussage im Griechischen. Teil I: ältere griechische Dichtung”, Münchener Studien zur Sprachwissenschaft 57, $129-167$.

UkLeJa, K. (2005), Der Delos-Hymnus des Kallimachos innerhalb seines Hymnensextetts, Orbis Antiquus 39, Münster.

USENER, H. (1903), Dreiheit: ein Versuch mythologischer Zahlenlehre, Bonn (reimpr. Hildesheim, 1966).

VAMvouri, M. (1998), "Fiction poétique et réalité historique à propos du Péan de Liménios", Gaia 3, 37-57.

(2004), La fabrique du divin. Les Hymnes de Callimaque à la lumière des Hymnes homériques et des Hymnes épigrafiques, Liège.

VAN DER BEN, N. (1986), "Hymn to Aphrodite 36-291. Notes on the pars epica of the Homeric Hymn to Aphrodite", Mnemosyne 39, 1-41.

Van Nooten, B. A. e G. B. Holland (eds.) (1994), Rig Veda: A Metrically Restored Text with an Introduction and Notes, Harvard Oriental Series, vol. 50, Cambridge, Mass.

VERDENIUS, W. J. (1960), “L'association des idées comme principe de composition dans Homère, Hésiode, Théognis", REG 73, 345-361. 260.

(1972), "Notes on the Proem of Hesiod's Theogony", Mnemosyne 25, 225-

(1979), "Pindar's Fourteenth Olympian Ode. A Commentary", Mnemosyne $32,12-38$.

(1987) Commentaries on Pindar I, Leiden.

VERnANT, J.-P. (1965), "Hestia-Hermès: Sur l'expression religieuse de l'espace et du mouvement chez les Grecs", in J.-P. Vernant, Mythe et pensée chez les Grecs, I, Paris, 124-184.

ViCAIRE, P. (1968), "Place et figure de Dionysos dans la tragédie de Sophocle", REG 81, 351-371. 


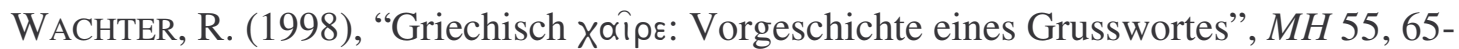
75.

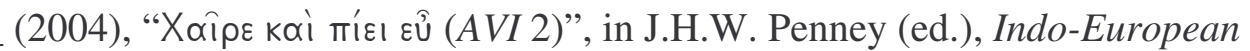

Perspectives: Studies in Honour of Anna Morpurgo Davies, Oxford, 300-322.

WACKERNAGEL, J. (1920-1924), Vorlesungen über Syntax (2 vols.), Basiléia. e A. D. DeBrunNer (1896-1957), Altindische Grammatik (3 vols.),

Göttingen.

Wagman, R. (1995), Inni di Epidauro, Pisa.

Walcot, P. (1957), "The Problem of the Proemium of Hesiod's Theogony", SO 33, 37 47.

(1966), Hesiod and the Near East, Cardiff.

WatKIns, C. (1995), How to Kill a Dragon. Aspects of Indo-European Poetics, Oxford. (2002a), "EחE $\Omega N \Theta E \Sigma I \Sigma$. Poetic Grammar: Word Order and Metrical

Structure in the Odes of Pindar", in H. Hettrich e J.-S. Kim (eds.),

Indogermanische Syntax: Fragen und Perspektiven, Wiesbaden, 319-337. 432-435.

(2002b), "Pindar's Rigveda", Journal of the American Oriental Society 122,

WeEs, H. VAN (1998), "The Law of Gratitude: Reciprocity in Anthropological Theory”,

in C. Gill, N. Postlethwaite e R. Seaford (eds.), Reciprocity in Ancient Greece, Oxford, 13-49.

WeISS, M. (1998), "Erotica: On the Prehistory of Greek Desire", HSCP 98, 31-61.

WeST, M. L. (1965), “The Dictaean Hymn to the Kouros”, JHS 85, 149-159.

(1966), Hesiod, Theogony, Oxford.

(1970), "The Eighth Homeric Hymn and Proclus", CQ 20, 300-304.

(1974), Studies in Greek Elegy and Iambus, Berlim.

(1975), "Cynaethus Hymn to Apollo", CQ 25, 161-170.

(1978), Hesiod, Works and Days, Oxford.

(1982), Greek Metre, Oxford.

(1988), "The Rise of Greek Epic", JHS 108, 151-172.

(1989), “An Unrecognized Injunctive Usage in Greek", Glotta 67, 135-138.

(1992), Ancient Greek Music, Oxford.

(1999), "The Invention of Homer", $C Q 49,364-382$.

(2003), Homeric Hymns. Homeric Apocrypha. Lives of Homer, Cambridge,

Mass.

(2007), Indo-European Poetry and Myth, Oxford.

Wilamowitz-MoellendorfF, U. von. (1859), Herakles. Euripides, Bad Homburg.

(1886), Isyllos von Epidauros, Berlim.

(1893), Aristoteles und Athen (vol. 2), Berlim.

(1916), Die Ilias und Homer, Berlim.

(1921), Griechische Verskunst, Berlim.

WILDEN, E. (2000), Der Kreislauf der Opfergaben im Veda, Stuttgart.

Willcock, M. M. (1995), Pindar - Victory Odes: Olympians 2, 7 and 11, Nemean 4, Isthmians 3, 4 and 7, Cambridge.

WiLli, A. (2006), "Unholy Diseases, or why Agamemnon and Tuthaliya should not have offended the gods", in D. Kölligan e R. Sen (eds.), Oxford University Working Papers in Linguistics, Philology \& Phonetics 11, 190-206. 
Williams, F. (1978), Callimachus, Hymn to Apollo, Oxford.

WÜNSCH, R. (1916), "Hymnos" in Paulys Realencyclopädie der classischen Altertumswissenschaft, Band IX, 140-183.

ZERDIN, J. (2002), "The 'iterative-intensives' in -бKov", in I.J. Hartmann e A. Willi (eds.), Oxford University Working Papers in Linguistics, Philology \& Phonetics 7, 103-130. 